(1)

3.1.

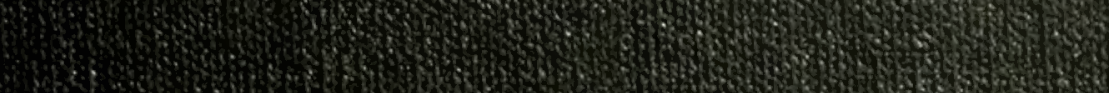

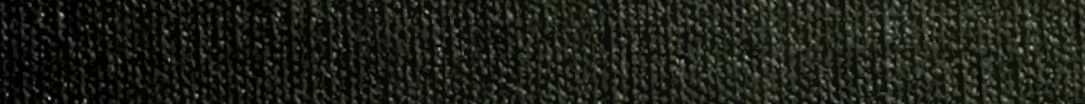
5. (1)

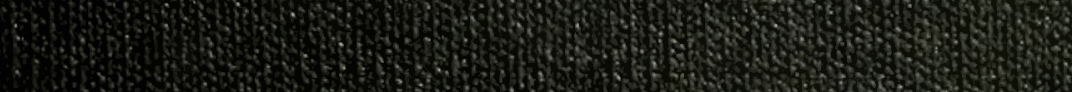

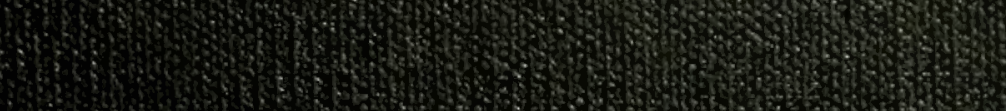
(3) 


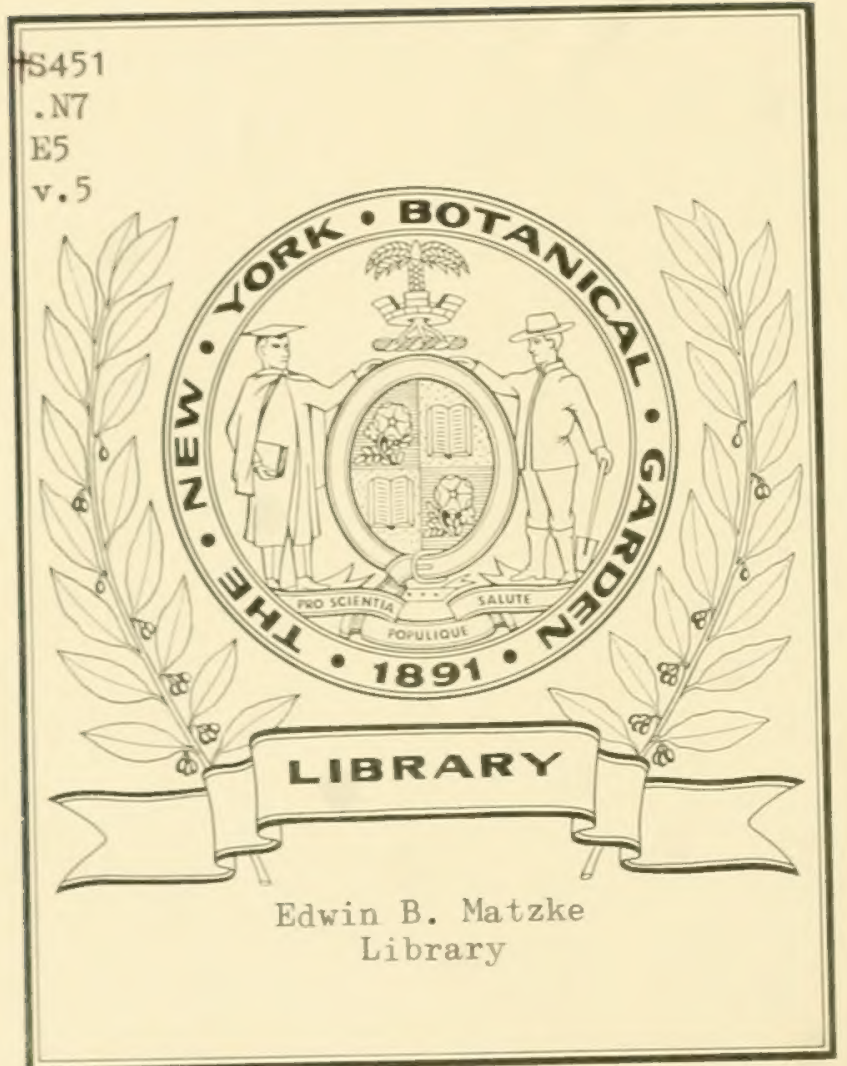








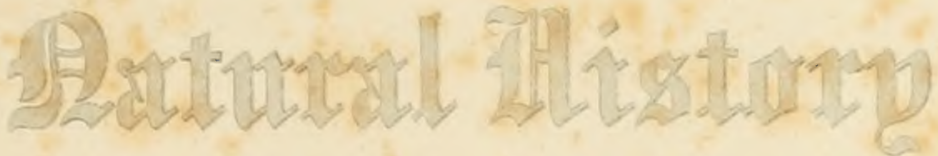

(1) F
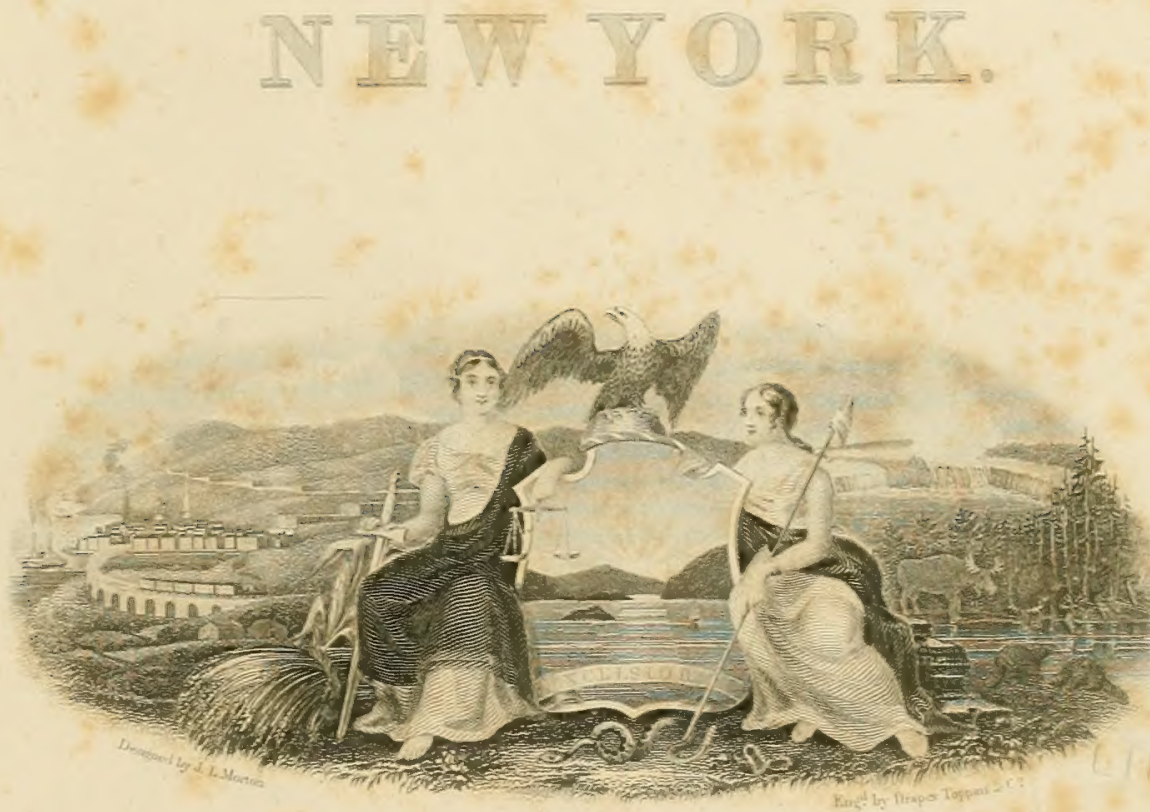

BY A UTHORITY.

\section{NGW TORIS:}

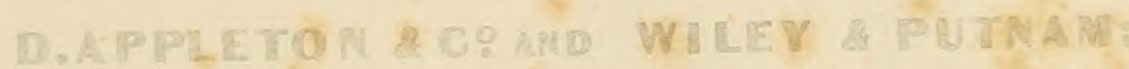

$$
\text { BOSMTOR: }
$$

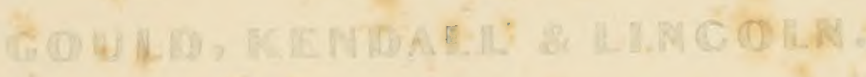

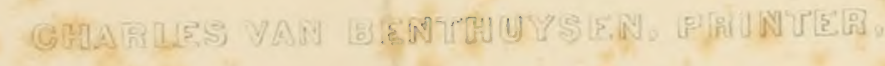





\section{AGRICULTURE}

oF

\section{N E W - Y O R K :}

COMPRISING

AN ACCOUNT OF THE CLASSIFICATION, COMPOSITION AND DISTRIBUTION OF THE SOIJS AND ROCKS,

AND OF the olimate AND AgRicultural PRODUCTIONS OF the state;

- TOGETHER WITH DESCRIPTIONS OF

THE MORE COMMON AND INJURIOUS SPECIES OF INSECTS.

B Y E. EMMONS, M.D.

VOLUME V.

A L B A N Y :

PRINTED BY C. VAN BENTHUYSEN.

1854. 



\section{T0 T. ROMEYN BECK. M.D.. LL.O.}

SIR :

THERE is more than one reason why the concluding divisions of the present work, undertaken to explore and illustrate the natural history of the State of New-York, and conducted under legislative patronage, should be dedicated to you. You were among the first to foster the cnterprise, and remained its consistent advocate in times when adverse circumstances seemed to jeopardize its continuance : much more than this your whole life has becn assiduously engaged in promoting the advance of science and the spread of popular education, and the published results of your scientific and literary labors may be referred to as reflecting an honor upon your native State. Would that the merits of the present volume were such as to render it more worthy its dedication.

THE IITHOR.

[Agricultural Repoet - Vol. v.] a 



\section{PREFACE.}

1 HAVE not attempted, in the preparation of this work, to place before $m y$ readers an account of all the rare and newly- discovered insects of NewYork and New-England, but have confined myself to those which are most conmon and widely distributed. The rare and the local possess an interest in the eyes of the learned; but those which are daily met with in the fields and in our walks, are the ones our interests demand us to know : the former do neither harm nor good; but a familiar acquaintance with the forms and habits of the common and widely spread, is an indispensable preliminary towards enabling the husbandman to take advantage of the services they may be made to render him, or to protect his premises and the fruits of his lahor from the depredations of noxions broods. This view has mainly controlled our undertaking : as the work is designed for those who are supposed to be mere beginners in entomology, and perhaps intend to prosecute the study no farther than practical results will warrant, it was thought fit to restrict the field of investigation to such insects as are sufficiently numerous to interfere in some way with the prosperity or comforts of the dwellers in this northern portion of our country.

One part of my labor has been to collect materials in the field, and another to collect them from the researches of others, the latter item constituting doubtlessly the largest and most valuable portion of the entire work; but it is confidently believed that naturalists and authors who have contributed largely to the common stock of entomological knowledge, and thereby earned and received a high and enduring reputation, will not be disposed to object to the diffusion of information fraught with such great consequence to the welfare of community. These distinguished investigators are honored by their discoveries; but their discoveries require to be made known to all the world, to the end that their results may redound to the common good of the human family. 
Atter saying thus much in general, it is scarcely necessary to add that

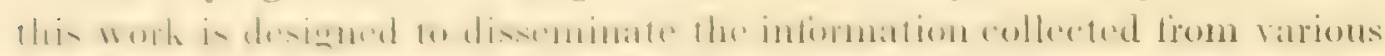

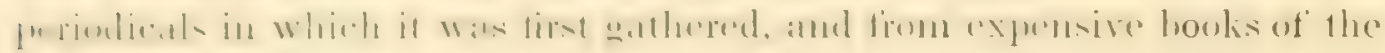
day in which a large amount is almost inaccessibly stored up, but is not

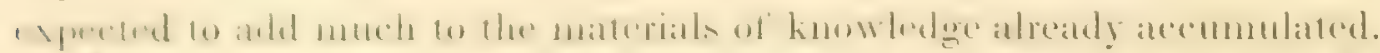

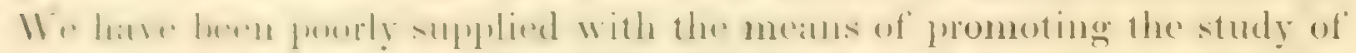

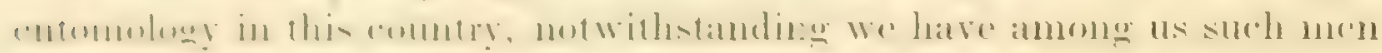
as the LECONTE's elder and younger, who both stand in the first rank of

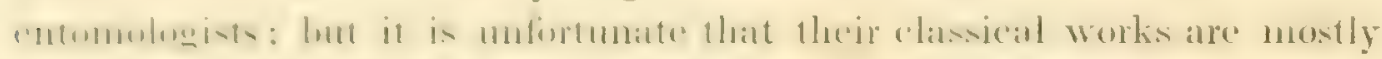
confined to the libraries of the learned.

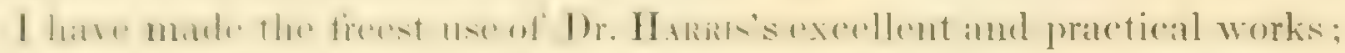

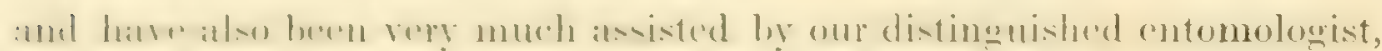
Dr. Asa Fitch of Salem, Washington county, N. Y.

I have occasion also to acknowledge a further indebtedness to Mr. HAL-

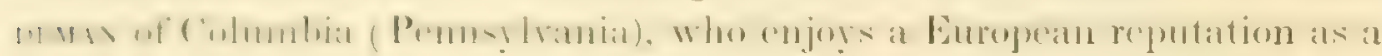
naturalist, for several valuable notes on various insects; and could his as-

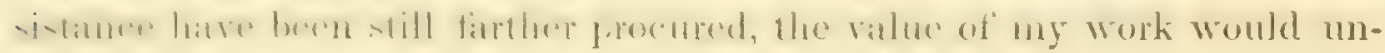
doubtedly have been greatly enhanced.

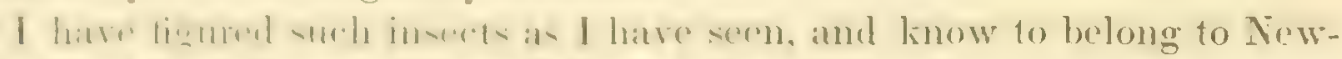

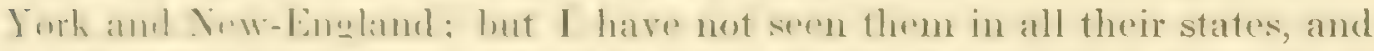
and therefine limeguently indelited to others for the figures griven of the larvat

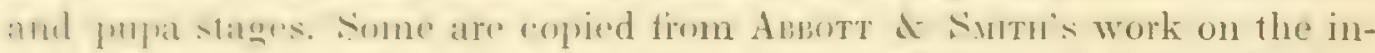

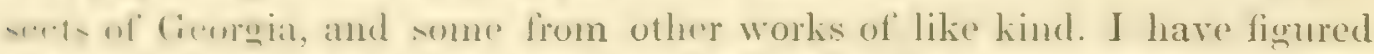
wry liew foreign sperics and the se have had some special purpose in view.

The liesure haw leen drawn from specinens of the insects themselves,

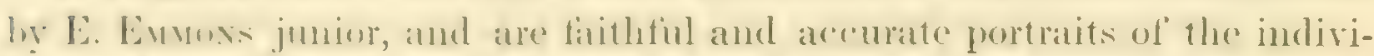
luat froun which they were taken. It is diflienlt, lowever, to secure a

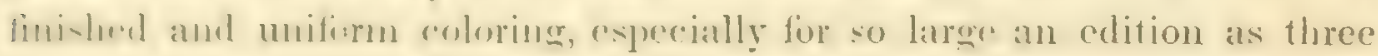
thousand copies.

I do not drem it meesary to point out the faults of this rolume; for the

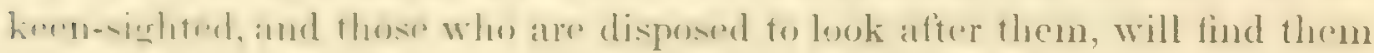

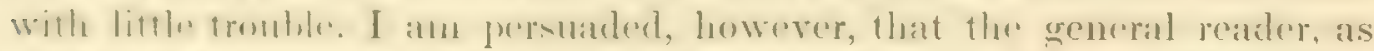

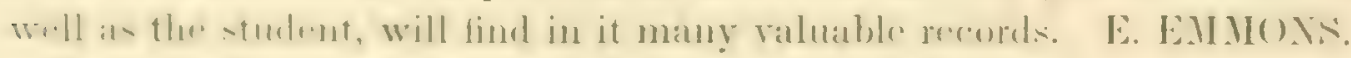

Albast, July $25,1 \times 54$. 


\section{TABLE OF CONTENTS.}

\section{CHAPTER I.}

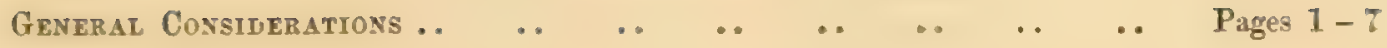

\section{CHAPTER II.}

SKETCH OF TUE ANATOMY AND PHYSIOLOGY OF INSECTS.

Anatonical description of parts - Funetion of digestion - Circulation - Nerrous system - Senses of touch, hearing, smell, sight and taste-Muscular motion-Function of propagation, pp. $7-24$

Appendix to Chapter II, embracing references to Plates A, B and E $\quad \ldots \quad \ldots \quad$ pp. 25-28

CHAPTER III.

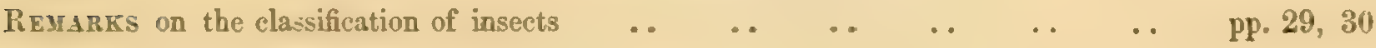

\section{CHAPTERS IV TO XI.}

\begin{tabular}{|c|c|c|c|c|c|c|c|c|c|}
\hline \multirow[t]{17}{*}{ ORDER I } & \multicolumn{2}{|c|}{ COLEOPTERA } & . & $\cdots$ & .. & . & . & \multicolumn{2}{|c|}{ pp. $31-138$} \\
\hline & Cictsdelid 五 & & .. & . & . & . & . & .. & p. 32 \\
\hline & CARABIDA & .. & .. & $\ldots$ & . & . & . & . & 38 \\
\hline & Drticide & .. & .. & $\ldots$ & $\ldots$ & . & . & .. & 55 \\
\hline & Nitidelide & .. & .. & .. & .. & . & . & . & 58 \\
\hline & EvaID $x$ & .. & . & .. & .. & . & .. & .. & 59 \\
\hline & StAPHYLINID & & .. & .. & . & .. & $\ldots$ & .. & 61 \\
\hline & BYRRHIDA & .. & .. & .. & $\ldots$ & . & . & . & 66 \\
\hline & Histeride & . & . & .. & .. & .. & .. & .. & 66 \\
\hline & Lrchinge & . & . & . & . & . & . & .. & 66 \\
\hline & GeotrtPid As & .. & .. & .. & .. & . & . & .. & 67 \\
\hline & SCARAB EID & & .. & .. & .. & .. & .. & .. & 68 \\
\hline & TroGID后 & . & . & .. & $\ldots$ & .. & . & .. & 70 \\
\hline & Drwastide & . & . & . & . & . & . & . & 71 \\
\hline & Melolonthi & & . & . & . & . & .. & . & 71 \\
\hline & BUPRESTID $\boldsymbol{B}$ & .. & .. & .. & .. & .. & .. & $\ldots$ & 83 \\
\hline & Elateride & . & . & .. & .. & .. & .. & . & 86 \\
\hline $\mathrm{P}$ & $\begin{array}{l}\text { LAMPYRIDE } \\
T \text { T - VOL. V.] }\end{array}$ & . & .. & .. & . & $\cdots$ & . & $\ldots$ & 89 \\
\hline
\end{tabular}


CONTENTS.

\begin{tabular}{|c|c|c|c|c|c|c|}
\hline TH:1 & . & $\cdots$ & .. & . & $\cdots$ & .. 1.611 \\
\hline CLERHA & . & $\cdots$ & $\cdots$ & . & . & . \\
\hline $1011 \times 11,2=\quad \ldots$ & . & .. & . & $\ldots$ & . & 12 \\
\hline 1,1:111,., & . & . & . & . & . & . \\
\hline Hatth & . & . & . & . & . & . \\
\hline 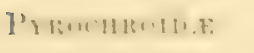 & . & . & . & . & . & . \\
\hline CANTHARIDE & . & . & . & . & . & . \\
\hline Cistelida & . & $\cdots$ & . & . & . & . \\
\hline 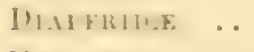 & . & . & . & . & . & . \\
\hline 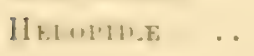 & . & . & .. & . & . & . \\
\hline TEXEBRIONIDE & . & . & . & . & $\cdots$ & . \\
\hline 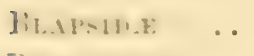 & $\cdots$ & . & . & $\cdots$ & . & . \\
\hline PIMELIID & . & . & .. & . & . & . \\
\hline Brechids $\quad$. & $\cdots$ & .. & . & . & . & 1110 \\
\hline Attelabida. & . & . & .. & . & . & . \\
\hline CuRCCLIONide & . & $\cdots$ & .. & . & . & . \\
\hline Scolvtrde & . & . & .. & . & . & $11: 2$ \\
\hline PRIONIDE & . & . & . & . & . & . \\
\hline CERAMBYCID五 & . & . & $\cdots$ & . & . & . \\
\hline LEPTCRID.E & . & . & . & . & . & . \\
\hline C'riocerin. . . & . & . & . & . & . & . \\
\hline Cassidide $\ldots$ & .. & . . & . . & . & . & . \\
\hline Chrysonelid & $\cdots$ & . & . & . & . & .. \\
\hline Galertcide.. & . & . & . & . & . & .. \\
\hline Cuccisellide & . & . & . & . & . & . \\
\hline
\end{tabular}

CHAPTER XII.

URDER II. ELPLEJOPTERA

.. p. 139

CHAPTER XIII.

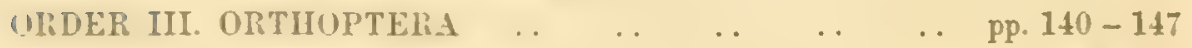

$\begin{array}{lllllllll}\text { Bhittih.: } & \ldots & \ldots & \ldots & \ldots & \ldots & \ldots & \ldots & 141\end{array}$

$\begin{array}{lllllllll}\text { Mantid E } & \ldots & \ldots & \ldots & \ldots & \ldots & \ldots & \ldots & 14\end{array}$

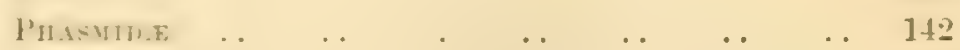

ACISETIDE

$\begin{array}{lllllllll}\text { CIRMHRHE } & \ldots & \ldots & \ldots & \ldots & \ldots & \ldots & \ldots & 144\end{array}$

$\begin{array}{lllllllll}\text { I }, H \text { THII, F } & \ldots & \ldots & \ldots & \ldots & \ldots & \ldots & \ldots & 145\end{array}$

CH.APTER XIT.

URIER IV. APMANIPTERA $\ldots$. 
CONTENTS.

\section{CHAPTER XV}

ORDER V. HOMOPTERA

pp. $149-165$

\begin{tabular}{lllllllll} 
Cicadide & $\ldots$ & $\ldots$ & $\ldots$ & $\ldots$ & $\ldots$ & $\ldots$ & $\ldots$ & p. \\
\hline
\end{tabular}

MEMBRACIDA

$\begin{array}{lllllllll}\text { APHIDID } & \ldots & \ldots & \ldots & \ldots & \ldots & \ldots & \ldots & 158\end{array}$

$\begin{array}{lllllllll}\text { COCCIDE } & \text {. } & \ldots & \ldots & \ldots & \ldots & \ldots & \ldots & 162\end{array}$

CHAPTER XVI.

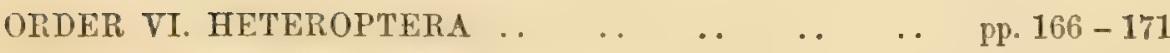

HYDRUMETRIDE

REDUVIIDA

$\begin{array}{lllllllll}\mathrm{LXGEID}_{\mathrm{X}} & \ldots & \ldots & \ldots & \ldots & \ldots & \ldots & \ldots & \mathbf{1 6 9}\end{array}$

$\begin{array}{lllllllll}\text { Cimicid } & \ldots & \ldots & \ldots & \ldots & \ldots & \ldots & \ldots & 169\end{array}$

$\begin{array}{lllllllll}\text { CoReide } & \ldots & \ldots & \ldots & \ldots & \ldots & \ldots & \ldots & 170\end{array}$

$\begin{array}{llllllll}\text { SCUtellarid } \mathrm{N} & \ldots & \ldots & \ldots & \ldots & \ldots & \ldots & 171\end{array}$

\section{CHAPTER XVII.}

ORDER VII. DIPTERA .. $\quad \ldots \quad$.

$$
\begin{aligned}
& \begin{array}{lllllllll}
\text { TIPULide } & \ldots & \ldots & \ldots & \ldots & \ldots & \ldots & \ldots & \text { p. } 173
\end{array} \\
& \begin{array}{lllllllll}
\text { MUsCide } & \ldots & \ldots & \ldots & \ldots & \ldots & \ldots & \ldots & 181
\end{array} \\
& \begin{array}{lllllllll}
\text { T }_{\triangle B A N I D E} & \ldots & \ldots & \ldots & \ldots & \ldots & \ldots & \ldots & 182
\end{array} \\
& \begin{array}{llllllll}
\text { XYLOPHAGIDE } & \ldots & \ldots & \ldots & \ldots & \ldots & \ldots & 183
\end{array} \\
& \begin{array}{lllllllll}
\text { SYRPHIDE } & \ldots & \ldots & \ldots & \ldots & \ldots & \ldots & \ldots & 183
\end{array}
\end{aligned}
$$

\section{CHAPTER XVIII.}

ORDER VIII. NEUROPTERA .. $\quad \ldots \quad \ldots \quad \ldots \quad \ldots \quad \ldots \quad$ pp. $184-187$

$$
\begin{aligned}
& \begin{array}{llllllll}
\text { LiBELlULIDE } & \ldots & \ldots & \ldots & \ldots & \ldots & \ldots & \text { p. } 184
\end{array} \\
& \text { MYrmeleonide } \\
& \begin{array}{llllllll}
\text { EPHEMERID } & \ldots & \ldots & \ldots & \ldots & \ldots & \ldots & 187
\end{array}
\end{aligned}
$$

CHAPTER XIX.

$\begin{array}{llllllll}\text { ORDER IX. TRICHOPTERA } & \ldots & \ldots & \ldots & \ldots & \ldots & \ldots & \text { p. } 188\end{array}$ 
CHAPTER XX.

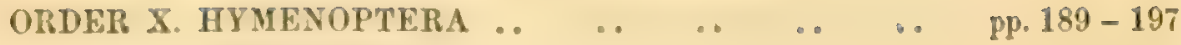

Tenthredinid

UROCERIDE

ICUNECMONIDE

SPHEGIDE

EVANIIDA

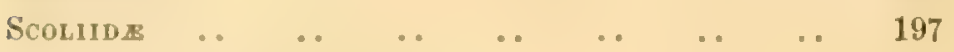

CHAPTERS XXI \& XXII.

\begin{tabular}{|c|c|c|c|c|c|c|c|c|}
\hline \multirow{2}{*}{ ORDER XI } & LEPIDOPTERA & .. & . & .. & .. & .. & \multicolumn{2}{|c|}{ рр. $198-256$} \\
\hline & Papilionide & . & . & . & . & . & .. & p. 199 \\
\hline & HELICONIIDE & .. & . & . & . & . & .. & 202 \\
\hline & NYMPHALIDE & . & . & . & . & . & .. & 206 \\
\hline & LYCANIDEE $\quad \ldots$ & -. & -. & $\cdots$ & - & $\cdots$ & .. & 214 \\
\hline & Hesperide . & . & . & . & . & -. & . & 215 \\
\hline & SPHINGIDE & . & .. & . & -. & .. & . & 216 \\
\hline & EGERIDE & . & - & . & -. & . & .. & 222 \\
\hline & Lithosind . & $\cdots$ & .. & - & . & . & .. & 224 \\
\hline & Arctild E & .. & . & . & . & . & .. & 225 \\
\hline & LIPARIDE $\quad \ldots$ & . & . & . & .. & . & . & 230 \\
\hline & SATURNIADX & .. & .. & .. & .. & .. & . & 231 \\
\hline & LASIOCANPADE & .. & . & .. & .. & . & .. & 234 \\
\hline & Hepialidx . . & -. & -. & . & -. & $\cdots$ & .. & 241 \\
\hline & Notodontide & . & . & . & - & .. & -. & 241 \\
\hline & Nonagriadx & . & .. & . & . & .. & .. & 243 \\
\hline & AGrotidx $\ldots$ & .. & .. & .. & .. & . & . & 243 \\
\hline & Noctuide $\quad$. & . & .. & . & .. & .. & .. & 244 \\
\hline & Geometrid & . & . & . & . & .. & . & 248 \\
\hline & TORTRICID & . & .. & . & .. & .. & . & 250 \\
\hline & YPONOMEUTIDE & . & . & . & . & .. & . & 2.52 \\
\hline & TINEID & .. & . & . & . & .. & .. & 252 \\
\hline
\end{tabular}




\section{INSECTS OF NEW-YORK.}

\section{CHAPTER I.}

\section{GENERAL CONSIDERATIONS.}

THE common idea of an insect is, probably, sufficiently exact for all practical purposes; yet it seems proper that the scientific idea should be expressed : indeed it is always important to define clearly the limits of all departments of Natural History, by stating in determinate language the boundaries which confine them. Insects, then, are animals whose bodies are covered with a coriaceous integument; and they are divided into three distinct segments or sections, the head, thorax, and abdomen. The head is provided with two antennæ; the thorax, with six articulated legs; and the abdomen with many rings, and contains the digestive organs : the sexes are distinct. They have a respiratory, circulatory and nervous apparatus : the first permeates the whole body; the second consists mainly of a long vessel extending through the body, and is called a dorsal vessel, from the position it occupies; the third is a symmetrical arrangement of nervous threads in two lines, placed upon the abdominal face, and connected by knots or ganglia at every ring of the body. The breathing is performed through small openings along the sides of the abdomen, at every ring : the air admitted permeates the whole system, and acts upon the fluids as in all animals. The most interesting peculiarities, however, consist in the changes which the insect undergoes during its stages of growth, which, although the developments are not more remarkable than in other departments of the animal kingdom, yet differ from the higher in being stationary for certain periods, during which it performs the functions of a perfect animal, except indeed that which belongs to the exercise of the sexual organs. These changes are called metamorphoses, and consist of three stages, the worm or larva, the pupa, and the perfect insect. 


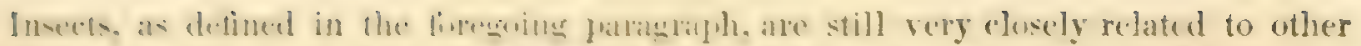

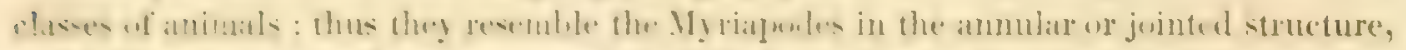

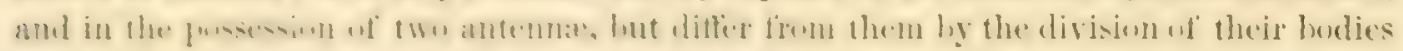

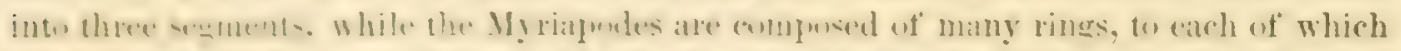

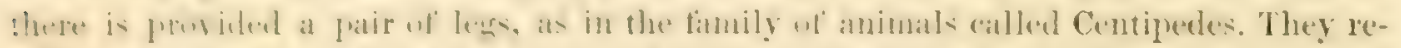

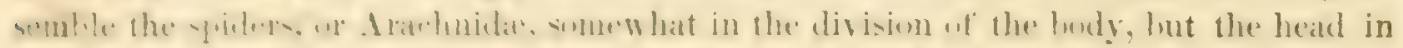

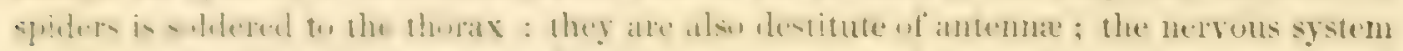

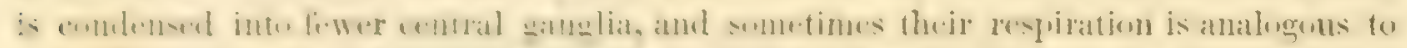

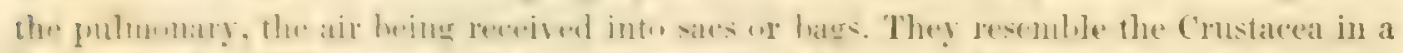

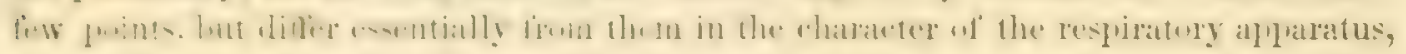

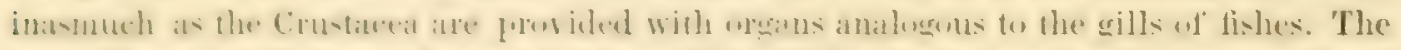

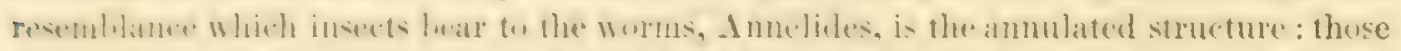

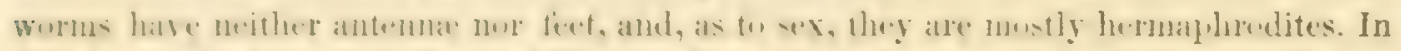

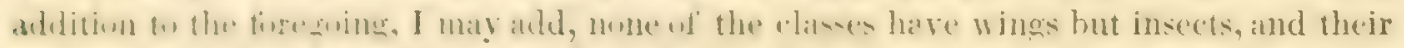

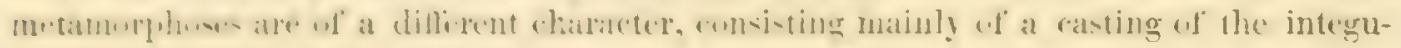
ments as in the erab and lobster.

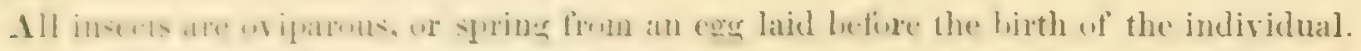

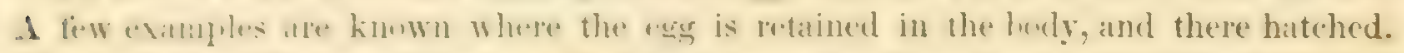

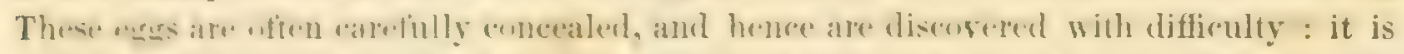

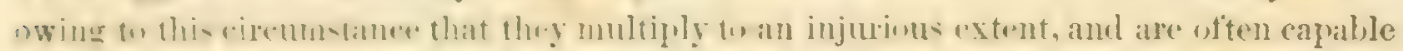

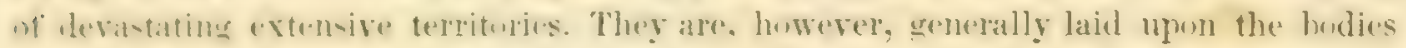

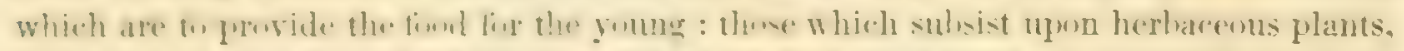

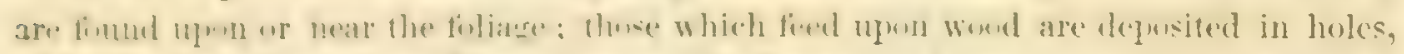

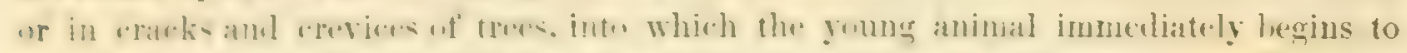

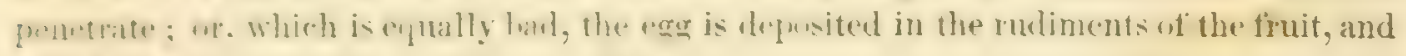
will be ready to devour it when it is mature.

Insects are extremely prolific, but the different species vary exceedingly. According to

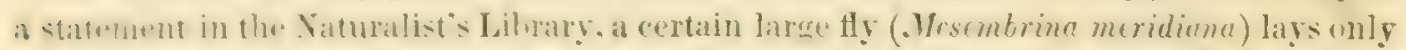

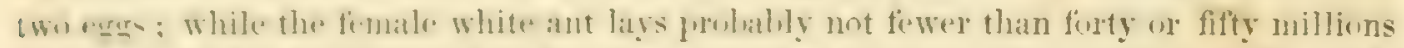
in a s.ar. which ate extruded at the late w sisty in at mimute when engaged in the ace* This -tatelanent "mblaces the ectremes. others are krown to lay, as the queen liee for

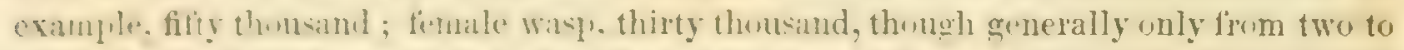

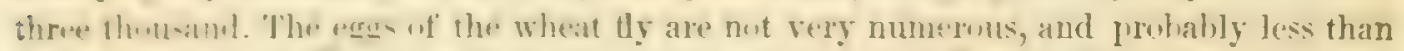
one humlral; sot eren in that small number the increase will be sufficient to secure the destruetion of the whatfinde in a latre distriet. But many inerets preduce several broods

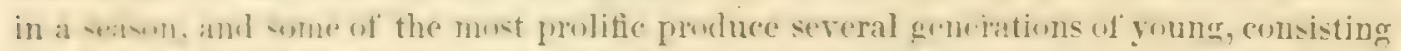
mainly of timuales. which are capalule of laying eqgs as son as they lave reached a stage

- Naturalist'в Library, Introduction, pp. 72, 73. 
of full development. But the law of increase secms to rest upon the surgly of fund : where. this is sure and constant, the increase is much greater than where it is precariun or uncertain : thus those insects which sulwsist on animal foul are comparatively limited. while the regretalle feeders are more numerons : this is in keeping with the harnony cif nature. and the original arrangements of the Creator.

The exgs of insects are mate up, cresitially, of the sabie parts as the eng of reltelruted animals. It consists of a polk, with its germinal dise and germinal :pot, which stem really to be nothing else than a cell with its nucleolus. The yolk is enveloped in a Iroper menbrane; and in order to defend and protect it, it is surplied with a hard cutside enrelope, analugous to the egorihell of the common furrl; but the shell, the white, and its tough membrane, are not essential parts in the constitution of the egg.

The eggs of insects, like all other eggs, whey the latr of temperature. The young are hatched at an earlier day it the temperature is increased, and the hatching is retarded in a medium of low temperature. It therefore happens that man is uften a gainer in conscquence of the warmth of suring, which brings furward insect life at an early dar, only to perish by the frusts which soun succeed. The eggs of insects are eidued with the pomer to resist, or rather withstand, wide rariations of temperdtule. It is erident that they sustain all the ordinary changes of the climate, and that it often happens that the $y$ are exposed to a temperature equal to $20^{\circ}$ below zero. The ability to withstand either extreme of tenperature depends upon the conditions of the egr : if it has plugressed cousiderably tumards the derelopment of an embroo, it porter to withstand those extreme changes is diminisherl. The pupa resists but feebly thuse changes then it first assumes this state; but when it has nearly reached the feriod of completing its metamor thesis, it is surprising that it can resist a high degree of heat. I expreed the pulre of numerons silkmorms, enclosed in a bottle. to $212^{2}$, without injuring them. I was surprised to find, not mant days afterwards, that hundreds of millers of both seres had escaped from theif cocons. The warmth of the stm, together with its light, is sufficient to destroy the vitality of the pupa when it first assumes that state; but the eggs of insects require air, oxyen, as much as the perfect animal : when enclosed in a racuum, they lose their ritality. Oxyen is essential to the derelopment of the embreso, and hence the outer corering must admit its passage.

The eqgs of some insects seem to grow : the increase in size, probalily by the absorytion of moisture from the atmosphere, or from the surface upon which they are laid.

The corering of eggs raries crcedingly : in some it is beautifully sculytured; in others it is smoth and shining. These different characters, il they could be fully delineated, would constitute important marks for the discrimination of species, for it is proballe that they differ in the species to which they belong.

The must remarkable fact in the history of insects, is their metanirrhosis. The egg, as has been observed already, is similar to the eggs produced by other classes of animals; hut it never sives birth to a perfect insect, the immediate product of the egg being really as 
unlike the perfect insect as possible; for what can he more unlike than the caterpillar and butterty ? How disgusting the one, as it crawls like a reptile; and how beautiful the other, as it thits in the air like a bird !

From the eqg, the first state in which the insect appears is the larva. This stage of existence is chatacterized by the remiform shape and construction of their bodies; and it is a stage which attrarts nur attention more frequently than that of the perfect insect, and it is one in which it nsually commits a greater amount of injury than in the perfect stage : it is, $t(w)$, in this stage that the agriculturist can more effectually exterminate these his lives. The term larra is applied generally to the immature butterfly or caterpillar. Grubs are white. suft-bulied animals, which are immature heetles; while maggots are immature flies, or ludong to the dipterus order of insects. All, howerer, are the analogous representatives of the different orders in the same stage of develepment, or that stage during which the insect grows and frequently easts its integuments : it devours immense quantities of forl. and is uften rery destructive to the folinge of vegetables. When it has reached its development fin the larva stage, it reases to eat, wraps itself in a mantle, simulates death, but is really undergoing internal changes preparatory to a higher stage of development. In its mintle it easts its old skin, which it presses down into the lower part of its envelope, and sun appears in a lirery peculiar to the pupa stage. The time during which it is confined to this stage varies with every insect : in some it is brief; in others, it is long.

Insects are composed of thirteen segments, including the head; but an obscurity often arises from the consolidation of segments, and often produces thereby a disproportionate derelopment of certain farts. The three segments immediately behind the head correspond to the prothorax, mesothorax, and metathorax of the insect; and these bear the three pair of lems, provided the larra pussesses legs. These are persistent, and hence are called true legs, to distinguish them from the abdominal legs, prolegs or props, which are caducous, or are never transmitted to the perfect insect : they are peculiar to the larva. The mouth-pieces or oral organs frequently differ in the different stages also. These are sometimes designed for suction in the larva, while the perfect insect is provided with jaws for mastication; hence, in such cases, the nature of the food is changed : in other cases the provisions for taking food are the same in both stages.

The larrs grow rapidly, as a general fact, insomuch that the whole structure of the animal indieates prorisions subservient to this result : they are provided with strong and effirient organs of manducation; their digestive organs are very large and capacious; the function of digestion is rapidly effected, and the consumption of food is immense in propurtion to the weight of the body. It is stated that tlesh-flies increase two hundred times their weight in twenty-four hours. Count Daxnowo remarks that the weight of the silkworm, when first hatehed, is alout one-hundredth of a grain, or it requires cone hundred of them to weigh a grain : alter the first moulting, one hundred weigh 15 grains; after the secnnd, the same nuruber weigh 91 grains; after the third, their weight is 400 grains; 
after the fourth, their conjoint weight is 1628 grains ; and after the fifth, when they have attained a length of three inches, they weigh 9500 grains. These changes of skin, called moultings, seem designed to accommodate the development of the body to its outer envelope : it is a critical period; and if any accident happens which interferes with its proper performance, the animal either perishes, or is left in an enfeebled state, and is unable to assume the form of the perfect insect. The number of moultings varies with the species, but is always alike in the same species : the same changes are repeated in each respectively. All these changes are best observed in the silkworm, in which their number is five, and require thirty days for their complete performance. In some insects the number of moultings extends to nine or ten, while in others it does not exceed three or four. The larva ceases to eat when it is undergoing this process : an internal change takes place, however, which greatly favors the casting of its envelope; it is the absorption of the fat beneath the outer skin, which becomes shrivelled, while at the same time it gives opportunity for the expansion of the internal parts. The motions are strange during this period : their bodies are curiously shaken and contorted, with jerkings of the head and posterior parts of the abdomen; these are designed to break up the attachments of the outer skin, and finally to detach it from the new skin beneath, which is bright, fresh, and moist. A rent is finally made in the old skin along the back, through which the animal now forces its way, in which process it is assisted by attaching itself to some point of support : this is managed so adroitly that the old skin remains whole, except the rent along the back, and so perfect that it might be mistaken for the perfect larva. The change is not confined to the outer envelope : the organs of respiration, though extremely delicate, as well as those of digestion, cast off also their membranes, which are ultimately expelled from the body. It is no wonder, then, that the moulting stage is one of great danger to the larva. This becomes still more hazardous to the silkworm which is placed in an artificial state, and which is increased by the numbers that are crowded into a small area. The last change is attended with circumstances somewhat peculiar. They first seek a suitable retreat, adapted to the nature of the insect itself; a crevice in the bark of trees, a shelter under the roof of a building, or a hole in the ground, in which they construct a sort of chamber, which they line and otherwise prepare in a mode suitable to their necessities. They form habitations with much skill, and the bestowment of much care, to defend their bodies from the extremes of temperature, or as a defence from their enemies. Sometimes, as in the dipterous insects, the old skin is converted into a pupa case, after becoming more rigid and stiff : in other instances a beautiful case is made, and a robe of silk is laboriously woven from a single thread, which is formed and spun from the juices of the body.

The silkworm is an admirable example to illustrate the instinctive powers of insects in perfecting their stages of development. We admire the skill by which it suspends itself in its case, and the beautiful mancuvres by which it manages to place the band of silk around 
its buly. The hathation of the lupa is nsually called its cocom : which term, howerer. is

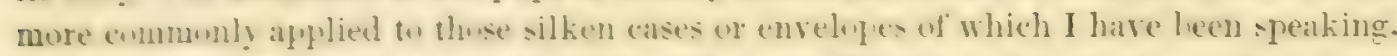
and of which we have an example in the silkwom. This is so clucly woren that it ex-

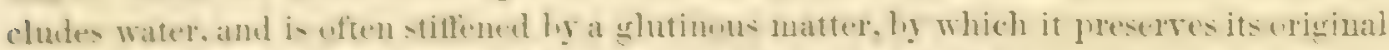
form even after the pertect animal has eseaped : it is alse liarther strengthened hy leares and pieces of wond, which undoultedly serve as a hetter protection firm its enemies. Thus this helphess state is guarded and protected hy a s! stem of me aws which are calculated wo seche the existence of the aninal in its utterly helpless state: a state which simulates death, and which, in its ultimate trinmph, resembles the resurection of the huly from the grave of real death.

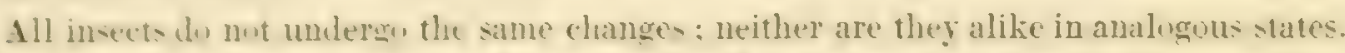
Thus the caterpillar of our lutterdies wraps itself in its mantle: where it silenty under-

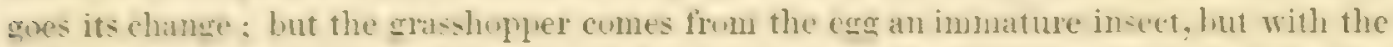
goneral form wi the perfect amimal. and hops abut with the ruliments of wing: upen its back. As it gruws rapidly, it onterums its skin, which it frepuently casts, like the larra of the buttertly : its wings coutinue to grow, and the body to increase; the partial wings keep pace with these change's, till at last they are perfected, and the animal has reached its perfect state withent having lant its activity durius its jeriud of glowth. The gras:hupper, then. nerer passes int. the inactive pula state; and in this it nuctumerph sis is similar to bugs, and dissimilar to beetles and eaterpillars.

There is andher difference in the history of insect life. which is interesting : it is not the inhalbiant of the same medium throngh life. It may hegin it carcer in the water, and end it in the air : the musunitu is an example. Who has nut ohserred the wiggler in stagnant water, and in wur ci-terns? It is the musquito enjwing its mater-life th the full. When the time arrive for its change, it rises to the surface, bursts its mantle, thrusts up

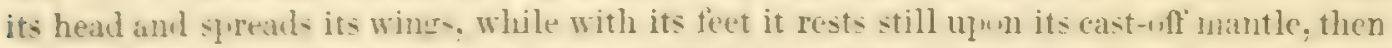
rises hu, tant frum its sinking bark, and tlies away in trimulh from the element which gave it birth.

Equally remarkahle are the arpetites of the insect in its larra and in its perfect state. Thus the larra. or, as it is usually called, the moggot. slurts and feeds umin the putrid

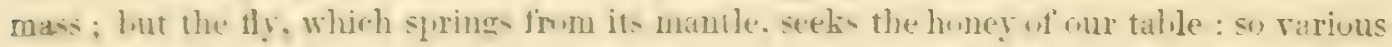

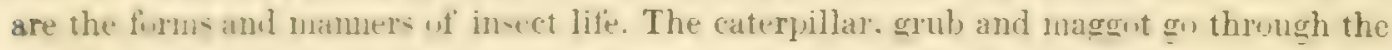

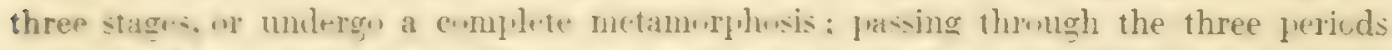

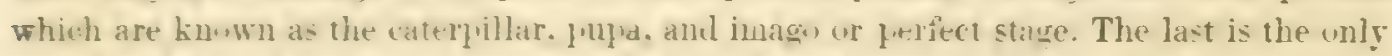
periml which is given them to entinue their kind and generatins : in many it is transient as the fireting day, and seems designed unly fur fulfilling the law of increase; which. wh n fulfilled, the insect dies. 


\section{CIIAPER II.}

\section{SKETCH OF THE ANATONY AND PHYSIOLOGY OF INSECTS.}

THE parts of the inscet which are emplyyed in description are the antennæ, the segments, the wings and nervures, the eyes, the parts forming the muuth, ete.; and these it will be necessary to describe somewhat at length. The three dirisions of the body are marked by deep incisions, by which the head, thorax and abdomen, or hind-body as it is sometimes called, are alwars distinct in the perfect insect ; but in the larva there are only two divisione, the head aml budy. The middle, or thorax, supports the head and wings. The head is armeel with jaws or mandihles and palpi, and ornamented or surmounted by the antennæ, which, in some insects, are much larger than their bodies, and are made up of many joints gradually tapering to a point.

The wings of beetles are comprased of dissimilar pieces, lying, when at rest, one above the other. The upper or outer wing is thick, and shaped to the parietes of the abdomen, heing ennrex above and concave helow : it protects the true wing, which is delicate and studiously folded, and is only elevated in flight, in order to give play to the true wings. The upper wings are called elytra, to distinguish them from the reticulated wing; they are alsu denminated wing-covers or cases, and are often finely sculptured, punctured or ornamented : to these the insect frequently orres its beauty; upon these, too, the fine colors are impressed, which are often of a splendent hue or lustre. In other orders of insects the four wings are entirely reticulated, or composed of a fine network traversed longitudinally and ubliquely by nerrures which branch in the same species in a certain manner, which, from their constancy, have been employed by systematists to aid in classifying, and as characteristics of genera. The mings are still farther modified in the Lepidoptera; the network is more compact and close, and is covered with fine scales but slightly attached, which appear to the unassisted eye like meal of a pearly hue. Butterflies and moths are provided with this peculiar wing, which, though extremely delicate and always injured when slightly tuuched with the finger, yet always appears perfect when first captured; showing thereby their power and ability to perform the natural functions for which they were designed, without sustaining the loss of this delicate substance. 
The external corering of insects is quite hard : it is called integument, or crust, and supplies the place of the internal skeleton, and is the part to which the muscles are attached. It is sumewhat horny, or corneous, but varies considerably in this respect in the different species : in certain beetles it is hard and inllexible; while in others, it is soft and quite texible. It resembles the true skin of animals in its divisibility into three layers, an epidermis, a rete mucesum, and a leathery tunic called the corium or dermis, the true skin. This outer integumeut is composed chemically of phosyhate of lime and magnesia ; but, what is interesting. it is foumd to contain a peculiar substance, termed chitine, which is insoluble in jutash. Phosphate of irun, allumen, and a peculiar coloring matter, are also among the substances composing this integument.

The shape of the head is rariable, but the spherical form predominates. The integument forms a kind of bxx, with an aperture in front, through which the organs of the mouth may be thrust. The pusterior part furnishes a place and attachments for the muscles which more the head upon the thorax. The eyes are large, usually, and occuly the lateral parts of the head. The external parts of the head hare receired different names. The epicranium is that prortion which extends from the eyes backwards. In front of the epicranium, is the forehead. The clypeus is the margin in front abore the mouth. Sometimes the whole region in frunt of the eyes is called the face. The inferior parts of the box enclosing the head has also its spaces, which have receired distinct names, as gulu, or throat, which lies immediately behinit the margin of the lower lip, and extends back to the prothorax. The cheeks are situated upon the sides of the head, from the eyes duwnwards to the mouth. The anteunir are situated between the angle of the mouth and the ejes : they have a subglobose joint at the base, upon which they more, and which is placed in a kind of socket; this is sometimes called a torulus.

The muuth, as may he supposed, is constructed so as to answer the ends designed, and it is either sucturial or manducatory, masticating : if the food is flud, it is sucturial ; if solid, it has jarrs fur mastication. In the mandibulate or masticating, there is perfect freedom of motion; in the suctorial or haustellate (hnustellatn), the parts are more or less soldered tugether, so as to form a tube for the transmissinn of fluids. The terms haustellata and mandibulutu aplyly, therefore, to two great elasses of insects, one of which subsists on the juices of plants and animals, which they wbtain ly suction; the others, the masticating, subsist on suld substances. Animals destined to ubtain find hy modes so apparently distinct, furnish many distinctive characters of importance. The labrum is the most anterior part scen frum abure; it corers the mouth, and is united by a memhranous hinge to the clypeus : it is empluyed in retaining the food in the mouth during mastication; it is, therefure, a true uryer lip, but of a variable form. Mastication is performed by the mandibles, which are two strung jaws that more laterally, and consist of wedge-shaped or triangular pieces mire or les elongated, and placed immediately below the labrum. These organs are alsu called uifuer jaws : they more like the blades of scissors. Their inner edge is fre- 
quently dentate or toothed, the teeth being arranged so as to shut within each other. Below the upper jaw are the feeler jaws, or maxillæ; these alow more horizontally : they are smaller, and, instead of notehes, their inner edges are furnished with bristles or hairs; they are articulated to the throat by a hinge (cardo), which places them at right angles to the stipe or stalk, which last is pyetty thick and strong at its upyer part. Attached to this is the feeler-bearer, so called because the maxillary palpus is inserted on its outer cdge. The terminal portion of the maxilla is the maxillary lohe, which is froguently trothed at its extremity. The maxillary palpus is a filiform, jointed process, which always distinguishes the maxilla from the mandibles. The proprtion of joints is variahle, and in number they never exceed six. The terminal joint is quite variable in form in the different genera, and hence becomes an important characteristic. The under lip is called a latium; it antagonizes the labrum : at its hase is the mentum or chin. The anterior part bears the labial palpi : the terminal portion is the ligula, and is often lobed. The labial palpi are jointed, but the joints never exceed four. The tongue, in the Carabidx, is a lining membrane of the under lip, which protrudes along its anterior angles, or in front : it is obscure among the Coleoptera, but more distinct among the Orthoptera. The month designed for suction is not vers dissimilar to the one formed for mastication. The mandibles have undergone micdifications which are referred to three types, that have receired the following appellations : prcmuscis, proboscis, and haustellum. The tube is formed by the elongation of the maxilla and accessory parts : so also it is formed by the mandibles.

The thorax is the section of the insect which lies between the head and abdomen : it supports the legs. Three principal pieces enter into its composition : the anterior supports the fore-legs, and is called the prothorax; the next, the mesothorax, which supports the middle legs and fore-wings; the last, the metathorax, which supports the hind-legs and hind-wings. The inferior part of the thorax is covered by a plate, called the prosternum by BurMeister. The scutellum is a triangular piece of integument interposed between the elytra at their base : sometimes it is concealed by the elytra. Connected with the scutellum. is the frenum, a membrane designed to regulate the quantity of morement belonging to the elptra : in the Fulgura it consists of cartilaginous elastic rings, which admit of tension and relaxation. The mesothorax has another important division, called the scapula : they assist in forming the articulating socket of the elytra; they pass down the sides of the second thoracic segment. The mesothorax has also its spiracle : on the under side of this segment is placed the mesosternum; it contains the sockets of the middle legs. The metathorax is the posterior segment of the thoras, which supports the hind-legs and the inferior wings: it is well developed in the Coleoptera and Orthoptera. The best authorities regard it as admitting of a division into seven pieces: the dorsal portion is the metanotum; it is quadrangular, and notched in front. The metathorax is separated from the abdomen by a parietal wall called the metaphragma, and from the mesothorax by the mescphragma. The lateral purtions of the metathorax are provided with horny plates, termed by kinex and

[Agricultubal Report-Voi. - . ] 


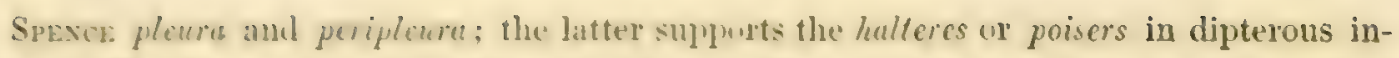
sects. The thuax invarialy supurts six legs: The wings are sometimes wanting, when the incet is satel to les upterous : thuse with two wings are dipterous; and those with four, tetmpterous. The sulerior wings are provided with an articulating sucket, which is lormed in part lig the organ called the scupulu : they lie cluse upen the sternum; they constitute the second furincipal gution of the mesuthorax, lying one on each side in front. Another distinet furtion of the mesuthorax is the mesostemum: it lies upon the under side, opposite the mesonotum; in its area the midelle legs are articulated. The mesusternum is not equal1y developed in all crilers of insects : it is most perfect in the Coleoptera and Orthoptera; the dursal purtiou has received the name of metunotum, quadrangular in forw, and emargiaate in front.

The parts suphnorted ly the thorax are the wings and legs; and, at has been observed alrealy, the latter are invariably six in number, and never wanting. The wings are variable in number, in form and in substance; and upon the variahility in form and substance, the orders are compused. Thus those with four wings are termed tetrapterous; those with two, dipterous; and those with nune, uplerous. The anterior pair in Tetraptera is attached to the mesuthurax : this pair is also sometines called the superior pair, while the pair attached (1) the metathorax is called the posterior or inferior pair. The pair which is wanting in the Diptera, is the posterior pair.

It has heen said that the wings differ in form and substance. Nature, however, preserves rigurunsly the symmetry of jarts. In Culeontera, the anterior wings differ from the posterior luth in sulstance and form. The substance of the first is leathery, more or less rigid, and horny : their firm is varions, hut adapted to the dorsum or hack of the insect; while the posterior are membranous, texible and elastic, and capalle of being folded beneath the anteriur wings. In another orter of Tetraptera the wings are similar in form and substance, and of equal size : these insects have received the name of Neuroptera. Where, however, in tetrapterus insects, the pristerior wings differ in size, but preserve the fugm and substance of the anterior, the urder is called Hymenoptera. Examples of Neturoptera are the draten flies: of Hymenopledia, the common honey-hee, wasp, ete. In flight, the rigid anterior wing of the C.ulewitera is of little use : it serves to protect the membranous wing and alulumen when at reat. Hence it is that the flight of beetles is short, and sustained evilently with much more latwor than that of dragon-flies or honey-hees. The insects whose wins are fenr. and cerered with scales, are called from this last circumstance Lepidoptera.

It is pronere here to remark, that while there is a great dissimilarity between the anterior wing of a hertle aml that of a dragon-fly, yet we are not to suppose that the difference is eflertenl ly a sulden leal': there is really a gradation in sulstance. We have insects whose anterior wing: are intermeliate in this respect, both in sulstance and form. Thus the common gras-hngrer has anterior wing which is hetween leathery and nembranous, and is 
elongated rery frequently beyond the body. This is the characteristic of the order Orthoptern of systematic writers; and in this order, the wing grows with the body of the insect. There is another modification of the anterior wing, which seems to arise from an arrest of derelopment, as the organ acjuires scarcely half its usual length : this modification has served to establish the order Hemipteru of authors.

A still more beautiful modification of the wing of the insect is finnd in batterflies and moths. In these the membrane and network, constitnting the frame and foundation-work of the organ, are corered with a mealy substance, or what appear's to the unassisted eye as such. This substance, however, is a scale of a beautiful workmanship, of a rariahle form and size in different insects, and in different parts of the wing of the same insect : they are beautiful objects for the microscope. Rude handling immediately destroys the beauty of the wing, by detaching these scales, and learing the membrane beneath naked and broken.

The wing, anatomically considered, is composed of two parts : the nerures, and membrane. The former are likened unto ribs, which start from the anterior angle, and branch in various ways as they pass to the posterior margin. They gire strength to the organ, and serve an important purpose in supporting and staying the outstretched membrane. The nervures are not, as might at first be supposed, solid ribs : they are traversed internally by a spiral vessel and nerre. The membrane is double, although extremely delicate : this delicacy, however, is no obstacle to the growth of appendages, such as hairs, etc., inasmuch as it is frequently densely covered with them. The wing, divided by the branching and anastomosing of the nervures, forms a network more or less fine. The spaces enclosed by the branches are called cells or areolets; and being quite constant in form and place, they are enployed in the determination of groups. Three areas are particularly noticed, namely, the costal, intermediate, and anal areas. The wing has a base, and anterior and posterior margins : the first is the part attached to the sternum; the two others define themselves. The apex of the wing is the part opposite to the base.

Various views have been expressed by different authors on the analogical relations of the wings, many of which are certainly rery fanciful. M. Atbot in takes a rational common sense view of these relations, and regards the wings as organs sui generis, intended for the exercise of special functions.

THE LEGS. Each segment of the thorax supports a pair of legs. The joint which unites them with the body is called the coxa or hip : it is held in its socket by a ligament. The motions of the leg are controlled more or less by the form of the coxa. The thigh is the largest portion of the leg : its form is varions; it is cylindrical or flattened, it is straight or arched. If the insect leaps, the posterior thighs are thick and strong. The legs are also more or less spinous.

The tibia is the next part of the leg, and furms an angle with the thigh. It is more 
slender than the thigh, and is rennected with it hy a joint similar to a knee-joint, called finglimus (anticulation) : it is as firmed that it may he (losely applied to the thigh. Spines and spurs are alw find undn the thin or shank: when the spines are short, they are regarded as teeth. The sururs are articulated with the part. and lossess some motion : they are commonly arranged in pairs at the extremity of each tibia.

The thliat terminates lielow in the tarsus, or linet : this consists of a series al pieces, more or lesi heatt-shaped, and never exceeding five in number. The combined motion of these pieces is consideralule. thumgh it is such as helongs to the ginglimus articulation : they are never of eplat lemgrh. and the first one is the longest of all. The termingl piece bears a bith claw, wten dentate or serrate on the edges; and a squrious elaw is freguently found . between the hranches. In ahlition to the forenamed parts, we often find cushions placed upon the lnottun wi the liwt, which serve as sucking cups, enabling the insect to support itself in a pendant position. Hairs also clothe the sole.

The furclegs uftur exhihit a firm nure or less divergent from the others, and hence serve an ahlitimal purnose in the economy of the insect : they are employed in prehension. So it is sumetimes the case that the hinllegs have a form specially adapted to a particular purpose, such as the rolling of the ball in which the eggs are enclosed, etc.

The third part of the lunly of an insect, which calls for our attention, is the abdomen: it has no appendage, and in this repect differs from the parts already noticed. Its exterual atructure is mot peculiar ; for. like the other parts, it is compused of a scries of horny rings or sermeuts, which are clisely commected tugether. The rings do not exceed nine in numher : if they aldear to he fewer than nine, it may arise from the overlapping of adjacent mes. A sertion of the aludomen exhibits a triancular outline. The aldomen itself is united to the thurax. lut not always in the same way : the area of junction is sometimes broad, or enual to that of the first segment; in wher "ases the micon is by a short stem, or petiole, consisting of a trumpetshaped tulve : the aludumen is sessile in the former case, and petiolatem in the latter. The rings or segments are united to each other in two ways : by the first, the interinr amd nithlle farts are joined or soldered together, leaving the sides and dorsal furtionsonly free : ly the seond way, there is no soldering of parts, but the rings are suptorted ly werlapping eache rother, and may slide into each other like the pieces of a telesingl... In the former mude, mution is reatricted, while the greatest frecdom exists in the latter. The sements are lined by a raembrane, but it is scarcely visible except in the case of a gravid female, when it is seen distended like a bag.

The alulomen, liting comparatively free, is woll fitted to sustain the function of respiration. To this whl, wheh segment or ring is furnished with an "pening for the transmission of asir, which funetrates thence in appropriate veswls thronghout the whole bedy. These upenings are sursum led ly rings, and are usually demominated spiracles. As the abdemen is deveted tw digminn. and is also the carity in which the generatire organs are ledged, it 
is necessary that it should be well supplied with air or oxygen : hence each segment has it pair of spiracles, which are capable of inhaling a large amount of this essential element. The extemal aritices are often protected by hairs, which shut over them, and thus serve to exclude foreign matters, while the air permeates freely into the interior of the body.

Besides the digestive urgans, and a portion of the respiratory apparatus, the abdomen c intains the genital organs, the piercer and sting of females. The piercer is a flexible jointed tube, and is used to puncture trees or other bodies for the purpose of depositing the eggs. It raries in length and form, and is fitted to perform its office according to the instinct of the animal to which it belongs.

I hare nuw described, in as few words as possible, the most essential external parts of insects; those parts which are particularly employed in the description of genera and species, as well as those used in general classification. From these parts the student will be able tu form a correct notion of the extent of this class of animals; but there are yet other portions, occupying the interior of the insect's body, which are important for us to stuly, inasmuch as they will yield information in regard to the economy of this interesting class which will be of essential serrice. I refer to the digestive, circulatory, and nervous systems. If the external forms of insects are curious and interesting, the student will find that the apparatus for carrying on the foregoing functions is still more so. There is especially one curious fact particularly worthy of notice in relation to the digestive apparatus : it is this, that the secretory organs are reduced to the simplest form, that of tubes; from which we learn that nature requires no special form of instrument for the performance of a given function.

All the essentials of a digestire apparatus, which belong to the higher classes of animals, are found in the insect. Some interesting differences, it is true, exist ; still when it is considered that the food of insects does not really differ from that of other animals, we may of course expect to find the digestive organs essentially the same in kind. As insects subsist upon rarious kinds of food; some upon regetables, others upon the elaborated juices of animals or upon flesh, so we find similar variations in the form and proportion of the organs as exist among the higher animals. The vegetable feeder has a larger and more capacious digestire appraratus than the carnirorous insect, nature always adapting her means to the end.

The function of digestion in insects, as in all other animals, is performed through the instrumentality of an alimentary canal. Our first object will be to describe this apparatus. The function itself involres the existence of two kinds of apparatus : the parts through which the frod nust pass; and the parts which supply the special fluids essential to effect oertain changes in the food before it can become aliment or nutrient matter. Beginning with the description of the first kind of apparatus, namely, the organ or organs through which the frod passes during the process of digestion, we may regard this apparatus as a 
canal open at each extremity, with an enlargement or dilatation more or less in its central portion; whence it is diminished, and hecomes tubular and folded repeatedly upou itself, increasing thereby in length until in some instumees it is many times the length of the body. Different portions of this canal have received different appellations, as is highly proper, from the fact that certain of its parts perform functions of a modified character, althongh all contributing to one general result. In this division of parts, comparative anatomists have employed the same names that have long been in use in the anatomy of the higher animals, as the following enumeration will show, to wit : the pharynx, esophagus, crop, gizzard, stomach or chylific ventricle, small intestines, cæcum and rectum.

The pharyx is the anterior portion or beginning of the canal. The cavity of the mouth opens into it, and it is an aperture more or less enlarged : it is, however, better developed in those inseets which masticate their food, the mandibulated class. Indeed it is regarded as having no existence except in this class; for in the suctorial insect, the next part, or esophagus, is in direct continuity with the haustella or sucking tube, which is connected with it by two distinct tabes.

The esophagus, commonly known as the gullet, is a tube connecting the pharynx with the crop, or first enlargement of the intestinal canal. It passes directly through the thorax and constricted part of the insect, terminating in the abdomen in the crop). It is rariable in length : it may form one-half the length of the canal, while in other instances it is less than one-sixth of such length. It has a peculiarity which has already been alluded to: its bifurcation anteriorly in the lepidoptera, each spiral sucking tube extending its branch to it just behind the head.

The esophagus is comected in the first place with the crop, an enlargenent having a close analogy in position and form with the crop of a bird. It is also called a stomach by some writers on entomology. It is sometimes placed on a line with the esoplagus, when it appear's as a simple enlargement of the tube; in other instances it is placed on one side, and then appears more like a sac connected with the esophagus by a short eanal, and serving as a kind of reserroir ; or, in other words, more analogous to the crop of birds*. In certain beetles, as the Cicindela, the organ is prorided with a glandular apparatus, which secretes an abundant and actire juice to soften and otherwise change the food deposited in it. In the hemiptera it is renarkably modified in function : it loses its importance as a depository of food, and becomes a part of a pumping apparatus; whence it has heen called a sucking stomach. The insect in this case has the power of distending the sac, and thereby

\footnotetext{
- It is proper in this place to notice the fact, that while there are numerous variations in the form and length of the alimentary canal of insects, there are two modifications that should be particularly spolien of, namely : the bot-1y has no opening at all answering to the mouth and pharynx, and bence can take no nourishment; and in the larra of the wasp and bee, the rectum is closed, and hence their econony does not reçuire the eracuation of ex. crementitions matter.
} 
rarifying the air in its interior; in consequence of which, fluids rise in it as in a pump. We have in this case an instance of a modification of an organ of the simplest kind, by which, however, the entire function is changed; passing from a digestive function to a transferring one, or one more immediately subservient to the mouth.

The gizzard is the next organ, and may be distinguished from the crop by its peculiar apparatus for mastication : its internal surface is studded "with teeth or spines, or horny ridges ; " the organ, therefore, is eminently fitted for performing a perfect comminution of the matters receired into it. It completes, in this respect, what has been performed but imperfectly. It performs a function somewhat analogous to that of rumination in the herbirora. All the insects which feed upon hard substances, those which might be regarded as nearly indigestible, are provided with a strong muscular gizzard, furnished with a masticating apparatus.

The stomach, or that part-in which we first observe the food reduced to a pulpy mass, and first exhibiting a chylous appearance, is bounded abore by the gizzard, and below by a constricted portion of the canal, which receives a bundle of vessels that give it an ana$\log y$ to the liver of rertebrated animals, and in fact it is strictly the hepatic organ of insects. The stomach is of an oral shape, or an elongated oval : it has been denominated the chylific ventricle by M. Leox Duforr. Its capacity is considerable : its surface is lined by a mucous membrane, and it is sometimes studded over with little mucous cysts or bags, which secrete a solvent fluid similar in composition and use to the gastric fluid of the higher animals. The organ, in order to increase the extent of surface, is frequently constricted, and also twisted upon itself, so as to form many eircumvolutions, and hence it is quite rariable in shape in the different orders of insects : its inner surface, however, is always villous.

From the stomach outwards or domnward, the canal becomes narrower, or passes along with a diminished calibre ; but as there are still enlargements or dilatations in its course, anatomists speak of a duodenum, ileum, cæcum, colon and rectum. But this is regarded by many as an unnecessary multiplication of names, inasmuch as it is extremely difficult to recognize the parts which are thus designated. The beginning of this part of the canal, however, is indicated by a constriction and the existence of a sphincter muscle, as well as by the junction below of the hepatic vessels. The tube is generally short, rarely exceeding the length of the body : sometimes it is inflated into an ovoid sac rather abruptly.

In following out the distinction of parts in the intestinal canal, we may recognize the existence of a colon, or what corresponds to the large intestines of the higher animals, by the character of the alimentary ball; for the food, after having passed the stomach and through the narrowed part of the canal posterior to the stomach, loses its viscidity, and becomes more or less dry and compacted into the form of an excrement, showing by its condition that the nutrient matter has been extracted from it. Here is also a valve to guard 
the pasaige of the canal, which it closes to prevent the hack ward movement of the digested mass. The segment recugnized as the carcum is short, and in direct communication with the anterior tube; but in sone cases it seems as if joincd laterally to it, and then it has the appearance of a purch. Fluds are suppesed to be secrefed hy warty excrescences situated upon the mucous face of this intestine, designed to aid in the digestive process.

The rectum is that jart of the large intestines which terminates the alimentary canal below : it is always short, and is furnished with a sphineter at its extremity. It is muscular, has thicker walls than the cecum, and gives shape and form to the excrements.

The function of digestion reguires, in addition to the formal tube through which the parent matter must pass, a supply of certain fluids which shall possess a solvent power upon the contained mass; and more than one kind of thid seems to be necessary. Though these different Huids agree in use and eflect with aualogons ones found in the higher ani. mals, the organs which secrete them have a very different firm : indeed, the difference is 80 great, that a student whose views of' the func:ion of digestion have been obtained solely from the obserration of the organs of a vertebrate animal would not at first recognize the parts which perform similar functions in insects.

The secretory organs, and those which are subservient to digestion, are always tubular in insects : the gland or parenchyna present in quadrupeds being entirely absent in insects, these organs are reduced to their simplest form. The kimbls of tubes taking their names according to the nature of the fluid secreted, are the salivery, biliury, and urinary. The salivary apparatus is quite complicated : it consists of tubes, single and double, and oven triple, situated around the esophagns and month, and provided with bags that serve as reservoirs. The tubes open into the mouth or esophagus by two or more excretory orifices. The salivary apparatus is most perfect in the haustellata or sucking insects; the tubes ascending into the abovenamed cavities in a meandering course, whereby the extent of socreting surface is much increased.

The operation of salivation is an important preliminary to digestion : mixed with the food, the saliva serves to soften its consistence, while it also carries along with it much air which appears to be necessary for some purpose in the economy. "The hile is a still more important fluid than the saliva : it is secreted in long capillary tubes, more or less flexuose and folded upon themselves, which connect with the alimentary tule below the stomach, or just behind the pylorus; though they sometimes continue farther down, and enter near the crcum. These tubes vary in number : there are usually two, especially in colerptera, hemiptera and diptera; but in these orders they are not absolutely uniform, as in the ccrambycidæ there are three, and four in some diptera, while in nenmoptera there are six, and in certain neuropterous groups as many as eight. Where the number of the lubes varies, however, it operates as a compensation for their length : for example, if the simple tubes are each five or six times the length of the body, their number is less; but when 
they are short, their number is proportionally increased. Although these hepatic tubes are generally quite uniform in diameter, there are some deviations from the rule; but it is perhaps unnecessary to describe particularly the few modifications that are known to occur. The function of these tubes, as has been intimated, is to secrete or prepare a fluid analogous to bile. They may be recognized in the caterpillar, when the abdomen is opened, by their position, and by their white vermiform appearance : they float apparently loosely in the cavity of the abdomen.

Among the secretions mentioned is the urinary, which seems to be far less constant than those already described. When the urinary organs are present, they terminate in the rectum : they have been found in certain carnivorous coleoptera. The fluid which has been called the urine in insects, is caustic and odorous : it is often discharged by the carabici, on handling them, in jets, which, when falling upon the skin, occasion a transitory burning. In connection with this secretion, may be noticed that peculiar to the bombardiers, which is discharged in explosive jets, and is supposed to be intended as a means of defence. The name of the genus possessing the power of producing explosive jets of fluid, is Brachinus. I am not aware of the fact, if it has been ascertained, that this fluid is similar in composition to that of the higher animals, or that it contains urea.

In concluding our remarks on digestion in insects, we may observe that the function is performed in ways quite as numerous as in the higher orders of animals, though there is no departure from the general principles which prevail in the vertebrate and molluscous types. There is always an apparatus for trituration, or mechanical separation of the food into fine parts : it is thereby prepared for the action of the several fluids which concur in the digestive process, and which exercise some peculiar chemical inflnence that serves to separate the nutrient matter from the useless portion of the food. These fluids are more or less acrid in their nature : thus the saliva injected into the wound made by a flea or a fly, for example, by the tabanus, occasions inflammation and itching; and this irritation is designed to favor the insect, inasmuch as it produces a flow of blood to the wounded part. An effect of saliva is seen upon leaves attacked by the caterpillar, which very soon suffer a loss of color; and as the morsel swallowed passes along from one receptacle to another, it is constantly undergoing changes : it is softened in the crop; in the gizzard, it becomes pulpy; and in the true stomach the chyle is formed, and is at once recognized by the globules it contains.

A controversy has been long maintained respecting the office of those tubes which have been called hepatic or biliary. Some eminent physiologists have regarded them as urinary, inasmuch as uric acid is sometimes found in them; but as this is not always the case, a compromise seems to have been made by regarding them as both biliary and urinary, and giving them a corresponding denomination urino-biliary. The circumstance that the same tubes which have since been found sometimes to contain urine were regarded as biliary 
tubes by the older amatomists and physiologists, is accurdant with known facts in the economy of the lower animals, amm which it is common for an organ to pertorm a double function.

The fiond in the alimentary eamal of insects is moved along by a peristaltic motion : the canal, therefore, is supplied with a muscular apparatus. Indeed, fom the phenomena exhibited. we might infer that the applaratus has a construction and parts such as have place in unadrupeds : thus the coats of the alimentary canal are three, a mucous, a cellular, and a muscular enat ; the first being the internal one, the muscular the outside, and the cellular in the midlle. The mucons coat is thiu, oftent transparent, and difficult to detect. The muscular cont is perfectly dereloped : its fibres are hoth lougitudinal and circular; and where the constrictions peculiar to the tube exist, there it is more perfectly developed, or in greater firce. These muscles serve partly as sphincters, and also to keep up a continual movement.

Crrectariox. Insects ane fiumished with a circulatury alluaratus : it consists of a dorsal vessel, which, as its nme indicates, is a tube ruming beneath the dorsal face of the external corering. This is the central organ, and is equivaleut to the heart in the higher orders of animals; and the circulation is continued from the dursal vessel, in channels excavated in the tissues. The structure of the dorsal vessel permits the blood to flow from the posterior to the anterion part of the animal, by means of a sexies of valves opening forwards. The hlood is transmitted to the thorax and head, the wings and legs, and returns through certain channels denominated reins, which open into the dorsal at different points through the valves; but the larger portion of the returned thid collects in the posterior chamber, and passes the whole length of the ressel. The ressel has been, and still is, regarded hy sume physiolugists as analuguns to the heart : others, however, consider it as more analogous to the aorta of quadrupeds.

It dues not seem to be a matter of much inportance whether we regard the so-called dorsal ressel a heart, an aorta, or an organ compounded of both, the posterior segment taking more expecially the lintm and function of an aortic vessel. Its visible contractions, as seen through the trancparent cowring of many insects, furnish ostensibly valid reasons for regarding it a heart.

The fluids which circulate in the rascular system of inserts are usually white, carrying along distinct curpuscules las ing forms like these which are found in the higher and more perfect animals.

In connection with the foremoing facts, it should also be stated that the circulation in insects is carried on in resels laving cluse proximity with those of another kind, namely, the air-ressels, or trarten. The two classes are masily distinguished from each other by the structure of the latter; fir in order that air may traverse the insect system, it is necessary 
that its conducting ressels be maintained in a tubular form : this is effected by means of a spiral elastic thread wound closely upon itself. By this means the vessels are prevented from collapsing, the air enters freely at the sides of the insect, and permeates perfectly the whole system. The air, then, is constantly in contact with the thin membrane intervening between the trachea and those vesscls which transmit the blowd to the different parts of the insect's body and extremities. Recent observations prove, in regard to the relations of blood and air, that the former mores through the space between the onter and inner membranes, in which a spiral filament winds, so as to bathe the exterior of the air-tubes themselres*.

It would therefore seem that there is in insects a most complex system of spiral vessels or air-tubes, in connection and close relation with the rascular system, both being distributed with the greatest minuteness throughout the whole body. There is still another prorision for keeping up a supply of air especially in those insects whose flight is rapid, and requires to be long sustained : it is found in the air-sacs that are distributed in different parts of the body; they serve not only to retain a due supply of air, but also to buoy up the body and render it lighter. The pulmonary system, by a combination of elastic tubes and sacs, receives an extraordinary derelopment, so as to compensate in the most perfect manner for the deficiencies resulting from a less perfect form of circulation; for powerful muscular motion requires a rich supply of oxjgen, rather than food, in order to give energy and activity to the muscular system.

From these facts, it appears that insects occupy no mean place in the scale of being, when they are ranked according to the derelopment of their circulatory apparatus and the accompanying tracheal system. This combination, su far as the power of muscular motion is concerned in the estimate, serves to elerate the insect to a rank but little below that of the vertebrate class.

Nervots system. The nervous system consists of a pair of chords extending through the insect, upon the interior abdominal face, and connected at each segment by a ganglion. Thus disposed along the rentral face of the body, the nerrous system forms a symmetrical whole. The ganglionic masses of the head, howerer, are more largely developed than those of the trunk : this is necessary, from the condition of the eyes and the perfection of the masticating apparatus. The cephalic centres are placed also above the esophagus. So the nervous centres which supply the wings and legs are larger than those of the abdomen. We see here again a prorision for the lucumotire apparatus, by which a due supply of nerrous power or force is secured.

There are probably but few instances in the animal kingdom, that exhibit such minute

- See Carpestea, p. 382 of his General and Comparative Physiology. 
subdirisions of matter as certain portions of the nerrous system do. Thus when it is stated for the first time in our hearing, that the eye of the common house-fly is compounded of no les than $4 m 0$ single eyes, it seems impusible that a nerve, originally microscopic, can he subulivided into threads or fibres sutliciently fiue to furnish a nerve to each simple eve; and when we are further informed that the eye of the dragon-fly has $(24,000)$ six times as many subdivisions as that of the house-fly, our faith is still more sererely taxed; but to suppose that a filament is wanting in an eye, is to suppose that the eye is made in vain; for the cre depends upon its nervous filament, however slender that may be, for its power of vision.

The sympathetic srstem of nerves in insects has been known from the days of SwasMERdaM, why tirst discovered it in the rhinoceros beetle. While this system is found more or less perfect in all articulated animals, it is specially perfected in insects. The imperfection of the nerrous applaratus consists in the absence of the cerehral masses, of of all that portion concerned in the firmation of ideas. Nothing apprears in the nervous system of the articulata, higher or alure the ganglionic centres which connect together the double ventral chord. The gauglia of this system which are more particularly deroted to the purely animal functions, undergo a slight change during the pasage from the larval state to that of the perfect insect ; the change consisting chiefy in a concentration of nerrous matter upon those ganglia which are subservient to the function of locomotion. The sympathetic system, howerer, undergues no change : it is equally perfect in the larra as in the mature animal, and reaches its full derelupment in this early stage of existence, thereby showing that it presides over the functions of vegetative life.

It is scarcely necessary to speak more particularly of the functions of the nerrous system. It mas, howerer, be ohserved, that it is upon this system that sensation depends, and the nerwus fibrils are the channels through which the properties of external bodies become known to the indiridual. If we may judge of causes by effects, we are warranted in believing that impressions are receired hy insects form without, in the same manner as is the care with the higher animals; and that they pussess all those special senses which belong to the latter, and some of them in much greater perfection.

Tocru. The sense of touch in insects, in consequence of the hard covering of their bodies, must be confined to certain parts. Those who have watched their motions are fully convinced that the palpi are the organs in which this sense is concentrated, or in which it exists in its greatest perfection. These organs are constantly applied by the insect, after the manner of feclers. to the external bodies with which it comes in proximity; and they are well adapted by their structure to fulfil such a purpose, being tlexible, and furnished with a soft and delicate integument. 
FUNCTIONS OF HEARING, TASTING, SMELLING, AND SEEING.

Hearivg. The phenomena which indicate the existence of the sense of hearing are perhaps more equivocal than those of touch. Still attentive observers have noticed that insects seem to place themselves in an attitude of listening, when loud sounds are emitted from any quarter in their vicinity : they erect their antennæ, and remain motionless for the time being; and when the disturbance has ceased to excite them, they resume their ordinary morements. From the position of the antennæ, then, under the circumstances alluded to, it is inferred that they are connected directly with the function of hearing. Beneath them is a nerve connected with a soft membrane, which seems to be adapted to this special end. The antennæ in themselves extending outwardly, must become sensible of the vibrations in the air, and transmit them to this delicate auditory apparatus lying immediately beneath. The organs are often long-branched, or plumose, so as to increase the extent of surface. This view of the office of the antennæ does not conflict with the one often entertained, namely, that they may also be useful and employed as organs of touch.

TASTE. The existence of this sense rests more upon analogy, than upon well determined facts to support and prove its existence.

Smell. Insects are attracted to odorous bodies from a distance : hence there can be no doubt that they are possessed of the sense of smell in great perfection, although its precise location is a matter of great uncertainty. Several different parts of the insect's body have been conjecturally assumed as the seat of this sense; and it has often been assigned to parts that are variable, evanescent, or of occasional existence only. If analogical reasoning were to be our guide in this case, we should point to certain inward parts of the body that are in direct relation with the external air. In the mammalia, though the organ of smell is located in the head, yet its distinguishing characteristic is its immediate communication with the atmosphere, and the sense itself is exercised only when the air is inhaled. It is not necessary to infer, that because in the higher animal it holds this intimate relation to the head, that it must occupy the same place in the insect : it is more consistent to suppose that its closest relation is with the respiratory organs. It is highly probable, therefore, that the trachea and spiral vessels, which conduct the air inwards, constitute the channels by which this sense is furnished with the odorous particles on which the sensuous nerve is to operate. Accordingly this view is looked upon with favor by Cuvier and many other distinguished physiologists.

Signt. Of all the senses, that of sight seems to be the most perfect in insects. The organ is compound, or, in other words, consists of many eyes comparted together, each of which is perfect in itself, being furnished with the proper humors and lenses essential to the exercise of vision. In addition to the compound eye, which often occupies the largest portion of the head, they are often furnished with simple eyes upon the forehead : these 
have received the names of ocelli and stcmmata, and are generally three in numb er, and arraneet in the form of a triangle; but there may be but two, or only one. Their structure qualifies them for viewing such objects only as are close at hand.

The compund eye presents a reticulated appearance under the microscope : the surface is convex or flotular: but the organ is immovahle, excent by the motion of the head. The reticulated appearance is produced by the lines that mark the foundary of each eye or lens : these are hexagonal, and their number is almost incredily great in some species. They vary in this respect from 50 in the ant, to 25,1100 in a species of . Hordella : the buttertly has 17,000 , and the dremgunly 12,51. Each eye is furnished with an mparatus sufficiently perfect for the exercise of vision in its sphere: it has its lens for refraction, its choroid for the correction of aberation, and its retina fir the reception of the images of exterual ohjects. Each single eye, howerer, must cmlruce an extremely linited field of vision, and there is no doulit that it requires the use of many of these eyes to see a single object; for only those rays of light that fall perpendicularly upon the eye can reach the optic nerve.

The eyes of predaceuns insects, such as the dragonlly, are large, prominent and globular: hence they enjoy, altugether, a large field of vision. In those insects, on the other hand, which are coufined in their range, or are parasitic, the field of view is diminished by a reverse of circumstances.

The nerve of each eye terminates in a common nerve : this must be regarded as the sensorium commune, the nervous plane upon which the image of an olject is spread. Sometimes the ere is peduzeulated, or placed upon a fortstalk : smetimes it is semicircular, in conseynence of the implantation of the antennie, and indect this implantation may be such as to gire the semblance of fuur eyes. In other instances the size of the cye is a sexual mark.

We are too mucls in the habit of looking raguely upon the insect tribs. While we recognize the morements of the rertehrated class as resulting from distinct acts of the will, and as contrulled by internal feelings, we are little dispused to entertain the view that the apparatus of a fly or a beetle indicates similar internal notives for actiom; or, in other words, we do nut pussess so lively a sense of the perfection of the being of the insect, as of the being of the higher arder. We see, however, that insects have eyes to see, cars to hear, and urgans of smell; a highly developed nervous appuratus, and an active circulation : in fine, the insect moves in a world of its own, which takes no part in the sphere belonging to the mollusca or rertebrata. Its senses and urgans of animal life, hwerer, gire it a wide sphere of activity, and have prepared it for fulfilling important functions, and furnished it with a eaprahility to affect rery materially the interests of man. Being widely diffused, and their life orerflowing with activity, always moring as if impelled forward by important business or engaged in errands of the most momeutous character, they seem to 
make the most of their brief" and uncertain existence. Witness the energy of the dungbeetle in finishing the ball in which it has deposited its egg : it often dies in the act of providing for the continuance of the lite of its kind. To some these actions may seem less interesting, because instinctive; but surely the faculty of instinct affords matter for deep thought to the ordinary observer, and to the philosopher it must possess an interest next to that of reason itself. Instinct urges the individual forward to the fulfilment of its destiny, but it makes no inquiry as to the cost.

Muscular motion. The insect enjoys a full development of the power of motion, especially in its perfect state : the two kinds of muscle, striated and non-striated, are always present. Erery part of the system is supplied with muscular fibres; not only are the legs and wings largely supplied with them, but also the abdomen and various parts of the trunk, head, and thorax. The most interesting faet which appears in this connexion, is the power of the insect fo sustain a long and vigorous flight : thus the dragonfly darts forwards, backwards, or sideways, and is able to outstrip the swallow in its most rapid course ; and this it can do for hours together. Taking into consideration the diminutive size of insects, we readily see, that in proportionate locomotive power, they far excel the vertebrate animal. We have already observed that their joints usually admit of but two kinds of motion, forwards and backwards, or the ginglimus movement : when, however, this motion is exerted in extension and flexion, as in the leaping of the grasshopper or flea, we cannot fail to perceive that their powers in this respect, also as in flying, are far superior to those possessed by any other class of animals.

Though the larval state of insects is generally sluggish, we are not without many examples where there is a great degree of activity. We often see the caterpillar hurrying aloug as if it were in great haste, though the space it is able to traverse is quite limited. We observe, in all these movements, an aim to preserve life : the life of self, however, is subordinate to that of kind or progeny.

Propagation. Insects propagate their kinds from eggs laid by the female, subsequent to the act of congress with the male : the sexes are therefore distinct. Their power of multiplication is immense, especially in those insects which produce several broods in a season. But there is a remarkable exception to the foregoing rule : the aphis increases by a process of gemmation; females being cast off at once for several generations, of which each possesses the power of multiplying its kind in the same way. CARPENTER likens it to the gemmation of the polypi, "the individuals being budded off from internal stolons, instead of being developed from ova provided by the female and fertilized by the male." It has long been known, that in the aphis, this method of propagation is repeated to the seventh or ninth generation. At the end of the season, the perfect individuals, both male 
and female in a winged state, are produced, by the congress of which ora are fertilized: these are preserved through the winter.

It would seem from this, that althungh in the articulated class budding is resorted to to multiply the number of individuals, yet it is not adeynate to continue the existence of the species. Calculations have been made of the numbers which an aphis may produce in a single seasun, provided the individuals are not destroyed by accident. According then to calculation, based upon observed facts, the whole brood in a season from a single aphis will ansunt to the inconceivable number of $1,000,000,000,000,000,000$ ! From such an ability to increase, we should at first thought be disposed to expect a result approaching the calculated numbers; but it is gratifying to olserve, that where the powers of increase are extended and multiplied as in the case of the aphis, the destructive powers are equally multiplied and active : there is therefore but little reason to fear an excessively injurious multiplication in the midst of so many enemies. The aphis is extremely fechle : the touch destroys it ; the winds, rains, and cold sweep off its numbers by hundreds of thousands. The excessire multiplication of individuals is only a means of supplying an increased number of consumers : hence instead of an approach to the enormous number indicated by calculation, their actual numbers will fall infinitely short of it. The balance of nature is always preserved; and whererer danger seems to point, there checks are provided, which put an effectual restraint upon inordinate increase. We may conceive of what is possible; but the actual just suffices to keep up a suitable equilibrium : at most the threatening is transient, and recurs only at wide intervals. 


\section{APPENDIX TO CIIAPTER II.}

\section{DESCRIPTION AND REPRESENTATION OF PARTS OF SUCH INSECTS AS ARE REFERRED TO IN THE FOLLOWING TREATISE.}

(Copied mostly from the Naturalist's Lubrary.)

\section{PARTS OF THE HEAD, MOUTH, \&c.-PLATE A.}

Fig. 1 . Head, upper side : $a$, forehead; $b$, vertex; $c$, occiput; $d d$, temples; $e e$, ejes; $f$, torulus, the carity for the insertion of the antennæ; $g$, clypeus; $h$, labrum.

Fig. 2. Cnder side of the head $: k$, posterior orifice; $l$, neck; $m$, mentum; 0 , eJes; $p$, mandibles; $s$, labial palpi.

Figs. 3, 4, 5. Forms of the labrum.

Fig. 5. Mandible of Hydrus piceus.

Fig. 7. Mandible of Garius.

Fig. 8. Mandible of Calosoma sycophanta.

Fic. 9. Maxilla of Necrophorus germanicus : $a$, maxillary palpus; $b$, external lobe of the maxilla ; $c$, internal lobe.

Fig. 10. Maxilla of Cicindela : a, external maxillary palpus ; $b$, internal ditto ; $c$, interior lobe, with an articulated hook at the apex $d$.

Fig. 11. Form of the maxilla of Hydrus piceus : $a$, insertion or hinge; $b$, dorsal piece; $c$, squamepalpifers of Strauss : $b c d$ form the stalk (stipes); $e$, external lobe; $f$, internal ditto.

Fig. 12. Labium of Cychrus rostratus : $a$, mentum ; $b$, ligula; $c$, labial palpi.

Fig. 13. Labium of Carubus, inside : $a$, mentum; $b$, lingua ; $c$, paraglossæ.

Fig. 11. Thorax of Scolia flavifrons, showing in succession the prothorax, mesothorax and metathorax, also the coræ: A, pronotum; C, mesonotum ; F, metanotum ; HH, parapleura ; $c$, scutellum; $d d$, patagia.

Fig. 15. Side riew of the thorax of Scolia flavifrons : $B$, mesosternum; $B$, prosternum; $C$, metasternum; $d$, patagium ; $c$. scutellum; $a$, first spiracle; $b$, second ditto.

Fig. 16. View of the same from beneath : BB, prosternum; $\mathbf{E E}$, mesosternum; GG, metasternum.

Fig. 17. Thorax of Cicada fraxini : A, pronotum; c, mesonotum; FF, metanotum; $c$, scutellum; $d d$, frenum.

Fig. 18. Hindleg of Melolontha vulgaris : $a b$, cosa ; $d$, trochanter; $e$, thigh ; $f$, tibia ; $h$, tarsus; $i$, elaws.

Fig. 19. Pectinated claws.

[Agricultural Report - Vol. v.] 4 
Fig. 20. (laws of Asihs: o, central filuments: ss, membranus expansion of the terminal joint, adranecd beneath the claws.

Figs. 25, 26: showing the upper and under side of the domestic cricket (Acheta arachnoidea).

Fig. 27. Maxillary palpi $(b c)$ of the ericket; $b$, galea.

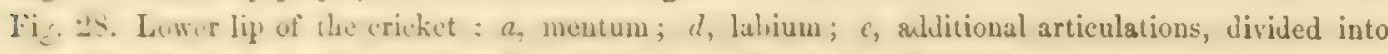
two, three, or more lobes ; $c c$, apparently 3 -jointed palpi, yet the basal joint enveloped or concealed in the lip.

Fig. 29. Mandibles of the grasshopper (Acrydium) : b, molar plate.

Fig. 30. Mandibles of the cricket.

Figs. 31, 32. Forms of antenna.

Fig. 33. Serrated antennæ.

Fig. 34. Lamelliform antennx.

Fig. 3.r. Peetinated antemina ; binectinated, if it produces tro lung teeth, instead of one; and flabellate, when the branches are very long, and flattened like the rays of a fan.

Fig. 41. Sutaceous antennac : filifurm, when the antenua are of unequal thickness; moniliform, as in fig. 42 ; ensiform, when tapering, and angulated at the sides; subulate, when short, and pointed at the tip; fusiform, when narrowed at the two extremities and thickened in the centre, as in fig. $\mathbf{4 3}$; elavate, when they gradually thicken at the top, as in $\mathbf{3 7}$ and 35 ; geniculate, when bent as in 39 abc; capitate, when terminated in a knob or head, as 36 . plumose, when the lateral filaments go off from a shaft, like those of a feather; nodose, when the joints are thickened in various parts like knobs ; rerticillate, when whorls of hairs are placed at equal distances upon the joints; fasciculate, when the hairs are gathered in bundles upon each joint; scopiferous, when a single bundle is placed upon one joint; palmate, when the antennx are short, broad, and divided by deep dirisions; auriculate, when one of the basal joints is dilated into a shield or ear partially covering the rest; fissile, when they are terminated by a cleft knob; ramose, when sereral of the joints throw out branches; furcate, when there are two branches like a fork; aristate, when the antennx are terninated by a fine bristle, as in the order MUSCA; dentate, when the joints are armed with short spines; cylindrical, when they are of equal diameter throughout; prismatic, when they resemble a prism, or are formed of three sides.

\section{PARTS OF TIE DIGESTIVE APPARATUS.PLATE B.}

Figs. 2, 3. a shows the esophagus, beginning in fig. 3 just behind the head, and terminating in an enlargenent which is the erop; or, if the crop is absent, it terminates in the gizzard $d$. The esophagus is a simple tube, except in the lepidoptera.

Fic. 1 c refresets the pr -iti in and relition of what has teen denmminated a sucling stomach. The gizzard is shown in position, fig. 2 c. The true stomach, or, as called by some entomologists, the chylific rentricle, is seen in figs. $2 \& 3 d:$ in this organ the food becomes semifluid or pulpy, and remains until chylification takes place. The intestine begins as represented in fig. 3, where the lateral tubes are inserted : it preserves a course more or less contorted, as is scen at $f$; and in some instances it is cnlarged or inflated, as at $g$. The caecum is seen at $g$ fig. 2. 
Fig. $3 h$ exhibits the termination of the intestinal canal in the rectum.

Fig. 5 aa exhibits the salivary apparatus, having fleshy organs at the base of the head, and tules that pour saliva into the mouth during mastication.

Fig. 4 al. General arrangement of the urinary organs, the secreting ressels disposed on the tops of small tranches; $c d$, the bladder; $b$, deferential canal.

Fig. 1 represents an arrangement that exists among the bombardiers : $a$, accessory bladder ; $c$, principal bladder.

Fig. 6 exhibits the biliary organs $c c$, fringed as in the cockchafer.

III. CIRCULATORY STSTEM. PLATE B.

Fig. 13 : aaa, dorsal vessel ; $b$, wings ; cd, diminution in diameter towards the head.

Fig. 14 shows the interior walls of the dorsal ressel, circular fibres, arrangement of its walls, and the ralres.

\section{RESPIRATORY STSTEM-PLATE B}

Fig. 12. Spiracles or stigmata:

Fig. 9. Another form of stigmata.

Fig. 16. Stigmata of Dytiscus marginatis, edges of which are beset with hairs.

Fig. 15. Stigmata of the cockchafer, where there is a membrane drilled with holes.

Fig. 8. A circular membrane stretched over the valves, and ornamented with colors.-

Fig. 17 shows the rows of stigmata along the sides.

Fig. 10 exhibits the system of the trachea or air-vessels : $a a$, stigmata; $b b$, ventral spiracles; $c c$; trunks elosed at their extremities; $e e$, bladder-like bag, receiving the longitndinal trachea; $f f f$, trachea for the wings; $g g \& h h$, bags for air; $k$, trachea for the thorax; $l l$, trachea for the head; 0 , base of the tegmina.

\section{NERVOUS SYSTEM.-PLATES B \& E.}

Fig. 2 (Pl. B), ghilll, exhibits the principal ventral chord, with its ganglia.

Fig. 2 (Pl. E). Nervous chord of the cockchafer : 11 , lobes of the anterior eephalic ganglion; a $a$, optic nerves; $b b$, eyes; 2 , posterior cephalic ganglion; 3 , prothoracie ganglion; 4 , mesothoracic ganglion; 5 , metathoracie ganglion; 6 , ganglion of the abdominal series; $d d$, mandibular nerres; $c c$, antennæ.

Fig. 1. Nervous system of the caterpillar of the Sphinx ligustri, a fow days before it becomes a chry. salis : 1 , cerebral ganglion; 2 , posterior ditto; $3,4,5$, 6 , thoracic ganglia ; $7,8,9,10$, 11,12 , abdominal ganglia; 000 , system of transverse nerves, more distinct in fig. 3 , in which 345 represent the three thoracie ganglia; $a a$, central nervous fillet; $b b b b$, nerves furnished by the fillet; eeee, nervous threads separating from the preceding nerves, and which, by uniting when they reach the ganglion, constitute the central thread.

Fig. 3. Nervous system of Sphinx ligustri thirty days after its change, showing a greater condensation of the nervous masses : the posterior thoracie ganglia are now united into one mass. 
FI. GENERATIVE APPARATUS-PLATE E.

Fig. 8. Generative organs of Athalia centifolia : aa, orarial tubes; ce, uterine cavities; $d$, separate oviducts; $e$, ejaculatory oriduct; $f$, spermatheca ; $g$, poison gland; $h$, its ressel ; 10,11 , terminal ganglia.

Fig. 7. Generative organs of Ranatra linearis : the letters correspond to the same parts as in fig. 8 ; $g$, supposed swimming bladder, with part of the intestine.

Fig. 5. Male organs of Athalia centifolia : $a a$, smaller testes; $b b$, ducts; $c$, larger testis ; $d d$, vasa deferentia; $e$, vesicula seminales; $h$, ejaculatory duct ; $i$, exterior valves.

Fig. 9. Hydrus picens : $a a$, testes; $b b$, rasa deferentia ; $c c$, principal seminal vessels ; eeee, rarious accessory ressels; $f$, ejaculatory duct; $g$, copulative armature of the ragina.

Fig. 4. Testicles of Silpha obscura, greatly magnified. 


\section{CHIPTER III.}

\section{REMARKS ON THE CLASSIFICATION OF INSECTS.}

THE nultiplication of species renders it necessary to resort to some kind of arrangement, by which they may be gathered into groups under one or more common characteristics. It matters not which of the kingdoms of nature we enter, if the individuals are dispersed singly or unarranged into families or groups, no one can hope to possess himself of an idea of their relations. Memory would be too much burthened in the attempt to comprehend the relations, or retain the characteristics of the species which belong to a single district of the globe. Hence the necessity for derising some scheme by which we may group together those which are alike, and to which we may apply a positive expression indicatire of that likeness.

There is perhaps nothing easier than to say on what general principle such a scheme should be based; for it is plain enough that resemblance must be the basis of all schemes, and indeed ever has been since attempts at classification have been made. Classification is founded on resemblance; and yet there are so many points of resemblance, that it becomes necessary to make a choice. It is evident that the resemblances in the mineral kingdom are not those of the regetable or animal, and those of the regetable kingdom are ret inapplicable to the aninal. This, howerer, is not the difficulty: taking each kingdom by itself, and selecting from among its individual members certain characters which belong to the many, they fail us in attempting to make a general application of them; they either cease to exist, or else possess an importance so rariable or inconsiderable that they become uncertain as marks suitable to be employed in classification.

There are two kinds of resemblances in the natural world : there are morphological and teleological resemblances. In the first $\pi$ e seek for external forms; in the second, we look for ends. The wings of a bird, of a bat, and of an insect, possess a teleological resemblance, but not a morphological one : the end, or final cause, is the same; but the form, arising from structure, is quite different. It can be scarcely possible that final causes or teleological resemblances should be arailable in classification, although they may be useful in many other respects; and we may remark here that it is only by an attentive study of morphology that a true basis for classification can be found, and all the schemes that have been successfully applied belong to this kind. Availing ourselves of the principles 
found in forms, we may proceed with a degree of certainty; and when forms are correctly defined, we may escape most of the graver erew's in the firmation of groups.

I do not propose to enter into the details of the principles of classification in this place, but shall proceed at once to the modes which have heen proposed and followed by the principal English entomologists.

The first classification is that of Sterness, in which the first grand division of the insect kingdom is into two subclasses :

FIRST SUBCLASS : MANDIBULATA.

Order 1. Strepsiptera.

2. Onthoptera.

3. NeUroptera.

4. Dermaptera.

5. Trichoptera.

6. HyMenoptera.
SECOND SUBCLASS : HAUSTELLATA.

Order 1. Hemiptera.

2. Homoptera.

3. Lepidoptera.

4. Diptera.

5. Hovaloptera.

6. APHANIPTERA.

7. APTERA.

Insects are classed by WESTWOoD in the following manner:

FIRST SUBCLASS : DACNOSTOMATA.

(Mouth with jews.)

Order 1. HyMenopteka.

? Osculant Order Strepsiptera.

Order 2. Coleoptena.

Osculant Order Euplexoptera.

Order 3. Orthoptera.

? STREPSiptera?

Order 4. NeUBOPTERA.

?

Order 5. Tricuoptera (Phryganea alone).
SECOND SUBCLASS : ANTHOSTOMATA.

Order 1. Diptera.

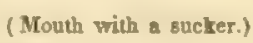

Osculant Order Homaloptera.

Osculant Order Aphaniptera.

Order 2. Heteroptera (including the water. bugs).

Order 3. Homoptera.

Order 4. Lepidoptera. 


\section{CHA PTER IV.}

\section{ORDER I. COLEOPTERA.}

The Coleoptera is the order which has usually been first described, and Westwood has followed the common practice in this respect in his Genera of British Insects. This order is thus characterized:

Anterior wings horny or leathery, concealing the posterior when at rest, placed parallel and joined by a straight suture. Posterior or inferior wings membranous, longitudinally and transversoly folded. Mouth furnished with transverse jaws. Pupa incomplete.

The insects of this order are denominated beetles : they constitute the most beautiful of the class, and occupy the foremost rank among the tribes. They are grouped.as follows by Mr. M'LEAY :

1. GEODEPHAGA : containing those beetles which have setaceous antennæ, with the

2. HYDRADEPHAGA. outer processes of the maxillæ palpiform.

In the first division the following families are included, being the old genus Carabus subdivided into

$$
\begin{aligned}
& \text { GeodephaGa: }\left\{\begin{array}{l}
\text { Cicindelide. } \\
\text { Carabide. } \\
\text { Harpalide. } \\
\text { Scaritide. } \\
\text { Brachimide. }
\end{array}\right. \\
& \text { HYDRADEPHAGA : }\left\{\begin{array}{l}
\text { Gyainide. } \\
\text { Dyticide. }
\end{array}\right.
\end{aligned}
$$

The above is regarded as a normal group, and is followed by an aberrant one, characterized by clavate antennæ, or such as become gradually thickened towards the apex, and the external lobe of the maxilla losing its palpiform character. This constitutes the RypopHags of Stephens. 


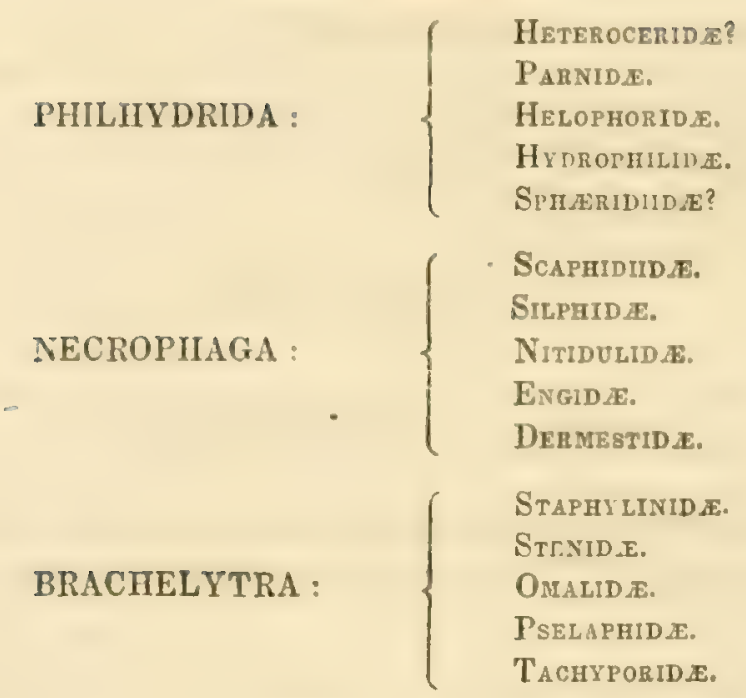

Westwood, howerer, in his work on the British genera, adopts, in preference to the foregoing, the tarsal system, and hence recognizes the following subdirision :

1. Pentamera : tarsi with five joints;

2. Heteromera : the four anterior tarsi 5 -jointed, and the two posterior 4 -jointed;

3. Pseudotetranera : tarsi 5-jointed, the fourth exceedingly minute;

4. Psevdotrimera : tarsi 4-jointed, the third joint very diminutive and concealed.

\section{Cicindelidx.}

Tur family of beetles, which are known under this name, are among the most beantiful of the insect tribes : their colors are hrilliant, and their markings acte to the beauty and elegance of the colors by contrast. In size they occupy a middle grumbl : the largest searcely exceed an inch in length, and the smallest are at least one-third of an inch long. Their hahits are as interesting as their colors are beautiful : their watchfulness is untiring; and though their llight is short, it is difficult to eaysture them. In the nature of their instincts they agree with the earnirora among the vertelurate class of animals : they are llesh-eaters; but in order that they may capture and secure the living insect as their prey, they are qualified to give chase either on the wing w on first, and they make war upon all insects that are not too strong for them. The cicindelidx lunt upun sandy and arid plains, aud seen to delight in the heating rays of the sun; for in hot days they alpear far more nunerros, flying and alighting upon the ground before us in dry gaths, and tuming their heads watehfully towards us when they rest for a moment. 
As the cicindelæ subsist solely upon other insects, or, in other words, are carnirorous, they cannot be regarded as injurious to the farmer : they are rather heneficial than detrimental to his interests. Their markings, together with their predacions hahits, have given them the name of tiger beetles. It is evident, from the prominence and size of their eyes, that they are rell provided with one essential powel to enable them to pursue successtully the means of subsistence, namely, keenness of vision. So too their jaws or mandibles are powerful : their legs, however, are long and slender, and are adanted rather for quick movements than for the performance of feats of strength.

The larræ of the cicindelæe are no less predacious than the perfect animal. They are represented by WEstwoon and others as having a large head armed with powerful jaws, and capable of burrowing in the earth to the depth of a foot. At the mouth of this burrow they lie in wait for their prey, which they seize and drag to the bottom to devour at their leisure. To aid in ascending and descending these burrows, they are provided with two hroks un the back : some observers, however, suppose these hooks may assist in holding their prey, when bent in a suitable manner; for, on entering the mouth of the burrow with their prey, they suddenly slide to the bottom.

These insects, then, in all their stages, are predacious; and inasmuch as their numbers are less than thise of many allied families, and their instincts are such as require a higher derelopment of lucum tive apparatus, they may well be regarded as occupying the highest rank in the articulated class.

The Crcisuelide are in general easily distinguished : their colors are usually green or gray combined with a hrassy or bronzed tint, with whitish spots for ornament in combination with hrindle spots or angulated lines, which give them all a pleasing and indeed an elegant appearance. From their powers of flight, the cicindelæ have sometimes received the name of Eupterinea.

The family Cicivoelide has been divided by Mr. Harris into the following groups :

1. Labrum with three teeth; thorax contracted behind.

2. Labrum 1-toothed; thoras quadrangular, flattened above and dilated bahind.

3. Labrum one toothed ; thorax nearly cylindrical.

\section{Labrum provided with three teeth; thorax contracted behind.}

\section{CICINDELA.}

The genus Crcmoela, as defined by Westwood, is described as follows: The males have their anterior tarsi elongated and dilated. The elytra are oblong-ovate and depressed. Th rax subyuadrate. Internal maxillary palpi with juints nearly equal in length; the two basal joints of the labial palpi short, the third is elongate and ciliate, and the fourth clavate and naked. Antennæ are inserted into the anterior margin of the eyes. The head

\footnotetext{
[Agricultubal Report - Voz. v. ] 5
} 
is bromler than the thorax, and the forehead is exeavated : the eyes are large and prominent; elytra tlat; wings two.

The larber of the ciriudelat have nearly the sime hathits ats the prefect inseret : they enstruct their habitations in the ground, penetrating it w the depth of eighteen inches, which labor is perfirmed ly means of their mandihle's and legrs. The henks upon their backs atd them etriciently in asceuding and descending their burrows : by means of these

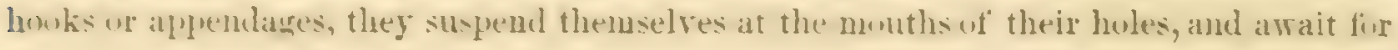
their prey.

The larvie are long. cylindrie, soft, whiti-h gruks, and furnished with six feet. The he ad

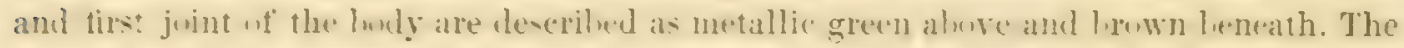
head is yuite large, armed with two long. sharp, and nearly vertical mandihles. I poun the back there are theshy tuhereles cluthed with hairs : each of these tuhercles is armed with a reeurvel horng spine. (See Plate xvii, figs. 9, 10, 11 : (ollied fivin Ratzibra, Forst. Insecten.)

Cicindeta velgaris.

(Plate xvii, fig. 10.)

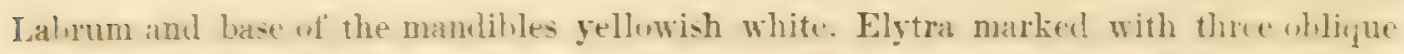
lines, yellowish white and angulated : these lines are in the firm of lunules; the one past the middle is double.

Length of the male $\frac{3}{4}$, of the ferale $\frac{2}{2} \div$ of an inch.

S.Ar in the Transactions of the American Philosophical Society, New Series, I, 409; P1. xiii, fig. 1.

This species apprars early in the spring. continuing until alwut the first of June : It reaplears in Lugust, and continues two months, and perhaps longer if the weather is favorable.

Cicindela generosa.

(Plate xrii, fig. 2.)

Q An whencely cup? wus abore. Elytra bright purplish ur subviolaceous; lateral marcin entire; humerat? and terminal lunule hroad and white; intermediate band hent at a right angle, and ccupring nearly the centre of the elytron : at its extremity it is widened, and extends nearly to the suture.

Length varying but little from $\frac{5}{5}$ of an inch.

Head is varied with cuplens and violet : the front is supplied with prostrate ashy hair. Labrum white: anterior elge furnished with three teeth. Antenna, or their anterior margins, cuprenus. Mandibles with abunt $\frac{2}{3}$ of the anterior and lateral yortions white, the rest black.

Trunk cupreous, Faried with riolet; sides hairy; thorax yuadrate, and somewhat narrowed hehind. Elytra bright subriolacesus, deeply pumetured with wreen. Feet and thigh: bright green, abore brassy. Abcomen greenish lilue, hairy; tail purplish. 
This species, like the vulgar is, has two broods in the year; the first appearing in May, the second in August. It lires in sandy districts, frequenting the sea-beaches, and is one of our largest species.

\section{Cicindela repandis.}

The markings of the repandis resemble those of the vulgaris : the cream or rellowish white of the labrum extends to half of the mandibles, and the insert is smaller; the lunules are wider and more dilated, the middle one extending to near the suture behind.

\section{Cicindela pUrpurea.}

Purple. Head, thorax and el ̣tra bordered with green combined with steel-blue and brilliant green. Thorax margined with brilliant purple; legs purple. Lunule upon the elytra ohsolete. There is a cream-colored dot upon the outer angle of the shoulder, an obsolete lunule behind the middle, a spot upon the outer and posterior angle, and a bar upon the margin inside of the green edge.

Length half of an inch.

SAY, Trans. Am. Phil. Society, New series, II, 5j; P1. xiii, fig. 8.

\section{Cicindela patruela ( Dj.).}

Buttle-green above, steel-blue and green beneath. Outer angle of the elytra marked with two oroidal sputs, nearly united by narrow and pointed elongations; middle marked transtersely by an oblique bar, posterior by a large round dot, and margin by a line inside of the purple edge. The lunules may be deseribed as broken.

It is rather more than half an inch in length, and nearly a quarter of an inch wide.

Head is bright green with bluish, naked, and finely granulated; labrum dingy white; teeth three, with six marginal punctures. Mandibles hare a white spot at base : the four basal joints of the antennæ green; terminal one rufous.

Thoras concex, narrowed behind, granulated. Beneath bluish green; legs green; trochanters purple.

It has a wide range, accurding to Gould ; being found in North-Carolina, and in Fermont as far north as Burlington.

\section{Cicisdela gutrata.}

Brilliant steel-blue and green. Labrum light buff rather than cream-color. Outer edge or surface of the mandible buff; middle and outer angle of the elytra dotted : posterior margin has a short transverse bar inside of the green edge.

Length rather less than half an inch, and $\frac{1}{5}$ in width.

SAY in Trans. Am. Pkil. Society, New series, P1. xiii, fig. 4. 


\section{Cicindela albilabris (White-lipped Cicindela).}

Labrum white, obsuletely tridentate, rather prominent in the middle. Elytra broadly punctured, with three marginal spots and a broken discoidal band, all white.

Kiks : Ggured on Plate $\mathbf{I}$ in Richardson's N. A. Fauna.

Bu.ly underneath green, or golden gleen elouded with blue; above, hack with a purplish tint. Lahmm white, frominent, armed in the midlle with three short teeth, the lateral ones ohtuse ; abue, with an intermediate obtuse lengitudinal ridge. Ely tra, under is powerful magnifier, corered with innumeralule minute granules, and also with numerous shallow impressious : a series of larger ones is parallel with the suture; the angnlar white discoidal hand reaches neither the suture, loor the lateral nargin. There are also thee marginal white lots, cue humeral, another between it and the band, and one between the latter and the apex.

Length of the body, $6-6 \frac{1}{2}$ inches.

Kıвв remarks, that though this species is common in this country, it is not noticed by $S_{A y}$, who perlaps mistonk it for $C$. syluatica (Lins.), "of which it may he regarded as the American representative, and with which it agrees in its prominent uprer lip and the shallow impressions and markings of its elytra, as well as in its genereal color ; but it is smaller, has a white instead of a black upper lip, with an whtuse longitudinal ridge and not an acute one, terminating in three almost obtuse short teeth instead of a longer one, and likewise by the want of the silky lustre produced by granulations much nore visible."

\section{Labrum with one tooth; thorax nearly cylindrical, sometimes elongated.}

\section{Cicindela hirticollis.}

Insect purplish gray ahove and brilliant green beneath. Outer anterior angle of the elytra marked with cream-colored spots : there is another just hehind the middle lunule, followed by another near the inner margin; posterior and outer margin marked by a Iumule. The lumules and spots less conspicuous than in the vulgaris or repundis.

Length rather less than half an inch; female, half an inch.

\section{Cicindela albohirta.}

(Plate xvii, fig. 1.)

Insect, head and thorax brassy green; hairs erect and white; sides brilliant and cupreous.

Elytra suhvidacens. Lumules and margin white, with the intermediate recurved hand. Govid : Cicindelæe of Massachusetts, in the Boston Jonrnal of Natural History, Vol. i, p. 49; pl. iii, fig. 1.

: The head is cuprenus varied with blue and green, and densely covered with long hoary - hairs except behind the eyes; labrum white; marsinal punctures ten; mandible 
' long and dark green; tips and teeth black, with a white spot at base; palpi yel' lowish white; terminal joints green. Trunk brilliant cupreous at the sides. Thorax 'quadrate, brassy green, hairy. Elytra densely punctured.'

Abdomen greenish blue; tail purple.

Gould, Trans. Bost. Nat. Hist. Society.

According to Gound, it is closely allied to the hirticollis, with which it has been confounded.

\section{Cicindela punctulata.}

C.lor obscure cupreous. Elytra purplish green and blue; beneath varied with blue and purple. An angular cream-colored line runs along the outer and posterior margin of the elytra; the anterior and outer angle marked with cream-color.

According to Gould, it has but a single brood in a season, which appears about the . middle of July and remains till September.

Common in dry places, paths in fields, etc.

\section{Cicindela duojecimguttata (Dejean).}

(Plate xvii, fig. 3.)

Insect bronze above. Elytra with a narrow interrupted lunule, with spots near the suture replacing the termination of the lunule. Head pale and obscurely bronze; front pubescent with cinereous hairs; labrum white; mandibles dark green, with a white spot at base; palpi dark green. Trunk quadrate and rather short; feet green; thighs cupreous. Beneath metallic greenish or blue; sides of the thorax and breast cupreous. It is a common species, and appears early.

Goow in Trans. Bost. Nat. Hist. Society, Pl. iii, fig. 3.

Cicindeta hamorrhoidalis (Hentz).

(Plate xvii, fig. 5.)

Henrz, Trans. Am. Phil. Society, New series, III, 254; pl. ii, fig. 2.

HARRI8, New-England Farmer, VII, 91.

C. hentzii, Dejeas, Spec. des Coléopteres, V. 1.

Color bluish black above, or obseurely cupreous. Small humeral lunule entire; posterior one subentire; intermediate one sinuate and angular, white. Marginal dot white. Abdomen ferruginous.

Length variable, not exceeding half an inch : one of the smallest of the species.

Head cupreous, with two lines between the eyes; eyes large and prominent, brown, with fine striæ around them; basal joints of the antennæ bronzed green, the others obscure brown; labrum dingy white, somewhat rounded before, with six marginal punctures bearing hairs; mandibles short, dark green; second joint of labials whitish. Thorax quadrate, as long as broad, obscure cupreous; marginal impressed lines greenish blue; 
siles hary. Elytra bluish hlack or obseure cupreous; humeral lumule ne arly inierrupted in the middle, and dilated at the extremities; intermediate band comprosed of two inperfect semicircles, or two crescents united at their tips; legs long, blush green; truchanters purple. Head and thorax metallic blue benteath; breast green; sides hairy.

Goold, Trans. Nat. Hist. Soc. Boston, p. 52-3.

Discovered hy Dr. T. W. Harris on the summit of Blue hill in Milton (Massachusetts), occupying the naked rock and the patches of mosses growing thereon. Its name is derived from the fact, that in tying, its ablumen apprears like a drop of bluod suspended to its tail.

\section{APPENDIX TO CICINDELA.}

Cicindela campestris (Linn.).

(Plate xvii, fig. 6.)

Above dull green, sometimes richly resplendent with coppery and golden reflections.

Elytra rery finely shagreened, green, with from three to six pale spots on each, dispused one externally on the shoulder, three on the outer edge of the elytra, one on the tip and one in the disk. Beneath green, with rich coppery red hues; legs bright copper glossed with green, especially on the tarsi ; labrum whitish.

Sterhens, p. 11, illustrations, etc.

This is a common European species, introduced here for the purpose of comparison with ours.

\section{Carabidie.}

THF. insects embraced in this natural family, or group, possess sereral characters in cummon, by which they are distinguished from the cicindelide, and from those which are to follow. The distinguishing characters, as giren by systematic writers, are as follows:

'Anterior tilia without emurgination on the inner side. Head narrower than the thorax;

'eyes rather prominent; palpi with the terminal joints often compressed, large, and

'somewhat triangular in shape ; mandikles simple, moderately long and rather thick.'

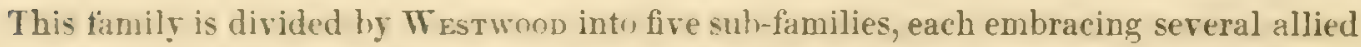
genera. With the intention of giving these shb-fanilies a natural arrangenent, WEstwood places first upun the list the Brachinides, which stand near the head of the Gronerhaga; and ends with the Bembidides, the sub-ayuaties, we sub-family which links the GeoDefuara with the Hyonodephaga. The order, then, in which the several sub-families stand to each other, is as follows: 


\section{Anterior tibia notched on the inside.}

1. Brachinjdes : Bombardiers. Elytra truncated behind. Tarsi of the males seldom dilated at the base.

2. Scaritides : Burrowers. Elytra rounded at the extremity. Abdomen pedunculated.

3. Harpalides : Blackclocks. Elytra rounded behind. Abdomen sessile.

$$
\text { II. Anterior tibia without a notch near the tip. }
$$

4. Carabides : Dischargers.

5. Bembidides : Subaquatios. This sub-family is distinguished from the four preceding by its palpi being terminated by a minute conical joint, while the same organ in the former is terminated by a joint equally large with the others.

The habits of these sub-families differ from each other in many respects. The most important fact, however, which should be stated respecting the numerous species belonging to this family, is that they are friendly to the farmer. Many of them live upon refuse matter : sume devour those insects that are injurious to the farmer : hence they should not be destroyed; and not only so, but it seems even possible to employ some species of them for the very purpose of extirpating injurious insects. To exhibit the mode in which this may be accomplished, I copy the following communication from Prof. Haldeman, which he had translated from the fifth volume of the Revue Zoologique. The facts and remarks are quite important, and should be generally known, and therefore no apology is required for introducing them in this place.

6 "There is," says M. Borscriraud, "a numerous family, composed of carnivorous species, most of them rohust and very voracious, which may be multiplied with impunity, and without fear, in our gardens. They do not, indeed, feed upon plants, which they are called to protect : on the contrary, they and their larvæ make great havoc of the herbivorous inserts, and at the same time of the limaces and helices," or land-snails, with and without shells; which, in Europe, are destructive to vegetation, but cannot be considered in the light of noxious animals in America. Nevertheless we are occasionally put in possession of the means to destroy them, taken from English horticultural works; just as we are told how to protect ourselves from insects which are not found upon our side of the Atlantic. This is principally owing to the fact that the same vulgar name is applied to distinct objects in Europe and America.

"The insects alluded to are the carabidæ. "Well, who would believe it," continues the a'thor, "the greater part of the cultivators crush these powerful auxiliaries with a kind of avidity; whilst the butterfly, which is to give birth to numerous caterpillars, which afterwards devour their plants, is the object of their admiration, and frequently even of their protection. A multitude of noxious inseets, after having for several years committed ravages upon our property, disappeared suddenly, without our being made acquainted with 
the cause. In louking more clisely into these matters, one might be assured, that in most cases, an enemy of the insect which has disappeared, has produced the hapyy result. I can furnish some proofs in support of this opinion.

... The thick filiage of a tine avenue of puplars was all at once attacked by an immense guantity of the calerpillars uf Bombyx diapar. I thunght of giving them the Calosoma sycophentu for comprany; as, like them, it prasses its life upon the trees, feeding upon the caterpillars which it meets, and even depusits its eggs in their nest, that its roracious progeng may procure nourishment mure easily and in greater abundance. Well! this insect multiplied itself with a rapidity truly ast nishing; and the caterpillars disappleared, without those who were witnesses to the destruction having the least illea of the causes which proluced it." The author then gives it as his opinion that the neighlorhord of the city of Touluse is so little ravaged by the. Melolontha vulgaris, which is so destructive in other parts of France, because the Carabus auratus is very common in the fields, meadows and gardens. It is knuwn, he remarks, that the Carabus aurutus seizes and devours the Melolontha prerious to the deposition of its eggs; and that it is more fund of these, than of any part of the insect.

".. one would be much deceived," he cuntinues, "in believing that it is always easy to make an adrantageous use of this means of destruction, a profund study of the mamers of insects heing often indispensahle to arrice at the eud proposed." Here is an example : The must rubust of our carahi, the Procrustes coriaceus (Livines), had served me admiralily in the centre of France to destruy the little insects which attack the plants in gardeus : here (in the suuth) this insect does not destroy the same species; and although rery crmmon, it is.unkawn, or hardly erery met with. The reason is, that in the centre, the west, and probably the north of France, this procrustes is diumal, recuiring only coul and shady places : with us (in the sulth, under a warmer climate) it is, on the contrary, essentially nocturnul, and therefire destrys only such insects as are, like itself, nocturnal, or which remain within its reach during the obscurity of night."

'.. In tranopurting inte my garden twenty of the Carabus auratus, I had thought to destruy the collections of Forfirula (no destructive species found in America) which had chosen it for the theatre of their rarages." To his great astonishment, the carabi, which will artually destroy the forticule. were either found starred to death, or left the place; and the latter continued their derastations: The reasin giren is, that the forficulce are "ssentially meturnal, and, during the day, keeg themselves hidden in crevices into which the curabi cannot fillow them : these latter, tox. are only actire during the middle of the day, and in the heat of the sun. But the resures of enu persevering entomolugist were and yet exhausterl; his next expedient heing to intruluce a smaller carnirurus insect common in France. the Stophylimus olew., which. he remarks, "filled all the necessary conditions for the destruction of the forficula." 
" "You see, then, gentlemen," says M. Botsgiraud, in conclusion, "that it is indispensible t, stuly the maners and habits of destructive insects, that their instinct and address mily be suresstilly empluyal for the destruction of the species able to do us injury. Then in plive of barlarously crushing the useful species which have the misfortune to be not alwars umamented with the rich colors of the buttertly or the buprestis, we will cndearor to protect them and propagate their race. We will find auxiliaries in them the more valualle. as they increase with our adversuries, and as they alone are able to rival the cunning of these ingenious enemies." ,

\section{Brachinites.}

THe sub-family Brachixides may be known hy the shortucs of the wing-curers, which are not sufficiently prolonged to cover the extremity of the abdomen. In addition to this character, the head and thorax are narrower than the abdomen. The labium is often oval or square, and is occasionally furnished with two small lateral linear lobes. The penultimate joint of the tarsi is bilobed in many of the small species : the anterior tarsi of the males are, very rarely, dilated at the base. Some species are destitute of wings (WEsTwOOD).

The most curious fact connected with the natural history of this sub-family is the means by which they defend themselves against the attack of an enemy. When pursued, they suldenly discharge from behind a highly volatile and elastic fluid, possessing considerable pungency : this sudden discharge, which is accompanied with an explosion, luth irritutes and confuses the pursuer, so that the intended rictim has opportunity to escape. From this singular mode of defence, these insects have received the name of bombardiers. The fluid discharged is caustic, and stains the skin yellowish brown. They live under stones, $\log$ s or boards in fields. Several individuals are often found in the spring together, as if their habits were of a social nature.

\section{Genus BRACHINUS (Weber).}

'Body oval, convex; thorax narrow; labrum transverse ; tarsi simple; palpi filiform ; 'claws simple.' Westwood.

Braciinus perplexus (Dj.). (Plate xvir, fig. 7.) Head, thorix, abdonen aud legs light brick-red. Elytra bluish black, faintly grooved.

Brachinus cephalotes (Dj.). (Plate xviii, fig. 4.) Head, thorax, ablomen and legs light brick-red. Elytra blue-green, or with a reflexion of green; the metallic hues strunger than in the perplexus : body also proportionally shorter, and more obtuse behind. Length about three-tenths of an inch.
[Agricultural Report-Vol. v.]
6 
Brachints conforms.

(Plate xviii, fig. 5.)

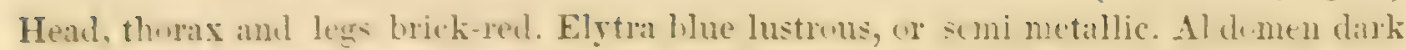
brown. Length one-fourth of an inch.

Brachines fumans.

(Plate xviii, fig. 6.)

Iteal. thorax, under and anterior part of the ahdomen, and legs hrick-red. Elytra lurplish. Sides of the abdomen brown. Length about half an inch.

Fonmel under stones, rails, ete. in June, July and August. Not nneommon in NeWEngland and New-York.

\section{Genus Cimindis (Latreille). Tarus (Clairville).}

- Bully depressed; thorax cordate truncate; clars denticulated; tarsi simple; labial 'palpi of the males with the basal joint securiform' (WEstwood).

Cimindis pilosts.

(Plate xviii, fig. 13.)

Insect dark brown, piluse; legs light hromn. Head and thorax ahout two-thirds the length of the abdomen, which is rounded, and nearly corered by the elytra.

\section{Genus Galerita (Fab.). Polystichus (Bar.).}

- Budy depressed; head triangular; thorax subcordate; pajpi long; tarsi simple; men'tum tooth triangular' (Westwood).

Galerita americana (L.).

(Plate xviii, fig. 12.)

Head elongate, small and hlack or brownish black; thorax and legs bright red. Elytra blue-black, submetallic with cupreous reflexions. Length frum six-to seren-tentlis of an inch.

\section{Genus Lebia (Latr.).}

-Body depressed, brad; thorax transverse, lubed behind; penultimate juints of the tar:i 'bilobed' (Westwood).

\section{LEBIA ATRIVENTRIS (Say).}

(Plate xviii, fig. 2.)

Head, throrax and legs brick-red ; elytra and abdomen glosey black. The lower and antering gart of the aludumen is of the same colur as the thorax, and the upper surface of the tarsi is black. Length one-fourth of an inch. 
Lebia smaragdela (Dj.).

(Plate xriii, fig. 3.)

Hedad, therax and elytra hrilliant metallic blue-grecu; luwer side glessy black. Length?

Lebia viridis (Say).

(Plate xviii, fig. 1.)

Brilliant green abore, glussy black beluw; legs black. Length from three-to four-tenths of an inch.

L. smaragdula and viridis searcely differ either in color or size.

\section{Scaritides.}

Tre must remarkable peculiarity in this sub-family is the wide space between the thorax and ahumen, by which the latter appears pedunculated : the posterior angles of the former are also so ruunded, that its form is lunate. The antennæe are short, moniliform, and the first joint is the longest ; the head is large; the tibir of the anterior legs are bruad and dentated, having the appearance of being palmated. The mandibles are large and porrertul, and armed with broad teeth; ?ałrum short, entire or dentate, sometimes trilulute; mentun tridentate, with the middle tuoth strong; labial pal pi two- and fuurjointed.

The scaritides are carnirorous, and in this respect bear a close resemblance to the allied subfamilies : some living in the ground, upon other insects or their larræ; and some frequenting the seacoast, burroming in the sand, and liring upon the dead carcases of shrimps. In this State, they burrow in the ground, or live under stones. A large species is fumd in decaring $\log$ s in Turth-Carulina, some ten or fifteen being frequently found together in one situation.

\section{Gentes SCARITES (Fab.). Texebrio (Linn.).}

'Ollung, suliderressed; antenuæ elhowed; mandibles with strong teeth internally; 'esternal maxillary palyi and terminal joint of the labia nearly cylindric; mentum 'trilobate. Antennæ with the basal joint subconic; thorax broad, luate; body 'depressed; anterior tibiæ strongly palmated, the rest simple' (STEPHENs).

Scarites subterravets (Fab.).

(Plate xviii, fig. 14.)

Color black : thorax marked with a fine central line. Thorax and head equal the aldumen in length, the latter supported on a short peduncle. Length eight-tenths of an inch. The insect, in consequence of its pedunculated abdomen, alpears as if bisected. It is a nocturnal feeder, and is found quite abundantly in Central New-York. Its singular form renders it easy to be distinguished. 
Genus Clitina (Latr.).

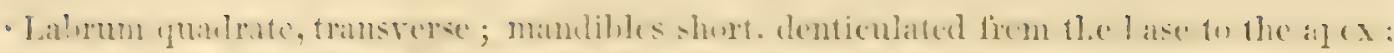

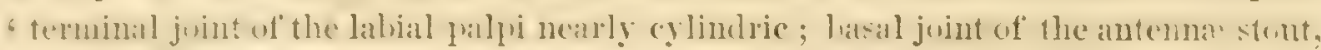

'the second long; body elongatcd, subdepressed; thorux quadrate; antcrior tibiæ 'palmated externally and at the tip' (Stephens).

Clivina lineolata (Say).

(Plate xviii, fig. 11.)

Color liuht glessy hrown: therax romded hehind and narrowed before, natked hy these distinct lines; elytra marked by distinctly punctate lines, of which there are abunt five to each elytrum. Length two- to three-tenths of a line.

Found under stones.

\section{Gexus DYSChirIt's (Panzer).}

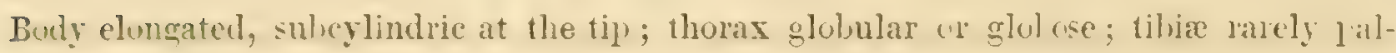
mated.

Dyschirtes globulosus (Say).

(Plate xviii, fig. 15.)

Insect hrorn, glossy; thurax globese, smooth; elytra punctated. I. neth seatcely twotenths of a line.

\section{Harpalides.}

Trie elytra of this sub-family cover the abdomen; the extremity is rounded : they are ulso sessile, and not pedunculated. The anterior tibix are deeply notched near their tipe. and, in the males, the basal joints are dilated. The mentum is cmarginate, thum it is occasionally entire : the centre of the emargination has generally a sjine. The untenrat

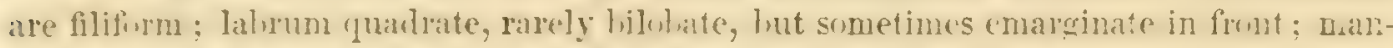
dilles generally with one or more denticulations ; mentum dueply emarginate anterionly. the emargination simple or sometimes toothed; body elongate.

These insects are not so voracious as those of the succeeding family, the CARABIDFs. The predominant culurs are liack, while a fi'w of them are alomed with lirillint metallic hues. Some are apterns, and run remarkally well. The lurva, like the perfiet insert, lires beneath stones, and feels upon other insects or their larrg. Ther ane cylim'ric anul elungate, hut slightly flattened or depresed; and they have twelve rings, which are more or less scaly: the last ring is armed with two small processes.

The ub-fanily contains many genera, which, though related to crch other, are mt readily separable into groups. STEPHexs divides them into three groups, riz: 
1. Mentum emarginate, and without a tooth.

B. Mentum enarginate : emargination furnished with a bifid tooth.

C. Mentum emarginate, and furnished with a simple tooth.

Genus agonum. Carabus (Lin.).

'Anterior' tursi with elongated joints; mentum tooth simple; thorax runded'(WEstWOOD).

Agonum octopunctatum.

(Plate xviii, fig. 8.)

Head, thorax and elytra brilliant green abore, and traversed through the middle by a hronze belt ; greenish bronze below. Elytra marked with four punctures each towards their inner margins.

Agonum cupripenne.

(Plate xviii, fig. 9.)

Body and thorax brilliant green; elytra brilliant bronze or green, as the light farors the reflexions. Elytra faintly lined, and punctured upon the marginal line.

\section{Genus HARPALUS (Latr.).}

'Palpi, external maxillary and labial with the terminal joint fusiform and truncate, and ' of equal length with the preceding, which is clavate; labrum subquadrate, slightly ' emarginate; mandibles short; mentum deeply notched, with an obtuse simple 'lobe in the centre; antennæ with two basal joints, naked; thorax transverse, sub'quadrate. Anterior and intermediate tarsi of the males with three dilated joints' (Stephens).

Harpalus pleuriticus (Raf.).

(Plate xix, fig. 16.)

Chestnut-brown; sides, both of the elytra and thorax, nearly straight, obtuse behind Length half an inch. The thorax is smooth, and without punctures upon the angles, and the male is darker than the female.

HARPALUS BICOLOR.

(Plate xix, fig. 15.)

Color dark chestmut-bromn. Sides rather curved, and posterior angles of the abdomen and elytra rounded. Length six-tenths of an inch.

The thorar is marked by a central line, which extends to the posterior margin : posteriorly it is indented by two impressions, and sculptured like the faunus.

Harpalus faunes (Say).

(Plate xix, fig. 14.)

Colur redulish brown, nearly uniform. The thorax is longer than in the pleuriticus, and 


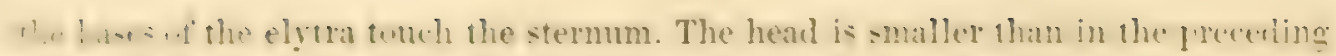
species. Length five-tenths of an inch.

The heal is withut punctures. exeept on the pusteriog and lateral anghs and the

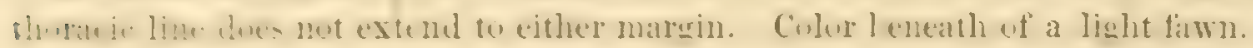

Harpalus erraticus.

(Plate xix, fig. 13.)

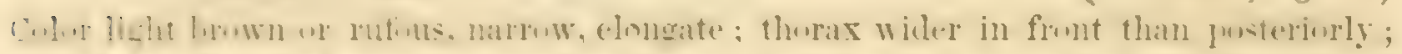
aytu lishely truncate, expreing the fuint of the aldemen. Length six-tenths of an inch.

Th, hath is furnished with strong mandihles, anl, in hoth exes, the hrown elytra are darker than the glossy head and thorax.

Gevis Paigls (Zeigl.). Harpalus (Stephens).

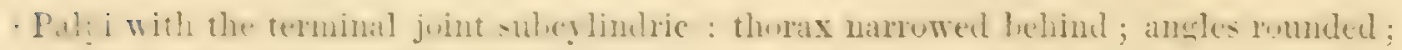

'antennæ rather short' (Westwood).

Pasgets caliginostes.

(Plate $\mathrm{x}$, fig. 7.)

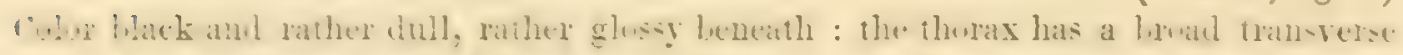

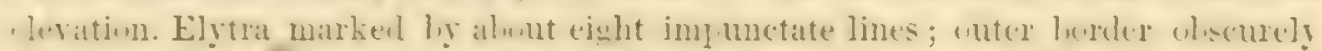
: Hnctate : lega turuished with ruws of redilish spines and cilia. Length cight-tenths of an inch.

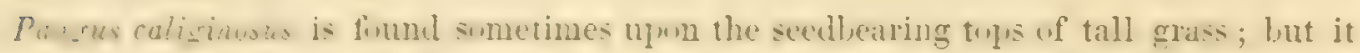

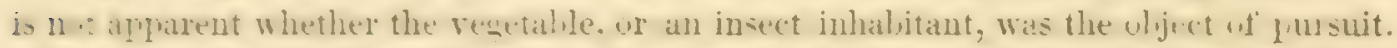

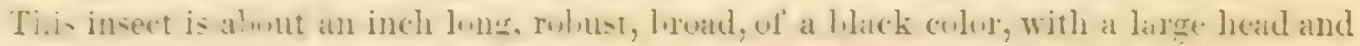

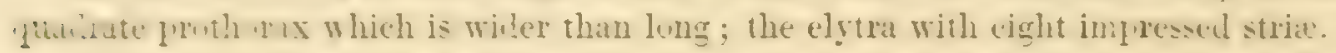

\section{Gents AMARA (BNo)}

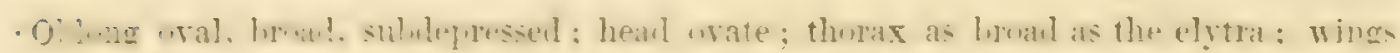

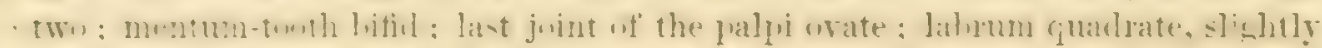

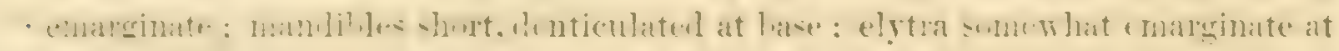

'the tip. Anterior tarsi of the males with three dilated joints' (STEPHENs).

A mara imponcticollis (Say).

(Plate six, fig. 11.)

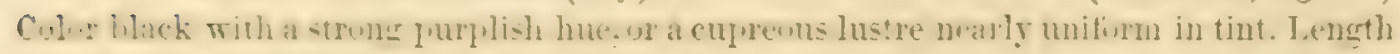
about four-tenths of an inch.

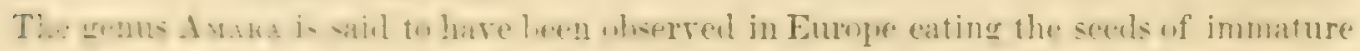

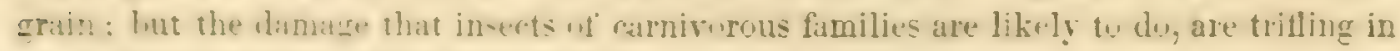
comparison to the benefits they confer. 
Geves AGONODERUS (DJ.).

Ileal suhpuadrate; thoras subquadrate, slightly narrowed behind, elongate : the thorax equals in width the base of the elytra.

Agonoderts pallipes.

(Plate xix, fig. 5.)

Head hack or rery dark hrown; thorax, elytra and legs brown : middle of the thorax darker. Inner margins of the elrtra darker than the outer and posterior marcins.

Geavos ANisodaCtyluS (Dј.). Harpalus (Steph.).

'First tarsal joint of the male small, the futurth largest; mentum-tooth olsolete; thoras 'subquadrate or trapezoid' (WEstwood).

Anisodactyles AGRICorils.

(Plate xix, fig. 9.)

Color dark brown or black; thorax about as wide as the base of the elytra; sides slightly curved. Length five-tenths of an inch.

Anisodactylue rusticus.

(Plate xix, fig. 10.)

Culor brown; the thorax rather wider than the base of the elytra. Length nearly half an inch.

Anisodactylus baltimorius.

Head and thorax dark brown; elytra, legs and antennæ much lighter, or light chestnutcolor. Length rather less than half an inch.

\section{Genus Chleenius (Bon.). Carabes (Lin.).}

: Palpi with the last joint orate truncate; mentum-tooth bifid : thorax, in the centre; 'truncate subcordate, broadest behind or subquadrate' (Wrstwood).

Chloenius emarginatus.

(Plate $\mathrm{xx}$, fig. 6.)

Head black, with green submetallic hues; thorax bronze, submetallic ; elytra blue-black, brilliant : beneath black, punctate, sculptured, but confined mostly to the thorax and anterior of the abdomen; thoras and head abore finely punctate; legs, palpi and feelers light reddish brown. Length half an inch. 
Chloentus memoralis.

(Plate $\mathrm{xx}$, fig. 5.)

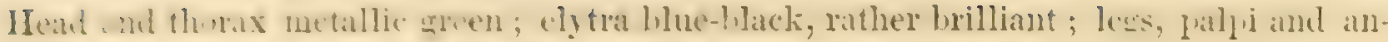
tenng brown. Length half an inch.

This species is rather broader than the foregoing.

Chlevitis sericeus.

(Plate xx, fig. 7.)

Ifeak. inuax and elyta hrilliant green above, glossy black lelow, punctate: legs, palpi and antennæ brown. Length from six-to seven-tenths of an inch.

Chronius tomentosus.

(Plate $\mathbf{x x}$, fig. 2.)

Hea: 'lake, dark lronze, punetate; elytra clark, bronzed and fint greenish hue, tomentose.

ChLonius hithophiLes.

(Plate $\mathrm{xx}$, fig. 8.)

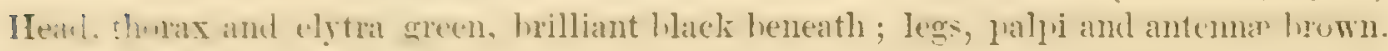
Lrength four-tenths of an inch.

\section{Genus TREchu's (Clátrt.).}

Ientum transwerse, tridentate anteriorly; central touth shortest; head orate: thorix cordate truncate; angles mostly rounded.

Trechos cinctus.

(Plate xix, fig. 8.)

Suall, -ining hrown; head darker; elytra rather lighter on the outer than the inner margin. Length two-tenths of an inch.

\section{Trechus conjunctus.}

(Plate xix, fig. 7.)

Swali. -lining liww: head liack or dark brown. Length rather nwe than two-tenths of an inch.

\section{Gemes Cal athes (Bon). Carabes (Lin.).}

Tarsal chaw turthed ; palpi simple and rather long; labial nearly filifirn, the terminal . ist truncate: luhrum transverse, a little emarginate; mandilics denticulated at the base; mentum with a bifid tooth in the centre of the notch; elytra clliptic; thorax subquadrate or trapeziform; head angular.

\section{Calatgus gregarius.}

(Plate xviii, fig. 16.)

Furtu wate: antennat long filifirm : bead, thorax and elytra of a ch ssy hown color; margin lighter; legs brown. Length about four-tenths of an inch. 


\section{Genus anchomenus (Bon.). Carabus (Fab.).}

"Mentum-tooth entire; thorax cordate, pusterior angles acute; elytra whing, suheonvex; ' head as broad as the thorax; third joint of the antennæ twice as long as the second. 'Elytra rather sinuate at the apex. Anterior tarsi of the males with three dilated ' joints' (WEST. \& STEPH。*).

Anchomenus extensicollis (Steph.).

(Plate xviii, fig. 10.)

Heat and thrix green. submetallic; elytra purplish bronze, suhmetallic; legs light brown. Length about four-tenths of an inch.

\section{Dicelús dilatatus (Say).}

(Plate xxi, fig. 13:)

Insect largo; thorax nearly as wide as the abdomen. Head black, smooth; thorax purple, indented before and behind. Elytra purple, strongly marked by eight plain lines: one begins in the acute upper and onter angle, running rather obliquely, and joins the fifth from the inner margin, the two enclosing one line : outer line next the margin depressed, and imperfectly punctured. Length about eight-tenths of an inch.

\section{Droglus erongatus (Say).}

(Plate xxi, fig. 9.)

Inwert narrutred; margin of the thorax and elytra uearly upon the same line, hlack; head and thorax smooth. Elytra marked with plain lines : line commencing at the outer and anterior angle, rather oblique, and becoming more so at the posterior extremity, where it cialesces with the other lines, and all together terminate in the pusterior and inner angle; the dotted line of the margin obsolete. Length about seven-tenths of an inch.

Sphieroderus stevostomus (Dj.).

(Plate xxi, fig. 10.)

Insect dilated behind, narrwed befure; head smouth, shining black; thorax smooth, lxilliant steel-Jlue, functured behind. Elytra dart purplish upon their disks, bordered by rich steel-Jjue, punctured and lined; lines interrupted posteriorly. Glossy black and punctured laterally beneath. Length from five- to six-tenths of an inch.

\footnotetext{
* Mr. Stephens remarks that the Anchomenos may be distinguished from Calzistes by the elongate form of the thorax, and its net being punctate throughout; and from Puatisus, by its acute simple notch in the centre of the mentum.
}

$$
\text { [Agrictitural Report-Vol. v.] }
$$




\section{Carabides}

Cossmert the fouth sub-fimily of the Cakandix. They are distinguished from the other suldimilies ly the alsence of the noteh, which, in the allierl sprecies, is situated near the extremity of the anterior tilia : the only alphomeh made to it, is by the presenee of a slight grouge in the place of the moteh at the extremity of the tilia. The elytrat are entire, and coscr the extrenity of the abdemen : antennx setaceous ; lathum may be simple, bilobate or trihubate: mandihles simple or merely one-twothed, rarely tridentate; maxilla ciliated internally, and furnished with a claw at the tip ; labial palpi fonr-jointed; mentum larese. lirad, and generally produced in the centre; anteriur tarsi greatly dilated in the males.

This suhlamily contains many large showy insects : they are mostly apterus, and their

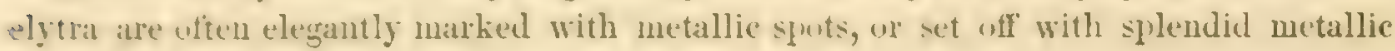
hues.

The arahides rum fast, and are very carnivorous in their halits : hence they shonld be preserved, as they are friendly to the farmer. Some of then discharge a powertul odor when taken, which is exhaled frum a fluid ejected from the ahdomen, and remains a long time.

The Germs Carabes, the typical one of the family, contains, according to Mr. Westwoon, notwithatanding the restrictions to which it has been subjected, nearly 200 species. By far the greater number of these species are confined to northern climes.

\section{Genus CYChrUS (FAB.). Tenebrio (Lin.).}

Ilead long and narrow; palpi with the last joint large and spoonshaped ; labrum strongly bilohate; mandibles bidentate at the tip; antennæ setaceous; mentum quadrate, toothless; thorax truncate; wings none.

\section{Crchrues videos ( Dj.).}

(Plate xxi, fig. 14.)

Insect large, dilated hehind and narrowed before : head and thorax bluish purple, sculptured on the borders. Elytra purple, marked by about fifteen strung dotted lines each, which are somewhat iuterrupted hehiud and partially broken, giring them an apyruach to a zigzat furm; beneatl, purplish, inclining to brown or cupreous. Length from one to one and a quarter inches.

This insect may be known by its remarkable elongation of the head and thorax, and its dilated elytra and ahdomen, the former of which are reflected over the latter. 


\section{GeNus CARABUS.}

Labrum bilobate; mandibles furnished with a tonth in the middle; mentum-tooth entire; thorax subcordate, emarginate behind; palpi with the last joint securifurm; antennæ linear, second joint shortest, third cylindric; wings rudimentary or none. Anterior tarsi of males dilated.

Carabus vinctus (Weber); C. interruptus (Say). (Plate xxi, fig. 11.)

Head and thorax smooth, blue-black. Elytra black, faintly bronzed, and marked with punctured lines : the three interrupted lines are sharply elevated, and the metallic points are reflected frum these interruptions. Length eight- to nine-tenths of an inch.

Carabus serratus (Say).

(Plate $x x i$, fig. 12.)

Color black, with blue and purplish hues which are reflected from the margins of the elytra and thorax : head and thrrax plain and glossy black; margins of the thurax elerated and punctured. Elytra thickly punctured in ahout twelve rows : if taken in threes, there are three ruws of ovoidal parallel impressions without punctures. Length seven- to eight-tenths of an inch.

\section{Carabus limbatus (Say).}

(Plate xxi, fig. 16.)

Color black : head and thorax smooth and glossy black. Elytra purplish black, bordered with blue and purplish hues, and marked by seventeen or eighteen punctured lines: three of these lines are broken by stellate or cruciform markings. Length nine-tenths of an inch.

\section{Genus Calosoma (Web.). Carabus (Lin.).}

Labrum bilobed; thoras transrerse, shorter than wide; abdomen subquadrate, wider behind than before; wings large; palpi with the last joint ovate, truncate; labium short bruad, the upper margin setose acuminated; mentum sublinear, rounded laterally, unidentate in the middle. Antennæ, second joint shortest ; third longest, compressed.

Calosoma scrutator.

(Plate x, fig. 8.)

Head hlue-black : thorax hlue-black, surrounded with golden green. Elytra green with purplish reflexion and bordered with cupreous, marked with punctured lines : the ridges between are transtersely marked with numerous lines; each elytrum is also ornamented with three rows of distant green dots, which are not very conspicuous. The whole body heneath is green, with steel-blue reflections : legs steel-blue, and the thighs are punctured with four or fire rows of dots; tarsi and tibiæ dusky. Length exceeds an inch : about $1 \frac{1}{4}$ inches. 
Cazosoma calidum.

(Plate $\mathrm{xxi}$, fig. 15.)

Head and thorax black, finely punctured Elytra ornamented by three ruws of motallic spots placed upon thick lines, crossed by obscure punctures. Length nine-tenths of un inch.

Both species of Carososu are abundant in the United States; hoth feed upon other insects, and are useful by diminishing the numher of insects injurious to the farmer. They are furnished with wings, are found upon trees, and feed upon the larvæ of lepidopterous insects : their larvæ also have the habits of the perfect insect.

Genus Notiophilus (Dun.). Elaphrus (Fabro).

Head as broad as the thorax; eyes large; thorax quadrate, flattened; lahrum large, rounded; palpi robust.

Notiophuts pohrectes.

(Plate $x x$, fig. 13.)

Insect brown, with a uniform bronze hue. Length from two to three lines.

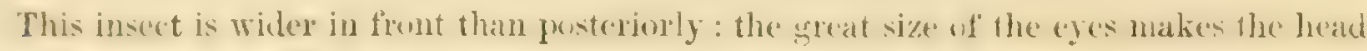
as prominent as the thorax.

\section{Genus Elaphrus (Fabr.). Cicindeia (Lin.).}

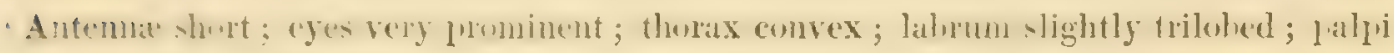
'slender' (WEstwood).

Elaphrus ruscarius (Lin.).

(Plate $\mathbf{x x}$, fig. 1.)

Heal. thurax and elytra hronze tinted with green, and singularly marked ly dark round sputs encircled with green, which give the incect a tuberculate alprearance; beneath green and metallic.

The insect's body is short, but it has the general appearance of a Cicindela.

Omophron labiatum (Fab.).

(Plate $\mathbf{x x}$, figs. 11, 12.)

II ad with a deeply notched fatch of green at the base, and frartially surrounling the eyes : thorax black, with green metallic hues bordered with light brown. Elytra variegated with hlark-green metallic hues, and bordered with light brown, traversed with many punctate lines; beneath brown.

Var. tessellatus. Say (fig 12). Ofoscurely banded; the elylat travered on their imed margins with black : the brown is more conspicumb, and ocenpies a larger portion of the elytra.

Length about one-fourth of an inch. 


\section{Bembidides.}

TuE maxillary and labial palyi in this sulfentily are terminated by ar very minute joint. The anterior tibie are always notched on their inside-, near their tips. The insects are small, and run with considerable speed : they are adurnod with metallic colders. They live und 1 - tontes in damp places, or in creviees in the ground; and they are carnivorous, feeding upon the larvæ of other insects, and also upon dead animal matter.

Genus BeMbiditu (Illigen). Cicindela (Lin.).

Thorax truncate cordate; elytra tubercled; eyes very prominent.

BEMBidium SigLLARE.

(Plate $x x$, fig. 3.)

Heal, eyes, thorax and elytra above metallic gray, bronzed with a faint purplish in some

lights; beneath, brilliant green : legs darker above. Length rather more than onefourth of an inch.

Sometimes very abundant on the leaves of water plants.

BEMBidium honestum.

(Plate $\mathrm{xx}$, fig. 4.)

Herd and elytra gray bronze, duller than the precting; thorax blue-black; beneath,

black with a greenish hue. Length about a quarter of an inch.

Bembidium inequale (Say).

Eyes very large; head, thorax and abdomen gray, metallic and bronze, unifirm.

Bembidium inornatum.

(Plate $\mathrm{xx}$, fig. 9.)

Head, thorax and elytra brown. Length about one-tenth of an inch.

Bembidium tripunctatum.

(Plate $\mathrm{xx}$, fig. 10.)

Head, thorax and elytra brown; metallic hues absent. Length one-tenth of an inch.

BEMEIDIUR VARIEGATUM.

(Plate $x x$, fig. 14.)

Head, thirux and elytra metallic green above, when seen in some directions; below, black and brownish : legs brown. The elytra are variegated with paler patches of lrown, and they alpear of a glossy brown when seen by direct light. Length twotenths of an inch. 


\section{HTDRADEPHAGA.}

Tue insects included in this section reside in water, aud heuce their legs are transformed into organs suitahle fin moving in this element. In addition to the transformation of the legs inte = wimming urans, the budy unlergoes a change of torm, hecuning oval or buatshaped : in time they are thromghly fitted for the element in which they are to more, being end.wed with the means of pursuing their pres, and furwished with all the conveniences which their congeners upou the land pusess. Although they subsist in water, yot they are nut provided in their perfect state for ohtaining a suply of air from the element in which they more : they are air-consumers, and are uhliged to rise occasionally to the surface to obtain a supply of air for respiration.

The Ifrorabephasa are predacious beetles; and although it is not innortant to the farmer to kuw them in an ecommical puint of riew, still some of the larger kinds prey up n the "ra of fish, and even unn their young; and in this respect, they are not entirely destitute of interest to the uwners of fish-ponds. Regarded as animals which live by the chase, they are truly mure greedy and gluttunous than the predacious land beetles : they are pre-eminently voraciuns and destructive. Their larve, of cumse, are acnatic; and they to feed roracinsly upon other ayuatic insects. The frerfect animal, thongh fitted for the water, is not contineel to it : it may take wing at erening, and enter dwellings, like moth: heing allured by the dazzling light of lamps near a window. They uhtain air by resting ulun the surfue, and raising their elytra : this lrings the air more immediately into contact with the spiracles of the insect.

Stephews divides the Hydradephaga into two families, viz:

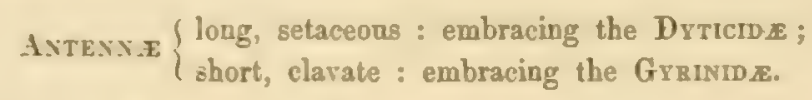

1. The Drticidx are furnished with rather long setaceous antennæ; their bodies are oval, heing rounded anterinly and Insterinrly; their thuras is short and transverse, and their legr are firmed linswimming : the l'sterior ones, howerer, are especially adapted to this end, ly their great length, and ly heing furnished with two rows of dense cilia arranged alıng the edges, with the view of increasing the width of the oar; the tarsi are also that in the males, and the anterior ones are nore dilated than in the females. The mandibles of the larra are much hent, and are picrced for the purpose of extracting the juices from the animals upon which they subsist. Their respiratory organs are situated behind, and consist of two segments fringed with hairs and terminating in two conical appendages. between which are two eylindric perforated tuhes : these communicate with the respiratury urcans. The larsa. as well as the imago, is obliged to rise to the surface to obtain a supply of air. 
2. The Grrinide are provided with short clavate antennæ : body oval and convex, as in the Drticide, but more glossy. The legs are unequal in this family : the anterior ones are long, and the four posterior are short, compressed, and formed for swimming. The larre differ also from those of the Drticide, by haring on each side of the fourth and seven following segments a membranous conical appendage, which is flexihle and bearded at the sides : these appendages are subordinate to the respiratory organs, with which they communicate by a small tube.

\section{Dyticidæ.}

\section{Halipides.}

Antennæ ten-jointed; posterior coxæ dilated into a large shield, covering the base of the legs.

\section{Genus Haliplus (Charrv.). Cememidotus (Ill.).}

Maxillary palpi with the last joint very minute and subulate.

Haliplus 12-punctatus.

(Plate xx, fig. 15.)

Head, thorax and elytra buff-colored. Elytra with twelve black spots, some of which are confluent; inner margin and anal extremely black; thorax with a lunate black or brown spot on its anterior margin; eyes black.

Haliples immaculaticollis.

(Plate $\mathrm{xx}$, fig. 16.)

Insect buff-color : elytra with ten black spots, the central comparatively large, and common to both elytra; thorax brown, immaculate.

\section{Genus DYTICUS. Dytiscus (Linn.)}

Anterior male tarsi patellated; claws didactyle; maxillary palpi with the second and third joints equal' (Westwood).

DYTICUS HARRISII.

(Plate $\nabla$, fig. 10.)

Color black softened into olive; front or forehead luteous; lateral margins of the thorax luteous : upon the latter it diminishes posteriorly, and extends to the under side of the same; beneath, the thorax and first pair of legs are luteous : posterior legs long, and furnished with two dense rows of brown cilia. Length one inch.

This species is rather common in small ponds of water, where the bottom is clear and sandy : a locality where it may always be found, is at the head springs which supply the city of Albany with water. 


\section{Parnides.}

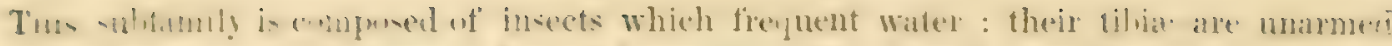

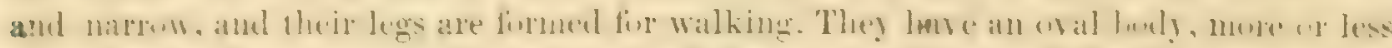

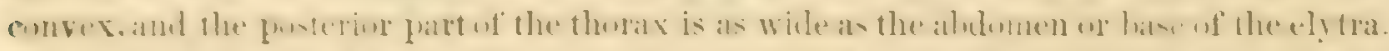

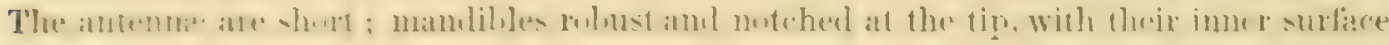
ciliated. As they frequent the water, their entire surface, as in Parnes, is corered with cilia to retain air; or, as in ELMis, in part ciliated, for the same ohject. This arrangement gives them oxyen when immersed in water.

The two genera Parvus and Elms are regarded as belonging to two subfanilies; but being closely related, it is sufficient for our purpose to place them in juxtaprsition.

Parnes fastigiatus.

(Plate xxiii, fig. 7.)

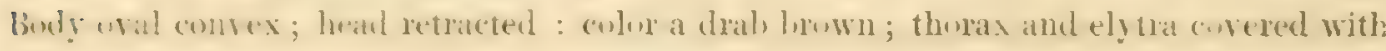
a cont of fine appressed hair; legs reddish on their outer sides.

Elamis cresatis?

(Plate xuiii, fig. 9.)

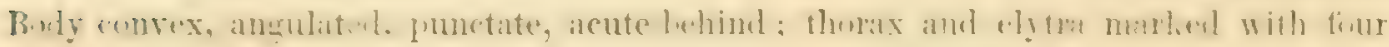
black dots, and a faint reddish stripe upon each; legs reddish.

\section{Silphides.}

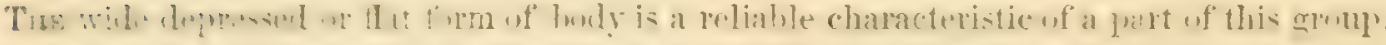

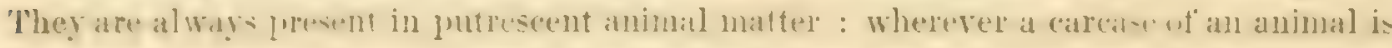

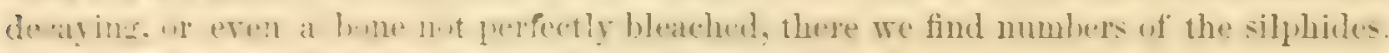
The Necrophorts, however, is much less depressed or flattened than the genus Silpha,

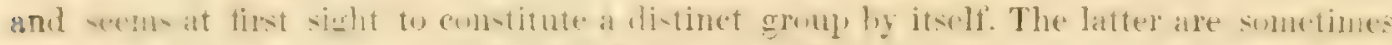

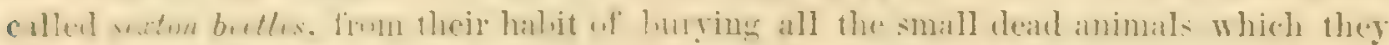

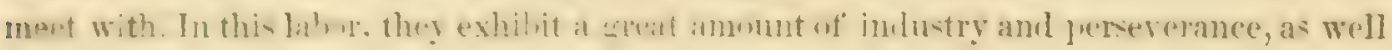
as a high grade of instinct in seemingly devising means to accomplish an end.

The anatomical characters of these beetles, as given by WESTwood and others, are: Antenne thickened at the tips; palpi filifom and slender; labrum transverse and

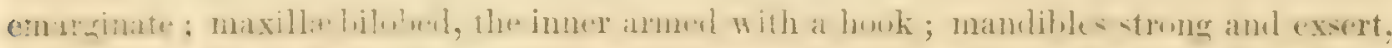

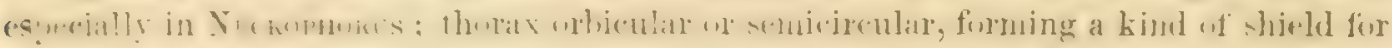
the head; tarsi five-jointed, the fourih nearly egualling the others.

\section{Genes Necrophorus (Fabo, Leach, Oliv.).}

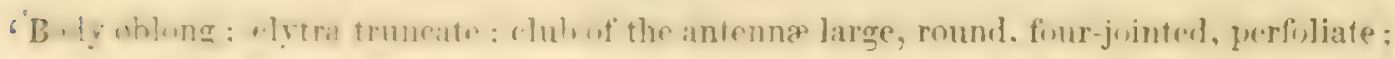
' maxilla unarmed' (Tiestwood) 
Fecrophoros americanus (Ol.).

(Plate xxii, fig. 8.)

II ead, thorax aud elytrablack, shining; forehead marked with a cordute yellewi:b brwu spot; thorax brown, except a black dentate border : elytra marked with four irregular yellowish hrown spots, the anterior prolonged uron the anterior margin; maryin gruved, and of the same color as the spots : club of the antenng yellowish brown, black beneath : anterior tarsi ciliate; eilia jellowish brown.

This large consplicuous beetle Iresents certain variations of color and marking, which indicate a difference either in sex or sprecies. The yellowish hrown spots described abuve are much darker in some individuals, while the forehead mark is rounded lehind, square in front, and behind and between the eres there is a rufuus spot which does not exist in all. The thorax is curiously indented upon its border. Length $1 \frac{1}{4}$ inch.

Necrophorus tomextosus ( Wb.).

(Plate $\mathrm{x}$, fig. 2.)

Black : elrtra chised by two rufous hands, hlack heneath ; th rax and sides pilose ; club of the antenna black. Length about three-fourths of an inch.

This species is quite hairy, especially upon the thoracie plate: hairs greenish.

Common in July in New-England and New-York.

Necrophomus pYgMeUs (Rich.).

(Plate xxii, fig. 5.)

Black : elstra marked with four angular lright red spots. Length rather more than half an inch.

The Necrophag 1 perform the part of scarengers in destroying and burying carrion. $\mathcal{X}$. fomentosus takes its trisial name from the jellow hair upon the prothorax. The family Dermistid $x$ is also destructire to animal matter : thej deposit their eggs in it; and when the are hatched, they feed upon it; but the dermestes attack and devour any animal luvil, whether in a state of decay or not. It is suppused that the perfect animal, howerer, prefers flowers to meat, though we always find it busy in the latter.

\section{Geñs SilPHA (Linn.).}

- Broadly oral, slightly conrex; antennæ gradually thickened, club four-jointed ; thorax ' often truncate anteriorly' (WEstwood).

Silpeia caudata (Say).

(Plate xxii, figs. 3, 7 )

Black. Elytra subyuadrate, papillated ; papillæ in about four rows, placed between sharp ridges; inner and posterior angle slightly prolonged; outer angle rounded : thoras tomentose. Length half an inch.

Silpha inequalis.

Insect depressed, llack : elytra finely punctured, and trasersed by three or four sharp slightly raised ridges. Length half an inch. [Agricultural Report-Vol. v.] 8 
Silpha votemoracensis.

(Plate xxii, fig.9.)

Buly depressed : elytra rufous; wuter margin of the thorax light and rather bright red, black beneath.

Silpha americana.

(Plate $\mathrm{xx}$, fig. 3.)

Ihepressed, hlack : thorax yelluw, with a subqualrangular black spot in the centre ; elytra kmolby. Wack or hrownish hack tipped with yellowish; outer angles truncate, or rombled from the mildle, and slightly notehed at their inner and posteriur angles, forming a moth when at rest : they are marked ly four rather irregular ridges.

\section{Genus NECRODES (Wilkin). Silpha (Linn.).}

- Body ohlong; clytra truncate; club of the antennæ gradually thickened; maxillx 'without a claw' (WESTWOod).

Necrodes SURINAMENSIS.

(Plate xx, fig. 4.)

Depressed, hack : thorax smoth and shining; elytra marked posteriorly with a short rufus hamd, and trarersed by three strongly marked shar ridges, black beneath.

\section{Nitidulidie.}

Turs fimily has the lanlits in part of the silphida, as some of them are found in putrid animal matter, or feeling upon mushroms; others, however, frequent flowers. They are wal, hroul, and much derresied; and they have filiform untennæ, terminating in a short cluh of two or thee joints. The thurax is transverse and emarginate : in some, the elytra are short, leaving the abdomen exposed. They are small insects.

\section{Genus NITIDLLA.}

- Birly uvat, suludepressed; thorax margined; tibia compressed; fourth tarsal joint bi'lobed; third joint of antenna longer than the fourth' (Westwood).

Nitidela bipustulata.

(Plate xviii, fig. 1.)

C Jur of the ledy and thurax dull hrown : central part of the elytra marked by a patch of lighter brown; margin light brown. Length about two-tenths of an inch. 


\section{Engidx.}

The insects of this family are allied to the Nitidtud a and Dermestide: from the former, they differ by their elongate form and simple tarsi; and from the latter, by their highly polished bodies, and more developed form of their mandibles (Westwoon).

The Evgide subsist upon wood in a state of decay, or upon fungi, in some species of which many individuals may be found. I procured a large number of individuals helonging to this family, in the gelatinous sap which was slowly oozing from a wound in the trunk of a yellow birch : they are also fonnd under the bark of trees, and never feed upon living or dead animal matters.

The anatomical characters, as given for the EvgID无 proper, are : Antennæ short, clarate, ten- or eleven-jointed ; maxillary palpi equalling the lobes of the maxillæ; labium adranced in front of the mentum; labrum transverse; mandibles bifid at the tip; tarsi in some four-jointed, in others five.

\section{Genus ENGIS (LATr.).}

- Body long ovate, subconvex; tarsi five-jointed, the fourth joint short; maxillæ bilobed; ' elub of the antennæ short, broad, flattened, three-jointed' (WEstwoon).

Engis fasciata.

(Plate xxiii, fig. 2.)

Thorax black : elytra brick-red, traversed by a broad black belt; posterior extremity black ; inner angles of the elytra black, terminating in a partial crossbar. The proportion of black and red upon the elytra is nearly equal.

These insects inhalit fungi, or decaying wood under the bark of trees : they are not, however, specially injurious to trees.

\section{Genus IPS ( Herbst).}

The body is oblong and subdepressed; tibia broad and serrated; tarsi five-jointed; lobe of the maxilla broad.

IPS FASCIATUS.

( Plate xxiii, frg. 4.)

Borly oblong, subdepressed; thorax and head black; elytra black, with two yellow angular spots upon each; legs short; tibia broad, subserrated; tarsi pilose. Length two-tenths of an inch.

IFS SANGUINOLENTA.

(Plate xxiii, fig. 3.)

Head and thorax black : elytra yellow, with a single round black spot near the middle; terminal extremity black; outer and anterior angles black. Insect shining. 
IPS QUADHISTGNATA.

(Plate xxiii, fig. 6.)

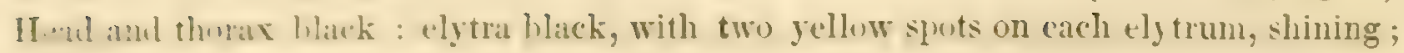
the posterior spot is somewhat oval; npper and outer angles black.

Ips bipustulatus.

(Plate xxiii, fig. 8.)

(Alur bewn, dull : elytra marked with two large yellow dots. Length about two and a lualf lines.

\section{Cucujides.}

Genus CUCUJUS. Colydicm (Herbst).

Autenne short, moniliform or clavate; basal joint short.

Cucujus Clavipes.

(Plate xxii, fig. 2.)

Depresed. Hat or comrressed : coler uniform, inclining to hrick-red; aldomen below dark, and nearly black upon the margins. Length about half an inch.

DERMESTES LARDARIUS.

(Plate xxii, fig. 5.)

Buly wal, sulrenvex, black, with a gray har passing across the anterior frart of the ely tra, in which are three dots on each elytrum.

The cenus Denswates is naned from derme, a skin, with which the larra matie great rasaces eating the surface su as to cause the hair to fall off. The Dermestes larderius commits its depredations in lwuses, usually in furs, meat, pork, bacon (whence it is sometimes called bucon bug), collections of insects, etc. when stored away without protection. It is abunt wne-fiurth wi an inch lons, nearly black; the base of the elytra ash-color, with three small black spots.

This sprecies is active in attacking all animal cullectirns of natural history : from this depredatur, they are hest protected hy arsenic. Articles of domestic consumption shonld lee preserved by lireventative measure, such as enclosing hams in canrass and whitewashing them.

The Dermestes velpinus is distinguished from the lardarius, by having the elytra entirely black, and the unlere sites and under lats corcred with white scales. It is rery destructive to hides, in which it is inporterl. In France, it has been ubserved to perforate walls built of stone wift enume to be liroken ly the nail. It is found in America, Europe and Asis.

There are several wher incects which are destructive to skins, and to anatomical and natumal histery collections: one of them is the Inthrenus museorum (Byrr. muscorum, Lita. ). It is not a native if this cuntry : it is, however, replaced by the .2. destructor, 
Melsh., which is a short wal insect ahout one-eighth of an inch in length, of a fuscous color, and marked by several waved whitish fascix. The larva of another small and much narrower insect, Dermophogus farsule of Melshenner, is also very destructive to entomological collections.

\section{Staphylinidæ.}

TuE characteristics of the insects belunging to this family are, their long, narrow, and depresed firm; the shortness of their elytra, and hence the great exposure of the abdominsl segments. Their true wings are closely folded beneath the curtailed elytra, although thiy are large when expanded. Their heads too are renarkably large; and when set unt ly their projecting manclibles, it is no easy matter to persuade oneself that it is safe to cat ch them. Their antenne are not very conspicuous, but are sometimes enlarged towards the extremity. The thwax is strong, and as wide as the first segment of the abdomen. From the shortness of the wing-covers, the abdomen is equally hard above as beneath, and is not cunfined by them : it therefore admits of free motion, and is employed as an intrument to a sist in folding and unfulding the wings. When the insect is captured, a curions organ protrudes from the extremity of the abdomen, consisting of two vesicles, which are extruded at the will of the insect, and from which it is not uncommon to perceive that a peculiar vapor escapes that is by no means pleasant.

WESTwoop regards this family equal in rank to the CARAEIDE, and susceptible of subdivisions of the same ralue : the name Brachyelitra has been generally employed in denoting it.

\section{Genus STAPHYLINUS (Linn.).}

'Body nearly glabrous; antenne subfiliform, with the fourth and tenth joints subequal; 'thorax subquadrate' ( Westwoon).

Staphylines villoses.

Head and thim bluck and glossy : back, sides, and abdomen beneath villose, or corered with a dense coat of hair; abdomen banded with greenish buff. Length six-tenths of an inch.

Staphylinus cyanipenis.

(Plate xxxi, fig.6.).

Head and thorax black and glossy; elytra steel-blue; abdomen hairy and black.

Staphylines chrystres.

(Plate xxxi, fig. 3.)

Abure an olive brown, chothed with shirt yelluw hair; sides and extremity of the abdomen golden jellow; thighs black, except at their tips, and a dorsal line. 


\title{
CIIAPISHK V.
}

\section{ORDER I. COLEOPTERA (Continued).}

\author{
PESTAMERA.
}

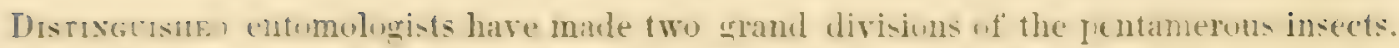
Some of the latnilies of the first division have been noticed: the sece not is foully imfurtant with the first, and almitsof suldivision int, natural groulsur families; but there is some direreity of ofinion where the lines heunding these fanilies shall he drawn, and also respecting the best terms for designating them.

A plain and connurehensive vululivisun into grengs has heen male by Stepnexs : 1,

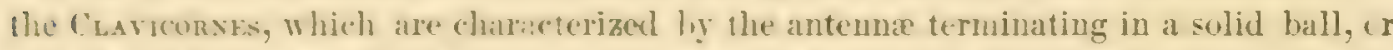

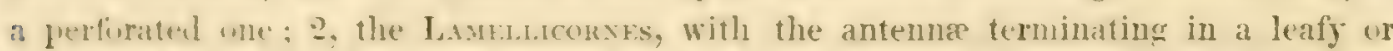

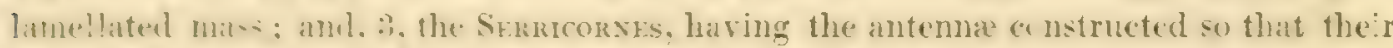
whole leneth is tmothed sumewhat like a saw. The Cravicorsts are divided into two funilies : the fint contains thuse insets which resemble the Limnean Genus Broruts, hatring straight elavifum antenne, and called the Family Brknuds, Leach. The seend family have also claviform antennæ, but each with a distinct elbow or angle.

The Brrande are small heetles with short oval cunvex bulies, and generally jiluse or hairy : the elytra corer the froly. and the legs can be fohled up; when alarmed, it folds them together under its lwaly, and then remains nutionless, ally aring like a seed, until the danger is past. In this fanily the antenna lecome gralually ('lavate, and the club is not solid.

The second family of clavicornes takes its name from the Genus IIstr:R : hence the funily name IIsterib. E, Leach. In these, the antenna. insteut of being straight, have a sudilen wr slowt angle in them. of are said to lwe elhowel. They are small insects, hard and

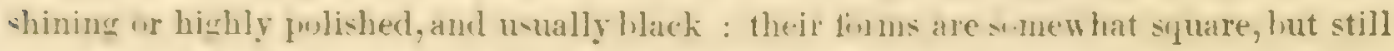

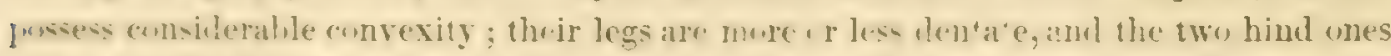
are set willy apart: the elytra are shert, and hener lowe a prortion of the abdomen

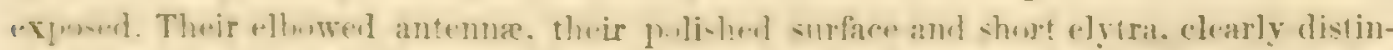
.quish them from the byrrhiclas. 
The Lameliconsas received their name frum the structure of their antenn; the extremity being a laminated knob, compused of three or more leaflike laminæ, which open and shut somewhat like the leaves of a book. The first division of this group consists of the Scarabides, the first section of which are named Coprophagi, from the kind of food on which they subsist : they feed upon and live in ordure, or excrements of all kinds. The ancients gave the name pillularia to certain species which have the curious instinct of rolling the excrement into balls with their hind feet, and in which they have deposited their eggs : when the ball has acquired a sufficient degree of solidity, it is pushed into a hole previously prepared for its reception.

A foreign species, the Atcuchus sacer, was an object of religious veneration and worship among the ancient Egyptians. With them it was symbolical of the world, the sun, and the warrior : of the world, from the globular shape of its balls, and perhaps also from the progeny they contained; of the sun, from the angular projections from its head in the form of rays : the six legs have five tarsi each, and hence they represented the days of the month. The idea of the courageous warrior was imbibed from the supposition that the species were all males. The Rowan soldiers wore its image on their signets; and it is said that it is still a custom with the Egyptian women to eat them, to render themselves prolitic : as the sun is the source of all fertility, so the eating of this symbol would impart to them the same desirable quality. When we reflect a moment upon the attention which these curious insects pay to their offisping, and the intense emotion they exhibit in rolling their balls, a work which they prosecute until overcome by exhaustion, it is not at all surprising that the ancients should have made them symbolical of the highest order of qualities.

The Copris carolina clusely resenbles the symbolical beetle of the ancients, just referred to. The lienus Copris makes its abode beneath the fresh excrement of the cow; and hence its hills of dirt are common in pastures, by roadsides, and other places where the cow is kept. This insect, huwerer, never rolls a regular ball, but collects a quantity into an irregularly shaped mass. The true pillularia helong to the Genus Geotrupes, and a few other allied genera.

The larra of the Geotrupes resembles that of the Melolostra, being of a dirty white culor, suft, and, when nut engaged in feeding, it lies coiled in a semicircle : they have six scaly feet and a scaly head. subsisting at first unon the magazine of food which the mother has provided in the offal in which they are enveloped, they afterwards penetrate into the earth, and feed upon roots. It requires a year or two for their perfection : they are then transformed into nymphs; and another year passes, before they are ready to become perfect insects.

The Lameldiconses consist of ten families, each presenting some peculiarity in the antenna, mandibles or maxilla, ly due attention to which the student will be able to determine the position an unknown insect may uccupy. The first of these ten families is 


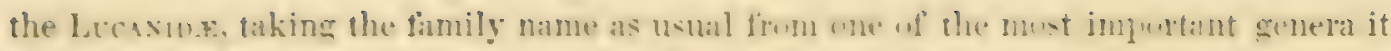

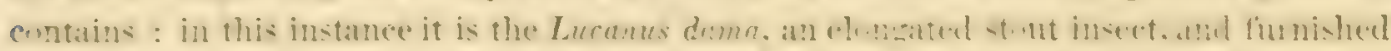

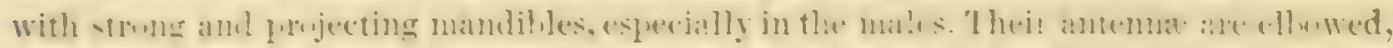

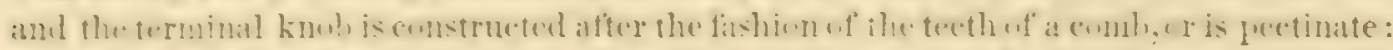

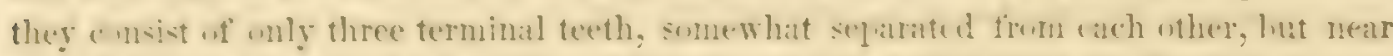

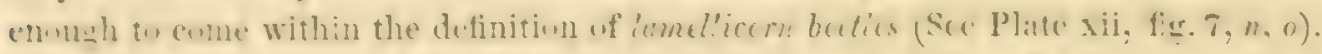

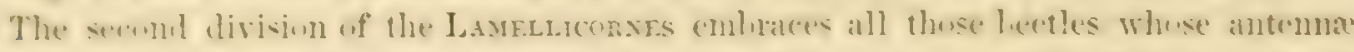

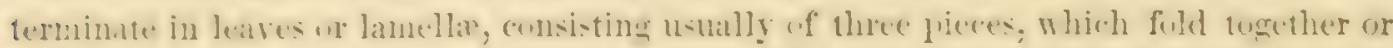

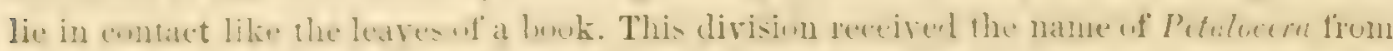

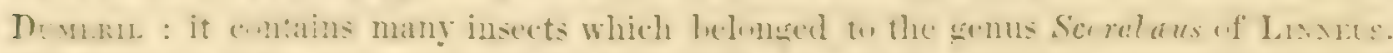

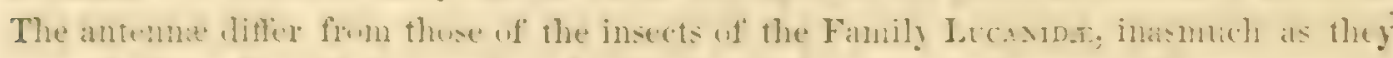

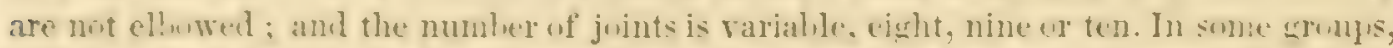
the males are remarkable for their aplendages unw the heat or therax, either in the form of horns or grofulerances. some of the largest insects ledeng to this division.

The halits of the insects of this division are rarions : some, and publully the majority,

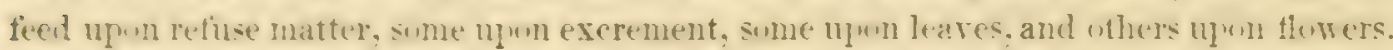
Their larre are consplewous fin their size : they are of a sift cuncistence, of a whitish color. and furnished with strung mandilles. We find them in the vegretahle mo uld, usually chiled. ur in derayine lugs. They have fourteen rines including the head, and the rings or segments are transtersely grooved.

Fren the diversity of character which exists in this great diri-ion, it has heen sul..livided

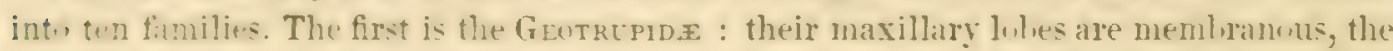
mandit? Their antemme have ten or eleven juints; and their budies are gluluse, wr thick and nore ur las romited and full. Their halits are peculiar : ther feed upon excrement, though some are said to feed upon roots.

The Sidrab.EIDE constitute the serond family of this creat division. They are furnished with a the dlike extension in front, the clypus, which extends over the moth; ant their antenum are eight-or nine-juinte- with the end terminating in a three-leared chlub. The middle luras are inserted mure wiclely arart than the whers: the posteriur legs are far hehind; the seutellum is n't present; and the elytra are shortened behind, leaving the abdomen eximsed. The claws are minute, and the anterior tibia are expluded and tri-

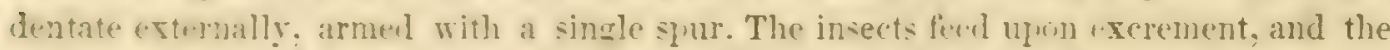
the erreater propwrtion of the fanily resile in warm clinates. They are many of them hallroller: and to ad them in this mork, their hindlecs are lone and inverted far behind, which grim them a grotesue appearance when walking. They lly mully ly day. (Plate xii, figs. 5, 7.)

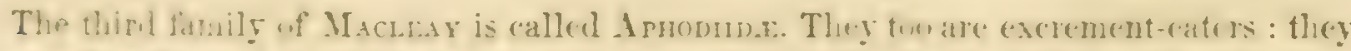
are orit an! rumbled at the preterior extremitr. In this fanily we fiml the minute instead 
of the large beetles, and they belong to temperate climates : the legs are placed at equal distances apart; the scutellum is distinct; the clypeus is entire, and the antenne are nine-jointed. The body is more elongated than in the former family.

The fourth family is small, or of a moderate extent : it is the Trogrde of Macheay. The insects are of a medium size, ovate or gibbous, and the elytra are inflexed at their sides. The scutellum is distinct, and the anterior tibie are imperfectly toothed. The head is deflexed; thorax short, posteriorly situated, and the anterior angles are advanced : the elytra are rugose. (Plate xxir, figs, 1 \& 3.)

The fifth family is the Dyastide of Macleay. The insects of the family are gigantic, and the males are very strongly identified by prominences and horns upon their heads or thoraces. The jaws are powerful, horny and prominent, and furnished with two teeth; the scutellum is distinct; the antennæ are ten-jointed, and the elytra are shortened behind, leaving the abdomen exposed : the color is a rich chestnut-brown. The insects reside in rich vegetable matter and in putrid offal, and the family belongs to tropical regions.

The RuTrume constitute the sixth family, which, for the most part, are brilliantly colored. The males are destitute of horns, in which respect they differ from the preceding family. The antennæ are ten-jointed, club three-jointed : the mandihles are short, but project more or less from beneath the eoriaceous labrum; they are also notched on the outside near the tip. The elytra do not cover the abdomen.

The seventh family is allied to the preceding : it has received the name of AroploGNATHID, and is composed, like the DrNastide, of foreign species.

The eighth family, the Melolonthide, constitute a well-known group, which contains numerous indigenous species, with furms as delineated on Plate $\mathrm{x}$, figs. $4-6,9$. They are orate thin beetles, sometimes scarcely thicker behind than before. The labrum is divided into two lobes trausversely ; the mandibles are strong and horny, the internal margin acute at the apex. The clypeus is separated by a transverse suture, which runs just before the eyes : antennæ 9 -10-jointed, terminated by a knob composed of a variable number of laminæ (from $3-7$ ), variable also in form. The anterior margin of the mentum is notched or emarginate. Some of the species are large; but the colors are not brilliant, the surface heing often pubescent and dull. The common horn bectle, or the goldsmith beetle, which fly about in the evening in the months of June and July, may well represent this family: they feed upon flowers or leaves, and are sometimes injurious in this way.

Passing the Glaphyrids, the winth family, which are all foreign to us, we reach the tenth and last family, the Ceтолде, a group which holds about the same place in the scale of importance as the Mecolonthide. The antennæ are ten-jointed : the labrum is eoncealed beneath an emarginate clypeus; the mandibles are comparatively slender, lanceolate; the menturn is pitcher-shaped, and conceals the lahium; the scutellum distinct: the elytra do not cover all the abdomen. The insects feed upon flowers, and hence do considerable mischief : their forms are delineated on Plate xii, figs. $4-6$.

[Agriculturai, Report-Vot. V.] 


\section{CLAVICORNES.}

\section{Byrrhidx.}

No species of this family have been fonnd in this State.

\section{IIisteridx. \\ Hister CONFORMIS.}

(Plate xxxi, fig. 8.)

Color liack: thutax bluish hlack, smooth, polished; elytra withouf punetures, striate: strie obsolete. Length one-tenth of an inch.

\section{LAMELLICORNES.}

\section{Lucanidie.}

\section{Genus LUCANUS (Lins.).}

"Depressed manditles of the male very large; female noderate : club of the antenna ' four-jointed, pectinated' (WEstwood).

Lucanus daMa (Fab.). L. capriolus (Linn.).

(Plate xii, fig. 7.)

The insect is litre, dark chestnut-brown, smooth and plain; thigl:s lighter : mandibles of the male long and lwwerful; female less powerfin than the male. Length about $1 \frac{1}{4}$ or $1 \frac{1}{8}$ inch.

The male Iancanus may he reconnized by its large and tonthed mandibles, which stand cut su prominently in firnt. The female differs from the male in the smallness of its hoad, which is partially encealed heneath the Jabrum and the ohlique truneation of the lateral margin of the thorax. There is a considerable rariation in the size of the individuals. It is nut an uncommon species in Sew-Juk and New-England. The larva inhabit the trunks of decaying trees, or in wood.

Platyceras piceus.

(Plate xii, figs. 10, 11.)

The Genu= Platrceisas belongs to this wroup. The mandibles are shorter than those of the Lucswos, in both sexes : it is also a much. smaller insect.

Colo hown : elytra distinctly punctate; suandibles exert, and each sbows a strong curved sulcentral twith : in the female, the mandibles are shorter and less conspicuous. Length from one-half to six-tenths of an inch.

Fig. 10, male; 11, female, with mandibles, antennæ and an elytrum. 


\title{
Geotrupidx.
}

\author{
Geotrupes - - (Plate xii, fig. 2.)
}

Color hrilliant steel-blue; heneath, clothed with yelluwish brom hairs. Clypens rough, with a central pointed tubercle (the thin elge of the clypeus is turned up in front); thorax smooth and shining upon its top, lut confluently punctured at the margins; elytra marked with numerous punctate ridges. Length five-tenths of an inch.

This species I hare been unable to refer to its proper name. "The $G$. microphagus is dark piceous above and beneath, and the legs are violaceous."

Geotrupes splendidus.

(Plate xï, fig. 3.)

Splendent green; purplish beneath. Thorax rather thick] punctured, and confluent on the sides; scutellum sinooth, on with two or more punctures; elytra subtuberculated near the outer basal angle, angle somewhat rounded, and their surfaces are marked by rounded ridges punctate in the groores : body beneath clothed with brown hairs. Length six-tenths of an inch.

\section{Genos COPROBIUS (Latr.).}

Body ovoid; thorax dilated in the middle; scutellum none; abdomen nearly square; clypeus bidenticulated.

\section{Coprobios hevis.}

Medium size : eolor dull black, finely punctured; elytral lines obsolete. The insect has a submetallic hue in some lights, but is generally dull. There are about eight obscure lines upon each elytrum : beneath, the body is naked, or destitute of hairs.

This insect is more common here than the Geotrupes. Common in June and July, when they may be seen engaged in rolling a ball of dung containing their ora, and which they finally bury.

A TEUCH"s sacer is a much larger insect, belonging to an allied genus, and is the sacred Scarabcus which entered so largely into the mythology of Egypt.

All these species fulfil an important place in the economy of creation; a fact which is more obvious in tropical regions than in the north. 


\section{Scarabieidie.}

\section{Genus ONthophagus (Latr.). Copris (IIl.).}

buly hablly wate, short, depressed : last joint of labial palpi evanescent; clypeus wider than long, emarginate; scutellum none.

OnTHOPHAgUS hecate.

(Plate $x \times x i$, fig.4.)

Small : lark brown, covered with white hairs, which give it a hoary appearance. Shield lather puinted and turned up; thorax terminated in a prominent plate, turned up at the angles; legs ciliated.

Osimophagus ovatus.

hitther small. wrid. brown, smoth alwre; hairs syarse upon the legs and beneath. Shield marked with two parallel sharp transverse ridges.

\section{Genus PHANaUS (Mc.)}

bisial articulition of the labial palpi larger than the others, and dilated at its internal "dere : scutellum none, but its flace is occupied by a small triangular extension of the thrax. Vales furnished with tuhercles or horns upon the clypeus, and prominences upon the thorax.

Phaneus carnifex.

(Plate xii, fig. 5.)

kather short, wile : lytra shorter than the head and thorax; shield with a single or

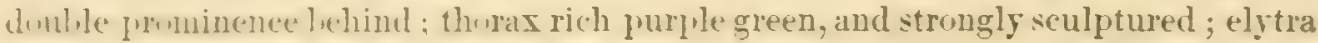
rich furnle-green, lunctated and ridged; beneath green; ulper surface of the legs purple.

The males are smaller than the fimales, and the clypeus is armed with a long and strong horn Ininting hackwark : in fomales, it is merely a tuhercle, or way be two close tugether. The throras wi the male presents a hrud, flat, nearly semilunar punctate disk. Length seven-tenths of an inch.

Occurs rarely in the vicinity of Albany : common in Maryland.

\section{Gexts APHOdís (Ill.). Copris (Ol.); Scarabeus (Linn.).}

Twaninal artirulation of the palyi cylimdrical; mandibles destitute of a corneous torth or lobe; form of the body gibbous.

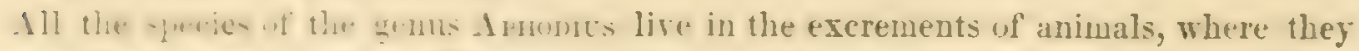
wert witen in ereat mumbers. Ther are small insects, about one-furth of an inch in length, 
of a cylindrical form : some of the species are spotted, or variously colored. During the days of autumn they take wing in great numbers, flying sluggishly through the air. In Europe, Lethrus cephalotus is said to derour the tender shoots of plants, particularly of vines; but this seems to be an exception to the habits common to the family.

Aprodius BICOLOR (S.).

Quite small, brown or black-brown; legs and beneath light fuscous : head and thorax finely punctured; edges of the elytral ridges finely notched; clypeus widely emarginate. Length one-fifth of an inch.

Aphodius strigates.

Small : head and thorax rery finely punctured, black, smaller than the preceding, obtuse at buth extremities ; clypeus convex; feet dark piceous ; posterior angles of the thorax rounded.

Aphodius terminalis ( S.).

Small, brown or blackish brown, shining : forelegs hairy; tips of the elytra and feet rufous ; clypeus trituberculate and emarginate before; thorax marked with subequal punctures; elytra marked with punctured striæ.

Aphodius copronimus (M.).

Quite small, light brown, shining : thorax rather mottled with darker brown, rery finely punctured.

Aphodius feworalis (S.).

Blackish lrown : edges of the thorax dilated and light brown; elytra fuscous and lighter in front; thighs light and translucent. Scarcely one-fifth of an inch in length.

Aphodius aterrimus (M.).

Small : thorax black; elytra dark brown; brown beneath.

Aphodius serfal.

Bromn : head finely punctured; thorax dark brown; elytra light brown and spotted, three in front, banded in the middle.

\section{Gexus COPRIS (Geoff.). Scarabeus ( Limn.).}

Bod 5 urate, thick and conrex; knob of the antennæ terminating in three leares; four hindlegs dilated and truncated; scutellum none; articulations of the labial palpi three : the first joint is cylindrical, and not dilated at the internal side. 
Copris carolines.

(Plate xii, fig. 8.)

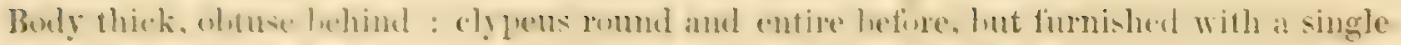

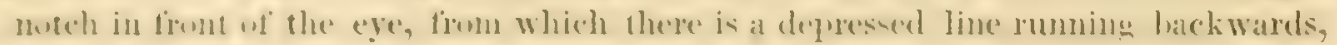
aud terminating at the base of the tubercles, the middle of which is much the most prominent and pointed. The front of the thorax rises into a strong serrated ridge, and there are two lateral rounded depressions : the puncta are fine, and the posterior part is smouth, and marked with a slight central furrow which does not reach the elytra. Elytra strongly furrowed, and punctate. The abdomen appears as if truncated. The color is dark chestnut-brown : body beneath clothed with reddish brown hairs; the margin of the thorax is ciliate. The dilatations of the tibia are similar to fattened fummels : the tibia of the forelegs are thick. and have find strong notches upon their outer edges. Length one inch.

This heetle is commom in Virginia and Maryland, lut I have not ohscrved it in New-

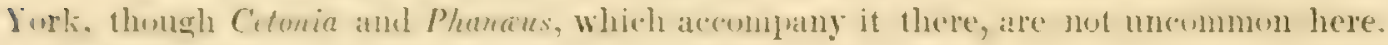

This insect does not roll uy a ball, but makes a collection or heap of soft and fresh

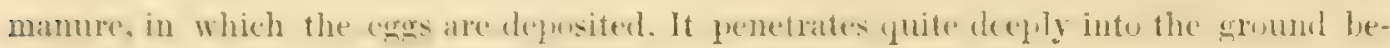
neath the droppings in pastures and by the roadsides.

\section{Trogidae.}

Turs is a family emharing hut a few genera : they are ovate and gillkse, with inflex elytra. The head is dellexul, the thomax short and transverse, and the surface of the clytra rmuh. The antemna are nine-or ten-jointed, and the extrenity is formed of three leares somewhat distant from cach other : the lahrum is coriaceous and exserted ; the lahium is concealed by the mentum; the mandibles are horny, and sometimes toothed.

This family is allied to the cisorseruaz. The most reliable information is that they feed u!n earrion. or desaying animal matter, being found in the carcases of deat animals :

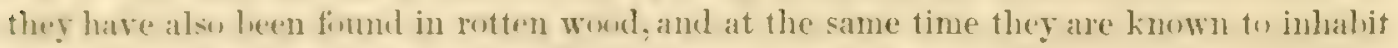
sandy places under ground. Some of the family are apterous.

\section{Genus TroX (Fabr.). Scarabeus (Linn.)}

Antennæ ten-jointed; body subovate, convex; thorax rugous.

Trox porcatus.

(Plate xxiv, fig. iii.)

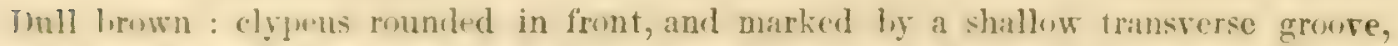
anculaterl in the midelle, with small pointed tuluereles on the line of flexure; therax widely growed in the midelle ; rlytra traversed ly a serienof reticulated lines, firming a symeres of urtwoth upun their surfaces aud angles hehind. Length half an inch. 
Trox capillaris.

(Plate xxiv, fig. 1.)

IBrown, duls : elytrat traversed by several rows of pointed or sharpened tubercles, standing between the fine parallel lines. Length two-fifths of an inch.

\section{Dynastidae.}

Turs family embraces the most gigantic heetles known : the genera are also numerous. The antennæ are ten-jointed : the first is robust, conic and hairy; the second, subglobose ; the next five are short, and the head is composed of three laminæ in contact. The clypeus is frequently horned, as well as the thorax : head subtrigonal; elytra truncate, leaving the end of the abdomen bare. The boty is large and thick, the legs strong; tibire broad and dentate.

This singular family have some of the habits of the Geotruprde : that of subsisting apon and in the excrement of animals, and decaying refuse matter from the vegetable kingdom.

\section{Melolonthidae.}

\section{Genus Serica (Macleay). Scarabeus (Limn.).}

'Form ovate. Antennæ ten-jointed : basal joint the largest; the second the next, and the 'claws bifid : last joint of the palpi subacute' (Westwood).

Serica vespertina.

(Plate xxiv, fig. 9.)

Color light chestnut-brown, uniform : body small; wider behind.

Trichinus (Trichits) viridars.

( Plate xxiv, fig. 5.)

Color of the head and thorax green : elytra obscurely striped; margins marked with dark spots; disls ferruginous, truncate, exposing the abdomen, punctured and marked by longitudinal lines; abdomen hairy.

Trichinus ASSIMilis.

Colur black, hairy and glossy. Elytra marked near their bases with a light brownish patch, from each outer angle of which proceed two white oblique lines that nearly reach the margins; and from the inner angles, two other white lines arise, which run parallel with the suture, and do not quite reach the truncated extremity : there is also an obscure line parallel with the last, and about half as long, which may not be coustant. Posterior segment of the abdomen clothed with a dense coat of yellowish white hairs: abdomen below shining, and less hairy than the breast. Length rather more than one fourth of an inch.

Found in Western Massachusetts. 


\section{Genus PHyllopitaga (Harris).}

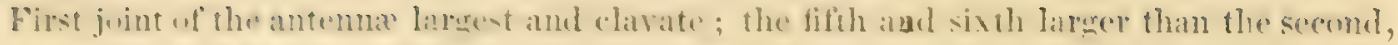

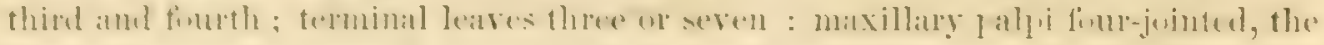
fourth long and ovate : clypeus divided by a transverse suture bef re the eyes:

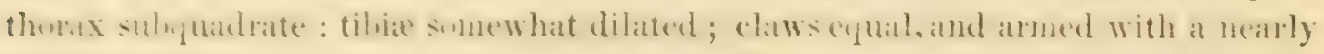
central tooth.

Phyllophaga quercina.

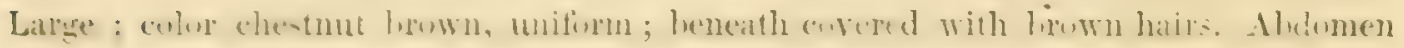
naked; labrum rounded before, and punctured; elytra punctured, and their tips separated behind. Length about eight-tenths of an inch.

Phyldophaga drakil.

Iarge : colur rather lighter hwow than the preceding. Lahrum traversed by a line dividing it into two unequal parts : rings of the ahdomen finely punctured.

This species is rather larger than the quercina : length alwut nine-tenths of an inch.

\section{Phyllophaga hirticula,}

Suticed ly I)r. Hakirs, is of a haty bown color, with punctures latger and more distinct than thuse upm the quecina, and, wh eatch wing-corel, the hair's are arranged in three lines. Length seven-tenths of an inch.

Appears in June and July.

\section{Phyllophaga georgicana.}

Sulfice wored with short grayish yellow hairs. Iength seren-tenths of an inch.

It occurs in New-York.

Phyllophaga pilosicollis.

(Plate xxiii, fig. 7.)

Color fule reddiwh hown : hairs longest upun the thorax and base of the elytra. Anterior ertar of the head entire, rounded and deflected, puncture dilated and shallow; lateral enlae w the thorax dilaterl in the middle : elytra pale, testacems, densely and efually functured, and corered with short procumbent hairs. I.ength half an inch. $\mathrm{S}_{\mathrm{AY}}$.

\section{Phylophaga rariolosa (Knoch.). Melolontha variolosa (Hentz).}

This ineres differs essentially from the foregoing in the form and strurture of the antennie. the kmul comisting of seren curved elongate laves. Its enlor is light brown, with irresular depressions upm the elytra, which alpear like aceidental flexures or indentutions ande by some extemal force : it is clothed with long yollow hairs upon the hestot. The rly lons is extemderl and reflexed, and the sutural line is hefore its middle. 
The hairs, both upon the thorax and elytra, are arranged in four rather interrupted longitudinal belts. Length eight- to nine-tenths of an inch.

This species I had not observed in the vicinity of Albany till this year, 1853 : many individuals have been taken.

It may be remarked that most of the species of this genus are much alike, although generally smaller than that figured. The color varies from yellowish brown to chestnut, according to the species. The breast is more or less hairy, and the elytra are in some cases sparsely furnished with erect hairs. In the larva state they feed upon the roots of grass, and probably of grain, and thus they commit great havoe upon pastures, whilst the adult insects live upon the foliage of various plants.

These beetles are well known in the country by the name of hornbugs, and become troublesome by flying into the open windows where a lamp is burning. Their proper name is May bectle, a designation implying the time of their appearance among us. They are injurious both in their larva and perfect states: in the former, by their depredations upon the roots of grass and other herbage; and in the latter, by the destruction of the young and tender leaves of fruit and other trees. They are supplied with strong jaws for entting the leaves of plants, for which they are admirably fitted; and their feet are strong, and fitted for digging in the soil after their transformations are effected. They were furmerly included in the Genus Melolontha.

Maybugs have rarely been sufficiently numerous to inflict serious injury upon the farmer : the Hon. Mr. Bariow, however, records an instance where they did much damage in Madison county, in 1849 and 50 ; they ate the leaves of the cherry, elm, apple, butternut, etc., showing that they are by no means restricted to our cultivated fruit trees. The must effectual method of destroying them was to kindle fires at night in the imnediate neighborhood of the trees they were injuring : attracted by the light of the blaze, thousands were destroyed with little difficulty, or at a trifling cost. Shaling the trees to dislodge them, was an effectual means of turning their attention to the light. They arpreared the last of May and first of June, and continued from eight to twelve days.

Another instance is related by Dr. Firce in the Journal of the New-York State Agrieultural Society, where the Phyllophaga quercina appeared in great numbers and suddenly. He states that on the farm of MiLo InGALSBE, an orchard, consisting of about seventy plum together with many eherry trees, had their limbs stripped of leares, luds, ete. while they were in bloom : the bugs were hatched out in the course of two nights, and completely destroyed all hopes of fruit for the season, even if the trees themselves survived defoliation.

The duration of the individual life of this insect is short, a week or two being the term during which it lives : there is, however, a succession of individuals of the species, so that the period which they remain is more than a month. After the pairing of the sexes,

$$
\text { [Agricultural Report - Vol. ע.] } 10
$$




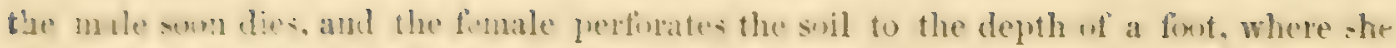
depwits heregrs: they are then abankmed, and she refurns to the surface to remain a

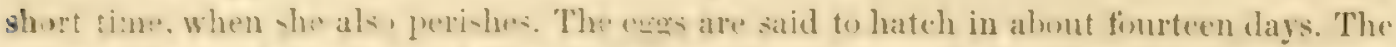

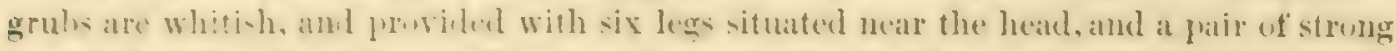

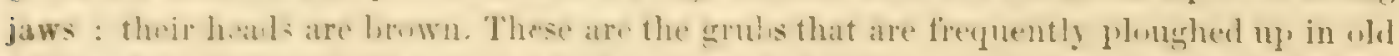

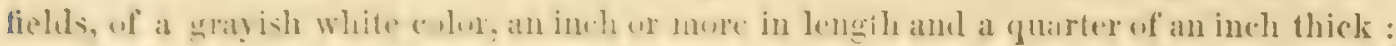

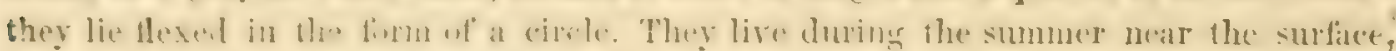

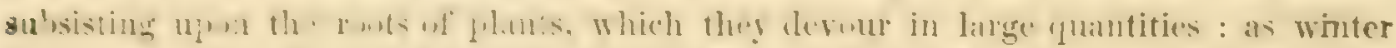

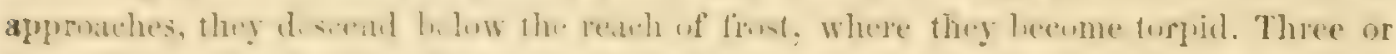

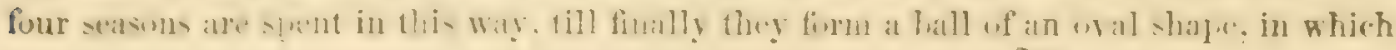
they enclose themselves and undergo their transformation.

The ravages of this grub may be much diminished by allowing crows and jays to

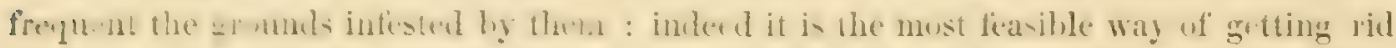

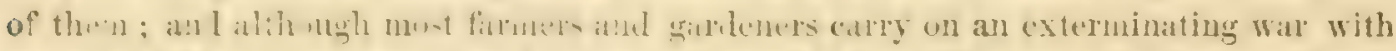

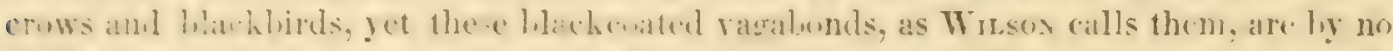

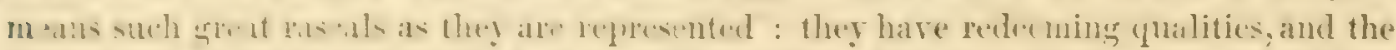

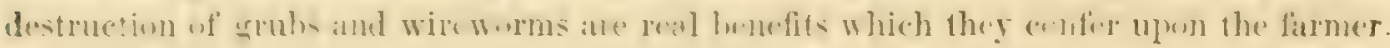
The beetles themselves are deroured ly skunks.

The bsetles of this genus have been rely aloundant at distant intervals : almost incredible accounts are given of their numbers, especially of the European specirs.

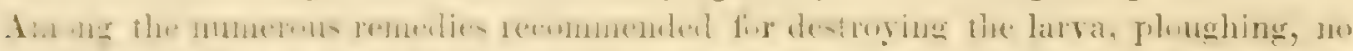

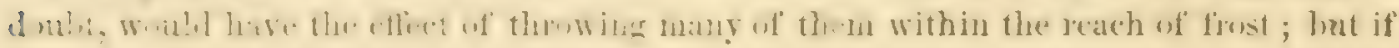
d ine too carly, they would have time to bury themselves again. The larva and perfect

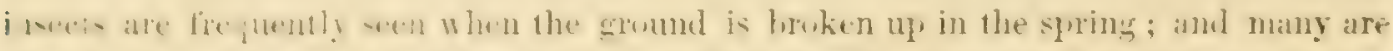

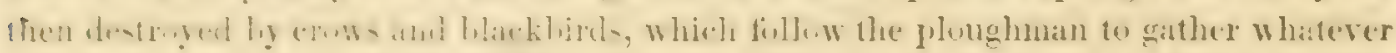
may be exposed suitable fur their sustenance : they are also destroyed by foxes, weasels, owls, and, according to Dr. Harris, the skunk.

The fullowing extracts are from Locdox's Magazine of Natural History, Vol. vi, p. $142-4$ : the rook is a species of crow.

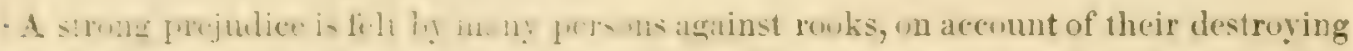

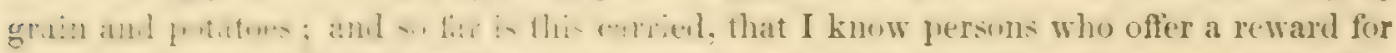

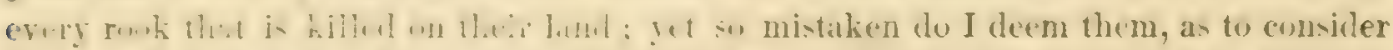

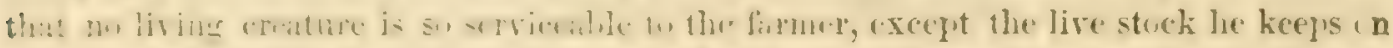

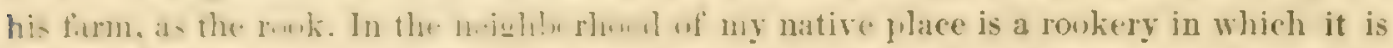

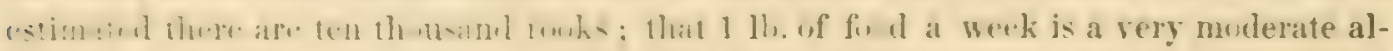
1) Wance for each bird; and that nine-tenths of their food consist of worms, insects, and

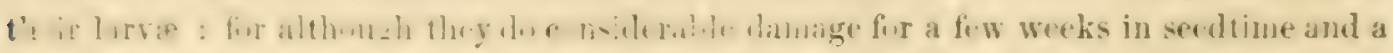

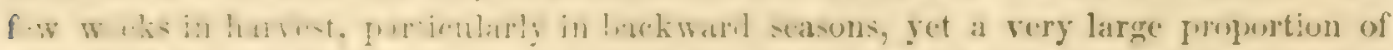

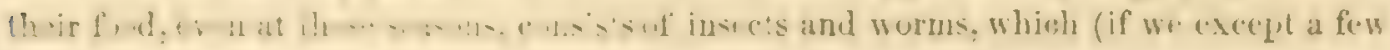


acorns in antunu) form at all wher tirnes the whole of the ir sul, istence. Ifere, then, il my

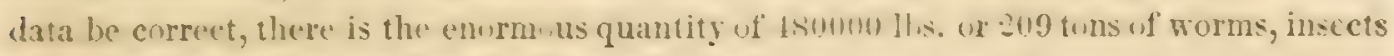
and their larva, destruged hy the hirds of a single roukery : and to every one who knows h w very destructive to vegetation are the larve whe trilesul inects (as well as worms) fed up, n by rooks, some slight idea may be formed of the devastation which rorks are the weans of preventing. I have understerd that in sullolk. and in sume of the sonthern counties, the larra [ of insects allied to Lachnoverma ] are si cecetingly alundant that the crups [of graiu] are almost destroyed lig them, and that their ravages do not ecase eren when they have attained to a winged state. barins plans have leen puenesed to 1 ut a ston to their degredations: but I bave lit? le bu uht that their alundance is to be attributed to the searcity of rouks, as I have somm here seen an arcount that jouks in those comities are not numerous.

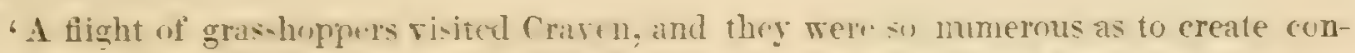
siderable alarm among the farmers : they were, homever, som reliered from their anxiety;

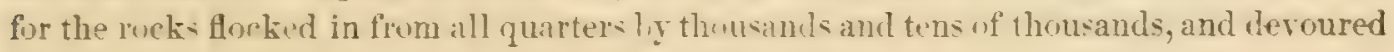
them so greedily that they were destroyed in a short time.

- It was stated in a niewsprer a year or two hark, that there was such an enormous quanty of eaterpillars upon skiddaw, that thes dievourel all the regetation on the mountain, and people were alprehensire that they would attack the cros in the enclused lands; but the ronks, having discorered them, in a very short time put a stop to their ravages.

- An extensive experiment apnears to have l cun made, the result of which has been the opinion that farmets do wrong in destroying ronks, jays. span rows, and indeed binds in general, on their farms, particularly where there are i rchards. That binds do mischief occasionally: there can be no doubt; but the harm they d., in autumn is ampls compensated liy the gurd they do in snring, ly the destructire haroe they make among the insect trikes. The cuantity of grubs destrored by rooks, and of faterlillare and their grubs by the various small birds, must be annually immense. Other tribs of hirds, which feed on the wing, as swallows and martins, destroy millions of winged insects. Eren scme, usually suppused to be so mischerous in gardens, have actually heen prored only to destroy those ?uds which erntain a destructive insect. Ornitholugists have of late determintel these fir.ts to lie true; and officers would do well to consider them, before they Waste the [mb? in ney in paying rewards to idle hoys and girls for the heads of dead birds. which only enewrages children and other idle persuns in the mischierc us employment ut fiwling. in some very large farms in Eeronshire, the proprietors detcimind, a

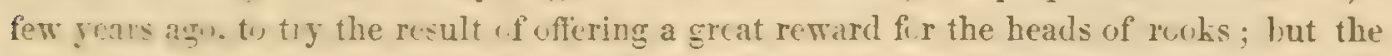
issur Ir ived destrue ire to the farms, for nearly the who'e of the crops failed for three sureweng years, a d they have since becn forced to impert rcolis axd other birds to re-stccks their farms with.' 
Areoda lanigera.

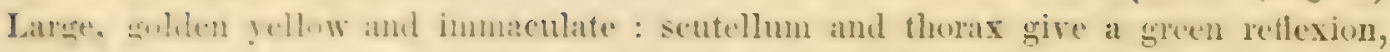

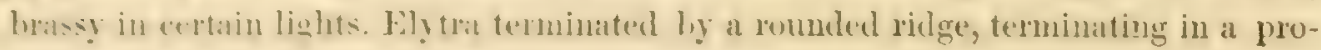
ninence behind, densely haired beneath.

It is whe of the nust commun and heantiful leetles of this comtry. It talies its specific

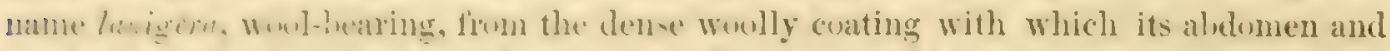

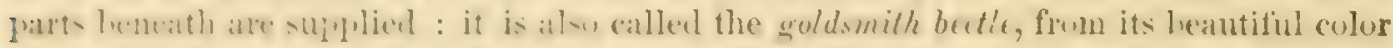

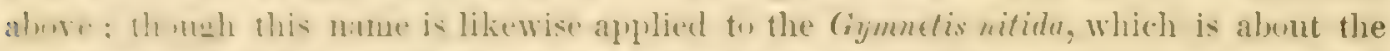

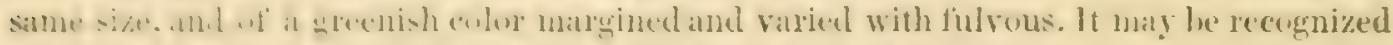

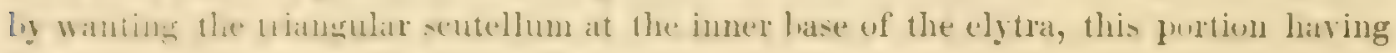
no apparent juncture with the prothorax.

The Areorla is about nine-tenths of an inch long, broad oval in shape, of a lemon-yellow

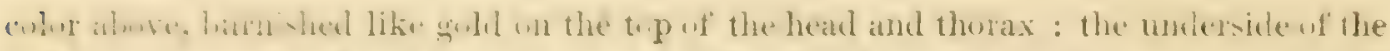

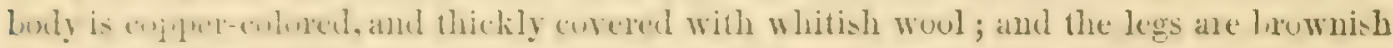
jelluw, or brassy, shaded with green.

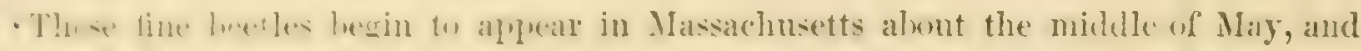
continue senerally till the twentieth of Jume. In the morning and exening twilight they cme forth from their setreats, and tly aluent with a humming and rustling reund among the branches w trees, the teuder leaves of which they devour. Pear-tress are particularly

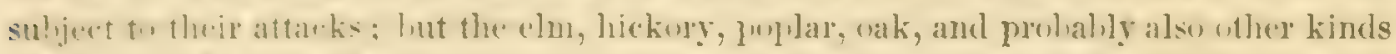

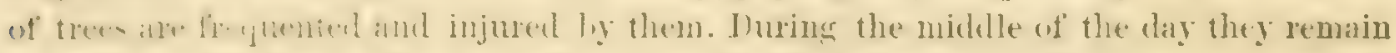

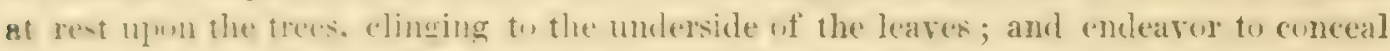

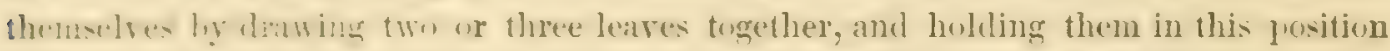

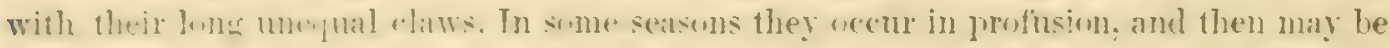

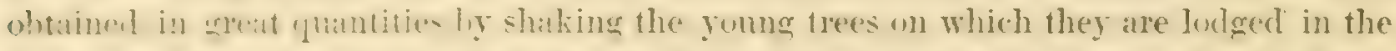
daytime. as they do met attempt to fly when thus disturhed, lut fall at unce to the ground. The larrar of thene ineets are not known : probahly they live in the ground, upon the roots of plauts.' Harris's Report, P. $22-3$.

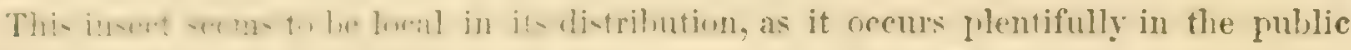
squares of Philadelphia, whilst it is rare in the interior of Pennsylrania.

\section{Pelidiota pixctata.}

(Plate $x$, fig. 6.)

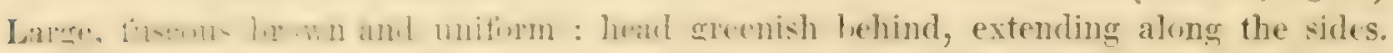

Sides of the insert marked with four black spots, one upon the thorax, and three upon the clytra and standing in a lime; beneath, the color is green, glossy or submetallic. The rings of the ahdomen are marked each with a single row of punctures.

The $P$. prenclata is a fine beetle, with elytra of a pale brown or tile-color, and marked

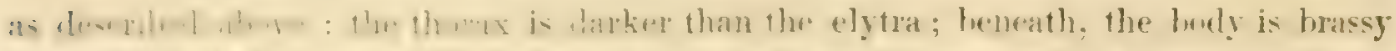

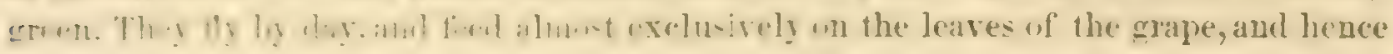


may prove injurious to the vine : still their numbers are rarely such as to render them a formidable tive. The only mole of destruying them, which is recommended, is to fick them off and crush them under the foot. The larvæ are scarcely injurious, inasmuch as they live in rotten wood, as stumps of trees, and such trunks as are decaying upon the ground: they may be regarded rather as beneficial, hy aiding the entire destruction of that which only cumbers the ground.

The perfect insect prevails during the months of July and August.

P. macuiata, an allied species or variety, has the legs and extremity of the abdomen of the same color as the upper parts. 'These beetles fly by day, but may also be seen at the same time on the leaves of the grape, which are their only food : they sometimes prove very injurious to the vine. The only method of destroying them, is to pick them off by hand, and crnsh them under foot. The larvæ live in rotten wood, such as the stumps and roots of dead trees, and do not differ essentially from those of other scarabæans' (Harris, p. 23). In the variety which Dr. Melsiemer has designated impunctata, the spots are absent.

\section{Genus CREMASTOCHEILUS ( К косн).}

Thorax quadrangular, anterior angles prolonged; first joint of the antennæ dilated: mandibles terminating in a strong curved or scythe-like tooth, and furnished with small spines in place of the internal lobe; last articulation of the palpi long and cylindrical : mentum a reversed heart in form; upper angles rounded, without emargination (Rềgne Animal).

Cremastocheiltes hentzir.

(Plate xxvi, fig. 2.)

Color black; form quadrate, sides parallel; upper surface punctured : elytra ridged and coarsely punctured. The whole surface is clothed with procumbent hairs; beneath, they are stiff, or somewht spinous. Length one-half of an inch.

Osmoderma scaber. Gymnotus s. (Kirby); Trichius s. (Palisot de Beauv.). (Plate xii, fig. 9 ; and plate $\mathbf{x} \mathbf{x}$, fig. 5.)

Color black, or very dark brown and brassy. Body ovate, flattened; thorax round, dilated transversely, purplish, strongly punctured, and marked by two rounded ridges before; elytra deflexed at the shoulders and behind; surface sculptured, and rather rough than punctured; scutellum very acute : beneath dark brown, smooth and glossy; legs long, purplish; tibiæ trispinons upon their outer edges.

The female is larger than the male, and measures an inch in length; the male, about eight-tenths of an inch. The name Osmoderma, given by the French naturalists, is indicative of the odor the insect imparts to the hands when handled. They lly by night, and are common in New-England and New-York in the month of July. 


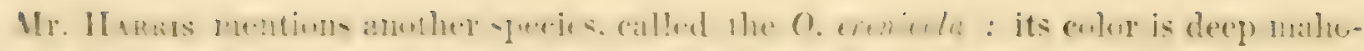

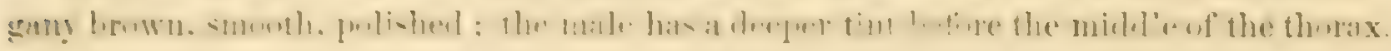

\section{Geris Dichelonicha ( Harris).}

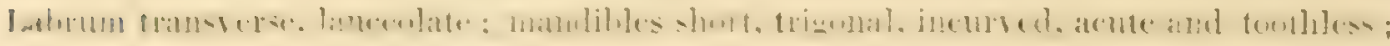
maxillæ miuute, linear, bidentate, tceth short; first joint of the palpi minute, the second longer than the third: antemne nime-jointed.

It is mire quadrangular and elongated than the frenus Macronactyus.

Dichelomycha elongata.

(Plate $\times x v$, fig. 1.)

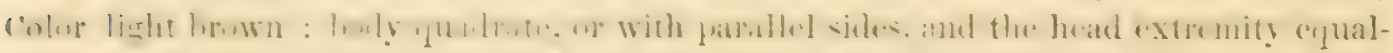

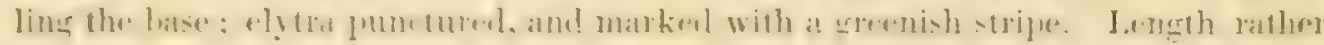
more than one-fourth of an inch.

\section{Gevus Euchiora (Macreay). Axomala (Mergerle).}

Euchlora coelebs (Gro).

(Plate xxiv, fig. 6.)

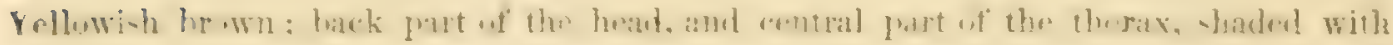
darker brown; elytra bordered with brown.

Var. atrata. Darker brown, nearly black (fig. 8).

\section{Geves HOPLIA (Illig.).}

'Antenna ten-jointed; claws simple, but unequal' (Wrstoon).

Hoplia trifasciata (S.).

(Plate xxir, fig. 4.)

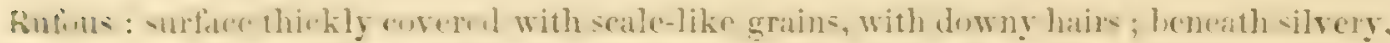

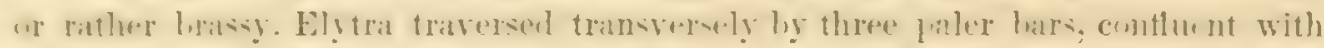

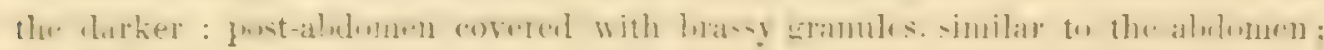
legs very long. Female darker than the male. Length one-fuurth of an inch.

Macrodactruus scbspinosa (Latr.). Melolontha s. (Fab.). (Pl. v, fig. 13.)

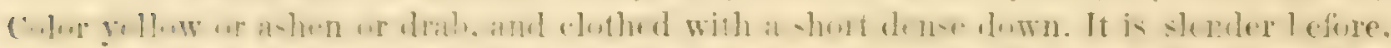

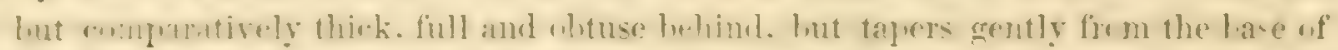

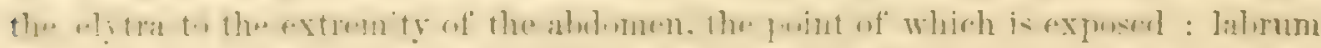

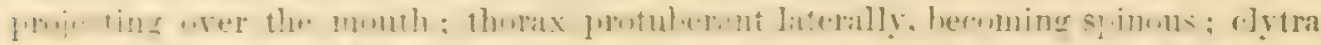

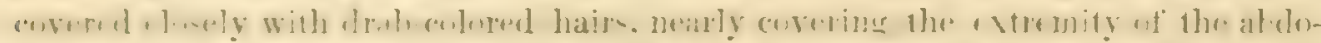

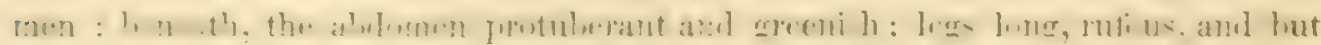

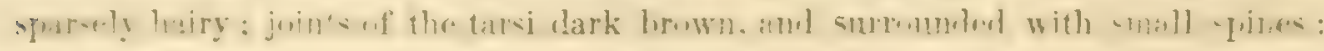
this is more conspicuous upon the hindlegs. 
The roscbug, or cherrybug. as it is called, is rery destructive. Its gencric nime Macrodactylus, is derived from the length of the feet; and its specific or trivial name subsyincsus, from an incipient spine or swelling upon the sides of the prothorax. It is of a dull yellow color, about three-eighths of an inch long, and appears in great abundance in the sir ring, destroying roses and the blosoms of various plants, as well as the folliage of firuit trees, including the apple, cherry, plum, and that of the grape.

Dr. Harris has the credit of being the first to give a satisfactory history of this insect, as published in his Report.

I have been in the habit of destroying this insect, as well as the Erioscma mali, or the applatec blight, by hand-crushing. When there is little w no grass leneath the nees, they may be beaten down and crushed with the foot; the best time being the morning, when they are somewhat torpid. They may be collected upon sheets, or in vessels with a little water to prevent their eseal e; to be sulsequently hurned or scalded. Plants infosted should be risited oner or twice is day, and erery effort made, hy destruction of the present brood, to diroinish that of the next season.

\section{Genes Cetonia ( Fab.).}

Antennax short, the basal joint largest and robust, glabrous; the head three-leared, elongated : palpi short, last joint cylindric tapering ; mandibles short ; clypeus quadrate, entire in front ; thorax subtrigonal; elytra sinuate at the outer margin near the base ; scutellum elongate and acutc; sternum produced and rounded anteriorly.

Cetoxis inda. Scarabcus indus (Lin.).

(Plate xii, fig. 6.)

Body ovate and rather depressed, pilose above and bencath. Clypeus deflexed and truncate : thorax subtriangular, sinuate before, centre of the sinus subdentate, broadly sinuate behind for the reception of the seutel; scutel an isosceles triangle; elytra light brown with black spots scattered over their disks and sides, margins sinuate, behind truncate, exposing the abdomen; legs hairy and brown; abdomen brown, glossy.

The thorax is more densely elothed with hairs than the elytra; the latter are sprinkled with suts anch dots which are nearly bluck, some angular, and others sinuate. Color of the abdomen and legs nearly uniform : the thorax is also spotted beneath the hairs; the sinuated base is naked and fusrous. Length six-tenths of an inch.

This insect appears twice in the season; first in March or April, and last in September: the latter, as Dr. Harris supposes, is a newly hatehed brood, as at no time during the summer is an indiridual to be found.

These insects appear upon various autumnal flowers, as the goldenrod, in search of pollen and hruey, and are fond of the sap and swet juices of trees amd plants. They are 


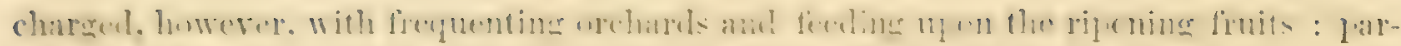

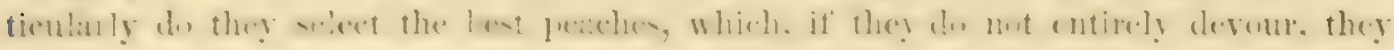

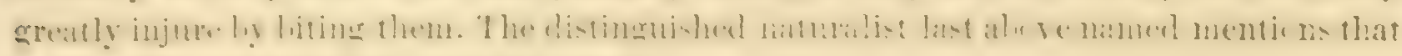
he has taken a dozen from a single peach.

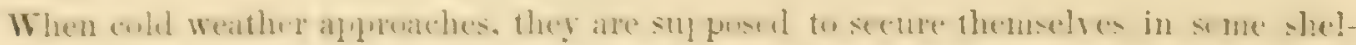

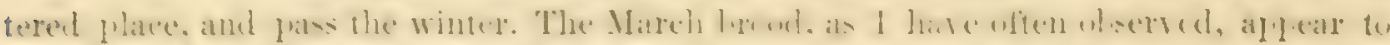

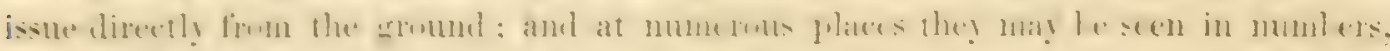

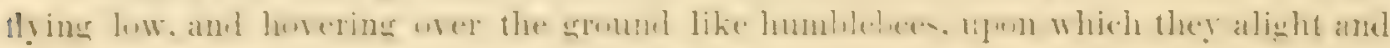
are lost in the dead grass and leares, or penetrate again into the earth.

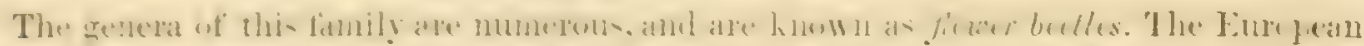

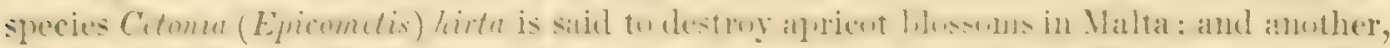

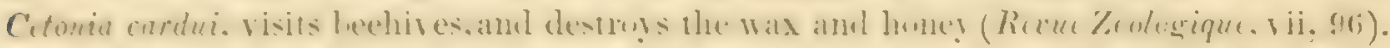

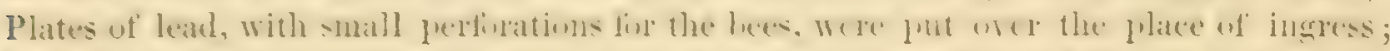

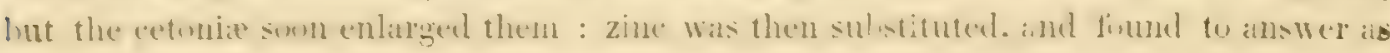
a protection.

\section{Cetonia flegida ( Fal. $)$.}

(Plate xii, fig. 4.)

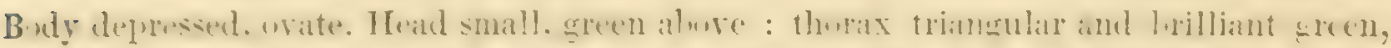
maroined with lutents: its sides alle also slichthly dilated; lase slightly sinums for the reception of the soutel. which is an isuceles triansle and areen. Elytra luteous,

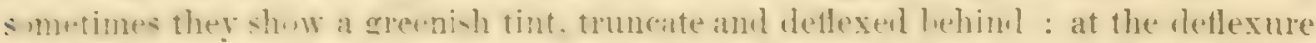

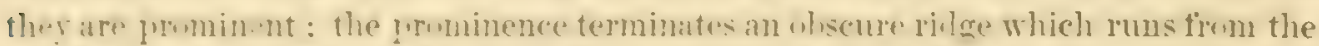

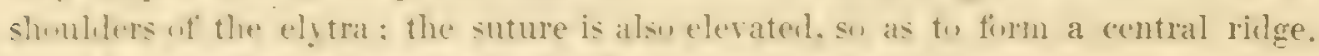

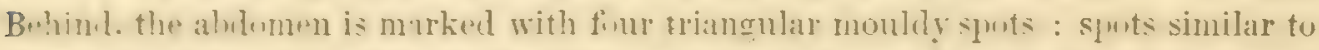

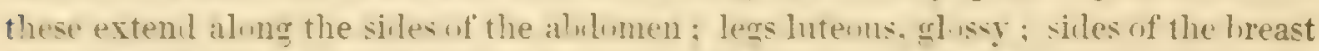
hairy; taris and have of the culits hwow, nearly lark. I.ength six-tentls w an inch.

This insect. which is rery common in Marylant, is nut rert numermis, as I have observed, in New-England and New-York : it is pure crinmon in the laths in groves than elsewhere. 


\section{CHAPTER VI.}

\section{ORDER I. COLEOPTERA (Continued).}

\section{PRIOCERATA.}

Tue next subtrile of pentameruus beetles is named Priocerata hy Mr. Westwood (Serricomu, Litr.). They comprise those fanilies whose antennæ are short, or only of a morlerate length, with an eyual thickness thronghout, and generally attenuated at the tip rather than thicliemed : they are eleven-jointed, hut their peculiar characteristic consists in being serrated upon their inside; hence the name servicornes by LATrerLLE : in the males, they are simetimes pectinated. The insect has two short robust maxillary and labial palpi : body elongate and narrow; elytra narrowed behind, covering the abdomen.

The Priocerata are divided into two sections, the Macrostemi and the Aprosterni, by WEstwood. The first comprises the old genera Buprestis and Elater, the consistence of whuse budie's is firm, and their forms elliptic and elongate, but narrowed behind : their legs are short, and either partially or wholly retractile; and their heads are short, and are received into a cylindrical excavation in the prothorax, or in front up to their eyes. The pectus advances beneath the mouth, and is also produced behind to a point.

These hectles, for leanty and splendor of coloring, are among the finest of the class of insects : they are rich in the metallic hues which ornament their hodies and elytra. They fly swiftly, but walk slowly, from the shortness of their legs. They make their escape, when in danger of being captured, by falling suddenly into the grass and weeds.

The Buprestide, or bupestrians, have an oval form, being widest behind the thorax and oltuse befure, but narrower behind and frequently acute : their bodies are also wider than deep, with a thorax mider behind than befure. The head, according to the typical character of the family, is sunk into the thorax up to the eyes : the antenne are short, and serrate on the inside. The thorax is widest behind, and fits rery closely to the base of the elytra. The legs are set widely apart, and are short, and hence their stand is firm : the soles of the fourth juints of the feet are furnished with spongy cushions, and the foot terminated with two claws : the scutel is small. The insects are rarely seen, except in hot sunny days, when they may be found on fences, limbs of trees, or sides of houses, basking in the sun : they never fly in the night.

[Agricultural Report-VoL。 v.] 


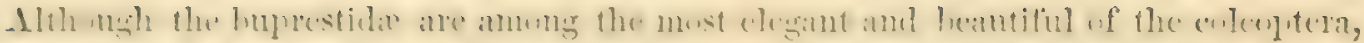

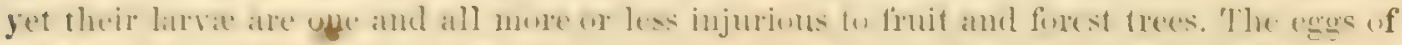

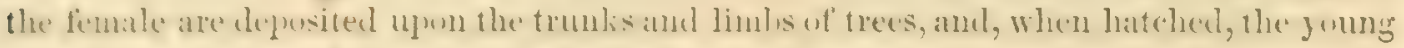

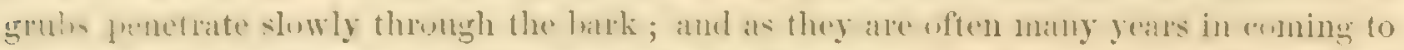
matrity, the and eppertunity in given lor extensive injury : it is here they molerge their transformation.

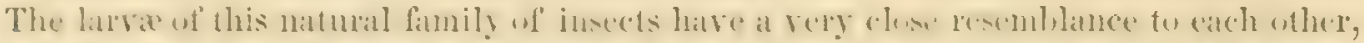

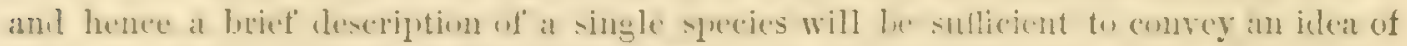
their general characteristics. These larva, them, are white or yellowish white, rather long, narrow and somewhat flitlened, and furnished each with a small hrown head sunk infor a sudenly and ahruptly widened out thorax, conveying at first view the impression that the heat is rery large, whereas it is only two or three of the list rings that ane thus sublenly widened ont and enlarged : the njerer jaws are surplied with thre biack teeth. The are are no lews or other apparatus for lecomotion, except two tulereles placed on the uncicr side of the secomel from the thobax. When drawn out of its hurew, the larra progereses loy a

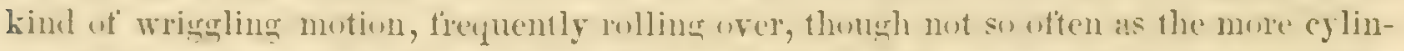
drical larra of the horing coleoptera. They are found loth beneath the lark and in the worl : under the bark, they lie partly coiled, or in the form of at semicircle. The pura bears a very close resemblance to the perfect insect : it is fimbl very near the outer surfice of the bark, so that when the transformation is complete, the insect has only to perforate a thin scale of bark to escape from its prison into open day.

The aaks, hickorites and pines are the kinds of trees most usually infected with the bupestrian larve; and, unfortunately, our knowledge of the ways and mens lyy which these larrie may be destroged are few and uncertain : the knife and wire are the only infillible means to remure them, when once they are in pussession of the premises. Our preventive means, however, in the case of fruit, are more eflectual ; such as scraping and washing the trunk and large limbs, at those seasons of the year when they are known to depusit their eggs. This kind of care and attention is rarely hestowed except in the spring, which, so for as the fimily of lurers is concerned, is perfectly ineffectual, as their eggs are laid in the montlss of June, July and August. The perfect insect, though it may feed on leares, is compraratirely harmless. There is, hwever, no provision which is so inportant to keep in check the ravages of these and all other insects, as the preservation and protection of birls. The womplyecker in particular deserves the protection of the farmer, inasmuch as it is eminently successful in detecting the presence of the larræ of the borers, as well as very expert in dragging them from their burrows. 


\section{Buprestidæ.}

\section{Genus BLPRESTIS ( Lins:).}

Antenna sulfilifirm, serrated in buth sexes; lasal juint elongate, subclarated; terminal one small. Palpi, maxillary subfiliform, the terminal joint slightly tumid; labial, minute, the linhum attenuated and slightly emarginated in front. Mandihles slightly bifid at the apex : maxillæ small, somewhat bilobed at the tip. Head deflexed, short, retuse : thorax with the posterior margin closely applied to the base of the elytra; the latter elongated, trigonate, entire or serrated : legs slender; tarsi with the penultimate joint bilobed (STEPHENs).

\section{A. Elytra dentate, and serrate at the apex.}

Büprestis (Chalcophora) Virginica (Drury).

(Plate $\nabla$, fig. 5.)

Form ovil : culor dark brown and sumetimes almost hlack, with brassy metallic reflections, more distinct beneath. Surfaces, above and beneath punctured; above, sculpturel in interrupted parallel lines. Top of the head deeply indented longitudinally; indentation linear, and extending to the front. Thorax marked by three distinct eminences, one of which is central. Elytra margined, sculptured or interruptedly ridged; base coarsely plicated; outer angle rounded and serrate; inner angle terminated by a very short spine : the under side is furnished with a short whitish down. It is nearly an inch in length, and quite robust.

The larrx inhalit pine trees, to which they are rery injurious. The perfect insect appears in June.

Buprestis fulvo-guttata (Harris). B. americana (Kirby).

Alure black bronze; underneath metallic, gloss, punctured. Scutellum rery small.

Thorar marked by waring transrerse lines. Elytra granulated and ornamented with six yellowish spots, but variable in number; tops rounded : underside of the abdomen, near the extremity, thickly punctured. Length 3- to 4-tenths of an inch.

The furelegs in this species are without teeth. It is the $B$. drummondi of the fourth rolume of the Fauna Boreali Americance.

Found upon trunks of the white pine in June.

Buprestis (Anoplis) fasciata (Fab.).

(Plate v, fig. 1.)

Flattened ahore. Color fine brilliant green, nearly of one uniform tint, punctured above and heneath. Mandibles stout and black : eyes black, orate : thorax has four slight depressions : scutellum small and triangular. Elytra finely lined, and marked by transverse yelluw hands : the first is a mere oblong transverse spot, near the middle; 


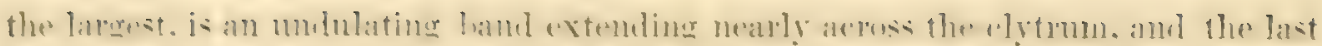

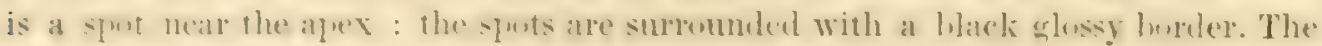
aper has a steel-blue reflexion, and is bidentate.

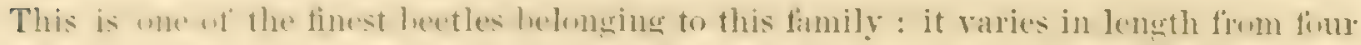
to six tenths of an inch. The hands are variahle in number : they are limml some with three, whers with twe, which is the must commen, and still amother variety has unly one.

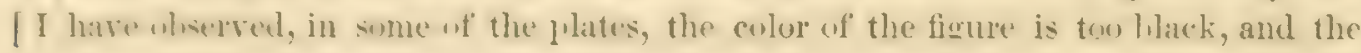
green too indistinct.]

BUPRESTIS

(Plate xxxi, fig. 11.)

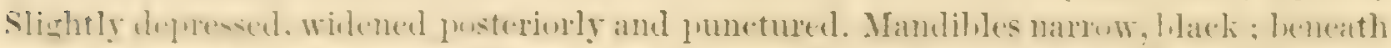

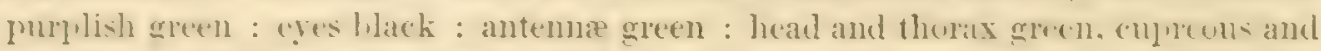
metallice Elytrat herdered with metallic purple; disk green, fimming a midelle longitudinal hand: alsu suarked with four elerated lines, trumcate, and terminated at the inner angle with a minute spine.

This heantiful species was foumd at Alhany : its elytra are finely bordered with puple : the sutural line is divided inte two near the hase, and is dotted between. It alpears to be rare, as it is the only one $I$ have seen in any of our collections.

Brprestis (Chry sobothris) dentipes (Germar).

(Plate $\mathbf{v}$, fig. 2.)

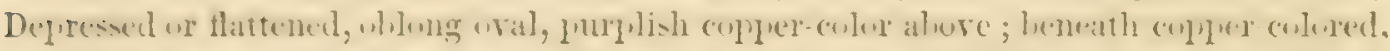

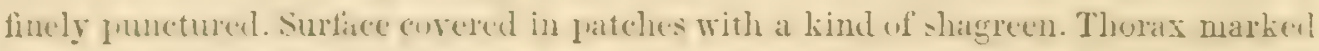
with two elevated lines : elytra rounded behind.

This sleces is still less convex than the divaricutu : its motallic hues are less distinct. it is de-titute of denticles at the apex of the wing-corers, its eyes are much smaller, and its month differently constructed. It inhal,its the different species of uals, and is mot finud alusut wur fruit wrehards or gardens. It is the B. charasteristica of ILArs ( New-England Farmer, Vol. viii, p. 2).

Buprestis (Chrysobothris) femorata (Fab.).

(Plate $\nabla$, fig. 3.)

Rather dequessed. Color hlack and bromzed aluse, glossy and metallic leneath : upluer side the aldemen is green, punctured alwre and underncath. Eyes gray. I Iead is marked with an clevated line, and corered with shert whitish hairs in front. Elytra rounded; the posterior edge subserrate, or scarcely serrated.

This species is smaller than the dentipes. It has a well marked torth inside of the thigh of the fureless. The elytra are rather shorter than the aldomen, and have an alymach to three frair of implessed gray trunsverse sputs. It varies in size; not exceeding, hutrever. half an inch in length.

I took many individualiof this specics in Canandaigua several years since, in June. uron a black sak. The foregoing sprecies alprear to be widely distributed. 
B. Margin without serratures.

Buprestis divaricata (Say). Cherrytree Buprestis.

( Plate $\boldsymbol{v}$, fig 4.)

Conver; grenish cupens almee, purplish amb metallic heneath, confluently punctured abre and beneath. Elytra attenuate, divaricate or divergent at their tips : thorax indented heture the scutel; seutel small and indented : elytra marked with lines and with ahleviated clevations ; tips narrowed and prolonged heyond the abdomen, and truncate and submucronate on the inner side. Length seven-tenths of an inch.

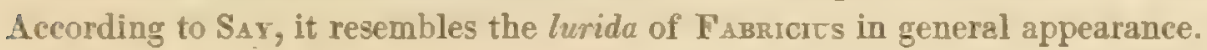

Buprestis rerida (Fab.).

Abuve dull liassy; beneath hrassy with purplish hues and bright, confluently punctured abure and beneath. Mandibles black : eyes dark hrown or black : thorax dilated before its middle, coarsely sculptured, and impressed with groores rather than lines. Elrtra cuirsely sculptured, marked with wider abloreviated lines, and connected by branching ridges; lechind thes are slightly attenuate, projecting just beyond the pointed abdomen, and terminated with two submucronate points.

This slecies diffel's from the furmer, in being destitute of lines, haring fewer confluent punctures, coarseness of the markings, less attenuated tips of the elytra, and their termination in two short spines instead of one. The larva is described by Mr. Harris as destructive to the pignut hickory : it is of a rellowish white; long, narrow, depressed in form, and alruptly widened at the anterior extremity : head brown, small, and deeply sunk in the forepart of the first segment; jaws three-toothed, black : no legs, nor substitutes except tro small warts on the underside of the second segment of the thorax.

These grubs exist in the wood and heneath the bark, sometimes in great numbers : the pupa resembles the perfect insect.

Agrilus rtficollis, a member of the Familj Buprestid 玉, was described hy Professor Hatdems in the Americun Quarterly Journal of Agriculture and Science, Fol, ir, p. 200. fig. 1, as follows : :This little insect, so hurtful to the raspberre, is about three lines long: black, winutels punctured, thorax and front brassy; front with a rertical impressicin: a wide shallin impressiun across the thorax posteriorly, and another at the base of the elytra. In this particular case, the knomledge of the appearance of the insect is not essential, as far as the means of preventing its depredations are concerned, although it is always interesting to know whence an injury proceeds.

'In its larra state, Agrilus ruficollis lires at the expense of the cultirated Rubus (raspberry), in the heart of which the pupa may be found in the month of May, the inago appearing in June. The larra bores between the wood and bark, injuring the plant, and causing a wide unsightly excrescence : it next penetrates to the pith, which it traverses for two or three feet, finally excarating a cavity in which it undergoes its transformations.' 


\section{Elateride.}

THe mos distinet chatracters of this lamily are formed in the firm and structure of the

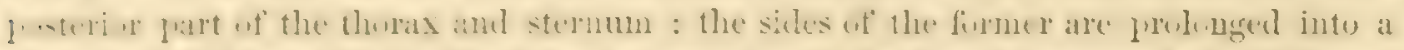

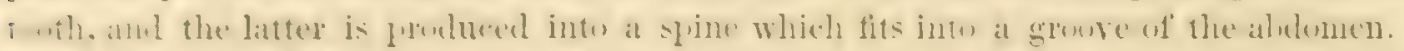

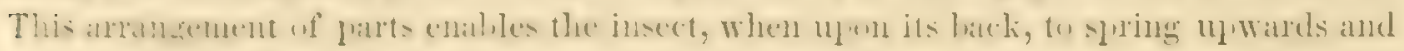
alight upon its feet : this is the only mode by which it can recover its standing, when

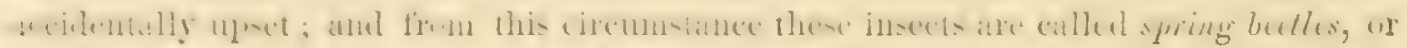

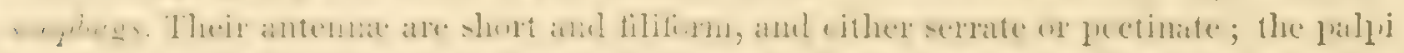

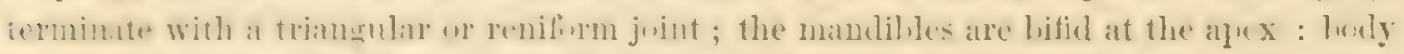

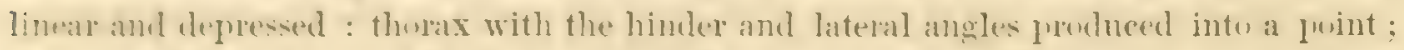

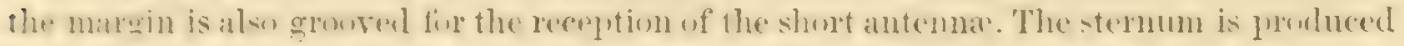

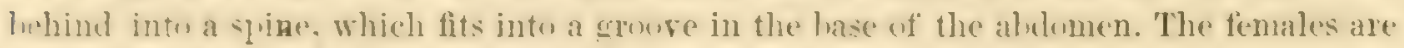
flurnished with a tripartite ovipositor.

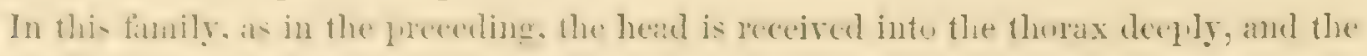
legs and antennæ are short and slender.

The larve live upon the roots of regetables, wood, etc., and are very injurious to corn and herbacens ronts. They are known in Few-York and New-England hy the name of

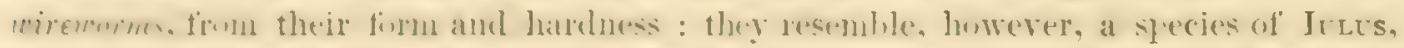

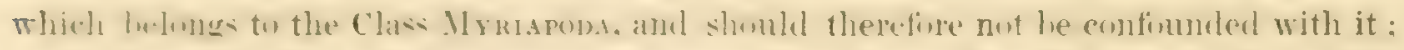
at mistake which it is guite unecessury to commit, as the my riaged has many feet, while the wireworm has only six.

Althush the elateridae, in their perfect state, are clusely allied to the lupurestida, yet their hurve have leet, while the latrat of the latter family are destitute of them : so the

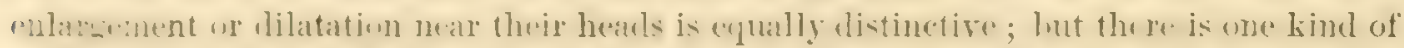

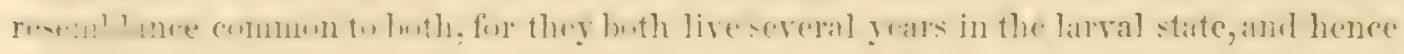
have abundance of time to do much injury. When a field becomes infested with wire-

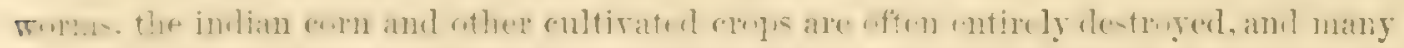

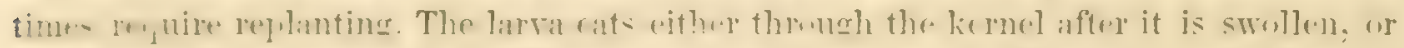

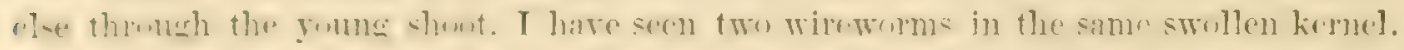
They attark wass, and all the rereals; and in conserpuence of their long continuance in this state, the soil becomes infested with them.

Srit. which are the mest infested with these larra are nsually por ; and one of the

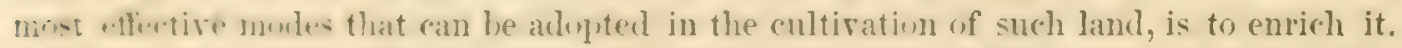

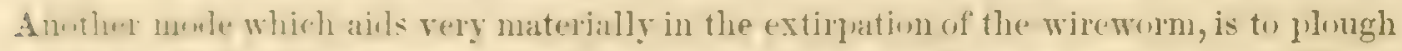

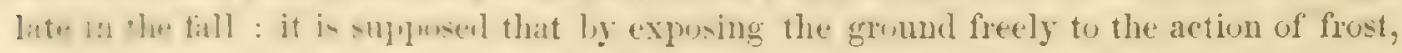
the larre must perish from cold. 
Much has been said in the agrcultural journals about the use of substances supposed to he mxims to this inseret, still there is no prout that any such remedy has been cffectual. . Salt is usually relied on, but experience does not sustain its use. So far as salt contributes to the amount of fertilizing matter, it will prove useful : beyond that, it is useless.

In gardens where these larvæ are common, Mr. Harris recommends the English mode of extirlating them : this mode consists in laiting them with slices of potatoes or turnils: which are scattered over the ground at night. Early in the morning the larvæ are found above ground feeding upon the bait, when they are collected and destroyed.

\section{Genus ELATER.}

This genus is characterized by the shortness of the antennæ, which have a short robust basal joint, the second and third joints small and subglobose, and with their margins serrate upon their outer sides. Head small and retracted; eyes small : thorax generally elongate, with the posterior angles produced : body only slightly convex, lincar elongate, sometimes suborate : legs short; tarsi simple.

Elater (Alaus) oculatus (Fab.).

(Plate v, fig. 6.)

Form elongate, depressed. Color black, sprinkled with gray. Head small : thorax large, quadrangular, and marked by two ovate black velvety spots situated rather in advance of the middle. Elytra are marked with slender lines; posterior angles rounded. The underside of the body, and of the legs, is covered with a gray mealy substance. This singular beetle is found in midsummer upon walls and fences. It is one of our largest beetles; varying, however, frum $1 \frac{1}{4}$ to $1_{4}^{3}$ inches in length : the largest specimens are nearly half an inch wide. It is glossy black, powdered with white specks. The head has a deep wide impression; the prothorax is an oblong parallelogram, and the eyelike spots are surrounded by a white ring. It is widely distributed, as I have found it south and north. It appears, therefore, at different times in different latitudes : in North-Carolina, the last of May; in Pennsylvania, in June; and in New-York and New-England, in July and August.

Mr. Haldeman has found the larva of this beetle in ash trees in an incipient decay : it is of various sizes. Mr. HARRIs has found the larva in old apple trees : it is not, therefore, confined to a single species of trees. In old trees infested with them, it is recommended to remove and burn them.

The larvæ are of a yellowish white color, or reddish ; and, when fully grown, the largest individuals measure two and a half inches in length. The head is rough, brown and broad; the mandibles are strong and curved : they have six legs, and the last segment of the body is furnished with a prop foot; and the sides are armed with hooks and short spines. 
Elater (Prrophorts) xoctilucts.

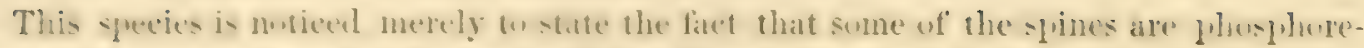

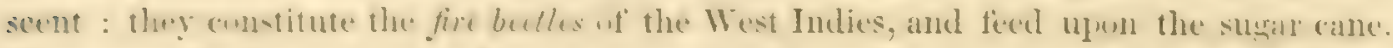
They renemble the unlutus in form and size, hut the eyelike spets give out a strong light; 80 also it is emitted from the segments of the body.

Elater (Melanotus) comunis (Schönhert).

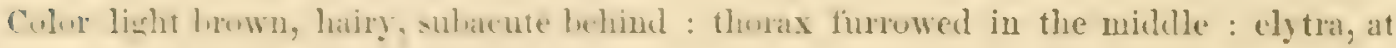
their bases, are marked with about five sulci. Length half an inch.

It is common during the spring and summer montlıs.

Elater ( Melanotus) glandicolor.

(Plate $\mathbf{v}$, fig. 9.)

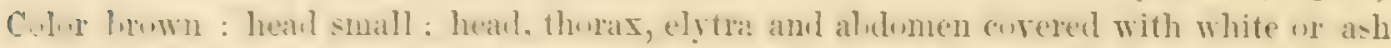
gray hairs. Elytra narrowed lehind; anterior margin or hase marked with : short sulci.

Elater ( Melanotes) cinereus.

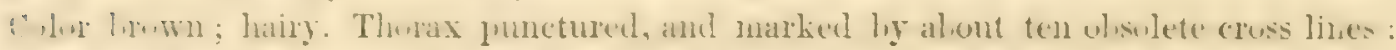
the's gise the alpealance of a reticulated stucture. Length aheut hall an inch, and is found in April, May and June.

Elater (Ledits) appressifrons (Say).

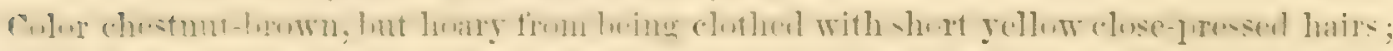

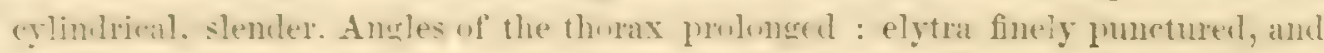
also marked by slender lines. Length about half an inch.

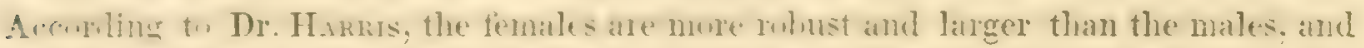

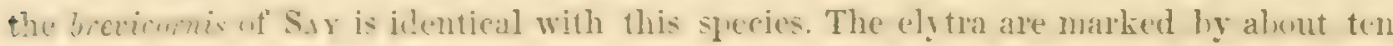
distinct lim san : the lews are lighter colored than the clytra, and cluthed with hairs; and the prolonged outer angles of the thorax are excurved.

Elater (Agrotes) obesus ( Say).

Culor redulish linwn : buly sumewhat dilated and shut : scutel munded and hairy. The ely tra are luncturesl, and clothed in much the same manner as the foregoing. Iength less thun half an inch. The lines of the elytra are only ahuut seven in number, and the hairs upon the upper side are arranged in lines or stripes.

It is find in the spring anong the roots of grass, and it is observed hy Mr. IIARris that its grub resembles the wireworm of Europe.

$$
\text { Elater —. }
$$

This - jucies wats find dead : it is much larger than the npuressifiens, and of a light brown colon. I helieve now that theugh it may mot he a comnen slecies, still, as it is ludenl, it will protialily he a matter of doubt to what species it really lelongs, and therefore I omit further allusion to it. 


\section{Lampyridie.}

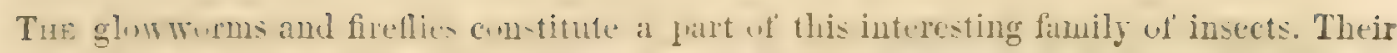

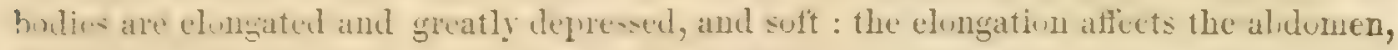
the therax and head leing rery short, and the latter concealed in the former. The fomales are sinnetimes desilute of wings. Their color's are dull, thongh a comsiderahle rariety exisls, and the mirlings of the lhurax are very leculiar, the ormainental colurs cumsisting of red and yellow combined with hack. They are said to be roraciuns, and fecders upon Aleill, sub-isting upu suals, etc. When alarmed, they fold up their antema and teet, and remain motionless : if disturbed, they fall into the grass or leares. They are common on fences and walls during the summer and spring. Some species fly into the windums at night, being attracted by the light of the candle.

The family is characterized anatomically by the different authors as har ing fliform or serrated antenne, with compresed joints; the penultimate joint of the tarsi bilubed the parts of the mouth small : mandible small, acute and curved.

GENUS LAMPYRIS (LIN.).

- Head not rostrated, corered by thurar : females apterous : mandibles entire: (Wrstwoop).

LAMPTRIS NIGRICANS (Knoch).

(Plate xxi, fig. 3.)

- Bromnish black : thorax with a rufuus spot each side within the margin' ( $S_{A Y}$ ).

The margin of the thorax appears wetted, and the thorax is edged with brownish.

LAMPYRIS SCINTILLANS.

(Plate xxi, fig. 5.)

Diste of the thomax rufous, with an angular bromin spet in the centre; burder jellow: elytra brown, bordered with yellow.

LAMPYRIS. ANGULATA.

(Plate xxi, fig. 4.)

Colur pale fuscous, the darker indistinctly defined. Thorax marked with an angular and printed patch of brown on its posterior part, and surrounded with rufous : sides of the brown anterior part furnished with a pair of oral yelluwish spots. Elytru brown, bordered with yellow.

LAMPYRIS LATICORNIS.

(Plate rxi, fig. 2.)

Antennæ conspicuous and compressed. Thorax urnamented with an oral central black spot, pointed befure, and bordered with rufous; margin pale yellow : beneath, the colors correspond to those ahore. Elytra plain dull black, black beneath. Length one-fourth of an inch.

[Agricultubal Report - Vol. v.] 
LAMPYRTS CORRUSCA.

(Plate xxi, fig. 1.)

Thorax with a black sput, rounded at the sides, and frolonged to the anterior exuremity of the thorax, bondered with rufurs and yellewish; margin with a black narrow border. Elytra black or dark brown.

LAMPYR18 VERSIOOLOR.

(Plate xxi, fig. 6.)

Bouly long. Thurax lined with hlack in the centre and pusteriorly, and with oval rufous spots un each side; margin velluw. Flytra dark hrown, margined with yellow, and with an acute band behind, running from the anterior and cuter angle to the clynsite interior angle. Length rather more than one-fourth of an inch.

GENUS DICTYOPTERA (Lto). Lrcus (Stph.).

'Head short: females winged : mandibles entire' (Westwoop).

Dict YOPTERA TERMINALIS.

(Plate xxi, fig.8.)

Thorax hate in the middle, Indered with reddish yelluw : antenna, legs and abdumen black : elytra pale wange, terminated with hlue-black, and longitudinally veined: inuseulating transrerse veinlets between and uniting them; wings burdered with pale orange, shaded at their extremity. Length ?

Dictyoptera Reticulata.

(Plate xxi, fig. 7.)

Thurax with a central hack spot, burdered with cirange : antennx, legs and alidumen black : elytra orange, with two large blue-black oval spots; veins six, alternately thick and thin : wings black at their tips, and shaded blackish. Length?

Both species are furnished with conspicuous antennæ.

\section{Telephoridx.}

TELEPHORES? -

(Plate xxvi, fig. 1.)

Buly suft, elungate, linear : elytra curering the ahdomen; terminal joint of the lalial palpi securiform; eyes grominent. Culor of the budy, head, and mildle of the thorax black or dark lirwn; middle of the elytra brown, edges rufous; labrum and outer margins of the thorax thin and rufous. Length half an inch.

Drazisus coccinatus ( Say).

Thorax inclented : elytra orange, reticulated with longitulinal reins and a tran-rerse netwirk of veinlets : antennx slightly rufuus, and bordering upnn brown or black. 


\section{Cleridx.}

Artexre sublavate, the three or fuur last joints heing thickened : the head is more or less retractile; anil the anterior parts, heml and thorax, appear elongated, while the alulumen is short. The thorax and body are both subrotund; the last joint hut one of the tarsi, bifid.

The family is composed of small but beautiful insects : they lire in wood, and sometimes in the dried remains of animals, in which respect they seem to resemble the dermestidæ. Others frequent beehives, and feed upon the larvæ of the bee.

\section{Genus CLERLS (Geoff.). Trichodes (Fab.).}

- Tarsi with the basal joints scarcely risihle; labial palpi terminated by a large hatchet'shaped joint ; terminal joint of the antennæ acutely produced within' ( $W_{\text {EsTwOod }}$ ).

Clemes apiarius.

(Plate ii, fig. 8.)

Color steel-blue, pubescent : elytra vermilion, with three transverse bands of deep violet.

\section{Genus thanasimus (Latro).}

Antennæ gradually clavate : maxillary palpi small; labial palpi terminated by a hatchetshaped joint; basal tarsi joint small.

Thanasimus dubius ( Latr.).

(Plate viii, fig. 7.)

Color brown and fuscous, pubescent ; madibles and eses black; head, thorax and base of the elytra fuscous. Neck surrounded with a collar : thorax emarginate before, deeply groored transversely behind, and exserted. Elytra fuscous and strongly punctured at base, banded with rufous white and dark hrown or black; thighs fuscous; tibia and first joints of the tarsi dark brown.

One-third of the basal portinn of the elytra is pubescent; the remainder, or banded portion, is elothed with close-pressed short hairs : on the undulating whitish bands, the hair is dirty white. Length one-fourth of an inch.

This species of Thanasimus is fonnd upon the pine, both in the liring and decayed state of the tree.

The larra of one of the English species of Clerts, C. apiarius, is found in beehives, and is highly injurious to the community, as it feeds upon the grubs of the bees. It is an European insect, and is not known in this country; but as other members of the family may have the same habits, it is important that they should be found out. 


\section{Ptinilite.}

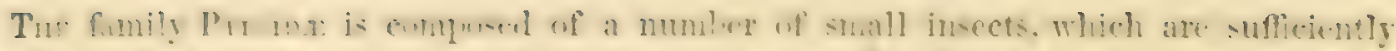

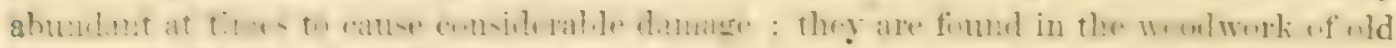

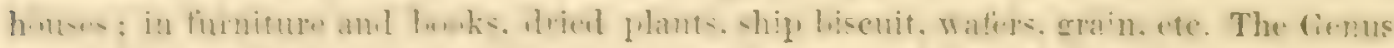

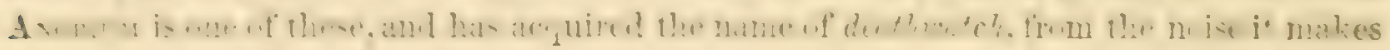

\section{Gexus PTinlis.}

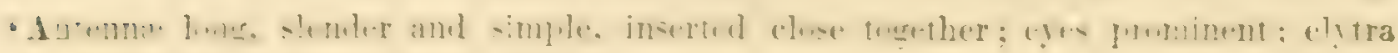
'separated; body oblong' (WEstwood).

\section{Ptists for (Linn.).}

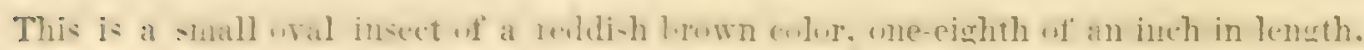
with the head and lwothurax snall and the feet and antenna lone and slender. The ely tra are ensered with hairs and hase a longitudinal striat dilled with functures. It is very

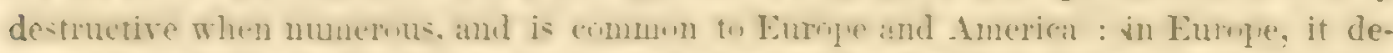

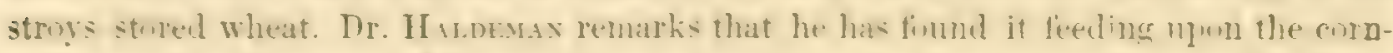
stidks useul to line cases of insects in an entumolugieal collection, in the month of $\mathrm{Fe}$ bruary. It seems to be a general feeder.

\section{Lymexylonidae.}

TuE destruetion of hipr-timber collected in duckyards. which so often haprens, is fre-

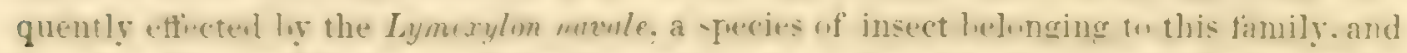

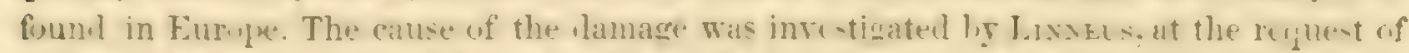
the King of swenlen: and when he disersered it. he recummented inmersing the timler

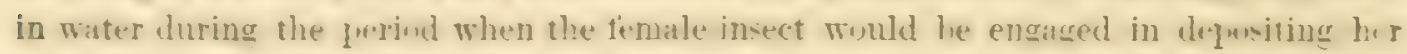
egos. I)r. Hatans describes an American species, or one belonging to the allied genus HYLEOCETS.

\section{Cepes capitata.}

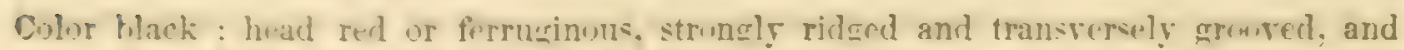
furnished with two prominent tulercles: thrars with three longitudinal rides:

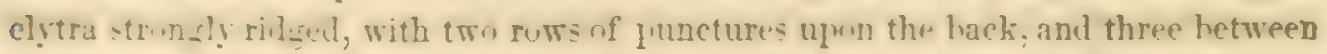
the lateral ridges. 


\section{Bostrichidx.}

'Tuns thuily is disinguished hy the eylindrisal form of the insect, and by the front of the

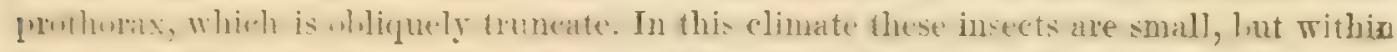

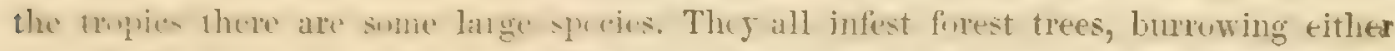

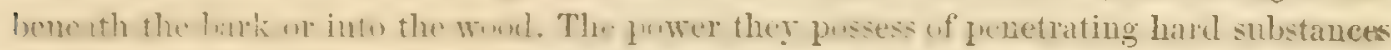

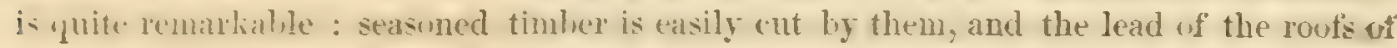
houses scarcely presents an obstruction. At Turin, cartridges stored in barrels were eaten through, and the leaden balls gnawed an eighth of an inch in depth. The Bostrichus capucinus, the species on which the genus was first established by Grorfrov, has been found gnawing type metal, which is considerably harder than lead. Their bodies are hard, and g'nerally black or uf a dark rusty brown : the thorax is diluted before; the antenne shori, and terminate in three large serrated joints. The larva are woud-eaters also, of a whitish colur, mrinkled abore, and furnished with six legs.

Genus APdTE. Bostrichus (Oliv.).

Flytra slinuse and retuse pusteriorly : antenux with the second joint elongate, cylindric ; terminal joints forming a perfoliated club.

Apate basilaris.

Color hlack or dirk hrown : prothorax rough and punctured; hase of the dytra red, punctured, and the posterior extremity obliquely truncate and furnished with three teeth on each side. Length rather more than one-fourth of an inch.

This species is found as far south as Carolina. It perforates the shagbark hickory diametrically through the trunk to the very heart, where it undergoes its transfirmations at the bottom of its burrow (Harris on injurious insects).

In Italy, the branches of the . Morus multicaulis are perfurated by the Apute scxdentatc. Many other species comnit great havoc in furests, perfurating the wood and burrowing beneath the bark, by which the circulation of the sap is cut off.

Dr. Haldevsis remarks in a manuscript note, that some strips of hickory which he had emplured to confine rose plants were destroyed in two years. The hickory is a tree that suffer's much from the attacks of boring insects; aud houp-poles made of hickory saplings are frequently destroyed, or rendered useless in a few months. Barrel hoops, made of this excellent material, are often attacked, so that much inconvenience, if not actual loss, may be the result. The proper remedy seems to be the immersion of the poles in water, or storing them in cellars, during the depnsition of the eggs. The latter mode is sometimes adopted, but the former would have the adrantage of destroying young grubs already deposited. 
From the great and increasing value of the firests in New-York and Pennsylvania, it becomes necessary to direct attention to these destroyers, that proper care may be taken to prevent their increase. Although living trees are subject to attack, these insects have the peeculiarity of thocking to recently cut timber. On this account, infected trees should be cut dow and the bark subsequently removed and burnt, and the word cut up and applied as fuel, turned into charcual, or immersed in water. Some European authors coutend that healthy trees are not attucked by these insects; and that when the attack has been commenced, it is an indication that the tree is in a state of incipient decline. 


\section{CHAPILR VII.}

\section{ORDER I. COLEOPTERA (Continued).}

\section{HETEROMEBA.}

THis dirision comprehends those insects in which the four anterior tarsi are five-jointed, while the pusterior pair are only four-jointed. They are mostly regetable feeders, some preferring leares, others flomers, and others farinaceous matters. There is great dirersity in their colur and habitat : some are beautifully ornamented, others dark and gloomy: some prefer the light of day, and are found upon the wing sporting in the beams of the sun; others inhabit dark and gloomy places, retiring from day, and abiding in obscure and unfrequented situations In these respects, however, we find elsewhere similar arrangements and diversities.

The Heteromera are subdivided by Westwood into two sections or tribes, the first of which he calls Tracuelia. The head in this trile is considerably dilated behind the ejes, and then narrowed again, so that the thorax does not equal the broadest part of the head. The body of the insect is also of a soft consistence, and the elytra are flexible, and folded or overlapped on their inner margin. The CANTHARIs is an exanuple of this subdivision, as to the character of the elytra and the softness of hody and gay color of the insect.

The other great tribe or subdivision is the Atracheira. In this tribe the thorax has the wilt of the head, the posterior part of which is often concealed by the thorax. The habits of the insects also serve to distinguish them from the first subdivision : they appear in dull colors, rarely fly by day, and seek concealment in darkness. Among the Atrachelin we find the Genera Braps and Tenebrio.

The Trachelia comprise the Notoxidæ, Pyrochroidæ, Lagriidæ, Horiidæ, Mordellidæ. Cantharidæ, Salpingidæ, Edemeridæ, and Melandryidæ; in all nine families.

The Atrachelia embrace only six fumilies, namely, the Cistelidæ, Helopidæ, Tenebrionidæ, Diaperidæ, Blapsidæ and Pimeliidæ. 


\section{Pyrochroidae.}

Bopy narrowed in front, and flattened; neck distinct; thurax sububicular; antenne rather longer than the head and thorax, pectinated in the males.

Dendroides camadensis ( Lt.).

(Plate $\times x v$, fig. 2.)

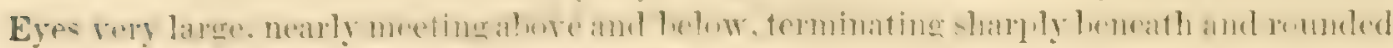
above : thorax rufous and punctured : elytra chestnut brown, glossy, beautifully

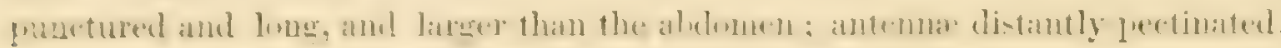

\section{Genus pyrochroa (Fab.). Cantharis (Lin.).}

Aneenne rather longer than the head and therax, pectinated in the males : ares distant.

\section{Pyrochroa flabellata.}

(Plate $\mathrm{xx}$, fig. 4.)

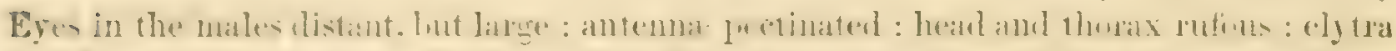
hlark or dark laww. finely punctured, and extending leycond the aldemen; thighs

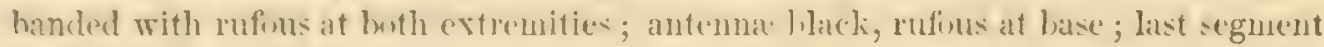
of the abdomen brownish.

\section{Cantharidae.}

Tur contharides, or histering flies used in medicine, alle reluesented anomgst us by the

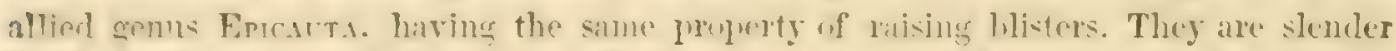

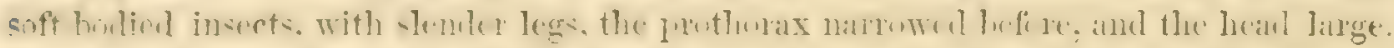

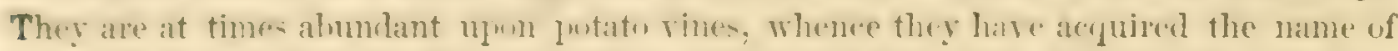

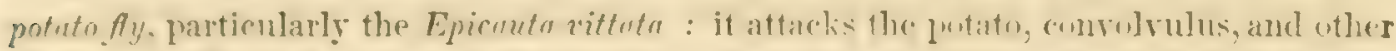
plante, from June to september. It may, with the wileer species. lee collected with a muslin bag having the month attached to a horel'; thrown inte water to prevent escape, and subsequently scalded and dried for the use of the druggist.

Epicauta vittata.

(Plate $\nabla$, fig. 14.)

Color hlack : third joint of the antennæ longest : front of the head marked by two hlack kidneyform sputs : thorax furnished with a small labial tubercle, and marked with three fusenus stripe, the two lateral nnes olsecure; the middle of the thorax prominent. Elytra margined all around with fuseous border, and narked in the nid?lle with a stripe of the same crolor : thighs fuscus at the articulation; lower extremities and tibire and tarsi black. Length six-tenths of an inch. 


\section{Genus Cantharis (Geoff.). Lytta (Fab.).}

Body narrow; wings two; elytra elongate; last joint of the maxillary palpi subovate.

\section{Cantharis cinerea.}

Insect elongated, narrow, cinereous, and covered with short close-pressed hairs : antennx dark brown.

The whole insect has a hoary appearance.

\section{Cantharis atrata.}

Insect jet black : legs, body and thorax shining : elytra rather dull.

Sometimes I have found great numbers of this insect devouring the flowers of the china aster, in the months of August and September.

\section{Genus MELOE (Linn.).}

Wings none: elytra short, lapping within; antennæ various.

Meloe aNgusticolis.

Insect steel-blue : head and thorax punctured; two ovoid spaces on each side of the thorax, smooth. Elytra sculptured : the two last and part of the third ring of the abdomen naked.

\section{Cistelidae.}

\section{Genus Cistella ( Fab.). Chrysomela (Linn.).}

'Ovate : thorax semicircular; mandibles bifid; maxillary nalpi subsecuriform' (WEsTwoop).

Cistela brevis (Say).

Brown, widest near the middle : thorax terminated behind and laterally by a sharp angle : elytra punctured and slightly ridged; legs rather long, and paler than the body.

\section{Diaperidae.}

\section{Genus boletophagus (Fab.). Eledona (Lat.).}

Obtuse, ovate, convex : thorax crenated; antennæ curved, clubbed and serrated. 
Bolemophagus CORNUTUS.

Brown, scabrous : elytra furnished with three rows of tubercles. Male thorax furnished with two curled horns leaning forward, yellow, villuse on their under sides; labrun furnished with two pointed upright horns, or pointed tubercles : thorax of the female furuished with two short notched tubercles; margin of the thorax dilated, tuberculate and serrate.

\section{Helopidae.}

THE culur's of this fanily of insects are rather lirely : their elytra are free, and the wings are usually simple. The larræ are found in wool or under the bark of trees : some, in the perfect state, frequent umbelliferous flowers.

Pitho americanos (Knoch).

(Plate xxv, fig. 9.)

Brumn, darker abore, and slightly brassy or submetallic; head and thorax darker than the elytra.

\section{Tenehrionidae, Blapsidae, and Pimeliidae.}

Aratomical characteristics. Tarsi and tarsal claws entire; sides of the head parallel ; antennæ rather short, monilifurm, and inserted beneath the widened margins of the head; mandibles short, triangular, tips bifid; internal lobe of the maxilla often armed with a corneous tooth; eyes oblong, and only slightly elevated.

General habits. These families possess many similar habits : they aroid the light, and live in damp places in cellars, basements, stables, etc., or upon the ground and under stones in sandy places. The term tenebrio is derived from the latin, signifying darkness (WEstwoop). The colors are all dark brown or black.

In the TeNebrionide, the budy is oblong orate and depressed, or supplied with short legs; elytra free; thurax square, and the head as broad behind as the base of the elytra: the palpi are enlarged at the tip; mentum narrowed at the base.

In the Brapside: Elytra soldered together; wings obsolete; legs of moderate length, hence the budy is less depressed than in the former family; palpi three-jointed; mandibles bifid; internal lobe of the maxilla armed with a claw.

In the PIMfind shaped as in the two preceding families; maxilla concealed in a large mentum, which is as wide behind as before. 


\section{Genus TENEBRIO.}

Body narrow elongate; thorax quadrate; antennæ filiform and eleren-jointed, basal joint orate, second small; palpi unequal; legs slender; anterior tibiæ curved, minutely spurred at the apex; tarsi with entire joints heteromerous.

The Texerrio resides in mills, granaries, meal-tubs, ete., upon the contents of which it subsists.

Tenerrio Molitor.

(Plate xxxi, fig. 10.)

Color black or brown : thorax darker than the elytra; beneath dark fuscous. Head thickIy punctured; thorax impressed on each side of the median line; elytra obscurely streaked and punctured; legs shining reddish.

Common in bakehouses, meal-tubs, ete.

\section{Tenebrio obscurus.}

Color black, or dark brown and dull ; beneath brown.

\section{TENEBRIO CURVIPES.}

Color black or very dark brown; lighter beneath. Tibiæ much curved.

The mealworm is a hard smooth shining cylindrical larva about an inch long, which lives upon flour, meal or bran, and is frequently very destructive to biscuits on shipboard. It is said to pass two years in the larva state, when it appears as the Tenebrio molitor found in Europe and America, and probably exported to other countries. In Europe, the larræ are raised in quantities to feed nightingales and other cage-birds. It is usually abundant in grain-mills and granaries.

\section{UPIS PENNSYLVANICA ( $\mathrm{Dj}^{\mathrm{j}}$ ).}

(Plate xxv, fig. 8.)

Dark brown. Elytra finely punctured in nine equal lines. 


\section{CHAP'TER VIII.}

\section{ORDER I. COLEOPTERA (Continued).}

\section{PSEUDOTETRAMERA.}

\section{Bruchidx. Genus BRUCHUS (Linn.).}

Antennæ filiform, slightly and gradually thickened at the tips : elytra oblong quadrate.

BrUChUS PIST.

(Plate ii, fig. 3.)

Insect small and hairy, oroid, gray : head black; thorax gray or mottled, with a centra] posterior whitish spot; elytra gray or mottled, with small inconspicuous dots or spots posteriurly; posterior abdumen with two black oval spots, and two just beneath the ends of the wings; scales black.

The female prabug deposits its eggs in the tender peapod, when the pea is soft and immature; and when the larva is hatched, it feeds upon the matter with which it is surrounded, until it has attained its full growth, when it bores a gallery to the surface, merely leaving the surface skin untouched, ready to be pushed off by the head of the perfect insect when ready to make its exit in April. An infinity of the young grubs are destroyed in preparing green peas for the table; but whether the epicure finds any difference in the taste of pure and infected regetables, we are not informed.

Seed peas more than a year old do not retain the living insects, and should therefore be preferred in planting new districts : if these cannot be had, the seed may be immersed in scalding water for a short time; a process which does not appear to destroy the germinating porrer of leguminous regetal,les, if carefully performed. This is proved by the fact that seeds of the lucust tree will grow in a single season, if boiling water be poured over them and allowed to stand until it has become cold. 


\section{Genus CALANDRA.}

'Antennæ geniculated and nine-jointed, inserted near the base of the rostrum : the club is biarticulate; rostrum elongate, rounded, slightly deflexed and bent ; thorax elongate, narrowed in front, depressed, the base and apex truncate; elytra shorter than the abdomen; body subdepressed; legs rather short; tibir armed with an acute spur; tarsi reflexed, the penultimate joint slightly bilobed' (STEPHens).

Catandra granaria (Clairv.).

(Plate ii, fig. 1.)

Color pale ferruginous : head finely punctate; thorax strongly punctate; elytra deeply striate and punctate; legs ferruginous.

This insect is an European species, but has been introduced here in samples of wheat received from France. Many bottles of sample wheat were entirely destroyed, although perfectly closed so that nothing could get in from without. It is called the Com wevvil.

I suppose this introduction of this insect, which was accompanied with another, the Silvanus surinamensis, is only a single instance of its occurrence in this way. When it was observed that the specimen grain was destroyed by these imported insects, Mr. J. E. Gavrt volunteered to describe and illustrate the insects for publication in the Transactions of the Agricultural Society of this State. I am permitted to republish this valuable account, furnished by the gentleman referred to ; as too much publicity cannot be giren to a matter so interesting to the wheat-growers of this country.

Mr. Garit, in his communication to the Secretaly of the Society, states, that 'in the specinens of wheat furnished me, I find two heetles : one the true corn weevil of Europe, Calandra granaria (Clairrilie); the other, Silvanus surinamensis, the weevil most commonly found infesting the granaries of this State.

'The former of these received the name of Curculio granarius from Lrsweus, but is now called Calandra granaria. It is somerhat depressed, and varies in color from a deep pitch to a chesnut tint. The head is semi-globose, produced anteriorly into a longish smooth cylindrical snout, which is shortest and stoutest in the males : it is slightly curved, and sparingly punctured with two lines extending almost from the base of the head to the apex, forming two deep channels before the eyes, where the rostrum is dilated. Eyes black, vertical, orate, finely granulated and depressed. The antennæ are nine-jointed : the basal joint being long, stout and clavate, it forms an angle with the remainder; the terminal ones forming an oval, conical, little shining club, pubescent at the tip. Thorax twice as broad as the head, oral, a little truncated : the surface is coarsely punctured with oval points. Scutellum minute and oral. Wing-corers exactly equal to the thorax and head, being ovate-truncate, and not corering the apex of the abdomen : there are nine deep punctured channels down each, producing short pale bristles; and the two raised furrows on each side of the suture have a line of long punctures. The six legs are punctured, 
strong and stent, esjecially the anterior and pusterior pairs. The thighs are stout : they all have a homk or claw at their extremities. The tarsi are retlexed and four-jointed, spongy bereath, hasil joint sulkelarate, second urate, third broader and slightly bilobed, fourth clavate and furnished with two minute claws. Length nearly two lines.

'This insect seems early to have attracted the attention of Daturalists. LeCWENHoEk chesty wervel its economy, and his observations were juhlished as far back as 1687 ; but to OLIVIER, howerer, are we indebted for the most accurate and full account of its habits pullished in the Encyclopidie. Hethodique. All subseyuent writers appear to have based their descriptions on his ubservations. No insect is more furmidalle to man than this little pest, since it attacks the principal hasis of his frod; and they are sometimes so numerns in a heap' "ff grain, that they destroy it altogether, leaving nothing hut the chaff. After the sexes have paired, the female makes a hole in the grain of wheat with her rostrum, and depuits an egg. These holes are not perpendicular to the surface of the grains, but oblique, or eren parallel, and are stopped with a species of gluten of the same color as the corn. Olwrer says there is but one to each grain : I, however, have repeatedly formd two, "ne in each lobe, and these larræ as plump and well conditioned as those who had the ginul fortune of a kernel to themselves. From the egg is hatched in due time a suall footless grub (fig. $b$ ), which, during its growth, eats out the entire cuntents of the grain, and, when ludged in the grain, is perfectly sheltered from all injuries from the air, because its excrements serve to cluse the aperture; so there is no use in stirring the grain, as molhing can incummode it. It is very white; has the form of an elongated suft worm, and the ludy is cownsed of nine frominent rounded rings : it is nearly a line in length, with a rellww punded head provided with organs (fig. $c$ ) proper for gnawing the grain. When the linva has eaten all the fluur, and is arrived at its full growth, it remains in the envelupe of the grain, where it is metamorphosed into a nymph (fig. a), of a clear white, and transfrarent : the fruboscis and antennæ can readily be distinguished; but it gires no sign of life, except when disturbed, and then but a slight morement of the aldomen. Eight or ten lays after, the perfect insect eats its way out. In general, that which serres as nutriment to insects in their larra state is unsuited to the perfect form. To this the calandra is an exception; for scarcely has it issued from its nympln state, than it proceeds to pierce the envelnie of the grain, to establish itself anew therein. I hare frequently watched the perfect insect feeding upon the farina of the grain, having pierced the skin and buried the proboscis to the hase. It is often found, however, lodged in the interior of the grain (fir. c); and its black color does not annume its recent iscuing from its state of nymph, since it is of a straw culor at the time when it has just left its sheath : nevertheless we must duhlitess beliere that it occasions much less injury in this state, than in that of the larva.

'The Culaudra has no swiner issued from its enreluperof nymph, than, like the majority of insectc, it is in a state of pairing for the reproduction of its species, and this act ever 
bears strict relation to a certain degree of heat : if it be under $50^{\circ} \mathrm{Fahr}$, it is insufficient to afford them force or vigor to desire copulation : if the weather be cold, they remain in a lethargic state, and are incapable of injury; if warm, they pair very frequently. The deposition of eggs commences sooner or later, according to the season or climate : the female deposits them in all months, when the temperature is up to a suitable degree, ceasing to lay when the mornings grow cold.

' From the moment of pairing to the appearing of the perfect calandra, there is an interval of forty or forty-five days. By this we may see that a year must produce many generations, which multiply still more in very hot climates. According to a table for the calculation of their increase, it results that the sum total of each generation added together is 6045 , proceeding from a single pair during five months, from the end of April until the middle of September, while the mercury continues above $65^{\circ} \mathrm{Fahr}$. We are therefore no longer astonished if enormous heaps of grain are destroyed by these insects. The injured kernels may be known by a very simple process : if several handfuls of the grain be thrown into water, those will swim upon the surface which have been robbed of their farinaceous substance by the destroyer.

'It is not upon the surface of corn heaps, but some inches beneath, that we find these insects; and there, unless dislodged by shaking with a shovel or sieve, they will remain so long as the weather continues warm, living, pairing, and depositing their eggs. When the mornings begin to freshen, all, both young and old, retire to clefts of walls and the flaws of wood and floors. They are sometimes found behind tapestry, chimnies, in fine every place affording a warm retreat.

'It has been supposed seriously that these insects remain lethargic during the whole winter, and return in spring to their abandoned grain-heaps, recommencing the deposition of their eggs; the cold incapacitating them for the exercise of the functions necessary for the multiplication and preservation of their species. Based upon the knowledge of this fact, is the substitution of cold as a remedy. It has therefore been proposed to have a ventilator, the effect of which would be to keep in a granary a degree of air sufficiently cold to reduce these insects to the above lethargic state. A general and constant rule among insects is, that those which have paired perish shortly after, and do not pass the winter except in the egg or larva state. It is doubtless rare that even those which have not been exhausted by fulfilling the intentions of nature, can survive the winter rigors. Mr. GayLORD, however, in his prize essay published in the Society's Transactions for the year 1843, says, of some specimens of wheat that he had received from the Patent Office, in which he found weevils, that "selecting some pure flint wheat kernels, all perfectly sound, we enclosed a dozen of these weevils with the wheat in a large phial to prevent their escape. The phial was wrapped in paper, and placed where it would not be disturbed except for examination. Opening it occasionally for more than a year and a half, I found my weevils, with the exception of one or two, all living, and appearing to enjoy themselves much on 
the wheat, a large portion of the kernels of which they had hollowed out." This would imply that they surve two seasums at least, and these I have in my possession sustain this assumption.

'Many and variuns modes of exterminating this foe to man have been tried. We first hear of funigations with herbs of strong and disagreeable vdor; but this seems useless, as it dines mot incommole the insect, while the grain receives a letid and disgustmg scent. The fumes of sulphur are fronomed equally ineflicient. All these funigations are still less adalted to the destruetion of the lante, as the smoke cannot penetrate among the grain, and their frerfectly clused envelene secures then from all such annoyance. Ouvier recomments the following, as one of the most eflectual and least expensive modes of destroyine them. At the return of spring, when the calindre are olserved to spread in the healls of winter-stored rrain, it will be necessary to firm small heaps of five and six measures, and place them at a suitable distance from the large heap : this stir with a shovel. The insects, who are singularly fond of tranruility, seek to escape, and, seeing anuther hedp "fi grain alongside, they take refuge therein. When all are thus cullected, boiling water is hronght and poured orer them, stirring it from time to time with the shovel to secure its penetration through the grain while hot. All these insects then die, being burned or sulfieated at the monent. The grain is then spread for the purpose of drying, and afterwards sifted to separate the dead insects.

:It is meessary to pretorm this oreration carly in the spring lefore the deposition of ergs, the weneration existing being (nnly dangerous in giving birth to its successors. This methel may he perfirmed on a large scale as well as a small one, without occasioning any considerable expense.

- Ocher experiments hare proved that a sudden heat of $75^{\circ} \mathrm{Fahr}$. is sufficient to destroy theve insects, without burning them; and a simple efficacious method is mentioned in the Tennessee Agriculturist, quoted by Mr. Garlond in his essay. "If a hogshead, with one head remned, be inverted orer a fire until thorughhly heated, and then immediately filled with wheat and reheaded, all weevils in the grain will be killed, and the grain may be kept in safety till wanted for use."

"A gentleman in Mardeira has e-tablished a heated rom, with hot water pipes, in which he receives anany as eight hundred hags of grain at a time : these lecome heated through at ahout $1: 55^{\circ}$ Fahr.; and the wheat, when resilted, is perfectly cleaned, making quite as goud hrean as befire, the seed also lo:ing nothing of its vitality by this process.*

"The French "lay upon the grain, fleeces of" wool which hare not been seoured : the oily matter attracts the insects among the wool, when they soon die, from what eause is not exactly known." $\dagger$

\footnotetext{
- Transactions of the Entomolrgical Society of London, Vol. 1.
} † London Lit. Gazette, July 1, 1825. 
- One essential point in all storehouses for grain is, undoubtedly, frequent whitewashing and thorough rentilation, as there appears to be much testimony corruburatire of this great preventive to the ravages of this minute destroyer.

'A correspondent of the London Mark-lane Express, in speaking of the corn weevil says : "Some years ago, we found a house overun with weevils : after numberless attempts to destrof them, we were led to ohserve that they were almust entirely on the suuth wall (our rainy side), and that they appeared to breed in incredille numbers in an unusually clamp spot or corner. Taking the hint, we cased the wall on the outside with slate, and made the house in every respect perfectly dry, and in a short time the weerils died off and disappeared. Since ad,pting this precaution, we have not the least trouble, and have only been reminded that such an insect exists when an accidental spot of damp has appeared to generate them again. We think ourselres, therefore, entitled to say, that these insects require moisture; and that if the grain and granary, as both ought alwars to be, are dry and healthy. weerils will not long remain. This plan bears the merit of costing less than nothing, because the injury that wheat sustains directly from damp is more than equiralent to the expense of keeping premises dry, learing its indirect influence in the generation of weevils out of the question." "

\section{Silvanus surinamensis.}

(Plate ii, fig. 3.)

The following is Mr. Gavit's account of this insect:

'The insect accompanying the Calandra, and usually found in granaries in this countrr, is named Silcanus surinamensis, the corn silranus. This insect was named by Lixxers, being sent to him from Surinam hy one of his pupils. Fabricits, from its infesting storts and warehouses, called it . Inobium frumentarium, and subsequently Dermestes scxdentatum, from the spines on the side of the thorax. Lisxers's name, howerer, has the right of priority.

'S. surinamensis is only one line and a quarter long, and very narrow : it is flat, of a ruity bromn color, thickly and coarsely punctured, and sparingly clothed with short depresed rell $\pi$ hairs. The head is large and subtrigmate : the nose appears truncated, hut it is semicircular in front, and conceals the mouth, which is composed of an upper and unler lip, and two little horny jaws, maxillæ and palpi. The antennæ stout, straight and pubescent, nearly as long as the head and thorax, and eleven-jointed; the basal joint stoutish, the terminal ones forming an elongated club (fig. $f$ ). The eyes are black, small, and coarsely granulated. The thorax is perfectly oral, and a little wider than the head at the midlle. There are three ridges down the back, forming two broad channels; and on arch margin are six teeth. Scutellum minute; the wing-corers long, elliptical, and broader than the thorax, with four slightly elerated lines down each : between them are double lows of punctures, and a series of little shining Jellow luristles : beneath are 1 wo ample 
wings. Legs short: thighs stont : shanks clavate; tarsi fire-jointed, three first joints short, fourth exceelingly minute, fith clavate and terminated by two small claws.

- The larva (tim gr) is a little depressed yellowish white worm : it is composed of a toleruhly larae head, with two pointed jaws and two little horns, and of twelve transverse segments: the tail is wmewhat conical, and it has six conical articulated legs.

'The pupa (tig.h) is of' the same color; the head is bent down; the thorax is suborbicular, with three ridges; the elytra wrapped over the sides, and striated : abdomen with distinct segments.

. Mr. Cirtis, from whom the alowe description is derived. says that "this insect appears to he naturalized in England and Scotland, lying under the hark of tres"." I have found it in sugall: and in buxes containing dried figs in great numlwis. It appears to be spread all nrer the hahitahle chlobe: Irobally carred in vesels with grain and dried fruits.

'This is the insert, as I am informed hr that excellent entomulogist, Dr. Fitcr, that infested the mill of Mr. Ricu of Shorehim (Vermont), mentioned in the cultivator of December 1816; , wh wh Mr. R. tried various experiments of fumigation, but found

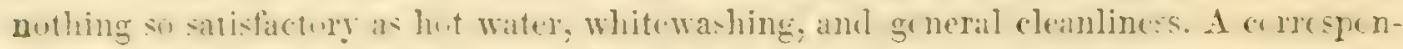
dent of the cime juurnal. in moticing Mr. Ricu's experiments, speaks of a remedy he nerer f.und to fail : placing sassafrat lowt among the grain infested ly them. He is evidently

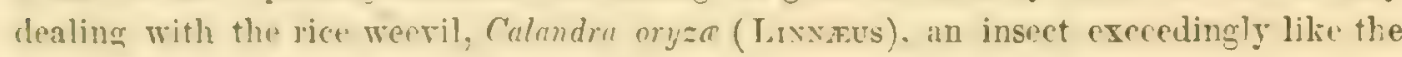
grain weevil in habits and appearances.'

\section{Attelabidie.}

\section{Brenthides.}

\section{Gexes BRENTHL'S ( FAB. .}

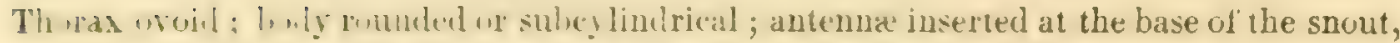
just hefine the ere. In the males the manditle: are strong and prominent : the female i- fruviled with a gentl! curved sncut, terminated with a much smaller pair. Thorax and head as long as the budy or abdominal portion.

Brenthus septentrionis ( Hh.).

(Plate ii, fig. 4.)

Males with distinet mandihle : females prorided with an elongated snout. Culor hrown, polished. Head small : eses prominent; elytra ridged and punctured in lincs, and marked with yellowish pratrhes of lighter brinn. Length seren-tenths of an inch. The whole insect is highly milished. A few years ago, I found great numbers of them aymn a recently felled black vak in Cauandaigua.

- I have sioce unet with them in the same situation.' 


\section{Attelabides.}

\section{Genus A'TELABUS ( Lin.).}

Broad : elytra subquadrate; antennæ eleven-jointed : head not narrowed behind the eyes.

Attelabus pubescens (Say).

Yellowish brown, pubescent : body short.

Atrelabus smilis (Kirby).

Head and legs steel-blue : body cylindrical; thorax conieal, rufous; elytra rufous, punctured.

\section{Attelabus anilis.}

Small : head, thorax, abdomen, and extremity of the elytra steel-blue; elytra with rufous upon the shoulders.

\section{Curculionidæ.}

\section{Phyllobides. \\ Genes PHYLLOBIUS (Schöx.). Cunculio (Lin.).}

Oblong-ovate, squamose : tibia rounded; rostrum short; two and three joints of the antennæ elongate.

Phyllobius teniatus (Say).

Gray or hoary, acute behind, widest near the extremity : elytra punctured, with four darker lines, and darker upon the top of the thorax.

\section{Genus Hytobitus (Germ.). Curculto (Lin.).}

Oblong-ovate, winged : rostrum much longer than the head; second antennal joint elongate.

Hriobius pales ( $\mathrm{Hb}$.).

(Plate ii, fig. 6.)

Brown, covered with close-pressed hairs; hairs gray, in imperfect oblique bands across the elytra; punctures of the elytra parallel ; antennæ angulated ; rostrum furnished with an antennal groove. 


\section{GENUS PISSODES (GERr.).}

Antennæ situated a little in advance of the middle of the rostrum.

Pissodes strobi.

Brown, with two huary patehes on the posterior extremity of the elytra and upon the middle of the thighs; somewhat hoary beneath.

The Rnycophors, as they are termed, constitute a very extensive group of coleopterous insects; some of which, as already seen, have acquired the popular name of wecvil. Many species are destructive to grain and the seeds of leguminous plants. The larva of the large Sphenophorus palmarum of the tropics lires in the trunk of palm trees; and the palmetto (Chamarops palmetto) of our Southern States is inhabited by an allied species, the Sphenophorus zimmermanni of Scroviner, which is the largest member of the family known to inhabit the United States.

Hylohius pales is a common member of a genus which destroys pine trees, by burrowing leneath and loosening the bark. In April and May, it may be seen in considerable numbers upon woolen fences : it is brown, marked irregularly with small whitish spots. Towards the south, this species and Hylobius picivorus, which is larger and more rolust, destryy pine firests entirely, leaving the dead standing or fallen trees as monuments of the mischief' which a small insect can commit when sufficiently multiplied.

The female of Pissodes nemorensis of Germar, according to Dr. Harris, pierces the leaking shimit of the white pine for the purpose of depositing its eggs ; and although a pine tree may recuser by sending up a lateral branch in the vertical direction, it will require three or four years to pass through this process, and the growth in consequence be retarded. This insect is named Pissndes strobi hy Dr. Harris, on the strength of a name given to it hy a Mr. PEck in an agricultural journal; which of course can have no weight, hecause such publications are unknown or inaccessible to naturalists who are not farmers, and seldom circulate beyond the boundaries of the district in which they are printed. It is too much ti) expect an entomologist in London, Calcutta, Berlin, Paris, or the city of NewYurk, to purchase an extensive series of expensive volumes to enable him to find descriptim "f half a dozen insects said to he contained in them, and which should have been made known through some other channel.

\section{Genus Balanines (Germ.). Curculio (Lin.).}

- Rnstrum nearly as long as the body, which is subtriangular : anterior tibiæ minutely ' hooked : antennæ inserted behind the rostrum' (STEPBENs). 
Balaninus Rectus (Say).

(Plate ii, fig. 5.)

Color brown, mottled with lighter patches upon the thorax and elytra. Snout longer somewhat than the body, and curved at the extremity, slender, elbowed : antennæ inserted below the middle, very slender. Rather less than $\frac{1}{4}$ inch in length.

This nut weevil inhabits the chinquapin nut, and renders useless almost the whole crop: the nuts, after being kept a week, are always wormy. It may be the nascicus of $\mathrm{S}_{\mathrm{AY}}$, but seems to be smaller.

Rhynchenus (Conotrachelus) nenuphar. Plum Weevil. (Plate ii, fig. 7.) Color brown, usually dark and somewhat variegated, and variable in individuals, rough and warty : thorax uneven; elytra interceptedly ridged, arranged transversely in three rows, the most prominent in the middle; abdomen thick, deep but short; thighs toothed.

It appears from the numerous accounts that have been published, that the mature insect may appear as early as the last of March, and continue until the first of August; remaining, therefore, for a longer period than most of the injurious beetles.

The habits of this species are peculiar and interesting. It deposits its ora in most fruits, as the plum, cherry, apple, quince, and even in the fruit of the hickory. It is also suspected of inserting its eggs into the tender limbs of plum and cherry trees : it is not known, however, whether those black excrescences are caused in this way, although it is not improbable. I have found some three or four different grubs in these excrescences, some of which belonged to a dipterous insect.

The plum weevil inserts in each fruit a single egg, having in the first place bitten a spot upon its surface; and although there may be scores of the insect upon the tree, it is very rare to find more than one wound upon a plum or cherry. The grub produced from the egg is small, and destitute of feet; and when mature, it falls to the ground and immediately buries itself in the soil : the next spring it appears in the perfect form at the usual time, when the different kinds of stone fruit are setting.

Among the remedies which have been proposed for diminishing the numbers of the plum weevil, there is none so promising as the practice of shaking them from the tree early in the morning and late in the evening, collecting them upon sheets, and committing them to the fire : the fallen fruit should also be subjected to the same treatment. When the tree is suddenly jarred, the insect folds up its legs, falls to the ground, and simulates death. It is easily captured, especially in the morning and evening, when it is stiff, and indisposed to take flight or attempt to escape. Strong-scented odors seem also to be disagreeable to this insect, as it is rarely found upon trees situated near the hogpen.

For a full history of this insect and the remedies proposed against 1t, see Harris's Massachusetts Report on injurious insects, pp. $65-70$. 


\title{
GENUS ITHYULRUS ( SchUNhERK).
}

\author{
Ituycerus vovronacessus (Echrenherr). (Plate xxvii, fig. 1.) \\ Curculio noveroracensis (Forster); \\ Rhventres cerculiondes (Herbst); \\ Pachyrhynchus scheineriri (Kirby).
}

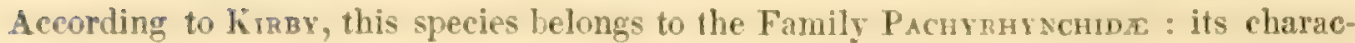
ters, as given by this distinguished entomologist, are :

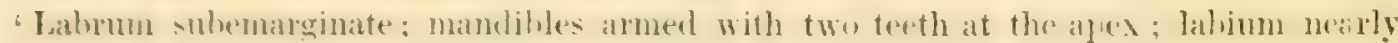
square; palpi conical; antennæ short, inserted into a roundish lateral cavity near the apex of the rostrum; joints eleven, seape short, ete. Body ublong pear-shaped. Rostrum nearly as wide as the head, subeylindrical, a little wider at the tip, ridged between the eyes and antennæ: eyes round, prominent; prothorax subcylindrical, rather narrowest anteriorly; anterectus not rmalyinate, nor kiled. Colcoptera oblung, depressed at the apex : thighs clubbed, unarmed; tibiæ unarmed; penultimate joint of the tarsi bipartite. Its antennx are straight, or only curved, not ellowed.

'Color gray, covered with a whitish pile; ground black : knob of the antennæ brown. Rostrum rather thick, widened anteriorly, having three rilges hetwern the eyes and termination : two diverent, from in impressed angular line between the eyes; and the other procecding directly from that line upon its middle, and which terminates anteriorly in a short fork, or near the emargination of the labrum, thuugh it is separated from this fork by a slight interception, which is just beyond two hyphen-like lines hy its sides. Anterior prat of the rostrum naked, and impersed with cualescent dots. Eyes brown. Thorax subcylindrical, marked with three rather obscure whitish longitudinal bands: punctures coarse and coalescent. Elytra have nine rows of punctures, and at the base a part of a tenth row. The alternate spaces betwcen the dotted lines have small black quadrate spots : on the sutural space, or ridge, they are smaller and more obscure than upon the others. These quadrate black spots are placed upon the four whitich longitudinal stripes, which are guite olscure. Beneath aray : legs gray. Length of the female, five-eighths uf an inch; of the male, half an inch.'

This Curcrio has the hatit of many of the species of this family. It devoms the tender loaves and hlossums of fruit trees. and has been known to do great injury to the alpule and pear. It sometimes attacks the hase of a romng shout. and rats it to the pith : at other times, it ferds upun the leaves of the cherry and pluns. Its strong noteherl mandihle fits it admirably for work of this kind.

The only way to rid a tree infested with this insect, is to shake it suddenly in the

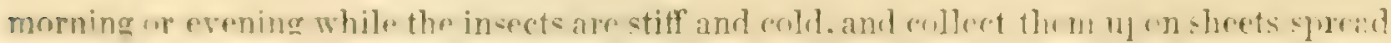
heneath : the insects, and the fruit that fall, should be put into boiling water. 
This species has a wide range : it is found in Canada, Northern New-York, Wisconsin, and Massachusetts.

The following remarks of Prof. Haldemax are highly appropriate in this place :

'Among rhyneophorous coleoptera, the Genus Balasixus is remarkable for having a rery long slender snont, frequently exceeling the body in length, and hearing a pair of antennix as slenter as a hair. Chesnuts are frequently found infested with a fleshy grub, which feeds upon the interior, and fills the cavity with its castings in the shape of dust. This is the larra of Balaninus nascicus ( $\mathrm{SAY}_{\mathrm{A}}$ ). It is densely clothed with short hair mottled with ferruginous. An allied but smaller species is found in the larva state in the nut of the Castanca pumila, or chinquapin. These larva are very difficult to raise to the perfect state when the attempt is made. and it is prohable that many perish from various contingencies.

'Conotrachelus nenuphar(HERBST), suhsequently named Rhynchanus argula hy Fabricics, is very destructive to the fruit of the plum, which the larvæ inhabit, and cause to fall prematurely. This damage is so great in some sections, that not a single plum can be raised to maturity. When the fruit falls. the gruls penetrate into the ground; so that to check their increase, it is advisable to collect and destruy these (as by boiling and feeding them to hugs), including such upon the trees as present a dwarfed, imperfect, or gummy appearance. Paring the ground around the trees is said to answer an excellent purpose, and it is well known that plum trees flourish well when planted in pavenents. This is a small rough iusect of a brown culır, irregularly marked with white, black and yellow; and the snout is held upon or near the hreast. It is said by Dr. HARRIs to have been raised from the black warty excrescences firmd upon the smaller branches of plum and cherry trees. The Rev. D. YaEgler of York (Pennsylyaia) has shown me specimens of the butterHy which dribuys the peach-tree (Egeria critiosa), raised from these excrescences, which differ foum thuse taken frum abunt the ront of the tree in being cunsiderably snaller : the two forms have not, however, been rigidly comparel.

'The Genus Sitophilus includes a number of small insects called weevil, which are destructire to stured grain, as wheat, rice and corn; and under circumstances farorable to their increase, great quantities are destroyed or depreciated in value. The use of salt, and kiln-drying, have been recommended as preventatives. The latter process may be performed in an ecomonicul manner ly erecting it stove with a vertical pipe fifteen or twenty fuet in height : around this pipe, and about three inches from it on every side, a second une of woud is to he placed; and whilst the heat from the fire passes thrugh the inner one, the grain is to be passed through the cavity lietween the pipes, and at such a rate as to prevent it from being injured by too high a temperature. The moisture will be more effectually driven uff if the vater pipe is made with open joints, hecause otherw ise it must rise through the whole column hefore it can esrape, and much of it will condense and be 
carried down the pipe again. The corn weevil is named Sit philus oryza finn having heen

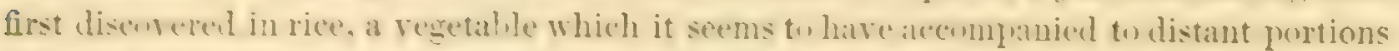
of the glule. Intested grain may le detected hy its luss of weight. which renders it easy

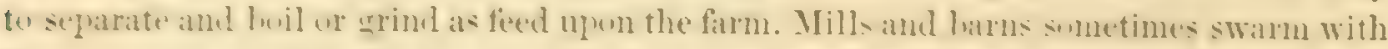
these insects ; and in this case multitudes may le collected and destringed by sweeg ing them from the posts, walls and floors.

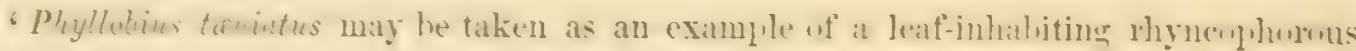

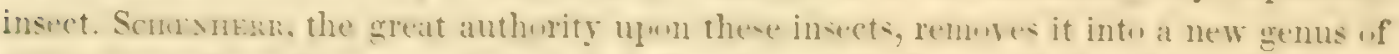
which it is the culy representative. It is found unum the leaves of the Incme trilubn. of papaw, and is perfectly harmless.'

\section{Scolytidæ.}

THE Scourride are small obseure insects, iuhahiting woud : they have a short rostrum; the head is glohular, and is concealed in the thorax; the boly is whlong or cylindric : their colors are dull. Among these destructive wood-eaters is the

\section{Genus HYLURGUS (Lat.).}

Budy cylindrical, whuse befure and behind: head concealed in the thorax; antenna terminated in a clublimm mass, consisting of three or four joints : the tibix are armed with a tooth.

Hylurgos terebraxs (Oliv.).

Pubescent : head rounded, and sunk in the thorax; antennæ short.

\section{Gevus TOMicUS (Lat.). Bostrichus (Erichs.).}

Funiculus fire-jointed; club four-jointed, tunicate; labium triangular.

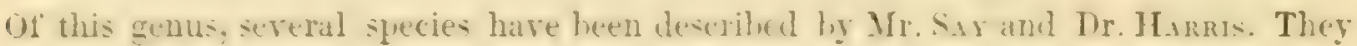

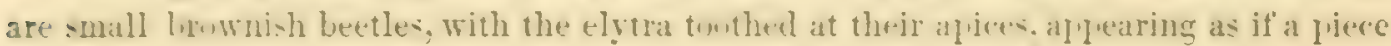
was bitten out.

\section{ToMicus EXEst's.}

Colur dark chestnut hrown. and somewhat hairy : thorax ovate, rungh hefore; elytra strunsly munctured in rums; apices excavaterl. the edges tonthed on the outer side. Length between one-fourth and one-fifth of an inch.

This small and ofisure insect is found under the bark of the fitch line tree, where it creavates numerno giqzag and parallel roads. It greatly injures forests in this way ; cuttine off the cirmlation of the sal. which nltimately causes the hark to berome lowsened, when the tree dies. 
Tomicus pisi.

This speres differs from the former in having only three or four teeth at the extrumity of the elytra, and in leing a smaller insect. Its habits are nuch the same as those of the cresus, in living bemath the bark of the white and pitch pine. The grubs of buth species acc mplish mure injury to forests than the perfect insect. I have taken the last species the first of septeml:er. Autumn, or late in the summer, is the period when the perfect insect goes abroad.

Miss Morris describes the T. liminaris in the Horticulturist, Vol.iv, p. 502. This distinguished entomulugist suggests that this insect may be some way or other connected with the yellows in the peach tree, as it is found under the bark. Its color is brown : thorax punctured, and the elytra both punctured and furrowed, and beset with short hairs. Length one-eighth to one-tenth of an inch.

Scolytus (Tomicus) pyri (Peck). Pear-blight Beetle (Harris).

'Color brown : antennæ and legs light ferruginous; elytra punctured in rows, very 'sloping behind; tibia flattened at the tarsal end, touthed, and terminated with a 'small hook' (HaRris).

This insect has been highly injurious to the pear tree in New-England, and especially in the eastern part of Massachusetts. It was first described hy Prof. Реск. The larra first eats its way inward into the rood, naking its entrance just at the root of a bud : it reaches the pith, and, by its irritation, appears somehom to poison that portion of the limb above the bud where it first entered. We say poisoned; because there seems to be something more sudden and effectual in cansing death, than a slight interruption in the circulation : the limb or twig looks as if it had perished from gangrene.

The remedr proposed is to cut the limh and burn it, destroying the insect before it is matured. A careful examination of the pear in June, in order to detect the first appearance of the approach of the insect, is one of the first steps to be taken. 


\section{CHAPTER IX.}

\section{ORDER I. COLEOPTERA (Continued).}

\section{LONGICORNES.}

The Losgicorses of Latreille (Etcerata of Westwood) deserte a special notice, in conseguence of their habits, and the singular prolongation of their antennæ, which is one of the most obvious characters of the group. The antenna are filiform or setaceous, and frequently considerably longer than the whole body. The eyes are peculiar, in consequence of the position of the antennx, which often appear to hare been implanted within them: the eye is therefore said to be emarginate, though not strictly so ; and it has a reniform shape, when considered indegendently of the hase of the antenna. The body is elongated and cylindrical. The elytra are bruader than the thorax, which they more perfectly encase by their sudden flexure at the shoulder, than is common in other groups. The head is short, and driven into the thorax up or nearly to the eyes : their jaws are powerful. The legs are long, and frequently the longest in front. The thorax is cylindrical, and in some species the sides are armed with a short pointed tubercle. The three basal joints of the tarsi are cushioned beneath : the filth is long and slender; the fourth, small.

The insects of this group come out from various kinds of wood in their perfect state, haring inhabited it from the first, or from the time of the deposition of the egg : they are therefore usually found in the ricinity of wool and dock yards, or where timber is stored. It may well be inferred from these facts that the larra is injurious to the tree it occupies; and the more so, as it is known to remain in this state for many years.

The larræ are prorided with six scaly articulated legs; but they are of little use as urgans for locomotion, ly reason of their small size : their movements are rather effected hy means of the warts or fleshy tubercles situated along the sides of their bodies. Their budies are soft, and of a dirty white color. The head is only moderate in size, flat and wide.

In conseruence of the long time the larræ are resident in variuus kinds of wood, there is, through commercial intercourse, a tendency to distribute in all countries the beetles of this large group. A piece of wood from South America is brought by a ship and thrown out uron some island in the West Indies, or is transported to one of our southern ports, Sarannah, Charleston, or eren New-York : the insects contained in the wood are liberated 
in a new and distant land; and in this way, this or any other country may become stocked with new species of insects. In the long run, and with the ever extending intercouse between the different nations of the earth, it is no visionary imagination that the time will come when these beetles will be found in erery country where the climate is not decidedly unfarorable to their propagation and existence.

This group of beetles is dirided into three families : 1 , the Prionidx, embracing the lurgest of the group, and provided with very prominent jaws and rery long bodies; 2 , the Cerambicide, containing beetles of moderate dimensions, ornamented with a variety of color's; and, 3, the LEPTURIDE, containing insects of a yet smaller size, with bodies dilated before and narrowed behind, and with antennæ of a moderate length.

\section{Prionidæ.}

Prionus pennsyluanicus (Fab.).

(Plate xxxiv, fig. 10.)

Cerambix unicolor (Drury);

C. BRUNNEUS (Forster);

C. Cylindricus (Linn.).

Insect chestnut brown; head dark chestnut brown. Antennæ stout, and two-thirds the length of the insect : elytra lighter than the head, extending beyond the abdomen, and nearly three times as long as the thorax and head together; sides parallel; abdomen, thighs, and tibire red chestnut.

The whole animal is some shade of chestnut brown, but the head and thorax are darker than the elytra.

Priontes laticollis.

(Plate xxvi, fig. 5.)

Cerambix laticolits (Drury);

Prionus brevicornis (Fab.).

Insect dark chestnut brown; head and thorax nearly black. Antennæ very stout, consisting of twelve joints : tibiæ armed internally with two short spines; tarsi beneath yellowish.

The insects of both species are light and dark chestnut brown; almost black in the latter species. Their jaws are stout, and project; and their bodies are longer in proportion to the anterior parts, the elytra extending a little beyond the abdomen. They belong to the large tribe of capricorn beetles, and form a family called Prionida, so termed from the structure of the antennæ, which are jointed, and give the general appearance of a saw. Some of the tropical species are very large. 
Drusy gives a long accunt of the.erruls of this fimily : he states that they, tugether with several other woul-eaters, constitute a delieate eating ; and that in the forrid zone,

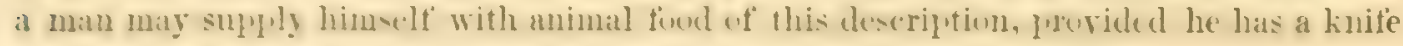
or other cutting tool strong enough to penetrate the decaying trees.

\section{Cerambycidx.}

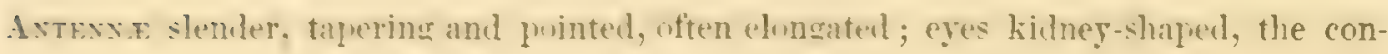
carity of which receires the base of the antenng; thorax rounded and convex.

Stexocorus cinctus.

(Plate xxvi, fig. 2.)

Cerambix barteatus (Degeer);

C. - cinctus (Drury);

STENochorus GARGanicus (Fab.).

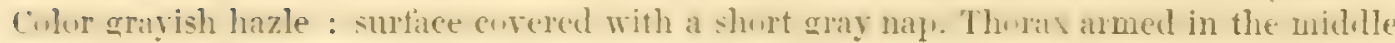
with a short spine : elytra ornamented with an oblique ochre-yellow bar near the thurax. Extreme length $1 \frac{1}{1}$ inch. Antenne of the males mowe than twice as loung as the body: scutellum is triangular, and yellowish in color; while the elytra are margined, and tipped with two small spines.

This inhalots the hickory : its larrat form galleries in the trunk of the tree, which rum parallel to the grain of the wood.

\section{Cerambix? -}

(Plate Xxvi, fig. 9.)

Culur hlack. Antenne ten-jointed; basal joint oral and short, tuherculated, tuhereles minute; last joint lung. slender; second joint nearly equal the last ; the remainder nearly eigual in length. Head with a prominence over each eye and a prolongation at the hase of each antenna, making upun the front a deep longitudinal growe. Thorax arpears to be transwersely rugose, cylindrimal, without tukercles or spines, but rather thickened behind, differing in that respect from the thoras of a Siperda, and slightly constricted near the elytra. Elytra thickly punctured, but scarcely confluent. The luwer part of the tilixe and tarsi hairy, but confined to the furelegs; the others being only slightly hairy, if at all.

This insect wuuld make a very good saperda, were it not for the extreme length of the antennip and the furm and character of the basal joint. I am not entirely satisfied with its reference to the Genus Cirambix, still its characters do not materially disagree with those given by Mr. Westwood. Length rather more than $\frac{1}{4}$ of an inch. 


\section{Genus Clytus. Leptura (Linn.).}

Thorax glohose, unarmed; antenne setacens, and shorter than the budy ; clytra entire at the tip ; hindlegs clarate.

Cuytus speciosus (Say). Beautiful Clytus.

(Plate xvi, fig. 10.)

Head yellow, with an obseure liack circle between the antemna, enclosing a yellow dot . collar encircled with a yellow band : base of the mandible yellow; lip black; eyes black; antennæ black: scutellum marked with an oval spot. Thorax black, with two yellow transverse lines on each side : beneath, there is a yellow spot before the insertion of the forelegs. Elytra black : outer angles marked with three yellow elongated spots, separated by obscure black lines. Upon the anterior part the letter $\mathrm{W}$ is inscribed; and the same above, with the inner lines reversed or inverted. Behind, there is an oblique narrow band running backward from the lower margin : the terminal third is yellow, with two dots of black. Beneath yellow, except at the insertion of the legs : legs yellow; tarsi of the forelegs dark brown or black, the others a shade of brown.

Clytus nobilis.

(Plate viii, fig. 2.)

Black or dark brown : head black, clothed with yellow hairs; eyes black; thorax black immaculate. Elytra marked with three yellow spots upon their basal third, and, below the middle, with two transrerse lines, and four dots near the apices. Legs black upon their upper sides; yellow beneath.

Clytus caprea (Say). Callidium caprea (Knoch). (Plate xvi, fig. 11.)

Color fuscous. Anterior edge of the thorax margined with yellow. Elytra marked by four yellow bands; tip yellow : front depressed or grooved between the antennæ. Thorax subcarinate : first and second bands unite so as to enclose a large spot; the others transverse and undulatory, and wider upon the suture.

SAY remarks that the bands are sometimes white.

Cly tus pictus. C. flexuosus (Fab.).

(Plate xvi, fig. 9.)

Color black, ornamented profusely with yellow figures and yellow bands somewhat after the pattern of the speciosus. The head is marked with three transverse yellow stripes. On the elytra the first and second stripes are nearly straight, the third forms a $W$, the fourth is angled, the fifth is broken by a longitudinal elevated line, and the sixth consists of dots arranged in the form of an arch. Length variable, but about sixtenths of an inch. 
Clytus undatus.

(Plate viii, fig.4.)

ITead anteriorly haiby ; parts about the front part of the head rufous; hase and anex of the interrupted hand, of yellow hairs : scutellum dark linwn. Elytra marked with

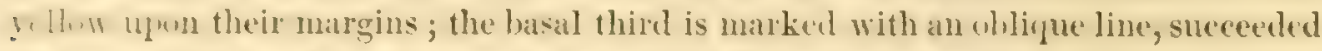
lis two gellow way hands : posterior angles of the elytra rounded off so as to show the lant segment of the ablomen. Beneath, upon the lireast, are thee yellow spots, and alwo at the top of the ventral segments of the alulumen. Length alont ejght lines.

Clytus campestris (Oliv.).

Thi is a small sprecies, from four- to six-tenths of an inch long. Its color is brown, marked with two wared bands across the elytra and tips. The pronotum has four yellow dots arranged in a square, and the under parts are marked with the same color.

The larva is injurious to fallen chestnut timber, damaging it for rails : they burrow betweell the bark and word, and also penetrate into the wood. The perfect insect alpears in May and June. It inhabits the Northern States, New-York and New-England, and extends as far south as Carolina (Hardeman, Am. Phil. Transactions, x, 40).

Clytus hamatus.

(Plate viii, fig. 7.)

Color brown : head handed with yellow; scutel yellow. Elytra marked with two bars and a dash; a yellow dash near the base, two curved lines opening towards the shoulders, the imner leg extending along the suture to the scutel, and a yellow transverse curve opening downwards and situated below the midhle : legs lrown. Length half an inch.

Clytus

(Plate viii, fig. 6.)

Culor brown. Head much concealed in the thorax, rather dilated, immaculate. Elytra Intrked with three transverse curved hars at cqual distances; outer angle of the apex pointed : legs long, brown. Length nearly half an inch.

\section{Cuytus?}

(Plate viii, fig. 3.)

Antenne shorter than the hody, setaceous; second joint the longest : thorax globose, unarned : elytra entire at the tip. Color black, somewhat yellowish gray from the presence of a yellowish nap. IIead black, impressed with a sutural line with a transverse pmminence or ridge at its hase. Thorax marked with hlack oculate spots on the tip) and centre: sides grayish, with a rectangular spot: helow it is hlack. Flytra rlotherl with a hort nap, marked by about three narrow grayish zigzag lines, and dishes of the same alout the shoulders: towards the apex they are slightly selarated; and un w the apex, running up the suture, there is an obscure oblong gray spot. Beneath, black and glossy : legs black. 
This species I found in many parts of this State in June, and supposed it commom. A]though rers peculiarly marked, I have been unable to satisfy myself as yet what name it has received.

\section{Cutrus -}

(Plate viii, fig. 1.)

Color rufescent, cuvered with prostrate hair : head black; thorax grayish, from the lighter culored hair : elytra purplish brown, with three bands of lighter, the basal obseure. the apicial ones confluent on the elytral suture. All the thighs dilated and robust.

This Clytus is obscurely marked; and though it may be described, it differs much from those in ny possession, and from accessible descriptions. The bands spoken of are brought out more distinctly in the figure than they appear in the specimens : the same remark will apply to the round black spot upon the base of the elytra; and, besides, I may add that the side of the trunk is marked by a distinct luteous spot, and another smaller one at the base of the middle legs.

\section{Genus SAPERDA (FAB.).}

Head rertical, as broad as the thorax, slightly compressed at the sides or cylindrical, destitute of lateral spines : antennæ fliform, and terminating in an elongated joint.

The Genus SAPERDA contains sereral species known to be injurious to the interests of husbandry. Most of them are rather sluggish in their mature state, manifest far less actirity than many other insects, and rarely attempt to escape when in danger of being captured. Some of them frequent flowers, but I belive all deposit their eggs upon trees or shrubs. When the eggs are hatched, the young larvæ penetrate the bark and wood, and injure very materially the growth of the tree in which they reside; and as they are generally two or more years in coming to maturity, their hurtful effects are proportionally augmented. The larvæ feed upon the wood as they penetrate it, and derire their nutriment from the juices it contains. Their excrement appears like sawdust; retaining in fact the color of the wood, after it has sufficed to nourish them, and has passed through their bodies. Their form is that which is common to the tribe, the rings near the head being: wider than those of the rest of the animal. The head is usually scaly, and is retractile in part within the first ring : it is supplied necessarily with strong jams, in order that the insect may eat its way into the wood. Their food is constantly before them in their path; and it is a very curious fact, that though they may make their way into the woud, yet they usually direct their course towards the outside when about to change from the larva to the imagi, state. The larvæ are without legs, soft, white or yellowish white, elongated, and more or less flattened.

One of the most destructive of these species is the larva of the Saperda candida. This 


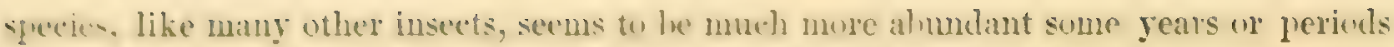

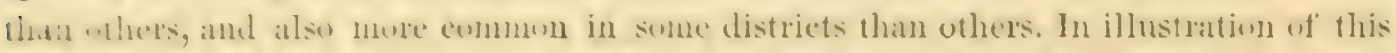

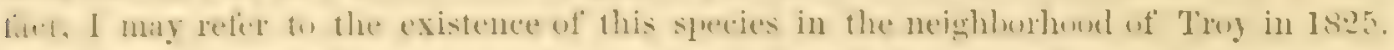

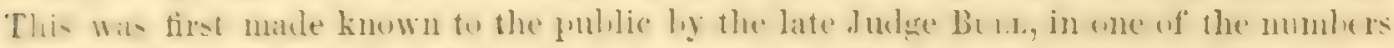
"f' the Allany Cultirator. He silys that the was sent for hy Mr. Mrante of Trey, to witnes the devastation manle in a tine young orehard hy a grub hitherto unkinown to the farmers of the vicinity, and which to know and guard anginst was a great pullic interest.' It anyears frem the letter that the erehated was injured to the extent of two thensand dollars, according to the estimate of Mr. Hearte.

The larvat of this sprecies penetrates the young tree just abore, or it may lue just lielow, the surfice. In its progress, it cuts its way in a wimling direction mownd and as it is three yars in coming to maturity, it continnes to mine onward, cuts off the circulation of the sap, and deprives the tree of" its necessiry nutrinent. (1ne burer is sullicient to stop) the grouth of a young andletree; and if several are mining at the sante tiwe, the tree is

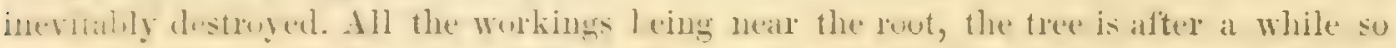

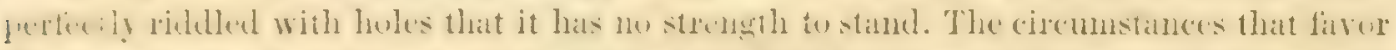
there re-ults, are first, a pror suil, containing hut little mutrincent ; the secend is the growth of sprents or sucliers from the rent, and of grass, which profects the hase of the tree frum sur-hine. and enceals from the verw of the owner the work which is going on. Hence all

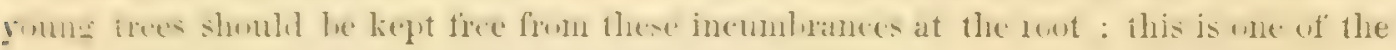
preventires of a fatal result, and should not be neglected.

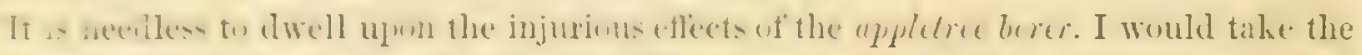

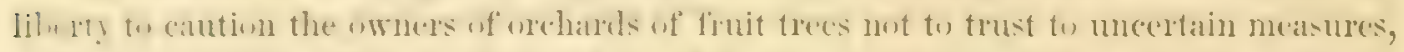

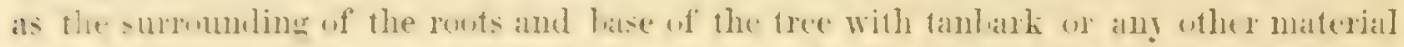

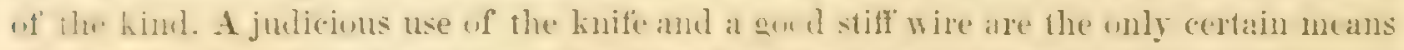

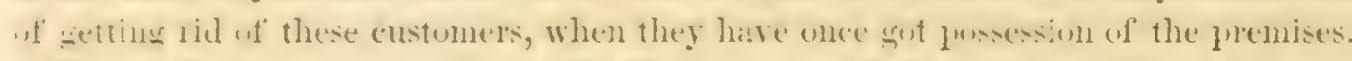

The lerfect insect, according to Dr. Hanks, comes forth in June : this, at any late', is the month during which I have fouml them. They come wot at night : in the daytime they

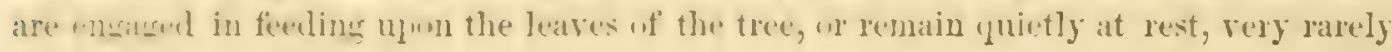
flying during the day.

That earelesentes and inattrintion to youncr and old orchards is the great cause of the frevilence of this ineet among us, is true ; and sol long as so many neglect the means for viluins their trees uf this jest, so Jong it will continne to harass thuse who are un the

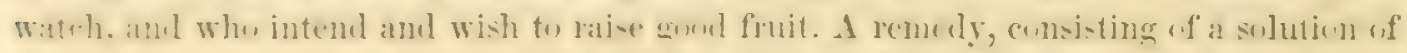

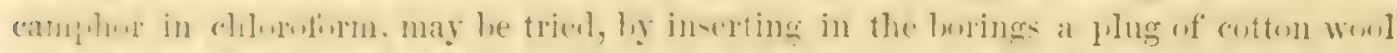

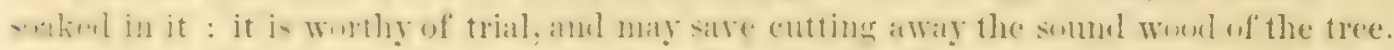

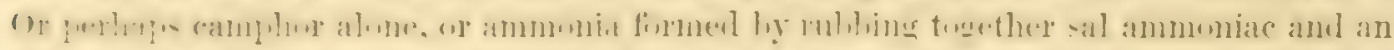

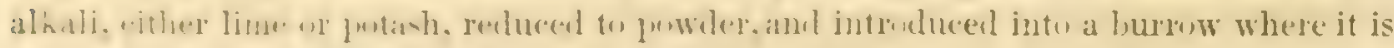
dangerous to follow the larva, may he worth the experiment. 
The larvæ of the Supcida calcarata infest lombardy poplar:s. They are yellowish white, and, when full grown or mature, are nearly two inches long : the body is thick, dilated before, and consists of twelve segments separated from each other by deep transverse furrows. In August and September, the beetle nay le fuund on the different species of poplar : it flies hy night. It is harnless in comparisun to the appletree saperda; but one of our finest shade trees is the aspen, which is often destroyed by this borer. Their presence may be known by their castings, which lodge on some part of the tree.

The Saperda (Obcrea) tripunctata seems to be equally destructive with the two former to forest and shade trees. It is about the size of the candida, but quite different in its markings, as will be seen by a reference to the description. It attacks the linden, and, by burrowing beneath the bark, destroys the vitality of the tree, large flakes of which fall off gradually and drop to the ground as their attachments are broken.

\section{SAPERDA VESTITA.}

(Plate xxvi, fig. 4.)

Color olive or light drab, nearly uniform : surface beneath the close-pressed nap, black.

Head and thorax immaculate. Elytra dotted, each dot giving origin to a small pencil of black hairs : dot-punctures in lines at the base and along the sides, and marked with four black dots a little ahore the middle of the elytra; and sometimes there are other dots, owing to the denuded nap upon little elerated points of the elytra. Length seven-tenths of an inch.

This species attacks the linden : the larvæ, by their burroms beneath the bark and within the wood, effectually destroy the tree in a few years.

\section{Saperda candida (Fab.). S. bivittata (Say).}

(Plate xvi, fig. 3.)

Color light brown, marked upon the upper side with two white stripes extending the whole length of the insect : face, antennæ, underside of the body and legs white. The white is due to the clothing, which consists of a white close-pressed short nap : where rubbed off, the surface is black. The white stripes decussate from the forehead, leaving the grey-brown stripe on the top of the thorax passing down the sutural line. Length six-to seven-tenths of an inch.

\section{SAPERd (ANEREA) CALCARATA.}

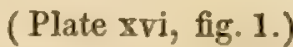

Color gray or ashen, and covered with a short dense close nap : surface covered with raised points or dots : thorax marked with three pale ochreous stripes, which decussate from the forehead. The elytra are also marked by partial stripes and bands of the same color : apex terminating in a straight short spine; beneath pale gray ochreous. Beneath the nap, the surface is black. Length nine-tenths of an inch.

[Agricultural Repost-Vol. v.] 16 
SAPERda TRIDENTA.

Anteme slemker, shorter than the buly, second longest. Color rusty hrown, alproaching to an olive : sutural line passing through the head and thorax. Insect ornamented with pale hrick-red stripes : face margined, and eyes surmunded with the colored stripe referred to. Stripes mearly unite between the antenat : from thence they divere aloruptly, and form lateral stripes upon the thenax; thence they proced to the prominnt or angular shoulders, run down upon the sides of the elytra, and meet the outer angle of the apex, and then pass round on the inside a short listance upon the sutural line. These stripes send off three diverging ones : the first is arched; the sce mol or midhle is stright, lut passes obliquely downwards near the suture; the last, or apical one is short. and arched. The sides of the the rax are marked by four wral spots. The two spots on the top of the thorax are olscure; hnt in some species there seem to be funr, thungh the two near the head may be protuced by loss of the drab-culured niap. Beneath hoary, the whitish nap covering a black ground. Extremity of the abdomen trancate. Outer angle of the elytra rounded.

\section{SAPERDA -}

Color yellowish drah, uniform : head, thorax and elytra covered with a close-pressed short nap. Thurax longitudinally marked with pale yellow stripes alternating with deeper. Elytra punctured, and marked with about seven obseure gellowish spots on cach.

Saperda (Oberea) tripunctata. Raspberry Saperda. (Plate xvi, fig. 7.) 'Color black : hreast and top of the thurax rusty yellow. There are usually two elevated Hack duts on the middle of the thorax, and a third on the hinder edge. Antennæ of a moderate length, and scarcely tajer. Wing-covers coarsely punctured : punctures in rows on the top, but irregular on the sides and tips. Length from three-tenths to half an inch' (Hariss). There is also a hlack spot on the sides of the thorax.

Dr. Harris (b)erves that this insect cunyletes its transformations near the end of July, and lays its exgs arly in Aurust on the stems of the blacliberry or raspherry. The grubs burrow into the pith of the stem, and destroy it by the end of summer.

The grubs are cylindrial in the middle. and thickened at each end. The first three rings are short, and bach is prurided beneath with imperfect legs in the form of minute pointed warts : the rest of the rings are smooth.

\section{GeNes MUYOCHAMLS.}

Elytra sumewhat parallel ; antenne glal,rous; anterior male larsi hairy; forelegs longest ; thorax laterally spined".

- Kirar, in his generic characters in the Fanna Boreali, sajs this genus has eleven joints in the antennæ. I believe it has only ten, and the last joint is the longest, or equal to the secoad. 
Monochanos titiliator.

(Plate xvi, fig. 5.)

Brownish, mottled with gray spots. Elytra tufted with patches of dark brown hairs : antennæ, in the male, twice as long as the body; in the female, they equal it in length. Length one inch and more.

The middle leg has a protuberance on the upler side. The motllings are sumewhat variable, owing in part to the removal of the shert cluec nay that covers the insect.

Mosochames maceloses.

Color blackish brown. Elytra mottled and furnished with small patches of raised syots tufted with hair, rather carsely punctured : al: $\in \mathbf{x}$, on the inner side, arned with a spine; outer angle rounded : protuberance of the tibire one-third the length from the tarsi. It is rather smaller than the titillator.

The two furegoing species are rather common in Albany county : indeed, common to New-York and New-England.

Monochasus scotellatus.

Color dark hrown, darker up $n$ the base of the elytra. Scutel white, hairy, strongly punetured : punctures confluent at the base. Antennæ and legs dark brown.

Mosochamus pelcher.

Color lighter brown than the scutellatus. Thorax and elytra rariegated with pratches of white nap.

Onciperes cingulatus (Serv.).

(Plate xxii, fig. 1.)

Ash-gray, banded : head inclining to brown : thorax ash, together with the middle of the elytra; base and terminal extremity darker, and somewhat mottled. Length sixtenths of an inch.

Dr. Haldemar remarks", that "this insect appears in Penncylrania during the last two weeks in August and first week in September. It feeds upon the bark of the walnut (Carya alba). The ova are a line and a half long, and are deposited in excarations in the small limbs. After the ora are deposited, the female gnaws a groore around the limb, which consequently dies in a short time : this scems to be intended for the future progeny, as the larræ are found feeding unon the dead wood. When the insert is abnndant, much damage may be done to the young growth of the hickory, when it is of the size suitable for homp-poles.' When the main stem is girdlet by the insect, a lateral shoot appears, that may be attacked the next year, to be in its turn anputated after undergoing the same operation : in a few years, the tree presents a curious appearance.

- Jour. Acal. Nat. Sci. Philadelphia; Hatdeyax, Am. Phil. Transactions, $\times, 52$. 
Lamia -

(Plate xxvi, fig. 9.)

Color aray, and hamled. Thorax spined at the sides : face marked with an inupresed line, depresserl between the antennx ; antenne ten-jointed, first joint narrowed at base, secund joint slightly longest, the upper half of each very black, the lower half gray. Front of the thorax is marked ly a hlack transerse line, in the rear of which there are two small hlack spots : justerior part of the thorax is punctured with black, esperially the transwerse grevere. Filytra thickly and coarsely punctured with black, and traversed hy four helts, the two front one's incomplete : they are zighang in form, and interupted hy gray spaces. Ahlunen narrowed some what hehind, and terminated

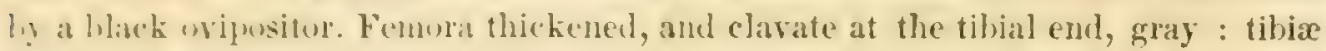
marked by black rings; tarsi black. Post-pectus decply emarginate and giay.

The fireguing is as rare species in this vicinity. Its ovipositor shows that its eggs are deposited in woul, and hence it is an injurious insect to timler. length, including the ovipositor, seven-eighths of an inch.

Tetraopes tetrophthalma (Forster). M. tomator (Fab.). (Pl.v, fig.11.) Color brick-red. Thorax marked with four black dots arranged in the form of a scquare.

Elytra marked with four black dots; two near the basal angles, and two placed longitudinally upon the middle. Antennæ black : hody beneath and legs black.

This insert is common on the silkweed (. Isclepias syriaca) in June and July, and is extensibely distributed, extending from Massachusetts to Carolina (IIatramas's Mat. Hist. Long. Am. Phil. Soc. $\mathbf{x}, 53$ ). It is a harmless insect in its mature state.

Elaphidion villosum (Fab.). E. putator (Peck).

(Plate xvi, fig. 8.)

Color brown, gray or hatry from patehes and stripes of grayish down : thorax more villuse than the elytra. Antenne guinuus : the second joint armed with a spine as long, wr nearly as lung as the third joint ; the spine of the third joint, one-third as June as the fourth juint: on the furth juint, the spine is shorter still. Elytra punc-

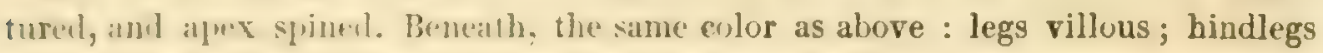
armed with at short spine.

Although about a dwen spu cies of this genus have heen discorered in the United States, the habits of this me only are knwwn. 'Tle latra feeds upon the wood of whiteoak or

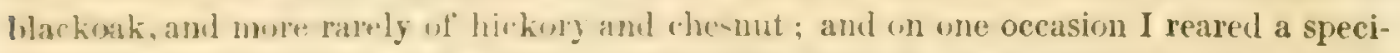
man, aplarenty of this species, from a laria taken from the dead trunk of a small spruce tree. The insert is half an inch or nure in length. and may be distinguished by its chesnut

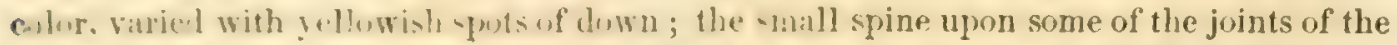

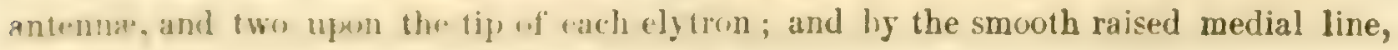
and tubercle, upon each side of the pronotum above. 
When the larva attains its full growth in the branch, which is about half an inch thick, it cuts it off transversely from the inside, leaving the bark alone untouched; and this slender hold is severed by the storms of autumn, when the branch and larva fall together. The larra does not leave its shelter until the next spring, when it appears as a perfect insect in May and June.

Elaphidion?

(Plate viii, fig. 9.)

Head small : thorax somewhat flattened, dilated at the sides. Antennæ ten-jointed : the tenth longest; the second, third, fourth and fifth spinous upon the inside. Thorax marked by two sharp impressed lines : legs equal or subequal. Color of the body luteous, from the close pressed hair or nap : thorax brownish, without tubercles or armature : elytra luteous, mottled somewhat by darker spots, narrowed somewhat behind, and terminated by two spines concealed in the hair. Beneath slightly brownish, and clothed with appressed hair, especially upon the breast.

I refer this insect to the Genus Elapuidion, though its generic character may not entirely warrant it.

\section{Lepturidæ.}

The insects under the name of Lepturide, or Lepturians, constitute a third family of the capricorn beetles. The body is narrowed hehind : eyes rounded, oval, and rather prominent; and the antennze are situated farther from them than in the other species, and are implanted near the middle of the forehead : thorax widened behind : head connected with the thorax by a narrow neck. Colors bright.

\section{Genus Desmocerus (Dej.). Cerambyx (Forster); Srenocorus (Fab.).}

Eyes lunated, surrounding the base of the antennæ : head sloped before; palpi terminated by a large joint in the form of an elongated compressed cone : thorax subquadrate or subcylindrical : antennæ setaceous.

Desmocerus paliatus.

(Plate xvi, fig. 6.)

Color deep violet or prussian blue : nearly one half of the elytra orange yellow.

The larvæ live in the stem of the white elder, and feed upon its pith. This year (1853) this insect has been very numerous in the vicinity of Albany.

\section{Genus RHAGiUM (Fab.). Leptura (Lin.).}

'Body broad, depressed : thorax with spines on each side; antennæ short' (Westwcon). 
Rhagerm lineatum (Oliv.).

Antenne short. Thurax narrow, eylindrical hefore and hehind : middle of the thurax is furnished with a prointed wart on each side. Flytra wide at the shoulders, and tapering, convex alove, with punctures between the snooth elevated lines, and ornamented with black and reddish ash colors, the former arranged in transverse hands. Enderside variegated with dull red, gray and black.

The grubs of this beetle burrow under the hark of the pitch pine; in consequence of which, it is loosened, and fills off, when the tree dies. The grubs are often numerous: when atout to become pulve, each one forms for itself an oval ring of woedy fibes. The beetle is matured hefore the close of winter, hut remains till the plring ' Jems (Harris, Injurious Inscets of Miassachusetts, pp. $92-93$ ).

I bave found the larva under the bark of the yellow pine and white pine, where it is

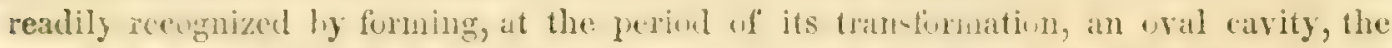
border of which is made of wooly fibres. The halits of the European Rhagium indagater (Fabr.), are similar. This insect is usually ahout seren-tenthe of an inch leng, although it is sometimes found no longer than fimr-tenths. Its color is gray, mirlicd with hack : the surface is somewhat downy; the antemnat are short; the ely trat wide at the base, and having several raised Jines; and the frothorax has a tubercle on each side. The perfect insect appears in May (HaLdeman, MS. Notes).

Purpuricenus mimeralis (Fab.).

(Plate xvi, fig.4.)

Black. Lilytra marked with a rightangled triangular scarlet spot situated upon the base of the elytron, the hyputhemuse passing hy the side of the scutel. Thorax, neck sculptured and rugose, and furnished with a lateral pointed tubercle and two elevated roughened ridges or eninences on the median line. I.ength variable : female, sixtenths of an inch; male, less than half an inch.

This insect secms to be rare in the vicinity of Albany, as not more than three or four specimens have been taken in the last three or four jears.

\section{Genus LEPTURA.}

Aatenna elongate, basal joint robust, second mimute; cyes narrowed above. Head exserted : thorax convex, marmed. Insect narrowed brhind from the base of the elytra to the extremity of the abdomen : legs elongate, slender.

Leptura vittata (Oliv.).

(Plate viii, fig. 13.)

Color black or very dark hrown : heat. theras and leogs hack : elytra punctured black, and marked with a rufous stripe extending from their hase to two-thirds of their length, and cocupying the middle of the elytrum. Benenth, the insect is clothed with short gray appressed hairs. 
LePTURA REBRICA.

Color black : head and thorax black, pubescent; fuur first joints of the antenna black, the remainder luteous at base. Elytra ferruginous, punctured; apex of the outer angle pointed, and longer than the inner, divaricate : legs black.

I refer this to fig. 10, pl. viii : the apex of the elytra in that figure is truncate.

LEPTURA MALACHITICUS.

Splendent green, with steel-blue reflections : punctures dilated deep, imparting a rongh appearance. Antennæ and scutel black : thighs rufous, and lower half of tarsi dark brown or black : prothorax with a lateral tubercle, oceupying nearly a central position.

This beatiful insect is quite rare in the vicinity of Albany, a single specimen only having been observed.

Leptura octopunctata (Say).

Elytra marked with eight irregular-shaped spots or dots, smallest upon the apex.

LEPTURA - -

(Plate xxvi, fig. 11.)

Color black ( the light color is due to a close gray nap). Antennæ ten-jointed : first somewhat turbinate, third shortest, second the next shortest; the three first black or dark brown, the remainder rufous. Pectus and thighs brown, and a stripe beneath the shoulders. The posterior part of the thorax surrounded by a sharp ridge, which extends down the sides : this ridge is bounded by grooves; and before it, and near the middle, are two elerations, scarcely tubercles : anteriorly it is surrounded by a broad groore. Behind the antennæ, there is a deep depression upon the median line of the head. Length three quarters of an inch.

LEPTURA SUBPUBESCENS.

(Plate viii, fig. 11.)

Color black, thinly covered with luteous hairs, punctured : head and neck roughened, corered with hairs. Antennæ black; third joint shorter than the fourth. Elytra punctured, rufous or dull brick-red, terminated by a black belt extending up the outer margin, divergent towards the apex; apex truncate. Point of abdomen $\epsilon$ zposed : beneath black, submetallic.

Genus PACHYTA (Serv.).

'Body robust : thorax subconical, with an obsolete obtuse tubercle on each side; elytra short, nearly parallel; humeral angles not very prominent' (WEstwood). 
Pachyta cordifera (Oliv.).

(Plate viil, fig. 12.)

- Front clothed with yellow hair; frontal line Impressed. Prothorax much widened and biarcuate posteriorly, corered with yellow hair, and having the median line obsolete. Elytra divaricate, and separately pointed at the tip : a minute black spot at the basal angle, and another (sometimes double) between it and the large median macula. Length nearly half an inch' ( Ias.demax, Longicomia, Trans. Am. Phil. Soc. x, 59). A variety, lunaris, also described in the same work, is black, tomentose : venter dull rafous; elytra yellow; alex, and a semicircular macula behind the middle on the anterios margin, black.

Grammoptera

(Plate xxvi, fig. 3.)

Body black : eyes black, and slightly emarginate on the inner side; color of the upper side luteous. Apex of the elytra black, and the spot toothed on the basal side. Length half an inch. 


\section{CHAPTER X.}

\section{ORDER I. COLEOPTERA (Continued).}

\section{PIIYTOPHAGA.}

This division (Evpoda of Latreille) emhraces a group of insects whose bodies are short, oral, thick, and hemispherical (for an example, see Pl. xir, 11). The thorax is sometimes angular, uniting closely with the hase of the elytra, and forming with them a circle or a broad oral. The head is short, and conceded; the antemue shorter than the body, filiform. The insects are usually small, hut their culurs are lively and brilliant, though only a few are metallic in this climate : the Eumolpus is one of the brightest. They are vegetable feeders in the larva and perfect states, and some of them are highly injurious; the Haltica destroying the turnip crop, and the Crioceris the asparagus plant.

\section{Crioceridx.}

THE budy is oblong in this family, and the hindlegs are often thickened for lenping. The he: $l$ and th rax are narrower than the abdomen. The antennæe are filiform, or only slightly thickened at the tips : they are inserted before the eyes, which are prominent. Found upon leares and stems of trees.

Crioceris (or Lema) trilincuta (Oliv.), is a yellow insect abuat one-fuurth of an inch lonrs; the elytra with three hlack lines, one along the middle of the hack, and one on each side. It belongs to an extensive division which contains many species that are destructive to garden regetition, generally devouring the leaves, hoth in the larra and the perfect state. The speries here cited attacks the foliage of the potato, and Dr. Harris recommends brushing them into shallow vessels of salt and water, or vinegar.

Crioceris duodecimpunctata.

Color yellow: thorax and head hrownish; heneath, rellow. Elytra punctate in many rows, and marked with six black spots : each side of the thorax has also a black stripe. Tibial extremity of the fenur black, as well as the tarsi. I.ength rathel les than a quarter of an inch.

[Agricultural Report-Vol. v.] 


\section{Cassidida.}

\section{GeNeS CASSIDA.}

buly filtened and dequessed : shitel or elytra dilated on all sides, concealing the head and body.

\section{Cassida clavata. Tortoise Bcetle.}

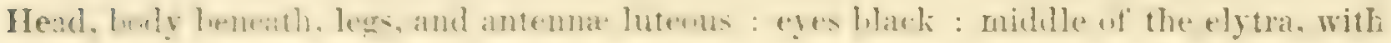

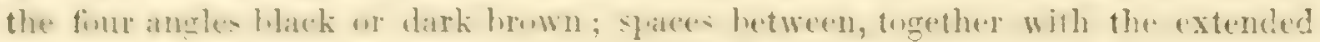
elspeus luteous and translucent.

Onontota scutellaris (Oliv.), Hispa sculellaris (Fab.). This iusect has, in conjunc-

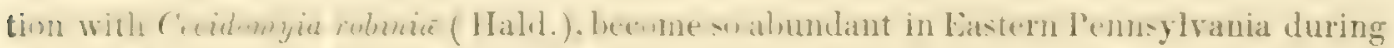
the lint few years, that the finliage of the lucust trees is killed fowards the end of August, as if hy dry wather. It is nearly wne funrth of an inch long, of a tawny (w)lor, and marked along the back with a black line.

\section{Chrysomelidæ.}

GENTS ELMOIPUS,

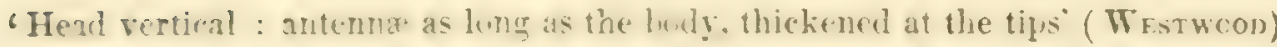

Eumoupes atrates (Fab.).

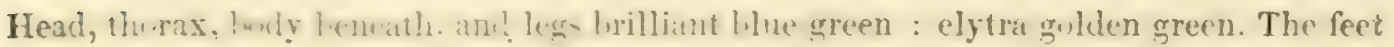
and antennæ incline more to black, yet exhibit the coloring described.

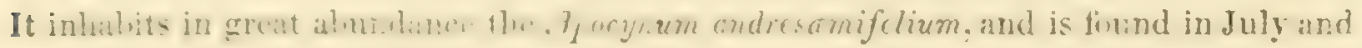
August.

\section{GeNE'S CJIRYSOMEI,A.}

Curgyomela phitadelphica.

(Plate xiv, fig. 12.)

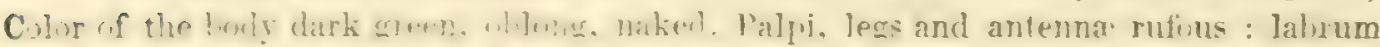

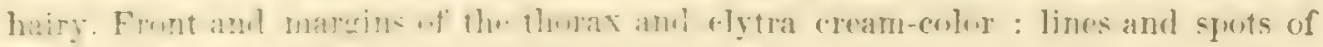
the elytra, posterior segment of the thorex, and scutel green : inner margin of the clyra trasered l.y two line: : mawinal line widened towards the scutel; the proximate line widened a! we and tweth slichty dirergent. Lines Iunctured in rows surpoumbiag the entire thirkened lander. The shoulders of the elytra marked by two 
stren spots which converge to cach other, the onter the largest : jarallel with the marginal line there are three large spots; the remainder are scattered and smaller. The dots are distributed somerwat irregularly, hut there is a tendency to arrangement in rows, as at the base of the elytra and along the lines and larger spots.

The insect from which the description is drawn is rallere conmon, but it does not agree

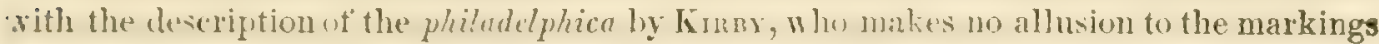
upon the thorax. The differences I regard as sexual.

In a few plates, I observe that the gronnd color is too green : it should be pale, or cream-color.

\section{Chrysomela decipiens.}

Head, thorax, hody and scutel dark green : elytra silvery white or white. Sutural line thickened, and divergent near the scutel : the parallel and proximate lines wide, divergent before, and narrowed towards the apex; the second is shorter, and united to it ; and the third is similar to two heavy dashes united at their points, but instead of being straight, they form a curve divergent from the other lines : these lines are dotted. The shoulders are marked by a heavy dash or oblong spot : two other spots are situated between the shoulder spot and marginal line; the upper roundish, and the lower oblong. There are thirteen spots on each elytrum, besides those already descrihed, each of which is enclosed by a row of dots. Antenne, palpi and legs rufous.

This species differs from the preceding, in liaving the thorax entirely of a dark green, and also in the distribution and form of the lines and markings upon the elytra.

Chrysomela scalaris.

(Plate xiv, fig. 10.)

Head, thwrix, hody and scutel dark green : elytra silvery white. Sutural line green, and extending to the base : a coalescing line falls into it just below the scutel, and forms with it an unequal stripe. There are two oblique dashes, which do not meet, on each elytrum. The spot upon the shoulder is double, and prolonged in the form of a curve, and there is another curved spot between the shoulder spots and sutural line. There are three coalescing spots upon the posterior flexure of the elytra. The other spots are arranged somewhat in two lines, parallel with the outer margin of the elytra; and there is a solitary dot near the middle, and upon the outer margin of the elytra. The dots are so arranged that they follow the boundaries of the spots. Antennæ, palpi and legs rust-brown.

In the specimen figured, a brownish color predominated instead of the silvery white: it may he a distinct species from the scrlaris, and is fuund in the autumn upon various plants. 
Chrisomela trimaculata.

(Plate xiv, fig. 16.)

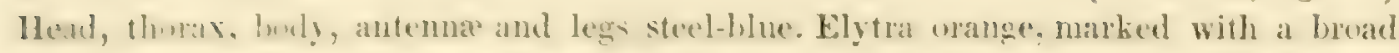
black hamb extending nearly accuss the base, amd two latge triangular buack spots near the apices: scutel and sutural line black. The margins of the black spots are mululating. The punctures of the clytra are aranged in lins. Iength thee-eighths of an inch.

Found in great abundance in Western Massachusetts and New-York.

Citrisomela pi LCHEK。

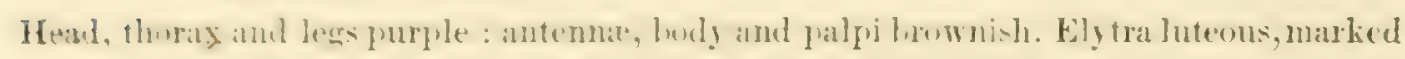
by a wide hack lomgitudinal stripe along the middhe. Sutural line double and punetured : margins marked by two narrow black punctate lines, which coalesce just below the middle.

\section{CHRY SOMELA -}

Hem, thwax, buly and legs reduin lrown. Elytra yellow, marked by a hrod double longitudinal brown band; the inner separated from the outer by a curre, leaving between them a line of yellow, acute at earhend. Sutunal line wide, and dilated at the bate. Scutel reddish brown: punctures arranged in lines garallel with the markings. Length nearly one-fourth of an inch.

Inhalits and feeds upun the Solidugo. It is not uncommen in Western Massachusetts, but $I$ have not succeeded in finding a description of it.

\section{Chrysometa Cerulipennis.}

C.lor of the heal, rytra and ledy beneath, dark Hlte; thorax and legs dull orange; antenne and fict liackish. The females are often seen walking with difficulty, on account of the great distension of the abdomen.

Chrysomela -

(Plate xiv, fig. 1.)

Hearl, thurax, antema and buly slicl-hlue. Elytra luteous, minutely punctured : punctures on the duargins linear. There is a very ohscure line of spots or dots along the suture, scarcely vicille withut the aid of a glass : the tip's of the elytra are also dark hrown. Autumn, and feeds upon the Solidago.

Crirysomera -

(Plate xiv, fig. 2.)

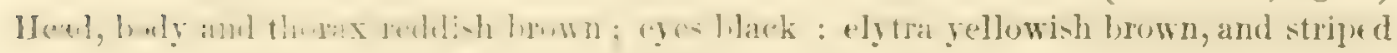
with reddish brown or ferruginous. The punctured lines are also reddish, of which there are about ten to each clytrum, running parallel to the margins. Length onefurth of an inch.

I anz unalile to determine whether it is a described species or not. 
ChR SOMELA TREMULA.

(Plate xiv, figs. 5, 6 \& 7 : larva and pupa.)

IIead, thorax, body, antennæ and legs blue : elytra brown, finely punctured.

Foreign : its larve feed upon the leaves of the poplar.

Chrysomela banksir.

Immaculate, obtusely ovate : head very small; antenux luteous; horax with the lateral edges thickened. Color dark brown, glossy, impunctate. Elytra of the same color as the thorax, punctated : beneath, the same color as above; soles of the tarsi creamcolored. Length nearly one-fourth of an inch.

Chrysomela americana.

Form orate. Color lwown, glossy : eyes black; thorax and head inpunctate. Elytra punetate in four double rows, besides the sutural one : between the rows the surface is flat, impunctured, and of a brassy bronze reflection; the punctured lines are purplish. Length one-eighth of an inch.

\section{Galerucidae.}

Tus fimily is exemplified by those very common striped beetles which infest and destroy the cucumber plant. They are oblong, and are furnished with a small head and a narrow thorax. Their antenne are about half as long as their bodies, of a uniform thickness, and inserted near together and near the mouth. Their legs are of an equal size, though in some the thighs are furmed for leaping. They are small insects and regetalle feeders, and often do considerable damage in gardens.

The family is divided by Westwood into two subfamilies : 1. Galerucides; 2. HaLTICIDES.

\section{Galerucides.}

\section{Genus adimonia (Schrank).}

Antennæ eleren-jointed, filiform throughout, and nearly equaling the body in length : joints mostly cylindric; the last acute, and pointed outwards; the second the shortest, obconic ; the third next in length, the two equaling the first or fourth; the remainder efualing the first or fourth : labrum entire : palpi indeterminate. Head small, exsert : eyes prominent : body ovate, elongate : legs rather long, equal or subequal; rosterior thighs only moderately incrassate. 


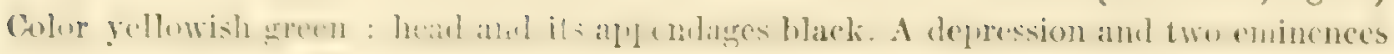
behind the antennx. The three first autenux yellowish green; on the outer side, brown; the remainder dark brown or black : pectus black : abdomen yellowish green. Thorax greenish jellow predominating, immaculate : two slight indentations on ench sicle, with a slight latcral ridge or dilatation. Elytra pale green, marked with eleven black rather qualrangular spots : most of them have their angles rounded, so as to approach an oral form; the hasal spot is common to both elytra. Legs black: upper half of the thighs greenish. Length one-fourth of an inch.

It will be evident from the above generie and specific descriptions, that this insect is neither a Cialeruca, Lema or Haltica, and probably not an Adimonia : it belongs, however, to the vast family Galerucidar. It is rather commou in Sejtember and Oetober on the

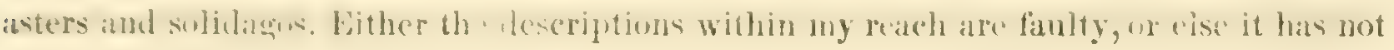
been described.

\section{LFMA TRIVITTATA.}

Rutons : thorax and head rufous; the former punctured transversely at its base, and marked with two black dots. Elytra marked with longitudinal black stripes, the middle sutural : punctures arranged in lines. Antennæ black; first joint rufous: lower tibia and tarsi black. One rariety more rufous, and marked with wider stripes and larger dots upon the thorax : sometimes the dots are absent.

Resenbles the striped cuiumber-bug.

\section{Galezreca vitTata.}

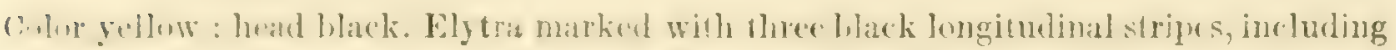
the sutural one : abdomen black; forelegs mostly of that color : knees and feet o the other legs black.

This insect is troublesome to various vines, and especially to young cucumber vines

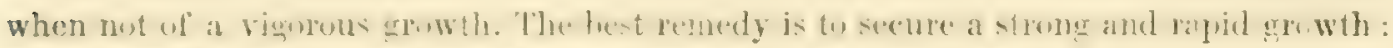

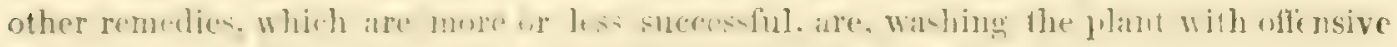

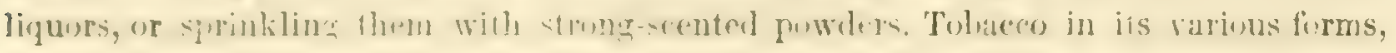
whale-oil soap, ete. are all more or less useful.

\section{Galeruca calmariensis ( Lin.).}

(Plate xii, fig. 12.)

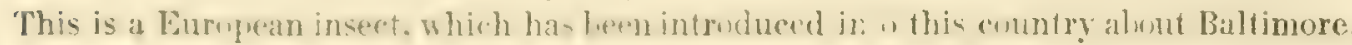
It is de vemetive to flue foliage of the clm. It is abut one-fourth of an inch long, and is described by Mr. Stephens as follows: 'Oblong-ovate; sbove testaceous, decply punctured : crown, furrow on the thorax, scutellum, a dash on the elytra, lyeast and lase of abdomen, black; apex of the ahdomen and base of the antenna testactous. 


\section{EDIONYCHUS THORACICA.}

Color of the elytra blue purplish, immaculate : thorax luteous, marked with eight black dots; outer margin luteous. The outer half of the tarsal joints and antenna luter us; the rest purplish.

\section{Halticides.}

\section{Gevus HALTICA.}

'Form oblong-ovate : thorax narrower than the elytra; posterior tarsi short' (WestWoov).

This genus comprises many species, all of which are small, and whese posterior legs are formed fur leaping. They feed upon the leaves of regetalles, mure especially upon the cruciform plants, as mustard, radish and turnip; the latter of which often suffers exceedingly, in consequence of the insects eating the young and succulent leaves, perforating them like a sieve. Their colors are often brilliant

\section{Haltica chalybea.}

Budy oblong oral : thorax marked with a transrerse fun ruw. Color steel-blue, but rariable and passing into greenish blue : underside green; antennæ and feet black. Length from one-sixth to one-fifth of an inch.

David Thomas, of Cayuga county, has given in Silliman's Journal an account of this species of Hattica. This excellent observer noticed that his vine leaves were infested with a small smooth chestnut-colored larva; and on feeding them in a tumbler partly filled with earth, they came to maturity and huried themselves, and in two weeks afterwards came out the perfect inscet, after having undergone their transfomation. The larra feeds upon the tender fruit buds while in a growing state, and hence destrors the fruit for the season. The use of a solution of whale-oil soap would undoubtedly protect the vine, and drive away the insects.

The cucumber is infested with another species of HALTICA, which has receired the name of $\boldsymbol{H}$. cucumeris from Dr. Harris. It is black, one-sixteenth of an inch long, with clay yellow antennæ and legs, $(x c e p t$ the hindmost, which is brown : the thorax is marked by a deep transverse furrow (Harris).

Another is the wary striped beetle, Haltica striolut a, and feeds upon the horse-radish, mustard and turnip; in which respect it resembles the European species, which fieds. upon and destroys the turnip crop. 


\title{
CIIATEER XI.
}

\section{ORDER I. COLEOPTERA (Continued).}

\author{
PSEUDOTRIIERA.
}

Turs division of coleopterous insects constifutes the Trimera of Latreicie. Taling the number of joints in the tarsi. the division would be regresented by insects sulplied with only three tarsal joints : on close inspection, however, it is found that there is a small

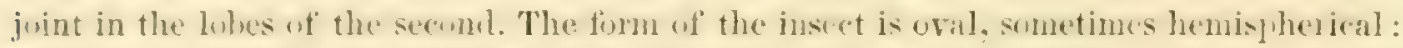
the elytra cover the aldumen. They often feed upon the .tphis, and thus pertim a vachul service to gardeners and farmers. Their colers are often liright, and their thorax and elytra marked in varions places hy dots and sluts (See l'late xi, all the figures; and letters a, $b, c, d$, larva and pupa state of the Coccinella).

\section{Coccinellidi.}

Coccinella borealis ( Lin.).

( Plate xi, fig 8.)

Color luteous : eyes black. Thorax marked with fim hlack dots, the largest lehind upen the central line, and minted hackwark. Elytra marked with seven liack dets cach, the largest ituated towards the apex. and two ulen the sutural line. Belieath lutecus : hro ast black.

Coocinella incarnata.

(Plate xi, fig. 7.)

Flesh-enlured abuve. Therdx maked with two latere transverse lack spots; elytra with sere, liark spots cach, or clewn as they appear when clesed, three heing common to each ( Rich. Faun. Bor.).

Coccinella quinquemacelata.

(Plate xi, fig. 5.)

Burly blark : thomax liark; anterior angles white : "Tytra tawny ; base batuded. and

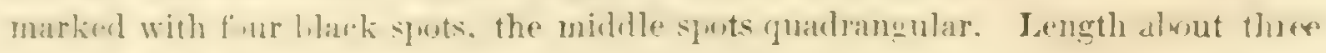
lines. 
Coocinella 20-3hacolata.

Color pale honey-yellow, marked with twenty black spots somewhat confluent on the middle of the elytra. Insect quite small.

In some of the plates the green coloring is too deep. There is a variable state of the ground color : sometimes it is entirely pale honey-yellow; in other instances, there is a grayish green tinge.

Coccinelia Notemnotata.

(Plate xi, fig. 6.)

Color luteous and reddish, marked with nine black spots; one common to each elytrum, situated near the base. Thorax black, margined in front with pale honey-rellow : the black portion extends in front towards the head : body black. The color of the elytra is somewhat variable, yellow and reddish predominating each in different indiriduals.

Coccinella immaculata.

(Plate xi, fig. 9.)

Color luteous : thorax black, margined with pale honey-yellow or whitish : elytra immaculate : body black. The flank of the thorax is quadridentate.

This insect does not agree with Mr. SAY's description in every particular, still it is not so different as to preclude the idea that it is a variety.

Coccinella eimaculata.

(Plate xi, figs. 10, 11.)

Color ferruginous, rerging into luteous. Thorax varied with black and white; the white dilated margins being marked with a black dot, the black arranged in the form of two decussating wide lines. Head marked with a central black line, which diraricates posteriorly, or sends off branches to the eyes. Elytra marked usually with a single black dot : body black beneath.

\section{Coccinelia trioculata.}

The black spot upon the elytra is larger than in the preceding species, and the dilated white margins of the thorax are immaculate : the color of the insect is paler. The abdomen is black, bordered with rufous.

\section{Coccivella dUODEcimotata.}

Body black : head black and quadridentate in front, margined with luteous : thorax black; marked with two oblique rectangular spots, and margined with luteous. Spots of the elytra twelve, and none of them sutural.

$$
\text { [Agnoutural Rapont-VoL. จ.] } 18
$$


Coccisella abreverata.

Filyta fermuinms, marked with eight black dots situated hetween the middle and the apices. Thurax black, with fuscons angular spots, and margined with fuseous.

Coccisella trassyersoguttata.

Elrtra marked with four black dots arranged in a line across the middle.

Cocciselda bisotata.

Color hlack, with two brown-red spots in the centre of each elytrum. Margin of the thorax white.

Coccinelia dectmmaculata.

(Plate xi, fig. 4.)

Color red, deep thesh-red and purple. Head and thorax marked with two black spots; elrtra with ten, one common to both at or near the scutellum, and another below the middle upon the suture : body and legs black. Length about two lines. 


\section{CHAPTER XII.}

\section{ORDER II. EUPLEXOPTERA (WESTWOOD).}

This order of insects (the Dermaptera of Leach) is extremely small as to numbers, but the individual species are widely distributed. It bears a relationship to the orders ColeoPTERA and OrThOPTERA, having by different naturalists been placed in each : it is, however, regarded as having a closer affinity with the latter than with the former, in consequence of the peculiar structure and foldings of the wings. In the structure of the mouth, and the transformation of the insect, it corresponds to the orthopter, but to the coleoptera in the folding of the wings. The order is characterized thus by WESTwood:

'Anterior mings leather $y$, very small and uniting in a straight suture, horizontal, partially corering the wings. Posterior wings large with radiating nerves, and with numerous transverse and longitudinal folds. Mouth with transversely movable jaws, the posterior pair being galeated. Anus forcipated. Pupa semicomplete, actire, resembling the imago, but with rudimental wings.'

The type of this order of insects is the common caruig, an insect far more notorious in other countries than in this. It will be readily recognized by its elongated form, its short wings like the Staphylinus, and the forked armature of its abdomen, which forms an organ of offence as well as defence. Its habits are somewhat peculiar : it is nocturnal, and goes abroad for its fuod hy night; but with the appearance of light, it seeks to hide itself in holes and crevices where it can escape obserration. Tradition affirms that it creeps into the ear, but it does not appear that there any lacts to sustain the assertion.

The Forficula is a vegetable feeder, subsisting upon flowers, fruits, etc., and is regarded as an injurious insect. Hence the English gardeners take advantage of its propensities, by placing in proximity to the flowers and regetables they wish to protect, crab's claws, or narrow reeds closed at one end, into which the insect takes shelter, where it is readily captured and destroyed. 


\section{Chaptere xiIf.}

\section{ORDER III. ORTHOPTERA (OLIVIER).}

Turs order (the Hempters of Linvel's) embraces thuse insects whose wings, when at rest, are finded longitudinally upon the body, and present a straight outline: for this reasin they have received the designation orthoptera, which literally means straight-ringed. In this name, then, we perceive one of the distinguishing characteristics of the order. In $\downarrow$ dition, lowever, to this single character, we find their wings folded like a fin : they "ve also a pair corresponding to the elytra in beetles, which are of a leathery consistence, aud perform the same oflice, that of protecting the delicate wing beneath. Their wings and wing-covers are deflected upon the sides of the hody, forming an angle with the top, and, hesides these peculiarities, they overlap each other upon the hack. By this arrangement, the males are furnished with organs wherewith to produce different sounds, while a particular moditication of the organ enahles each species to form its peculiar note.

Orth ptervus insects are provided with jaws which move transversely, similar to beetles, and hence the name mandibulata applies to them.

Another and still more important characteristic is found in the kind of metamorphosis they undergo. In this respect, they differ greatly from beetles and the butterflies : their metamorphoses or transformations are incomplete; their young, in the early stages of life, resemble the parents in miniature, their wings being the most imperfect parts; they eat and move about like the adult, and, like the young in other classes, they grow until they reach the perfect state. From these comparisons, we see why they should be separated from the beetles, and placed by themselves in an order expressive of the characteristics that belong to them.

The order has been divided into four sections, formed from differences of habit due to the peculiar construction of the organs of locomotion. The sections have received their names from the modes in which these organs are used : the first embraces the RUNNERs, Orthoptera cursoria; the second, the Graspens, Orthoptera raptoria; the third, the walkfas, Orthoptera ambulatoria; and the fourth, the Jumpers, Orthoptera saltatoria.

In the section comprising the runners, we find the cockroaches; in that of the graspers, the mantis, whose forelegs are used as arms and hands; in that of the walkers, the Walkingsticks; and in the section of jumpers, the grasshoppers and locusts. 
The arrangement seems to be clear and satisfactory, and yet it will be seen, as in most other arraugements, that the lines of demarkation are imperfectly drawn; for in the section containing the cockroaches and earwigs, the insect possesses the power of tlight : still it is probably sufficient for all practical purposes.

Some of the species of orthopterous insects are extremely prolific : thus cockroaches become inmumerable, and locusts appear in clouds that darken the sky; and, even in our own more favored country, who has not seen the red-legged grasshopper multiply to such an extent as to devour all the herbage of hundreds of acres!

\section{Blattidx.}

Thrs family (Cursoria, the runners) is represented by the well-known and troublesome cockroach. The body is oval, llattened : wings coriaceous, with their inner margins overlapping each other. The thorax is large, often concealing the head : antennæ long, simple and setaceous, being formed of from fifty to one hundred and fifty joints; mandibles short, strong, and toothed at the tip; upper lip entire; labium bitid; eyes kidney-shaped; legs long, formed for running; tarsi five-jointed ; abdomen furnished with two articulated processes. The males are smaller than the females.

We have several species of cockroach, which either inhabit fields or woody places. The common domestic one (Blatta orientalis) is an imported kind, and is very troublesome in basements, cellars, etc.; while the former, or indigenous species, never comes into our dwellings.

The methods that have been proposed for destroying the domestic cockroach are numerous : they consist in the use of substances which are generally poisonous, and therefore should be used with due precaution. Arsenic, red lead, or other mineral poisons may be mixed with mashed potatoes or meal, and set upon the shelves, floors, etc. frequented by the insects; and as they are fond of almost every kind of vegetable mixture, they greedily devour the mess, and are speedily poisoned.

These insects penetrate the most hidden parts of a building, even into the brick work of walls, where their young are frequently produced. They sometimes disappear from the premises without any known cause : at other times, their numbers greatly diminish in a short period of time.

Buatra NiveA.

'Head and antennæ yellow; thorax and abdomen pale green; wings and wing-covers white and transparent; legs and underside of the abdomen pale yellowish green' (DroRY, Vol. ï, p. 39, f. 1). 


\section{Nantidx.}

Tus family, which succeeds the cersones or runners in the natural arrangement, consists of iuspets technically called RAPTORES or graspers. The larger and more remarkahle species, of which the Vhentis is une, are not found in Few-York or. Tew-England, but smaller hinds are vecusionally met with. Plate rii, fig. $t$, exhibits the structure of an insect similar to the mantis, which takes its prey by grasping or seizing it with its forelegs. Its habits, too, are much like those of the mantis : it remains motionless upon a twig or limb of a lush, in a sitting fusture with its front parts elevated, until a desirahle ohject eomes within its reach. The family are all carnivorous, and hence aid in diminishing the number of regetable teeders.

\section{Phasmidæ.}

TuE insects of this family (. Ambulatorin, the walkers) are distinguished liy the undereloped state of the wings, or hy their total absence. One w two of these remarkable animals are fund in Yew-England and Yew-York : they are commonly called walhingstichs, and the most common species is the

\section{Spectraca femoratum (Say).}

(Plate vii, figs. 1, 2.)

Apterous : intermediate thighs dilated, and furnished with a spine near the tip; posterior also spinous.

The color of the male is greenish with a mixture of brown, especially on the forelegs and the tihia and tarsi of the others : abdomen equalling the body, and furnished with nine segments, terminated with two curred appendages. Female bromnish, thick, with the trunk and abdomen nearly twice their size in the male : legs greenish, but less so than in the male; the thighs less dilated.

This species is rather common, in the montbs of August and September, in the ricinity of Albany and in Western Massachusetts.

\section{Saltatores.}

Turs section (Saltatoria, the jumpers) is represented by the common cricket, and embraces thuse insects whose tarsi are three-jointed, antenum setacens, head large, with a convex cruwn. and inserted deeply into the thorax ; with orate eres, and two or three ucelli. The thurax is truncated in front ; elytra horizuntal ; bidy elongate; wings folded longitudinally; abdumen cylindric; legs stuut and short; tarsi without foot-cushions between the olaws. 


\section{Achetidae.}

Acheta abereviata.

Color black : elytra turgid, brownish posteriorly; abdominal appendages elongated and pilose; posterior tarsi armed with a donble row of spines.

Crickets are nocturnal in their habits, and hence seek their food and their mates in the erening. If numerous, they become injurious in gardens ; feeding upon the different kinds of fruit, melons, tomatoes, potatoes, beets, ete. : when in fields, they eat the tender grass. They are not, however, confined to a regetable diet, but they kill and devour such insects as they can overpower. The insect lays its eggs in autumn : they hatch in the spring, and the young are three years in coming to maturity.

To diminish the number of crickets in gardens, arsenic may be resorted to.

The mole cricket, Grillotalpa brexipennis, differs from the common cricket in the dilated form of the tibia, the lower side of which is strongly notched to fit them for burrowing. These notches hare a distunt resemblance to fingers, and they give to the organ the power of a hand. From the construction of the forelegs, then, and the use to which they are applied, the species has received the name of mole cricket. They are fawn-colored, and corered with short relrety down : they reside in soft moist soil, and throw up ridges of loose earth; they feed upon roots, and, if numerous, might do considerable damage : they are, howerer, rarely seen, and the effect of their feeding is scarcely perceptible. Length about one-fourth of an inch.

No one, who takes much notice of the habits of insects, but must hare obserred the extreme timidity of the cricket. This is especially true of the field crickets : when they issue from their dwellings, it is with extreme caution; and when the slightest approach of danger is risible, they seek at once their asylum, and do not again appear abroad until all their suspicions are allayed.

It is well known that the black cricket flies well; but it has been observed by naturalists upon whom we may place confidence, that field crickets never use their wings. This I beliere is mainly true; but yet frequently when they are pursued, they spread their wings, and make a more extended leap by their use. Their wings are not defective in construction, but seem to be well organized and fitted for flying. The males, it is said, carry on a destructive warfare upon each other during the breeding season.

In some crickets the wings are undeveloped : some species profer damp and even wet places; others, dry and stony.

Crickets have been destroyed in great numbers by placing in their way vials half-filled with beer, into which they crowd and are drowned. 


\section{Gryllidæ.}

Turs family (the Grasshoppers) is characterized by the possession of four jointed tarsi, long setaceus antenni, a large vertical head and convex forehead, vertical prominent eyes, a thurax llat above, and its sides suddenly deflexed and rounded behind : body more or less compressed : the breast furnished with two oval foliated plates; elytra coriaceus, descending the sides; abdomen compressed slightly, and furnished in the male with two processes, and in the female with an ovipositur. The legs are long behind, with thickened thighs and spines.

\section{Platyphylum concavem ( Harris). Katydid.}

(Plate ix, fig. 1.)

Color of the body pale brown; elytra and wings, grass-green. Antenna long, setaceous, yellowish, dilated at the hase; eyes prominent, hemispherical; head greenish, brownish on the top, front ridged, terninating between the antennæ in a triangular apex : thurax greenish, rough, its integument saddle-shaped. In males the musical apparatus occupies a triangular space, corered with a dense parchment-like membrane. Elytra narrowed before, dilated behind and laterally widest near the extremity of the abdomen. and longer than the wings : nervures consist of one principal trunk, sending off numerous branches below at right angles to it. Wings narrower and shorter than the wing-covers; branches of the nervures two. Legs green : tibiæ quadrate; each corner serrate or short spinous. Budy of the male over one inch long. The female is furnished with a curred uripositor (see the figure) about one fourth of an inch long, and buth sexes with two projections between the forelegs. The wing-covers, in their natural position, form a convex corering extending in the female far enough to cover the oripositor.

The katydid is in its state of perfection in September : the female, about this time, deposits her eggs in a row upon the twigs of the tree she inhabits. Dr. Harris describes the musical instrument as consisting of a pair of taborets : they are formed of the membrane already spoken of, which is situated at the base of the wing-covers. This parchmentlike membrane is stretched upon a strong, half oval frame, fitted into the space at the base of the thorax. Their notes are emitted during the evening and night, and sometimes in dark luwering weather in the afterpurt of the day. It is not common, neither is it easy to discurer the retreats of this singular insect : the color of their wing-corers farors their concealment among the foliage of the trees.

The katrdid feeds upon leares; but it would not comport with the truth, to charge it with doing much damage to the farmer. 
Phylloptera oblongrolia.

This species differs from the preceding in having the wing-covers narrower, flat and not concave, the true wings extending beyond them, and they are deflected down the sides ahruptly. The must clistinctive characteristic is the alsence of the projecting integuments between the forelegs.

Phaneroptera angustifolia ( Harris).

(Plate ix, fig. 1.)

Color brownish green : wings and wing-corer's green, the former narrow, their upper and lower edges being nearly parallel, forming an organ equal in width except at and tuwards the hase, shorter than the wings and rounded behind. Abdomen terminated in the male by a short projection, which curres upward. The wings do not conceal the body. Length of the body, three-fourths of an inch; the whole length, about the same as the katydid.

The habits of the three foregoing species are much the same, each kind coming to perfection in September; but the sounds they emit are different.

\section{Locustidae.}

Tre name locust is applied usually in this country to our harvest-fly, which is commonly called the seventeen-year locust. The term locust, however, is here improperly applied, inasmuch as the insects which have been known from time immemorial as locusts belong to a different order from the harvest-llies. The rule of priority should be regarded in this instance; and, besides, the name harvest-fly is sufficiently appropriate. The true locusts, on the other hand, hare been called grasshoppers; a term which, by better usage, belongs to the green insects of which the katydid is an example. The true locusts possess the following characters : their antennæ are shorter, and usually filiform; the elytra longer than the body, though, in forms removed from the typical, they lecome abbreviated and distorted. The ovipositor of females is not exserted.

\section{Genus LOCUSTA.}

Antennæ filiform, inserted into a slight depression between the eyes : head large; eyes ovate; thorax furnished with a central sharp ridge; elytra longer than the abdomen : fuur anterior legs subequal, short; posterior long, and formed for leaping; tibiæ all furnished with a double row of spines.

LOCUSTA CAROLINA.

( Plate ix, fig. 9.)

Color hrown, rariegated with darker spots : wings black, margined with yellow; apex spotted with bromn or blackish. Length an inch and a half; breadth, or expansion of wings, nearly three inches. Common by roadsides.
[Agricultubal Retort-Vot. v.] 
LUCL'STA CORALLINA.

Color lieht hrown, wometimes dark. The wing-envers ane minked hambls their tips with a triangular yellowish spot, and two or three others on the same line more or less obscure. Anterior border of the wings brown and variegated : the base is vermilion, and widely bordered with brown or dusky and nebulous; the inner portion of the border darker than the outer, and the apex is still darker or more dusky.

Apueas carly in the spring : is rather smaller than the preceding, and nore active.

LoCUSTA SULPHUREA.

Colur hrown, rather unitiom in this respect, the wing-covers rather lighter at the alvex; basc of the wings sulphur-yellow, rarying in brightness in different individuals; marein lorenly hordered with dusky, which cxtends in a sharp triangular patch upon the thee nersures towards the base; wing translueent, darker at the anex : ablomen yellowish.

This is suhequal to the corallina, appears rather later in the season, and frequents dry places.

Locusta nebulosa? (Harris).

(Plate ix, fig. 7.)

Culor huwn : therax ridged, or funished with a keel-like elevation, and divided in the middle by a tramsrerse fissure; wings transiarent, with a duskiness of the anterior margin; thighs banded transversely with yellowish and brown; tibiæ brown.

This sprecies, though very common in Western Massachusetts, is described in part from the figure, the oricinal specimen being lost. So far as I can determine under the circunstances, it is the mbulose of Harris, and yet he does not speak of the handed markings of the thighs : in other respects, it agrees with his description of that species.

\section{Grand ACRYDIUM.}

Thi genus differs from Loctsta, in having a spine beneath, between the forelegs : the ridge upun the tol of the thorax is wanting or obsolete; and the antenna are generally longer, in conserpuence of the joints being more elongated, consisting of 24 or 25 joints.

ACRYDIUM FEMORRUBRUM.

(Plate ix, fig. 4.)

Culur ulive-briwn above, yellowish green beneath : antenne pale yellow or olive, darker at the tips; fice green or yellowish green; thorax marked with two yellowish lines extending lietween and along two outer angles, olive-brown upon the top; also anothel triangular area extending backward from each eye, the base resting upon it. Wine-corersulive-hrown, lighter upon the angles. Lower end of the femur surrounded ly it harek helt, and the upler end of the tibia marked in the same way. Yellow I) Henloninutes $11 \times n$ the thighs beneath and inside; top brown and reddish brown; tihige and tarsi hright red, terminated hy four spines : heneath yellowish 
Acrydium flavovittatum.

This common species is larger than the former, and is marked with a yellowish stripe on each side from the forehead to the tips of the wing-covers. Length $1 \frac{1}{4}-2$ inches.

Very common in haying time, and often found in barns among the newly gathered hay.

\section{GENUS TETRIX.}

This genus differs from Locusta and Acry dium, by the long and sharp triangular outline when seen from above, or rather the double triangular form of the body of the insect, the base or widest part heing between the middle legs, from which it tapers each way; the head being smaller than in the former genera. The insect is small, with small wing-covers; but the wings are large in proportion to the size of the body, and scollopped on the edge. The females have four boring appendages, which are notched on their edges.

Dr. Harris divides the genus into two groups : first group, antennæ 13- or 14-jointed; second group, 22-jointed, with additional characters not necessary to be noted here.

For a very full account of these three genera, see Harris's Treatise on Insects, $2 d$ ed. 


\title{
CHIISTIR XIV.
}

\section{ORDER IV. APHANIPTERA (KIRBY)}

\author{
SUCTORIA (DEgerr). APTERA (LaMarck).
}

To avid incumputites in classification, all that fumily of insects known as fects, have heen separated firm their associates, and made an order under the name above given: the creler therefore consists of the single family of the Prurcusa, of which the common 1lea, Pulex irritans, is the leading tyle. The body of this insect is covered with a firm integument, sumewhat shining, and more or less covered with hristles arranged in rows. Its mouth is sucterial, and is composed of a complete apparatus both for inflicting wounds, and for sucking the blood or juices into the stomach.

The P(-urne. are all small insects, yet their anatomy is well known, as made out in a rery elalwiate manner hy Cortis, Westwoon, and M. DLGes. The month is composed of seren pieces: it las two rumd eyes situated upon the sides of the head, and antennx placed behind them in a small cavity which is usually clused with a lid or scale. The thurax has three segments : the aludomen is large; the wings are represented ly small seales; the lecs are lung, hut muscular, and hence are calable of perturming wonderful feats in leaping.

The tlea appears to have a choice among the animals it selects for its prey : the pig and chig seem to enjoy a preference; and for its favorite haunts it selects filthy straw, shavings, litter of most kinds, and dry sandy spots. In these places, under favorable conditions, fleas increase enormously; and the surface of sand where hogs have been littered during the winter is often black with them, especially in southern countries.

The chigre, or jigger, Pulcx penetrans, of the West Indies, lelongs to this family : indeed the species of PLLEx are quite numerous; thus the dog, bat, hedgehog, mole, mouse, and rat have each their peculiar species. Su even birds are infested with parasites belonging to this genus.

It is in warm climates that the pests of this family most particularly abound, and their furments are nust felt and dreaded, rendering a residence there extremely uncomfortable. In our own country, cleanliness is the antidote to fleas. The dooryard is frequently the nursery fin them, especially where chips and decaying wood are allowed to accumulate, mixil with straw, the refuse of the kitchen, and the blood of domestic animals that have been killed for food.

In intusion of tobares is an effectual remedy for domestic animals against fleas, and the hraps of tilth in which they are engendered should be removed and burnt. 


\title{
CHAPRER XV.
}

\author{
ORDER V. HOMOPTERA. \\ omoptera (Leach). HeMiptera (Latreille).
}

THE insects of this order are provided with a suctorial mouth, resembling in this respect the Heteroptera, but with the mouth placed nearer the sternum. Notwithstanding this resemblance, the two orders are quite distinct, and the lines of demarkation well defined. The wings of the Homoptera, in the first place, are entirely membranous, and do not overlap when at rest; the antennæ are short and setiform, and the tarsi number three joints. The metamorposis is of that kind called semicomplete, and the pupa is therefore active.

In this order are found insects of very remarkable forms : it is true, such a remark is often made respecting other orders, yet probably no insect shows more grotesqueness of outline than the leafhopper. Some subdivisions of the order contain insects which singly are perfectly insignificant; yet as they increase to an enormous extent during a single season, they become, from numbers alone, a formidable foe to the interests of the farmer.

The Homoptera are divided into three families : 1. The Harvest-Flies, called in systematic arrangement Cicadida, or cicadians; 2. The PLAnT-Lice, Aphidide; and, 3. The BARK-LICE, Coccidr.

\section{Cicadidae.}

Antense short, awl-shaped, and terminated with a bristleform point : eyelets three; wings and wing-covers inclined at the sides of the body, transparent and reticulated; feet three-jointed; integument of the body hard and firm. Females furnished with an ovipositor lodged in a furrow beneath the abdomen. Insects walk and fly.

The harvest-flies are so called from the circumstance that they make their appearance alout the time of harrest. They possess some remarkable characters which have served to give certain species a great notoriety, particularly the seventeen-year locust, whicb makes its risits only at intervals of seventeen years, and then in great numbers : hence its systematic name, Cicada septendecim. 


\section{Cicada septendecim.}

The males are distinguished from the females hy the possession of an apparatus for the preduction of a rather sharp and rattling sound, which may he heard unto the distance of a mile. The females are destitute of this apparatus, aud may be known from the males hy the ovipositor before alluded to. The musieal or sounding organs are situated on the sides of the insect, just hehind the wings. They consist of plaited convex membranes, of a texture somewhat like thin parchment, and lodged in small cavities in the sides : these membranes emit their peculiur sound ly means of muscles attached to their insides, which serve alternately to increase and diminish their tension with a rapidity almost inconceirahle, while other accessory memhers assist in augmenting the loudness of the tone thus produced by the vibrating membranes.

The ("icuda septendecim is hlack or dusky : anterior margin of the wing-covers, and larger reins or nervures orange red ; eyes, rings of the hody, and legs of the same color. Expansion of wings from $23-31$ inches. The figure near the tip of the wing-cover resembles the letter $W$.

The most interesting fact connected with the history of the serenteen-year locust, is the mule in which the species deposits eggs and makes provision for its future progeny. The insert, in this climate, issues from the ground about the middle of June. As soun as the wings of the perfect insect are in a condition for flying, it selects a tree for the scene of its future nperations. The sexes pair, and, soon after, the female prepares to deposit her eggs. She selects the extremity of a limb for this purpose, and applies the ovipositor, which is fittel both for perforating the liranch, and for sawing it in such a way as to separate and detach the fibres, which are afterwards made to serve as a surrounding protection to the eqgs. The egcs are deposited along a line in which some ten or fifteen perforations are made, some of which receise two eggs apiece. Soon after her lahor is accomplished, the incet dies of exhaustion. The linbl) or twig, which has received its burthen, speedily perishes, and, being nearly severed from its supporting branch, falls to the ground, hearing with it the eggs; or, if the twig he not detached, the eggs are hatched in place, and the young fall or precipitate themselves to the ground. Whether hatched above or upon the ground, they soon penetrate the earth, descending among the deeper roots, where they attach themselves; and there they remain, extracting the juices of the roots hy means of the sucker with which they are provided.

Miss Marganetta H. Morris has the credit of having first observed the fact that the larra of the cicadidx were injurious to fruit trees, by wounding the roots with their suckers, and drawing therefim their sustenance. It would seem that in conseguence of thesp wunils, and the drainage of sal by the numerons individuals thus attached, the rowt becomes unhealthy, and incompetent to supply the tree with its requisite amount of mutriment. Lniler sume circumstances, therefore, where a fruit-tree hecomes sickly without an apparent cause, a search alout the roots may disclose the fact observed by Miss Morris; 
but the long settled distriets of the State, those which were reclaimed trom the forest ifty years ago, will not be so much subject to attacks of the kind. Observation at the time of Whe alyearance of these incects will tend to throw some light upon the question, whether, for instance, a certain tree was known to have been infested by them.

The Cicudu lays between fur and tive humdred eggs; and hence the provision for the continuance of the species, it would seem, is ample : in consequence, however, of the accidents to which it is suhjected in its larva and pupa state, its increase is by no means great, and in the older sections of New-York and New-England it certuinly does not hold its own in numbers.

The lirva dues not necessarily descend deep into the earth : never beyond the reach of the roots of the trees on which it feeds; and in some places where $I$ have seen it issue from the earth, it cuuld not have penetrated directly more than six inches, in consequence of the underlying rock. It is hardly necessary to repeat the old notion respecting them, that they continue tu descend for eight and a half years, and then begin their return to the surface ; jet it is well established that they appear only at intervals of seventeen years, making some allowance for the irregular appearance of a few which may precede or succed the main brood a year or two carlier or later than the rule allows. For a similar reason, probably, the cicada does not appear the same year in different parts of the country

Mr. Harris has given, in his treatise on insects injurions to vegetation, a long list of the times when and places where the serenteen-year locust has made its visits, together with an interesting history of the economy and habits of this singular animal. The insect, according to the author referred to, does not select any particular species of tree in preference upon which to deposit its eggs : most, if not all kinds of trees except the pine and fir, have been found with their limbs pierced by it.

The eggs, according to the ubservations of Miss Morris, are hatched in forty-two days: others say in less time; but however this may be, prior to the time of hatching, most of the wounded branches which have receired eggs are detached, and have fallen to the ground : at least this was the case when they appeared in the vicinity of Troy about the year 18:30. The twigs perish much sooner when wounded by this insect, than if a wound of equal magnitude were inflicted upon them with a knife : indeed, in a very few hours after receiving a deposit of eggs, the twig is perfectly dead.

The extent of injury inflicted by the these locusts upon forest and fruit trees does not seem to be very serious : it amounts to only a foreshortening of the limbs; and if the tree is injured at all, it speedily recovers. The injury is far less than that which often follows when the wound is made in the axis of growth. No remedy seems to be required,

- Harris : Insects injurious regetation, p. 183. The septenderim appeared in Madison county (New-York) in 181 i 
unless when a fruit-tree hecomes infested, in which case all the dead hranches nagy he removed and burned.

Cicada canicularis. Dogday Harvestfly.

(Plate ix, fig. 3.)

Borly black : the head beneath, breast and sides mealy; top of the head and thuax urnamented with ulire-green lines cumected together so as to firm characters, une of which upon the thorax resemhles the letter $W$. Legs, front of the principal roins of the wing-covers and wings edged with green. The borly of this species is thicker and proportionally shurter than the septendecim : aludumen of the male tapers rapidly. Appears late in July, and continues into September.

Accurding to the uhservations of Mr. Harris, this species is very regular in the time wi its aprearance : fir many years in succession, it has heen heard for the lirst time at Cambridge on the twenty-fifth day of July, between the hours of ten in the forenorin and tro in the afternoon. It is therefore an annual visitur, in which respect it diflers widely from the preceding species, while its other habits are much the same. It deposits its eggs in the extremities of the branches of rariuns trees. It is not particularly injuriuus to fruit trees, nor indeed to any other species of vegetation; besides, it never has appeared in sufficient numbers to excite any apprehension of injury.

Cicada noveboracensis.

(Plate ix, fig. 2.)

Buxly black : veins of wing-corers and wings, thorax and abduminal rings edged or ornamented with orange.

This sprecies is smaller than either of the preceding; but it appears annually, and has the same hathits as to the mode of depositing its eggs. It is never in sufficient numbers to inflict serious injury to forest or fruit trees.

\section{Tree-hoppers, Leaf-hoppers, etc.}

Furm triancular, hut rariable in the different genera : ejelets two; musical instruments none; locomotion by leaps aided by wings.

These grotesine insects inhalit the trunks, limbs and leares of trees : they are small; culurs areen, crar, with sputs or cloudiness of the wings; faces often rertical or nearly so, with the thorax and anterior parts thick, whence they taper rapidly to the extreme points of the wines; lecs furnished with spines. The species are very numerous, each tree and shrub being inhabited by its own peculiar kind.

I: this grup of insects hare habits much the same as the cicadians, and whain their mutriment by sucking the juices of plants, it is suppwed that in some cases they may he detriundal to regetation : they cannot, howerer, injure the firmer very materially, though as a class they are quite numerous. 
The following species are among the most interesting, and deserve attention as much, if not more, from their peculiar forms and habits, as from their infliction of injury upon the products of the farm*.

\section{Membracidae.}

\section{Genus ENTJlia (Germar).}

(Plate xiii.)

Back more or less notched or sinuate : thorax foliaceous.

Evtilia sindata (Fab.).

(Plate xiii, fig. 11.)

Back deeply sinuate-notched, or slightly angulated. Color brown : wings rariegated with a patch of grayish white, broad upon the lower margin, and becoming narrow upon the superior.

Entilia emarginata.

(Plate xiii, fig. 13.)

Back deeply notched or sinuate. Color brown : proportionately shorter than the sinuata.

Extula concava ( Say).

(Plate xiii, fig. 10.)

Back simply sinuate, more depressed than in either of the preceding species. Color brown: wings obscurely banded with gray posteriorly.

The preceding species differ but little in size : they are about a quarter of an inch in length, and inhabit the Canada thistle and other herbs and trees, but are not known to injure any of the cultivated plants.

\section{Genus SMLLIA (Germar).}

(Plate iii.)

Back rounded; the front sometimes orerhanging the head, and higher than the back.

Smilia adricolata (Fitch).

( Plate iii, fig. 23.)

Back rounded, high and arched anteriorly : color green; front projecting along the median line.

Smilia guttata.

(Plate iii, figs. 21, 22.)

Back slightly arched, nearly straight, fuliginous : oblique anterior band narrow and obscure; posterior is a large greenish spot, extending nearly to the inferior margin of the wing-covers : a still more obscure grayish marking posteriorly.

\footnotetext{
- For specimens and names of the following genera and species, I am indebted to our distinguished entomologist, Dr. Asa Frtcr, of Washington county.

[Agricultural Report-Vol. v.] 
SMilia riridis.

(Plate iii, fig. 25.)

Areh of the hack lopine towals the head; the projection orer the face wanting; face mumbel. Color of the sides green. duky along the hack : wings uruanented with a trausrerse gray patch near their extremities.

Smila vittata.

(Plate iii, figs. 27, 28.)

Back only sliwhly arehed: middle rather concave. Color browish, ornamented with a ereenish hamd which extends diagomally from the front to the lower margin of the wing-curers: also fwo transverse green spots, one on the niddle, the other upon the posterior part of the wing-corers.

\section{Gevus CYRTOSIA ( Fitch).}

(Plate xiii.)

Humeral ancles roumded, not salient : dorsum cumpressed, fuliaceous, forming a regularly arehed keel highest near its middle, and at most with a slight concavity posteriorly; apical cellule triangular, its end rounded ( Frтсн).

Cyrtosia arceata.

(Plate xiii, fig. 14.)

Bodr recularly archel, highest about the centre of the back. Color light yellowish, marbled with finscous : a shade of fuscous passes transversely across the sides, back of the middle.

Cyrtosia fuliginosa.

(Plate xiii, fig. 15.)

Back reqularly arched. Color dark fuscous or brown, variegated with lighter anterior to the middle.

\section{Genus TElaMONA.}

Body or back surmounted by an angular foliaceous protuberance or crest.

Telamona ampelopsidis (Har.). Woodbine Telamona.

( Plate iii, fig. 17.)

Crest or protulerance rather concave in front, sloping moderately on its dorsum, and firming with the steel) fosterior slope an obtuse angle. Color light fuscous, traversed hy a darker clunded line from the concavity of the crest to the middle of the inferior margin. Inhabits the woodbine.

Telamona fagi (Fitch).

(Plate iii, fig. 19.)

Dursal crest notehed posterimly. Color dark fuscous : sides of the head light; wing posteriorly light, terminated with a darker shade.

Telaarosa UNICOLOR.

(Plate iii, figs. 5, 5.)

Dorsal crest rounded. Color yellow, or only slightly tinged with fuscous. 
Telamona CORYLI.

(Plate iii, fig. 11.)

Crest straight upon the superior edge, which inclines slightly backwards; posteriorly it is concare. Culor dirty yellow : margins of the crest fuscous. There is a semicircular spot on the sides beneath : apex of the wing-covers also marked with fuscous.

TELAMONA CRATEGi.

(Plate iii, figs. 3, 4.)

Dorsal crest narrow at base, high and slightly concave behind and convex befure, placed in adrance upun the thorax. Color of the crest black or rery dark brown, which is prolonged upon the sides to the inferior margin of the wing-covers; wing-covers tipped also with black : sides anteriorly light, and with a light band between the two dark bands. Inhabits the different species of thornapple.

Telamona ornata.

(Plate iii, figs. 15, 16.)

Crest $\pi$ ide, rounded anteriorly, sharply angulated behind : color fuscous. The pattern of the ornamental markings resembles those of $T$. cratagi, only they are lighter and the proportions somewhat different.

TELAMONA ACCLIVATA.

(Plate iii, figs. 9, 10.)

Dorsal crest twice as wide at the base as at the summit, the posterior half rising only half as high as the anterior half.

Telamona RECLIVATA.

Anterior edge of the crest forming a straight line with the head; superior line nearly straight; posterior margin large, concare. Color fuscous, lighter before than behind.

TeiaMroNa QUERCI.

( Plate iii, figs. 7, 8.)

Dorsal crest wide at the base, bounded by a large concavity before and behind, conrex or rounded above, and about half as wide at the summit as at the base.

Telamona tURRICULATA.

(Plate iii, figs. 1, 2.)

Thorax surmounted by a high narrow erest, rising somewhat in adrance of the face; posteriorly the concavity is large, and continuous with the entire back.

\section{Genus CERESA (Amy \& Serv.).}

(Plate iii.)

Ceresa diceros (Say).

( Plate iii, figs. 33, 34.)

Brown : sides of the wing-covers ornamented with two dark and pointed patches of brown.

Ceresa bubalus (Fab.).

Wing-covers and thorax greenish : sides mottled with fuscous. 
Dorsal moluchunce hurn-like, advancing in tront, rising high obliquely upwards and furwards.

Themia mimaculata (Fab.). (Plate iii, figs. 31, 32.)

Colur dark fuscous along the back and sides : inferior part of the sides marked with an elongate patch of yellowish (male).

THELIA LCTIPES.

(Plate iii, fig. 18.)

Crest advanced beyund the front : posterior margin forms a straight line with the back.

Thelia Bixotata.

(Plate iii, fig. 17.)

Crest arched anteriorly, narrom, concare behind. Colur light brown : back lighter, and marked by two brownish spots.

Gargara cinereun.

(Plate xiii, fig. 3.)

Color hrown, punctured : towards the front it is traversed by a pretty broad belt of limlater, in firm and shape like an arrowhead, with its point towards the head, and resting upon the median ridge; posteriorly it is tracersed hy a narrow belt, which runs directly across the back. Length two-tenths of an inch.

Gargara maculifromtis.

(Plate xiii, fig. 1.)

Color light brown and lightly mottled : front marked by an oblong dark brown spot, situated nearly between the eyes; posteriorly it is traversed by two faint or lighter bands directly across the back.

Gargara majes.

(Plate xiii, fig.6.)

Color hlackish, punctured. Apex of the wing-corers black or blackish lrown, extending farther unon the sides than upon the ridge, nearly meeting another transterse liroad band of the same color, and learing an oral or roundish lighter space between them : the dark anterior band does not cross the sharp ridge of the back, but leaves a continuation of the same color as the anterior and middle parts. Thighs dark brown. Length one-fourth of an inch, and sometimes rather exceeding that measure.

This species has the regular rounded outline somewhat broken by the sudden filling off of the ridge posteriorly.

Gargara QUERCT.

(Plate xiii, fig. 8.)

Color lirown, and dark brown upon the middle of the sides : middle of the back marked by a lung oval yellow patch. Near the apex of the hemelytra there is a small roundish patch of yellow: legs yellow. Length two lines. 
Gargara discoldalis.

Color brown, and traversed by two light bands; the front band pointing forward, its edges undulating, with a much darker space behind it, and crossing the back. The posterior band crosses the back directly, and is also bordered behind by a darker belt : legs brown. Length rather more than two-tenths of an inch.

It cesembles the cinereum, but is more elevated at the centre of the back, and the distribution of the colors is rather different.

Gargara pobescens.

( Plate xiii, fig. 3.)

Color dark brown : sides marked by a light punctured band enclosing a half-oral black space, or very dark brown; posteriorly it is traversed by a light band directly across it. Wings terminated by a dusky patch, hefore which there is a large patch of white.

This species is rather depressed, and flat upon the top of its back. Length two-tenths of an inch.

Gargara inermis.

(Plate riii, fig. 7.)

Back rounded. Color yellow bordering upon green, punctured : punctures and color distributed very uniformly over the individual.

Gargara pectoralis.

(Plate xiii, fig. 12.)

Color greenish yellow, dotted with green : there is a patch of yellowish and greenish white above the eyes. The wings are traversed transversely by narrow belts of light green and white, when they are uncovered by the hemelytra : legs obscurely banded with brown. Length nearly two-tenths of an inch.

Gargara Nigricephata.

Elevated in front. Color very dark olive brown, banded transversely in front, directly behind the eyes : sides banded transversely, which bands meet in the front band behind the eyes; head black; legs yellowish. Length two-tenths of an inch.

The general reader will be able, from the figures which are given of a few of the genera and species belonging to this subdivision of the Homoptera (or Hemiptera), to distinguish them from other insects. It is true they are small in number, or at least less numerous than the plant-lice, aphide : still their forms and habits, as well as consistence, will always serve as diagnostic marks. So far as their food is concerned, as well as their mode of obtaining it, they resemble plant-lice : they wound the plant by puncturing it with their beaks, and suck the juices. When they are few in number, they do but little mischief : on the contrary, where they are numerous, the wounds they inflict, and the diversion of sap they occasion, have quite an injurious effect upon the health and perfection of the plant. Among the plants most liable to be injured by them, the vine probably suffers the most; for it abounds in sap, and hence offers support to large colonies of these insects. 
In the eichth volume of the Encyclopadia Americana, Dr. Harnis has described the leathopper, Tothigmit vitis. It is about the tenth of an inch long, and arrives at maturity in the month of August : it is of a pale straw-color, and inhalits both the native and foreim urape vines, amb, in some seasms, is sommerous as to aflect seriously the vines and fruit. They athere to the underside of the leaves, and hence the remedy proponed, which consists in fumigation with tobacco, will be more effectual than if they inhabited the uprer side. For the purpose of fumigation, the vine or its trellis should he corered with a tent, and the process may be persisted in until the inscet is thoroughly routed or destroyed.

listhushes sometimes become infested with a kind of leafhopper, the Tettigonia rosa, which may be treated in the same way.

As the insects of this fimily hop briskly, they cannot be dislodged from the vines by shaking, nor is it practicable to cateh them : it hence becomes necessary to destroy them hy fumigation, or by the application to the leaves and rines of some substance destructive to the insects, but which will not injure the plant. Whale-oil soap in solution is another remedy whose application has been followed with success.

As these insects take refuge anong the fallen leaves and underlying grass, where they survive the winter, the leaves and grass should be carefully removed and burned, either after the weather has becume culd in the autumn, or in the spring before regetation has put firth. All these methods should be resurted to, where vines suffer from too great an abundance of these insects.

\section{Aphididae.}

Tine Apunins ( plant-lice) are a group of insects with soft hodies of an oral form, and furni-hed pusteriorly with two tufts or pores. The females are generally wingless, though nut always. The upper pair, answering to the wing-covers in the Henpters proper, are larger, and are used for the purpose of flight, or to assist in leaping.

The leaping plant-lice belong to the Genus Psruda : the young are corered with a cottony sulistance, and are found upon the alder and some other plants in the spring.

The genus to which the name Apris has heen giren, from which the name of the family is derived, and which signifies to cxhaust, is one of the most remarkable in the class of insects : feeble and entirely unprotected, the insect is crushed by a touch, or swept away by a breath. It is, howerer, prorided with the means of increase to an immense extent; and. hence, in conserguence of this extroordinary power, in rirtue of its numbers alone it is compretent to intlict the most serious injury urun the jlants it inhabits. Most plants are inti-atel with theru: and each particular kind of plant, shrub and tree, supports its own formliar surve, thengh it dees not seem to be groved that the juices of many plants may 
not furnish wholesome nutriment to several different species of insects. Indeed the same plant may hear two or more kinds of lice, and they may occupy the root, leaf, stem, or bud.

I hare alludel to the greatness of the number of aphides. Considerable attention has been paid to this part of their natural history. REausu has probably inrestigated the mode and rate in which they increase, better than any other naturalist : he ascertained that a single individual may be the progenitor of six thousand millions of individuals during the life of tire generations. The eggs are laid in the antumn upon the buds of the plant, and are hatched in the spring : this takes place when the leaf is just expanding and tender, to which the delicate aphis is attached by its sucker, and from which it sucks the juice. They grow rapidly, and speedily come to maturity. The most remarkable fact connected with this first hrood, which is hatched from the egg, is, that the indiriduals, howerer numerous, are all wingless females, which present this anomaly, that they are competent, without intercourse with the male, to beget another generation of females, and this another, and so on to the seventh generation. After these generations hare succeeded each other, another generation, consisting of males and females, is produced in the autumn : pairing takes place, and the eggs are laid upon the buds as has been stated, and in due time are hatched; and thus the broods are produced in the successive seasons after the same fashion. The generations all perish in the autumn, and the subsequent continuation of the race is committed to the egg. The males have wings.

A young leaf that curls, or looks unhealthy, is probably infested with aphides : they will often be found clustered together, engaged in sucking the juices of the leaf; and as they are roracious feeders, nature has provided them with the means of ejecting their food in an uncommon way. This is done through the two posterior tubes : the ejected matter appears first in the form of a pellucid fluid, which is sweet, and has received the name of honeydew. Ants, heing fond of sweet fluids, are in the habit of frequenting plants infested with aphides, which they treat in a very gentle and tender manner, feeding merely upon the lluid without inflicting the slightest injury upon the insects that draw it from the plant. Another insect, howerer, the lacewing, unceremoniously thrusts its curved beak into the sides of the aphis, and sucks the insect dry, leaving nothing but an empty skin. The presence of ants upon a plant indicates also the presence of aphides.

The aphis, as already stated, infests most plants : the rose, the asters, apple, peach, pear, cabbage, etc. etc. are only a few among many upon which we may find it to an injurious extent. Besides it is not unfrequently the case that the exist beneath the soil and upon the roots, where they cluster together in rast numbers, and extract the ascending nutriment : these are usually white.

The peach-tree is known to suffer extremely from the aphis, which, when numerous, affects it in a way that prevents its bearing fruit. My own trees suffered for three succes- 
sire seasons from this insect : the young leares of the first product curled, thickened, became red or lowm, and most of them perished. The trees afterwards put firth a new crip) of leaves, and all survived, thongh the fruit was destroyed in the hlussum. (For a delineation of the peachtree aphis, see Plate xxix, fig. 7.)

It is evilent from the foregoing remarks, that plant-lice are injuriuns, both through the mounds they intlict upon the parts of the plant they inhabit, and from the fluids or nutriment they abstract from the circulation. As a fimily, their habits are the same, but some sprecies or kinds aprear to be more injurious than others; and it seems difficult to accuunt for all the effects they produce, unless they pussess a proisonuns principle. In support of this observation. I may state that the pear is infested with a kind that kills the tree when young. Of this fitct. I was infirmed hy Dr. Orub Purmb of Salisbury (Connecticut): the limbs or twirs which he showed me were brown and dry in patches. Afterwards Mr. Harris of Cambridge investigated the matter, the results of which he has conmunicated in his work on insects injurious to regetation. In. PLrMb, who was the first to notice these minute parasites of the pear-tree, entered with much zeal and spirit into the investigation of their effects, and of the remedies to destroy them.

The genus to which this insect belongs is Psvira, one of the jumping plant-lice, but destitute of the cuttun-like curering. From the olservations of Dr. Pucmb, it alperars to give hirth to twu or mure brouds during the year, being fuund upon the pear from May to (1)twher. They first appeared upon imported trees. My own trees, which were ubtained from kuchester, and were alsu imported, had many limbs that appeared rusty and dry; and thungh these limlis were lost, the trees surrived. The appearances of the limbs were sinilar to thuse of the hranches preserved by Dr. Pursi; but I was unable to find the aphis, although I sought for it diligently.

This insect is described as of a dull orange color, and one-tenth of an inch long when perfect : the thrrax is brumish orange. The female is more pointed behind than the male. According tu Mr. Harris, it may prove to be the Psylla pyri of Europe. It may be well to remark. that when the branches of a pear-tree become dark and dry in patches, it is advisable tu search fir this insect. The remedies reenmmended are, first, rubbing off the lice with a hrush. Mr. HARRIs alvises the aprlication of strong soapsuds with sulyhur, by means of a lirush, befure the buds expand : so also the use of whale-oil suap".

The invects of the Genus Turips, likewise belonging to the Family ApHidide, are also injurious. Their wings, instead of lying olliquely upon their backs as in the Genus ApHs, lie fiat, and are fringed. They are supposed to poison plants by their puncture, producing therely curls and a thichening of the tissues of the leat. They may be treated with soap and water, or whale-vil soap dissolved in water : a strong decuction of tansy may serve.

- Es rrig on Insects injurious to vegetation, p. 202. 
A species of Thrips infests the kernel of wheat while in its milk state; and it is quite doubtful whether this one can he destroyed hy the andication of fine slaked line, as has heen recommented : still, when the dew is un the llant, a free surinkling nay be tried, which, if not successful in the way designed, will at least benefit the soil.

The disease called appletree blight is due to another menus of aphides, the Eriosoma. It is a woolly insect, destitute of wings, hut is watted from tree to tree hy the buogancy of its woully envelope. The egrs, only risihle under a microscope, are cureloped in a cottonlike substance found in crotches of the tree and chinks of the bark; and if there are suckers standing aroumd the tree, it may be found on then alsw. The full-grown insect is one-tenth of an inch long, emits a sticky juice frum its extremity, and is covered with flakes of durn : when this is removed, the color of the antenne, head, sucker, and spines is blackish; abdomen honey-yellow (HARris). It feeds upon the sap of the alturnum of the apple-tree; and the wounds it inflicts give origin to warts, excrescences, and inequalities upon the bark : the final result of its attack is the death of the tree.

It appears lrom the accounts which have been published of the rarages of this aphis in Eugland and in this country, that the only hope of arresting the evil lics in beginning at once, or as soon as the insect makes its appearance. After it has extended itself far and wide upon the large trees of an orchard, it becomes exceedingly difficult to arrest its progress, and this probably only happens in cases when the weather becomes unifarable to the life and propagation of the insect. The rational way to go to work, will be to scrape thoroughly all the trunks and larger limbs, and then to scrub the surface with strong soapsuds, or whiterrash them. When the trunk beneath the soil and the roots are infested, extend the treatment to these parts also. Mr. Harris recommends a solution of potash, and to protect all the wounded parts by grafting wax, and also the removal of all refuse from and about the tree that mar contain the eggs or the living animals : cut off, likewise, and burn all the smaller limbs. It seems that all strongly scented solutions, such as tobacco water, ammonia, etc. are more or less effectual remedies against the depredations of the various kinds of aphides.

Another interesting and important fact in natural history is that plant-lice have numerous foes, that prey upon and destroy them in great number's : among these fies we may rank the numerous species of Coccinella, or ladybirds (See Plate xi, where several of the most common kinds are figured). A person unacquainted with these small and beautiful insects, on seeing them upon an infected plant, night mistake their characters and office, and attribute to their presence the sickly state of the plant. He could not well commit a greater mistake; and to convince himself of this, he would only need to watch the morements of the little beetle for a short time, when he would find that its crrand was one of kindness to him and his plant, for he would soon observe it feeding mon the plant-lice: these constitute its food, hoth in the larva and mature states, sn that it. services iu re[Agricultubal Report-VoL, v.] 
moring the plant-lice are hy no means inconsiderable. He night, indeed, advantagcously stock his house-plants with the roccinclla, for the purposo of keeping them clear ul lice.

I have alrealy adverted to the lacewing : in its larva state, it is probally one of the most sanquinary enemies of plant-lice. Where these ahound, the egg of the lacewing may he seen each supported on the end of a slender thread. The larva or grub is provided with a large pair of eurved prointed hollow jaws, with which he seizes the aphis, and sucks all the fluid contents of its body, leaving nothing but a collapsed skin.

Mr. Krisy states the fact, which is also now well known to many, that a fly belonging to the Genus Syrphts is equally etfective in exterminating the aphis; their lartæor maggots having completely exterminated a colony which had a week befure infested his currant-bushes.

\section{Coccilae.}

TuE BARK-LICE form a third division of singular insects, from which, judging from the appeance of a few individuals among them, we should never expect serious injury to trees or plants. They vary in form : sometimes they are kidney-shaped scabs, beneath which, at some period or other, may be found a brood of minute lice : others are oval, quite large and glubular, of a dark gray colur, and are fixed to the surface of the bark, or have lost the power of locomotion; these are females.

Is an illustration of the charicter of the Coccide, I may state that the matter of the cochineal of commerce, brought to us from Mexico, is an insect of this family.

These insects are usually known under the name of bark-lice, of which the kind that inhabits the branches of the appletree is probably the most common. They differ in structure from the aphides, their feet consisting of a single joint terminating in a claw. The male is quite small in comparison with the female, and, like that of the aphis, is provided with wing;, which are two in number, and lie flat upon the budy as in the Genus Tursps. The female, after she has hecome fixed to the limb or bark of the tree, having lost the jower of locumotion, brings furth beneath her a brond of young, which, when able to run about, escape from the dry skin of the parent, and fix themselves by their beaks to the bark, where they grow and become mature upon the sap of the tree.

A maple at my dror in Hudson-street, Albany, is infested with thousands of individuals of a species of Coccus, about the twentieth of an inch in length, and covered with the woolly matter peculiar to the family, which imparts to the limbs a snowy appearance. On the first of September, the back of the leaf supports some twenty individual females of a green color, beneath which are the young.

Trees suffer from the minute yunctures of hark-lice; the apple-tree particularly, which is iufested with a kind that resembles a dry scale, having the color of the cuticle of the bark on which it rests. The remedies for these depredators are the same as have been re 
commended against aphides, particularly the brush, soap and water, and scraping the bark with a suitable instrument. Several sorts of birds, such as wrens, chickadees, creepers, etc. feed upon the larger coccidæ.

A large brown coccus, the tenth of an inch in length, inhabiting the chestnut and blackoak, gives origin to one kind of honeydew. These trees, in Warren county (New York), were teeming with a species of coccus in 1838 ; and from their bodies drops of a sweet fluid were cast, which, on falling to the ground, were formed into minute threads. These appeared in sunlight like the threads issuing from the gossamer spider. The leaves and grass were covered with this substance. The insect had an oval form, about the size of half a marrowfat pea, with a brown, wrinkled, naked skin; that is, it was destitute of a woolly or cottony covering.

The currant-bush at present suffers from the attacks of an aphis, which has been increasing in numbers for three or four years past. The insect occupies, as usual, the under surface of the leaves. The female is uniformly green, and provided with antennæ longer than the body, and three rows of bristles along the back : body ovate, thicker behind, with the honey-tubes near or along the outer row of bristles. It produces a thickening and reddening of the leaf, and the crisped condition that comes from punctured wounds of the parenchyma. This valuable plant should receive a timely attention, before the insect has increased much in numbers; and as a remedy, whale-oil soap is undoubtedly the best.

The snowball (Viburnum) has been infested for years with a peculiar aphis, which effectually destroys the beauty of the shrub. In some cases the leaves are all crisped and rolled, and the consequence is the total loss of the beautiful and ornamental flowers peculiar to this species of Viburnum. The insect makes its appearance with the expansion of the first leaves, and continues through the season. The usual applications which have been recommended, should be employed upon this plant.

The black cherry, also, is infested with an aphis in July. The community consists of males and females. MaLes : antennæ black and equal to the body in length, pointed forward; head and thorax black or greenish black; abdomen green; wings twice the length of the body; thighs and tarsi black. Females green; antennæ two-thirds the length of the body, turned over the back or pointed backwards; tarsi black; wings rudimentary. This aphis lives upon the uppermost leaves of the young virginian cherrytree, where the females produce their usual effects, the curling, thickening, reddening, and finally the death of the leaves.

For fruit trees, it appears to me that the best remedies against insects are those of a preventative character. Trees that are kept in a thrifty growing condition by the application of manures, ard the use of means to keep the bark clean and smooth, rarely suffer from lice. Among both plants and animals, the feeble are generally those which suffer from parasites. It is not, I believe, because the tree has become weakened in the first place by them, but, on the contrary, the plant (and so also with the animal) first suffers for the 


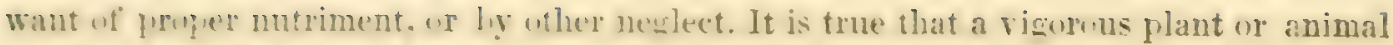

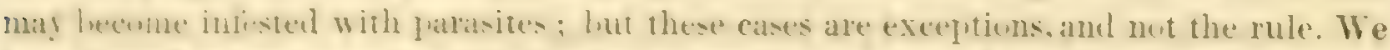

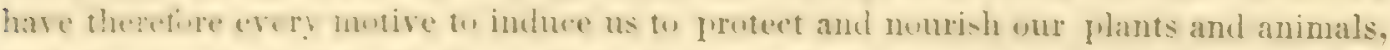
luth fur the arreater flolit they will reuder us, and as a security against disease and the attacks of parasitic animals.

\section{Atmospherie Blight.}

Turar. is a disease among cultivated herharens plants, the origin of which is not determined. The Mant, as the june peat for example herins to dry and whiten helow : this

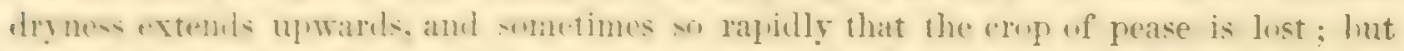
whether this he the ease or not. the crop will he greatly diminished, and the early death of the whele plant is the conseduence. The disease matr le said to he a premature decay and weath of the plant : it is equivilent to a blight, or to the putato disease. The question that arise recpecting it. is. I it due to an insect, or tw atmospheric causes ? The answer to this yustion is neither detinitely negative nor pusitive. Yo inserts have get leeen detecterl uyom the pea ; and yet its rout, which has not perhays heen sutficiently examined, may disclise some insect that hrings on this decay. As to the atmenpere, phrsiolugists may well differ : we ascribe to changes of the weather, there disedses and injurits that cannot he referred to the attacks of insects. Remedies have not heen propused : but it is sugrested that a change of seed may divert the calanity, or frerhaps saling the seeds in muriate of ammonia or a weak solution of copperas, and the n rolling them in plaster.

The lychnden becomes sometimes affected with a white mondiness, which makes its alprearance upon the leares early in July, and destruss the heauty of the plant, heginning urwn the lowermust fart of the leaf, and extending upwards until the whole is coated with a filmons matted mucor. It does not applear to he of animal origin : under a single lens, I hare not been alle to discover any thing that lowk like the work of an insect. The guestim is. Whether this fungus is the cunseguence of a two feehle vital action; or, to sperak more catutimsly, whether what we call vital actions are enfeeliled by any causen other than there which may he attriluted to wounds hy insects? The barenchyma of the leaf is not destrued, lut the surface is covered with a white fibrous fungus, analogous to the coverng of the gooseberry when affected with mildew.

In undertaking tw assign a cause for effects of the foregoing kind, it should not he forgitten that a minute puncture may result in the production of a fungule growth : the juire exuling fiom a wound, whether possmed or not. undergues a change that fits it fir th. growth if tungi. whirh may be in some instances small and invisille, while in others they exteml orer large surtaces. and as in the lychuidea and gorseherry, occuly in time the whele leat. or the whole surfice of the fruit ; so that a punctuse, to us invisible, and which may he male hy in insect, can ret he detected in its consequences. The greater 
effect may be the fungous growth ; the lesser, the exudation of sap from the puncture, so that in these cases the effect might he mistaken for the cause. The effect of remedies may aid us materially in arriving at a correct determination of the cause.

There is still another affection of the leaf, which results in the injur if not the death of the plant. The elm. maple, chestnut, and sereral other trees are affected in the way about to he described. Their leaves dry at the apex or on the edge, become bromn, and curl up. This affection may appear upon a small part of the leafonly, or it may corer the whole surface of a part or all of the leaves upon a branch : if only a few leares are discased, the branch will live; if all, it dies simultaneously with the leares; and in some instances the disease affects so many limbs, that the life of the tree is inminently threatened. An elm standing before my door in Hudson-street has lost a part of its branches erery year for many jears in succession. Another thrifty elm was extensirely affected, and must of its large branches died in the course of two weeks. The disease is the same in both cases, and, I think, in all the instances which begin by the drying of the apex or margin of the leaf, whatever mar be the species of the tree. In no case could I find an insect to which the effects could be attributed, but the affection seems to prevail most under the intluence of certain peculiar states of the weather; and I have also obserred, that when the potato rot has been prevalent in its worst form, the trees have been most severely affected with this disease.

This disease constitutes a form of blight, which, on a close examination of the leares and limb, prores itself to be independent of the cause that sometimes produces the pear blight, and which Dr. HArris ascribes to the Scolytus pyri (Peck). The external appearances in the two cases are identical, and yet the causes of the blight are different: in the one case, it may originate in the wounds of the insect alluded to ; but in the other, there can be no doubt that it is produced by atmospheric changes resulting from heat and moisture combined. Some of our elms are affected erery season; and when the cause operates intensely, sereral kinds of trees suffer in the same way : sometimes an entire limb wilts and blackens in the course of two or three dars; and then again the disease is confined to a ferr leares, which fall off, and the limb lives; while in yet others the edges of the leares dry and blacken, or one half of a leaf, the other half remaining unaffected. I am of opinion that we should not attribute to insects a disease that runs the course abore described; and as it occurs only in certain states of the atmosphere, it is more agreeable to analogy to assign the cause to which I have referred it. 


\section{CHAPTER XVI.}

\section{ORDER VI. HETEROPTERA.}

Turs order embraces those insects whose forewings or wing-covers are coriaceous at the base and membranous at the apex : the body is depressed ; antennæ elongated and filiform ; and the mouth, which is placed on the inferior part of the head, is promuscidate. Metamorphosis semicomplete, with an active pupa state.

It is the Hemptera of most American and English authors; but Heterortera is the designation preferred by WESTWOD, for reasons which make it appear to be the more appropriate name of the two.

The order is dirided into two sections : 1 . Hydrocorisa, the residents of water; 2. Aorocorisa, those which breathe air.

We have three families at least under the first section, the Notoxectidx, Nepide, and Gargelide.

The Genus Noтosectes is not uncommon in the springs that furnish the city of Albany with water, and which rise in a high sandy plain some four miles west of the city.

\section{Notonectus}

Body much depressed; mouth promuscidate, short, and composed of two joints ; antennæ lost in the specimen; eyes orate : the forelegs advanced, and the tarsi armed with a single two-jointed claw; the middle and posterior three-jointed; the third minute, and the last armed with two claws. Color brown or olive brown; beneath lighter than abure, uniform, and without ornaments or spots. Thorax in the form of a segment of a triangle; niddle impressed with a longitudinal line, crossed by a transverse groore; margin of the thorax ciliate. Scutellum large; base rather greater than the height : the posterior pair of legs obscurely barred with brown; forelegs raptorial, and without bars. Length an inch and a quarter. Swims rapidly upon its back, and is carnivorous.

The damage which the . Notonectus occasions, consists in the destruction of young fish, or $f r y$ : in this respect it is as voracious as the Dyticus. 


\section{Genus GALGULUS.}

Body short, dilated; antennæ short, terminated with a round knob, and placed in a cavity beneath the eyes; eyes subpedicellate; mouth promuscidate; head triangular; arm or humerus dilated; tarsi single-jointed, armed with two claws : on the hindlegs, the tarsi are two-jointed, and armed with a double claw.

\section{Galgulus oculatus.}

Color brown or dark brown : head vertical, appears truncated before; eyes somewhat kidney-form, elevated, with their front and sides formed for vision. Head and thorax rough or warty; posterior edge of the thorax thickened, and edge luteous, emarginate. Scutellum large, traversed by a ridge, and impressed with a line upon its middle; sides tuberculated : the whole appears rough. Wing-covers rough, with two or three rows of small tubercles running parallel with the sides. Forelegs placed in front, raptorial, and with a large dilated humerus : thighs of the middle legs somewhat dilated; hindlegs long and slender, the two last pair are banded. Length rather less than a quarter of an inch.

Resembles a small toad, and inhabits muddy places, where it may be seen running, and sometimes leaping. I have found it in great numbers in the latter part of May, running and hopping upon the mud beside streams of water.

\section{Hydrometridae.}

The habits of the Hydrometride are peculiar. Though they have wings, they scarcely ever use them. They do not live in water, nor upon the land. In the spring, summer and autumn, almost every running stream, and pool connected with it, will furnish many individuals of this family, which, from their mode of progression over the surface of the water, have been called skippers. Their legs are long and angulated, and their bodies are raised considerably above the surface over which they glide. The antennæ are long and slender, and the surface of their bodies is protected from the wetting action of water as perfectly as if varnished : a skipper, immersed in water, comes out as dry as if it had been protected by an india-rubber coat. The surface of the insect, examined under the simple lens, is bright and glossy or lustrous, from the presence of a close nap, which is doubtless the means whereby the water is repelled.

The antennæ are four-jointed; the first longest, and in the Greris they are placed directly before the eyes. The forelegs are very much advanced, and seem to belong to the head, but are still attached to the breast; the tarsi are two-jointed.

The appearance of the Gerris is not very much unlike that of Reduvius, and the forelegs might be used for grasping. Gerris marginatus is the most common speeies. Dr. Harris 
enumerates unly three species. The insect lires upon other small animals, which it can capture. amel never ulnom the juices of plants : it is not known how it provides for its security durime winter. It moves upun the water by a kind of rowing motion, but withunt immersing its feet.

\section{Reduriidae.}

ONa uf the ulvious characters of this family is the constriction behind the head. which makes it appear to he frolonged or extembled hehind into a narrow neck. The eyes are cach

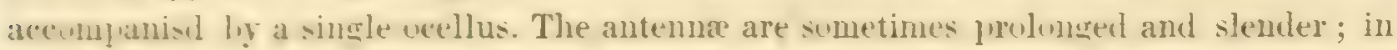
other ease, shert. The thorax is utten armed with a laterd spine. The legs are long, and the fureleg: rather stunter and raptorial : tarsi three, and sumetines quite minute.

\section{REDOVIOS -}

(Plate vii, fig. 3.)

Basal joint rery short : secund joint longer than the head and neck, two-thirds as long as the whole wrgan: fourth longest. slemeler : probuscis as long at the head and neck, stout : tarsi three-jointed; joints minute. Body elongated, narrow : thorax armed with two lateral spines, and in front transversely ridged : wings large : legs lung and hairy.

REDUVIUS

(Plate xxix, fig. 8.)

Culor hromn. Burly elongated, oral or dilated behind : humerus dilated and handed, and forele gs raptorial : eres prominent : thorax faintly striped longitudinally : abclomen orate; its edges spotted with red, brown and white, the brown ollung spots occulying the greater part of the margin: legs brown.

This species is rather cummon unn luw busbes during the mouth of Seltember, in the vicinity of Albany.

\section{Hamatoceros percis.}

Chaex purcis (Drury). Redutus myathemerus ( Illiger).

(Plate $\mathrm{xxx}_{\text {, fig. 6.) }}$

Head, eres, thurax, abdumen, and legs black : antennæ setaceous, with numerous joints : scutellum large, triangular, black; corium white, terminal membrane black : wings white and transparent : edges of the abdomen marked with scarlet spots : rostrum blarek and hort : thighs of the hindlegs searlet (Drery, Tol. iii, pl. xlr. f. 1).

This is not an unrommon species : it is frecruently met with in autumn ujon plants growing in shady places. 


\section{Lygæidæ.}

Astruxe are four-jointed, inserted directly on a line drawn from the eyes to the base of the rostrum. The body is narrow. The membranous portion of the hemelytra is furnished with about five nervures : tarsi three-jointed.

The species are small in size, and resemble the ConEIDE in form : some are marked with bright colors.

To this fumily belongs the chinck-bug, which figured so largely in Wisconsin in 1845 , and was described in the Prairie Farmer. According to Dr. Harris, it is the

\section{LYG.eUS LEUCOPTERUS (Say). Whitewinged Lygeus.}

This insect I have not seen. Its wing-covers are white, marked with an oval black spot on a central line. The body is black and downy; the beak, legs, antennæ at the base, and hinder edge of the thorax reddish yellow. Length three-twentieths of an inch.

The young and immature are bright red, but change to brown and then to black, and always marked with a white band across the back ( HARRIs).

It appears that the wheat and cornfields of the West have suffered severely from this insect.

\section{Cimicidx.}

The next family has received the name Crmicids, and contains the bedbug, an insect too well known to require any very minute description for its identification.

Cimex lectularius (Linnæus).

Body depressed or flat : antennæ four-jointed; thorax sublunate; abdomen circular; wings rudimentary, scale-like g tarsi three-jointed.

The history of this bug is not uninteresting, and it is not yet decided what country is entitled to the honor of having first given it birth. The English entomologists say that it was unknown in London, or in England, until after the great fire of 1666 ; and it is asserted by some that it was about this time introduced into England from America, in the fir timber imported to rebuild the city. This is partly sustained by the fact that it is still unknown in some of the remoter parts of the kingdom. It is further proved that SHAKESPEARE was unacquainted with it, as no mention is made of it in his writings. Whether this fact is decisive of the question, I leave it for others to say; only I would observe that it seems to me that none of its habits are calculated to awaken poetical associations. On the other hand, according to the statement of WESTwoon, it appears to have been known as early as 1503.
[Agmiculturat. Report-Vol. v.] 
The cheapes, cleanliest, and best way to get rid of the bedbug, is to employ a satarated solution of salt in water. The free use of salt will drive them from the bedstead to the covering, and to chinks in the wall or lool' whither the solution nust follow them, of the remedy will fitl, as often happens with others that have been recommended, and for the same reason.

If all is true that is affirmed of this bug, we cannot deny that its instinets are of a high order. If, for instance, it is unable to mount the bedposts, it climbs the walls and gains the ceiling, and, when it has reached a position immediately above the sleeping individual, drops down upon him. This devising of means to accomplinh an end, shows the insect to possess a high instinctive power. It is also a curious fact, and one worthy of note, that the bedbug is only found in a domesticated, never in a wild state.

The liworite find of this insect is blood, but it is not confined to this diet : hence it subsists, and coutinues to perfirm the common functions of life when deprived of blood. Any alhuminous matters either in a wet or dry state, juices of wood, ete. etc. suffice it when its farorite source of food is inaccessible. It is, however, said, upon high authority, that mahogany, walnut, oak, and cedar are fatal to these hugs; and that when enclosed in a box made of either of these woods, they speedily perish.

Their powers of increase are considerahle : a female lays at four different periods during the year, and produces about fifty young hugs at each litter; so that at this rate, if she is fortunate in escuping the persecution of the housekeeper, she will rear two hundred a gear. The young attain their full growth in eleren weeks. It requires, therefore, considerable diligence and activity to get ahead of this little foe to quiet and comfortable repose.

Fumigation with sulphur is an effectnal remedy against bugs when they infest the entries, wordwork, or crevices of old houses, or when intolerably numerous in the cabins of ressels.

\section{Coreidx. .}

THE Coreme resemble very closely the RencruDs; but it requires only a slight comparison of the families, to be satisfied that they are essentially different. The species of the first named fanily are characterized by the last joint of the antennæ, which is either thicker or longer than the others. The joints are still four in number, and are inserted near a line running from the eye to the base of the rostrum. The rostrum is three-jointed, and the middle joint is the lungest : in some of our species, it extends to the base of the hindlegs. There is an ocellus near each round eye. The hemelytra terminate as usual in a membrane mrre or leis diathanous, and in this family they show numerous longitudinal nerves. The margins of the athdomen are not concealed or covered by these organs, and hence they may often be seen slightly projecting in the furm of a sharp edge. The tarsi are thee-jointed. 
We hare many species belonging to this family. Probably no one, who has ever heen engaged in gathering our small fruits, but has observed these narrow or rather elongated bugs, some of them ornamented rery elaborately with bright colors, as for instance the red and yellow that border their elytra and superior surface.

\section{Genus COREUS.}

'Anteunæ four-jointed : second and third longest; the fourth rather enlarged or thickened, and shorter than the second or third. Sides of the thorax not dilated' (WEstwood).

Coreus tristis. Squashbug.

(Plate vii, fig. 1.)

Color dark brown, rusty brown, yellowish beneath : head marked with a red line extending to the front of the thorax; two others, parallel with the former, pass by the side of the eyes. Thorax roughened with elevated black points, concealing the red ground beneath : lateral edges also reddish; posterior angles rounded, and base hroadly grooved transrersely. Membranous part of the hemely tra black, and showing numerous longitudinal nervures. Beneath rusty ochre-yellow, and each segment of the abdomen marked with a row of black points near the outer edge, and a parallel row of small black spots, the latter rather obscure.

The squashbug is a common insect in gardens and fields, and is found not only on squash leaves, but upon those of the pumpkin also. It is injurious by inflicting numerous punctures upon the leaves, which cause them to wither and dry, and, if the plant is feeble, will destroy it. The first remedy for the effects of minute wounds of this kind, is to cultirate highly, so as to impart to the plant sufficient health and vigor to resist injuries by a rapid growth. If this does not answer, it will be necessary to find the insects and destroy them under foot, before their eggs are deposited for the new brood. The eggs are laid about the last of June, by the insects that hare surrived the winter. During the summer, it will frequently happen that the young appear at different times, and they may be found collected together in little groups.

\section{Scutelleridae.}

THis family is perhaps better known through some of its species than others. The disagreeable smelling bugs that frequent berry bushes and strawberry vines belong here. They are depressed and of an oval form, and are furnished with a very large scutellum. The rostrum is composed of four joints, instead of three; and the antenna sometimes has five joints, but not always. Two ocelli are always present, and the tarsus is three-jointed.

of this family, the Genus Pextatoma is one of the most common, and feeds upun the juices of plants (Plate vii, fig. 2). Sometimes it has only to pass over a fruit, to impart to it its offensive odor. 


\section{CHAPTER XVI.}

\section{ORDER VII. DIPTERA (ARISTOTLE).}

ANtliata (Fabricies)。 haLteriptera (Clairville).

Tue obrious characteristic of this creler is the possession of two wings only, and a pair of small knobled appendages just behind them, which are called halteres or poisers, as in the common $\sharp y$. The wings are nembranous and placed upon the mesothorax, and, when at rest, remain expanded as in the Hryexoptens; that is, they are never folded upon themselves. The tarsi are five-jointed. The mouth has a fleshy proboscis, which is merely a modified labium. This proboscis encloses several lancet-like organs, capable of penetrating flesh or the sufter parts of regetables : the mouth is therefure sucturial. In a few genera, as the CEstris, the mouth is closed. The thorax is complact, and the prothorax is reduced to a collar. The wings, which represent the fure pair in other four-winged insects, are memlranous. naked, or rather clothed with scales. The disc is divided into a moderate number of areolets, by the inosculation or junction of the nerrures or veins.

This order of insects is clearly separated from each of the other orders: where some species belunging to the Order YELROPTERA are deprived of a pair of wings, they may still be distinguished by the absence of halteres or balancers. The jaws of the diptera are never furmed fur biting or nipping : so the neuration of the wings of the diptera are quite different from that in the other orders.

The size of the individuals composing this order may be called small; but what is lacking in this respect is more than made up in numbers, and this whether we take into consideration the number of species, or the rast number of individuals that sometimes swarm together.

Some of the diptera hare domesticated themselres in our drellings, to the great annorance of all good housekeepers; and notwithstanding the brush and the broom is freely used to drive them awar, they seem to entertain no fears of the consequences of returning to their uld quarters. Arsenic fly-powder, and all the various traps that the ingenuity of man has yet devised, have not thinned the ranks of the housefly. Wherever man gues, the fly folluws in his steys, and makes a free use of his dwelling whenever the weather without becomes uncomfortable. 
It is scarcely necessary to say that many of the diptera, though snall in size, are great annoyances to man and animals : the cestrido are perpetual torments to our domestic animals; and musquitoes, in the warmer regions especially, are so troublesome as to require special means of protection from their stings.

The transformations in this order are incomplete. The larvæ are white and fleshy, cy lindric, and without feet : they are usually called maggots.

\section{Tipulidae.}

\section{Genus CECIDOMYia.}

It is a very curious fact in natural history, that the most serious injuries the crops of the husbandman receive are inflicted by insects the most minute and insignificant in size : the very weakest among the tribes of animals are the greatest destroyers of the products of man's industry. The whirlwind or the hailstorm, it is true, sometimes sweeps over his fields of wheat and corn, or a flood of water may pass over them, and leave desolation in its track; but these terrific visitants are harmless in comparison to the tiny tly that sports and dances over his grain-fields. With all our wisdom, we have not yet devised a weapon to extirpate this foe, nor a defence to secure us from its ravages : our most successful efforts have been but failures; and were it not for the aid of the elements, or the secret influence of an unseen but benignant hand, the foe would maintain the field in the face of him who has subjected to his will the proud warhorse and the colossal elephant.

Cесіромуіa is the generic name of these destroyers : they are flies, each with two wings, antennæ, poisers, etc. Several species have heen described, one of the most prominent of which is the C.destructor of SAY, the hessian fy. The genus is characterized by the joints of the antennæ being variable from fourteen to seventeen : the form of the joints in the female also differ from their form in the male; the former being oval, and the latter globular, but both are furnished with hairs issuing from the joints in the form of a whorl (See Plate iv, fig. 1). Wings three-nerved, ciliate or fringed : joints of the tarsus short.

\section{Cecidomyia Destructor. Hessian-fly.}

( Plate iv.)

This species is black, except that the abdomen is only tawny, though each ring is more or less black : legs pale red or brownish, with black feet. Length of the body one-tenth of an inch : the expansion of wing rather exceeds the length of the fly. See fig. $1 c$, which represents the natural size of the Cecidomyia destructor.

The hessian-fly has occasioned as much controversy as any species in the insect kingdom. I published in the American Journal of Science in $1846-47$ an article furnished by Dr. Fitck, which contains all the important facts in its history. I deem it, therefore, unnecessary here to go over all of the ground occupied by that paper. 
Ls resards its origin. it appears from the numerons accomts published at diflerent times during the last half century, that the hessinn-tly is not ind genous to this conmtry tut was importen in straw from Euroge ly the lle-sians in the empley of the English gersermment

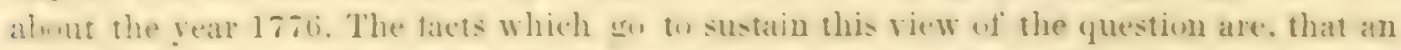

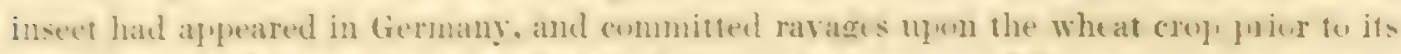
an!e teance in this conntry : and that the hahits and chanders of this german insect agree

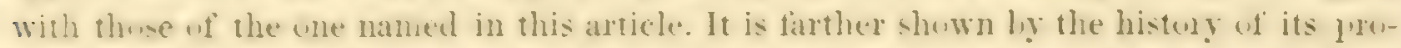
gress in this country, that it was first whelred nun the westernextremity of Long Island,

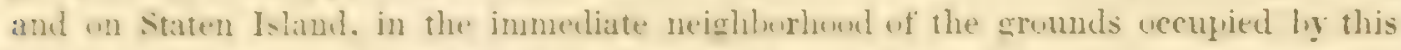
branch of the Enelish army ; and that from this centere it sfread in all directions, tratrel-

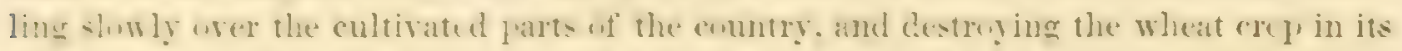
conrse. Its mareh and the conseguent destruction of the wheat crop, was marked ly an inereate in its numbers, and in the ammunt of its injury ling an meertain number of years, when it aradually disalpeared from the conntry it had occupied and wasted. Alter long intervals of freetum from the ravages of this fly, it gradually returns and renews its attarks ulwn the wheat crop, rumning almont the same course in its second as in its first

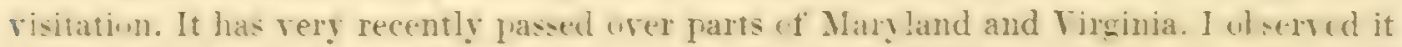
in the former state in 1849 . I think we may infer from its history and furegress, that in all farts of the Lnited sates where wheat is cultivated as a staple product, it will continue its injurious career hereafter as in times past.

The species of tly which has received the name ('ccilumyia destructor from the distin-

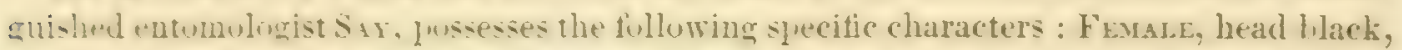

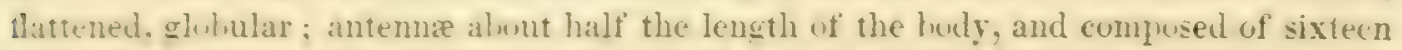
oval juints furnished with a whorl of ninute hairs. the two basal joints close and glubular, teruinal joint the longe:t ; palyi three-jointed, hairy ; thurax black, oval, hroadest behind the wing-suckets; sentel hlatk; Juisers unly dusky; abdomen black alove; sutures tamny fulvus, elongate wate. sarcely equalling the thorax in width; ovipusitur rose-red;

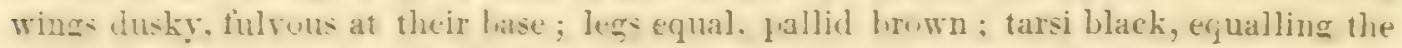

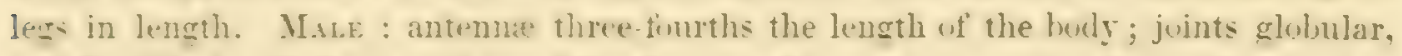
and fumished with hairs as thene of the female; filaments sefarating the joints, ahout as lung as the juints : alubumen hrownish hlack. cylindric, seven-juffited and slightly tapering, the extremity armed with two rulust processes haring incurred hooks at their tips.

It appears frum Dr. Fiтcis statement, that in the spring the perfect insect remains but abut a week, during which time it dejusits its egg- for the summer brond. The tirst brood

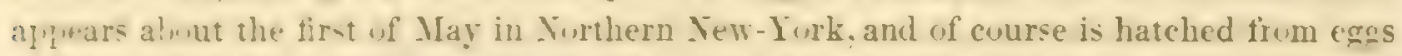
that were laid the freceding autum ; the insect having subsisted upon the juices of the her age. or lain in a durmant state from that time. Early in May, then, the fir de pusits its ergs, in the sime field. uln, the mure succulent leaves. near their insertion with the -tem of the plant, which it may readily reach after being hatched. After a time the worm 
is found attached to the stem, near or upon the first and second joints. Dr. Fitcr remarks that the secind brood is less injurions than the first, in conseruence of the more advanced state of the grain and the firmer consistence of the stalk. The worm, by its irritation, diverts the current of flowing sap to itself, and produces an enlargement of the stem at the place where it is attached. The culn is weakened by the change of structure that has taken place in consenuence of the numerous worms usually congregated near its hase. $\mathrm{By}$ the first of June, the worm has changed into its llaccid state; and about the last of July, or early in August, the mature insect. the fly, appears for the second time. This last brood of flies is now ready for the roung wheat that mar he sowed, upon the leares of which they deposit their eggs, and there finish their transformations so as to appear in New-York the last of April.

Thus careful observation has prored that but two broouls appear during the rear, though it has been maintained by some observers that there are three. This latter cpinion seens to have arisen from the fact that an entire brood does not appear at once, or on the same day, hut the Hy may and does continue to come forth for as many as ten or twelve days after the first of the brood are hatched.

The most important question which stands connected with the hessian-fly, is, By what means shall the farmer protect himself from its ravages? Now we have very slight grounds for expecting, or even for hoping that a remedy will ever be found that shall meet our wishes in this respect. The evil is rather to be warded off ly a judicious use of means that are related to the habits of the fiy, and to the habitudes of the wheat plant itself. When a district, howerer, is extensirely affected, the true course undoubtedly is to cease cultivating wheat, and perhaps barley also, until the fly has disappeared.

Recurring to the habits of the insect, the most significant are the time of its appearance, and the time it continues in its perfect state, during which it is engaged in laying its eggs, an operation, the exact time of which it is essential for us to hnow in this case ; and it is a law of nature in the insect class, that when swarms are produced, they come forth at regular periods of time. The habits alluded to are well linown in the case of the hessianfly. As to the time when the insect appears, it is established by observation that about the first of May, or at time in the spring when the earliest trees and plants are flowering, this tly is maturing, and comes forth near the time specified; and the first brood is hatched from eggs laid in autumn. These two facts unite to suggest the same precautionary measure to be taken for the eradication of the fly from both the winter and the spring crop, namely, to delay sowing the grain until the fly has disappeared, or to that period when the plant will come up too late for the deposit of eggs upon it. Experience has proved the efficacy of late sowing in both kinds of wheat.

Another remed $y$ is connected with the place where the eggs are deposited, and where the transformations are undergone. It seems estahlished that the real hessian-fly deposits its eggs upon the roung leaf, near the stern, and near the base of the stem. The consequence 
is, that in reaping or harresting the grain. the straw is cut above the place where the larve or egas are usually found: and it would he well, in all cases where the fly is found, to cut the straw higher than customary. Now if the stulble is furmed under for the next crop, a large fropurtion of the eggs will mature, and the succecding wheat-plants will form a habitation for the forthcoming August brool; but if the stubhe is first hurned, the eggs will he destroyed, or hut dew will eseape. The ubjection to this summary remedy is, that it also destroys thuse little insects that jrey upon the hessian-fly. I deem this a rery light whection, for the tire will destruy hundrests of egos where the enemy of the fly would levur one. Burning off the stubble, then, must be ranked among the best palliative means for saring the wheat-erop.

There are also two remedies haring relation to the habitudes of the wheat itself, and to its rarieties. It appears to be established by observation that some varieties are less subject to injury than whers, or indeed that some are nearly fy-pronf : this is one of the earliest ficts on record, and all experience hitherto has fully sustained it; the straw of these varieties heing ton siliceous to allow of a ready lodgment and home for the larva of the 11y. The ther remedy here alluded to, rests on the practicability to push forward and mature the flant sufficiently to give it strength to resist effectually the injuries the stem receives from the maggot in its flaceid state. High cultivation should be called to our aid here, and it unduubtedly will prove a very efficient safeguard : its effects are twofold, as exhibited in an aummentation of the power of the plant to resist injury, and in the production of a better crop; so that the remedy is not entirely lost, errn if it does not succeed in the way we wish.

Olijections hare been made to the first twu remedies abore proposed : for instance, by late suwing. the grain is liable to be winter-killed; but would not this risk be greatly dininished. or even uhviated entirely, by drilling in the grain? The burning of the stubble is uljected to, because it destroys the flarasites of the ty ; but this, as I have said hefore, is scarcely an ohjection: while for the utility of the remedy, we have the testimony of IIArris, Herrick and Hasats, the latter of whom originally proposed it, and the two firmer are entitled to the highest consideration as observers and men of science.

of the numerous applications to the grain crop, for the purpose of killing the insect directly. I hare no faith. Rolling the seed in plaster; steeping it in rarious salts; sowing lime, etc. orer the field of young wheat, are beneficial remedies in an indirect way: they give vigor and strength to the plant, and hence are useful as palliatives.

Cecrdomyia triticr. Wheat-fly.

This species is rery distinct from the hessian-fly : its habits sufficiently show this diff-rence; and the remedies which are in some degree palliative in the case of the hessianfly, are valueles against the ('cridomyin fritici. Among its peculiarities, some of the most reluarhable are that it deprisits its eggs in the wheat-head, and undergoes its metamorphoses 
in the soil; and that the mature animal is engaged longer in the work of depositing its eggs, than is the hessian-fly. These distinctions must govern our attempts to guard against the attacks of these insects.

The wheat-fly possesses the following characteristics : Body orange; wings transparent, rounded at the tip, ciliate, or fringed with minute hairs. Fesale, the antennæ are headed; joints twelve, whorled with hairs; eyes black : length about one-tenth of an inch. Males, the antennæ with trenty-four joints, globular, and whorled with hair as in the female : size somewhat rariable, but less than the female. Its general appearance is that of an orange-colored gnat.

The first account of this insect was giren by Mr. JEWET, in the nineteenth rolume of the New-England Farmer, 1820. According to Judge Brec, it was observed here in 1828. Its first appearance in this country was in the eastern part of the Lnited States : several of the Eastern States, and the Canadian provinces, have been risited by it. The cultiration of wheat was suspended for many rears, in consequence of its injurius attacks.

The time of the appearance of this $\mathrm{fl} y$ raries according to the situation of the country, being in some places early in June, and in others as late as August; indeed, according to Mr. Harris's Report, as late as the 20th of August. The first half of July, howerer, is the period when the largest number of eggs is deposited; a period which, in New-England, would fiad the spring and winter grains in the best state for receiving their eggs. The insects are actire in the morning and evening, and appear in swarns; but during the day, when the sky is cloudless, they conceal themselves among the grain and grass. After about eight days, the eggs that have been deposited in the heads of the grain are hatched. The maggots are orange-yellow, and, according to the obserrations of Mrs. GAGE of NewHampshire, they attain their growth in about twelve or fourteen days : they are then about an eighth of an inch in length, but their size is not uniform. Their number is also variable, as many as forty being sometimes found on a single plant, and at other times two or three only. They seem to be influenced by exposure; for in hilly places, where the grain is exposed to the wind, they are nuch less numerous than in sheltered spots.

The injury that wheat sustains from the presence of this fly depends upon its state of forwardness. As the worm is unprorided with boring instruments, it is principally during the soft state of the grain that it has the power to do the most hurt. If the egg is deposited so as to be hatched when the plant is in blossom, it is then capable of inflicting the greatest amount of injury; for at this time it is supposed to subsist on the pollen, and may therefore prevent the fertilization of many kernels in the same head; and then also it obtains the milky fluid that begins to be formed at this period, and is now accessible through the softness of the skin or epidermis of the grain. But if the time of deposition of the egg is such that it becomes hatched after the plant has florrered, and the kernel has acquired some considerable hardness, the worm is incapable of absorbing nutriment, and perishes for want of food.

[Agricultural Repoit - Vol. V.] 
The worms acquire their full size and perfection, cast their skins, and descend to the ground early in Anunst, or perhalls as late as the middle of the month. They liury themselves in the sull at the depth of alout an inch, where they remain through the winter. There is therefore but wne hrond in a sasun. The worm is speedily changed into a ful a, in which state it remains until ready to issue from the ground in June or July of the next year, in the imago state, or the perfect lly.

The means that have been propused to destroy this lind of wheat-lly are numerous : if any of them are to be ellictual, it is evilent they should be resorted to over the whole district infested by the insect.

Among the reucelies which seem to have heen at least partially successful, is that of the abandenment of the cultivation of winter wheat for the suhstitution of the spring rariety, and late sowing. The remedy operates on the principle of starvation, and would probably be completely succesful, were it not that grasses and other grains, as oats, rye and harley, ofier suitule recipients for the eqgs of the insect, and furnish nutriment for its progeny.

It is recommended to smoke them out. To carry on this plan of warlare, the flies nust be attacked in the erening, when they rise from their lurking places in the depths of the grain. Brimstone, mingled with other combustible matter, should be burned in a position to give them the full hemefit of the smoke and vapor when they rise upon the wing, and hover over the grain.

Another recommendation is to sow fine quicklime orer the field when the heads of the grain are moist : this may be repeated several times.

It is recommended hy Dr. Fiтch to first catch, and then kill them. The method of doing this is sufficiently simple and easy, and deserves a trial. Take a long rope, attached to a wide upen tirht lagr; and let two men, one at each end of the rope, pass through the field, dragging the viren wille-numthed net orer the heals of wheat. Go over the whole field in this way, and millions of the fly will be caught if the net or bag is properly managed.

Deep ploughing is also a remedy that deserves trial, and indeed has heen tried and followed with success. This, of course, is to be resorted to after harrest : the olject is to burr the insects so deep that they will be unable to find their way out of the ground the next season.

The Cecidrimyia which has appeared in this country is now regarded as identical with the (' tritici of' Eurnpe, which has been known in England and Scotland for two-thirds of a century, and was described at an early period. In this country, especially in the rivinity of $A$ lbany and in the county of Berkshire in Massachusetts, it has been disappearing gradually for the last teu years, and the wheat crop has again becume a profitable one; and the probability is, that with our present knowledge of its habits, and of the means for its extirpatium or for aroiding its worst injuries, we may hereafter escape its depredations. 
Cectomyia robinia ( Haldeman).

(Plate iv, figs. 3, 4, 5, 6.)

Color of the fly orange red; antennie and wings dusky; thorax marked by three dark lines : two dusky spots on the sides of the body. Length three-twentieths of an inch. The larva is a maggot of a whitish color, faintly tinged with orange, rather deeper towards the head : pupa or chrysalis naked, or destitute of a cocoon.

This species inhabits the locust-tree, and was first described by Prof. Haldenas*. The leaf becomes thickened on its edge, and rolled over; and thus a carity is furmed, which contains two or three larvie of this species.

Cécromyta salicis (Fitch). Willow Cecidomyia†.

Color of the 11 black abore, paler beneath and downy; wings smoliy; legs gray. Length of the body, one-fifth of an inch; expansion of wing, three-tenths.

Inhabits a reddish gall upon the low willow bushes of wet places : it is of an oral form, three-fourths of an inch long, and is terminated by a conical beak. Within a silken lined carity, early in the spring, there will be found a single orange-colored maggot one-fitth of an inch long. Soon it changes to a pupa, but without moulting; and in a very few days it passes from its prison, after casting the pupa skin, and takes the winged form. Its size, together with the rapidity of its changes, renders the species an interesting object of study. Its damage to the basket willow is but slight.

Cecidomyia colmicola (Morris).

The $C$. culmicola is a provisional species, whose habits have been investigated by Miss Margaretta H. Morris, by whom also it was discovered. Its habits are quite different from those of either of the foregoing species. The fly lays its eggs upon the grain, in or over the germ, where they remain unhatched until the grain germinates; but when the plant is three or four inches high, the rorm may be seen, by the aid of a glass, feeding abore the top of the joint in the centre of the culm, until it is ready to become a perfect insect. It is said that the pupa resembles that of the $C$. destructor.

As the fly deposits its eggs early in June, it is difficult to understand why they should remain unhatched so long, or until the future germination of the same ripened grain after it is sown, and then to feed upon the culm; for it is the usual habit of flies to deposit their eggs near or upon the magazine of food on which the larvæ are to subsist.

It is an interesting fact that most, if not all of the species of Cecidomyia are preyed upon by some one or other of the family of Ichrecmonides while in the larra or pupa state. These parasites deposit their eggs within the body of their victim, where they are hatched in due time, and the larvæ subsist upon and destroy the body before its change into the

- American Journal of Agricultare and Science, Vol. vi, p. 188.

† Idem, Vol. 1, p. 283. 
imago state. In this way the increase of sereral species of destructive flies is kept in check, and their excesive multiplication prevented. No doubt, also, unfavorable seasons operate as a still greater meins for preserving a balance between excessive multiplication and entire extirpation.

Dr. Eicnts, of Albany, has furnished me with the following communication respecting the plutysaster, a minute ichneumon fly. His remarks, and the facts stated, illustrate in a striking manner one of the most important features in the insect world, the checks which are interposed to the excessive multiplication of the injurious kinds.

\section{Platygaster tipule (Kirby). Wheat-midge Parasite.}

This insect, though exceedingly small in size, has claims to our consideration, which should justly cntitle it to an exalted station in the rank of public benefactors; for it has had assigned to it the peculiar and important duty of keeping in proper subjection that unrivalled pest of our fields, the wheat midge (Cecidomyia tritici).

The female $\mathrm{fly}$ of this parasite bears some considerable resemblance to the winged ant, and may frequently be seen in our neighborhood during the months of July, August and September, in the greatest profusion, when our pernicious devastator is most numerous; llying about the grasses, or ruming over the grains of wheat in search of the midge larva, fur the purpose of depositing in each a single egg, and by this means preventing an immense number of them from developing themselves into a perfect state; although when seen thus abundantly, they have often been unjustly accused of being themselves the authors of the mischief.

This insect expands to only one line and a half in breadth. The female is of a shining pitch black color, with long, ten-jointed, flail-shaped antennæ or horns, slightly clubbed at the ends. The head is round or globose, with the eyes conspicuously placed on the sides. The trunk is oval, and bears a scutel terminated by a strong rusty spine. The body or abdomen is obovate, small, and narrowed at the base, with a long curved oviduct, concealed, when

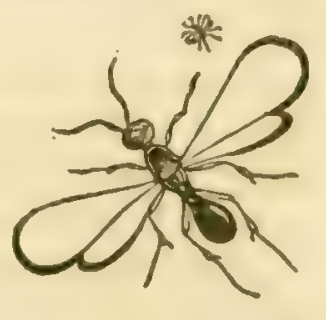
unemployed, in the abdomen. It has four transparent wings without nervures, the superior pair very large; and the legs are strong, and of a bright ochreous color, with the thighs and shanks clubbed : the feet are long, slender, and five-jointed.

We regret that some means have not yet been discovered to multiply this interesting little insect, and thus effectually preserve our wheatfields from the fearful depredations of the midge. James Eiguts. 


\section{Muscidae.}

THE character of the mouth and its organs restricts and defines this natural family : it is formed by a distinct proboscis, which is thick and membranous, retractile, and terminated by lateral lobes; and it encloses two setiform organs and a pair of palpi. The antennæ have but three joints, the third of which is the largest, and is prolonged into a seta or long slender bristle, sometimes articulated with its base. The nervures of the wings are few, and extend to the margin.

The true flies feed upon both regetable and animal substances. The common housefly is typical of the family, and its habits in some respects are very well known. They are all small : their larvæ are white, soft, and without feet, and are usually called maggots. MEIGEx, it is said, has described 1700 European species; from which we may infer that it is a large family.

\section{SARCophaga geORGINA.}

Color grayish, hairy; eyes copper-colored; face silvery white; thorax striped with gray and black; abdomen lustrous, and checked with white and black; legs black. It is common during most of the summer. Length about half an inch.

MUsCA Vomitoria?

Body thick, steel-blue, especially the abdomen, hairy and mixed with bristles : antennæ pilose; thorax bluish black; legs black. Length about half an inch.

\section{Genus LEPTIDA.}

LEPTIS -

(Plate xxix, fig. 1.)

Eyes brownish : antennæ four-jointed, small, porrect, approximate, standing a little below the crown, the last setiform pubescent; thorax semiglobose, striped, bairy ; wings diverging; anal areolet open; abdomen with seven rings, tapering, and marked with clay-colored rings, somewhat silvery. Metallic points are scattered upon the sides of the thorax.

Leptis? - -

(Plate xxix, fig.4.)

The eyes are brown, and larger than in the foregoing species : rings of the abdomen seven : top of the thorax less prominent.

LEPTIS -

(Plate xxix, fig. 10.)

Color brown : thorax bordered with an ochreous line; abdomen tapering and pointed, the three last rings being attenuate, and all of them bordered with yellowish. 
Yeither of the foreguing species are figured or described in SAY's American Entumology, but there is very little doubt that they belong to the Genus LEPTiDA. The flies are found in thickets in the summer : they feed on other small insects, and their larva live in offal or on decaying wood.

\section{Tabanidae.}

\section{Tabandos plembeus (Linnæus), Gad-fly. Horsefly.}

Tabanes plumbets (Drury)。 T. ruficornis (Fabricius)。 T. limbatus (Pal, de Beaurois).

'Head ash-culored ; eyes hlack; antennæ reddish brown; ocellus one; thorax greenish,

- with a white spot at the hase of each wing; abdomen dark brown, each segment of

"which on the underside is margined with gray; wings transparent, anterior edges

' hrown and opake; legs dark brown, the middle ones being armed with two spines

' at the tip of each tibia : the ungues have two small brown scales under them.

'Breast hairy; back colored, but white on the sides' (Wrstwoon, Illustrations of

DrURY, Vol.1, p. 97).

This species appears in Vew-York in July, and is most common in woody places, hut is often in open pastures, and frequents roalsides, alighting on horses and cattle. In NewYork and lew-England they are too few in number to occasion much trouble, though their prohosces are armed with lancets sufficiently long and sharp to wound cattle severely. Were they as numerous as the smaller kinds of flies, our pastures could not be occupied during the months of July and August.

\section{Tabanus americanos (Drury). \\ Tabanus atratus (Fabricius). T. niger (Pal. de Beaurois).}

Head, antennx, sheath of the proboscis, extremity of the abdomen, breast and legs black; thorax brumnish black; wings dark l,rownish, scarcely opalie; anterior part of the abdomen dark plumbeous; spines of the middle legs two ; breast hairy.

The lighter part of the abdomen appears as if corered with a whitish bloom. The eyes are very large, and meet at their lower edges, but are separated above by a narrow yellowish space : their color is black and bronzed. Length seren-eighths of an inch, or nearly one inch; expansion of wings, nearly two inches.

This species is rather smaller than the plumbcus, with wings less robust and strong : it appears at the same time, and attacks cattle and horses in the same savage way. Both are found as far south as Maryland. 


\section{TaBanus -}

Sooty black. In some lights, the abdomen above is glaucous; beneatl, it has a shade of greenish blue : eyes faintly bronzed. Face obsolete, in consequence of the great extension of the eyes, which meet on the top, divaricating only just above the base of the antenna, learing a small triangular area through which the median line passes, and which is also traversed transversely by two grooves : this area is occupied by six or eight little glossy eminences. Legs and breast covered with a jet black pubescence.

The form of the eye is remarkable; the top of the head being capped, as it were, with the organ, which projects directly in front. The insect differs entirely from the two preceding species, and has not probably received a specific name.

\section{Xylophagidae.}

Midas filatus.

Musca clavatus (Drury).

(Plate xxviii, fig. 11.)

Black : second abdominal segment yellow upon the superior parts; wings copper-brown and submetallic, scarcely transparent. Length $1 \frac{1}{4}$ inch ; expansion of wings, $2 \frac{1}{4}$.

This species, so far as my observations extend, is a rare insect in.New-York. It is easily distinguished by the yellow segment of the abdomen referred to, which extends only to the sides, the inferior part preserving the black color of the remainder of the organs. Its larva is a white maggot, and exists in decaying stumps and logs. It is usually found in the forests in its perfect state in midsummer, and is one of the largest dipterous insects of New-York.

\section{Syrphidae.}

Milesia virginiensis.

(Plate xxviii, fig. 3.)

Musca virginiensis (Drury). Mrlesia ornata (Fabricius).

Eyes black; front of the head cream-color; antennæ like short hairs; thorax yellow, with two black rings; abdomen black, ornamented with yellow rings, every alternate one of which is interrupted in the middle : it is marked with a yellow dot at the base, and terminated with yellow. Legs yellow; wings dusky. Cnderside, breast black, with yellow spots : ocelli distinct.

It is rather more than three-fourths of an inch long; expansion of wings, $1 \frac{1}{8}$. 


\section{CHAPTER XVII.}

\section{ORDER VIII. NEUROPTERA.}

THE wings, in this order of insects, are made up of a fine network, membranous, and usually naked and without down or scales : they are subequal or equal. Sometimes the lower wings are broader than the upper; but, if narrower, they are longer. The mouth is fitted in sume families for mastication, particularly in the libellnlidæ, which are furnished with transversely morable jaws. The abdomen is usually long, but is destitute of a sting. The antenna are not uniform in the different fanilies : in some they are long; in others, short. They have two or three simple eyes. The trunk is formed of three segments clusely united : the abdomen is sessile. The larva has six feet. The metamorphosis is not always complete.

The order contains several well-known families, as the dragontlies, mayflies, white ants, aud the ant-lion flies. In all these families, as well as in those not yet mentioned, the wings are formed of a fine netrork of nervures, so arranged in the minute details of structure as to constitute a great number of areolets of much beauty.

In this order there is one family, the termitides, which are extremely interesting in their economy and habits, as well as an instance of a remarkable development of the faculty of instiact : they are social, and live in large communities; while most of the other fanilies are solitary, and do not construct habitations fur the common convenience and defence.

\section{Libellulidae.}

Libellumes is the family name of the dragonfies : they are insects which become familiar to every body, and are frequently called darningneedles or devil's-needles. Their heads and eyes, especially the latter, are always large : their hodies are long; the thorax is thick and strong, and the abdomen long and rather slender, though not always so, and is terminated by two inarticulated appendages. The antennæ are short. They have three ocelli : two lateral ones, and one seated in the median line. The mouth is well formed, and the mandibles are strong and horny. They have four wings, which, when at rest, are extended horizontally or carried over the abdomen. 
The libellulix are widely extended in their distribution : they are voracious in their hahits, of strong muscular powers, and able to remain long upon the wing. Their larre are yuite as roracious as the perfect insect. The female deposits hel cggs on the water, while upon the wing. They may be regarded as serviceable to man, especially in their perfect state, by feeding upon insects that are annoying, as musquitues and the like.

The family has been subdivided into three genera by Fabricius : 1. Lirellula proper, with wings horizontal when at rest, eyes large and approximate, and having also the three ocelli; the middle division of the lip is the smallest, and the abdomen is ensiform. The second genus is Esuna, having two ocelli situated on a transverse keel-formed elevation; the intermediate lobe of the labium larger than the lateral, and armed with a strong tooth and a spinous appendage; abdumen narrow and elongated. The third genus is AGRion : it carries its wings perpendicularly when at rest; the middle lobe of the lalsium divided in two; the antennæ with fur articulations : there is no vesicle upon the forehead; the ocelli are equal, and the abdomen filiform.

Libellula pUlchella.

(Plate $\mathbf{x} \mathbf{v}$, fig. 5.)

Color black. Abdomen sometimes wholly black both above and below, and sometimes light slate above and black below, or partly slate color : individuals seem to vary in this respect without regard to sex. Wings marked by three black or dark brown spots or bars : the basal is confined to the costa, and does not extend to the posterior edge; the external covers the apical area, and sweeps around so as to form a circular curving edge towards the base.

Fig. $t$ is closely allied in its habits and appearance to the pulchella, and its abdomen presents in different individuals the same varieties of color.

Fig. $f$. Larva of the Libellula.

\section{Myrmeleonidae.}

(Plate sxxiii, figs. 4, 5, 6, 7.)

A Famly of insects familiarly known under the name of ant-lions, while in the Jarva state. The insect has always arrested the attention of the curious, from its peculiar habits, the singular form of its larva, and the ingenuity it displays in making traps or pitfalls to catch the prey that must serve for its sustenance. In its perfect state, it resembles a Libeliuta; but when it is in its larval form, we would by no means suspeet that it belongs to, or is the embryo of one of the most beautiful of the insect tribes. There is always, however, a wide difference between insects in these two states.

In the family of the LIBELlulide, the larva is aquatic, and is provided with the necessary form of mouth and mandible to seize and devour other insects : it is in fact a voracious animal, and carries on its depredations in the water; while in the Mrrmeleo-

$$
\text { [Agricultural Report - Vol. v.] }
$$


Ni1.F, the larrac are terrestrial, and the parent insects select for their habitations the places farthest remured from water, the driest sand being the only material suited to their habits and mode of life, or adapted to their essential wants.

The ant-lion, which is the common name of the inseet about to be described, is a spiderlexking animal, having a thick, short, and full ablomen, and narrow and elongated front, which is terminated by two long or exsert mandibles, strongly toothed npon their inside edires, and also perforated, so that the insect may snck the juices from its victims (See Plate xxxiii, fig. 2 : larwa). The mandibles have three teeth each, and a row of stiff bristles below them, probably used partly for supporting their prey, when engaged in the act of suction. The mandibles are curved, and as sharp as a needle; and in this respect are well adapted to the oflice they are designed to fulfil, the piercing or transfixing the ant, which seems to comstitute their favorite food. The three teeth are slender, and but slightly thickened at the point of junction with the jaw. The body is clothed with a few bristlelike hairs, but in other respects it may he said to be naked. But what is quite peculiar and interesting in the construction and habits of our species of ant-lion, is the position and structure of its legs : they only permit it tu move with its abdomen in front, or, in other words, it is obliged to walk backwards.

To oltain a surply of food, the larva forms a conical depression in dry sand under a shelving rock, where the surfuce will remain undistubed; the depression heing over half an inch in defth. At the hottum, the owner places itself concealed in the sand, with only its ruandihles standing a little ahove the apex of the depression. Now as sheltere $\$ places of this kind, which the ant-lion selects, are also excellent highways for all small animals to travel, and especially suited to the habits of the ant, if the ant is not cautious in his passage through these dry and shelving grounds, it will probably fall into some one of these sand-trays : this haprening, there is little chance of its escaping from the jaws of the lion, which are always open and ready to seize the unfortunate traveller. If, however, the ant does at first escape the clutches of the lion, and attempts to clamber up the side of the pit, it is sure to he orerwhelmed with a shower of sand cast up by its cunning fue, and most certainly precipitated again to the bottom.

Notwitstanding this lion is furnished with strong mandibles, they are not for the purpose of chewing or biting its ford, but are so constructed as to hold its prey securely, and to extract its fluids by suction. When this is finished, the lion tosses the empty skin from its pitfall, by means of its lung mandibles and the free and extended motion of the head in its thorax.

Like other larra, the larra of the ant-lion changes its skin. When about to undergo its transformation, it glues trgether a portion of sand by mixing it with a kind of nucilaginous and filmous or silky secretion, which it forms into a perfectly round hall having a sufficirnt cunsistrency to bear handling freely. At the time of the final change, which vecurs atent twenty days after the ball is rulled, the pup pierces a round hole in the side 
of its gluhular envelope, and comes forth, casting off its pupa skin, which is left partly adhering to the orifice as represented in fig. 4.

The myrmelion is a four-winged insect, at first view resembling a libellula; but it will be perceired that its antennæ are peculiar, and quite diflerent from those of that family: they are larger at the extremity than at the base, generally curved, and sometimes appear like a hook. The eyes are wide apart, and do not touch upon the upper and posterior parts. The wings are extremely delicate, like the finest gauze; and the abdomen is rather slender, and tapers each way. The color of the insect is brown. The wings are transparent, and all the nervures are spotted with brown and white. The rings of the abdomen are brownish, but much the darkest on their posterior half : the abdomen is also clothed with short hairs. The wings are attached to the thorax at a distance apart, and the thorax is divided into two parts, the first supporting the forewings, the last the hindwings : the first has rounded eminences, separated by oblique fissures; the last has properly only two, which are separated by oblique ridges, that begin at the sides and nearly meet in the middle. The abdomen has five rings. The feet are black. Length of the larva, about $\frac{1}{2}$ an inch: length of the perfect insect, $1 \frac{1}{4}$ inch; expanse of wing, $2 \frac{1}{2}$ inches.

The species above described and figured were furnished me by Mr. J. GeBhard, Curator of the State Museum, and were procured under the limestone ledges at Schoharie. I have also found the larva of the ant-lion beneath the limestone ledges near Burlington (Vermont) : almost every suitable place furnished specimens of the insect.

I am unable to determine whether this American species has been described or not.

\section{Ephemeridae.}

MAYFLY is the common name for the insects of this family. If not characterized by the shortness of their lives, it is a well-known feature in their economy : they live but three or four hours in their perfect state; hence the modifications of their mouth are quite different from those of the libellulidre, which have a much more prolonged existence, and are therefore provided with ample means for taking sustenance. Their antennæ are minute and three-jointed, and their four wings are of an unequal size. The mouth is nearly obsolete or wanting, and the extremity of the body is furnished with articulated setæ. Their bodies are rather long, slender, and soft; the eyes rather large, and there are also three ocelli placed in a triangle between the eyes. In some species the clypeus shuts over the mouth.

The name of this family is derived from the greek ephemeros, diurnal, in allusion to the shortness of their lives. The only function they perform is to couple and deposit their eggs in the water. Their larvæ live in the water, and their existence in this state is prolonged for two or three years. They take refuge under stones, or in the earth or mud. They feed upon the slimy mud that contains decomposing particles of organic matter, and which suffices for their nourishment. 


\section{CHATHR XIX.}

\section{ORDER IX. TRICHOPTERA (KIRBY).}

TuE English have given the name caddicefies to the insects of this order. The consistence of the buly of the perfect insect is considerable, and hesides they are thickly clothed with hair. Their eyes are rather prominent and large, and they are provided with three orelli. Their antenna are variable in length, being sometimes nuch longer than the bedy ; at others, shorter. They have four nembranus wings; the front unes are fibrous, and the nerves are branching : the posterior wings are the largest, and fulded when at rest. The mouth is imperfect and unfitted for mastication, the mandibles being only rudimental. The maxillary palpi are long, and almost setaceous. The larva has six legs : it resides in a case in water, which it forms of little fragments of shells, or of sand or sawdust. The mature insect is often employed as a fish-bait.

Phryganea semifasciata (Say).

(Plate xxxii, figs. 9 \& 10.)

Culor browish or ferruginous. Wings ferruginous, marked with irregular black lines and a distinct point near the inner and basal angle : inferior wings light ferugiuous or yellowish; the hindwings have a dilated mark near the inver margin. 


\section{CHAPTER XX.}

\section{ORDER X. HYMENOPTERA (LINNEUS).}

THIS order resembles the NeUroptera in the number, texture, and organization of the wings; but they have a fewer number of nervures, and are less delicate in their construction : the forewings, too, are larger than the hind ones, and their fuldings are horizontally disposed upon the back. The mouth is provided with horny jaws, and the maxillæ are metamorphosed into a sheath for the membranous tongue. The eyes are large. The thorax is composed of three consolidated segments, and the abdomen is attached to it by a pedicle or thread, provided with a sting in the females, or terminated with a multivalved saw or oripositor. The tarsi are five-jointed. The larva is without feet, except in one group; and the pupa is inactive and incomplete.

This order probably furnishes the most remarkable families for the development of social qualities and instinctive powers; and if instinctive endowments have claims for consideration, the hymenoptera should rank first and foremost among the insect tribes. Some of these remarkable qualities appear in the bee, the ichneumon, the wasp, and the gallfly.

This is the most populous of all the orders in the insect world, unless we except the Coleoptera ; its estimated numbers embracing one-fourth of the insect population.

Mr. WEstwoon adopts the following divisions for this order :

Section I. Terebrantia (Latreille) : the abdomen of the female being furnished with an ovipositor, which combines the characters of a saw and a perforator or borer for depositing its eggs.

Section II. Aculeata (Latreille), embraces those whose abdomens in the females are provided with a sting connected with a poison reservoir. The antennæ of the males have thirteen, and those of the females twelve joints. 
The first section has two subsections, the second containing two divisions :

Subsection I. Purtipraid : Ahdomen sessile : larsa feeding unon vegetable matter. This contains the fanilies Tenthredinida and Urocerida.

Sutsection II. Exтoмupuatia : Abdomen attached by a portion of its transverse diameter : larvæ with slightly developed trophi, and fur the most part feed parasitically upon other living inseets.

Division 1. Spicclifera : Abdomen with an elongated plurivalve oviduct : larra for the most part feeding upon other living insects. This division contains, as at present constituted, the Cynipida, Exaniida, Iclneumonida, Claalcidida and Proctotrupida.

Division :-. Trbetifera : Extremity of the abdemen tubular, retractile, and furnished with a minute sting : larræ feeding upon the larva of other hymenopterous insects, or upon dead insects deposited by the parent with her eggs for the support of the young when hatched. The Chrysidida.

The second section has two subsections :

Subsection I. Presooxes (Latreille) : The basal joint of the tarsi cylindrical : larva feeding upon stored insects, or animal fluids prorided by neuters. Families Crabronide, Larrida, Bembecida, Sphegide, Scoliida, Mutillida, Formicida, Vespida.

Subsection II. Merlifers (Latreille) : Basal joint of the posterior tarsi dilated for pollen-bearers: larva feed upon honey or pollen-paste deposited by the neuters. Fanilies Andrenida, Apida.

\section{Tenthredinidae.}

Turs family comprehends those hymenoptera usually called saufies. The antennæ are more variable as to the number of juints, than in most of the insects of other families. The families of the order are formed from considerations that relate to the number and form of the joints of the antennæ, and the number and form of the cells of the wings.

The insects of this family are less active than the wasps or ichneumon-flies : they fly sluggishly, and do not appear anxious to escape when about to be captured. The wings fuld horizontally upon the body when at rest. The female is provided with an instrument resembling a saw, or rather a duuhle saw, which is ludged in a fissure beneath the abdomen, and corered by two narrow pieces that perform the office of a scabbard. The two blades of the saw are placed side by side, and so skilfully articulated that when withdrawn from the scabbard they more up and down. This saw, however, has different forms in different sawflies : it has, moreorer, one adrantage over the carpenter's saw, which only cuts in one direction, and therefore is liable to pinch if it is not well set, especially when empluyed in sawing green wood; but the saw of the fly has teeth upon the sides, so that it can more easily by cutting a free groore. It might perhaj's be called a rasp ur file, as its teeth hare the form of the teeth of these instruments. When in use, the saw moves in a 
grooved piece that serves as a back to lieep the instrument sufficiently supported : the edge, upon which the teeth are cut, is circular. The use of this singular instrument is to prepare a place for the insect's eggs : slits are made in the stems and leares of plants, into which the eggs are dropped. Some of the species, after depositing their eggs, girdle the branch, which consequently dies, when it forms a suitable kind of food for the young. In other instances, protuberances are formed which become highly charged with sap, in consequence of which the quantity of food is greatly increased.

$$
\text { Cimbex dim (Peck), americana (Leach). }
$$

(Plate xxvi, fig. 11.)

The generic characters of Cimbex are :

Body obscurely villose : first joint of the abdomen strongly emarginate above : joints of the antennæ before the club, five; club two-jointed, and soldered together.

The insect I have figured is the CімвеX of authors; but the antennæ are properly only three-jointed before the club, leaving out of the number the basal support, which is fixed. The first joint is the longest, and is equal to the second and third together. If the support is a joint, then the antennæ are only four-jointed.

Description ( female). Head black, shining; antennæ luteous; thorax black, margined in front by a circular brownish ridge similar to a collar : abdomen bluish black with brownish, marked upon the sides by four ovate yellowish white spots, and anteriorly there is a whitish space between the rings similar to a belt. The substance or membrane resembles fine parchment or paper. Wings smoke-brown, semitransparent and shining; thighs blue-black; tibiæ pale brown, and armed with blunt spurs; tarsi yellowish or pale yellow. Length $\frac{3}{4}$ of an inch : expanse of wing, $1 \frac{3}{4}$ inch.

The body of this tenthredo or sawtly is thick and large. According to Dr. Harris, Prof. Peck had called this insect $C . u l m i$, because it inhabits the elm.

The male is more slender, and the spots are wanting on the abdomen : length about one inch; breadth, two inches. The larvæ feed upon the leaves of the eIm.

The foregoing species is one of the largest of the family of the Tenthredinide. It does not appear to be very common in the vicinity of Albany, inasmuch as but few are found in our collections.

\section{Uroceridae.}

\section{WOOD-WASPS : HORNTAILS.}

TuE head of these insects is large, convex before and flat behind : antennæ fliform; wings long, and overlap each other upon the back; body long and cylindrical; rings of the abdomen close and compact. Females are provided with an ovipositor in the form of a slender horn projecting from the extremity of the abdomen, or from beneath it, the sheath of which is attached to the inferior side of the ahdomen by a hinge. In the male the horn is short compared with that of the female, and is either conical or triangular. 
The sexes ditler considerahly both in markings and size. The horer of the female consists of live pieces: the two untside pieces are grouved for the reception and suphrt of the

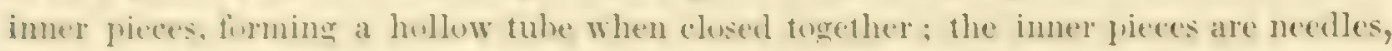
with which the trunks of trees are pierced tor the purpuse of depositing the eggs. Their goung ate grub-like larrat which are woul-eaters, and destrey forest trees by extensive hurmwing in the green solid matter. Pines, elms, maples, buttouwood and fruit trees are all subject to attacks of the uroceridx.

Urockros albicornis (Fabricius).

(Plate xxxii, fig. 3.)

Femule : Color deep blue-hlack : stemmatia three, situated behind the antenna in a triangular firm : head contliently functured ; antenne rather long, white, the base and extremity dark buwn or hack. Behind the eyes there are two oval crean-colored spots. Thorax pulescent, punctured, and deeply inplressed with a fissure running in a circular manner from the hase of une forewing to the other, and also extending down the base of the wings, leaving an elevation with its point directed hackwards. Abdomen cylindrical, smooth, shining, marked by a lateral oval white spot, and terminated hy a lanceform appendage. Legs black, with white joints. Leugth one inch : oripositur, nearly three-fourths of an inch; expanse of wing, nearly 2 inches.

This insect resembles the female sirex, but may he distinguished at once by its white markings.

TremeX COLUMba.

(Plate xxxii, figs. 1, 2.)

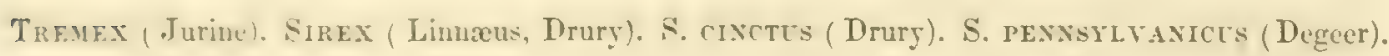
Pigeon Tremex (Harris).

Ileat and thwax yellowish brown, thick : antenus of the length of the thorax, and made up wf sixteen juints : abdomen bluish black, cylindric, ornamented by six rings, the last interrupted at the median line of the hody; extremity yellow : ovipositor short and stout : wings opake brown and clouled : legs and feet yellowish ; tibia armed with a spur.

This insert is common in Alhany ecunty. In compang with the Pimpla lunator, multitules resirtel to a half-grown majle tree in the hack yard of the Odd state Itall for the furpme of depusiting their egrs. So completely was this tree riddled with holes when the insects escaped after transformation, that it died in a few years, when it was found to be perfectly mined through and through.

I have taken this species also in Maryland, so that it appears to he widely distributed. The origm-itor is nearly half an inch in ledgth: the ledy, an incly and a half; the male

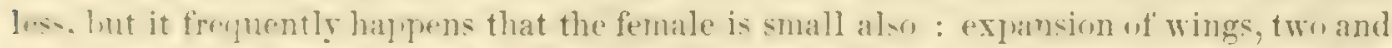
a puarter inches. Their wants are not confined to the maple tree : they lore or pigere the

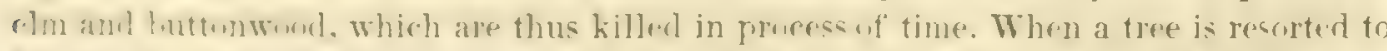
fire the depesition of their exses, it furnishes the larvat during every season of the ycar. 


\section{Ichneumonidae.}

The characters of this fumily, as given by Westwood, are : The abdomen is attached to the hinder extremity of the thorax, and between the base of the coxæ. The anterior pair of wings exhibit perfect cells upun their dise. The ovipositor is straight, and often exserted. Antennæe setaceous or filiform, not elbowed, and composed of more than sixteen joints, except in a few minute adsciti. The pupa is enclosed in a cocoon. The head is small and free : eyes lateral ; mandibles slender and bidentate ; maxillary palpi five- or six-jointed, pendulous : wings moderate in length and size : legs formed fur running. When the ovipositor is retracted, the abdomen terminates in a point.

The larvæ are parasitic upon other insects.

Plate I. illustrates some of the characters of the family.

The antennæ are in constant vibratory motion. The insects themselves are exceedingly actice, and exhibit a remarkable degree of instinct in depositing their eggs where their progeny will be provided for. They are very important in the economy of nature, especially in keeping in check other species which would be bighly injurious to man. They are particularly useful in reducing the numbers of the lepidoptera, scarcely a species of which are exempt from the attacks of ichneumon-Hlies. These deposit their eggs in the back of the larva, through a puncture so minute as not to interrupt its growth and perfection : the larva winds itself up as usual; but in its pupa state, the eggs of the ichneumon hatch, and the progeny feed upon it : it is consequently destroyed; and instead of the butterfly, there comes forth a brood of ichneumons. Before this subject was understood, the singular fact here stated was accounted for on the supposition that certain animals were susceptible of transformation into others.

The ichneumons have been divided into Ichneumones genuini and adsciti : the forewings of the former have two, of the latter, one recurrent nerve.

\section{ICHNEUMON BREVICINCTOR?}

( Plate xxvil, fig. 10.)

Color black. Antennæ with joints twenty and more : yellowish white annulus beginning at about the ninth joint, and ending at the serenteenth from the base. Wings light smoky brown. Scutel pale yellow : a sharp well defined ridge extends from each anterior angle of the scutel, to the middle of the ridge surrounding the base of the wing. Knees and tibia of the anterior feet rufous.

This individual differs from the brevicinctor described by $S_{A Y}$, in the beginning of the pale annulus, which, in his account, commences at the seventeenth joint, and extends only to the twenty-first. The cellules of the wing agree with his figure, and also the opake costal spots.

[Agricultural Report-Vol. จ.] 
ICHNEUMON -

(Plate xxvii, fig. 7.)

Golor black. Scutel yellowish, with a sharp ridge extending from the anterior angle to the base of the wing. Secend and third ablominal rings orange, with the posterior fart of the secund black upon the top : beneath, the orange culor covers the entire rings. Face and lers orange; the face pale. Auteunæ eutirely black. Wings transparent, and only slightly smoky.

IcHNEMON —-

(Plate xxvii, fig. 9.)

Colur black. Wings smoky brown. Antemne with a white annulus beginning about the sixth ring from the base.

Pimpla lunator.

(Plate i, figs. 1, 2, 3, 4, 5, 6.)

Antenne brown, darker at hase. Eyes hlack. Head hrown, encircled with a ring of two yellow hauls, and one of a pale brown : front yellow, with a brown band extending trom one eye to the other. Thurax brown, marked upon the top by a trident, or a lingitudinal band terminating before in three divaricating lines. Laterally there are two hraad hrown bands parallel with the first : between the wings, the middle band divides and forms a circle, the inside of which is yellow. Abdomen compressed, sabreform and narrowed hefore. The seven rings of the abdumen are marked by semilunate hands at their posterior margin, and succeeded by a black ring : the lateral jarts of the rings furm an acute arch in the female, which enables her to flex the abdumen as represented in fig. 4. Ahdomen greatly dilated at its extremity in the female, and terminated hy a greatly elongated ovipositor. Wings transparent, and marked by a brom patch. In the male, the abdomen is slender. Legs yellow and light brown. The fermale is sometimes $1 \frac{1}{2}$ inch lung, with an ovipositor some three inches long.

Fig. 4: Female in the act of introducing its ovipositor into the trunk of a maple tree.

Figs. 1 \& 6 : Males.

Fig. 5 : Female at rest.

The selluw hands represented as lunate, are prohably ton sharply arched to admit strictly of the appellation.

This insect furmerly frernented a half-grown maple in the yard of the State House in this city. I sulyesed at first that the pimpla was attracted to this tree, in consequence of the sircs having also made it the flace for depositing its eggs. The larva of buth insects were found in great numbers in different stages of growth; but it did not appear that the larva of the furmer bed upon those of the latter, for they were both in many instances full grown and separate. In sone cases the pimpla passed her ovipositor very near to a larra of the sirex; hut it could not he ascertained, atter a very careful examination, that the oljowt of the first was to picre the larve which infested the tree, after the manner of ichneumrn-tlies. Still the habits of the family faror the view that the larræ of the pimpla 
feed upon the larræ of the sirex. The tree was perfectly riddled with holes and burrows, and was undoubtedly selected on account of its sheltered position. As happens with some other species, the females sometimes perished from inability to withdraw their ovipositor; and this does not seem at all strange, for they frequently succeeded in introducing it into the wood to the depth of three inches, slender as it is.

\section{Sphegidae.}

THE collar is dilated laterally, and extends to the base of the wings. The legs are long, the posterior being more than twice as long as the head and thorax. The antennæ are filiform or subsetaceous, long, and composed of elongated joints. The body is long, and the abdomen is attached by a long peduncle. Mandibles elongate, curved, narrow, and notched on the outside at the base : eyes entire : legs fossorial.

These insects appear like wasps, except in their pedunculated abdomen : they are exceedingly active, restless, and difficult to capture.

Sphex PENnSyltanica.

(Plate xxvi, fig. 9.)

Color steel-blue and purplish : margins of the wings fading into brownish, scarcely observable. Head transverse, short : eyes prominent; hindwings dilated behind. Abdomen greenish steel-blue, oval, acute, and attached to the thorax by a slender thread. Antenne brownish : thorax and head pubescent : tarsi black.

\section{Vespidae.}

Vespa fraterna.

(Plate xxvi, fig. 6.)

Color brown. Surface without puncture and smooth. Antennæ paler on the under side. Wings smoke-brown, translucent. First ring of the abdomen marked with a yellow ring. Legs brown, except the joints, and a short stripe of lustrous upon the upper side of the femora : tarsi luteous.

The wasp and hornet exhibit skill and patience in preparing their habitations : they are natural paper-makers, and fabricate an article that is impervious to water.

The wasps form their habitation beneath stones, fixing it to the inferior surface. They feed their young upon regetable juices, and the softer parts of other insects which they capture. They are fond of the juices of our domestic fruits, and seem to have a preference for the expressed juice of the apple, as they are observed to abound about cider-mills and in apple-yards. 
Antenne llack, long and liliform, marked with two yellow bands at the extremities: melli distinet. Head, eyes, thorax, alulomen, and legs black. Palpi fomr, slender, two long and two short. Legs slender, but the hind-tibie are thick and strong. Abdomen elongatted, consisting of six joints; the elongated rings long oval. Wings pellucid and brown.

This singular insect is not uncommon in New-England and New-York in autumn. By the roatsides, in september and oetuler, it is seen flying slowly, is if borne down by its long abdomen. When caught, it attempts to sting, amd is capable of intlicting a slight wound.

Ophron macrurum (Fabr.); Ichneumon (Drury). (Plate xxvii, fig. 5.) Head small, dark orange : eyes large, black, oblong; ocelli shining black. Antenna nearly the length of the insect, hrown orange and thread-like. Color of all the other parts of the insect hrown orange, except the wings, which are transparent. Thorax short. Aludomen arehed, three times as long as the thorax, and attached to it ly a very narrow or thread-like base, widening in depth, but compressed laterally: extremity oblipuely truncate. Legs slender; hind ones the longest: tips of the foretibiæ single, the others double-spined. Length of body one inch.

This is one of the most remarkable of our ichneumon-tlies, and appears during the latter flart of summer and early in autumn, when it is observed buily hovering over places where there are thickets of brambles, solidagos, asters, ete. in search of caterpillars or other suitahle objects for the deposition of its eggs. It is common in Massachusetts and New-York.

OPHYN MUNDUS.

(Plate xxvii, fig. 4.)

Color black : antenne, tibiæ and tarsi yellow : antennal nasus, anterior orbits, and front greenish yellow; the antenna are black or brownish black at base. Thorax clothed with hairs. Aldumen compressed : basal joint cylindrical ; second joint as long and rather linger than the first. Forelegs fulvous yellow, except a brown stripe on the under side : tibia of the hindlegs fulvous yellow, except the tips, which are brown; feet all yellow, except the middle, which is brownish above. Length one inch.

Ophion gilabtatus.

(Plate xxvii, fig. 3.)

Antennx shorter than the body. Color dull honey-yellow : head and orhits yellow; wings hyaline, transparent, with an oval longitudinal glahrous spot on the large cubital c..ll just heynd its middle; eyes dusky or brownish. Metathurax with a transverse rilge near the articulation of the abdomen. Length four-fifths of an inch. 
Ophion pURgatus?

(Plate xxvii, fig. 6.)

Antennæ nearly as long as the body. Color honey-yellow, somewhat brownish : orbits yellow; wings hyaline, with two opake dots in the first cubital cellule.

This insect, though not longer than the foreguing, is rather thicker and stouter. Length about four-fifths of an inch.

Xylocarpa virginica.

(Plate xxvii, fig. 1.)

Body thick, pubescent and hirsute; thorax globular; abdomen ovate; eyes brown; antennæ short, slightly thickened at the extremities. Thorax and adjacent part of the abdomen clothed with jellow hair : two-thirds of the posterior part of the abdomen black. Wings hyaline, rellowish, tipped with a dull ochre-yellow. Beneath the body and legs hairy, black inclining to brown.

This insect attacks the dry woodwork of porticos, ceilings, etc. and completely burrows the inside, learing a mere shell to support the framework. It always makes its entrance on the lower side of the railing, whence its operations are not readily detected.

Cerlioxis annularis.

(Plate xxvii, fig. 2.)

Color black : face yellow : antennæ black : thorax black; margins lighter, and the disc black : abdomen black; rings annulated with yellowish white, pointed. Beneath the body and legs, black.

\section{Scoliidæ.}

Scolita fossilana.

(Plate xxvi, fig. 10.)

Scolia fossilana (Fabricius). Sphex plumipes (Drury).

Head pale yellow in front, black on the top and hairy : antennæ black, shorter than the thorax : neck hairy, lemon-colored : thorax black, and covered with yellow hairs : wings dark brown, translucent : abdomen lemon-colored above, crossed by three black lines, dark beneath : breast and arms black : legs hairy and black; hinder ones furnished with two remarkable long spines at the tips of the tibiæ : tarsi furnished with strong pale yellow hairs.

Scolia octomacolata.

Thorax black : scutel marked with a yellow line. Back of the abdomen dusky rufous, and marked with eight yellow spots, four on each side of the median line : the middle spots are oval, the first and last linear. The head is black; the anterior margin of the clypeus and base of the antennæ, dull rufous : thorax black, and feet rufous.

The scolice are fond of dry sandy places, and feed on the honey of flowers. 


\title{
CHAPTER XXI.
}

\section{ORDER XI. LEPIDOPTERA (LINN גUs).}

\author{
GLOSSATA ( Fastictus).
}

TuE insects that llit before us in our daily walks, and are known under the common name of butterfies, are representatives of this order, to which also belong the numerous winged risitants around our lamps during the summer evenings. Those which are olserred flying in the daytime, nerer enter our windows by night; and neither are the moths, so commun at night, ever seen sporting by day, or flying abrod by the light of the sun.

Our tirst inquiry is, In what respect do the insects of this order differ from those already described? They have four ntembranous wings, cluthed with minute scales : their bodies are soft and corered with hair, and their mouth consists of a tubular filamentous organ desinned for sucking the juices of tlowers, and which, when not in use, is rolled into a compact cuil; and, lastly, their metamorphosis is complete. We cannot fail to see how widely they difter from the Colmoptera or Orthoptera; although could all the species of the different orders be spread out before us at once, we should find that they are all connected by intermediate links.

The lepidoptera exist in three states : the caterpillar, the pupa, and the imago or perfect state, in the last of which the insect prupagates its kind. In the first or caterpillar state it grows, or increases in size; and it is cluring this state that it is necessitated to change or cast off its outer integument, in order that this process may be perfected. It changes its skin four times, and it frequently happens also that its colurs and markings undergo a succession of changes. Each insect is invariably furnished with sixteen feet. The mandibles and maxilla do not differ materially from those of the insects of other orders. The true legs are horne by the first three segments of the body : the other legs are called false, or sometimes prop-legs.

As it is in this state that the insect grows, it becomes necessary that it should take a large quantity of food, which it mostly derives from the regetable kingdom, feeding upon routs and leares, and sometimes upon wood. When the larva has acquired its proper size, it ceases to eat, and proceeds to form for itself some kind of case, impervious to water, and 
in this it undergnes a change. It is then inactive and defenceless, and aprears dead; and as if aware that it is ahout to assume a condition in which it cannot protect itself, it seeks a secret place where it may be secure from the attacks of foes. The transformations of the lepidoptera are of the most complete kind : in some other orders, the pura is active; here it is inactive.

The LEPIDOpters are divided into three great sections. The first section contains the Butterflies proper, Papilioxes : their antenna are thread-like, and bear a knob. The second contains the SpHisges, or Haukmoths : their antennæ are thick in the middle and often hooked at the tip. The third contains those familiarly called Moths : their antennæ are neither knobbed at the end nor thickened in the middle, but somewhat naked, tapering or bristleform, or else feathered on each side. The order has also been otherwise divided into two sections : the Diurnal lepidoptera, which fly by day; and the Nocturnal, or those which fly only during the night.

\section{Papilionidae.}

THE distinguishing characters of this interesting fanily are taken from the feet, all of which are perfect, formed for walking, and furnished with simple or bifid claws. The antennæ, which hare a distinct club, have no appendage as a hook at its extremity. The hinder wings have a slice cut out of the inner margin, for the accommodation of the body, or else are grooved to receive it.

The larræ of this family are naked, and the pupa is supported by threads of silk passed around the middle of the body : they are both angulated and smooth in the different genera.

The buttertlies of this family are among the largest and most splendid of American insects : examples are the Papilio asterias, philenor and turnus. The family is advantageously subdivided into Papilionides and Pierides. In the former, the anal angle of the posterior wing is concave or folded, and the middle longitudinal nervure of the forewing emits four branches, while no other species have more than three; and the palpi are short. From their size and beauty, Linndes gave them the name Equites.

The subfanily Pierides have a gutter in the inner margin of the hindwings, for the reception of the abdomen. The caterpillars are finely pubescent, and taper towards the extremities. The pupæ or chrysalides are angular, slightly compressed, and terminate in a point at each extremity : they are supported by a thread of silk passed around the pupacase. Some of the common butterflies belonging to this subfamily, the white and yellow ones that flit about our walks, are less beautiful than those of the first subfamily, but still deserve our admiration. 
The genera of the family have the following characters:

In PAPILIo, the antennx are long, but the club is not flattened : posterior winge angulated.

In GONIAPTERIX, the wings angulated; antenna short.

In CoLras : club of the antenna not compressed ; posterior wings rounded, and covered with scales.

In PIERIs, the club of the antenna is compressed : wings naked.

In PoNrIA, the club is compressed : forewings trigonate, and both covered with scales.

The Couss is the genus that contains our common sulphur-yellow hutterfy bordered with hack : the Gosiapterix and Ponta are white, and our Piens is orange with a black border.

\section{Papiliones.}

PAPILIONES (WesTWOOD), EQUTTES \& HELICONIT (LINNAUS).

Papilio asterias (Cramer). P. rroilus (Drury, Abbott \& Smith). Butterflies.

Antennæ long. Head hlack, marked with four yellow dots; eyes llue : body black, marked with linu ruws of rellow. Wings black : beneath there is a reflection of olive greeu; nervures stroug. Forewings marked by two rows of yellow spots, aljout eight in each row : imer row, the spots are large and triangular, with apices directed tomards the insertion of the wing; outer row, smaller and nearly round. Outer edge of the wing spotted with pale yellow : near the anterior margin, there is a single spot of yellow within the rows. Posterior wings tailed : upper side marked by a continuation of the yellow spots, the inner row being rounded and the outer lunate; between which rows, there is a row of large blue spots placed betwixt the nervures. There is an eyelet upon the inner margin, the ring of which is orange with a black centre : the hindwings are margined like the forewings. Beneath, the yellow spots are converted into orange, except those of the outer row upon the forewings, and some of the crange spots are margined with yellow : the line spots have become lunate, and softened into-olive-green. Expansion of wing, three to four inches.

The caterpillar is fund in the month of June, feeding unon umbelliferous plants, as the parsley and carrot. When perfect, it is smooth, and of an apple-green color; each segment or ring being marked by transverse alternating hands of black and yellow spots. When first hatched, it is black, and banded across the middle : it undergoes a succession of changes during its moulting. It has a peculiar mode of defending itself from the attack of thies; as when touched, it protrudes from the first segment of the body a pair of orangecolored horus, which exhale a disagreeable odur. The pupa is of an ochre-yellow or pale green. 
Papilio philexor (Fabricius), P. astinots (Drury).

Head, thorax and ahdomen black; the breast marked with two rows of yellowish dots: antennæ and eyes brown or brownish black. UPPER SIDE: Forewings black with a green lustre; apical area brownish; outer margin marked with five spots, and edge trimmed with black and white : hindwings polished green, silky, darker at the base; posterior margin marked with five white lunules; anal angle excavated and edged with white; tail rounded, its angles trimmed with black and white, the crenx being white. UNDER SIDE : Forewings black; apical area olive; margin marked with five yellowish spots; edge black and yellowish white : hindwings highly polished, green and lustrous, with the outer and inner margins marked with large fuscous spots surrounded with a velvety black ring, with a single spot of yellowish white on the outer side; edge trimmed with black and yellowish white; tail dilated. Legs and feet black.

Papilyo turnus (Linnæus). P. alćtdamas (Cramer). (Plate xxxviii, fig. 3.)

Antenne black : body black abore, marked with a yellow stripe leginning at the neck, and passing over the insertion of the wings and along the sides of the abdomen : sides of the breast striped with yellow; palpi yellow. UPPER sIDE: Wings yellow, marked by five subcostal bands : the first is a marginal one, extending from the shoulder to a yellow lunule at the anal angle; the second extends as far, but grows thinner and terminates in a point, and the other three are abbreviated and confined to the forewing : costal edge black. The outer marginal band is wide, black, and common to both pair of wings, and is ornamented with six lunules, larger and mcre perfect in the hind- than in the forewings, the first and last fulvous. Hindwings scollcpped and tailed : tail rather long and narrow; anal angle fulvous, edged with white, and ornamented with three lunules, yellow, black and blue, and a ferruginous one below. The hindwing edges are trimmed with jellow; the forewings with white. BenEath, the yellow is pale; the subcostal bands are less black and velvety, and bordered with greenish. Outer margin, the edge is black : there is a dusky yellow band, succeeded by a broader and more dusky one, showing greenish yellow, and bounded on the inside with a strong black line of scollops. Hindwings, the edge is yellow, succeded by black and yellow lunules : the black line within is bordered with blue. Expanse of wing four inches. Length from the head to the extremity of the tail, $2 \frac{1}{4}$ inches.

This is one of our common butterflies, and resembles the Machaon of Europe, but its markings and form are more like those of the Podalirits. Its lartre are not known as injurious to the cultivated vegetables.

[ Agricultugal Report - Vol. v.] 


\section{IIeliconiidae.}

\section{Genus DANAUS.}

The generic characters of the Davaus, as drawn up by Mr. SAY, are as follows :

'Auterior feet sfurious in both sexes : antenna terminated by a club; palpi distant, sub-

- "ylindric, short : inferior wings runded, not forming a groove for the reception of

'the abdomen : nails of the tarsi simple.'

\section{Dayaus plexippus.}

(Plate xxxviii, fig. 1.)

Head and budy hack, marked with two rows of white dots : sides also marked with many white dots : fire posterior rings of the alulomen edged with white, with two rows of dots beneath. Wings entire, fulvous red varying in depth in different individuals: nervures and costie hlack; lateral and posterior margins trimmed with a black border, and two gows of white spots with a black and white edge : apical area black, and marked with elongate and subyardrate spots of the ground-color of the wings, with smaller spots of white extending along the costa. Bexeatu, paler: hind-paler than the forewings; in other respects, the narkings are not dissimilar to those of the upper surface. Eyes and legs steel-blue : tarsi velvet-black. Expanse of wing, four and a quarter inches.

Common, and widely distributed. The larva are harmless, feeding on useless plants, as the asclepias, etc. : they are annnlated with white; the pupa is green, and dotted with golden spots.

Limenitis Dissippos.

(Plate xlvii, figs. 1, 2.)

Ground-color of the wings precisely the same as in the Danaus plexippus. In the alical area, a somewhat triangular spot of black extends from the apex to the outer angle, within which there are four oblong spots of the color of the wing, and a small one at the junction with the marginal horder : this hlack spot is marked with three white spots, and sometimes four in the row; the lower one is a mere dot. Between these white spots and the apex, there is an elongate white lunule, or an elongate pointed sput. Beneath the custa, there is sometimes a white spot towards the hase of the wing. The hindwing is marked by a narrow hlack belt, extending from near the middle of the costa, acros the wing to the anal angle. BExkatu, paler : upon the forewing there are two suherstal hluish white spots, and a dash of white on the costa near the black triangular spot. In the apical area, the fulrous spots are five in number, and mur distinet than these abure. Hindwings, the black belt is bordered on its hasal side with three or more bluish white spots placed between the nervures. The border in hoth pair of wings is trimmed with blark, upon which the inner row of spots forms 
a distinct lunule, succeeded on the outside by interrupted curved blue lines : edge trimmed with black and white.

Head and body black : the back of the head is marked with four white spots, the first pair placed at the base of the antennæ. Antennæ black, tilped with rufous : palpi black, striped with white on the outside. Eyes blue, with a white spot posteriorly. Each side of the thorax is marked with three large white spots : coxæ white; the rentral portion of tive rings, white, and an abbreviated lateral white line. Leos black: tarsi of the forelegs striped with white in front. Expanse of wing varies from two and a half to three inches.

This species is found accompanting the $D$. plexippus in the ricinity of Albany, and is usually regarded as a mere rariety of the same; but the many differences in the markings, taken in connection with the constaney in size of the numerous individuals I have examined, leave no doubt of its distinct character.

LimeNitis URSULA.

(Plate xxxiii, figs. 1 \& 2.)

Color black abure, black and brownish beneath : antennæ black; knob rather slender: eyes bruwn : head black. Behind the antennæ there are two white triangular spots, and a white line beneath and outside of each eye. Thorax and abdomen black above: sides of the former marked with three white spots; on the latter, the edges of the rings of the renter white, and sides marked with a wide white stripe. Outside palpi white : upperside of the imperfect forefeet white. Forewings subfalcate; outer margin slightly sinuate; nervures of the wings with four branches : posterior wings slightly angulated, without tail, subtrigonal. LPPER sIDE, velvety black : forewings marked with subnarginal bluish and rather obsolete lunules; apical area marked with two white triangular spots; edge trimmed with white and black : hindwings marked with two rows of pale blue quadrangular spots, the third upon the inner row from the anal angle being a lunate spot. Outside of these there are two rows of sublunate spots, the outer white, the inner blue; the former are placed upon the edge. BЕхеАтH, the apical area is brownish, and marked with white spots, which become obsolete as they extend towards the outer angle. Base of the wing bluish in some lights, and marked with two brown and four blue subcostal spots : the blue spots are snall, and stand two and two; the margin is trimmed with two rows of lunules, and the edge with white and black. Behind the disk is brownish, similar to the apical area, and the base is marked with a cluster of rufous and blue spots. The margin inside has five rufous spots surrounded with liack, and two rows of lunules parallel with the edge, which is trimmed with white :nd black.

This species is found as far south as f:corgia, yet does not appear to be commcn any where : it feeds on the gooseberry leaf and wild cherry, and is figured in Aввотт and Surtu's Lepidoptera. 


\section{Pierides.}

\section{PIERIDES (WESTWOOD)。 DANAI (LINNAES)。}

Comss rumbonce (Cindant). Clouded-sulphur Buthfly. (Plate xxxr, figs. 1, 2, 4\& 9.)

Papilio paleno? (Limngus). Colias etropone (Swainson).

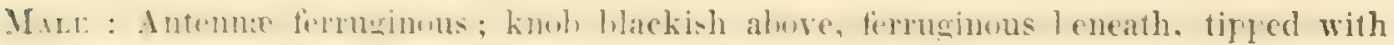
ferruginous or rosy color : palpi yellow, clothed with long hairs, greenish at base : eyes brown. Head blackish above; tips of the hairs often reddish. Trunk and abdomen blackish above, or rather greenish; beneath, yellow. Wings yellow, broadly luretereal with biack. Anterior wings above marked with a central diamend shaped black spot, which is matehed by a faint yellowish spot upon the posterior wing : beneath yellow, with a greenish tinge, especially beneath the black border of the forewings. Posterior wings of a deeper tint of sulphur-yellow than the anterior, and marked with two brownish spots each : the first is near the middle of the wing, and coalesees with a smaller spot towards the anterior margin, and both are comanented in the centre with a spangle of silver; the other, a reddish oblong brown spot, is placed directly midway upon the anterior margin of the wing, pointing to the coalescing central spots. Wings ciliate : ciliæ rosy red.

Frumer: The colurs of the wines are nuch like these of the male. The border is rather paler, and shows six spots of the ground-color of the wings, placed two and two: finu wh the synts are nearer the apreal angle. The prosterior wings show oholetely the marks flaced leneath : the black lorder is fainter and narrower than in the male. B.neath, the anterior wings scarcely differ from those of the male; the posterior are paler, and, if any thing, show a faint rosy tint, with three or four small dots. Expanse of wing, about two inches.

The females differ as to delth of coloring : scme are nrarly as yellow as the male; in other. the yellow is pale and whitish. The caterpillar is described as puluescent, green, with yellow lines and black dots:

Fig. 1, male ; 9, upper side female; 2, lower side female ; 4, lower side male.

\section{Pontia oleracea (Harris). Potherb Pontia.}

Knol. of the antenne Hattened. black, and tiplued with feruginous; setaccous part, white bentath; alnse back, with the lower margin of the rings white. Head white, with a Hack spot upon the back of it. Thorax and body hack, with the ends wany hairs and scales white : the sides of the abdumen are striped with white. Anterior wings 
white, and tips and hase dusky, which color extends outward along the nervures. Posterior wings white above, slightly yellowish green beneath.

Dr. Harris has giren a minute description of the eggs and caterpillar of this species, from which it appears that the lemale lays its yellowish eggs un on the leares of cabhages, radishes or turnips, about the first of June; that they are hatched in alout a wcek, and that the caterpillar attains its full size in three weeks : it measures an inch and a half in length, is of a plale green color, and feeds indiscriminately upon any part of the leaf, perforating it in many places. The pupa state lasts about eleven days.

This butterfly, as may be supposed from its habits above described, is injurious to garden plants. There is no other way to save cablages, etc. when attacked by the caterpillar, than to crush it under fuot. It is common, but less so than the Colias. Neither inflict rery extensive injur: upon the farmer; and if the birds could have their own way so far as to inhahit the trees about the garden without molestation, they would always keep these minor evils in check : the indviduals of any species of insect would never increase to an extent such as to call the husbandman or gardener from his other duties.

The Pontia oleracea has a resemblance to species of the Genus Apterix : in all these, however, the antennæ are shorter, not flattened, but clavate, and the wings are angulated; and finally the individuals are all larger than the $P$. oleracea.

\section{Pieris nicippe?}

(Plate $\mathrm{xxx}$, fig. 7.)

Head and body black above, but crossed at the back of the head and thorax with yellowish; beneath, yellow and orange along the sides. Antennæ rather short : knob yellowish. Wings yellow or orange : horder wide, black, and edged with orange about the middle : below the anterior edge there is a short black line; the anterior border rather greenish. Beneath yellow, with a few splashes of red particularly on the hindwings. Forewings, the outer burder is yellow, while the basal part is a deeper yellow: the outer edge of the forewing is dotted with brown; and the fore-edge of the hindwing shows many sharp dark lines, but frequently obscure.

Though this species does not agree in every particular of colcring with the nicippe, it is not so far removed as to admit much doubt of its being the same. It has a wide range, being found in Pennsylrania and Virginia as well as in New-York; but here it is far from being common.

Some of the figures hare been colored of a deeper orange than the specimens ordinarily exhibit : indeed some individuals scarcely partake of this color at all, bearing mostly upon yellow.

Fig. 7 , upper side; 6 , lower side. 


\section{Nimphalidae.}

THE distinguishing characteristics of this family are found in the forelegs, the antennæ, the pusterior grenre of the hindwings, and the peculiar manner in which the pupa is susprented. The anterior legs are defertive, heing short and unfitted for walking : the antennx have a distinct cluh, it may he compressed or somewhat prolonged below, but never hooked at the tip : the two himd pair of lears are furnished with bifid claws, the hinder tibia with a single fair of spurs; and the pusterior wings receive and protect the aludomen in a groove. The larra hear spines or else tubercles, and are cylindric : the pupa is angulated, and suspended by the tail.

This family embraces thr heautiful slecies that have received the cummon names of red and white admirals, puinted-ladus, fritterluries, etc. Their tlight is strong, and more than makes up for the imperfection of their feet.

The genera may be known by the following characters:

The VAviss $x_{\text {I }}$ have angulated wings; antennæ rather abruptly clarate; ejes pubescent.

The Crмтuा.e have rather rounded wings, or only subangulated : in other respects, they closely re-

- semble the ranessa.

In the Linexitrs, the wings are more or less rounded ; the antenna are straight ; the club gradually thickens : eyes pubescent.

In the IIrparcuix, the eluh, of the antennx gradually thickens, and is more or less curred.

The ARorvises have the antenna rather abrurtly clavate, and club short; cyes naked; wings broad, and the head large.

\section{Nympalides.}

VAnessa antiora. Willowo Butterfy.

(Plate vi, figs. 5, 6, 7.)

Papilio antiopa ( Linnæus, Donotan).

Abore the medium size. Wings angulated : upper sides deep purplish brown; surface appearing like velvet. Inrdered with a lwad wary belt of black, in which there are angular riolet-blue sints : outer unargins cream-colored, spriukled with dots arranged somewhat in lines; the salient angles of the horder more distinctly marked. The anterior margin of the primary wings has cream-colured spots beyond the middle, towark the cuter edge : the underside of the wings darker brown, terminating in the seullorped mottled gray border. in which there is a row of darber angular spots. The secondary wings are prolonged slightly into tails.

The caterpillar is back, with a series of sputs along the back, and each joint armed with spines. It cunsumes the leares of the puplar, willow, etc., but injures mure especially the 
elm. from the branches of which it often hangs in clusters; and when once stripped of its foliage by the larræ of this species, which are more numerous some years than others, the tree rarely recovers.

The pupa is suspended by its tail from the underside of a stone or rail, and is pointed and armed with a double row of spines upon its ventral surface.

The antiope or villow butterfly survives the winter : it seeks a warm secluded place, and hence in the spring it appears early. The young butterty comes forth from the chrysalis state in July; and in August a second brood of caterpillars appear, which pass through their changes before winter.

In consideration of the extensive injury these caterpillars inflict upon some of our best kinds of shade trees, it is very desirable that they should be destrojed, by shaking them from the limbs on which they congregate, and crushing them under the foot It is only by taking this advantage of its larval state, that the increase of the species can be effectually checked.

Vanessa interrogationis. Semicolon Butterfy (Harris). (Plate xxxv, fig. 5.)

Head and body brown, hairy. Anterior wings angulated and reddish or dark reddish orange, with their borders broadly shaded with black and obscurely marked with reddish spots, of which the longest is situated at the superior and outer angle, and dotted or marked within with black : middle spotted with seven angular black spots. Posterior wings all black except their bases, but the black is not sufficient to conceal rows of reddish spots : posterior and lateral margin edged with a black line, within which there is a reddish white line extending and spreading over the short tails. Inderside of both pairs of wings the color is rust-red or marbled : the border of the hindwing is also ornamented with faint bluish green lunate spots. The centre has the

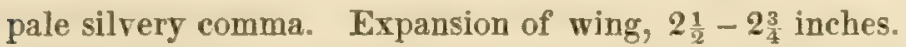

The caterpillar is spinous, brownish and variegated with yellow and brown, and lives upon the hop.

There seems to be some variety in the markings of this butterfly, though the general pattern is much the same.

\section{Vanessa progne (Fabricius). Progne Butterfly.}

Antennæ brown : knob dark brown, tipped with lighter; outside spotted with black and white; beneath light brown. Head with a black spot at the base of the palpi. Body brown, light beneath and black above. Wings angulated, brown, and spotted with black. Anterion wings : Outer margin black, marked near the centre with five round spots placed in a right angle : above and near the margin there is an oblong 
larger spot than either of the five: begunl, a clusky patch with the apex black. Postremer waves, motly dusky hack, hut hrownish towards the hase : tails and marrin gowdered with reddish white : lemeath grat ish, mottled redlish or a range,

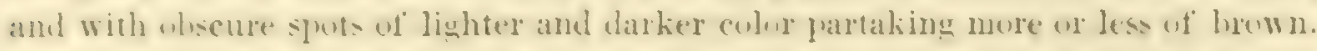
Hindwings marked with a silvery o opening outwards.

This sfectes furnishes considerable variation in the nurkings. as well as in expansinn of wings. It is a commen suecies. generally smaller than the red admiral and comma butterily.

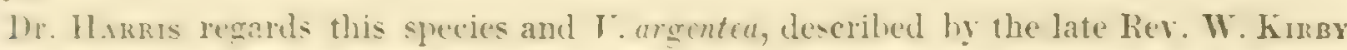
in the Fauna Boreali Americana, as the same.

\section{Vanessa comma (Harris).}

Dr. Harris has recently describet an American comma butterfly, which had been regarded as identical with the European : although closely resembling the latter, the hinder wings are not so deery y indented, which feature may serve to distinguish the two. For description, see Harris's Injurious Insects, 2d edition, p. 241.

\section{Vasessa polychloros? Comma Butterfy.}

Axterno wiscos. dusky wanee, darker at hase, marked with fuur large subquadrate spots ulon the disk, of which three are in a line, and the other is placed helow the middle slut wh the three : custal margin with three large abbreviated fascia, the middle one the larest. the aljeal one smallest and whiter : vuter margin dusky, and marked with an irregular pale line. Posterion wings have a large black or dark brown cortal siput : whter margin marked with crescents, which are not sufficiently distinct fo walrant insertion in this description, owing to injury : a slender pale line is visible running faralle-l with the edge. Beneath the wings are clouded, the basal portion much the darkest: the higher pertion, or hroad hand is striated transversely hy numerous darker interruted lines. In the midcle of the fosterior wing there is a silvery curved line.

The individual alwe descriled differs alunt as much from the English polychloros, as uur banessu atahnen or Cynthic cardui from theirs. The must important point not made out. relates to the blui-h lumules upon the outer margin; but on applying vur polychloros to the Encli-h firure, I find it fits in length and breadth, and also the angulated and scollnyma edges. There is a clise correspondence in the latterns abure and beneath; and the genr.ral reventance is so near that it will not be safe to treat our specics as distiuct frem the English. 
Tanessa URTica? Tortoise-shell Butterfly. (Plate xlvi, figs. 8, 9, 10.)

Papilio tritace (Linnaus).

Epper sides of hoth pair of wings bright red-orange, dark at the base, and corered with long olive-brown hairs. Costal margin of the forewings marked with three large black subquadrate spots : between these spots, pale orange, with a whitish figure towards the apex, but within the border. Under the three black spots mentioned, there are three unadrangular spots upon the disk : the one nearest the base, rectungular and largest, and bordered on the outer edge with yellowish; above which are the two smaller spots. Exterior margin of both pair of wings black, and ornamented all around with blue lunules : beneath, the basal half of the hind-pair is nearly black; outside of which there is a belt of brown marked transversely by darker lines, and then the blackish border ornamented with obscure or black lunules. On the forewings there is a large pale orange patch, corresponding to the reddish orange markings above.

Antenses : rings marked with white and brown; knob brown, terminated with pale orange; palpi gray, from an intermixture of white and brown hairs. Expanse of wing, $1 \frac{3}{4}-3$ inches.

I am unable to say whether this is a common species in this State, or not : it has been taken in the vicinity of Albany this season (1853), and I believe frecuently. It resembles SAY's V. furccllata, obtained in the Northwest Territory; but in the latter there are two subquadrate yellow and reddish spots near the costa upon the black ground, and the broad belt is orange, bearing upon the costa a large black spot.

\section{Vanessa atalanta (Fabricius, Curtis, Stephens). Papilio atalanta (Stephens).}

Base of the anterior wings rich brown; of the apical half, brownish hlack with a tinge of blue, in which there is a series of white spots arranged in a curved line, the two largest spots separated by the two smallest. Between the broad orange fascix and the series of white spots, there is a large white spot upon the costa. The orange fascia crosses the wing, but does not quit the posterior angle : the scollopred edges are trimmed with white. Posterior wing, two-thirds of the basal part rich velvety brown, ornamented with a broad border similar in color to the fascia of the forewing, and dotted through its middle with black, besides the two confluent blue spots of the anal angle. BExEATH, the forewings are black; and hetween the midhle orange hand and base, there are red and blue lines: apex ashy brown. The hindwings are brown, black and grayish, traversed transversely by black narrow interrupted wary bands : beneath the orange belt the color is ashen, marked with black angular lines. On the costal margin there is an ashen patch, with a darker middle.

[Agricultural Report - Vol. v.] 27 
Crstia cardor. Vanessa cardui (Godart).

(Plate xlvi, figs. 1, 2.)

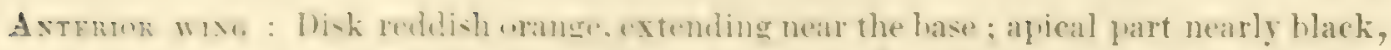

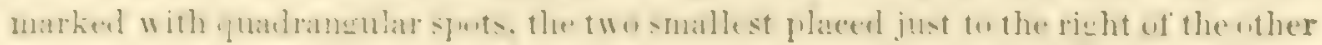
two : the large costal spot within the four spots spoken of, is divided into three parts by the nertures : marein and ederes trimmed with white hrown, and an interrupted line which reaches the costa between the white spots and apex. Posterior wings redili-h wanter. their inner margin corered with lung hwown hair : npon the disk of

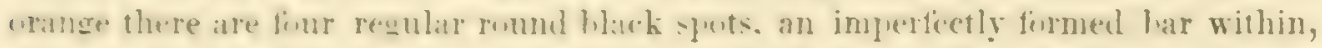

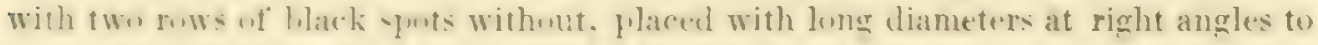
each wher: the edien is trimmed with white. The hindwing is orange, sputted all orer with black spots : the costal margin, which is connected under the forewings, is white. Bexratu. the coloring is hrighter on the firewings, hut the fattern is much the same as ahwre. The himbrings are ornamented with four distinct cyes, the two smallect in the middle : the evente is liack; then a partial ray wi the then of hlack, then a di-tinet one of buff marrined with black. Towards the snter angle there is chen a fifh much smaller ere, arranged on a line with the wthers. The whele of the furtion within the eres, and the nerves are all white, with numerus large and small White and light brown angulated spots and bars.

\section{CyNthis hustera ( Kirby).}

Papilto cabder vibgimensis (Drury). P. iole (Cramer). Vanessa huxtera (Dale, Stephens).

Edges of the wings rounded. "Ir only sulangulated. Disk of leth pair of wings orange red, hrown at hase. and darker at the apex; disk broken ly back irregular transwerse har: connected hy delicate lines : apical part marked with finr silvery white slots; the two smalle-t are out whe of the lareer, and the costal wne is divided ly the black nervure inse two garts. There is also a large subpuatransular spot resting on the

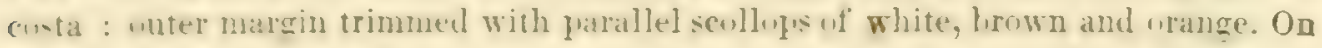
the lusterior wing the ornaments consist of two hlack circles with lulue centres, between which are two liack siwts. The margin does not differ much from that of the firewing.except that the scollngis take the firm of lunate spots : uphn the anal angle, these synt have blue discs. BЕхелтн, there is much greater complexity as well as beauty of culuring. The principal and rharacteristic ornaments are the eyes on the apied angle of the furewings, and two large eyes surrounded with hack upon the

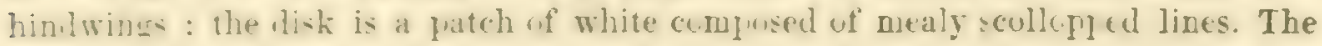
margin below resembles that abore.

The caterfillar is said l, $\mathrm{D}_{\mathrm{KL}} \mathrm{RY}$ to be green, with black rings around the budy, and feeds on balsam or lady's-jewels. 
Limenitis ARthemis. Nymphalis arthemis (Drury). (Plate xliii, figs. 2-9.)

Wings black, marked hy a broad white band common to both pair, reaching vers nearly to the margins : apical portion marked with three white spots, to which a fourth is sometimes added. Beneath, the basal portion is black, perhaps greenish, and ornamented with a cluster of brown spots and bluish green bars situated near the base : at the apex there are three white spots. Posterior wings beneath are marked with six or seven brown spots outside of the white band : margin trimmed with white, black and blue. The last-mentioned spots are in two parallel lines, and bear the form somewhat of lunules.

The anterior pair of feet are white before : abdomen black, and the renter has a jellow stripe on the specimen before me.

This species seems to have a wide range; being found as far north as Lake Winnepec, and south into Virginia.

\section{ARGYNNIS APHRODITE.}

Stipe of the antennæ long, buff-brown; knob black. Head and body buff, with black upon the thorax and upper side of the abdomen. Color of the wings bright buff-yellow or fulvous : forewings spotted and banded with black, and both pair darker at base as well as hairy. In front there are six or seven black subcostal bands : the four from the hase are connected with a zigzag band which extends across the wing; or they may be regarded as a connected series of lunules, having in frunt of their concarities a row of six round black spots, beyond which is a regular row of seven lunules smaller than the former : margin trimmed and edged with two black lines, which are dilated where they cross a nervure. Hindwings marked with distant rows of lunules, between which there is a row of roundish spots : they are trimmed and edged like the forewings. BENEATH paler, and the subcostal bands are more distinct : there is a double row of lunules, with three spots between. At the apex, the black spots and lunules of the upper sides are replaced by silvery ones. Hindwings, base deeper colored than the wide margins, and oruamented with three parallel rows of bright silvery spots, and several more which cluster at the base : among the rows, there are small silvery spots scattered about without order : margin trimmed with a plain brown band edged with black. The silvery spots are surrounded with a black ring wholly or in part; and there is a straight line also on the forewings, between the third and fourth subcostal bands. Expanse of wing, 23 inches.

This species si very common in the western part of Massachusetts and Eastern NewYork. 
Akgtris inearta.

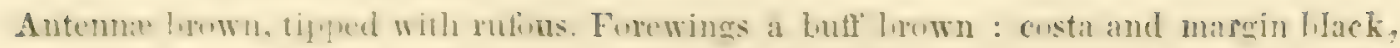
marked by fire subcostal bands, besides the straight band which furms a delta with the fourth : apex black, marked with four white elongated subcostal spots : disk marked by a row of tive romed spots, hesile's which there are two lumules in reversed position with respect to each other, and two rather quadrangnlar sputs; the outer marein is trimmel with hack, hearing a row of eight or nine white spots. Hindwings dark or very dark hrown, hut lighter at the hase, and marked with two rows of large

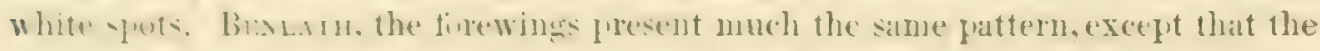
white border spots are more distinctly in the form of short arrowheads bordered with black. Hindwings very unifornly dark brown, and spotted with large white spots: there are three parallel rows, and the basal cluster might be called a fourth; the slunhich have alon a white strige rumuing along the edge of the wing. Exyme of wing, four inches.

This species is far less common in the vicinity of Albany than the aphrodite.

Melite phaton.

(Plate xliii, figs. 4, 7.)

Stipe of the antemat lingud with hack and white: knoh, hase fulvens. middle liack, tip gray : palpi, eyes and feet rufous. Head black, with a ring of white around the eyes, and a row of white spots passing around the head just behind the antennæ. Thorax and upper side of the abdomen black, with a few white dots along the top, and two rows along the sides. Beneath the abdomen is marked wilh a rufous red series of largish spots on each side, and the venter with a row of jellowish white spots. UPPER SIDE : Wings black : outer margins ornamented with four rows of spots; the outer row rufous, resting on the nervures, and divided; the three inner, yellowish white; the innermost row short : beyond the rows there are two or three dashes of red, parallel with the costa. Hind-marked like the forcwings, except the short row of spots is wanting. BЕхЕАтH, the surface of both pairs is marked with four rows of yellow spots between two of brown, except the inner brown row of the

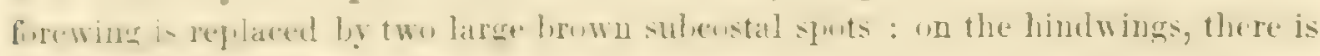
a cluster of brown and yellow spots at the base. It should be noted that the yellow

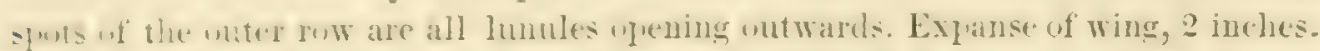
This reason (14,0) this hutterty is yuite common, while in former years it was scarce.

\section{Melttea pharos.}

(Plate xliii, figs. 5 \& 6.)

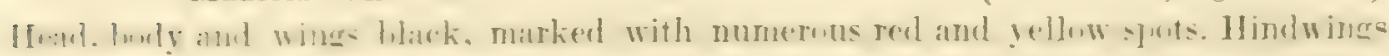
marked with six orange-colured spots extending across the wing, the concavities turned towards the base of the wing. Outside of these spots, there is a row of six 
ocellate spots with black centres : these ocelli stand hetreen the nerrures. Jear the base there is a lunule, with a round spot in its concavity. Underside reddish claycolored, mottled and clouded. Forewing the red is deeper, and the outer angle or apex has a dark triangular space dotted with red : outer margin clouded with reddish of different hues. Spread of wing, about one and a half inches.

This beautiful species is less common here than the preceding.

\section{Il ipparehiides.}

\section{HIPPARCHIIDES (WESTKOOD). SATTRIDES (BOISDEVAL).}

Tre palyi of this sulfanily are three-jointed and elongated, and their antenne thickened very inalually at the tips. The insects are not rulust. hut rather feeble in flight. Their colors thengh frequently beantiful, belong rather to the neutral tints : they are brown and relluw, with ucelli for ornaments. The larre feed upon the grasses during the night seasin : their bodies are widest in the middle : some of them undergo their trausfurmations in the earth, and others suspend themselves by their tails.

Hipparchia ALOPE.

(Plate xxxiii, figs. 5, 6.)

Brown; paler leneath. Antenne slender and arcuate : knoh a mere dilatation of the upper end; stipe annulated with white. UPPER sIDE: Forewings marked with a browl lutens hand, or rather oblong spot placed upon the outer hall of the wing, and ornanented with two erelets with a black iris and bluish pupil. Hindwings more distinctly crenate than the firewings, and marked towards the posterior margin with a single small eyelet with a black iris and blue pupil. BEnEAtH, the ejelets are ruther more distinct than above. Wings harred transrersely by darker lines : posterior are marked by six small eyelets arranged in two lines, three in each; the largest in the middle, and each surrounded with a perfect brown ring wutside of the black iris. The margins of the wings are traversed by black and brown lines running parallel with the edge, which is densely ciliate. Legs ashen. Common.

Hipparchia nephele. Clouded Hipparchio. (Plate xxxiii, figs. 3, 4.) Culor brown above and beneath, but paler heneath. Antennæ annulated with white; knob slender. UPPER sIDE is marked with an obsolete but broad submarginal band, in which there are two eyelets with a clouded white or bluish white puril, and a black iris with a rert indistinct brown ring. The posterior wings are crenate, and marked with a minute or obsolete black spot. UNDER siDE, the belt of the anterior wings is much more distinct, the eyelets bright, and the outer ring of brown plain : margin of the wing traversed with two or three lines parallel to the edge. Outer half of the hindwing laler, and marked with six small eyelets, which form three rows, the largest 
erelet being in the middle : the anal angles divaricate, learing a wide triangular space.

This species wats tirst described, I believe, by the Rev. Mr. lingy in the Funna Borcali Americana.

\section{Lycænidae.}

LYCAXIDE (LEACR), POLYOMMATIDA (STAINSON).

Tue insects of this family are small and weak, but finely and delicately colened and

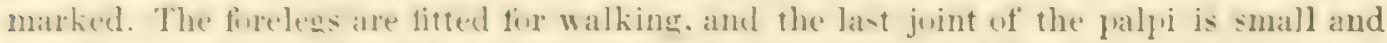
maked. The cattrpillar has a mall head nearly concealed under the tirst ring, and secures itself: when alwut to undergo transformation. by the hindfeet and a lowe about the budy. The chrysalis is flat on the underside; its ends are round: the imago six-tinted. Social, and often collected into groups upon sweet-scented flowers.

THECLA ACIS.

(Plate xliii, figs. 2, 3.)

Polmomates (Latreille \& Godart). Papilio acrs (Drury). P. ixion (Fabricius).

Supering wings immaculate and dark brown above, paler heneath : josterior, bicaudate; the two inner the longest, and immediately above are two red spots, and two more upun the anal angle. [xime side, the wings are lead-colored, crossed by a narrow white and hlack line running parallel to the external edges; the posterior are crossed ly an indented irregular line : the four long reddish spots stand abore four black ones.

\section{Thecla homol ( Harris).}

Anterin or prinary wings dusky hrown on their uper sides, tinted with bluish gras; and, in the males, they are also marked with an oval spot on the front edge. The fustrinor wings are slenlerly tailed, but, unlike those of the acis, they are tipped with white: and the margin posteriorly is also marked by a row of pale blue spots, among which is a crescent of urange marked in the centre with a black dot. It is a little lingrer alor than the acis; expanding about an inch and a tenth, while the acis is only about an inch.

In its caterpillar state, the T. humuli feeds upon the heads of the hop, as is inplied by it: - Irecitic name : its culur is green, and its skin is downy. Described by Harris in his work on insects injurious to regetation, p. 235, 2d edition. 


\section{Hesperiidae.}

\section{SKIPPERS.}

HEAD larue, with large and prominent eyes : hodies short and thick; feelers short. hairy, and ends square or angular. Autenne short and distant frrm each cther. ending in a kmol prolonged and bent into a hook, and pointed. Legs six, and the four hindshanks furnished with two pairs of spurs.

LARva : Head large : budy tapering frum a crlindric middle, spineless, and generally naked. Solitary, concealed within a rolled leaf; their transformations taking place in envelopes of leares and fragments of straws bound trgether by a few silken threads. Chrrsalids taper from one end, and are rounded : they make imperfect cocoons, which are formed of rolled leaves and threads.

\section{Eudayus tityres. Tityrus Skipper.}

(Plate xxxriii, figs. 4, 5.)

Antennx brown : eyes brown, with a white spot beneath. CPPEn side: Head, body and wings brown, lighter at base. The middle is crossed with a wide yellow band, narrowing towards the posterior angle : between it and the apex there are two yellow dots or spots. Hindwings tailed, rounded upon their anal angle : beneath they are marked by a large oval and central white spot; the edges trimmed with yellow or

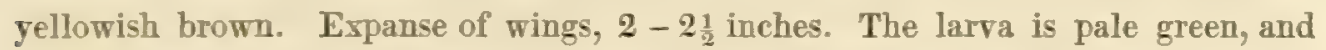
striped transceriely with darker green and dotted : head and neck red and tuberculated (fig. e); fig. $f$, pupa.

The tityrus inhabits the locust-tree, making its habitation of the leares drawn and kept together br threads of silk, which serre also for its transformation : it feeds on the leares, and sometimes nearly strips the tree of foliage.

This seasin (1853), which has furnished many other rare insects, this skipper has not been common.

\section{Pamphila phylors.}

UPPER side : Thorax and abdomen rellowish olire. Superior wings tawn yellow, margined with a black toothed border : three dark brown spots trarerse the wing, the outer corner one coalescing with the border. Inferior wings yellow, subangulated : margin with a dark brown border, sharply indented : anal angle truncate. BExEATH, the wing: are paler, marked with brown somewhat triangular and lined spots : one elongated spot near the shoulders. Expansion of wing, $1 \frac{1}{2}$ inches. The caterpillar feeds upon the panic and buffalo grasses.

This is a rery common butterfly in Western Massachusetts, in August, in meadows. 
Chrisophanes phleas. Copper Bulterfly.

(Plate xlvi, tig. 4.)

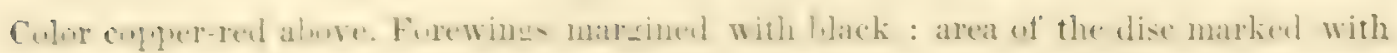
six or seven oblong black sputs. Hindwings, disc and base dusky black : posterior

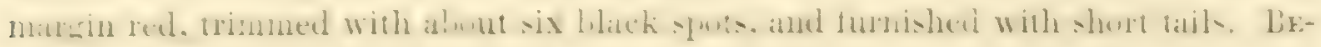
NEste : Forewings, the dise is orange or cupreous orange, spotted with black, and

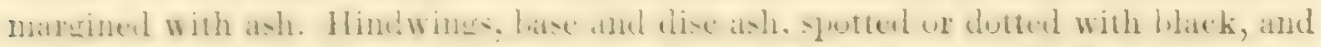
bordered with faint copper-red.

Common at midsummer in the ricinity of Albany and Testern Massachusetts.

Hesperia peckios (Kirby). Pech's Hesperia. (Plate xxxii, fig. 8.)

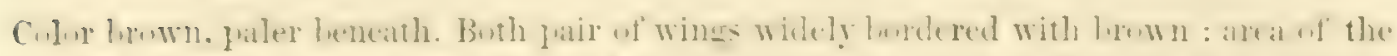

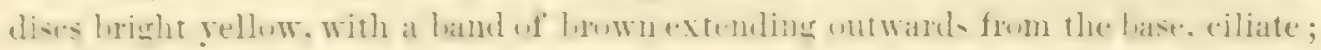
ciliæ fuscous. Bexestr, the area of the discs is occupied with yellow patches, irrexular in form: that unun the hindwing is uskally double. The lunly in chothed with Iong yellowish brown hairs, especially upon the breast.

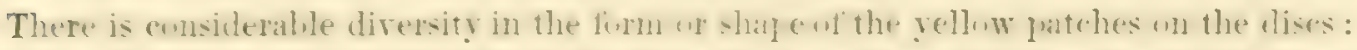

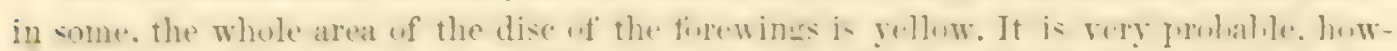
erer. that this may prore a speries distinet from the prlines. The latter is common in fields in Western Nassachusetts and Eastern New-York, in July.

\section{Splingidae.}

\section{HAWKMOTHS.}

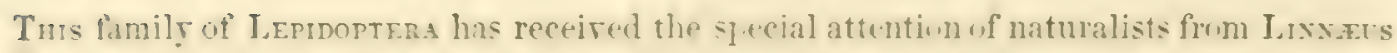

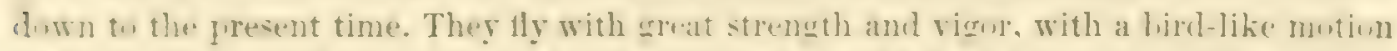

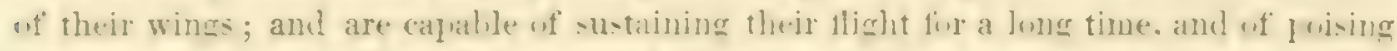

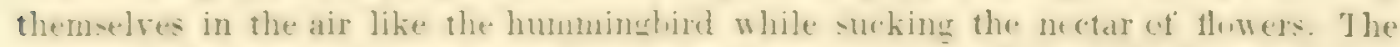

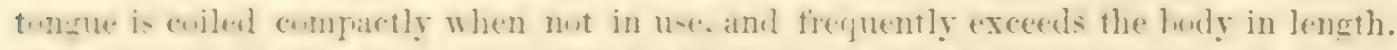
The antennar are prisultir. freventing in a cross section the sf sment of a circle con one side. while others are firmed hy two curred lines meeting in such a was as to make an eilge on the oppoite sibe : it often terminates in a feather-like tuft. The labial ralpi are hroad and compresed: lut the labrum and mandibles are rudimentary, as they are not required for taking food.

The larre are naterl. eylindrical, and snrylied with -ixteren fect and ordinarily a horn

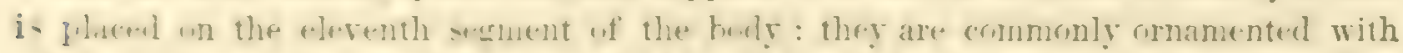
whilice stripes on the sides. They usually descend into the earth when their transtormation 
is ahout to take place. The pupa too will be found naked, and somutimes an appendage exists in the firm of a bent hrok, like the handle of a pitcher : this is a distinct case, and contains the tonewe. Where this organ is short, the appendage is alsent. The wings are gencrally corered with scales; but in some cases they ure transparent, as in the Sisia, from the absence of scales.

Many of the larva, when not engaged in feeding, fix themselves lis the hindlegs, and, elevating their budies at a considerahle angle, remain stilly fixed in that position for hours: in colur and pusition, they then resemble a broken twig of the bush unon which they have been feeding (See Plate xxxvi, fig. $a$ ).

The humminghird moths, or sphinges, fly in the early morning, or in the dusk of the erening, when they visit the garden or the wild flowers of hedges, flitting rapidly from one blussom to another, and poising themselves with the utmost ease by the rapid motion of their wings, which are long and pointed, but of unequal expranse, the forewing being the longest. Their bodies are thick and robust, and frequently pointed behind; or else they terminate in a fan-like tail, as in the SEsI.

There is a diversity in habit in this family, as in all others: while some fly swift, others are sluw and sluggish in their llight; and while some prefer the twilight of the morning or erening, whers take the wing only during the day. The Smerinthers has a slow heary tlight, and 1lies only in the night; and it is dubtful whether it takes ford in the imago state, as its tongue is two short to be useful for that purpose. When at rest, the wings are horizontal or a little inclined; and the posterior have an apraratus cousisting of a setiform prucess at its base, which passes through a hook to the anterior, for the purpose of regulating the extent of their motion.

This family contains but few genera, which may be indicated by observing the following characters :

1. Syrrinturs : Wings more or less angulated; flight heary: tongue tery short : antennæ in the males biciliate beneath.

2. SpHinx : Tongue long : wings entire, acute : labial palpi robust : antenna not elavate.

3. Deilephila : Antenna clavate.

4. SesiA : Wings partially elear and transparent : abdomen terminates in a short flat brush.

5. Peilampilus : Wings subfalcate; inner margin sinuous.

6. Chezocaupa : Antennæ short, areuated, terminating in a long slender hook : margins of the wings sinuate; hind-angle angulated.

7. Ceratocimpa : Antenna in the males with distinet joints, doubly bipectinated : wings entire. Larva with horns upon the shoulders. 
Sphrsx moontes (Drury).

(Plate xl, nig. 1.)

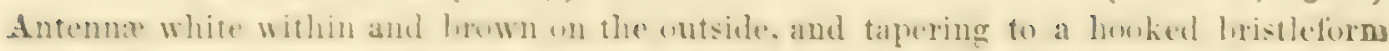
point. LPPER side, fuscons and clouded, but traversed transrersely by two or three sets of black crinkled lines, the outer one forked at the outer angle of the anterior wing, having the shape of the letter $\mathrm{U}$ : disc of the wing dirty yellow, and marked with a white spot. Pusterior wings, outer half brown; base gray : the brown part is

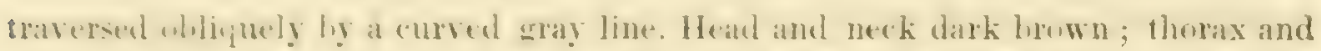
aluhomen gray : the rims marked on ench side of the median line hy narow hack bars. UxDER sIDE : Breast white; abdomen white, marked by four reddish spots

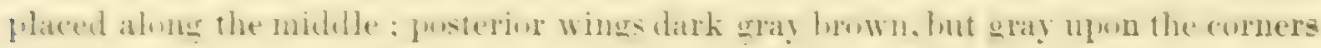
and abduminal edges; ciliæ white and brown (DRURx, Plate xxix, fig. 4).

SpHisi octomacolatus.

( Plate xxxviii, fig. 2.)

Color hlack. Forewings marked with two ohlong yellow spots: hindwings with white sputs : thurax has also yellow spots. Rings on the upleer side of the aldumen white; extremity black.

This insect makes its appearance rery early, and feeds ujun the tender leaves of the grape-rine : its larva goes into the ground, where its transformations are cumpleted.

Sphisx carolines.

(Plate xlii, fig. 10.)

Color gray, gravish hruwn. Forewings marked with narrow zigzag hands, and with white sluts. one at the hase, and a small central one : hindwings banded. Abdomen marked with two mows of orange-yellow spots, five in each row. Expanse of wing from three to four inches.

Sphinx contolvuli. Potato Harkmoth.

This arecies has eight transrerse bands upon the aldumen : the $q r u m$ d-culur is reddish. Its pusterior wings are marked with oblique black bands. The larra leeds upon the sweet-potato vine.

Spuinx chonanthi. Fringetree Moth.

This moth has three yellowish round spots on each side of the ahdomen. The larra is greenish yellow, and is marked whliquely with black and yellow on the sides.

SpHIsx vitis. Vine Hawkmoth.

Wings narrinet with red, and marked with yellow stripes : two interrupted stripes on the back, and several transverse on the abdomen. 
SpHinx - ?

(Plate xlv, fig. 9.)

Foretrings sulufilcate, and sinuate upon the anal margin. Color of body and wings buff of various shades. Antennæ strongly and doubly pectinated. Forewings banded; inner margin maxked with a quadrate brown spot. Beneath banded : middle of the hindwing marked transversely with a light ferruginous band.

This species I obtained at Williamstown (Massachusetts). It is closely allicd to the Philampelus in the form of the forewing : the abdumen, however, is terminated by a short brush as represented in the ligure. I have been unable to refer it to a described sfecies.

Sphinx cinerea.

Wings greatly elungated and narrow. Color gray, and the forewings dashed with black lines: there is a black spot at the base. Hindwings gray, and banded with black; the bands are broad, transverse, and towards the outer margin. Margin of the abdomen marked with alternate bands of black and white : abdomen more pointed than in the 5-maculatus. Back gray, without spots, but marked with a longitudinal line along the middle.

\section{SPHINX QUINQUEMaculatus.}

Forewings gray : area of the disc darker than the margin. Hindwings gray, and marked with four black zigzag lines, the outer broadest; the next is a zigzag line : the basal is scarcely more than a spot. Abdomen broad at the base, upon which there are black and white bands : margins ornamented with four or five yellow spots, alternating with black bands and square spots. Expanse of wing, $3-3 \frac{1}{2}$ inches.

The pupa-case is brown, and furnished with a long curved handle which encloses the tongue. This is the common potato-moth, the larva of which descends into the earth to transform, where it forms a rounded smooth chamber with its sides. The larva is green, and marked with oblique whitish stripes upon the body : it is also furnished with a horn placed posteriorly.

Philampelus satellitia.

(Plate xlv, fig. 5.)

Color ahove light, and marked with spots of dark olive. Head light olive, with two spots of light olive on the front of the thorax; below which is a large angular spot of dark olive, which extends to the base of the forewing, and forms an abbreviated kand. Back of the thorax there is a transverse band, which connects itself with a dark hairy olive spot upon the hase of the hindwings. The hasal half of the margin of the forewings light olive, clouded, and extending itself to near the posterior margin, where it meets a darker submarginal band, the latter extending to the apex, and landed 
inwardly ly wavy lines of olive and dlesh-color : outer half olive, bot narked with transterse ahbreviated lines of darker. Apical area has a patch of flesh-color, but branched so as tw include a costal spot of olive : posterior margin olive, and the olive

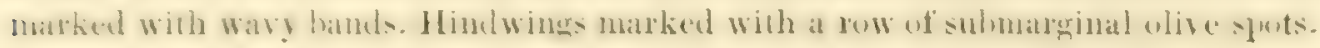
The conspicuous dark olive spot near the body has been noticed : there are also al-

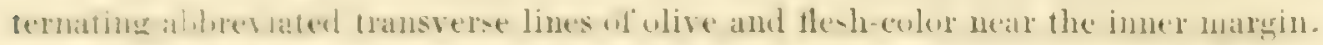

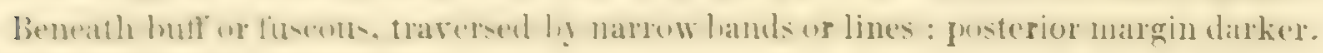
Expanse of wing about four inches.

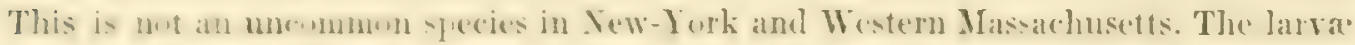

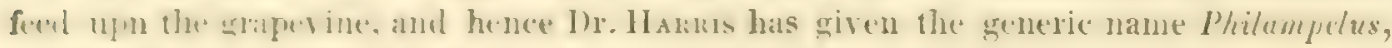
'I love the vine.' They also feed upon the Ampelopsis.

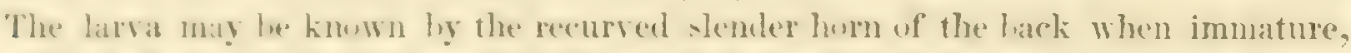

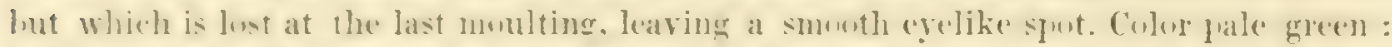

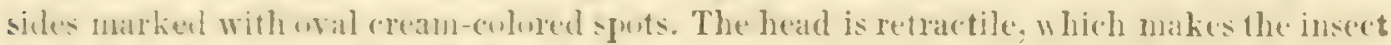
appear shortened and blunt before.

When mature, the insects are thee inches in length : they are great feeders, and, wheu in numbers, injure vines in proportion to the leaves consumed.

\section{Philampels — (Harris). Sphinx pampinatrix? (Plate xliv, fig. 2.)}

Color ulive. Heral olive, from which fucceds divaricating hands along the angles of the thorax, lighter between the forks. Antennæ light buff. Forewings banded : at the base olive, marked with a costal spot of flesh-color : middle band broad and fleshcolor, with a dot of olive : external band olive, wide, subbanded or marked with a stripe of flesh; edge brownish. Hindwings flesh-colored, with an olive spot or imperfect band upon the anal angle. BENEATH, buff : basal part of the forewings

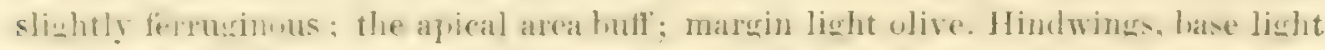
buff; onter half darker buff, marked with a wavy line parallel to the edge; edge

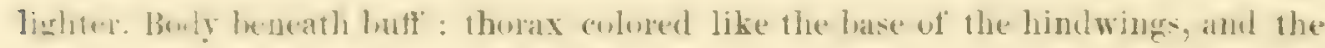
abdomen like the outer half, without spots.

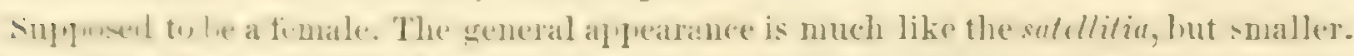

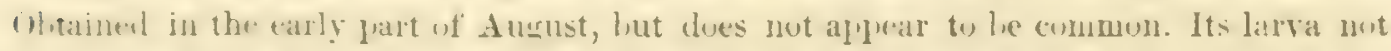
observed. Expanse of wing, $2 \frac{1}{4}$ inches.

\section{Gexts SMERIITII'S.}

Wings angulated, entire. Autenna hieiliated in the wales. 
Smarinteus (Latreille). Sphinx astylus (Drury).

Head, thorax and abdomen rusty gray-brown. Wings cinnamon-brown : anterior, ornamented upon their outer margin by three curved yellowish stripes, situated between brown stripes; margin brown : posterior wings reddish ol cinnamon at the bases, and marked centrally by a round black spot, the centre of which is yellow. This spot is placed upon an oblique yellowish belt ruming from the base to the lower and outer angle of the wing. UNDER sIDE : Breast, abdomen and wings cinnamon-brown, and marked as upon the upper side; legs black : black spots absent. Expanse of wing, $2 \frac{1}{2}$ inches.

\section{Genus SESIA.}

In this genus of the sphinges, the antennx are gradually thickened towards their ends, and terminate in a minute feathered style.

\section{Sesia pelasgus (Cramer).}

(Plate xxxii, fig. 9.)

Color brown, with all the wings transparent in the middle, terminated with a plain brown border. Antennæ brown, if viewed from their tips towards their base; steel-blue or blue-black, if viewed from their base towards their tips : breast and underside of the palpi cream-white : legs and tarsi brownish. A воve, the thoras is clothed with olive-colored hairs. Base of the hindwings purplish brown : two first segments or rings of the abdomen light purple-brown; third and fourth, deep purple-brown; fifth and sixth, purplish upon the top, lighter upon the sides terminating in tufts, purplish brown in the middle and black outside : the fifth and sixth segments have one side or patch of yellowish hairs. BENEATH, abdomen brown.

Sesia fuciformis? (Abbot \& Smith).

(Plate xxxii, fig. 10.)

Wings with large transparent dises, trimmed upon the margins with dusky brown or nearly black, with apical area rusty red. Antennæ black above, brown below. Thorax and breast with the palpi clothed with pale yellow hairs, and marked by a black stripe running from the insertion of the forelegs through the eyes. Four first segments of the abdomen black, with steel-blue reflections where the scales are thin; sixth and seventh clothed laterally with a patch of yellowish hairs : the terminal tufts are mostly black, with brownish yellow hairs upon the middle. Expands two inches.

Less common here than the foregoing. 


\section{Aegeridae.}

(See Plate xxri, figs. 1, 3.)

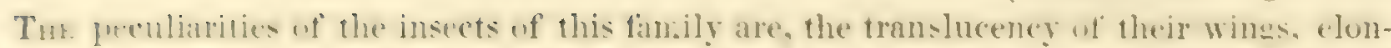

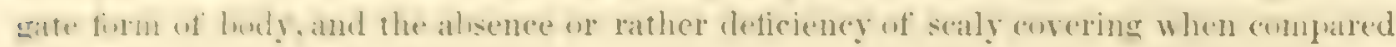
with the SpHisgids. They bear some resemblance to the Hrmkxoptera : their antennæ are simple and when terminated hy a small freneil of hairs. The insects are interesting, tren the fact that they are highly injurions to trees especially fruit trees. They ale fles hy grub of a el lindrical shape ( fig. 4). with brown heads and strong jaws; but unlike many of the larva of this order of insects, they have no caudal horn. They have the ordinary true six legs, eight ventral feet, and two feet at the extremity of the abdomen.

The different glecies feed umon different kinds of trees; some upon the currant, moun-

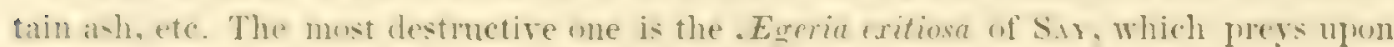
the prach-tre. The earg is deposited urn n the bark near the rent, and, when hatched, the goung penetrattes to the wixul, when it either continues its course intu the woul, or burrows between the woul and hark : usnally, however, it proceeds into the soft wood, sometimes just helow the surlace of the soil, at wher times above. In either case, such is the extent of the injury inflicted, if allowed to maintain pussession, that the tree is killed. Probahly the peach-tres in this country have suffered more from the Egeriu, than from all wher insects put together.

\section{Egeria Exitiosa.}

(Plate xxvi, figs. 1-5.)

Fig. 5, feruale; 1 , male; 4, larva ; $2 \& 3$, cocoon and pupa.

Colur steel-hue. Wings of the wale transparent, and bordered behind with steel-hlue: palpi, feelers, edges of the collar, and shoulders yellow; smaller than the female. Female, steel-blue : wings steel blue; hindwings transparent : middle of the abdomen marked with an orange-colored ring or belt. Expanse of wing, $1 \frac{1}{\mathrm{z}} \mathrm{inch}$.

Mr. Hinkis remarks that the aegeria does mot confine its attacks to the peach-tree, hut may be fiund alsu on the cherry. its larva heing developed in the black knotty luanches of the tree. It dees unt always lincate itself at the hase of the trunk of the peach-tree, but frengently lures into the limbs, in which case much less injury is douse to the whele tree. The interstent tree maty le discovered ly the presence of the dust and cuttings which the

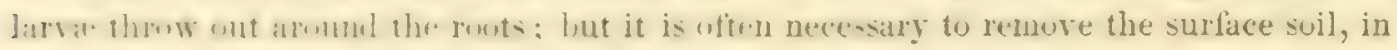
order to detect their presence.

The mule that is most successully pursued for extiryating these insects, is to cut them

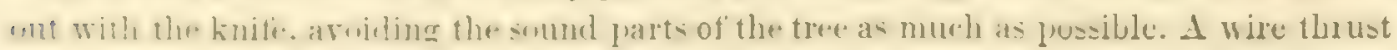
into the burrows may destroy the larvæ, without cutting the tree. 
The cocoon is constructed partly out of the castings of the larre, which, hy means of gum and silk, is formed into a common oral shell surrounding the pupa : these may he destroyed at once.

To protect a tree, Dr. ILARris long ago recommended the use of sheathing fraper, secured by strings and matting to the neck of the tree after removing the earth. This paper should he cut in strips eirht or nine inches wide, and fixed below the soil by means of mortar and fresh luam. The application recunires renewal every spring; but whatever means may be adopted, ('areful examination during the months of June and July should not be neglected. Wounds that may be made in the remoral of liring hark and wood, should be covered with grafting wax, or something to protect the surface from water.

The currant-bush is injured by the Egeria tipuliformis, which is not a native of this country, but is of European origin. The eggs are laid near the buds, and, when hatched, the larse penetrate the bark and wood, and eren into the pith : the stems become brittle; but, before this, they show marks of disease by yielding an inferior fruit.

Dr. Harris describes another insect allied to the EGERIA, the Trochilium denudatum (HARRIS) : the color is brown; the edges of the collar and of the abdominal rings, the shins, the feet, and the underside of the antenna are yellowish; the forewings opake, and the hindwings transparent. It attacks the ash : this tree, especially the english mountain ash, when planted for ornamental purposes, seems to be quite as liable to the attacks of these borers, as the peach; and Lence it requires the same attention and treatment.

\section{Glaucopis pholus.}

(Plate xl, fig. 3.)

Gladcopis (Fabricius). Sphinx pholds (Drury).

Antennæ hlack, and thickest in the middle. Upper side black : hasal half of the wings orange. Beneath the color is paler, but after the same pattern.

The larva feeds on lichens growing upon stones, and hence is more common in bleak stony places. 


\title{
CMAPrin XXII.
}

\section{ORDER XI. LEPIDOPTERA (Continued).}

\author{
BOMBVIDES.
}

PHALANE (LrNaEs). MOTHS.

Tur: antenna of moths, as has already heen olserved, talyers from the base to the apex : it may he simple, or plumed like a feather; but the organ differs much arcording to sex, the prectinated antemna heing more strongly narked in the males, who are also provilud with a sucking tule which takes the flace of at tongme. and is rolled up very complatety, leing sometimes rery long, in ther cases very short. The palpi orow fom the uprer lip, curve upwards, and cover the face, the tongue being coiled up between them.

The larre of the moths ditler much among themselves. 'The number of lege is usually sixteen, hut sume have only ten, aud sone are ohscure and incomplete. They differ tor as to their clothing, sume heing rely hairy, others nearly or quite destitute of hairs; some are smouth, others warty or spinous : some go into the earth to transform, others remain above ground.

In treating this division of the Lepinoptera, I shall fillow very nearly the arrangement of Dr. Harkis. By Lrwares, the moths or spinners were divided into eight groups, viz: 1,. Ittaci ; 2, Bombyces ; 3, . Voctua ; 4, Geometra ; 5, Tortrices ; 6, Pyralides ; 7, Tinea ; 8, Alucite.

\section{Lithosiidae.}

TuE moths of this family have slender boties, are never rery large, and their wings when at rest lie llat upon their bodies. The antennes are hristlefirm and rather long, and but slightly feathered in some of the genera; in others. in the males, there is a doulle row of short hairs on the under side. The tongue is distinct. but only moderately long. The lack is not wislly, and the thorax is not crested. The wings are often beautifully spotted or 
speckled upon a white or yellow ground. The larvæ dwell in stony places, and many of them feed upon the lichens that grow on the stones : some feed upon grass.

Deropera bella. Beautiful Deiopeia.

(Plate xlvi, fig. 5.)

Culor of the forewings yellow, traversed by five or six white bands : hands dotted in row with black. Posterior wings scarlet, though pale, and bordered irregularly with dusky black or dark brown. Body white : thorax spotted with black. Expanse of wing, nearly 2 inches, or $1_{4}^{3}$ inch.

It is found in Albany county in midsummer.;

\section{Arctiidae.}

THE feelers and tongue mostly short and thick. Antennæ doubly feathered : feathering narrow on the inner or upper side, and less distinct in females. Wings inclined : thorax thick. Both the caterpillars and moths hairy or downy, especially the thorax and head of the moths. They are more or less white, and ornamented with black or dark-colored spots upon a white or buff-colored ground. They are nocturnal, or fly only by night.

The caterpillars move rapidly, and are covered with hairs that spread out in tufts from warts. They make, in clefts of rocks and sheltered places, rough cocoons of the hair of their own bodies, interwoven with some fibres of silk. The chrysalis is smooth, and its joints movable.

Spilosoma ACras. Saltmarsh Caterpillar.

(Plate xli, figs. 2 - 5.)

Spilosoma (Stephens)。 Phaldena (Bombyx) acrea (Drury)。 Bombyx acria (Fabricius). Arctia psedierminea (Peck).

MaLe, upper side : Head and thorax white on the upper side; lower side yellow huff, embracing the wings, abdomen and thorax. Forewings cream-colored, marked and margined with many black spots : hindwings buff, and marked with six somewhat angular spots; the lower side is deeper colored. Antennæ and eyes black.

MaLe, lower side, buff-colored. Forewings margined with five or six elongate black spots, the posterior margin dotted with black : the other black spots upon the dise show through the wing, and appear to belong to the upper side. Hindwings marked with seven or eight spots somewhat lunate in form; one of which is quite prominently so, near the middle and outer margin of the wing, but stands in reverse position to one upon the margin. Abdomen of a buff upon the upper and inferior sides; the sides being marked with a white line, which also extends to the tip of the abdomen : upper side ornamented with a row of black spots, and two rows that stand upon the margin of the white lateral line, and another line upon the lower and central part or face of the abdomen.

[Agricultural Report - Vor. v.] 
Femile : Head, thomx, wings, and lower ahdomen white or faint cream-color : apper fart of the ahdonen. and lower part of the thorax exceft extrenity, huff. Wings spotted with bak : hindwings prominently marked with al hack lunate spot near the centre. Abdomen marked with black spots as in the male.

The eaterpillars appear in the salt marshes in the vicinity of Boston, according to Mr. Harkss. fwiards the end of June, and glow rapidly till the first of August, when they attain their size, which is about 13 inch long, and clothed with hairs. They then retreat to the Iblands, in order to undergo their transfimation : for this end, they seck a sheltered

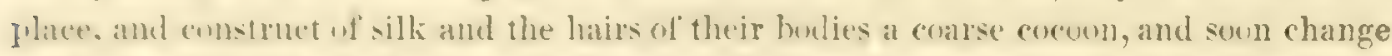
to a chryalid: in which state, in the latitule of bustem, they contime until the next year, when they are translinned inter moths. The caterpillar is clothed with long tufts of hairs, which grow fiom warts, either brown or black, or of various shades of liown : the skin is yelluw, though sharled at the sides with black; the back is also marlied with a blackish line*.

This insect not only inhahits the coast or saltmarshes, hut is found abundantly inland in Berkihire county, and in Alhany and vicinity. It is destructive of the grass of saltmealuss; and when it retreats firum them to undergo its transformation, it devours the more valuahle vegetalules, as corn, beans, and garden plants. The remedy proposed hy Mr. Hanms is to nuw the marshes early, while the caterpillar is inmature : it is thereby destrojed.

Spilosoma ARge.

(Plate xli, fig. 3.)

Antenne dunhly pectinated : teeth short on the upper side. Color at the base whitish, or cream-colored; extremities dark brown.

Моти : Cрper side crean-colured, somew hat variable in its shades. Cullar marked by two black lines; upper side of the thorax by three black lines, widely separated. Anterior wines cream-colured, and marked with many triangular spots : the inner margin has a wide line ruming parallel with it ; the other sprots are suall acute triangle's : margin heneath pale fuscous. Posterior wings narked mostly on the posterior margin by four black spots, sometimes only dusky. Posteriur margins of beth $\mathrm{l}$ air ciliated ; and just within this border there is a fuscous or reddish line. Inferior surface dusky creamcolored, and marked like the superior, except that the anterior margin of the anterior wings is bordered with fuscous. Neck corered with vermilion red hairs; throat black. The cream-colored abdomen is ornamented with five rows of black spots; two upon the sictes, and one upon the centre of the back. Femora red anteriorly : joints and tilik black in front ; tarsi black. Expansion of wing, nearly two inches, but variable.

- Barrs : Insects injurious to vegetation, p. 269, 2 d edition. See also 7 vol. Mass. Agr. Rep. \& Jour. 1828. 
The flight and habits of this moth are much the same as those of the $S$. acraa, which it also rescmhles in figure, hut is smaller. The caterpillar is brown, with five pale longitudinal lines, and covered with long hairs growing from fulvous tubercles : it feeds upon plantain, leaves of indian corn, peas, etc., and is frequently quite injurious.

The moth aprears in the vicinity of Albany, and in Western Massachusetts, in June; perhaps earlier. While they are said to be occasionally injurious to corn in the Southern States, the insect is too rare here to give rise to much apprehension.

Euchetes EGLE.

(Plate xli, fig. 11.)

Phal ena eqle (Drury), Spilosoma egle (Westwood), Euchetes" (Harris).

Antennæ slightly pectinated. Head, thorax, underside of the body, and legs gray. Wings thin, blisish gray, paler on the front edge, immature. Neck cream-colored : top of the abdomen indian yellow, and marked with three rows of black spots, one on the top and two on the sides, each row consisting of about seven spots. UNDER SIDE : Tongue spiral, a little longer than the head : abdomen pale yellow : wings gray; margins entire.

Caterpillar : Head, body and legs black, and marked with a light-colored line on each side, hairy; hairs grow in short tufts from warts. The first and second rings support four long pencils or tufts, which bend orer the head.

The caterpillars feed upon the milkweed (Asclcpias syriaca), and may be regarded as harmless : they are sncial, and, when feeding, their heads are turned to the edge of the leaf.

Callimorpha firguncula (Kirby).

(Plate xlvii, fig. 5.)

Color black. Ifead and thorax striped with black and orange. Forewings, ramifications of the nervures orange : hindwings orange marked with black, roundish. Abdomen orange above, marked along the middle with triangular black sputs : beneath paler. Lateral portions of the abdominal rings nuarked by a couble row of angular spots placed close together : renter pale orange. Expansion of wing, $1 \frac{1}{2}$ inch.

This is a common species in the vicinity of Albany : found in meadows in August.

Figured in Richardson's Fauna Borcali Americuna.

Callimotraha parthenice.

(Plate xlvii, fig. 6.)

Body beneath black. Head and thorax pale orange, marked with five oblong spots, two before and three behind. Forewings black and orange : the orange follows mostly the nerves, but transverse bands are sent off so as to form many triangular spots. Hindwings red, marled with large black patches surrounded hy narrow luteous rings; beneath paler and more dusky. Beneath, the rings of the abdomen are black, and the

- Evoндтrs, meanigg fine flowing mane; a nane applicable to caterpillars. 
extremity pale and pointed. On the top there is a row of triangular spots, the apices of which point towards the thorax. Expanse of wing, $2 \frac{1}{4}-2 \frac{1}{2}$ inches.

The markins of the forewings are quite similar to those of the virguncula found in the vicinity of Albany.

Calimorpha eptrenss. Phalona epimenis (Drury). (Plate xliii, fig. 10.)

T Prer sune, hlack. "Anterior wings ornamented with a single large rellow spot just outsile the milllle of the wings. Posterior wing ornamented with a large single red spot, whuse whter margin is nearly paralle] with the posterior margin of the wing. Cxure sine, black, and similar to the upper, except two additional straw-colured sputs between the large ones and shoulders." Druny, Vol. iii, p. 40 ; pl. 29, f. 3.

\section{Callimorpha fhyllira (Latreille). \\ (Plate xliii, fig. 8.) \\ Phalexa phylura \& boniby (Drury). Hypercampa (Stephens).}

I'PPER sine: Interior wings hack. Cilize cream-colored. The margin next to the body marked with cream-color : the outer half is marked with a $B$. The posterior wings are scarlet, marked with fuur angnlar spots, and margined with black. The under side is like the upper, but with fainter colors.

The caterpillar is marked with small diamond-shaped yellow spots unon its hack and sides, emitting fascicles of hairs : it fee ds on corn, peas and wheat, and breeds most of the summer.

Sprlosora nars (Stephens). Phalena (Drury).

(Plate xli, fig. 9.)

Antenne hack and pectinated. Head and hody light yellowish hrown. The thorax has three Wack lon fitudinal marks, and several spots upon the abdomen. Anterior wings hack. marked with hruad ochre-yellow lines : ciliæ light yellowish brown. Posterior wings light relewish or ochre-hromn, marked with a faint black spot on each, and having a lirout irregular horder of a dusky hack ruming along the external edges, lut very narrw in the middle : wings entire. Tnder side marked like the upper, but paler. (Westwood : Illustrations of DruRY, Vol. i, pp. 15, 16.)

Spilosoma conea (Drury).

(Plate xlvii, fig. 7.)

"Antenne pectinated, hlack : no tongue : head white; back and aldomen ash-color. Anteriur wings white : spots numerous, of many forms, and of a scoty black : external nuargin malkeal with five spots; those nearest the tips, triangular. Posterior wings white, with dalk crot near the external ee? ge, and faintly marked near the external angle. Expansion of wing, one inch and five lines." Drery.

Thi mint has not fallen under my nutice either in the vieinity of Albany, or in Western Massachusetts 
ArCtu isabella ( Harris)。 Isabella Tiger-moth.

Antenne filiforn, tawny yellow. Thorax tawny and brownish. Abdomen tawny, deeper color beneath, and marked with three rows of black spots, ahout six or seren in each row running upon the back and middle of the sides. Forewings tawn, and marked with a few hlack scattering spots. Hindwings nearly transparent, slightly tawny, and marked with six tawny spots. Legs black or dark brown.

I have found this moth in Williamstown, though it does not seem to be rery common, as unly a few indiriduals are taken by the different collectors here. The caterpillar, however, is common, and is frequently seen trarelling aeross our paths in autumn, always moring as if in great haste. It is brown, and thickly clothed with hairs of a uniform length, stifl' and short : the hairs are black on the first four and two last rings. On being taken up or touched, it rolls itself up. It feeds upon sundry kinds of herbs, but it is not to be ranked among the decidedly injurious insects.

Arctis virginics. White Miller, or Virginia Ermine-moth.

Culor white. Forewings marked with a black point, and two black dots on the hindwings. Abdomen marked with three rows of black dots, one on the top of the head, the two others lipon the sides, between which there is a yellow stripe. Thighs of the forelegs ochre-yellow.

ArCtia (var. of VIRGINica).

The wings of this moth are entirely white, except that the hindwings hare two black dots upon the underside, and one at the base of the forewings. The abdomen is ochreous, with the three rows of black dots, and a broad belt of ochre-yellow between.

The Arctia figured on Plate $x l v$, fig. 4 , may also be a rariety of the virginica, but its abdomen is white.

Arctia virgo. American Tiger-moth.

(Plate xli, figs. 3 \& 4.)

Wings deflexed : color pink-red, with two central triangular black spots; spots abore and below, angular, oblong : near the posterior margin, a thick black mark extending nearly its whole length; outer margin bordered with a fine black line. There are trelve black angular spots in each wing, the smallest upon the upper and outer angle. Secondaries jellow and red : in the male, the black dots large, and arranged somewhat in the form of a triangle. The spots near the anterior margin have quite a small one between them. The female has about nine black spots on the posterior and middle half of the wing.

raterilat brown, with four rellum or yellowish white and green stripes, interrupted with paler brown, upon each bulging ring, and ornamented with a double row of round dots; I w w which, ulon the sides, there springs a heary brush of brown hairs arranged in a thick pencil. 
Thi ineet ferds unn corn and a rariety of other plunts, as the plantain, peas, ete. : when the corn is young, its feeding is injurious to the plant.

\section{Liparidae.}

Arrkxy: dubly pectinate, short and hent. In the males, the teeth are longer than those of the fetnales, which are alsu narrow. Feters hairy, like those of the artide, but linger. Tongue slowt and invisihle. Frunars : Bondy thick, and furuished with only rudiments of wings. Males : Body slender; wings broad.

These sinular moths are hairy like the arctiens; but the female, heing wingless, is alway: find unn or near the cucoun from which she has escaped, and hovering around her is the mile ur mate. When at rest, the torelegs are extended considerably forward; while the wings, sloping but little, are folded together over the back.

sime of the females of this finily are provided with wings, though only imperfectly, as they 1ly but slusgishly. The males are diumal, and Hy during the day in search of the females.

The caterpillars are also peculiar, being half naked and the covering of the remaining purtion comsists of long tufts of hairs arowing from the sides of the bedy, and from warts, of which there are sume sis or eight. Sume have funr or five thick tufts of hair upon the back. cut shnit and even: and from the extremities. or from the first ring, two beautiful tufts of long hair project forward in the form of feelers.

There caterpillars are called tussocks, frum the tufts upon their backs. They resort to trees and vines of different kinds, and feed upon their leaves. Their cocoons are oval, thin, an 1 male of silk interwoven with the hair of their bodies. They are more or less injuriuus to regetation : indeed some of them inflict fatal injuries upon fruit-trees.

Drovia tefcostigma. Pale Emperor. Woth. (Plate xxxrii, figs. $1 \& a, b, c:$ female.)

Autennie of the males brown upon two-thirds of the josterior part, whitish upon their anterior margin. The markings are two transverse wared lines and one white towards the base, with four thick dashes towards the uuter angle : there is also a white angular siot uron the middle of the pusterior margin. Secondaries brown and black upon the nervures, and margined with a lighter shade of brown.

FEMre wingless, or with only rudiments of wings : culor ash or bruwnish ash : abdomen Jarge.

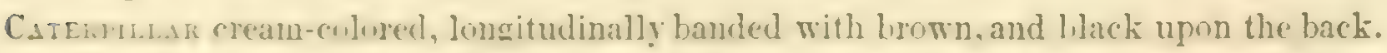
Head red, with two large jointed piencil-shajed tufts of hairs upon the pasterior palt 
of the head, and one of equal length upon the posterior extremity. It is also ornamented with four equal cut hrushes of hair upun its back, situated upun the anterior halt of the body, and is finged along its abdomen and extremities with long hairs. This caterpillar is common here in the spring, and feeds upon the leaves of the oak and the horse-chestnut.

\section{Saturniadae.}

BOMBICID E (Stephens).

THE caterpillars of this family are naked, crlindrical, and, as Mr. HARris describes them, have hunched backs. They are furnisled with warts, which are often bristled, and may be either simple or compound in form. Ther construct a coconn of silk, which is placed within a single leaf. ur else within sereral drawn together so as to form a partial protection against the outside; or sometimes they are fastened lungitulinally to a twig by gummy matter. They are unlike the I'ura-cases of the Papilioses, which are angular, spinuus, and suspended by a short thread with the head downwards.

The antenne of the muths are strongly and doubly pectinated, especially in the males, and their bodies are thickly corered with a dense mat of hairs or mool. The tongue is rarely risible. The wings, when the moth is at rest, are extended horizontally so as to eshibit both pair : they are also destitute of hooks. The wings are commonly ornamented by one or more conspicuous eyelike spots.

The insects shun the broad daylight : their eggs are large and numerous : their cocoons are cumposed of a strong silk, which might possibly be converted to use; and they offer this adrantage, that they feed on the leares of the common forest-trees, and hence there would he no danger of the loss of silkworms from an accidental scarcity of food, occasioned by untimely frosts, etc.

The Satcrsiade may not he regarded as specially injurious to the farmer, or to forest or fruit-trees : at least the injurr they produce is small, compared with that inflicted by cankerworms, leaf-rollers, ete. which are far less conspicuous in themselves.

The males of this family, according to Mr. STEpHexs, fly well, and go abroad in the after part of the day. The females fly sluggishly, probably from the weight of the abdomen. The wings are gray or drab, usually of a neutral tint ; and the ornaments consist of ocellate spots, some of which exhibit the brightest of colors.

Saturita mata. Corn Emperor Moth. (Plate xxxix, figs. 2, 3, \& c, d,e.)

Wings black, with a broad band of pale yellow trarersing the middle, translucent and thin. Forewings marked by a sellow lunar spot near the margin of the inner black part of the base of the wings : lunar spot also upon the middle of the jellow of the pos- 
terior wings; the wide hack horder margined interiorly with dark gray. Antenno brown, pectinated in both sexes. Front of the thorax yellow, hairy; hairs of a rustcolor posteriorly. Abdomen black, marked with three reddish rings, and the male has the last ring of the same color.

The male and female have a very close resemblance : the male, however, is a little smaller, and has two tufts of reddish hair upon the lateral parts of the thorax; while the females are marked with forked redlish lines upon the anterior wings, which terminate in the yellow stripe across the thorax. Pupa-case black.

The caterpillars of this species are of two kinds, or rather are marked after two different patterns. The head and feet are red, and each ring is ornanented with three pair of reddish compund spines. These spines sting sharply; and though not at all common, they have heen found in an oak and hickory grove three miles south of the city of Albany, tugether with the larra or cocoon of the insect. The figures were copied from Aввотт \& Swrн's Insects of Georgia.

Fig. 2, female; 3 , nale; $c$ and $d$, varieties of caterpillar; $e$, pupa.

\section{Saturia io. Corn Emperor Moth.}

Antemn pectinate : head and thorax purplish hrown : abdomen ochre-yellow.

Toper side, male: Color indian yellow. The anterior wings are marked with two ohlique wary lines torrards the hinder margin, a zigzag line near the same, and several spots arranged so as to furm the letters $\mathbf{A} \mathbf{H}$, all of a purplish red color. Posterior wings hairy and purplish, red at the base : on the posterior margin there is also a curved band of the same color; and within this band is a curved black line, and on the miklle of the wing a black spot with a bluish centre, upon which there is a silverwhite line or dash pointing to the inner and posterior angle.

Fenale : Anterior wings purplish lirown or cream-color when faded, and marked in the midlle with a brownish spot. Thorax and legs purple brown. Abdomen same as male. Greatest expanse of wing about three and a half inches.

The caterpillar measures two and a half inches when fully grown : its color is peagreen, marked on the sides hy a brown stripe edged with white, the stripe beginning at the furth ring. The surface is corered with stinging prickles, standing and spreading in clusters and terminating in black.

The moth is hatched in July from the pupa, in which state it has remained through the winter.

These caterpillars feetl upm the leaves of the elm, lmplar, dogwood and sascafras, and alsi, uirn clorer and indian curn. I) uring a part of their lives they are sucial, and, when they move, they march in regular files. 
Atracus zuxa. Green Emperor Moth.

(Plate xxiv, fig. 1.)

Actias (Leach)。 Piralikna luna (Linnæus.)

Head small, white, encircled with a faint brown and narrow ring. Antenne brown, pectinated. Thorax pale yellow and woolly, ornamented with a stripe in front continuous with that upon the front margin of the wings. Wings pea-green, marked with eyelike spots near the middle : outer margin bordered with purple brown. Posterior wings prolonged into long narrow tails bending outwards. Body covered with a white woolly substance, and rather close-pressed : legs purple brown. Expansion of wing about five inches.

The caterpillar is fully grown about the first of August. It is of a bluish green color [wrongly colored in the figure], striped with yellow on the sides, and transversely also between the rings : rings marked by about six small reddish or purple warts. Length, when in motion, nearly three inches; but when at rest, only about two inches.

In feeding, it prefers the leaf of the hickory, though it may be kept upon the leaves of several of our forest-trees. In North-Carolina it feeds upon the leaves of the liquidambar or sweet gum, as also upon the persimmon.

$N$. B. In some of the figures I have observed that the body and abdomen are colored a light brown, the thorax and neck being yellowish white or cream-color in the animal.

\section{Hydrocampa? nivalis (Harris). Delta-moth.}

UPPER SIDE : Antennæ filiform and brown. Wings pearly white, ciliated, and cilia brown. UNDER sIDE white pearly immaculate. Expanse of wing $1 \frac{1}{8}$ inch.

\section{DR YOCAMPA imperialis (Harris).}

Phalana imperialis (Druty); P. imperatoria (Abbott \& Smith, Insects of Georgia); CeratoCaMpa (Harris, Catalogue of Insects of Massachusetts); Cerocampa, Kirby \& Spence); Inasiocampa (Latreille, Schrank.); Bombrx (Fabricius); Odonestis (Germar, Stephens); Bомвут Didrua (Pal. de Beauv. Ins. Lep. pl. 20).

Male, upper side : Antennæ broad in the middle, pectinated, filiform, nalied, and curved at the extremities; in the females, filiform, naked. Color reddjsh and yellow. Thorax yellow, clouded by fire brownish spots, the anterior one placed upon the median line. Abdomen yellow, each ring of which is marked with broad heartform bands. Wings yellow, sprinkled with brown purplish linear dots; the outer edge broadly margined with brown, which connects itself from its middle by a curved band with the basal curved band : the connecting band curves and extends to the anterior margin below the middle, and borders it to the base : the basal band extends along the posterior margin beyond its middle, where it expands and encloses a yellow dot[Agricultural Report-Vol.v.] 
ted patch. The posterior wing is marked by a round spot with a sellow centre, below which there is a distinct transverse brown band : the base is also marked with four roundish spots, or which appear to have become conlluent.

IXFERBon striace yellow, sprinkled with elongate dots ats above. Lpper wings marked with two round spots, the smaller above the other : anterior margin lordered with hrown half its length; outer margined with a broad reddish band, and scollopped mpon its interior marrin. The posterior wings are marked with a single central s! ot, bordered with purplish brown.

The male expands nearly five inches, and the female six inches.

The species is said to breed twice in the year : its caterpillar feeds upon the buttonwood (Platunus occidentulis, Lixisers), oak, and sweetgum. The caterpillar is greenish, tawny green or orange green : holy spinous, lrairy, and the second and third segments armed with two pair of short rugose horns.

Almost erery seasun, I have seen a few specimens of the Dryocampa : it is, however, a rare insect in the ricinity of Albany, or in the western part of Massachusctts.

Mr. Harris has renoved the foregoing species from the Genus Ceratocampa, where he had placed it in his Catalogue of the Insects of Massachusetts; and refers it, though with some hesitation, to the Genus Dryocampa*.

\section{Lasiocampadae.}

THE caterpillars of this family are hatched from eggs glued into a gummy substance insoluble in watel : the substance entirely surrounds a small limb, forming thus a thick protuberance, in which are contained some three or four hundred eggs. These eggs are hatched as early as April or the beginning of May, ur with the develoment of the leaves. They immediately spin from their mouths a tent like a spider's weh, into which they retire at milday and erening, and where they remain until the sun has warmed the air the next morning.

The caterpillars are snaringly hairs, and free from warts : they are social in their habits, and congregate hy hundreds in their impervious tents. They trarel with considerable speed.

The moths are woolly, and their wings are without hooks; but the anterior edge of the hindwings is turned up, and laps upon the forewings; and when at rest, they are inclined and cover the back of the insect like a steep roof. The under wings project beyond the upper, when closed upon the body. The moth flies only by night.

The lasiocampians are among the most injurious insects the farmer has to contend with: they are, however, easily managed, and only require attention and ind ustry when they first

- Hazare : Lojurious Inescts of Massachuects, p. 209, $2 \mathrm{~d}$ edition. 
appear in April or May. Their habits enable us to take advantage of them, and destroy whole broods at once : numbers of them retire in a body to their tents at stated times of the day, when both houses and inhabitants may be destroyed by one sweep with a pole properly armed.

Clisfocampa americana (Harris). American Tent Caterpillar. (Plate xlv, fig. 1.) (Plate xlvii, fig. 6 : eggs)

Color rust-brown or reddish brown, variegated with gray especially on the middle and base of the forewings. Anterior wings crossed obliquely by two dingy white parallel lines : margin ciliate and whitish. Hindwings without lines or spots : a portion of the costal margin whitish. Beneath darker.

The caterpillar has a black head, and its back is marked by a whitish line. On each side of this white line there is a broad longitudinal stripe, formed by a yellowish ground marked by crinkled lines coalescing below, so as to make a row of spots upon each ring of the body, in the middle of which is a small blue spot : below is a narrow wavy yellow line; and lower stıll, the sides are rariegated with black and yellow lines. Underside of the hody dusky. The eleventh ring bears a small blackish hairy wart, and the body is sparingly clothed with hairs.

The caterpillars come to maturity and begin to leave the trees by the middle of June; or, in other words, they then break up their encampment, and each sceks some suitable crevice in which to make its cocoon.

This is one of the most injurious caterpillars known to infest gardens and orchards. As the eggs are deposited upon the trees, they are enabled, as soon as hatched, to begin their depredations upon the young and tender leaves. We cannot, as in some other instances, prevent the ascent of the young caterpillars up the trees, for they are already there; but we may, after the fall of the leaves, search for the eggs, which are deposited in quite conspicuous rings around the twigs, and remove them by hand, whereby an entire brood will be totally extirpated; and if a general attention be given at this period, an orchard need never suffer from the operations of this insect.

The danage that trees occasionally suffer by neglect is very great; for the tree, when deprived of its leaves, will die, or else must put forth a new crop, an alternative that seems always to produce a state of great exhaustion, and from which the tree scarcely ever entirely recovers. From this cause, when a tree has been neglected for several seasons, and consequently has become stocked with these devourers, it barely sustains itself, and soon shows marks of old age and premature decay : many limbs actually die the first season, and the whole tree wears the appearance of poverty and distress.

The direct means to be instituted for ridding an orchard of these destructive visitors, must be such as can act upon the whole brood while sheltered in their tents. These means 
are various. Some furmers low and burn off the tents, and all their inhabitants, with a small chare of gumpwer : others twist off the tents with a forked stick, or a fole with a stifl brush fistened to its end. and trample the dislodged insects under foot; others still empley a swah charced with whale-cil soap, a very little of which article will kill many of the insects, and compel others to disperse. Whichever of these means is resorted to, it must be fut in reguisition either late in the day, or at noon, or early in the morning before the insects an wht to feed. It is also advisable to begin early in the season, with the first apprearame of the cateryillars : their tents are then small, and a whole community may be destroyed with the greatest ease.

To crablicate cumpletely the tent caterpillar. it will he necessary to give attentiun to the wild cherrytres that are scattered over the farm and by the sides of fences : the cherry, it will be seen, is a liworite tree with this insect, and scarcely passes a season with entire freedom frum it.

It will be ohserved, that if the furegoing remarks are true, the farmer has no need of receipts to heal the ravages of these insects; for, to ensure freedum from their attacks, he has only to exanine his trees after the fall of the leaves in autumn, for the rings of eggs on the small hranches, which may be remored by the hand or a knife; or if this has been neglected. then search for the tents of the young catcrpillars when the buds begin to open in the spring.

As the caterpillar grows, the tent is enlarged by the construction of an additional web orer and around the first, enclusing therehy a space large enough to meet the demands arising frum increased size; and so it crntinues to add successirely new webs over the old, which have hecome filthy, and unft and unhealthy as dwelling-places, though a few of the weak and more indolent remain still within them.

Attaces folyphemes.

(Plate sliv, fig. 1.)

Color dull ochre-yellow, somewhat clouded with black. Wings ornamented with an eyelike spot : adjuining their margins there are two parallel belts, the outer one reddish and the inner black. Outer angle of the superior wings marked with a black spot, divided by a reddi:h white line. Eyelike spots round outer narrow border black; inner ochre yelluw, surrounding a white centre. Posterior wings are ornamented with a similar eyelike sprit, but surrounded by a large bluish black spot extending upward towards the base of the wings : inner posterior angle truncate. Thorax traversed in front by a narrow grarish belt, and connecting itself with a similar border on the front edge of the wing. The wings expand to six inches.

The caterpillar inhabits the vak and elm, and may be found in August and September.

The alisence of yellow stripes on the sides and transverse bands on the back, and the presence of a mark of the shape of the letter $V$, will serve to distinguish these caterpillars from those of the luria moth. 
Attacus CECropia.

(Plate xliv, fig. 4.)

Color dusky brown, reddish brown. The pattern of both pairs of wings is nearly alike. The base is reddish, bordered with white. The broad middle is dusky brown, in the centre of which are lumate spots, centrally white, but bordered with light brown. The middle of the wings is traversed by a uarrow reddish white band, beyond which there is another broad dusky hrown band; in the outer and upper corner of which, there is a black velvety eyelike spot, marked by a narrow lunate line placed upon the inner edge : this outer border is bounded by a distinct black waving line, beyond which is a white border edged with brownish. The posterior wings, however, instead of the black waving line, have a row of black spots amounting to twelve or more, placed by a dusky brown waring belt : margin dusky white. Expansion of wing, six inches.

This moth aypears early in the summer, in sheltered warm places : it is out as early as the middle of May.

The caterpillar is of a fine light green color. The second and third rings bear two rcd glubular warts, around which are numerous bristles : the seven succeeding rings bear oval yellow warts; and upon the eleventh ring, there is only one large wart. The sides are ornamented with two xorrs of elongated blue warts, and the five first rings have an additional row below.

The young is yellow, and marked with rows of small warts upon its back. It fastens its cocoon longitudinally to the side of a twig : the cocoon is usually three inches long, tapers from the middle, and is constructed of double walls of silk separated by loose fibres of the same, and has a resemblance to brown paper.

The caterpillar is found upon several of our fruit-trees and shrubs, but I have never been able to discover that its injuries were very serious. It is not very common : some seasons, however, furnish more than others.

Attacus promethevs.

(Plate vi, figs. 1, 2, 3, 4.)

MALE, upper side : Color deep smoky brown; the shoulders and basal parts deeper than the borders, succeeded by a central band of lighter color : this is terminated towards the border by a wavy line, beyond which is the clay-colored border, ornamented on the anterior wings by a wavy line, and on the posterior by black oblong spots between the line and middle band. Onter angle of the superior wings is ornamented also by a black eyelike apot, upon which there is a lunate line or crescent.

Female, color brown, deepest upon the basal parts, which are marked by a curved whitish line.- Each wing bears spots, sharply lunate on the anterior wings, and bordered by black : besides which, the anterior wings are marked by an eyelike spot at their ansles, within a bluish white crescent. The moth expands about four inches. 
The eggs are depusited on the trigs of trees in clusters, and are hatched in July. By the first of septemlere, or as late as the middle, the caterpillar acquires its full size, when it measures ahout two and a quarter iuches : it is naked, of a green color, and marked by six or eight small dark warts, and is furnished with a pair of simple coral-red spines for the sccomd and third rings. There is a short spine upon the last ring but one, and the last is furnished with about six short black bristles.

The lilic seems to be the farorite shrub to which the prometheus attaches its cocoon, which is ahout an inch long, and gray like paper : it is attached longitudinally to a leaf, that serves to protect and conceal it.

This moth is one of the most common in and ahout Alhany, some lilaes furnishing as many as a dozen coconns. The caterpillar, though not perhaps entirely harmless, yet in this respect searcely deserves attention. The large moths, appearing late in the season, after the leaves are fully grown, do not seem as injurious as they might be if they arrived when the leaves were expanding and tender; and trees do not suffer so much from tho loss of foliage in the early autumn, as in the spring.

\section{Ceratocampa regalis (Harris)。 Regal Walnut-moth.}

"Antennre short, and, in the males, pectinated on both sides; in the fimales, thread-like.

Wings without hocks : forewings ulive-colored, ornamented with several yellow spots, and veined with broad red lines."

This insect I have not yet seen : it is fully described by Mr. Harkis, and, according to his description, it is one of the finest and largest of our moths, having an expanse of wing equal to six inches. The larva are spinous, but harnless; that is, they do not sting when handled. When fully grown, it is four or five inches long and three-fourths of an inch in diameter, and of a green culor banded with pale blue transversely*. It feeds on the walnut.

The moth is said to appear in June, and is more rare than the Dryocampa imperialis.

Frum the ald fumily of Bombrcide or Saturnians, Dr. Harris has separated the Ceratocampa and Dryocampa, and a few others, and has constituted a new lamily under the name of Ceratocaspada, after the name of the chief genus contained in it : the name signifies homed caterpillars. On the second, and sometinues also on the third ring, these horns are stiffer, more rigid and curred, agreeing more perfectly with their definition as homs.

All the species here referred to feed upon the leaves of forest-trees : they go into the ground where they undergo their transformations, and this without making cocoons. The chrysalides are nutched or touthed, with the design of assisting their ascent from the ground at the time just prior to their final and last change.

- Harris : Injurious Insects of Massachusetts, p. $307-8$, 2d edition. 
Dryocampa pelLucida.

(Plate xxxvi, fig. $1-3$. )

a. Pupa : c. Larva (Аввотт \& Surte).

MALE, upper side and forewings : Color of the costal margin and base brown, reddish and purplish; in the angle of this marginal and basal part there is a white spot : central part clear; posterior margin reddish or purplish. Posterior wings buff, similar to the antennæ, head, thorax and abdomen.

Female, buff with a white central spot; outer margin paler. Beneath buff and uniform.

I have a specimen of the male, the color of which is purplish buff without any variation of tint, but preserves the pellucid wing with its white central spot. The wing is abraded, but still has a close agreement with Mr. Harris's description of the pellucida, which certainly does not agree with Aввотт \& Smith's figure.

\section{Dryocampa ViRginiensis.}

(Plate xl, fig. 5.)

Phalena virginiensis (Drury). P. pellectoa (Abbott \& Suith).

UPPER side: Antennæ, basal half doubly pectinated. Wings pellucid, brown. One half of the anterior wings darker upon the upper part, in the middle of which there is a single white dot : lower margin of the posterior wings lighter brown than the basal parts.

CNDER sIDE, the legs, sides, thorax and abdomen are dark orange. Wings divided into two unequal parts by a bar : abore the bar, the color is reddish jellow; below, the same as the upper side.

I have taken a single pair of this species in Albany county, and it is of rare occurrence in this State, although during the present season (1853) it has been somewhat more numerous, so that specimens have been obtained and placed in several collections.

The larra is described as being naked, striped, rigid, and supplied with acute tubercles : the second ring has two threadlike horns. It subsists on the leares of forest-trees : the moths were found in a young forest of oaks and hickory.

The spring of 1853 has been unfarorable to the growth and perfection of this caterpillar: at an early day they were quite numerous, but the subsequent cold weather seems to have killed many in their tents. I have numerous balls consisting of dead dried caterpillars inside of their habitations, which appear to have all perished from excess of cold when about half-grown.

\section{Cristocampa sxuvatica (Harris). Tent Caterpillar of the Forest.}

Head blue. First ring marked with trro yellow spots and four black dots : the next eleren rings are marked upon their tops by a row of white spots, and also two small elevated 
Wack hairy duts, except that on the eleventh ring there is only one large dint. Sides of the back marked by a reddish strige, which is leordered ly slender black lines: they have also a yellow stripe letween two hack lines. Belly lilue-hlack. Hankis.

This caterpillar inhalits oaks and walmuts : less common wh the cherry and alphle. It attains its tull size in June, and is then two inches long. It is also sucial in its habits, and constructs tents like the $C$. americana.

The moth appears carly in sejtember, and is of a light drab, brownish or yellowish color. The anteriur wings are marked ly two obligue. hrown, straight, and parallel lines. The greatest expansion of ming is a little less than two inches.

The trees upon which the caterpillars of these noths feed are injured in the manner represented in the foreging sketeh; and though few persons are so pratrictic as to give their services to the fullic for the purpose of destroying moxions insects, much private henetit would accrue from the extermination of these forest caterpillars. To this end, our special friends the birds come in aid, and rid us of thousands of them : the cuckow, catbird, rulin. jay, and many uthers feed upon them, and thus dininish their numbers very materially: The murderous gun should therefire never be puinted at birds who make it their business to serve us so effectually, especially as we seem little disposed to do any thing this way fur curselves ; and even were the dispusition not lacking on cour fart, the hirds are certainly letter adapted to do the work, and, no doult, if spared ly the fowler, would be competent, from their conseyuent increase of numbers, to hold the increase of insects so much in check as to sare us from serious danger frum that source. Indeed any man has a perfect right to prevent the destruction of hirds, on the same ground that he has a right to protect himself from personal harm.

The direct means fur destruying the firest tent caterpillar are the same as required in the case of the Camericana, namely, destruction of the wets and their contents at the proper time, that is, when the inhabitants are at home.

\section{Cusiocampa netstoria. (Plate xxxvii, fig. 2-4, and $a, g$, pupa and larva.)}

Primaries of the male pale sulphur-yelluw, marked with two distinct dark lurown bands: the unter margin handed with brown, interupted with two oblong sulphur-yellow spots near the outer angle. Secondaries dull brown, with a deepw narginal stripe parallel to the fwsteriur margin, and marked with deeper brown also on the nervures running from the base to the posterior margin. Femate yellow. inclining to orange on the primaries, with the same distribution of hrown and brown stripes as in the male.

Caterpilaak $₫$ reen, with a ruw of ublong white sputs on the back. enclosed in rectangular markings of yellow. which are formed hy two grllow parallel strig,es ugun the sides of the hack. comnected recularly with serrated cluss bands : enclised rectangles shaded with black. Head brumn. Body furnished laterally with greenish and yellow 
hairs, and brushes on each side of the head; when mature, two inches long. The tail is terminated by an oral spot surrounded by yellow enclosing green and white, the white in the form of a stripe.

Cocoos bluish, oral, tapering, with eight rings, and dotted along the sides; less than one inch in length.

This insect feeds upon oak leares, and dnes considerable danage to the white oak by nearly defoliating it. The caterpillar appears as early as the first of May. It is regarded by Aввотт and Sмитн as identical with the European insect of the same name. (See Aввотт and Switr's History of the Insects of Georgia, pa. 117, pl. 59 ; and the figures I have giren are those of Аввотт and Surth, from which it will appear, on reference to plate xlv, that they differ from those of our common orchard moth named by Dr. Harris Clisiocampa americana.)

\section{Hepialidae.}

THE antennæ of the insects of this family hecome gradually attenuated at the tip : they are short and filiform, but never feathered at the tip; but those of the males are sometimes doubly pectinated at the base. The tongue is either very short or obsolete. The abdomen is elongated, and provided with an oripositor. The thorax is never crested. The wings are narrow, but complicated and strengthened by numerous nerrures. The larræ hare sixteen feet : they are white or reddish, soft and naked, only slightly downy, and furnished with brown heads : they feed upon wood, and construct their cocoons of bits of the wood upon which they have been feeding. The chrysalids are ridged transversely, and notched.

This family does not appear to contain many species in this country. Dr. Harris has described the Hepiolus argenteomaculatus belonging to the same genus as the European hoprine hepiolus, and figured the same in the Lake Superior Expedition conducted by Prof. Agassiz, plate vii, fig. 7.

\section{Notodontidae.}

THE wings of the moths of this family are folded, and slope like the roof of a house over their backs : they are held by bristles and hooks. The antenna are rather long, usually doubly pectinated in the males, and become narrow and short towards the tip. The feelers and tongue are small and short : the body is long.

The larva are provided with toothlike prominences upon their hunched backs : they are usually naked, or only downy. The posterior appendages used for feet are sumetines [Agricultural Report-Vol. v.] 
moditied so as to exhibit a furked shape, upon which the soles of the feet only are sect. The cocens are firmed of silk intermixed with frigments of wood and bark. The ehrysulids are not notched upon the back. The larva feed upon leaves.

Pygars albifrons.

(Plate xxxvii, fig. $3-5$. )

Wings detfexed : primaries clouded; anterior margin marked with an elongated spot of cream-color terminating in the outer angle and dutted slightly with brown, transvervely hanled with white, black or dark brown : secondaries brown, margined with a lighter shade. "Thorax of the male banded with two distinct black lines joined by two shert parallel comecting lines, between which there is a square yellow or creamcolored or light buff spot. The thorax of the female is ormanented with three crossbars : antennæ setaceons, with a terminal enlargement. Antennæ of the male?

Caterpillar striped upon its back with jellow and brown; underside lake, and furnished with three pair of legs and four pair of proplegs : it is half an inch long. It spins a thin white web between the leaves late in autum, and appears early in the spring in perfect state, feeding upon the leaves of the white and other oak trees. They are gregarious when young. The cocoon is 3 inch long, and has eight or nine segments.

The larve of this species feed at times upon the leaves of the oak, and sometimes nearly defoliate a tree when they are numerous. An instance has fallen under my observation, in which a tree of this kind was well nigh deprived of leaves by these insects for two or three years in succession.

\section{EUdryas grata. Woodnymph.}

(Plate xlvii, fig. 8.)

Furewings pearly white; basal half trimmed with purplish brown : outer margin widely bordered with purplish brown, the inner edge of which is banded with olive, which extends and widens upon the pusterior border, furming near the middle a large patch: exteriorly, upon the border and near the edge, it is ornamented with a delicate bluish line. IIndwings a yellow buff, hordered behind with purplish brown, which does not reach the outer augle, hut extends along the inner edge : it is trimmed with silvergray ciliæ. BExEstr, the forewings are pale buff, marked upon the basal half with brown, hut confined to the costa, which terminates in two roundish spots. Hindwings paler yellow buff, and marked in the middle with a single brown spot. Ahdomen buff brown, silky; the rings are banded with lighter, and terminated with a zone of the lighter buff.

This heautiful moth is rare here. I have taken it only in Berkshire (Massachusetts), but it exists in collections in Washington and Albany counties in this State. 


\section{Nonagriadae.}

TuE body of the moths of this fanily is long; the thorax is smooth; the colors are yellowish or clay-colored, and the forewings are faintly streaked or banded. The larva are naked, long and slender, and taper at each end : they live within the stems of reeds, and feed upon the pith and upon the inside of roots, and hence are destructive. When about to transform, they gnaw through the stem to the cuticle, whick is left entire, but is easily broken through afterwards by the nymph. They are known by the common name of spindleworms. Some attack corn, to which they do great injury; others, the stems of garden flowers, such as the dahlia, etc.

The Gortynia zea of Harris belongs to this family, and is described by him as having its forewings of a rusty red, and mottled with gray almost in bands : there is also an irregular tawny spot near the tip, and on the veins a few black dots. Expanse of wing, an inch and a half.

Another Gortynia attacks the roots of columbine, and has been named by Dr. Harris leucostigma. The forewings are tawny yellow, sprinkled with purple brown dots. (See HARris, Insects injurious to vegetation, p. 341, 2d edition.)

\section{Agrotidae.}

The larvæ of this family are subterranean, and come forth from the soil to feed in the night, and return to their burrows before morning : they are called cutworms, and are exceedingly troublesome in cornfields. The moths are usually brown, and sometimes fly by day, and feed upon the honey of wild plants : their wings are nearly horizontal when at rest, and the forewings completely conceal the hind ones when closed. The thorax is not crested. The antennie of the males are sometimes pectinated at the base, but taper to slender filaments. The forelegs are spiny.

The larva are smooth, cylindrical, dirty white, and rather thick bodies, naked or furnished with only a few scattering hairs : their rings are dotted. They change to chrysalids in the ground.

The attacks of these larvæ extend to many of our most useful cultivated plants, corn, cabbages, wheat, buckwheat, grasses, together with cultivated flowers. In the maize-fields, however, about the middle of July, they seem all at once to cease their injurious work to the corn plants.

It appears from Dr. Harris's researches that we have mally different species of this family, all of which have the similar habit of feeding upon young and tender plants, and of cutting off their stems just above the soil. 
Color dusky hrown. Forewings dusky or blackish, especially along the costal edge : one Inalf of the subcortal base is blackish; and, beyoud the middle, this dusky subcustal hand estends towards the inner margin, forming a partial transverse band : apical and narginal area light hrown and silky, of the same color as the area of the dise. Hindwings white with a pinkish hue in certain lights, silky and ciliate : beneath, unite pale, and without markings. Body dusky, and as dark as the forewings : the venter is slightly ferruginous, and terminates in a short brush. Expanse of wing, two inches.

This is one of the common species of Agrotis in Western Massachusetts and Eastern New-York.

Agrotis -

(Plate xlv, fig. 2.)

Color mottled gray : thorax and head brown. Forewings gray at the base : in the middle, resting unon the inner margin, is a large quadrangular spot of a cinnamon-brown, beyond which is a broad transverse grayish green band; margin brown : costal margin mottled with gray and brown, with an intermixture of short slender transverse lines. Hindwings smuly, especially upon the posterior and inner margin : costa poarly aml yellowish white, leneath smoky and pearly. Hindwing beneath marked with a central black dot. Expanse of wing, two inches.

A common species in Western Massachusetts.

Agrotis? -

(Plate xIv, flg. 10.)

Culor of the thorax black, from which a longitudinal band extends upon the forewing, reaching its middle; the extreme end, howerer, is separated from it by a small space of gray. Costa black in front : outer margin banded transversely hy two dusky white hands, between which are hroader bands of dusky brown. Hindwings pearly white. Abdomen whitish, or of the color of the hindwings.

\section{Noctridae.}

TuE antennæ of the insects of this large family are mostly simple : the bodies are thick, stout and strong ; their wings are of a moderate length, and strengthed by their nervures, and their tongues are long. The wings, when not in use, are deflexed upon their sides, and the buly is clothed with scales rather than wool or hair. The majority of the larve of the different genera are naked, and have sixteen feet, though in some the second rentral pair, in others the first ventral pair, are wanting : thry underge transformation under ground, aml firm comerins of silk in which particles of sand are often glued. The moth 
nies by night, and conceals itself during the day : its thorax is crested. The larva are solitary. The colors of the perlect insect are not bright, but often have a silky lustre.

Noctua squamularis.

(Plate xlii, fig. 1.)

Antenne filiform, brown. Superior surface, hasal portion chocolate, outer portion slatecolored; the junction of the two colors deepest. The anterior wings are traversed by two scollopped lines; the inner running entirely across, the outer only across the inferior half. Posterior wings traversed by a chocolate band, apparently between two black parallel bands; the slate on the posterior half shaded into chocolate, or paler : margin slate, and slightly dentated. Expansion one inch and nine lines.

Noctua undularis. Phalana undularis (Drury). （Plate xlii, fig. 4.)

Antennæ filiform, brown, slightly toothed. Insect very dark brown, bordering upon black. Wings slightly dentated, and obscurely marked by five or six narrow transverse bands of black, imparting a very black hue to the whole animal : both pair of wings marked and colored alike. Inferior surface lighter, exhibiting the same kind of markings.

Noctua margaritata (Drury).

( Plate xlii, fig. 9.)

UPPER SIDE : Antennæ setaceous, brown. Thorax and abdomen silvery white. Anterior wings silvery white at the shoulders, the remainder being of a shining red-brown; edges fringed with white : there is also a large silvery marginal spot on the outer half of the anterior wing. Posterior wings silvery white at the base, and extending over one half of the wing; the remainder brownish, but margin silvery.

UNDER side : Breast, legs and abdomen white. Anterior wings silver gray, but fringed with yellow. Posterior wings colored as on the upper side, without markings. Druny, Vol. ili, pl. 21, fig. 6.

\section{Phaldana quercaria. American Oak-beauty. (Plate xxxvi, figs. $2 \& 4, b-k$.)}

(Аввотт \& Sмiтн, pa. 205, pl. 103.)

Antennæ of the male pectinated : wings brown. MALE : Primaries banded parallel to the outer edges; marginal black, succeeded by a waved cream-colored band, which is bordered with black : towards the base there is a parallel shorter band shaded with brown. There are two black central spots encircled with light brown, extending towards the posterior margin, and also dashes of black lines from the base outwards. Secondaries banded with black upon the margin and central part, with a lunate black 
line towards the base; broad radiating dashes of brown upon the nervures from the hase backwards, and reaching the posterior margin : posterior edge slightly scolloped.

Fema.e : Primaries mottled and dotted with cream-color, centrally banded with brown and cream-culor, which has a cream-colored oblong spot towards the upper margin; helow, it has wared black coalescing spots : upon the margin, two large brown spots with cream-colored spots. The secondaries exhibit a similar pattern; the brown is placed upon the base and posterior margin, with cream and black angular spots within. Boty hown, with a row of spots down the abdonen : the posterior third of the abdomen has the sides cream-colored, and spotted with buff or brown.

Caterpllar a loner, brown ringed with black at each joint, the last with yellow, and striped on the side with white. It is two inches long, and has the habit of fixing itself in an ohlique position. Feeds upon the black oak : it spins its cocoon on the ground in May or June.

Cocoos brown, and about one inch in length.

Noctua (Acontia) nUndina.

( Plate xlii, fig. 7.)

Antenne filiform, reddish brown : tongue coiled spirally: head and thorax ash-color. Anterior wings greenish, faintly marked with brownish, and with a darker angular mark placed tuwards the outer angle. Posterior wings silvery white, marked with faint discoidal spots, and bordered with a light brown.

BExEATH, the anterior wings are silvery white, indistinctly bordered with brown, with two dark sputs just opposite the single dark spot on the upper side. Posterior wings silvery white : oblong brown spots appear as on the upper side.

Erebus edusa (Latreille). Phalcena (Drury).

(Plate xlii, fig. 3.)

L'Pper side : Antennæ filifirm, sandy brown, deeper color towards the margin. Anterior wings ornamented with two large bluish white spots upon the outer margin, and several crooked spots on or near the basal part. Posterior wings marked with one large oral spot on the posterior half, and margined with brown dots : edges crenate.

UNDER SIDE bruwn; but the anterior wings are marked with two whitish spots placed upon the external edges, one near the tip, the other at the lower angle: they are also crossed by a whitish bar one-fourth of an inch from the body, and a small white spot appears next the shoulders. Posterior wings brown, narked by a whitish oblong spot ylared aloner the external edges : cilia brown. Underside, paler beneath, and marked with obscure dark spots. 
Catocala -

(Plate xliv, fig. 3.)

Color grasish brown. Ilead marked with a white spot between the cyes. Thorax black, marked by three transwerse reddish bands. Abdomen dusky, with a reddish hue. Forewings brown, marked with pale cinnamon bands. Hindwings hlack, marked with tro carmine zigzag bands, and a submarginal one more or less interrupted : edge dressed with carmine.

Catocala eptone.

(Plate xlii, fig. 8.)

Thorax and abdomen sooty ash-color. Wings crenate; the anterior ones dark chocolate, narked with an undulating dark ferruginous line running from the anterior to the posterior edge : another line of the same color crosses the wing near its articulation; a broad dark patch occupying one-third of the wing's surface, showing within two oral lighter spots. The whole appearance of the wing is nebulous, exhibiting broad belts and dark and ferruginous lines arranged transversely. Posterior wing dark or black, lighter along the abdominal border : cilia white.

INFERIOR SIDE, the anterior wings are dark ashy at the base, and become black towards the outer edges, but the tips are soot-colored : external margin ornamented with seven whitish spots, above which there is a white line running from the anteric $r$ to the posterior margin, and narrowing as it goes. There is a large oblong whitish spot between the line and shoulders. Posterior wings, upon their abdominal margin, ashcolor, deepening to black : a faint white streak runs a short distance down the wing from the anterior margin. Spread of the wings 2 inches 6 lines.

Catocata affinis. Painted Catocalla.

(Plate xlii, fig. 5.)

Phalena (Linngus). Catocala (Schrank).

Antennæ filiform, obscurely serrate upon the inferior side : tongue coiled, of a moderate length : feelers thick, hairy and pointed. Anterior wings ashy gray, marked by a wide line or narrow belt of a chocolate color, running from near the base of the anterior margin towards the outer pesterior angle, when it becomes a zigzag line terminating in the anterior margin towards the outer angle : outer margin marked by obscure short lines of a chocolate-color. Posterior wings orange, marked by black or dusky belts parallel with each other; the outer belt parallel with the posterior margin, learing an orange patch upon the outer angle, and dots posteriorly : a black line runs parallel with the inner margin, terminating at its base. Inferior side marked by alternating belts of orange and fuscous; margin and base lighter colored : the colors are all dull and faded below. Head and thorax dusky. Abdomen dusky above and light below. Expanse of wing $1 \frac{3}{4}$ inches. 
There seems to he considerable variation in the size and colors of this painted moth, possibly due in part to sex. In the figure of Dron, the anterior wings are dark, with yelluw marginal duts. A C'alocule finme in Western Massaclusetts has the dark anterior wings and dotted margin; while the moth is larger, the red helts of the hindwings are brighter, and the posterior margin is almost ciliate and yelluwish gray. But unother, nearIy as large, is pale and ashen, and the inferior wings have yellow instead of vermilion red. Another still is small, ahout $1 \frac{1}{2}$ inch in expansion, with yellow also; but has the angular spot, and other markings similar in fashion to Drery's figure.

There scem to be gradations both in size and depth of colering, which are not sufficient to distinguish species, hut may estahlish varieties; but as I have before me only six individuals, I may be mistaken in my estimate of the importance of their differences.

\section{Geometridae.}

\section{SPANWORMS, LOOPERS, \&C.}

Tre insects of this family more orer the ground, or along the branches of trees, in distinct steps, as if measuring their progress, by alternately tlexing and extending their hodies from pint to point. The manceurre is performed by first extending the anterior extremity of the buly as far ahead as it will reach, and then hringing forward the posterior extremity by clevating the midlle prortion of the hody, so that the extremes are hrought into contact, and the whole takes the form of a loop; and thus by successive steps they measure their rute according to the length of their bodies. Their legs, which are usually ten on each worm, are employed rather in fixing the body at its successive points of rest, than in independent muvements of the feet. They necessarily move slow; and as they vceupy bushes and trees in feeding, and must seek the ground to undergo transformation, they are provided with the apparatus and means of spinning a thread, hy which they are enabled to let themselves quickly down to the ground; and in cases of alarm they frequently do this, remaining suspended until the danger is past, when they return to their feeding hy aid of mouth and feet, seizing the thread above with the jaws, and then drawing up the body by doubling it as before described. They are destitute of hairs.

When the spanworm gnes to rest, it fixes itself hy the posterior feet, and lifts its body up and sustains it stifly in an angular and motionless posture, therehy counterfeiting the appearance of a short broken dead twig of the branch on which it reposes, with the instinct of eluding if possible the seurching eyes and devouring beaks of hungry birds.

To the Family Goometrine belong some of the most destructive moths, particularly the cankerworms. Those which are injurious to fruit-trees have usually thin angulated wings; but they are wanting in the female, or merely modinentary, and hence are very unequal in this respect : this fuct gave origin to the name aniscpterix, 'unequal-wings.' 
Geometra tratsversata.

(Plate xlii, fig. 2.)

Antennæ filifurm, orange brown. Wings angulated, dashed with short darker lines, and shaded with about three dark parallel stripes. Anterior and pesterior wines malked with a waving contimuous line, leginning at the acute outer angle of the forncr, and terminating a little below the middle of the latter : they are also bordered with a narrow helt of a similar color. Inderside of the wings similar in colur and markings, except in the brown waring line. Expansion of wing, two inches. (Westwoods Illustrations of DrURY, plate viii, fig. 2.)

Geometra serrata.

(Plate xl, fig.6.)

Antennæ setaceous or filifurm. Head reddish buff-color. Thorax, abdomen and wings yellowish buff. Both pair of wings scollopped, and broadly bordered with brownish or deeper buff : also the same color is found at the base of the forewings, but paler; and a transrerse hand upon the posterior, with dashes of the same orer the yellow part. The border of the forewings is forked near the outer angle, and the anterior edge is ornamented with brown and white oblong spots. (Westwood, Illustrations of Dronx, plate $\mathrm{xx}$, fig. 4.)

Geometra catenaria (Drury). Chain-dotted Geometer. (Plate xli, fig. 10.) Phalfina catemaria. Bupales catenarius (Leach).

Antennæ in the male doubly pectinated, slender. Head orange. Thorax, ahdomen and wings white : the former is marked with three orange-colored spots, and each ring of the abdomen with dots or black trausverse lines; the wings are also marked by two parallel denticulated lines running across them. The wings are rounded behind, and margined with a black dotted line having some resemblance to a chain. (Seo Westwood, Illustrations of Drery, plate viii, fig. 3.)

Genetra? - -

Wings subangulated, suberenate on the outer margin.

(Plate xlv, fig. 3.)

This moth I am disposed to refer to the Genus Geometra, relying upon the form of the wings and the pattern of their ornamental marking. The color is cinnamon-brown, and the white transterse band near the middle is bordered by a deeper hrown on the lasal side. The costa is darker, being connected with the transterse band already referred to. Hindwing lighter colored at the base than the outer half.

I hare been unable to obtain the larva, and hence it cannot be determined whether it has the progression peculiar to the geometridæ. There is some doubt as to the genus to which it should be referred.

[Agricultural Report - Vot.v.] 


\section{Tortricidae.}

LEAF-TOLLERS.

Tue insects of this family mostly have the habit of rolling up the young leares of trees, either one or more in a single rull. and contining them with silben threads. 1 hey are small, sallom in the larval state exceding an inch in length. The moth is nocturnal, small, usually gray and ohscurely handed, rarely ornamented with bright colors. The larvæ have sixteen legs each, and their berlies are naked, or only clothed with a few hairs in tufts : they spin a thread of silk from the mouth, with which, when disturbed, they let themselves party down to the ground, where they remain suspended until the danger is frast. The moth, though small, is bruader across the forepart than in those of other families. They inflict serious injuries upon trees, by feeding on the buds and blossoms.

LoXotxinu rosacesna? Rose Leaf-roller.

( Plate vi, figs. 8-11.)

Color light brown, grayish brown, light cinnamon-brown. Forewings traversed three narrow brown bands : when the wings are closed, the bands form a quadrangular figure on the back; these bands are variable. as well as the colors of the nuth. Hindwings yellowish white or gravish yellow. Exranse of wing ahout one inch.

The larva is green, naked : head hrownish, smooth, glossy : rings of the integument sheathing the head, yellowish white : six true less, eight middle and two prop-legs. At the extremity of the ahdomen, two or three small greenish warts, which give crigin to a few hairs. Feeds upon plum, rose, and other leares and flowers. Largest, three quarters of an inch long; sometimes one inch, but usually a little less : the figure is smaller than common.

The puna is hrown, enclosed in the rolled leares, and suspended by the tail.

This is a rery troublesome insect. In $m y$ garden. the larræ every gear destroy most of the plums con a fine tree, hesides checking the regular growth of the young linbs, which, when the huds are destroyed, never grow more than an inch or two in the spring; and the efferts of the insects are also seen in the knotty condition of the young shoots. The eggs are laid in patches unon the hark in the month of June or July, where they remain until the tree begins to put forth its leares, when the larra make their appearance, and almost every twig has been for some years infested with them.

The hest way to deal with this species of Tortrix, is to rub the hark of the trunk and limbs of the tree with a knife or some other proper instrument, by which means the eggs will be destroyed; and then wash the bark thoronghly with an alkaline solution, or with whale-oil suap : or if the trunk and limbs are whitewashed in the autumn or spring, just 
as the eggs are about to hatch, it will mostly destroy the eggs; and if any escape, the use of a syringe with soap and water, will probably finish the work.

This leatroller attaclis the rose, and several other plants belonging to the different orders : it is not. therefire, particular as to its food; but it effectually juts a stop to the expaniling hlossoms, whenerer it makes its habitation in the leaves that surround the bud.

I have referred this insect to the species rosaceana, although it does not agree in every respect with the descriptions within my reach. It is variable in its markings and size, in buth the larral and perfect states. It does not spin a cocoon, unless one is constituted by the few threads of silk it employs to bind up the rolled leaves with, in which its transformation takes place.

CAmpocapsa pomonelia.

(Plate xlvii, fig. 4.)

This insect is a native of Europe : it was brought to this country with the apple, and has become naturalized. The moth is gray, but lustrous like satin, and is delicately streaked and dotted. The posterior border of the furewing is marked with a reddish brown spot, which is surrounded by a golden mark in the form of a horseshoe. The hindwings are brownish inclining to yellow, and surrounded by a fringe : they are sparkling and brilliant. The thorax and abdomen are yellow and brownish gray.

The moth appears in the evening, haring been secreted in a secure place during the day. It may then be seen husy about branches of apple and pear-trees, selecting the fruit for a depository of its eggs : in a few days, if the weather be warm, they are hatched. It requires three or four weeks to come to perfection, when it is reddish or flesh-color, with a brown head and collar. Before it changes to a pupa, it leaves the fruit, and seeks a secure place in the cracks of the bark, where it spins its cocoon.

According to Koldar and other authorities, two broods are produced in a single seascn. The first pupa changes to a perfect insect in a short time, and, by the last of August, much fruit will be injured. If the weather and season be farorable, numerous insects of this kind will come to perfection, and the quantity of fruit injured will be in proportion to the number of insects hatched from the eggs of the first brood.

The means to be adopted for diminishing the numbers of this moth, are mostly of the palliatire kind. It is evident that all infected frait should be immediately gathered and destroyed. The tree should be shaken, that all diseased fruit may fall as soon as possible, and before the larra leaves it to change into the pupa state. The defectire fruit may be picked, remored and scalded, and fed to swine. It is obrious that the nearest approach to the extirpation of this injurious insect will happen when cultivators of apples and pears shall unite their efforts in the use of the remedies proposed. 


\section{Yponomentidae.}

A famin of the Lepidoptera, made up of very small moths, whose lahial palpi are long and sleuter, and still but slightly developed : it is allied to the Tortricides and Trserds.; hut from the firmer it differs in the length of the palpi, and from the latter in their nondevelopment.

The body of the insect is slender, and somewhat elongated and depressed. The antennæ are very long and simple in both sexes. Wings alsu leng, or a long oral and acute : they are entire. lut often ciliate or fringed. The colors are white or slate, marked by a few bands of black : some, however, are ornamented with brilliant metallic colors.

The larre are wten highly injurious to fruit-trees, especially those living in communities, which inhabit a common tent after the manner of the American tent caterpillars. They have sixteen feet, and form cocoons in the midst of their webs.

Plate xlvii, fig. 7. represents the trpical form of the family : it is the .Adcla degecrella, from WESTWOD. The species have not always the long antennæ of this one.

\section{Tineidae.}

Tus finily contains some of the smallest of the Lembortera. Their wings are narrow, in which respect they differ from the Tortricide; and their palpi are well develored. The head is witen densely clothed with scales in front : the antennæ are only moderately long; the spiral tongue is short; and the wings are entire, but convoluted when at rest.

The larvir are very destructive to woollens and household furniture, carpets, clothing, furs, etr.; and when nnce they have taken pressession of a house, it is difficult to disledge them. They are usually of a dirty white, sometimes of a brown culsur, with long hairs from the Imeterior extremity: hut sometimes also naked, or furnished with a few hairs scattered over the hody. They form encons, which thes frequently carry ahout with them; and their dewrordatinns consist in gnawing heles through the wollens, and other goods, when they met pusession of them: so that when unfilded and held up to the light, the articles are often fisund to he perfectly riddled. They underco transformation in the little cases or cocoons they have firmed. and which may often he found in great numbers adhering to spots where they were fixed hy the larræ when about to undergo transformation.

One of the minst effectual modes of preserving wollens, furs, etc. from the depredations of the moth. is to exprise them to sunlight. and suhject them to frequent examinations. When such artirles are kept in dark closets, and left undisturbed during the months of June and July, they will sulfer more or less from moths. Tobacco leaves, eamplhor, turpentine, are prisonous to the moth, and may be employed as protectires against it. 


\section{Tines centera (Fabricius). Honeycomb Moth.}

This moth is notorious for its depredations in the beehire : its larra feeds unon the honeycomb, or beeswax.

Kollar, in his treatise on injurious insects, describes this moth in detail ; and from the matter he has furnished, I have derived the following facts :

The color of the male is yellowish; the antennx, head and back clay-yellow; the abdomen yelluwish brown, and feet yellowish gray with lighter spots. Lpon the back and behind the scutellum there is a blackish brown tuft of hair, the point of which is white. The upper wings are broad, short and obtuse, of a dusty ash-gray, banded from the base to the middle, and dotted with brown : the fringes are brownish white and jagged. The hindwings are light ash-gray, marked by a yellowish spot cn their inner boundary.

The female is larger than the male : her color is of a dark rusty brown on the head and back; the forewings are darker, obtuse and straight, while the hindwings are much lighter. Length of the male, six lines : expanse of wing, one inch.

The caterpillar is cylindrical and spindle-shaped, and, when fully grown, is nearly an inch long : it is of a dirty white color, and has sixteen feet of a cream-color.

Following its singular instincts, the larra, immediately after it is hatched, forms its web of silk, which becomes for it a corered way and protecting screen, wherewith it boldly enters the hive if hatched without, and establishes its home in the midst of enemies. When the bees are at mork, however, it does not appear abroad; but when thes are at rest during the night, it feeds roraciously upon the wax. It increases rapidly, and comes to its full size in about three weeks : it then makes its web stronger, and is transformed to a pupa. If it is late in the season, it remains till spring before it changes to an imago.

The effect of these intruders is first to diminish the wax of the bee-cells, which occasions the loss of the honey; and when this takes place extensirely from the presence of numerous larva, the bees cease working.

There are two generations of moths in a season, according to KoLLAR; the first appearing early in the spring, and the second in July. The female lars her eggs in the cracks of the lower part of the hive, in the night, and the larvæ feed at first upon the young comb ; but they afterwards ascend to the upper part of the hive, where the older kind is deposited.

Many inrentions have been proposed and resorted to, to secure the bees from these intruders : none, it is said, succeed perfectly; and so far from requiring no attention, it is maintained by KoLLAR that the only sure method of cleansing beehires from this moth is to look after and destroy them, both larræ and puræ. The moth is fond of streets, and may therefore be attracted to dishes of sweetened water and rinegar in the night, and by that means may be drowned : some other kinds of obnoxious moths may be destrojed in the same manner. 


\section{Rhivosia posetelda. Chatochelus pometellus (Stephens).}

A moth has been descrihed by Drs. Harris and Fitcr, belonging to the family Tineidex, which has done considerable damage to the apple orcluards in the vallies of the Hudson and Housatonic during the spring of 1853. Dr. Harks has called it Rhinosia pometella, and furnishes the following description :

'Forewings ash-gray, sprinkled with blackish dots, three of which are larger than the rest,

' and placed triangularly near the middle : a dusky transrerse band near the tips,

' and a curved row of seven black dots at the origin of the terminal fringe. Hind-

'wings dusky, with a leaden lustre, black veins, and rery long black fringes. Endy

'and leas beneath yellowish white, with the lustre of satin. Expansion of wing, five

' eighths of an inch' ( Journal of the N.Y.S. A. Society, September). The markings,

however, according to Dr. Firch, are somewhat variable.

The larra is cylindrical, has a pale greenish color, sixteen feet, and a dusky stripe on the back : above this is a narrower whitish stripe, which runs along the middle of the back. The head is yellowish and polished. Length about half an inch. Its marks and colors are variable.

This larva has inflict col considerable injury upon orchards durin It eats not only the leaves, but also the apples. Like the tortrix, it sometimes rolls up a leaf for a habitation; and when the tree is shaken, many let themselves down by threads of silk.

Whale-oil snap, dissulved in water and thrown freely upon the trees, is found to be an effectual remedy against this insect.

\section{Butalis cerealezla. Angoumois Grainmoth.}

Color pale cinnamon-brown; lustre silky : hindwings ashy or dusky lead-color : feelers blackisl near the tip; second joint blackish on the outside : body pale brownish gray. The hear is smooth : antennæ threadlike, jointed : feelers long and curved upwards, with the terminal joint naked and acute; basal joint hairy and short : tongue about half an inch long, and spirally coiled. Forewings rather long and narrow, pointed at the end, and fringed : surface sprinkled with blackish dots, especially near the tips. Hindwings blackish with a leaden lustre, narrow, and obliquely contracted to a point at the tips : fringe blackish, widest on the inner margin. Forelegs blackish; hiud ones fringed on the inner side with long hairs.

The caterpillar, when fully grown, is whitish with a brown head : legs six, with ten wart-like proplegs. Chrysalis is obtuse at both ends : rings of the hody smonth : wingcases extending nearly to the hinder extremity. The skin of the chrysalis remains in the kernel of grain apon which the larva has fed. The insect hatches from June till August. 
The community is greatly indebted to Mr. HARRIs, for his discoveries in relation to the Angoumois grainmoth. He had expressed his conriction, in the first edition of his treatise on insects injurious to the farmer and to regetation, that a certain grainmoth would prove to be the true European angoumois grainmoth, and it seems that this prediction is fully sustained by farther discoreries of our indefatigable and distinguished entomologist.

This insect, in its perfect state, is known to lay from sixty to ninety eggs in clusters of trenty or more upon each grain : these hatch in about fire or six days into threadlike worms, which disperse themselves about the grain-bin. After selecting a kernel by fixing upon its teuder part, the worm burrows into it, and there remains feeding until it arrires at maturity : it then spins a web, diriding its carity longitudinally into two unequal parts by a silks partition, where it undergoes its transformation, the larger carity serving the purpose of a cocoon.

It appears that infected mheat, when somn, may germinate, but the plumule will be weak and small : the insect, however, still remains in the grain, feeding upon the starchy matter, till it is ready to undergo its changes. These take place while the grain is still in the field, and the mature insects may be found flying about the fields in the night, and are ready in due time to deposit their eggs in the growing grain.

It appears that the angoumois moth not only attacks wheat, but also indian corn. Mr. Richard Owex, of New-Harmony, first called the attention of the public to this fact in a communication to the Cultivator in 1816 . In indian corn it attains a rather larger size than in wheat, the wings expanding to about six-tenths of an inch.

The method that has been found most effectual in destroying this grain-morm, consists in exposing the grain to a temperature of $167^{\circ} \mathrm{Fahr}$. for twelve hours; or if the heat is only 104 or $5^{0}$, it is sufficient to destroy the worms, prorided it be continued for fort 5 eight hours. Fumigation is another remedy which has been successfully emplored. Exposure to cold destrors both the larra and its eggs : if the grain, for example, in New-Iork and New-England, is housed when it will be exposed to a cold at zero, the insect will be destroyed.

In addition to the foregoing, it is recommended to thresh the grain at an early day ; inasmuch as by that operation the insect is destroyed to a great extent, after which the grain may be preserved in bulk. Grain, howerer, should not be exposed in open casks when it is liable to become infested : the insect may be excluded by keeping the grain in closed boxes or hogsheads after threshing. Corn in the husk, too, is less exposed to depredation than when husked, especially when it remains standing in the field. 


\section{Tines granella. European Grainmoth.}

Forewings marlled with white or gray, light brown and dark hrown spots, and one square dark spot near the middle of the outer edge. Hindwings blackish. Head tufted. Length three- to four-tenths of an inch. HARRIs.

Moths appear in May, June and August : they breed twice a year.

The caterpillar of this grainworm, instead of lurrowing in the grain like that of the angoumois graiuworm, feeds upon the external surface only, and spins a web in which it entangles sereral grains fir that purpese. When the peried for transformation arrives, it leaves this weh, and secks a crevice in which to spin its cocoon. Altogether they occupy about six weeks in leeling on the grain, which they soil and otherwise injure ly covering it with their webs and excrements.

Such are the characters of the European grainmoth. It appears from the olservations of our distinguished entomologist, Dr. A. Firci of Salem, that he olserved many years ago that grain in some of the mills in his neighborhood was affected much in the way described above, only the caterpillar formed its cocoon within its web.

Although the halits of the foregoing grain insects differ somewhat, the remedies that have been successful in destroying one are equally eflicacious against the other, to wit : fumigation with carbonic acid; exposure in close vessels to heat of 130 to $110^{\circ} \mathrm{Fahr}$. 


\section{ADUTTOLS AND CORRECTIOLS}

Barbarts annelates, Plate vii, fig. 3 (Fitch's Catalogue).

Antennæ, mandibles, legs, thorax, tudimentary wings, green; eyes prominent, black ; posterior part of the head, and all the upper parts reddish; sides greenish : legs long. Inhabits bushes in meadows and borders of woods in September.

Cantuaris atrata, refer to Pl. iv.

Calimorfha parthenice, refer to fig. 3.

Cremastocherlus hentzir, refer to Pl. xxir, fig. 2.

Ceranbix, refer to PI. xxxiv, fig. 9.

LAura, Pl. xxri, refer to Pl. xxxiv, fig. 8.

Leptcra, Pl. xxvi, refer to Pl. xxxiv, fig. 11.

Priones laticollis, refer to Pl. xxxiv.

Stenoconcs cinctus, refer to Pl. xxxir.

Saperda tridentata: refer to Pl. xxsir, fig. 6.

Rhagicm lineatum, refer to Pl. $x$, fig. 1.

Leptura malachitica, tefer to Pl. sxxi, fig. $i$.

Saperda vestita, refer to Pl. xxiir, fig. 4.

SAPERDA - page 122, refer to Pl. xxriv, fig. $\rightarrow$.

Refer Thecla Acis to figs. 1 \& 3.

Page 232, for Pl. xxiv, refer to Pl. xxxix, fig. 1.

Phryganea fasciata, refer to Pl. xxxii, figg. 7 \& 9.

Correct Grammopters, p. 128 , and read Telephores, Pl. xxxiv, fig. 3.

TELEPHORts, refer to PI. xxxir, fig. 3.

Podabres modestes, instead of Telephones, Pl. xxxiv, fig. 1.

Megacephata virginica (Fab.), Pl. xvii, fig. 15.

Clytus votates? p. 118, Pl. viii, fig. 3.

Lradels turcicts, Pl: xxx, fig. 9, var. a (Frten's Catalogue).

Phytucoris lineolaris, $\mathrm{Pl}$. $\mathrm{xxx}$, fig. 7.

Phytocoris coccineos, Pl. zxx, fig. 2 (Fitch's Catalogue).

$$
\text { [Agricultural Report - Vol. v.] } 32 \text { * }
$$


Purtucoris brites, PI. xax, fig. 1.

Pextatona carilex, Pl. dax, fig. 3.

PENTATUMa PENXSYlyaica, Pl. Xxx, fig. 4 ; young (undetermined), fig. 8.

Pige 168, for Redevits, read Sinea stimllatrix, Pl. xxis, fig. 8 (Fitch's Catalogue).

LAPHina TEktissa, Pl. xxiii, fig. 6 .

Latura thuracica, Pl. xxviii, fig. 5.

Laphiba sericrea, Pl. xxriii, fig. 8.

Lapura (undescrilhed), Pl. xxix, fig. 3.

sraputs puladelphete, Pl. xxviii, fig. 1.

STrputs? Pl. xxix, fig. 6.

('tesuphora tminacteata, Pl. xxix, fig. 5 (Frecu's Catalngue).

For Grillus, substitute Orchellisios gracile (Harris), Pl. ix, fig. I (femalc).

Color green shaded with brown, especially on the back and wings; wing-covers and legs green, faintly tinged with brown; oripositor brown, and cimetar-shaped : ${ }_{4}^{3}$ inch in length. This grasshopper is conmon in mealors in August.

Leptis okNata? Pl. xidi, fig. 1.

Leitis etadrata? Pl. xxix, fig. 4.

Leptis (undeseribed], Pl. xxix, fig. 10.

Paje 195, fur Tespa frater.a (Pl. xxri, fig. 6), read Polistes anxelaris.

TEsPA, Pl. xxri, fig. 8.

Plate $\mathbb{x}$, fig. 5, appeurs to be closely allied to the (renus Srvobennoxox? (Fab.). Antenna 10jointed, shorter than the thorax; second short: club 3-jointed. It agrees better with the Genus SINODENnRoy, than with either of the genera of the Licasid E. Referred in the description of the flate, erroneous 15 , to the Genus Scarites. The specimen from which the drawing was made is lost; but the insect is rery common, especially south, in decaying wood and trees. 
Arctia americana. Great American Tiger-moth.

Male. Back of the antenne white, tipped with brown; pectina hrown. Head and thorax l,rown, covered with long hairs : front, at the base of the hairs, ornamented with a white band, surmounted with a crest of hairs trimmed with crimson, and which extends around the thoracic part. Forewings buff-brown: base of the wings marked with white branching spots, which resemble somewhat a cross : wing beyond the middle also marked with a white irregular cross something like an $\mathbf{X}$, extending entirely across the wing, except to that portion which is directed towards the apex : anterior margin has two white spots, a large and a small, between the two crosses: isuer margin has an oblong patch of brown parallel with its edge. Hindwings orange, marked with three round blue-black spots; between them is a lunule : on the under sile, the margin has two brown patches. Aldomen orange, marked in the middle with four transverse lines; beneath brown, except at the extremity. Thighs crimson; legs brown.

In the female the markings resemble the male, but the white is more conspicuous.

Expanse of wing of the female, $2 \frac{1}{2}$ inches.

Captured near Albany.

Thi - moth clusely resembles the English Caja, or Great Tiger-moth. It is rare in NewYork, or rather but few have been taken to my knowledge. Dr. Harris received a specimen frun Trentrn-falls, of which he has given a description in his Treatise on Insects, p. 217. 1852. It is easily distinguished from all our moths by its peculiar markings. 



\section{INDEX OF SPECIES.}

\begin{tabular}{|c|c|c|c|}
\hline & & & \\
\hline & CTIA VIRGINICA, & & TALIS CEREALELLA. . \\
\hline$\ldots \ldots \ldots \ldots \ldots$ & riA VIRGO ... & & e-flies ..... . \\
\hline BUM. & GNNIS APRF & 211 & ALANDRA GRANARIA... \\
\hline UN FLAVOVI & YYNNIS IDEALIA... & & ALATHUS GREGA \\
\hline$\ldots \ldots \ldots$ & ACUS CECROPLA ... & & MORPHA EPIMENIS . \\
\hline GeRIA EXITIOSA ....... & TTACOS LCNA........ & & ALLIMORFHA PARTHENICE, \\
\hline UGERTA TipcLIFOKMIS.... & TTACOS POLY & 236 & MORPHA THYLI \\
\hline DINONIA $-\ldots . . .134$ & TTACUS PFOMETHEES... & & ОRРНА VIF \\
\hline GONIDERLS PALLIPES.... & TTELABUS ANIL & & OSONA CALI \\
\hline GONOM CUPRIPEXYE .... & TTELABUS FUBESC & & SOMA SCRO \\
\hline GONON OCTOPUNCTATUM . & TTELABUS SIMILIS $\ldots$. & & THARIS ATR \\
\hline GRILES REFICOLLIS $\ldots . .885$ & NINES RECTUS $\ldots$. & & THARIS CINI \\
\hline $\mathrm{Tls}-\ldots \ldots \ldots .244$ & e $\ldots . . . . .$. & & BUS LIM \\
\hline MMPENCTICOLLIS $\ldots$ & & 229 & BUS SERRA \\
\hline .... 215 & DIUм нол & 53 & . \\
\hline terpillar . & IDIUA IXEC & 5 & $A P O$ \\
\hline$\ldots$... & IBIDIOM INO & 5 & \\
\hline COLLIS, 49 & MBIDIUM SIGIL & 53 & A A \\
\hline$\ldots 254$ & EMBIDIONI TRIP & 53 & A EPION \\
\hline LLIS, & IBIDIOM VARI & 53 & DMYIA CUI \\
\hline MOREUS, 47 & IVEA & 141 & MYYA DES \\
\hline TICUs . 47 & OPHAGUS & 92 & OMYIA ROI \\
\hline .... 185 & CHINUS CEPH & 41 & OMISIA \\
\hline$\ldots .93$ & CHINUS CONF & 42 & IIA \\
\hline$\ldots \ldots \ldots 158$ & HINTS FON & 42 & 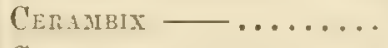 \\
\hline DITS ATERRLMUS .... & INUS PER & 41 & $P A \quad R$ \\
\hline ODIUS BICOLOR........ & US SEPT & & SA 1 \\
\hline odies copronimus.... & S PISI .. & & $A$ \\
\hline ODICS FEMORALIS $\ldots$. & STIS AMET & & NIA FULGIDA. . \\
\hline PHODIOS SERVAL ....... & RESTIS DENT & & IIA INDA $\ldots$. \\
\hline PHODICS STRIGATUS .... & ESTIS DIVA & 85 & \\
\hline NALIS .... & PRESTIS FASC & 83 & ENIOS EMARGIN \\
\hline Blig & PRESTIS FE & 81 & ENIUS LITI \\
\hline ........ & HRESTIS FTLVO-GUTTATA, & 83 & ULCENIUS NEMORALIS. . \\
\hline REODA LANIGERA $\ldots$. & RESTIS LURIDA....... & 86 & Chlogidus sh \\
\hline RCTIA ISABELLA....... & & & Chlaenius t \\
\hline
\end{tabular}

[ Agricultubal Report - Voi. v.] 33 


\begin{tabular}{|c|c|c|}
\hline & & \\
\hline SOMELA AMERICANA. & ToCCINELLA BOREALIS .... & Elater applessifrons... \\
\hline IRYSONELA B.AKSH. . . 133 & CINELLA DECIMAACULATA, 13 S & lilater chafreus ....... \\
\hline IRYSONELA CCEVLIPENNIS, 1 & CCINELLA 12-NOTATA ...137 & Elater comminis... \\
\hline HRYSONELA DFCLPIENS . . 1 & CCINELLA MMACCLATA. 1: & Elater noctilucus ... \\
\hline IRY SOMELA PHILADELPHCA, 1 & CCINELLA INCARNATA... 1: & Elater obesus ....... \\
\hline YSOMELA P'LCHER,... I & Coccinella Novennotata, 13 & Elater oculatus ..... \\
\hline YSOMELA SCALARIS ... 1 & Coccinelea 5-iy & Exgis fasciatus ....... \\
\hline RYSONELA TREMCLA ... & C. TRANSYEY & Extilia concava..... \\
\hline RYSOMELA THIMACELATA, 13:- & CINELLA TRI & TILIA ER \\
\hline YSOPHANES PHLEAS ... & CINELIAA 20 & LIA SII \\
\hline ADA CAXICULARIS..... I & DOXIS ANNE & emerides.... \\
\hline ADA NOYEBORACENSIS . & LIAS PHLODICE ....... 2) & $T A \mathrm{~V}$ \\
\hline CADA SEPTEXDECLM..... 1 & Copris carolinus...... & BTS ED \\
\hline CINDELAA ALBILABRIS.... & Coprobies Lavis....... & OSOMA MVALIS . \\
\hline ICINDELAA CAMPESTRIS $\ldots$ & US TRISTIS. & CHXTES EG \\
\hline CINDELA DEODECINGGTTATA:37 & Corn Emperor-moth ....... : & CHLORA CEI \\
\hline ICINDEZA GEXEROSA..... 34 & Crenastocheilus hentzil, & DAMUS TITYRUS. \\
\hline ICINDELA GUTTATA...... & CreMASTOCHELLUS SCARER . & DRYAS GRATA $\ldots$ \\
\hline ICINDELA HAMORRHOIDALIS, $3 \bar{i}$ & Criocemis 12-runctata .. 12:! & EvMolpUS AUBATUS.. \\
\hline ICIXYDELA HIRTICOLLIS ... & Cucujus clayatus ...... & Fonfictza ....... \\
\hline ICINDELA PATRUELA ... & Cupes capttata ....... & Fleas.......... \\
\hline ICINDELA PUNCTULATA... & Crchres sideos ........ & Galerita americana .... \\
\hline ICINDELA PURPUBEA .... & Cinthia cardut .........210 & Galem UCa Calmariensis.. 134 \\
\hline ICINDELA REYANDIS .... & Cynthla huntera....... 210 & Galervea vittata ..... 131 \\
\hline CICINDELA VULGaRIS .... 34 & Cyrtosia arcuata ..... 15. & Galerucides...... \\
\hline Cinbex americana ..... 191 & Cyrtosia fuligliosa $\ldots . . .154$ & GALGULUS OCULATUS \\
\hline HMEEX VLMI .......... 191 & Danats plexippus ...... 20.2 & GARGARA CINEREUM $\ldots$ \\
\hline IMEX Lectularius...... 169 & Deiopera bella ........ 2.2.ti & GARGARA DISCOIDALIS $\ldots 159$ \\
\hline IMEX PCRCIS.......... 163 & Ita-moth ............ & GaRGARA INERMIS \\
\hline imundis plLosts ...... 42 & Dexidoides canadensis.. & GaRGARA MACD \\
\hline ISTELA fREVIS ........ & Dermestes lakdarius ... & 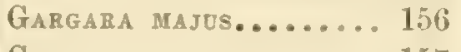 \\
\hline LERUS apiaries....... 91 & Desmocerts palitatus... 1:.; & Gargara NigRICEPHALA. \\
\hline CLISlOCAMPa AMERICANA .. 235 & Dichelosycha elongata. TK & Gargara pectoralis .... \\
\hline GLISIOCAMPA SEUSTRIA ... 240 & Dicelues dilatatus .... & Gargara pubescens .. \\
\hline LISIOCAMPA SILVATICA... 239 & Dicelus elongates..... & Gargara querci........ \\
\hline VIVINA LINEOLATA ..... 44 & TYOPTERA BETICULATA. & Geometra catenaria .... \\
\hline CLytes CAMPESTRIS..... 118 & DictYoptera terMANÁLIS 。 & Geometra sertata ..... 249 \\
\hline 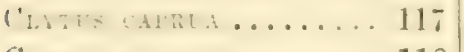 & YOCAMPA IMPERIALIS ... 233 & GEONETRA TRANSTERSATA, 2 \\
\hline Clytes hamates........ 118 & OCAMPA PELLUCIDA _.. $\quad 239$ & Geotrutes Splendens ... \\
\hline IUs Nobilis........ 11 & DRYOCAMPA VIRGINIEASIS . 239 & RRIS MABGINA? \\
\hline Tis firti......... 11 & Dirschirity Globuloses . . 44 & LAUCOPIS PHO \\
\hline TUS SPECIOSUS ....... 11 & ICUS HARRISII........ & GORTYNIA LEUCOSTIGMA... 2f \\
\hline IUS ExDATES........ 11 & HIDION PITATOR..... 124 & GORTYNIA ZEA... \\
\hline CCINELLA ABBREYTATA 1 & PHIDION VILLOSLM.... 124 & Grammoptera...- \\
\hline & & \\
\hline
\end{tabular}


II LICA CHALYBEA ...... 1:3.1

IAlirlus 12-punctatus.. 55

HalipLUS INMACULATICOLLIS, 55

Haumatocerus purcis . . 16 16

IIAfipalus blColor ...... 45

Harpalus erraticus .... 46

Harpalós FaUNUS ...... 45

Harrest-flies .......... 149

Hawk-moths .......... 216

HerioLUs ........... 241

Hesperia peckius ...... 216

Hessian-fly ........... 173

Hipparchila alope ...... 213

Hipparchia NePHELE ....213

Histe conformis....... 66

Honeycomb-moth .......253

Hopla trifasciata .... 78

Horntail............ 191

IITLOBIUS PALES ....... 107

HYLURGUS TEREBRANS ... 112

ICHNEUMON BREVICINCTOR 193

Ips bifustulatus ...... 60

Ifs Fasciatus ........ 59

IPS QUADRISIGNATA .... 60

IPS SANGUINOLENTA...... 69

Ithycerus Noveburacessis, 110

Ladybirds ............. 161

Lamia _... . . . . . . . 124

LAMPYRIS ANGTLATA ... 89

LAMPYRIS CORRESCA ..... 90

LAMPYRIS LATICORXIS .... 89

LAMPYRIS NIGRICANS ..... 89

LAMPYRIS SCINTILLANS ... 89

LAMPYRIS VERSICOLOR.... 90

Lasiocampians......... 234

Leaf-hoppers.......... 152

Leaf-rollur. . . . . . . . 250

LEBIA ATRIVENTRIS ..... 42

Lebia smaragdula ...... 43

I.EBIA VIRIDIS ........ 43

Lema trivitTata ....... 134

LEPTCEA MALACHTICUS... 127

LEPTCRA OCTOPUNCTATA.. 127

LEPTERA BCBRICA ........ 127
Page

LEPTURA SUBPUBESCENS... 127 OMOPHRON LAEIATtM..... 52

LEPTURA VITTATA ...... 126! - rar. TESSELlates, 5:

Libellưla pulchella ... 185 Oncidebes cingulatus . . 123

LiMexitis arthemis ..... 211 ONThOphages hecate.... 68

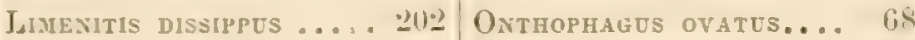

Linevitis ursula ...... 203 Ophion glabratus ..... 19)

Leptis _........ 181 Ophion Macrertu ..... 196

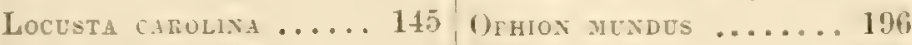

Locusta corallina ... 146 Ophion plrgatus ...... 197

Loctsta vebrlosa ...... 146 Orimia levicostigma .... 2.30

Locesta stlpherea ..... 146 PAchyta cordiferd .... 128

Loxotexia rosaçeava... 250 Pale Emperor-moth ...... 230

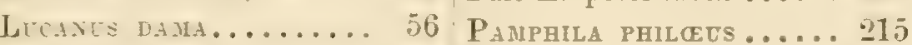

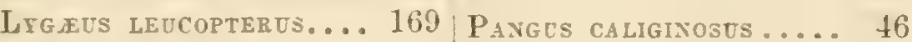

Macrodactylus subspinosa, 78 Papilio asterias ...... 200

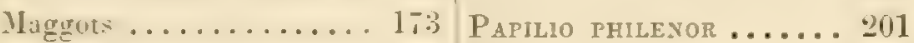

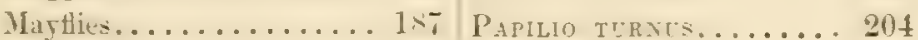

Melited pheton ...... 212 Pafllio tritica......... 209

Melital pharos ......2212 Parnes crenatts..... 56

Meloe axgusticollis .... 97 Parnes fastigtates . . . 56

Midis filates......... 18.3 Pelecrivos politcrator .. 196

Uilesia virginiedsis .... 183 Pelecinus policerator .. 196

Moxochayus maculosus . 123 Pelidnota maculata... T

Monochamus pUlcher ... 123 Pelidvota penctata .... T

Monochanus scutellatus, 123 Phalena lixa....... 233

Movochanos titillator . 123 Phalema quercaria ... 245

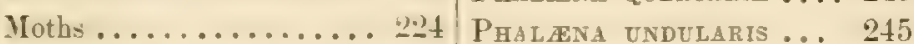

Mesca vomitoria ...... 181 Phanets carcifex .... 68

Mrmelion ........... 185 Phaneroptera angustifolia, 145

\begin{tabular}{l|l|l} 
Necrodes surinamensis .. 58 & Phelanpelis satellita . 219
\end{tabular}

9 'Necrophorus americanus, 57 Phrganea semifasclata, 188

99 Necrophord s pymeus... 57 Phyllobius texiatus ... 107

9. Necrorhorus tomentosus, 07 Phyllophaga drakil .... 72

0 | Nitidila bipustulata ... 58 Phyllophaga georglana 72

Noctua margaritata.... 24. Phrllophaga hirticula.. 72

Noctua nundina........ 246 Phyllophaga pilosicollis, 72

Noctua squamolaris .... 245 Phyllophaga qtercisa .. 72

Noctua uxdularis ......24.5 Phyllophaga tarlolosa . 72

Fotiophiles porkectes .. 52 Pieris niclppe........ 205

Sotonectes —...... 166 Pigeon Tremex........ 192

Nymphalis arthents .... 211 ! Pimpla lunator....... 194

Odontata scutellaris .. 1:0 PIssodes strobi ....... 108

Fidonichus thoracica .. 19,5 Pitho americasa ....... 98

Osalises coccinatrs .... (0) Plant-lice .......... 114 


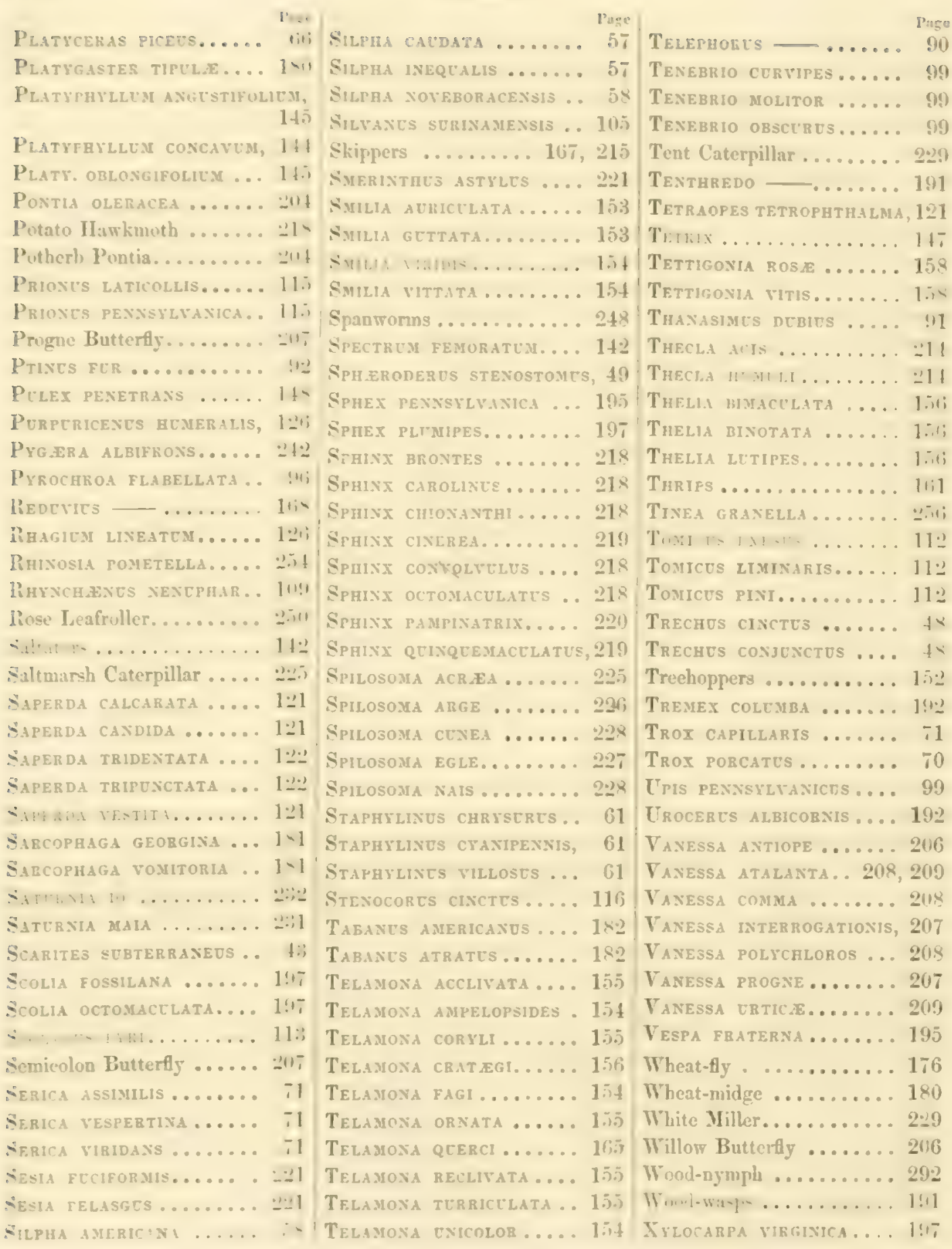




\section{ENGLISH INTEXX.}

Admirals, page $200^{\circ}$.

Angoumois grainmoth, 254.

Antlion, 185 - 187.

A phanipterous insects, 148.

Apbides, $158-162$.

Aphis-eaters, 136, 159.

Appletree blight, 79, 161.

Appletree borers, 87, 120.

Appletree insects, 162, 251 .

Appletree worms, 110.

Ashtree borers, 87, 222, 223.

Asparagus insect, 123.

Aspentree borers, 121.

Aster-bugs, 134.

Atmospheric blight, 164, 165.

Baconbug, 60.

Balancers, 172.

Balsamine butterfly, 210.

Barklice, 149, 162, 163.

Barkwormas, 85, 98, 118, 119.

Beanmoths, 226.

Beulbugs, 169, 170.

Beechtree insect, 154.

Bee-eating beetles, 80, 91 .

Beeswax-moth, 253.

Berrybugs, 191.

Binds destroy insects, 74, 82, 163, 240 .

Blackberry worm, 122.

Blackeherry insects, 163 .

Blackelocks, 39, $\$-49$.

Blight, 161.

\section{[Agriculteral Report - Vol. v.]}

Blistering-flies, 96, 97.

Bombardiers, 39, $41-43$.

Bookworms, 92.

Buckwheatworms, 213.

Burrowers, $39,43,14$.

Butterflies, 199 - 216.

Buttonwood caterpillar, 284 .

Cahhage batterflies, 20 5.

Cabbage-Trorms, 243.

Caddiceflies, 188.

Canada-thistle insect, 15 วิ.

Candle-owls, 89.

Carpet-eating insects, $25 \%$.

Carrion-beetles, 57, 58, 70.

Carrot-butterfies, 100.

Ceiling-bugs, 197 .

Cellarbugs, 98.

Cherrybugs, 73, 79.

Cherrytree worms, 110, 222.

Chesnut-rail worm, 118.

Chesnut weevil, 111.

Chigre, 148.

China-aster insect, 97.

Chinchbugs, 169.

Clonded butterfly, 213.

Cockroaches, 141.

Coleopterous insects, $31-138$.

Columbine-worm, 243.

Coruma butterfly, 208.

Copper butterfly, 216.

Corneating worns, 86.

Corn emperor-moth, 231, 232 .
Corn weevils, 101 - 106, 111.

Crickets, 143.

Cucumber-bugs, 134, 135.

Currantbush insects, 163,222 , 223.

Cutworms, 243.

Dahlia-worm, 243.

Deathwatch, 92.

Deril's-darningneedle, 184.

Dipterous insects, $172-183$.

Dischargers, $39,50-52$.

Dogday harrestfly, 152 .

Dogsbane insect, 130 .

Dogwood-moths, 252.

Dragonflies, 184.

Dung-beetles, 63 - 71 .

Eartrigs, 139.

Eatable grubs, 116.

Elder-pith worm, 125.

Elmatree blight, 165.

Elnitree bugs, 134.

Elmtree caterpillars, 232, 236.

Emperor-moths, $220-233$.

Euplexopterous insects, 139.

Fire-beetles, 88.

Fireflies, 89.

Fisheating bugs, 166.

Fleas, 148.

Flies, 181.

Flower-beetles, $63,80,119,139$.

Forest tent-caterpillar, 239.

Fringetree moth, 218. 
Fritterlaries, 206.

Fruit-bectes, 73, 110, 139

Fruitbugs, 171.

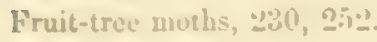

Fur-beutles, 60.

Fureating insects, 25:?

Gatfles, $1: 2$.

Garden crickts, 142 .

Gigantic beetles, $i 1$.

(j)ororms. 89.

Goldenrod insect, 79.132 .134$.

(iooseburry buteifly, 2013.

Grainmoths, 2.it, 256 .

Grain-weerils, $101-106,111$.

Grainworus, 92, 91.

Grapevine beetles, 76,77 .

Graperime insects, $157,158,220$.

Grasping bectles, 140 .

Grasshopper:, 14 .

Grassmoths, 226, 227.

Grassworms, $73,86,88,-2 \pm 3$.

Harmless insecte, $59,112,124$, $1+4,152,153,21,202$, $227,229,231,237$

Harvestflies, 149, 15:

Hawknoths, $216-2.23$.

Hay insect, 147 .

Hazletree insect, 15. .

Ifessianfies, $173-176$.

Iteteropterous insects, $166-171$.

ITickory horess, 82, 93.116, 123.

IXickorytrec caterpillar, 209, 2411.

Homopterous insects, $149-165.5$.

Iloncycomb-moth, 253 .

IIoneyder, 159, 163.

Hooppole insects, 98, 19:3.

Hop hutterfly, 214.

Horn-bectles, $6 \%$.

IIorntuges, 73.

Horntails, 191.

IIorsechesriut-1noth... "SI

Torsenfies, 1‥

Horseradi-L-hnga, 1:95.

Ilumminglir l-nioths, 217 .

П5rucnonterous ins. 189-151\%.
I Icheeumon-flics, 193, 194.

Insects serviceable to the furwer and gardener, $33-41,43$. $46,50,52,53,57,67,136$, $161,162,193,196$.

Jigger, 148.

Jumping beetles, 114 .

Katydids, $144,14$.

Lacewing, 159.

Ladphinds, $136-138,161$.

Leadeaters, 93

Leafeating eaterpillars, ․․ $131,2 \%$, $233,234,238,239,241,242$.

Leaf hoppers, 152 .

Leafrollers, 250.

Lepidopterous insects, 128 - 2.56. Lichen-(rorms, 2.23, 22.).

Lilac-moth, 238 .

Lindeutree borer, 121.

Locusts, $145,146$.

Locust-tree insect, 130, 179, 217

Loopers, 249.

Lychnis blight, 164.

Maggots, 173, 181.

Maize-bugs, 169.

Vaize-moths, 226 - 22R, 223:? $24: 3$.

Iaize-worms, 8l?,

Mapletree insects, $19 \%, 19 \%, 194$.

May-beeles, 73 .

Mayfies, $18 \%$.

Yealmorms, 99.

Messuring worns, 248, 249.

Milkweed-maths, 22-27.

Mi!ler: , 2-2n?

Mulecrikkete, 1f:

Mountinash insect=, 2229. 22.3.

Mulherry beetles, 9:3

Mu-tur.l-lues, 135.

Neuropterous insects, 14 187 .

Nutweevil, 109.

Oals-beauty, :24:is.

Oaktree bertes, 82. 8s, 106, $1: 4$.
Ouktree eaterpillars, 234, 236. $240)-24: 2$

Oaktree inscets, 231, 245.

Orchard caterpillars, 235, 239 254.

Orchard-wornıs, 120

Orthopterous insects, $140-147$.

Parasitic insects, 53, 179, 180 193,196 ,

Parsley butterfly, 20 ?.

Peabugs, 100, 228.

Peachbug, 79, 80, 111.

Peachtree insects, 160, 22:2.

Peachtrce yellows, 113.

Pear-blight, 113, 165.

Peartree beetles, 76, 110, 113

Peartree insects, 160, 251 .

Pignut-tree borer, 85.

Pinetree beetles, $82,83,91,108$, $111,112,113,126$.

Plantlice, 149, 158 - 162.

Plumtree beetles, 73 .

Plumtree silkworm, 250.

Plum-тrecrils, 109, 111.

Poplartrec korer, 121, 133.

Poplartrec moths, 232.

Potato-blight, 164.

Potato-flics, 96, 129.

Potate hawkuoth, 21 .

Potato-moth, 219.

Praying beetle, 142.

Radish-bugs, 135.

Raspberry borer, 122.

Raspberry insect, 85.

Pice-wecril, 106, 112.

Rooks destroy caterpillars, 74 .

Rooteating worms, 86 .

Rosebug, 79.

Rose leafhopper, 158.

Rose leafroller, 250.

Tinttenwood beetles, 59.

Ilunning beetles, 140 - 142.

Sacred beetles, 63, 67 .

Saltmarsh caterpillar, 225

Sassafras-moths, 232. 
Sawbectles, 115

Sawflies, 190 .

Searenger bectles, 57.

Scmicolon butterfy, 207.

Serentecn-year locust, 10 .

Sexton-hectles, $56-58$.

Silkweed insect, 12t.

Skin-destroying beetles, CO.

Skippers, 167, 215.

Snaileaters, 89.

Snaplugs, 86.

Snowball insect, 163 .

Social ant: 184.

Social butterfies, 214.

Social catcrpillars, $222,23 \frac{1}{2}, 210$.

Spaumorns, 248.

Sphinges, 215 - 221.

Spindlew orms, 243.

Spring-beetles, 80 .

Squashbugs, 171.

Syuirting bcetles, $41-43$.
Stag-beetle, 66 .

Stinking bec les, $50-52,61$.

Strawberry-bugs, 171.

Tent-caterpillars, 235.

Thoruapple insect, 155.

Tiger-beetles, $33-38$.

Tigermoths, 229.

Timber insects, 92-94, 114, 124.

Tortoiseshell butterfly, 209.

Treehoppers, 152.

Trichopterous insects, 188.

Tumipeaters, 129, 135.

Tussocks, 230.

Walking beetles, 140, 142.

Nalkingsticks, 142.

Tralnuttrec girdlers, 123.

Walnuttrec noths, 238, 240.

Wasps, 195 .

Water-beetles, $54-56$.

Waterskippers, 167.

Weerils, $101-106,108$.
Wheatbug, 92.

Wheatflics, $176-178$.

Wheat insects, $101-106,108$, $111,161,169,228$.

Wheatmidge, 180.

Wheatstalk insect, 179.

Wheatworms, 243.

Whiteants, 184 .

Wildeberry butterty, 203.

Wildeherry caterpillars, 236.

Willow butterflies, 206.

Willow insects, 179 .

Wireworms, 86, 88.

Woodbine insect, 154.

Woodeating beetles, $66,93,112$.

Woodeating caterpillars, 241.

Woodwasps, 191.

Woodworms, 98, 114, 119, 124. $192,211$.

Woolleneating insects, 252. 


\section{MULX OE ANGLULELD NAHES.}

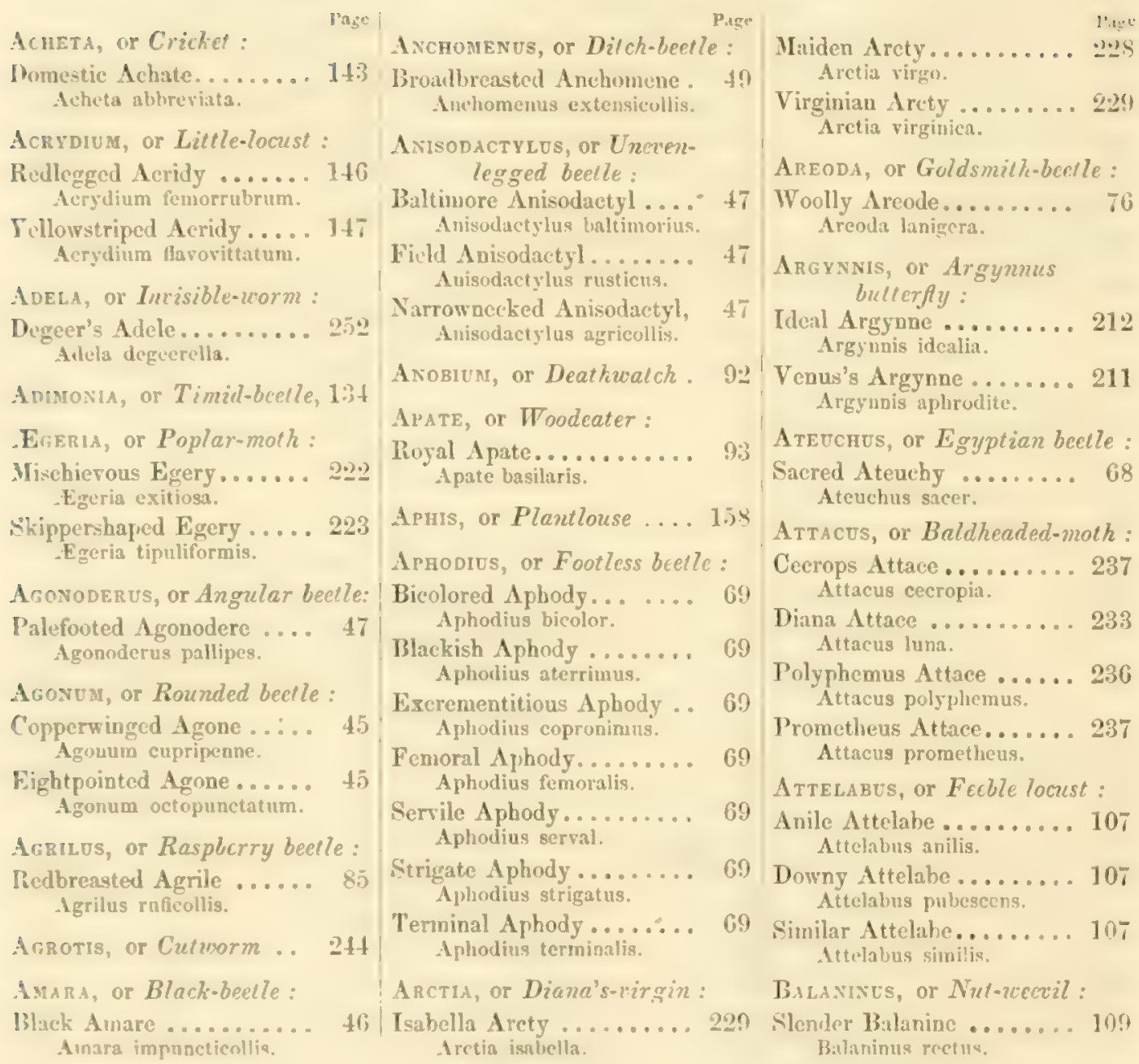


Snouted Balanine ........ Page B.blininus nascicus.

BExbidium, or Topshaped beelle:

Ilandsome Bembidy...... Bembidium honestum.

Homely Bembidy ........ Bembilium inornatum.

Sealshaped Bembidy...... Bembidium sigillare.

Threepointed Bembidy.... Benbidium tripunctatum.

Uneven Bembidy ........ Bembidium inequale.

Variegated Bembidy...... Bembidium variegatum.

Buatta, or Cackroach :

Domestic Blatter ........ $1+1$ Blatta orientalis.

Pale Blatter ........... 141 Blatta nivea.

Boletophages, or Musherom. eater :

Horned Boletophager..... 98 Boletophagus cornutus.

Bомвух, or Silkworm, 225, 23\%

Brachivus, or Shortwing :

Earheaded Brachine ..... 41 Brachinus cephalotes.

Groorewinged Brachine... Brachinus perplexus.

Smoking Brachinus ..... 42 Brachinus fumans.

Wellshaped Brachine ..... 42 Brachinus conformis.

Brenthus, or Longsnout :

Northern Brent ......... 106 Brenthus septentrionis.

Bruchus, or Peaborer :

Pea-eating Bruchy....... 100 Bruchus pisi.

BUPREstis, or Burncove :

Banded Buprestis ....... Buprestis fasciata.

Brownspotted Bupresti.s ... Buprestis fulvoguttata.

Dentipede Buprestis...... Buprestis dentipes.

Divaricate Buprestis...... Buprestis divaricata.

85
Page! Page Femorate Buprestis ..... 8 Buprestis femorata.

Lurid Buprestis ....... 85 Buprestis luridus.

53 Virgin Buprestis ....... 83 Buprestis virginica.

53 Butalls, or Angoumois moth:

Graineating Butaly...... 25t Butalis cerealella.

Catandra, or Corneater:

Granary Calandre....... 101 Calandra granaria.

Calathus, or Baskel-beelle:

:) Social Calathy .......... 38 Calathus gregarins.

Calimorpha, or Comely moth :

Leaf Callimorph ........ 228 Callimorpha phyllira.

Maiden Callimorph....... 227 Callimorpha virguncula.

Monthly Callimorph...... 228 Callimorpha epimenis.

. Virgin Callimorph ...... 227 Callimorpha parthenice.

Calosoma, or Handsomebody:

Lively Calosome ....... 52 Calosoma calida.

Searching Calosome ...... 51 Calosoma scrutator.

Cantharis, or Blisterfly:

Ashy Cantharis.......... Cantharis cinereus.

Blackish Cantharis ...... 97 Cantharis atrata.

Carabus, or Leapbeetle:

Chained Caraby ......... Carabus vinctus.

Fringed Caraby ......... Carabus limbatus.

Punctured Caraby ....... Carabus serratus.

CARPOCAPSA, or Fruilworm:

Orchard Carpocapse..... 251 Carpocansa pomonella.

Cassida, or Tortoise-beetle:

84 Clubbed Cassid.......... 130 Cassida clarata.

Shielded Cassid......... 130 Cassida scutellata.

Catocala, or Brounmolh:

Sooty Catocale........ 247 Catocala epione.

Versicolored Catocale..... 24i Catocala aftinis.

Cecidonxia, or Hessianfly:

Destroying Cecidouny..... 173 Cecidomyia destructor.

Locusttree Cecidomy ..... 179 Cecidomyia robinia.

Wheat Cecidomy ....... 176 Cecidomyia tritici.

Wheatstalk Cecidomy .... 179 Cecidomyia culmicola.

Willow Cecidomy....... 179 Cecidonyia salicis.

Cerameyx, or Hornbug . . 116

Ceratocampa, or Hornmoth:

Regal Ceratocamp.... . 23s Ceratocampa regalis.

Ceresa, or Fatulfy:

Buffalo Cerese ........ 155 Ceresa bubalıs.

Twospotted Cerese....... 15J Ceresa diceros.

Cetonia, or Rose-beetle:

Clothed Cetony ........ 78 Cetonia inda.

Shining Cetony........ 80 Cetonia fulgida.

Chlannus, or Grassgreen beetle :

Emarginate Chleny ...... 47 Chloenius emarginatus.

Grove Chleny......... 48 Chloenius nemoralis.

51 Silky Chleny.......... 48 Chlonius sericeus.

Stone Chleny ......... 48 Chloenius lithophilus.

51 Woolly Chleny........ 48 Chlonius tomentosus.

Chrysomela, or Goldenbug :

American Chrysomel ..... 133 Chrysomela americana.

Banks's Chrysomel....... 138 Chrysomela banksii.

Beautiful Chrysomel...... 13? Chrysomela pulcher.

Bluewinged Chrysomel.... 132 Chrysomela carulinennis. [Agricultobal Report-Vol. v.] 3.j 
Deceiving ('hrvsomel ..... Ti: 1: Chrysomola decipizas.

Ladderlike Chrysomel .... 1:31 Chrysometa scalaris.

l'hilaulelphia Chrysomel ... 13U Chrysumela gibiladelphica.

Threspotted Chrysomel .. 132 Chrysomela trimaculata.

Curpsomaxis, or Goldenlighe:

Shorttailed Chrysophane .. 216 Chrysophanus phleas.

Creada, or Harecslly:

Dugday Cieade ........ 1.i2 Ciemala canicularis.

Term-Yurk Cicade....... 1.i.2 Cicidla noveburacensis.

Serenteen-pear Cicade.... 150 Cicada septendecim.

Crcrisdela, or Glorcicorm; called also Tiger-beelle, and Sandleaper:

Broulluned Civindel...... ;, i Cicindela repandis.

Common Ciciulel......... Cicindela rulgaris.

Cousin Cicindel ......... Cicindela patruela.

Dutted Cieindel ......... Cicindela guttata.

12-dotter Cicindel........ Cicindela duodecinguttata.

Eimervidal Cicindel........ Cicindela hamorrhuilals.

Field Cicindel .......... Cicindela canpestris.

Gentle Cicintel.......... Cicindela generosa.

Punctulate Cicindel ...... Cicindela punctulata.

l'urple Ciciodel ......... Cicindela purpurea.

Roughnecked Cicindel.... Cicindela hirticollis.

Whitehaired Cicindel ...... Cicindela albohirta.

Whitelipped Cieindel ..... Cicindela albilabris.

Cimaex, or Saufly:

f.Intree Cimbice ....... 1!1 Cimbex ulmi.

Crsex, or Domestic bug :

Burlitead Cimice ........ 169 (imex lectularins.
Crandas, or Lillebug: ${ }^{\text {Puge }} \mid$ Throespotted Coccinclle ... 137

Hairy Cimindis........ 42 Cimindis pilusus.

Cistela, or Cashet-beelle:

Short Cistel ........... Cistela brevis.

Clert's, or Buthirc bectle:

Bevecating Clery ........ !1 Clerus apiarius.

Clisiocaura, or Temlmoth:

Ameriean Clisiocamp..... 235 Clisiveampa ancricana.

Forest Clisiocamp ....... 239 Clisiocampa sylvatica.

Whiteoak Clisiocamp..... 240 Clisincampa neustria. Coecinclla trioculata.

Twelvespotted Coccinelle.. 137 Coccinella duodecimnotata.

Twentrspotted Coccinelle. . 137 Coccinella vigintomaculata.

'Iwodotted Coceinelle.... 13: Coccinella binotata.

Twospotted Cocrinelle .... 185 Cuccinella binaculata.

Coccus, or Barklouse.... 16:

Cestoxis, or Ceiling-uasp :

Ringed Celiox ......... 197 Cuelinusis annularis.

Colias, or Baslard bullerfly:

Loyal C'olias ........... 201 Culias philodice.

CLIVINA, or Soothsaying beetle:

Iuined Clivine ........... 44 Clivina lineolata.

Copris, or Excrement-beetle:

Caroline Copris......... it Copris caroliuus.

Clritus, or Noisy beetle :

Buatiful Clyte........ 117 Clytus speciosus.

Chesnut-rail Clyte ...... 118 Clytus campestris.

Gazelle Clyte......... 117 Clytus caprea.

Hooked Clyte......... 118 Clytus bamatus.

Noble Clyte ........... 117 Clytus nobilis.

Painted Clyte.......... 117 Clytus pictus.

Waved Clyte .......... 118 Cletus undatus.

Coccinella, or Ladybird:

Abbreviate Coccinelle .... 138 Coccinella abbreviata.

Coprobics, or Dung-beulle:

Dullcolored Coproby...... 67 Cuprobius lavis.

Conels, or Squashbug :

Sombre Corey.......... 17 Coreus tristis.

Crfomastocheilus, or Hanglip:

Hentz's Cremastochile .... 77 Cremastocheilus hentzii.

Crioceris, or Ramshom :

12-pointed Criocere ...... 129 Crioceris duodecimpunctats.

Crcoses, or Mixed-beetle :

Clubfooted Cucujy....... 60 Cucujus clavipes.

Crossbarred Coceinelle.... 138 Coccinella transversoguttata.

Firesputted Coccinelle.... 136 Coccinella quinquomaculata.

Fleshcolured Coccinelle ... 136 Coceinella incarnata.

Yinespotted Coccinelle..., 136 Coceinella novemnotats.

Sorthern Coccinelle ..... 136 Cuccinclla burealis.

Cepes, or Epicure:

Riedheaded Cupes........ 9.2 Cupes capitata.

Cercelo, or Bean-beetle:

New-York Curculy ...... 110 Curculio noveboracensis.

Cycuros, or Longheaded lcetle:

Tapering Cychre ...... 50 Cychirus viduus.

Spntless Coccinelle ...... 137 ('occinella immaculata.

Crntula, or Cynthian lnutlerfy:

Tensrutted Caccinelle.... 138 Hunter's Cinthy........ 211) cociulla recinmaculata. Cynthia hurters. 


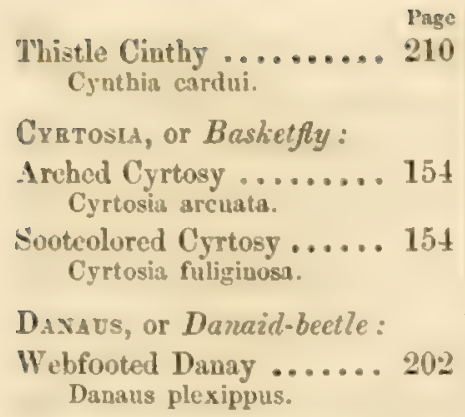

DelopeIA, or Juno's-nymph :

Belle Diopey .......... 225 Deiopeia bella.

Dendroides, or Branching beetle:

Canadian Dendroid....... 96 Dendroides canadensis.

Dermestes, or Skineating beetle:

Baconeating Dermester ... Dermestes lardarius.

Furdestroying Dermester . . Dermestes vulpinus.

Desmocerus, or Closehorn beetle :

Cloaked Desmocere ...... 125 Desmacerus palliatus.

Dichelonycha, or Clovenfoot :

Elongate Dichelonyche.... 78 Dichelonycha elongata.

Dicosus, or Carred bette :

Broad Dicele ........... Dicolus dilatatus.

Long Dicele ........... Diccelus elongatus.

Dictyoptera, or Netwing :

Reticulate Dictiopter..... Dictyoptera reticulata.

Terminal Dictiopter ...... Dictyoptera terminalis.

DRYocaripa, or Woodmoth:

Imperial Dryocanu ..... 233 Dryocampa imperialis.

Pellucid Dryocanip....... 239 Dryocampa pellucida.

Firginian Dryocamp...... 239 Dryocampa virginjẹsis.
Page Puge

Dyschinius, or Clumsyfinger :

Globeform Dyschiry...... 43 Dyschirius globulosus.

Dyticos, or Diving beetle :

Harris's Dytice......... 5. 5i Dyticus harrisii.

Elaphidion, or Fawn-beetle:

Shaggy Elaphidion...... 124 Eliphidion villosum.

Eraphits, or Nimblebug:

Brushy Elaphre........ 52 Elaphrus ruscarius.

ELATER, or Springing beetle :

Ashcolored Elater ...... 88 Elater cinereus.

Common Elater ........ 88 Elater communis.

Flatfronted Elater...... 88 Elater appressifrons.

Nightshining Elater ..... 88 Elater noctilucus.

Speckled Elater........ 87

Elater oculatus.

Swelled Elater........... 88 Elater obesus.

Walnutcolored Elater..... 88 Elater glandicolor.

Eunis, or Worm-beetle:

Notehed Elmis ........ 56 Elmis crenatis.

ENGis, or Narrow-beetle:

Swathed Engis ........ 59 Engis fasciatus.

Entilis, or Thistlefly:

Concave Entily......... 153 Entilia concara.

Emarginate Entily...... 153 Entilia emarginata.

90 Sinuate Entily . . . . . . 153 Entilia sinuata.

90 Eercauta, or Blistering beetle:

Striped Epicaut ........ 96 Epicauta vittata.

Erebus, or Darkworm :

Sweet Ereby ......... 246 Erebus edusa.

Ephemera, or Mayfly... 187

Eriosoma, or Woolfly.... 161
Euch.stes, or Finchaired Page moth:

Bright Euchate ........2.27

Euchres ægle.

Euchuona, or Broun-beeile :

Bachelor Euchlore...... 78 Euchlora cuelels.

Eudamos, or Happy butterfly :

Tityrus Eudame........ 215 Eudamus tityrus.

Eudruas, or Woodnymph:

Gracious Eudryad , ..... 242 Eudryas grata.

Evmolfus, or Melodious beetle :

Golden Eumolpy ........ 130 Eumolpus auratus.

Forficula, or Pinching beetle,

Galerita, or Larkbug :

American Galerite ...... 41 Galerita americana.

Galeruca, or Capubeetle:

Calmarian Galeruce ...... 134 Galeruca calmariensis.

Striped Galeruce ....... 134 Galeruca vittata.

GALGULOs, or Toadbug :

Large-eyed Galgule...... 167 Galgulus oculatus.

Gargara, or Drovefly:

Blackheaded Gargare..... 157 Gargara nigricephala.

Cinereous Gargare ....... 156 Gargara cinerea.

Discoid Gargare ......... 157 Gargara discoidalis.

Downy Gargare ......... 157 Gargara pubescens.

Great Gargare ........ 156 Gargara majus.

Frontspotted Gargare .... 156 Gargara maculifrontis.

Oak Gargare.......... 156 Gargara querci.

Pectoral Gargare ........ 157 Gargara pectoralis.

Snooth Gargare........ 157 Gargara inermis. 
GeOMetra, or Measuring- "'ag" norm:

Chainnarked Geumeter ... 24? Geumetra catenaria.

Crossbarred Geometer .... ¿4! Geometra transversata.

Scollopped Geometer..... : $f$ !) Gevenctra serrata.

Geotrlpes, or Burrowingbeetle:

ipplendent Geatrupe ...... (iT Geotrupes splendeus.

lyearts, or Shipper:

Marginate Gerris ....... 167 Gerris marginatus.

Glaucopis, or Oulmoth :

Stony Glaucope ........ 223 Glaucopis pholus.

Gortrini, or Spindlencorm :

Maizeating Gortiny....... 243 Gortynia zea.

Whitersinged Gortiny .... 243 Gortynia leucostigma.

Grammoptera, or Letcemoing,

Grillotalpa, or Molericket :

Shortwinged Grillotalp.... 143 Grillotalpa brevipennis.

Haliplos, or Sea-beetle:

Browubreasted Haliple.... 55 Haliplus immaculaticollis.

12-pointed Haliple....... 55 IIaliplus duodecinpunctatus.

LALTICA, or Leaper:

Cucumber Haltice ....... 135 llaltica cucumeris.

Steeleolored Haltice...... 135 IIaltica chalybea.

Tarystriped Haltice ..... 1355 Ifaltica striolua.

Hasatocenos, or Crookhom:

Shady Hamatocere...... liv II matocerus purcis.

Harpalus, or Dog-beetle :

Bienlored Harpaly ....... 45 II:arpalus biculur.

Fawncolored Harpals .... 45 Ilarpalns faunus.
Straitsided Harpaly ....... 45 IIarpalus pleuriticus.

Wandering Harpaly ...... 46 Harpalus erraticus.

ILEPIoLUs, or Fecermolh :

Silverspotted Hepiole..... 241 Hepiolus argenteomaculatus.

Hesperia, Hesperian butterfy:

Peck's Hespery ........... 216 IIesperia peckius.

Hirsarchia, or Hipparchian bulterfly:

Cloudy Hipparchy ......... ㄴ. Ilipparchia nephele.

Smooth Hipparchy ....... :1: Hipparchía alope.

Hister, or Player-beetle:

Polished Hister ......... Hister conformis.

Hoplu, or Mailed beetle:

Threebanded Hoply ...... Hoplia trifasciata.

Hycosius, or Wood-beetle:

Struggling Hyloby...... 107 Ifylobius pales.

Hrdrocampa, or Watermoth:

Snowy Hydrocamp ...... 233 IIydrocampa nivalis.

HyLURGUS, or Woodeater:

Boring Hylurge ........ 11'? Hylurgus terebrans.

ICHREUMON, or Hunter-vasp :

Shortbanded Icbncumou .. 193 Ichneumon brevicinctor.

Ips, or Vine-beetle:

Foursigned Ips ......... 60 Ips quadrisignata.

Shining Ips ......... 59 Ips sanguinolenta.

Swathed Ins......... ह!) Ips fasciata.

Trospotted Ips.......... 60 Ips bipustulata.

ItAYCERCs, or Siraighlhorn:

New-York Ithycere ...... 110 Ithycerus noveboracerisis.

LAMIA, or Sorceress..... 121
1 Page

LEPTIS, or Slenderfly .... 181

LAMPYRIS, or Glonorm:

Angulate Lampyre ...... 89

Lampyris angulata.

Blackening Lampyre ..... 89 Lampyris nigricans.

Flathorned Lampyre ..... 89 Lampyris laticornis.

Lightening Lampyre ..... 90 Lampyris corrusca.

Sparkling Lampyre ...... 89 Lampyris scintillans.

Versicolored Lampyre ..... 90 Lampyris versicolor.

LEBIA, or Ketllebug :

Blackbellied Leby ....... 42 Lebia atriventris.

Emerald Leby ......... 43 Lebia smaragdula.

Green Jeby ........... 43 Lebia viridis.

8 LEMA, or Bleareye :

Threestriped Leme....... 134 Lema trivittata.

Leptura, or Thintail :

Downy Lepture ......... 127 Leptura subpubesceus.

Eightpointed Lepture..... 127 Leptura octopunctati.

Greenish Lepture........ 127 Leptura malachitica.

Reddish Lepture ....... 127 Leptura rubrica.

Striped Lepture ........ 126 Leptura vittata.

Libellula, or Dragonfly:

Handsome Libellule..... 185 Libellula pulchella.

LIMENITIs, or Border-butlerfly :

Artemis Limenite......... 211 Limenitis artemis.

Stripefooted Limenite. . . . 202 Limenitis dissippus.

Wildcherry Limenite ..... 203 Limenitis ursula.

Locusta, or Locust:

Caroline Iocust ........ 145 Locusta carolina.

Cloudy Locust ........... 146 Locusta nebulosa. 


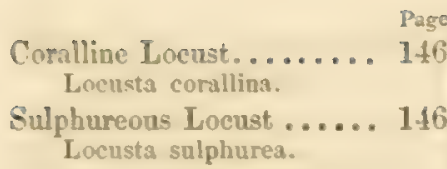

LoxOT ENLA, or Twisling-worm:

Rose Loxoteny......... 250 Losotrenia rosaceana.

Lucanos, or Hornbecle:

Deer Lucan ........... 66 Lucanus dama.

LTGAUs, or Blackfly :

Whitewinged Lygey....... 169 Lygreus leucopterus.

Macrodactylus, or Longfoot :

Spinebreasted Macrodactyl, 78 Nacrodactylus subspinosa.

Mevtis, or Praying beetle, 142

Malitea, or Maltese lnuterfly:

Lighthouse Melitey ...... 212 Uelitrea pharos.

Phæton Melitey ......... 212 Melitrea phaton.

Melor, or Spanishfly :

Narrowchested Meloe .. . 97 Meloe angusticollis.

MIDAs, or Turnipfly :

Threadlike Midas....... 183 Midas filatus.

Micesia, or Social-fly :

Virginian Milesy ........ 183 Milesia virginiensis.

Monochamus, or Lone-beetle :

Beautiful Monochame..... 123 Monochamus pulcher.

Sbielded Monochame ..... 123 Monochamus scutellatus.

Spotted Monochame...... 123 Monochames maculosus.

Tickling Monochame ..... 123 Monochamus titillator.

Mrsca, or Fleshfly:

Carrion Musc .......... 181 Yusca vomitoria.

Mrrueleon, or Antion . . 185

Necrodes, or Sexton-beetle:

Surinam Necrode ....... 58 Necrodes surinamensis. ge Page Necropmonts, or Undertaker :

American Vecrophore..... 57 Necrophorus americanus.

Hairy Necrophore ...... 57 Secrephorus tomentosus.

Pigmy Necrophore...... 57 Necrophorus psgmaus.

Nitidela, or Bright-beetle:

Doublespot Nitidule..... 58 Nitidula bipustulata.

NoctuA, or Owlmoth :

Market Noctuy......... 246 Noctua nundina.

Pearly Noctuy ......... 245 Noctua margaritata.

Scaly Noctuy ......... 245 Noctua squamularis.

Wary Noctuy ........ 245 Noctua undularis.

Notiophilos, or Notion-beetle :

Bigeyed Notiophile...... 52 Notiophilas porrectus.

Notonectus, or Backswimmer,

Odontata, or Toothed beetle:

Shieldform Odontate..... 130 Odontata scutellaris.

Edronxchus, or Swellclavo:

Breasted Edionyche ...... 135 Edionychus thoracica.

Omalisus, or Evemueb :

Reddish Omalise ....... Omalisus coccinatus.

OMOPHRON, or Urion-beetle :

Lipped Homophron ..... 52 Omophron labiatum.

Tessellate Homophron .... 52 Omophron tessellatus.

Oncideres, or Clawneck :

Girdling Oncidere ....... 123 Oncideres eingulatus.

Onthophagus, or Dungeater :

Eggshaped Onthophager .. 68 Onthophagns ovatus.

Hecate Onthophager .... 68 Onthophagus becate.

OrHJov, or Snakewasp :

Clean Ophion .......... 197 Ophion purgatus.

!':s.

ngtailed Ophion ..... 1! ,

Oplion macrurum.

Teat Ophion........ 1!n; Ophion mundus.

Smooth Ophion........ 1! 1f; Ophion glabratus.

ORGYIA, or Fathoming-nioth :

Whitebanded Orgey ...... 231 Orgyia leucostigma.

Osmoderas, or Scentshin :

Rough Osmoderm....... T Osmoderma seaber.

Pachyta, or Thickbody :

Heartshaped Pachrte... I. Pachyta cordifera.

Pamphila, or Lorely butlerfly:

Meadow Pamphile....... 215 Pamphila phyloeus.

Pangos, or Planter-bectle:

Black Pangy........... 46 Pangus caliginosus.

Parilio, or Butterfly:

Conjugal Papilion........ 201 Papilio philenor.

Stardotted Papilion ...... 200 Papilio asterias.

Turnus Papilion........ 201 Papilio turnas.

Parnos, or Grasshopper-beetle :

Sharppointed Parny ...... 56 Parnas fastigiatus.

Toothed Parny........ 56 Parnus crenatus.

Pelecinos, or Hatchet-uasp :

Polishing Pelecine ....... 196 Pelecinus politurator.

Pelidnota, or Leadcolorea beetle:

Maculate Pelidnote ...... 77 Pelidnota maculata.

Punctate Pelidnote...... 76 Pelidnots punctats.

Phalena, or Caterpillar, 225.

227,228

Blackoak Phalene....... 245 Phalæna quercaria.

Phaneus, or Torch-beetle

Butchering Phaney...... 68 Phanzus carnifex.

[Agricultubal Report-Vol. v.] 
Phaneguriega, or Lightring:

Sarrowwinged Phaneropter, 145 Phaneroptera angustifulia.

Phacasuelus, or Vinelorer :

Satellite Philampely......219 l'hilamplus satellitia.

Tineleaf Philanipely ..... 219 Plitampelus pampiuatrix.

Prrygaxea, or Caddicefly :

Bandwinged Phrygane.... 188 Phrygatuea semitasciata.

Pryllogics, or Leafbetle:

Tapelike Phrlloby ....... 111; Phyllubius tauiatus.

Perylophaga, or Leafeater:

Dralse's Phrllophager.... 7. Phyllophaga drakii.

Georgian Phyllophager.... :. Phylluphuga georgicana.

Hairychested Phyllophager, T:Phylluphaga pilosicullis.

Oak Pbyllophager ...... T.: Phyllophaga quercina.

Pitted Phyllophager..... T.: Phyllophaga rariolosa.

Punctured Phrllophager .. T1 Phrllophaga hirticula.

Pinris, or Muse-butterfly :

Snowfuotel Pieris........ ? 11, i Pieris nicippe.

Pinpla, or Longsinger:

Lunate Pimpla......... 1!1t Pimpla lunator.

Prssones, or Pitchpine beetle:

Pine-eating Pissode ..... 108 Pissowies strubi.

Piтно, or Pythoness :

American Pythoness...... 98 Pitho americanus.

Puatrceras, or Flathorn:

Pitcherlored Platycere. . . G6 Platyceras piceus.

Platygaster, or Broadbelly:

Wheatfly Platygaster..... 180 Platy gaster lipula.

Platrphylum, or Flatuing :

Concave Platyphyl ...... 14t Platrybrtlum concarum.
Narrowwinged Platyphyl.. 145 Platyphyllum angustifolium.

Oblongwinged Platyphyl .. 115 Platyphyllum oblongitolium.

Postia, or Seanymph:

Garden Ponty ......... 204 Poutia oleracea.

Priovus, or Saubeetle:

Broadbreasted Priony .... 115 Prionus laticollis.

Pennsylvanian Priony .... 115 Prionus pennsylvanicus.

Prives, or Decourer :

Robber Ptiny ........ 9. Ptinus fur.

Pclex, or Flea :

Boring Pulice ......... 118 Pulex penetrans.

Tormenting Pulice...... 148 Pulex irritans.

Purpuricenus, or Purplebug :

Shouldered Purpuricene... 126 Purpuricenus humeralis.

Prgena, or Whitelead:

Whitefaced Pygere....... 242 Pygara albifrons.

Pŕochros, or Flamebug :

Fanshaped Pyrochre...... 96 Pyrochroa flabellata.

REDUTius,or Looseneck ... 169

RHagum, or Berry-beetle :

Lined Rhagy .......... 1:2ti Rhagiuns lineatum.

Ririsosu, or Flatnosed moth :

Apple Rhinosy........ 254 Rhinosia pometella.

RhyNChENUs, or Bigsnout :

Plumeating Rhyochene ... 109 Rlynchanus nenuphar.

SAPERd, or Fishlike beelle:

Clothed Saperdy ........ 121 Saperda restita.

Rough Saperdy......... 121 Saperda calcarata.

Tridentate Saperdy...... 122 Saperda tridentata.

Tripunctate Saperdy..... 122 Saperda tripunctata.
Page

White Superdy ........ 121 Saperda candida.

Sarcorhaga, or Fleshealer :

Rural Sarcophager....... 181 Sarcoplaga georgina.

Saturnu, or Satumian moth :

Io Saturny ........... 232 Saturnia io.

Maia Saturay ........ 231 Saturnia maia.

Scarabeus, or Tumbleturd, 68

Scarites, or Slone-beetle:

Underground Scarite ..... 43 Scarites subterraneus.

Scolis, or Bentarmed wasp :

Eightspotted Scoly....... 197 Scolia octumaculata.

Sandy Scoly .......... 197 Sculia fossilana.

Scolytus, or

Peartree Scolyte........ 113 Scolytus pyri.

SERICA, or Silken-beetle:

Evening Serice......... $7 \mathbf{1}$ Serica vespertina.

Sesia, or Brushinger:

Fuciform Sesy ........ 221 Sesia fusiformis.

Grecian Sesy.......... 221 Sesia pelasgus.

Silpra, or Carrion-bcelle:

American Silph........ 58 Silyha americana.

New-York Silph........ 5s Silpha noveboraceusis.

Tailed Silph ......... 57 Silplı caudata.

Unerual silph ......... 57 Silphs inequalis.

Sulvavis, or Weeril :

Surinamian Silvane....... 105 Silvanus surinamensis.

Sirex, or Wooduasp.... 192

Smerintuos, or Corduing :

'Tongueless Snerinth ..... 221 Smerinthus astylus.

Smilia, or Shoeknife :

Auriculate Snuily ....... 153 Smilia auriculata. 
Green Snily .......... 154 Smilia viridis.

Spotted Smily......... 153 Smilia guttata.

Striped Smily ......... 154 Smilia vittata.

SpectruM, or Ghostfly :

Longlegged Spectre ...... 142 Spectrum femoratum.

SPHARoderus, or Ball-beetle:

Narrowmouthed Spherodere, 49 Sphreroderus stenostomus.

Sphex, or Spider-wasp :

Pennsylvanian Sphex..... 105 Sphex pennsylvanica.

Spgivx, or Hawkmoth :

Ashy $\mathrm{Sphinx}_{\mathrm{p}}$......... 219 Sphinx cinerea.

Caroline Sphinx ........ 218 Sphinx carolìnus.

Cyclopian Sphinx.......218 Sphinx brontes.

Eightspotted Sphinx...... 218 Sphinx octomaculatus.

Firespotted Sphinx ..... 219 Sphinx quinquomaculatus.

Fringetree Sphinx...... 21 . Sphinx chionanthi.

Potato Sphinx........ 218 Sphinx convolruli.

Vine sphinx ........... Sphinx vitis.

Spilosona, or Spotbody:

Saltmarsh Spilosome ..... 225 Spilasoma acrsea.

Waternymph Spilosome ... 225 Spilosoma nais.

Wedgemarked Spilosome .. 228 Spilosorna cunea.

White Spilosome ...... 226 Spilosoma arge.

Staphrlinds, ox Carrotshaped beetle:

Bluewinged Staphyline.... 61 Staphylinus cyannipennis.

Hairy Staphyline ........ Staphylinus villosus.

Yellowtailed Staphyline ... Staphylinus chrysurus.

61
Page

Cinctured Stenocore. Stenocorus ciactus.

TABanus, or Gudfly:

American Tabany....... 182 Tabanus americanus.

Leadcolored Tabany...... 182 Tabanus plumbeus.

Telamona; ar Crestfly:

Beech Telamon......... 154 Telamona fagi.

Hazle Telamon......... 155 Telamona coryli.

Level Telamon......... 155 Telamona reclivata.

Oak Telamon ......... 155 Telamona querci.

Onecolored Telamon..... 154 Telamona unicolor.

Ornate Telamon........ 155 Telamona ornata.

Thornapple Telamon ..... 155 Telamona cratregi.

Turreted Telamon ...... 155 Telamona turriculata.

Uphill Telamon ........ 155 Telamona acclivata.

Woodbine Telamon ...... 154 Telamona ampelopsidis.

Telephonus, or Netcarrier, 90

Tenebrio, or Nightwalker :

Crooklegged Tenebrion.... 99 Tenebrio curvipes.

Dusky Tenebrion ....... 99 Tenebrio obscurus.

Mealeating Tenebrion..... 99 Tenebrio molitor.

Tenthredo, or Saw-wasp, 191

Tetraores, or Fourspot-beetle:

Foureyed Tetraope...... 121 Tetraopes tetrophthalma.

Tetrix, or Pheasant-locuest, 147

Tetrigonia, or Little-cricket :

Grapevine Tettigony...... 158 Tettigonis vitis.

Rosebush Tettigony ...... 158
Thanasimus, or Death-beetle:

Doubtful Thanasime...... 91 Thanasimus dubius.

THECLA, or Blue-butterfly:

Hopeating Theele ....... 214

Thecla humuli.

Puny Thecle.......... 214 Thecla acis.

Thelia, or Nipplefly:

Twodotted Thely ........ 156 Thelia binotata.

Twospotted Thely........ 156 Thelia bimaculata.

Yellowfooted Thely ..... 156 Thelia lutipes.

ThRIPs, or Stingleaf. . . . 160

Tinea, or Bookmoth :

Grainskinning Tiney...... 256 Tinea granella.

Honeycomb Tiney ....... 253 Tinea cerella.

Tomycus, or Woodcutter :

Gnawing Tomice........ 112 Tomicus exesus.

Peartree Tonice........ 113 Tomicus pyri.

Pinetree Tomice......... 113 Tomicus pini.

Tortrix, or Tuister.... 250

Trechus, or Rongh-beetle:

Conjoined Trechy........ 48 Trechus conjunctus.

Girded Trechy ........ 48 Trechus cinctus.

TREMEX, or Boring wasp :

Pigeon Tremex......... 192 Tremex columba.

Trichinus, or Hairbeetle :

Assimilate Trichine ..... 71

Trichinus assimilans.

Greenish Trichine........ 71 Trichiaus viridans.

Trochilidm, or Wheelmoth :

Naked Trochily ........ 223

Trochilium denudatum.

Trox, or Chewing beetle:

Capillary Trox......... 71 


\begin{tabular}{|c|c|c|c|}
\hline & Page & Page & Page \\
\hline $\begin{array}{l}\text { Swinish Trus ........... } \\
\text { Trox porcatus. }\end{array}$ & 70 & $\begin{array}{l}\text { Vanessa, or Sunny butterfiy: } \\
\text { Antiope Vaness ........206 }\end{array}$ & 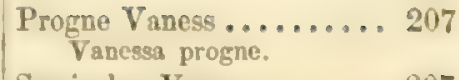 \\
\hline Upis, or Slender mealroorm & & Atalanta Vaness......... 209 & $\begin{array}{c}\text { Semicolon Vaness......... } 207 \\
\text { Vaness interrogationis. }\end{array}$ \\
\hline $\begin{array}{l}\text { Pennsylranisn Upis ....... } \\
\text { Upis pennsylvanica. }\end{array}$ & 99 & $\begin{array}{l}\text { Vanessa atalanta. } \\
\text { Comma Vaness........... } 208 \\
\text { Vanessa comma. }\end{array}$ & $\begin{array}{l}\text { VEsPa, or Wasp : } \\
\text { Social Wasp ............ } 195 \\
\text { Vesps traterna. }\end{array}$ \\
\hline CROCERUS, or Horntall: & & $\begin{array}{l}\text { Manycolored Vaness ..... } \\
\text { Vanessa polychloros. }\end{array}$ & OPA, or Carpenter-vasp : \\
\hline Urocerus albic & 18 & $\begin{array}{c}\text { Nettle Vaness............. } 209 \\
\text { Vanessa urticie. }\end{array}$ & $\begin{array}{l}\text { hian } \mathrm{Xylocope} . . . . . \\
\text { slocopa virginica. }\end{array}$ \\
\hline
\end{tabular}




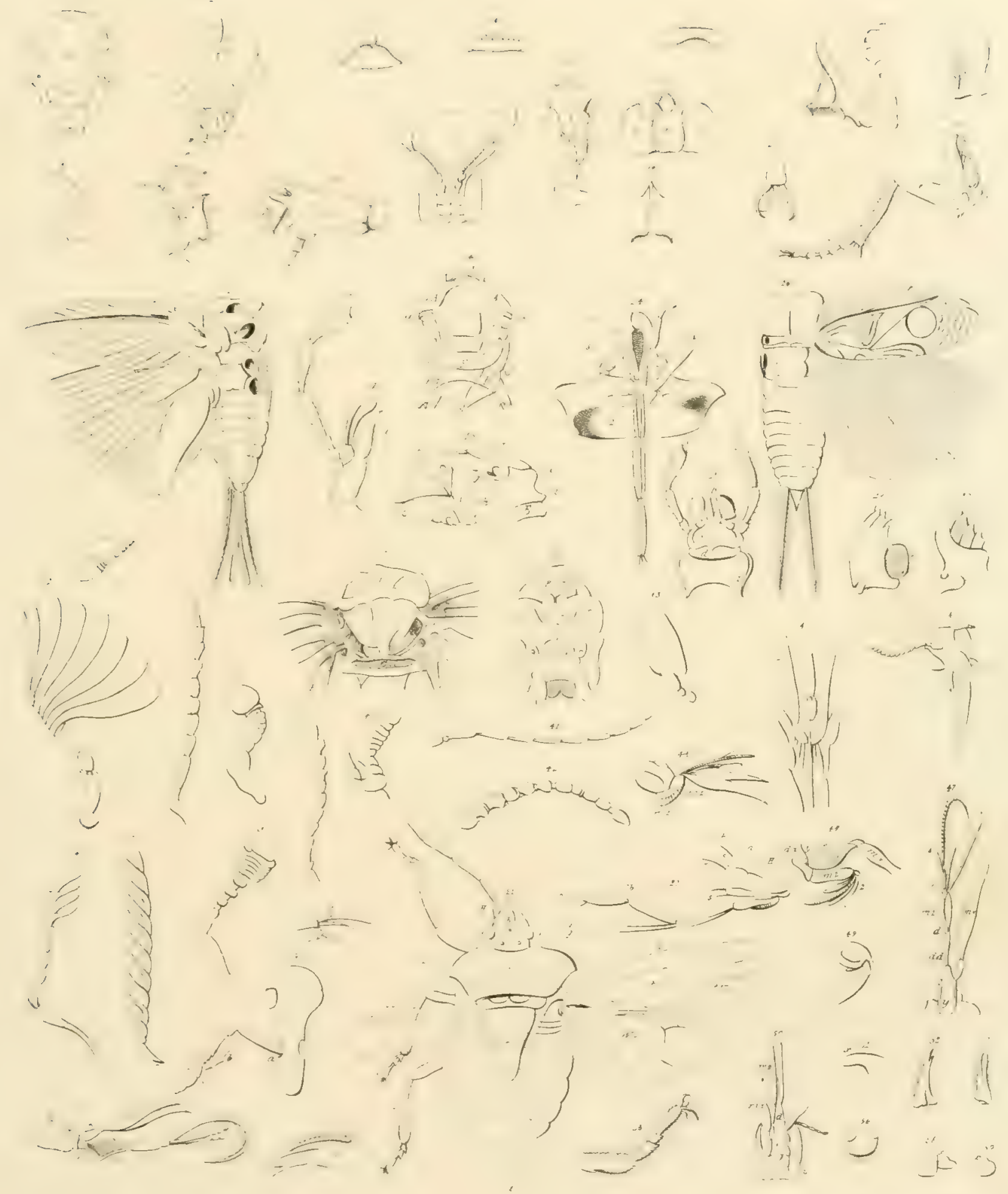





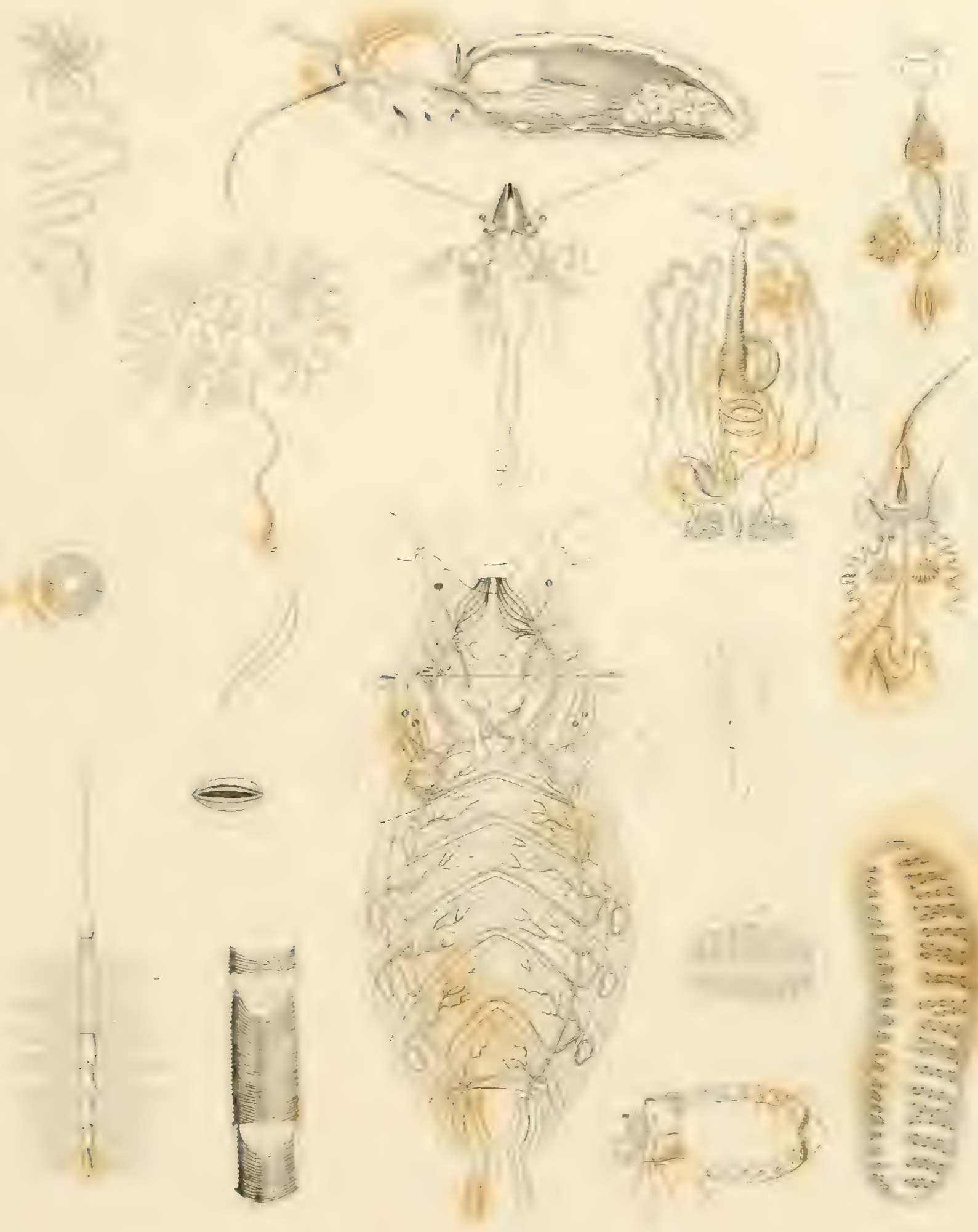



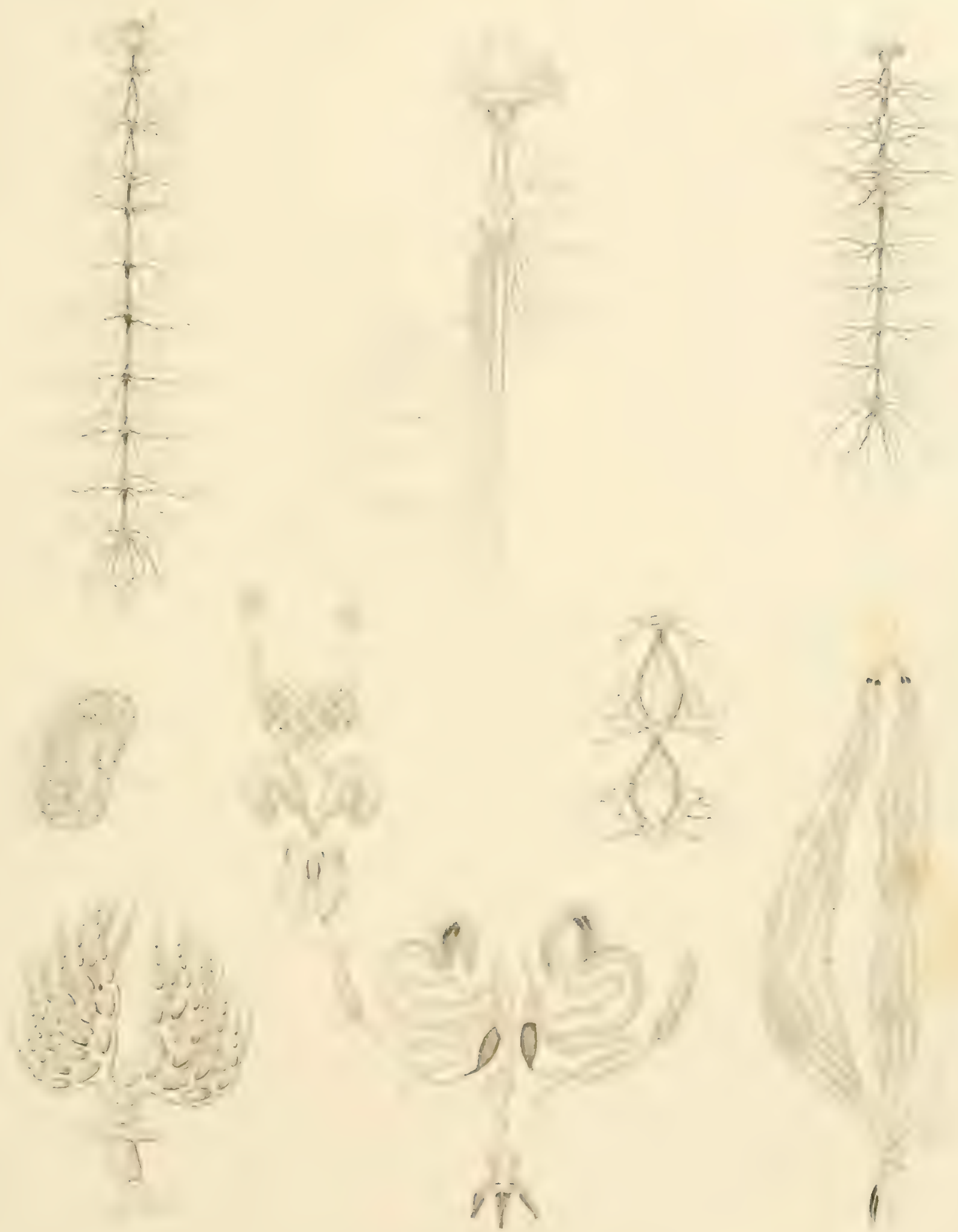




\section{PIATE 1.}

H. I. Pigpia nenator (nale).

$\because$ Fiemale perforating the trunk if a tree.

$:$ Female at rest.

1. Male at rest.

". Antenuse unagnified.

l. Tani unaguificul.

. 1. Laria, uatural siz.. 


$$
1,1
$$





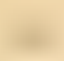

$+2$ 


\section{PLATE 2.}

Fig. 1. Caldandra granarta.

$2,2 a, 2 b, 2 a$ Strvands strinamensis.

$3,3 a, 3 b, 3$ co BREchos PISI.

4, 4 a. Brenthos septentrionalis (male and female).

$5,5 a, 5 b$. Balaninus rectus.

$i, 6 a, 6$ b. HyLOBIUS PALBS.

$\tau, \tau a, \tau b$. Conotrachelus nentfaAr.

$\therefore$ Clerdos apiariug. 

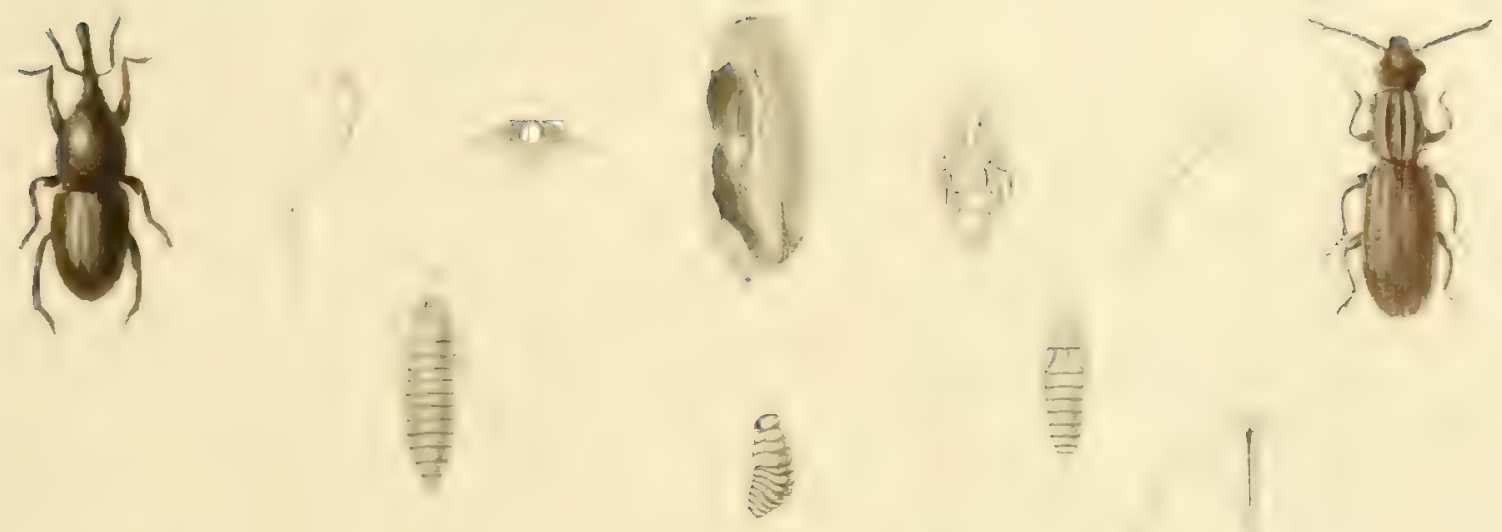

$-4$
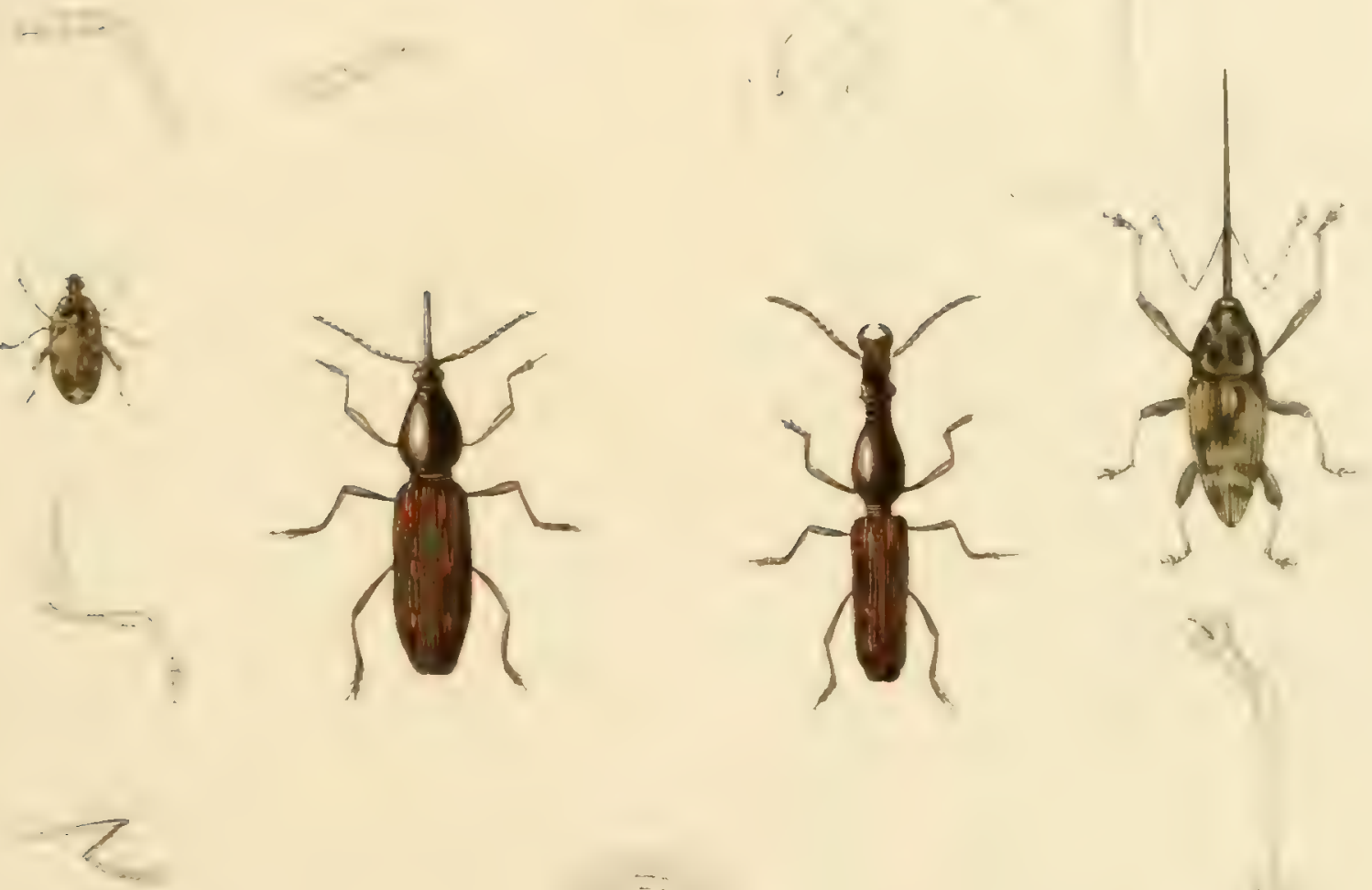

1

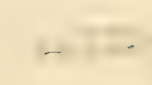

$-\ldots$,
$\vdots$
$\vdots$

$=$

$\therefore$
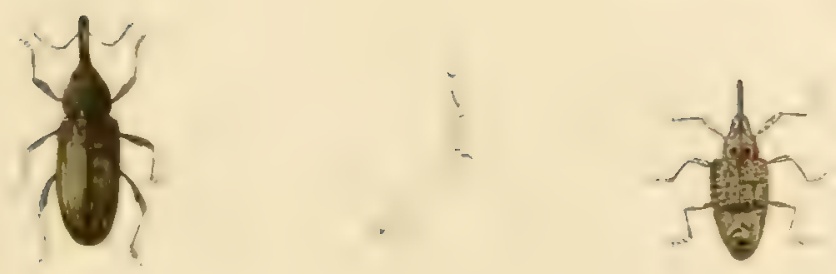

a 



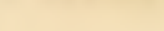

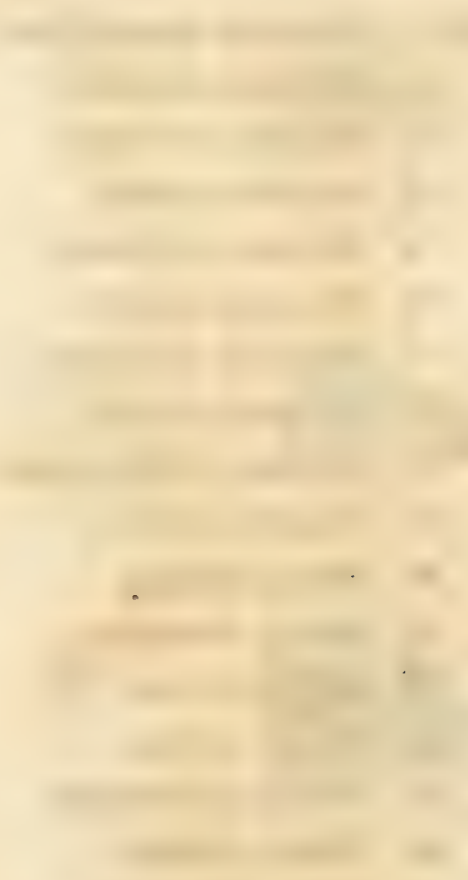




\section{PLATE 3.}

Fig. 1. Telemona turictiata.

2. Telemona cratari.

3. Teleutivi inicolor.

4. Telmona gierci.

5. TElbmona aćl.ivata.

6. Telfmona compio.

7. TrLemUNa RECLIVATA.

8. TELTMONA URYATA.

9. TELEmona ampFiopsims.

10. TELEMONA FAGI.

11. Smila eqtata.

12. Smilia auriculata.

13. SMilia viridis.

14. Smilia vittata.

15. Thelia bimaculata.

16. Ceresa diceros.

17. Cerrea bubaldo. 

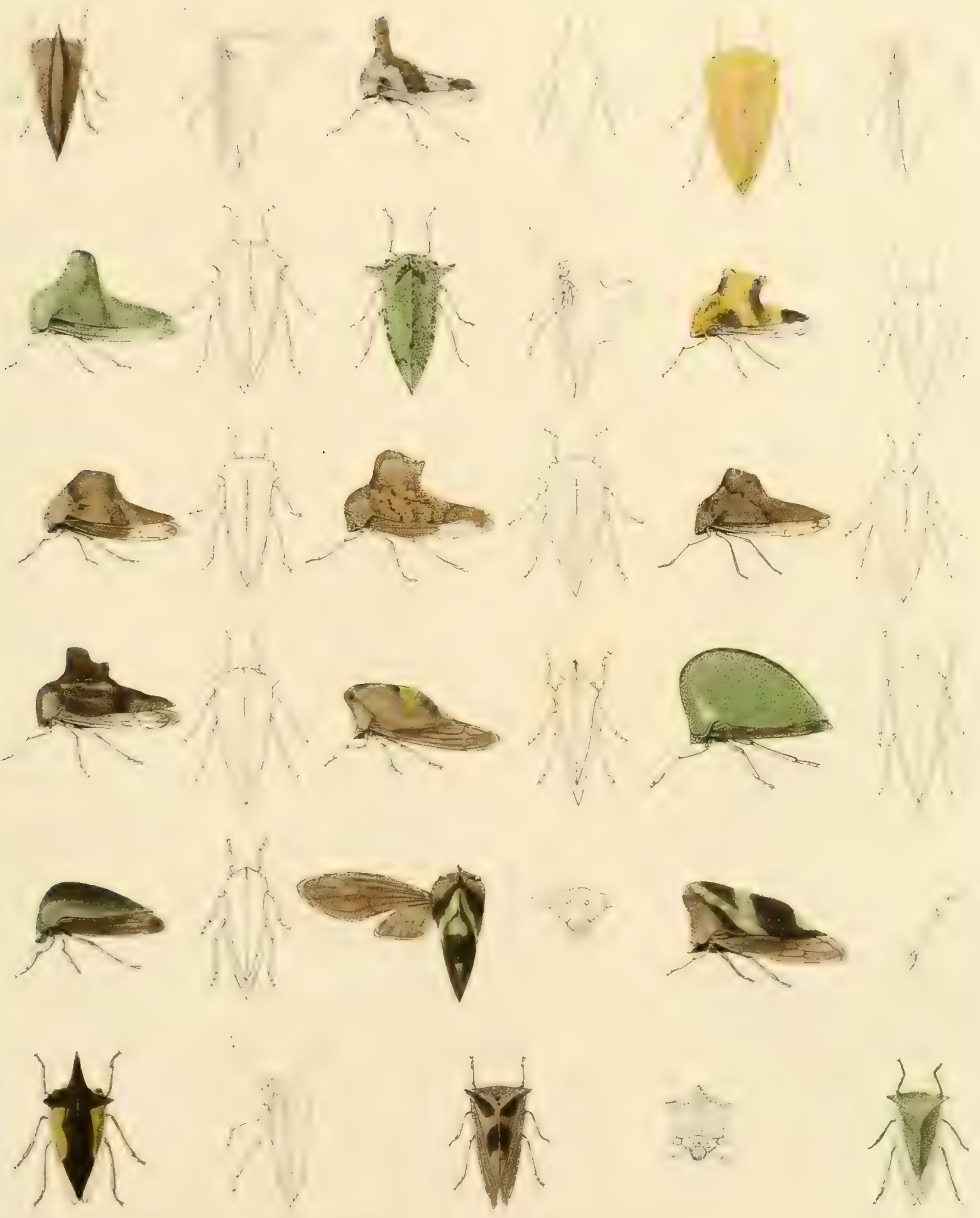



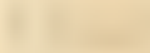

The

. 


\section{PLA'TE 4.}

Figa. 1 \& 2. Cacidomia destructor (male and female).

c. Segments of the abdomen.

b. c. Antennæ magnified.

d. $e_{0}$ The same, natural size.

f. Profile view of the head, palpi, and origin of the antenax.

g. Dorsal view of the worn.

h. Of the flasseed state.

i. Ventral view of the same.

j. Lateral ditto.

k. Dorsal view of the dormant larva.

1. Ventral view of the pupa.

A, B. Wheatstalks infested with the insect.

m. Wheatstalk broken away, showing the joung worns.

i. 4. Cecidomyia robinia (pupa enlarged). 5. Mouth.
6. Larva.
7. Wing. 


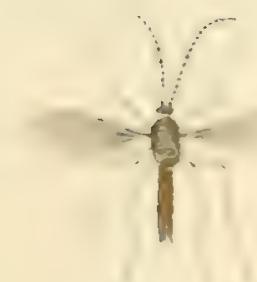

1
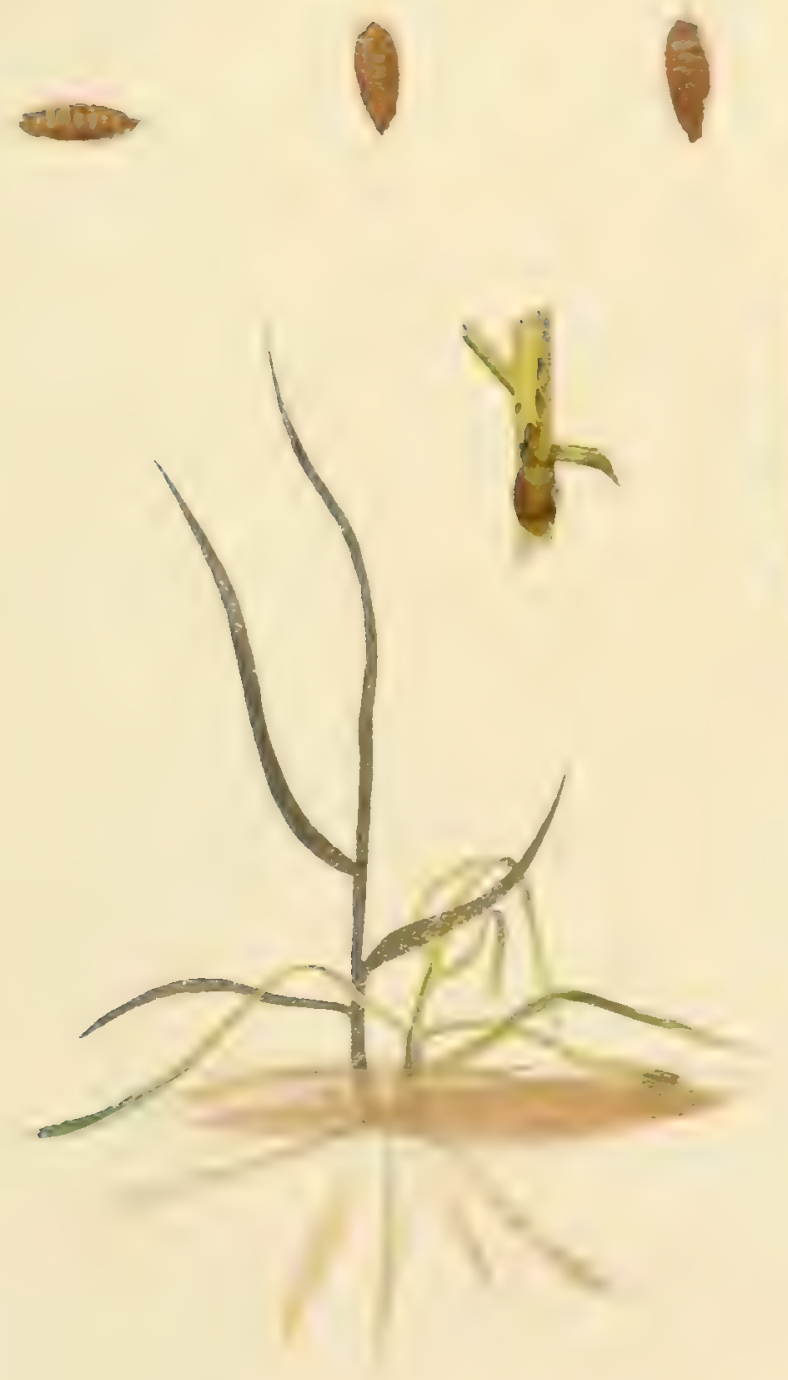

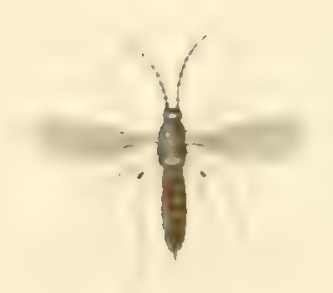

$+$

I

1







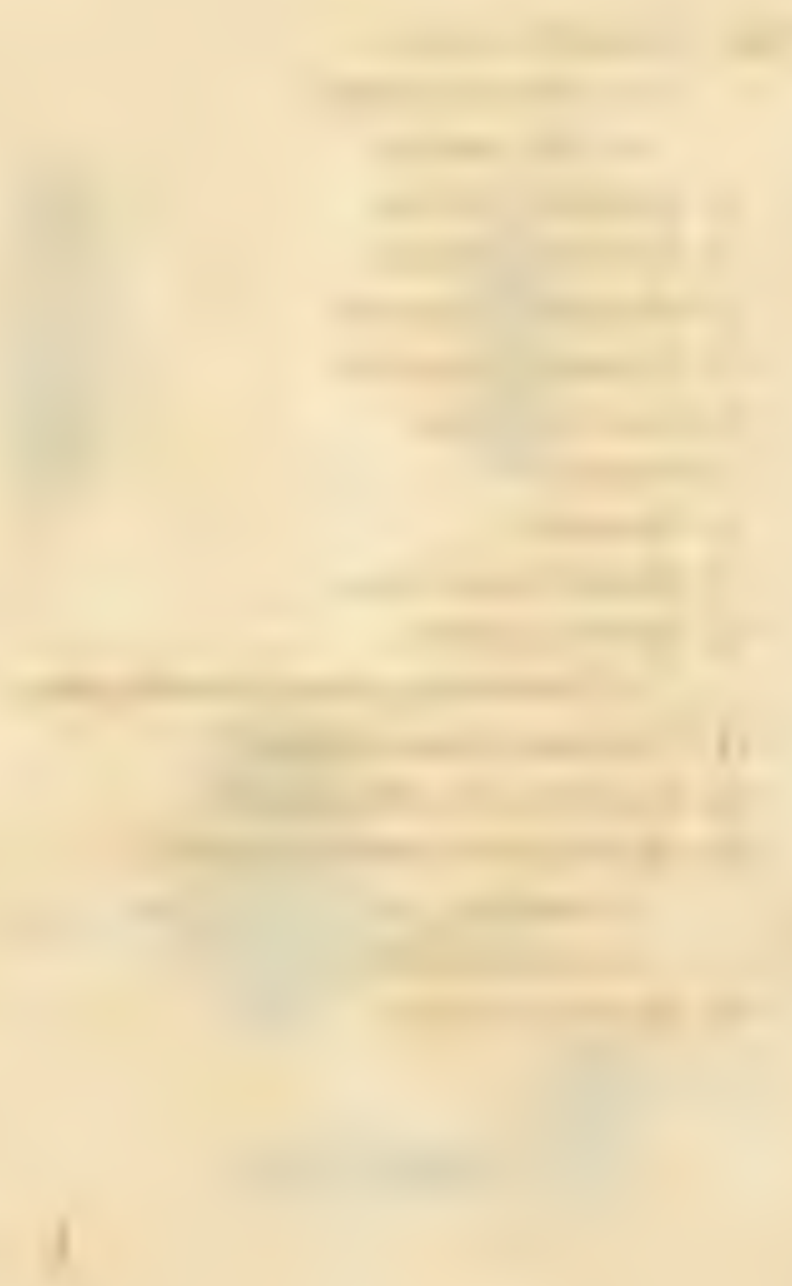




\section{PLATl' 5.}

Hig. 1. Brprestis fasciata.

a. Antennæ magnified.

6. Tarsi magnified.

$\therefore$ BupRESTIS DENTIPES.

3. Bi preatis FeMURATA.

4. Buphestis UTrabicata.

5. BupRestis VIRGINICU8.

(i. Alaus nclitatus.

†. Elater?

*. Btprestis.

?. Elater olandicolor.

10. DTTICUS HARRISII.

k. Anterior tarsus, showing the sucking disks.

II TETRAOPES TETROPHTHALMA.

12. Boletophagus cornutus (male).

13. Machodactylug gubspinosa (rogebug).

m. Antenna.

l. Tarsue magnified,

14. Ericauta vittata. 

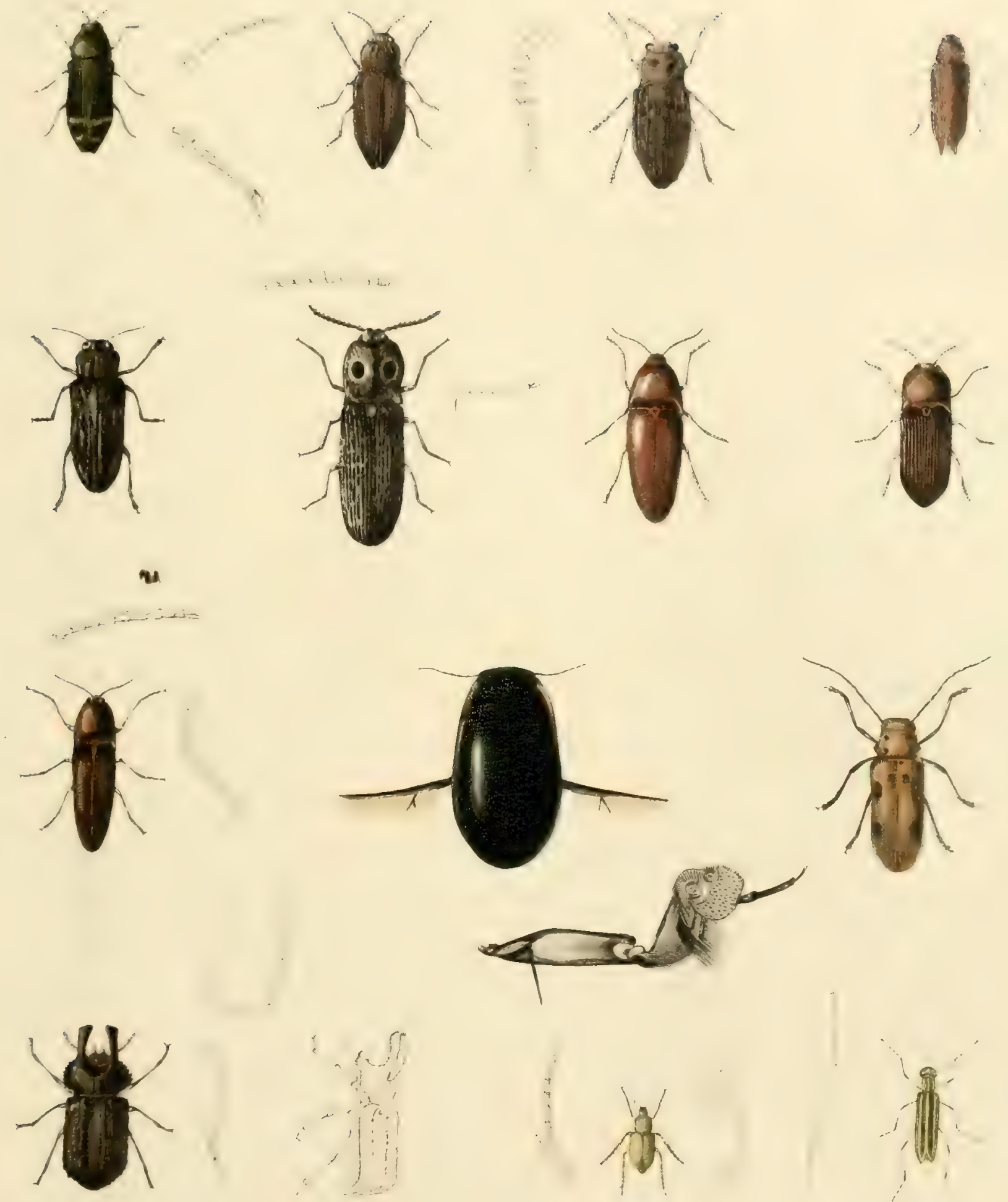




\section{PHATE 6.}

Higs, 1 \& 2. Atracos proserueus (male and female).

3. Larva.

4. Cocoons.

5. Vanessa antiopea.

6. Larva.

7. Pupr.

8. 9. 10. Lnxoternia rosaceana (the leafialler), in the perfeet, pupa and larval states.

11. Eygs deposited upou bark. 


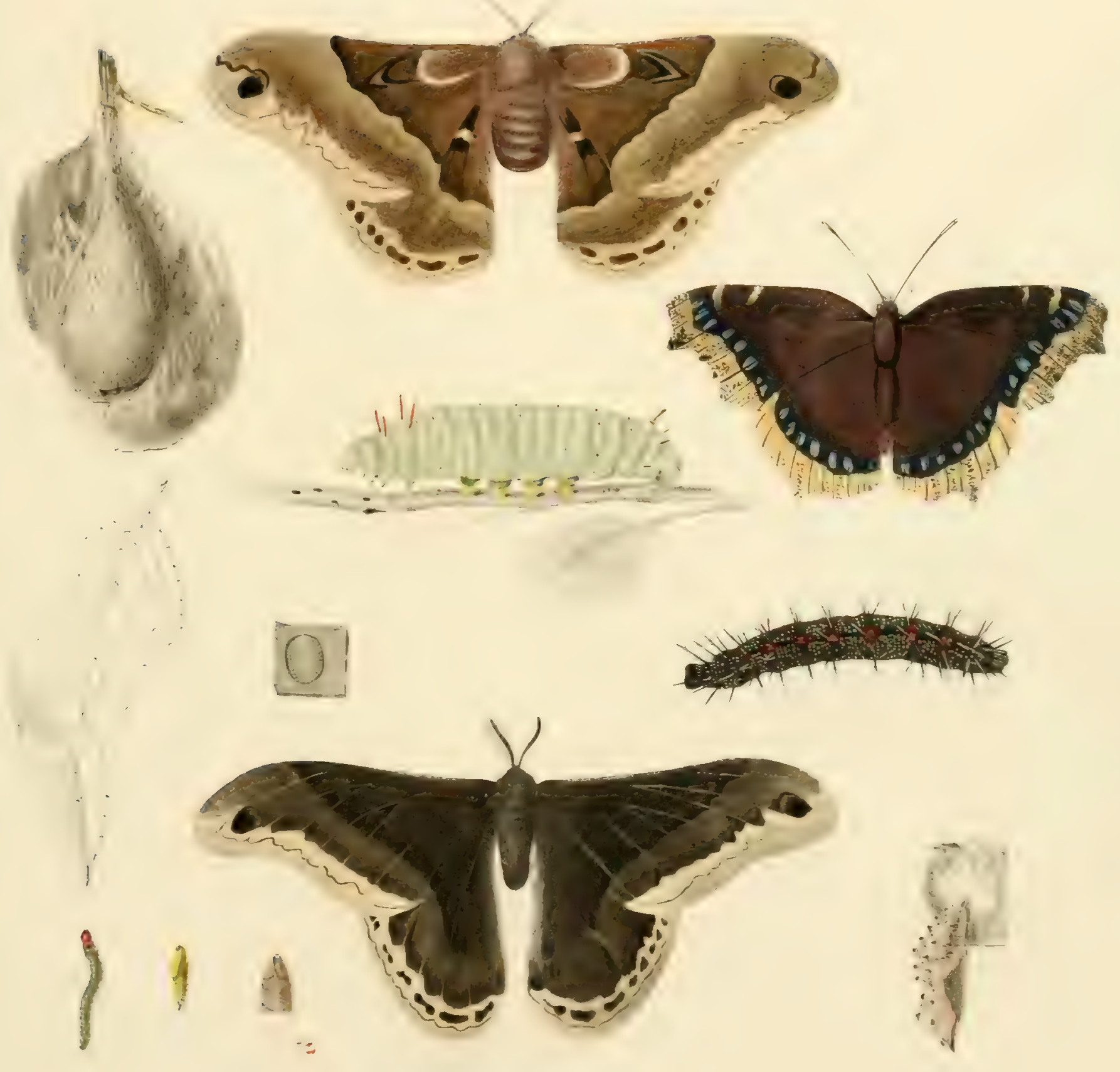





\section{PHATE i.}

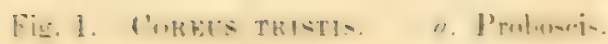

‥ J'FrTimose -

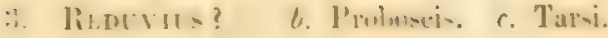

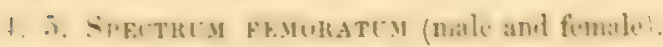

. Caudal appendages of the male.

f. Dittn of the female. 


$$
\text { 木本 }
$$





\section{-}




\section{PLATE \&.}

Figr 1. Clytus colonus?

2. Clytus nobilis.

3. Certus ?

f. Clytus undatus.

5. Clytus —.

1i. Cuytus?

7 Clytus hamatus.

২. Thanasimub dubius.

9. Eitaphidion?

11). Leptura rubaica.

11. LEPTURA SUBPUBESCENS.

12. PAChyta CORDifera.

13. Leptura vittata. 

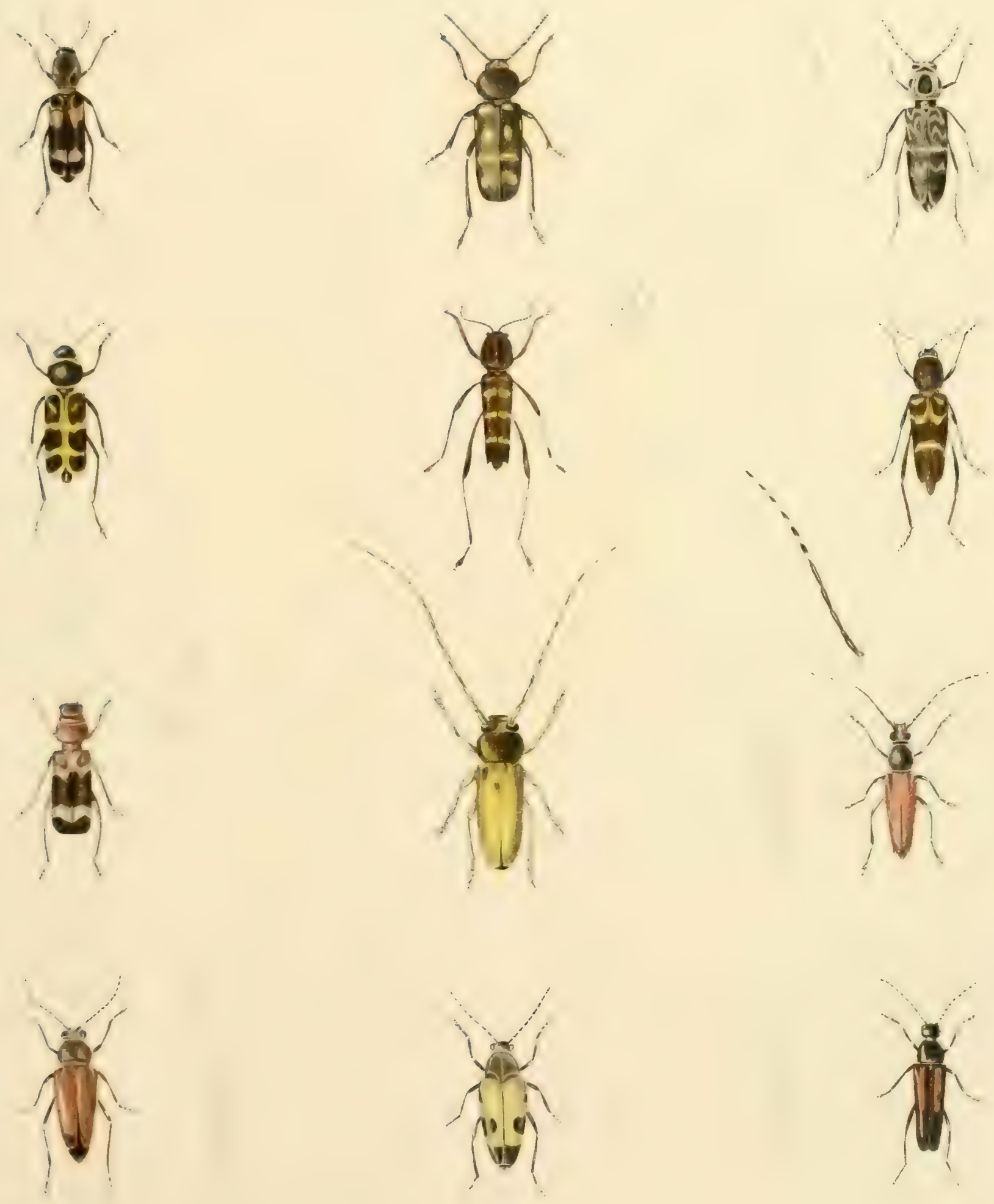



\section{PLATE 9.}

Fig. 1. Gryllos —? (female).

2 . Phaneroptera angestifoliem.

3. Cicada septendecim.

1. ACRYDICM FEMORRUBRUM.

j. Cicada canicolaris.

fi. Cicada noveboracensis.

$i$ Loctsta nebdlosa?

- Platyphylum concaytu.

a loctsta carolina. 

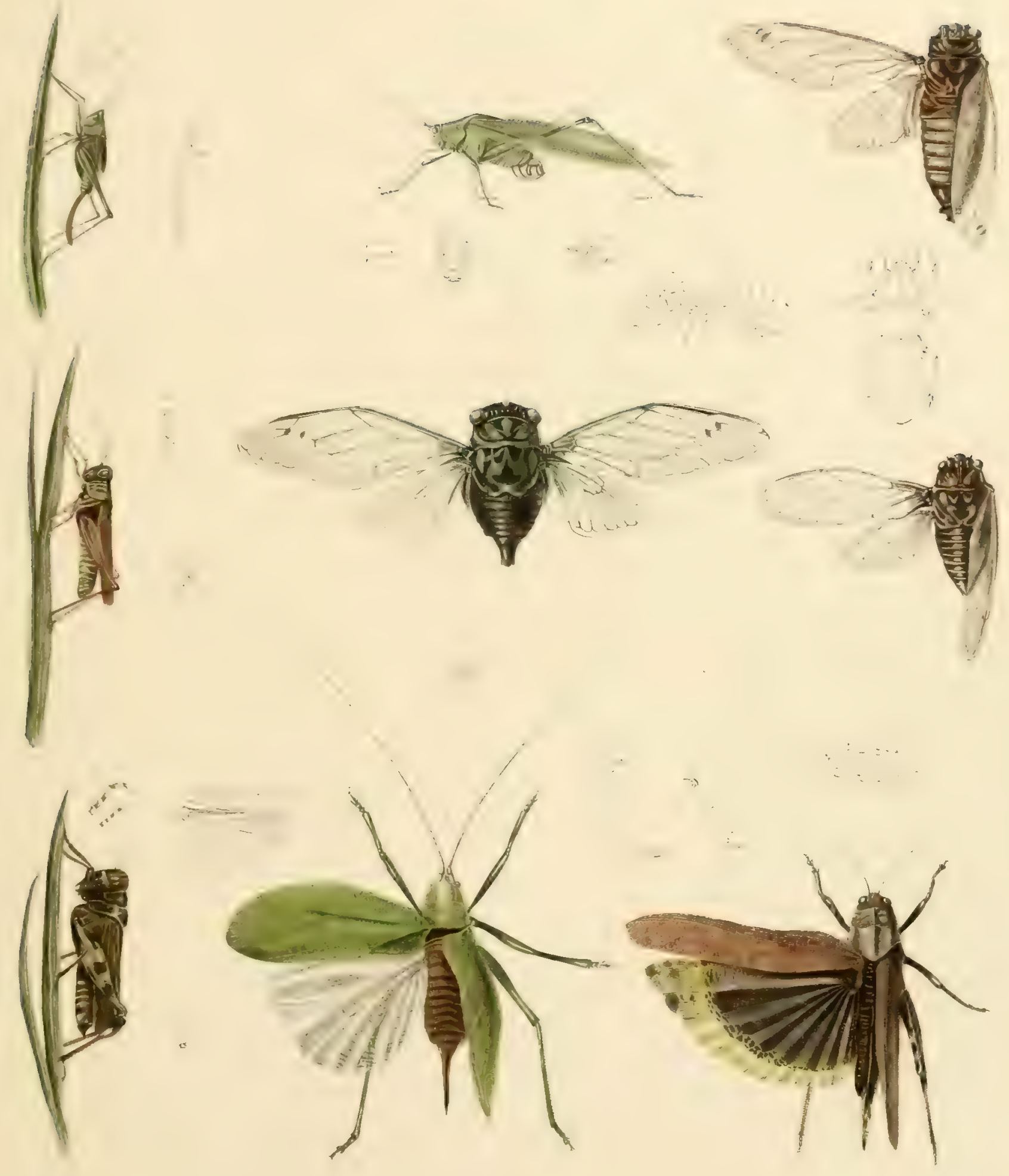



\section{PLITE II!}

Iie. 1. Reagrom lineatedo

$\because$ NeCROPHORES TOMENTOSTS.

$\therefore$ TEXERIO MOLITOR.

4. Areuda layigera.

5. Schrites -

(i. Peinfota pexctita

7. Payites caldimosis.

$\therefore$ CALALOMA ACRTTATOR.

9. Pirllopitaga glerina. 

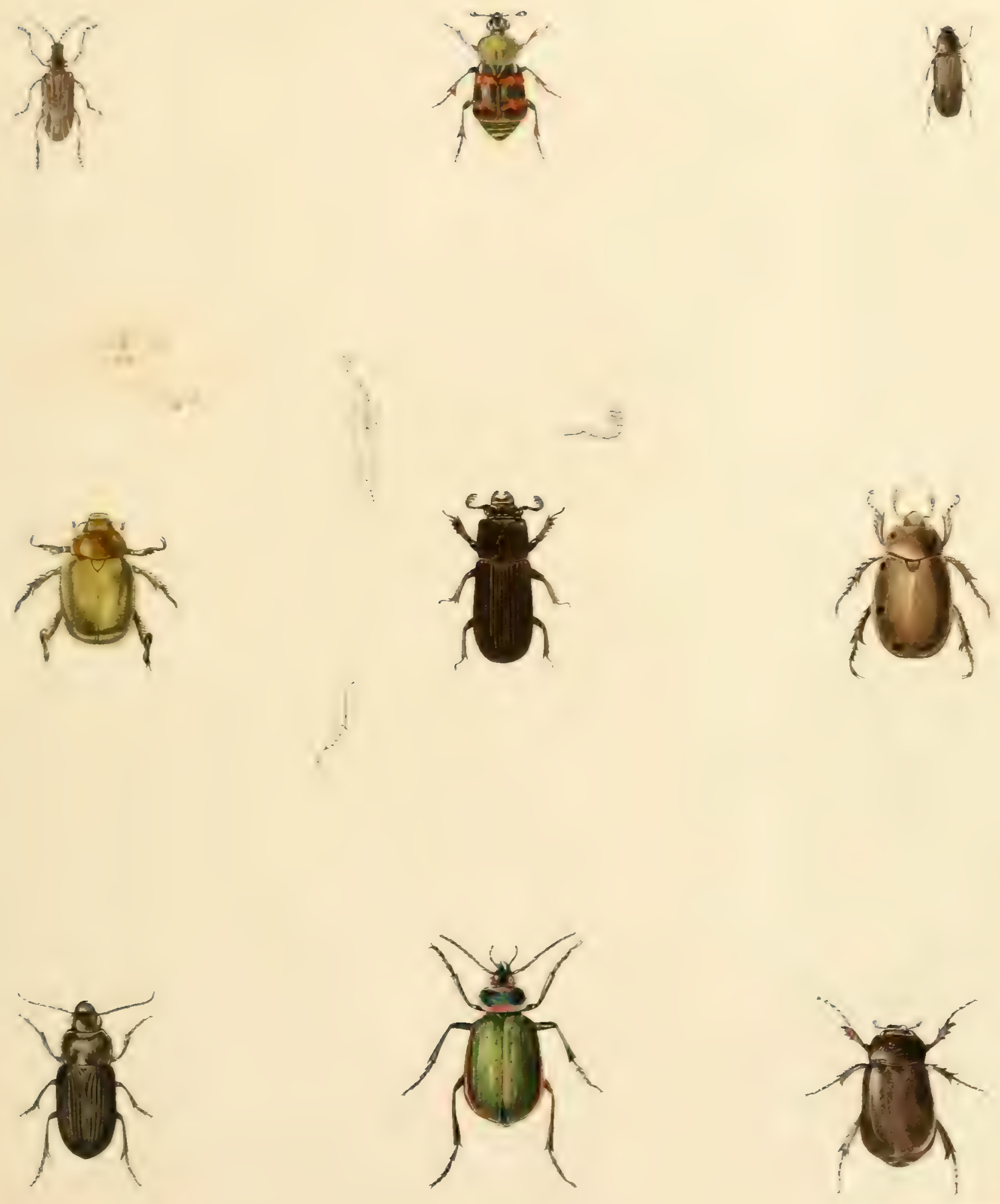




\section{PIATE 11.}

Fig. 1. Corcinella 10-maculata.

a. Antennæ magnified.

b. Tarsus magnified.

c. d. Larra and pupa.

$\therefore$ Coccinelua -.

$\because$ Coccinella 10-Notata.

+ Cocinella :0. macteata.

5. Coccinella j-sioxata.

i) Coccinella 9-yotata.

; Coccinella incarsata.

- Coccinella borealis.

" Coccinelia imyacclata.

10 Coccinella bimactlata.

11 Coccinelua binocelata. 


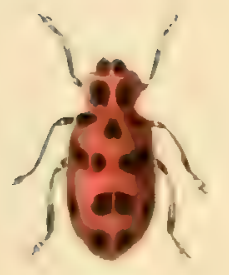

6
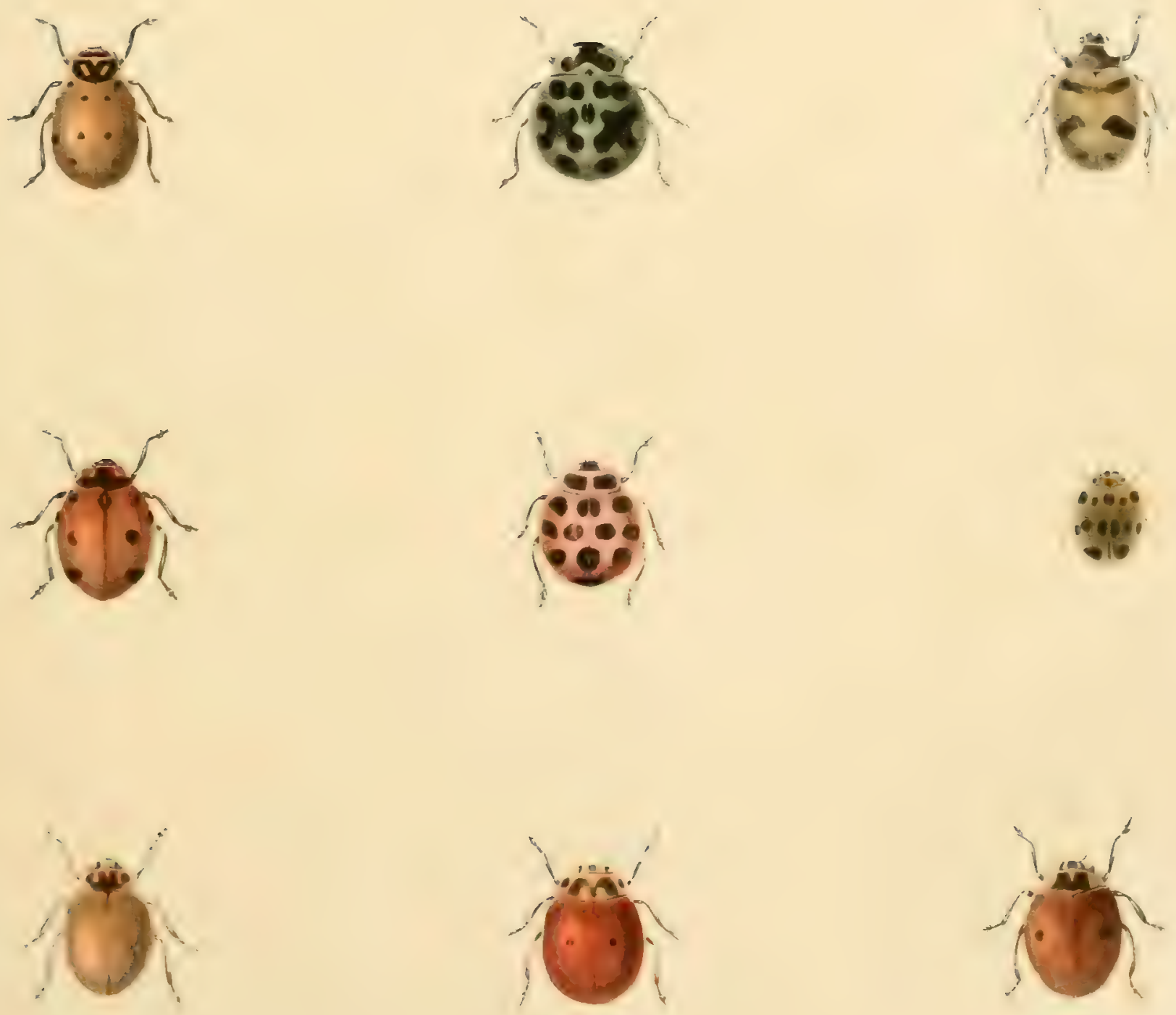



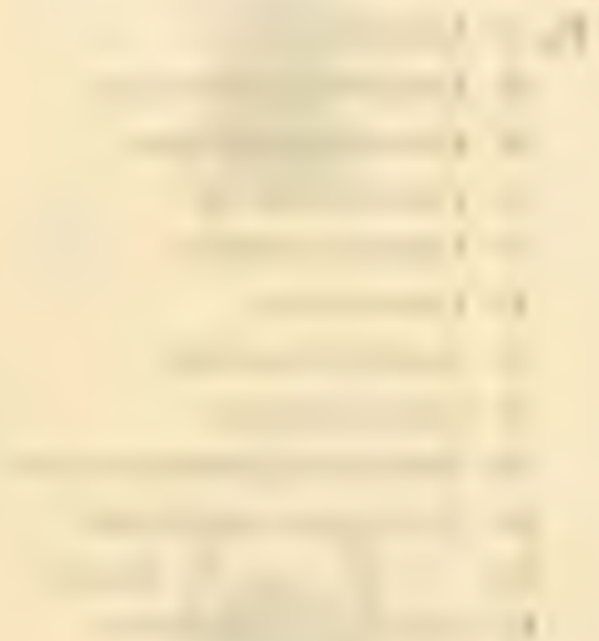


PLATE 12

Fig. 1. GEOTRUPES -

2. Geotrupes microphants.

3. GFotruper 8Piendens.

4. Cetonia fulaida.

5. Pitangus carmifex.

6. Cetonia inda.

7. Lucanus dama (male)

8. Copris oamolina.

9. Osmoderma (Grnodes) scaber.

10. Puatyceras piceus (male).

11. - - (female)

12. Gateruoa calmariensis. 

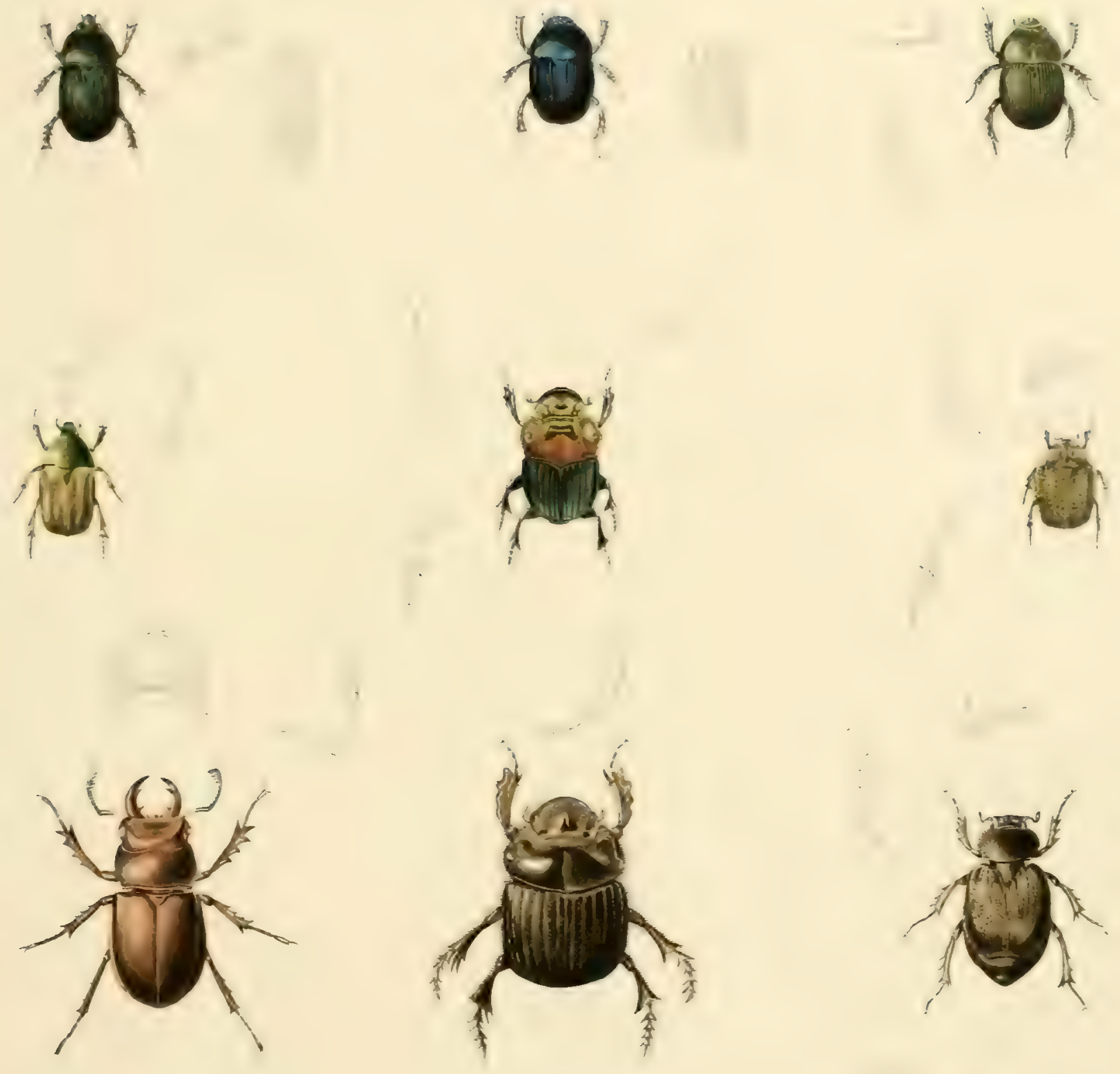

d
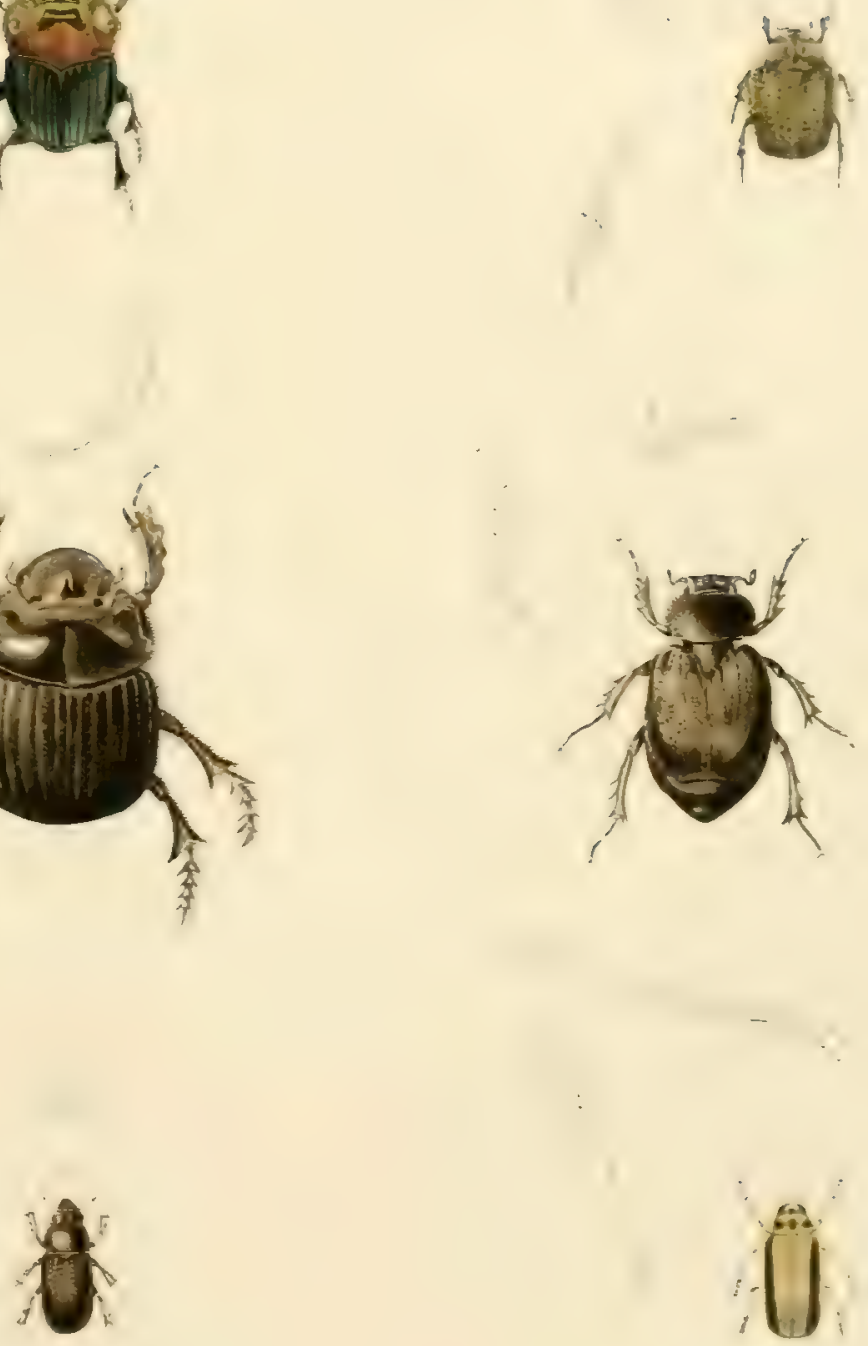



\section{PLATE 13.}

Fig. 1. Smita -

$\therefore$ SNILIA -

3. Gargara ptemeseng.

f. Gargara discoidalis.

i. Gargara nigricephala.

ii. Gariara majus.

†. Gargara pallidirontis.

- Gargara geerci.

$\because$ Garaara inermis.

10. Entilia concava.

11. Extilia sinuata.

12. Gargara pectoralis.

13. ENTILIA EMarginata.

14. Crrtosia arceata.

15. Ctrtosia pelieinosa.

16. Crrtosia intermedia.

17. ExchophylleM binotata.

14. ENchophyLluM Latifes. 

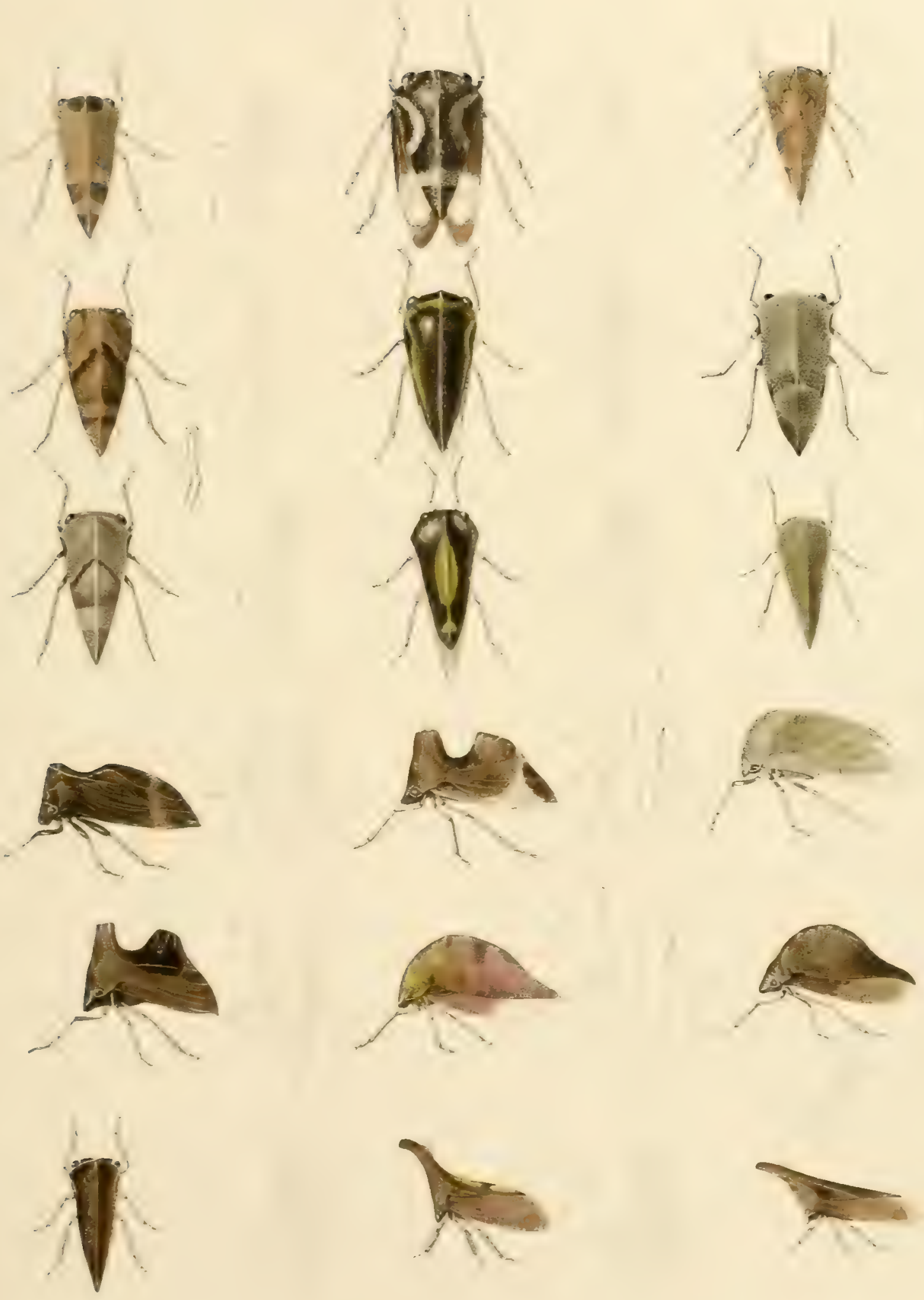




\section{PLATE 14.}

Fig. 1. Curysomela immacelata?

2. Chrrgomela -

3. Cursoomela -

4. Galeruca -

5. Chryomela tremola.

6. 7, 8, 9. Larva and pupa.

10. Chrysomela gealaris.

11. Cassida clavata.

12. Chrysomeia philadelphia.

13. Chrysomela -

14. Chrybomela cerolipennis.

15. Ermolpes aurates.

16. Curysomela trimacularis. 

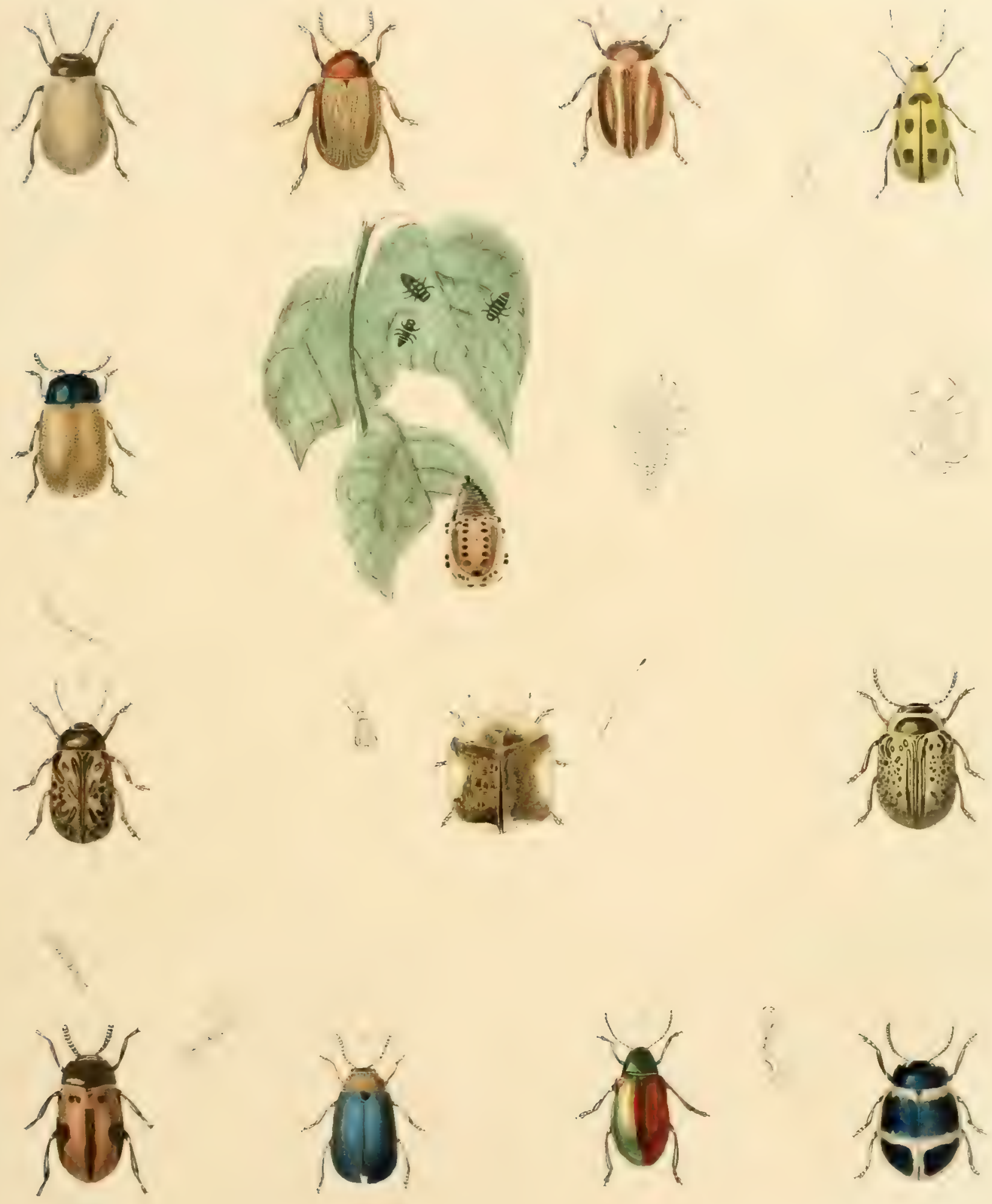

PLA'TE 15.

Fig. 1. Libellua?

2. Libelluma?

3. ESHNA -

4. LibELLLA, var.? PULOHELLA.

5. Libelela polchelia. $f$. Latra. 


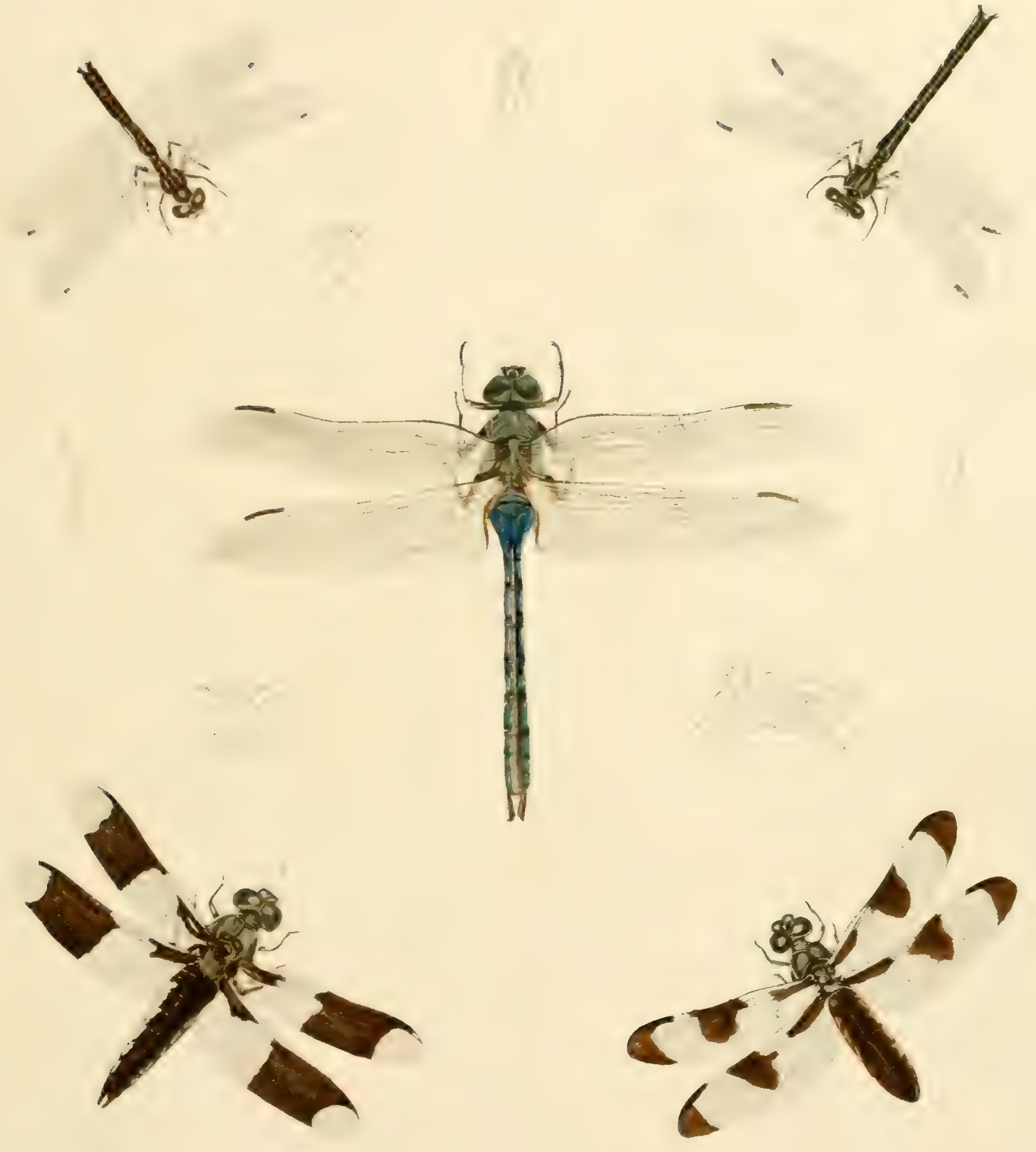






\section{PLATE 16.}

Hi.. 1. SaPERda calcarata.

$\therefore$ Monochanto

$\because$ Saperda candida.

4. Purpuricend8 huneralis.

$\therefore$ Monochames titiliator.

i. Desmockats palitates.

i. SAPERDA TBIPENCTATA.

- Fifafmidior petator (villostm).

?. Curtug pictes.

11. Clytus speciosts.

11. Clites catrea. 

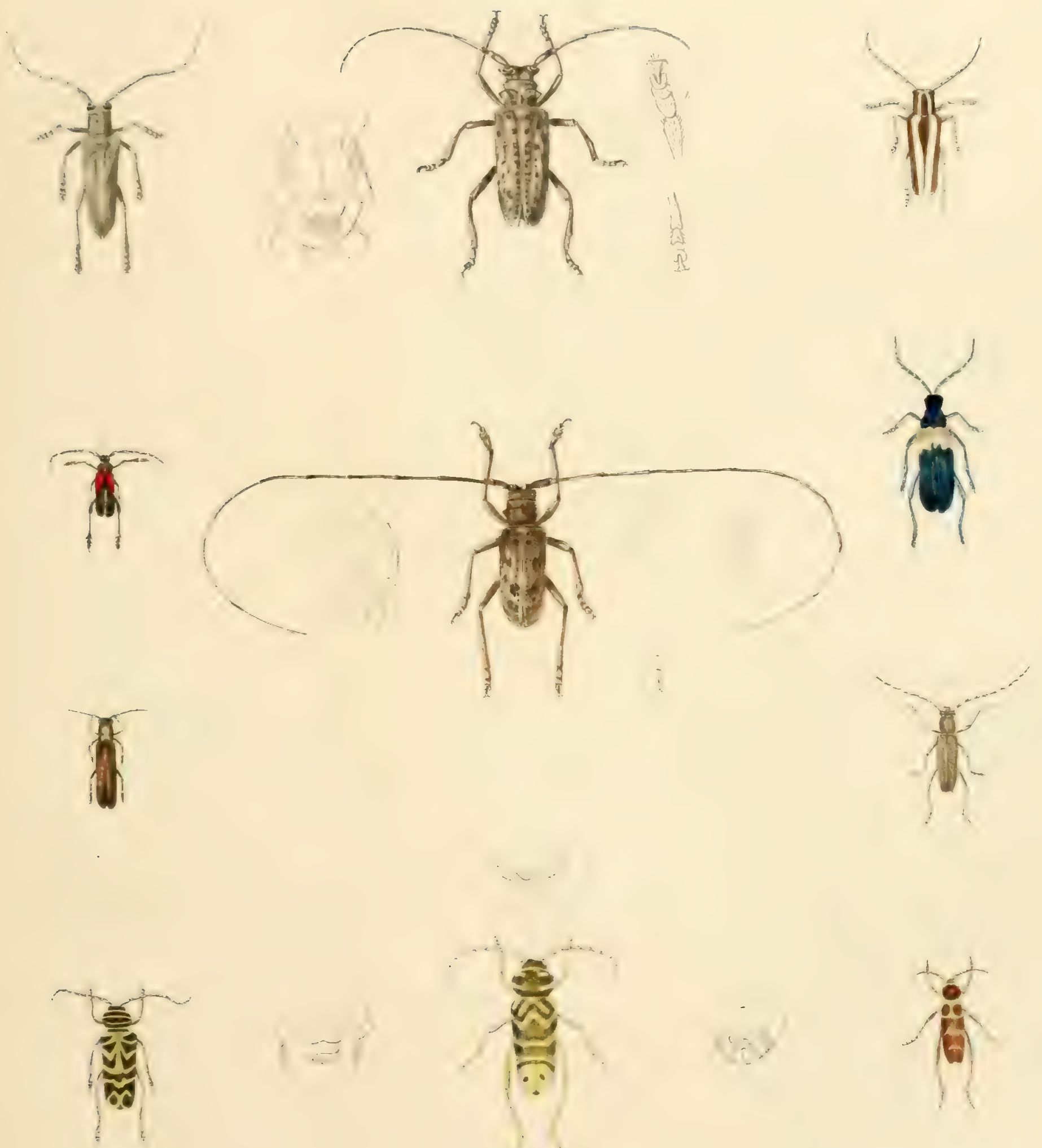




\section{PLITE 17.}

Hig. 1. Gicrnela albohrata.

$\because$ Cicisuela gexerosa.

:3. Cicindela 12-rittata.

4. Ciersdela patilela.

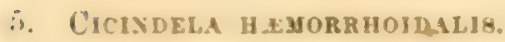

b. Crendela campestris.

-. cicivela gettata.

- Menuth and appendages of $C$. compestris.

9. 10, 11. Larva and pupa of ditto (European).

12. CIMISHEA VILGARIS.

13. Cicinifera albilabeis.

14. Cicisidea -

15. Creindela? (Maryland). 

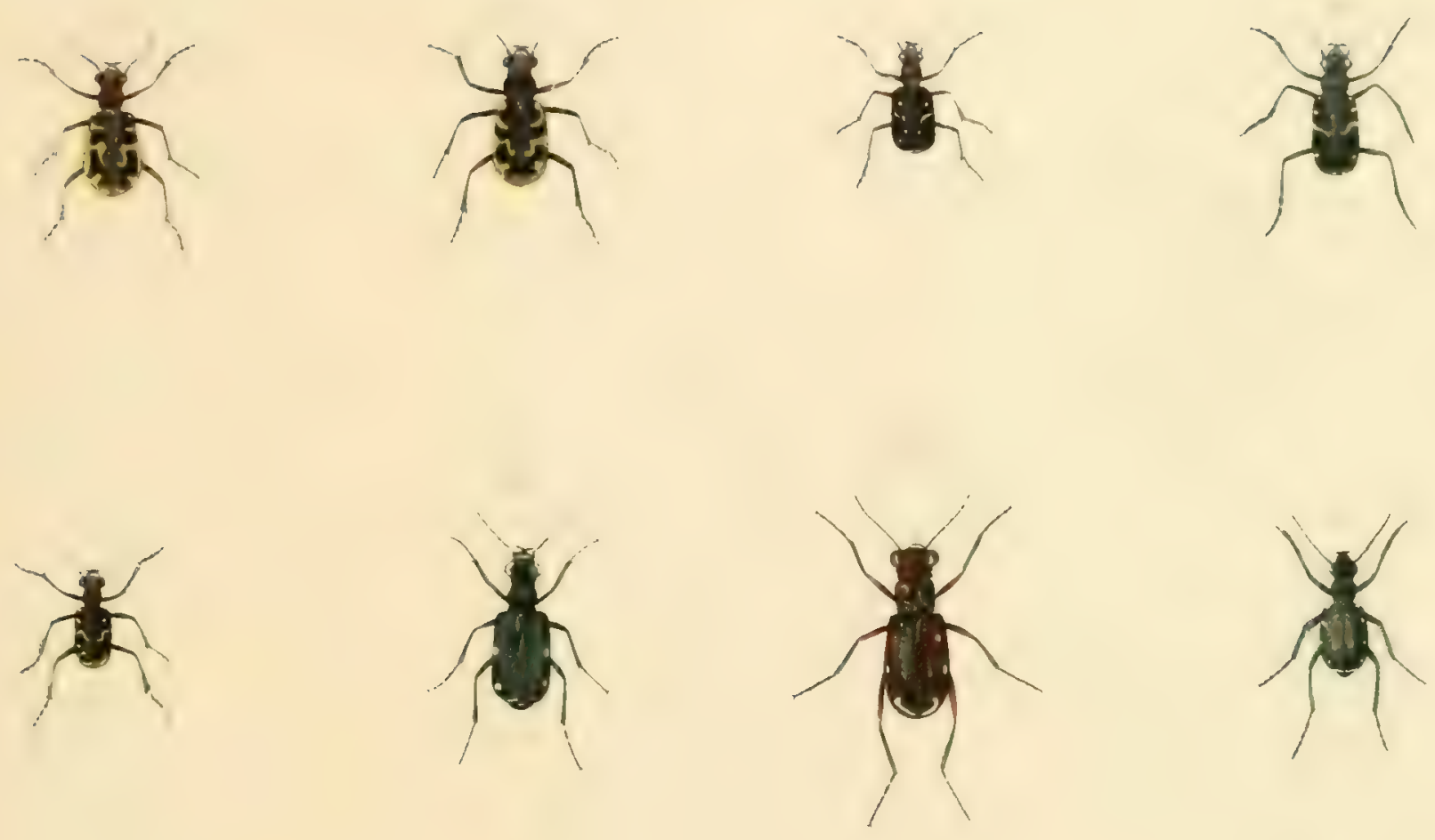

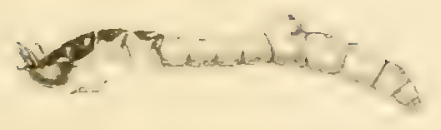
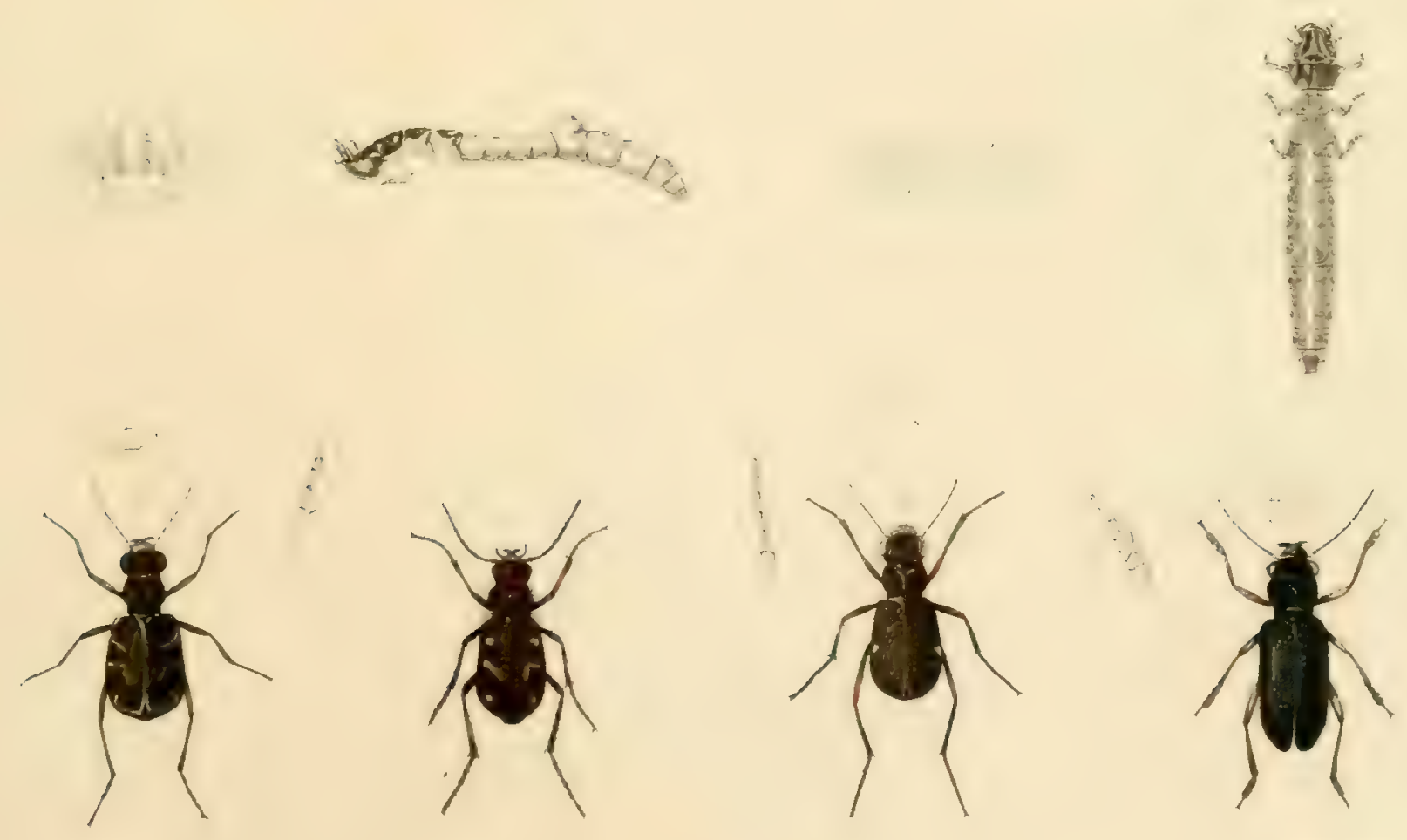



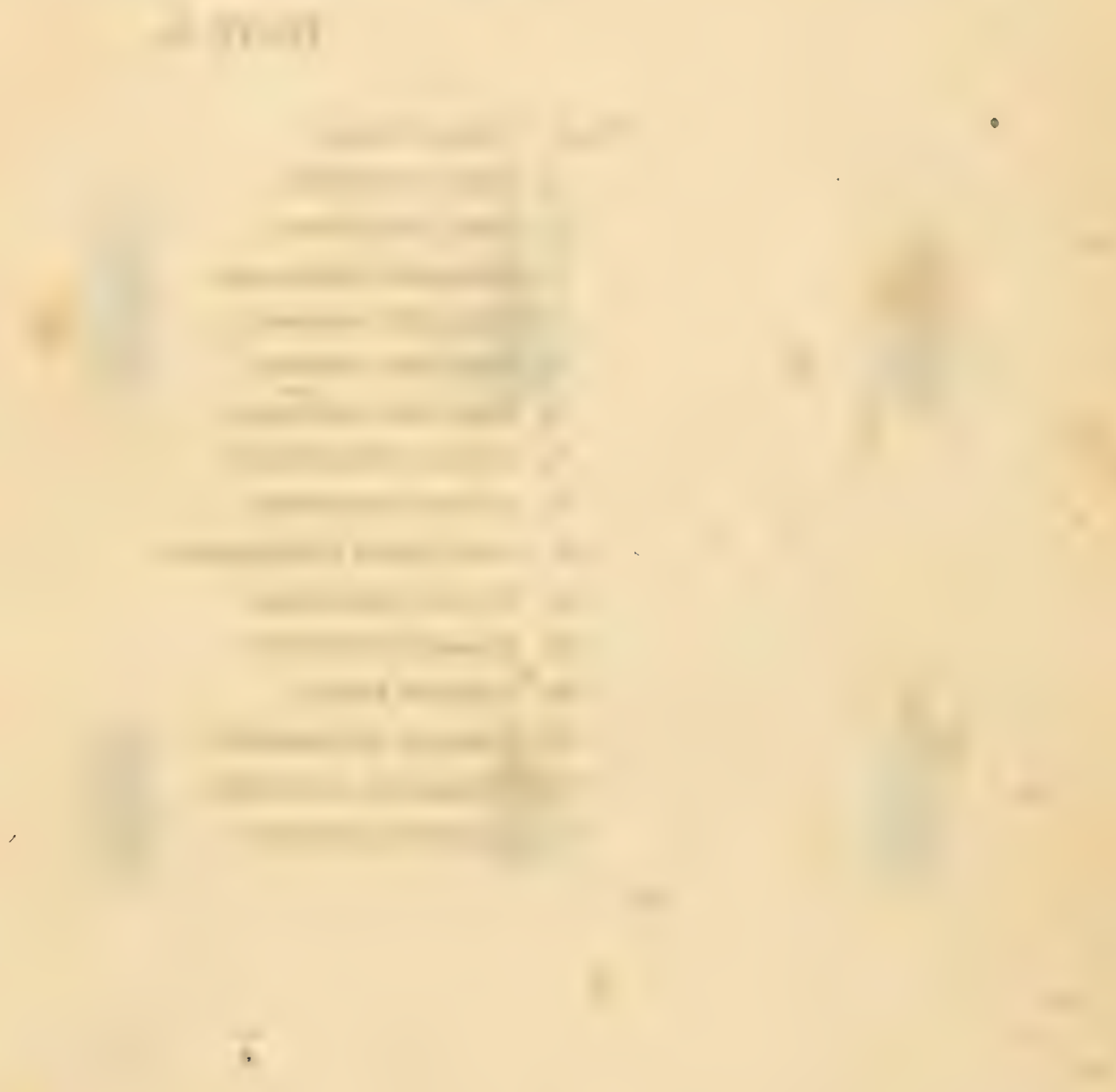

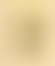




\section{PLA'LE 15.}

Fig. 1. LABi. virIIIS.

2. LEBIA ATRIVIREXS.

3. LABIA EMIRAGDKLA.

f. BRACHINTS CEPHALOTES.

j. Brachines conformis.

i. Brachines frmans.

7. BRARHATS PERPLEX's.

$\therefore$ Aanese ortorevetata.

1. AGosty ctpripexse.

10. ANCHONEYTS EXTENŞTCOLLIS.

11. Clivisi liveolata.

12. Gaterita AMERicaYa.

13. Cimindis pilosa.

11. Srarites scbterranets.

15. Dyschirits globlloses.

16. Calatules Gregarius. 

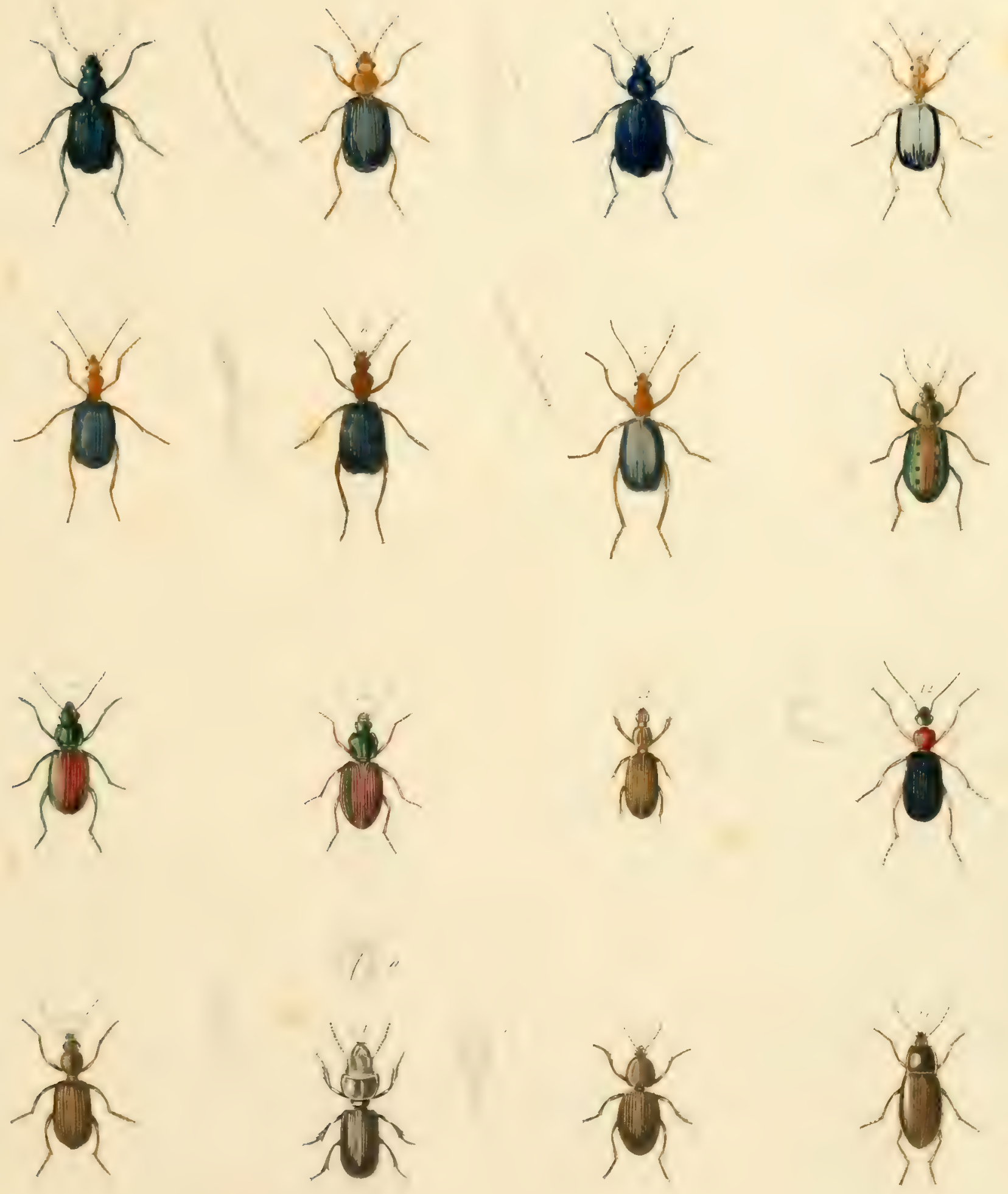


PLATE 19.

Fig. 1. Pecillets chalcites.

․ Pecilius leciblaida.

3. Feronia etrugica.

4. Feronia adoxa.

i. Igonidents pallipts.

i. Axisonactyles baltivorils.

i. Treches conjesctes,

6. Trechis cinctís.

9. ANIEODACTYLTS AGRICOLIIE.

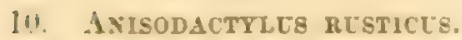

11. AMara IMPENCTICOLLIS.

12. Adelosia mita.

19. Harpalug erraticus.

14. Harpaltes gateres.

15. Harpalus bicolor.

16 Harpales pleviticts. 


nyin

$-$

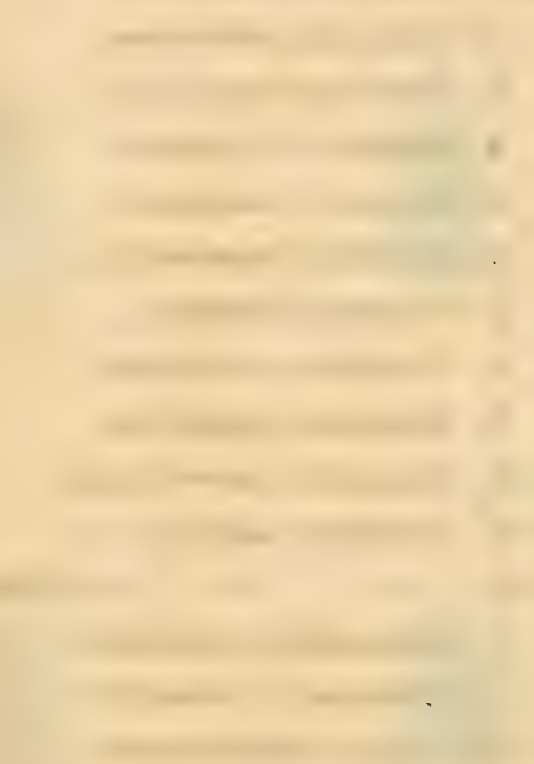




\section{PluATE 20.}

lig. 1. Elaptroves risciariug.

2. Celanilo tomextostis.

3. BEMBIDIYY SICILLAR.

4. BeMbIDICM hosestey.

5. Chravier memoralis.

6. Chlenils maroinajub.

־ Chlovits 8ericets.

8. Chlesite hithophils.

9. BEMBIDILM INOR:ATLN.

10. BEMBIDIM TRIPENCTATLM.

11. OMOPHRO LABRATLY.

12. - - rar. TESERLIATUS.

13. Natiophllus PORRECTUE.

14. Bembidicm Variegatum.

15. Haliples 12-punctatés.

15. Haltplus imacelaticollis. 

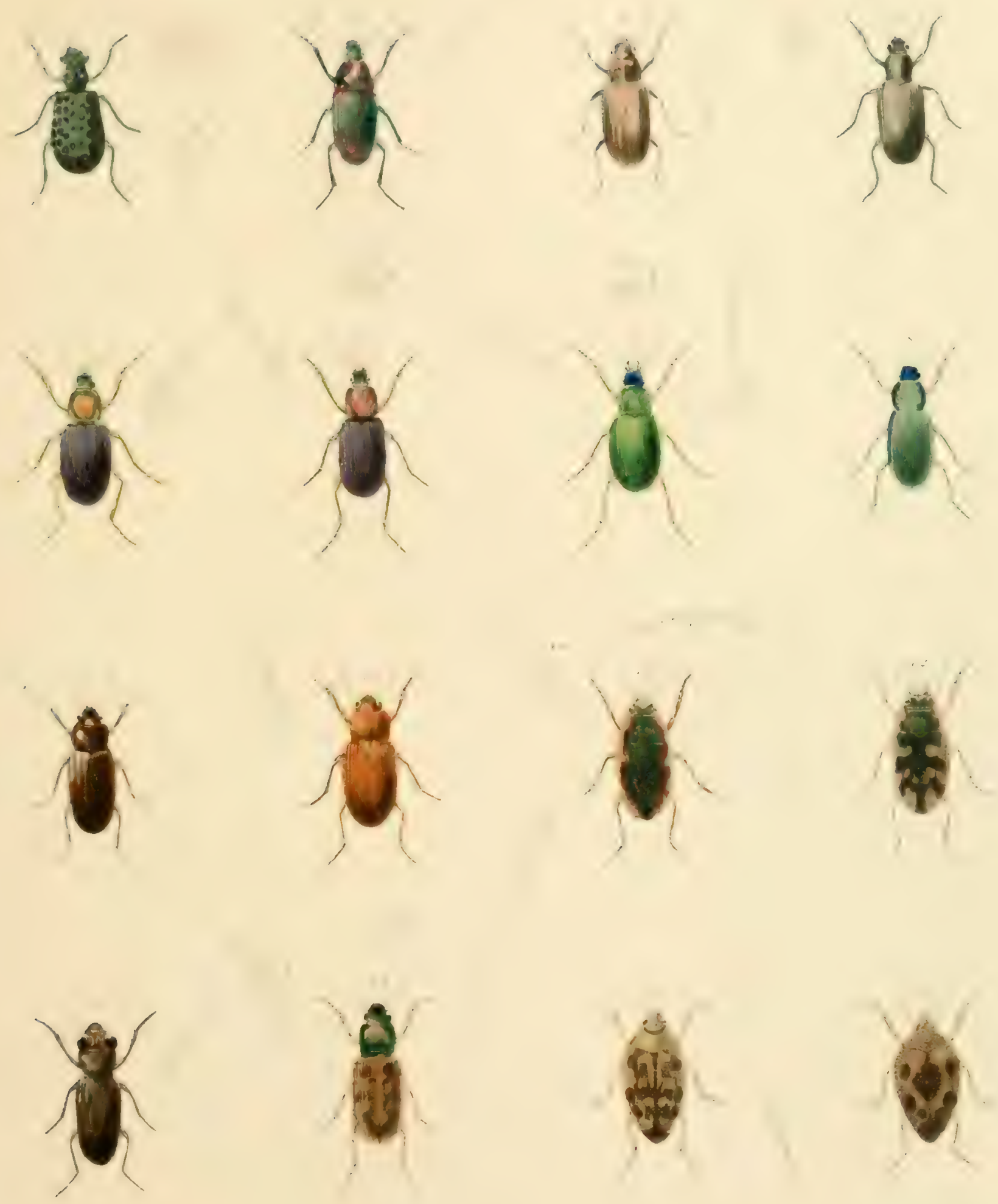



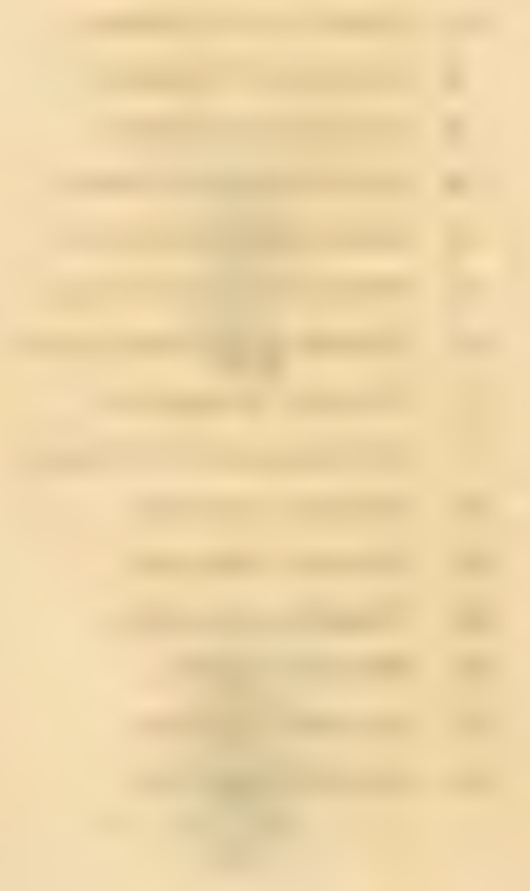




\section{PLATE 21.}

lig. 1. LAMPYris CCHRESCA.

2. LAMPYHIS LATICORNIS.

3. J.MMYRIS NIGRICANS.

4. Lamprers Unetiat..

5. LAMPYRIS SCINTHLLARIS.

6. LAMUYYRIS VERSICOLUR.

7. Dictroptera reticilata.

8. Dictromera telsMisalos.

9. IHCELUS DHIATATIS.

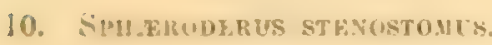

11. C.hases vinetus.

1.. CarabUs semvates.

1\%. Diceine klongates.

14. Crohros videus.

15. Caronoma calinem.

ii) Carabub mimbatue. 

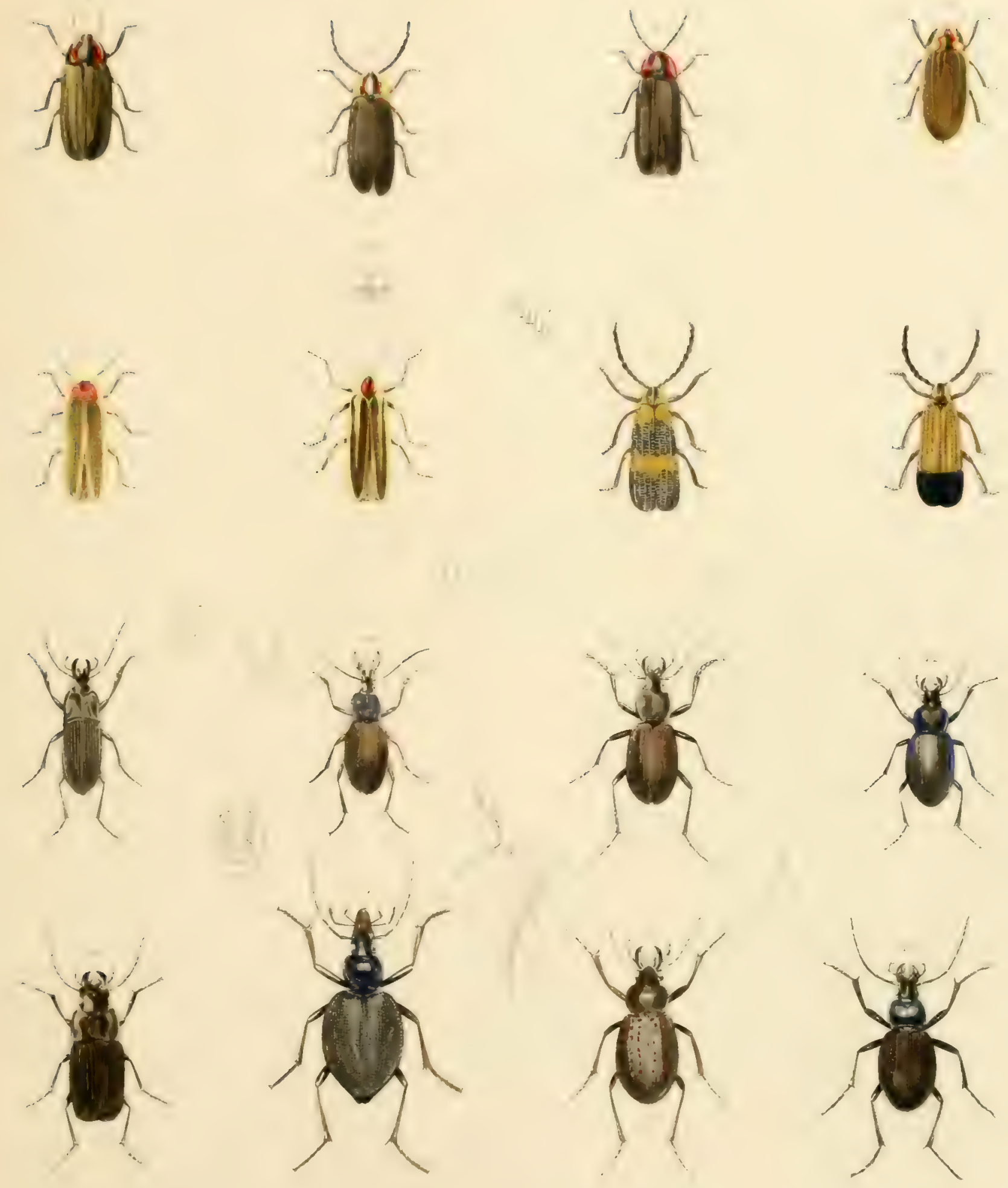

PLATE 2.2.

Fig. I ONCHERES CINGUdates.

¿ Cecejes clavipes.

3. SILPIIA AMERICANA.

$\mid$ Necrodes serinamensis.

i. Necrophages pygmets.

(i. SILPHA INEQTALIS.

7. SilPHA OAUDATA.

8. NeCROPHAGtS AMERICANTS.

9. SILPHA NOVEBORACENSI8. 

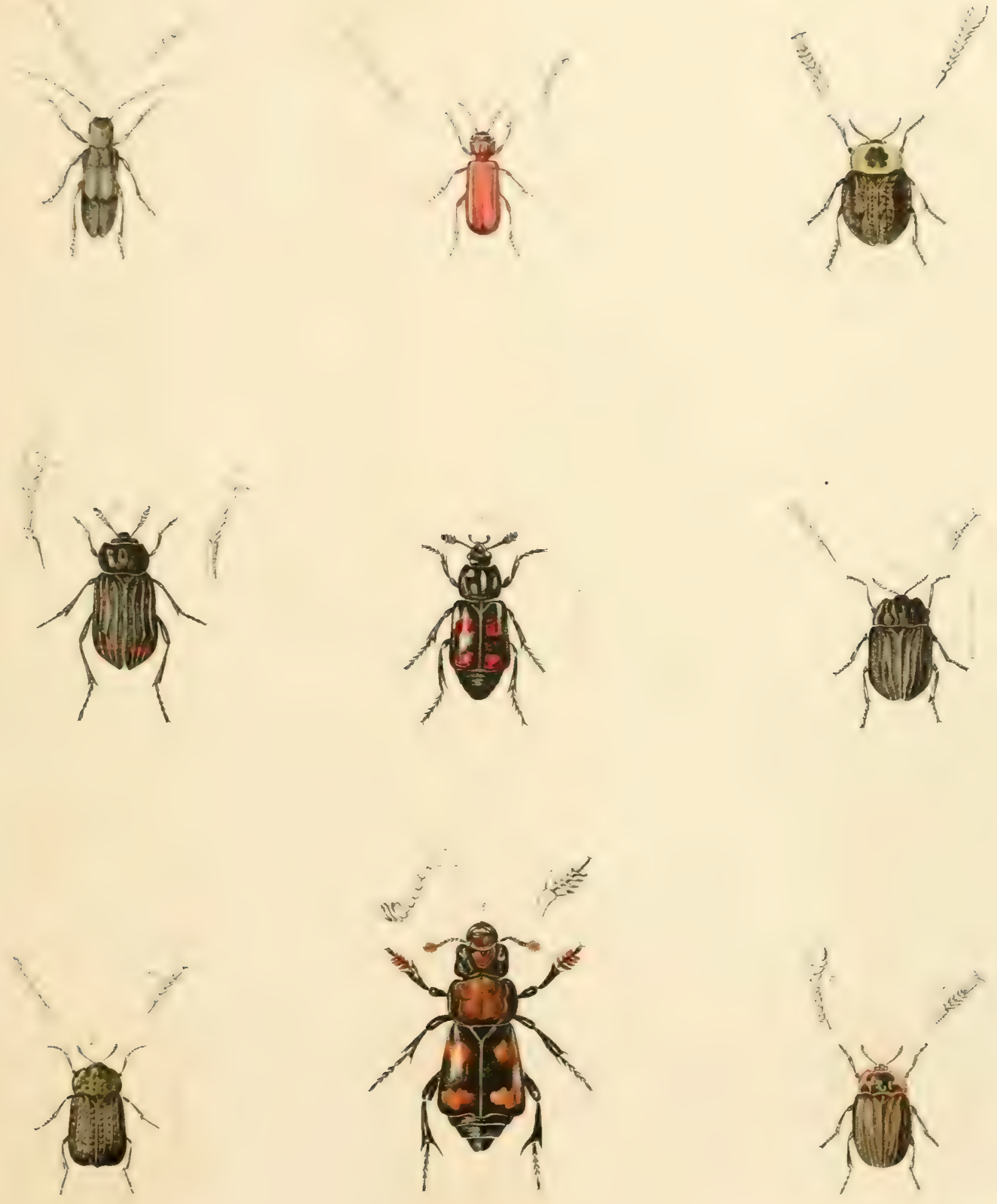




\section{PLATE 29.}

Fig. 1 Nitidula biptstelata.

2. ENois fasciata.

3. Ifs savacinolenta.

4. Ips fasclata.

j) DERM FSTES LARDARITS.

6. IP8 QUADRISIGNATA.

7. Parinus fastigiates.

8. Ips bipugtulatub.

9. Etais crenatis. 

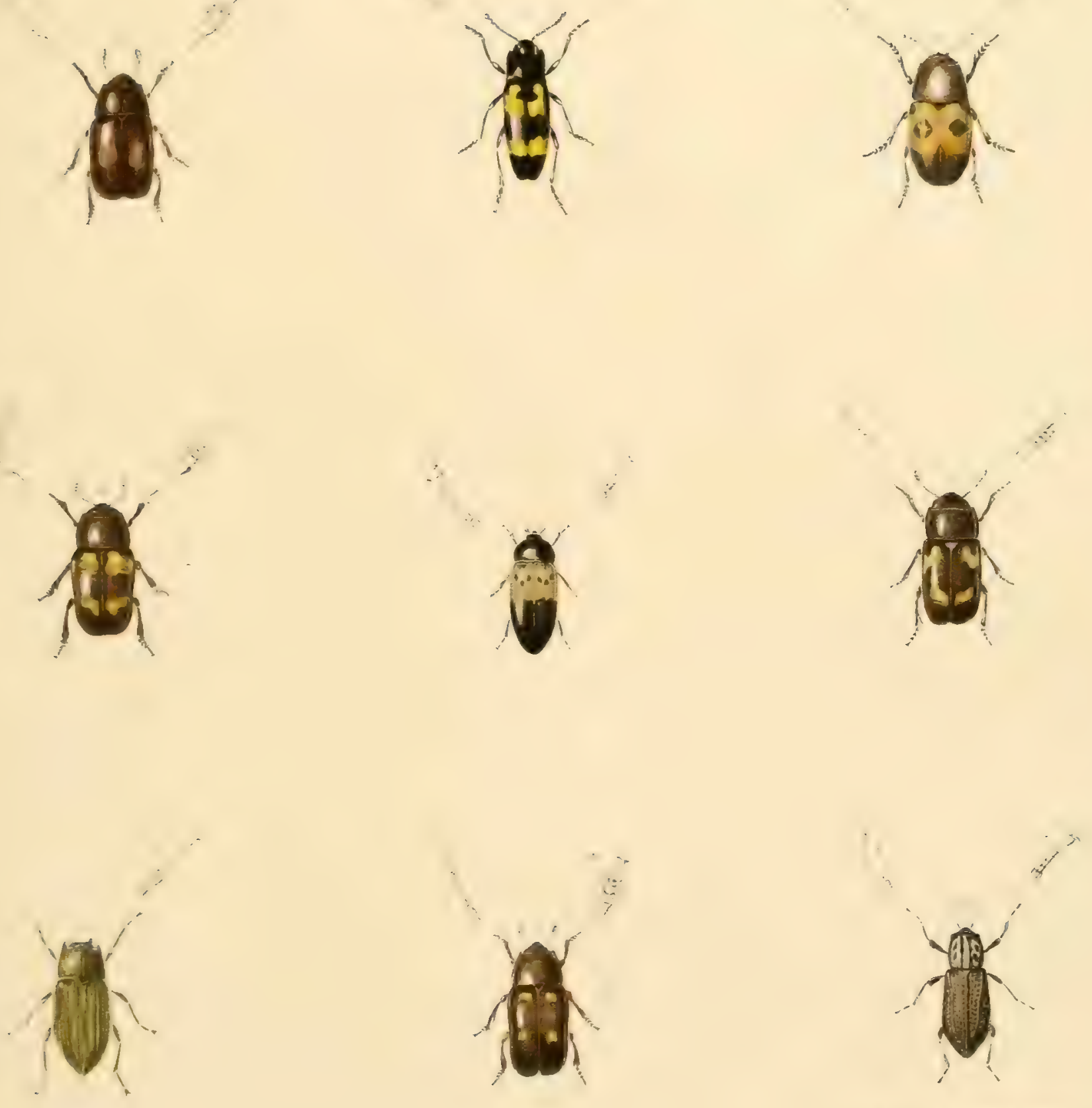



\section{PLATE}

Fig. 1. Trox mapillaris.

2. Crenastocheilus hentzil.

:) Trox porcatus.

4. II opla trifasciata.

5. Tricuinus viridans.

6. Fuchlora calebs.

7. MIISOTROGCS GEORGIANICA.

8. Eichlora atratus.

9. Serica Vespertina. 

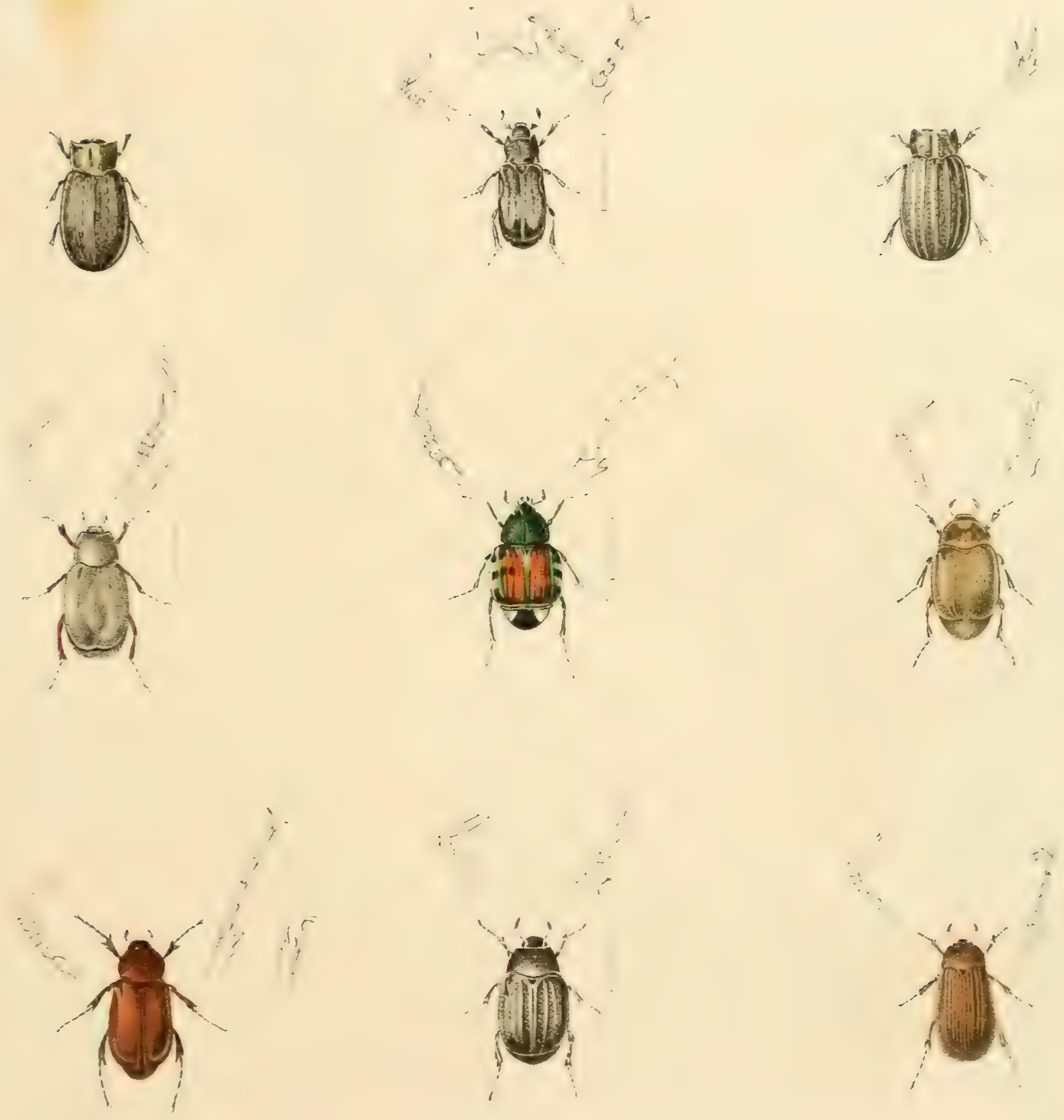



\section{PLATE 25.}

Fig. 1. Dromelontcha elongata.

2. DENDROIDES CANADENSIS.

3. Platyceras picets.

4. Canthariz atrata.

5. Osmonerma scaber.

i. Prrochroa flabellata.

7. Pitmo americayis.

×. Tris ienneyidanices.

9. RHIsotroeds pilosicollis. 

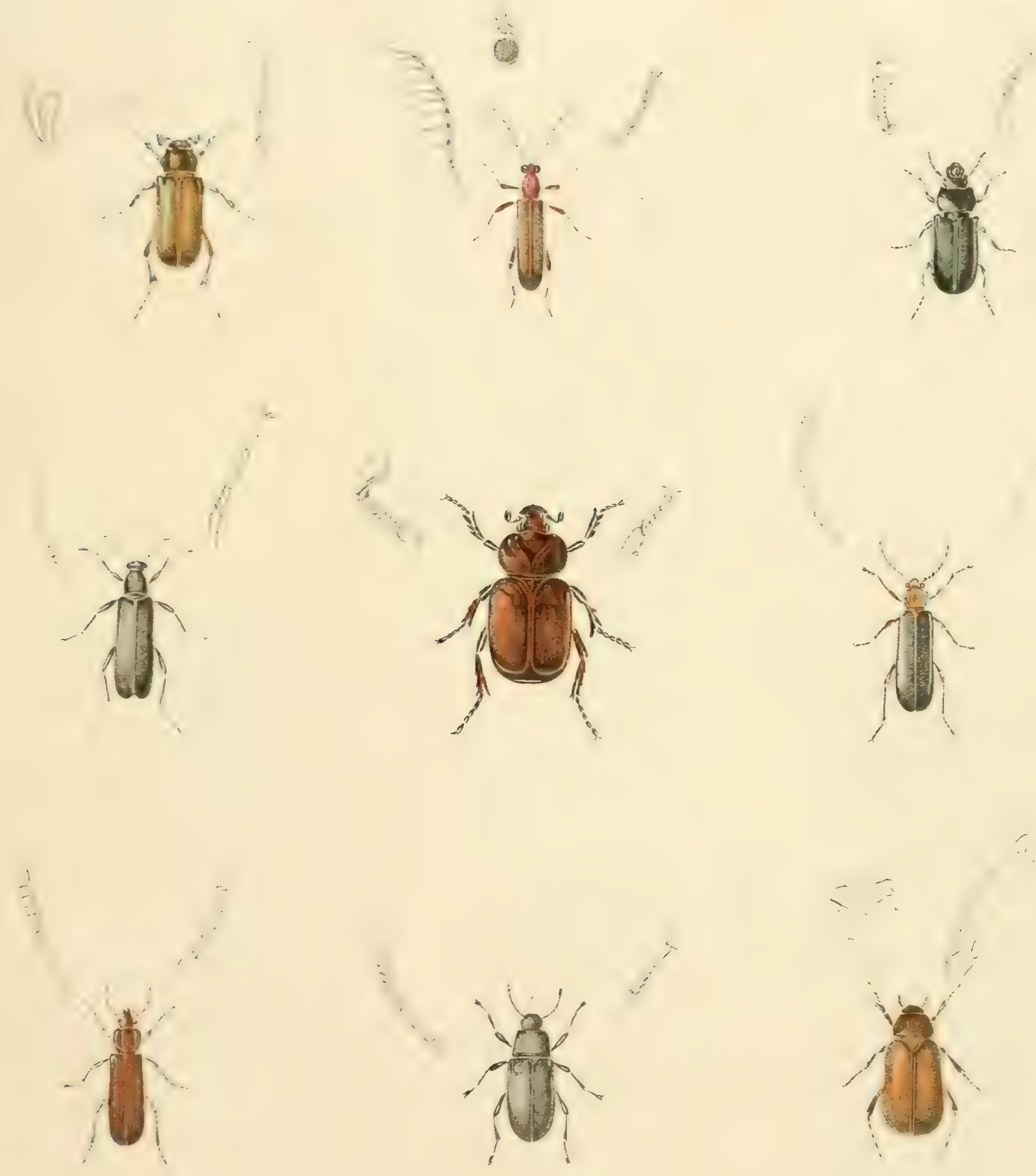




\section{PLATE 26.}

Fig. 1. Eorria exitiosa (male).

2. Pups of the same.

3. Cocoon.

4. Larva.

5. Egeria exitrosa (female).

6. Vespa fraterna.

†. Pelecints politurator.

8. Undescribed?

9. SPHex PENNGYLVANICA.

10. Scomia fossilana.

11. Crmbex tim. 

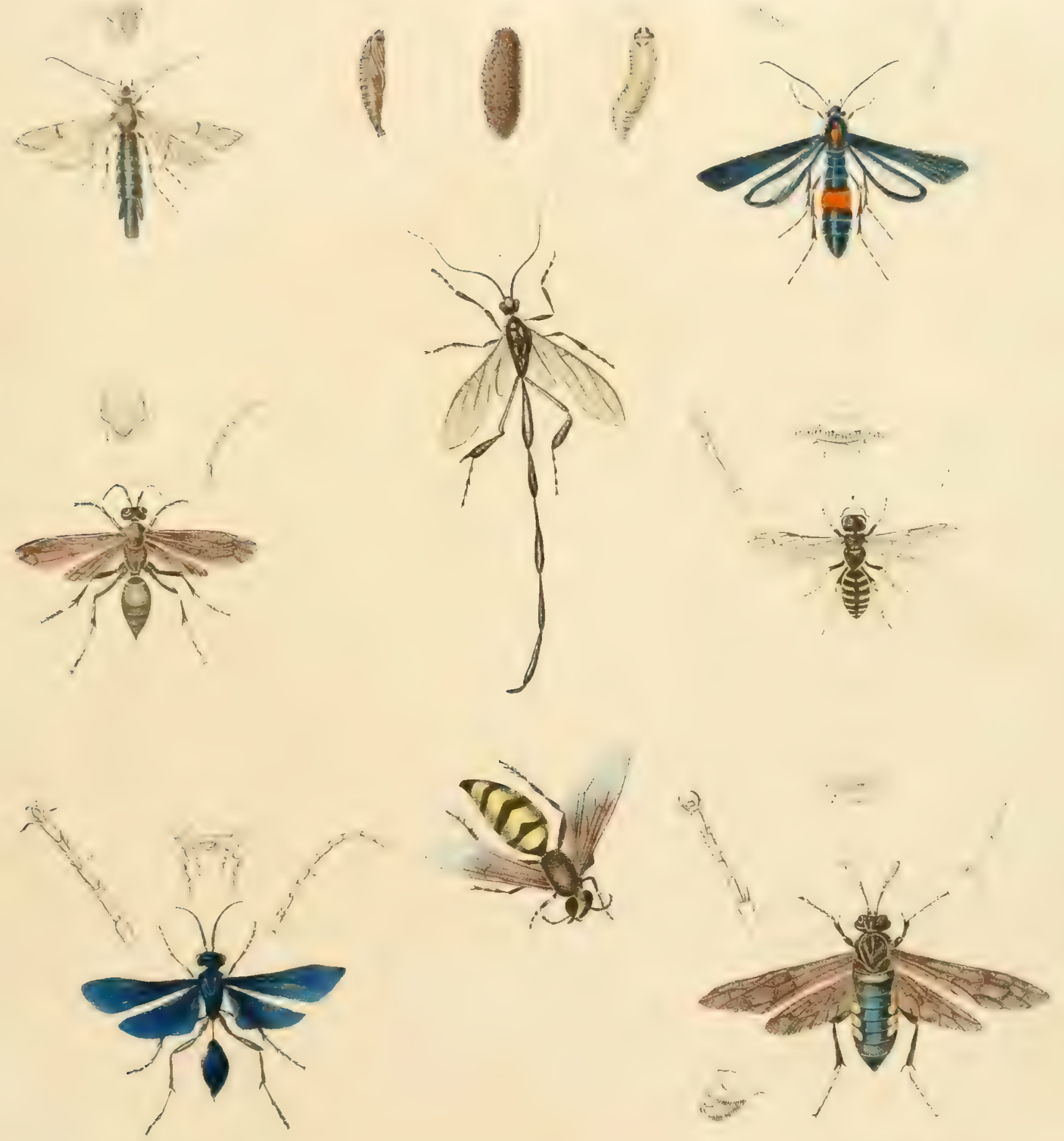




\section{PLATE 27.}

Hï. 1. Xrlocarpa virginica.

$\therefore$ Celioxis annelaris.

$\therefore$ Ophion glabrates.

t. OpHION Mendes.

5. OPHION MACRTRCM.

i. Ophion pergates.

i. ICHNEUMON —

$\because$ Pimpla

1. ICHNELMON.

11. ICHYECMON BREVICINCTOR.

11. T"ndescribed.

1:. Tndescribed. 

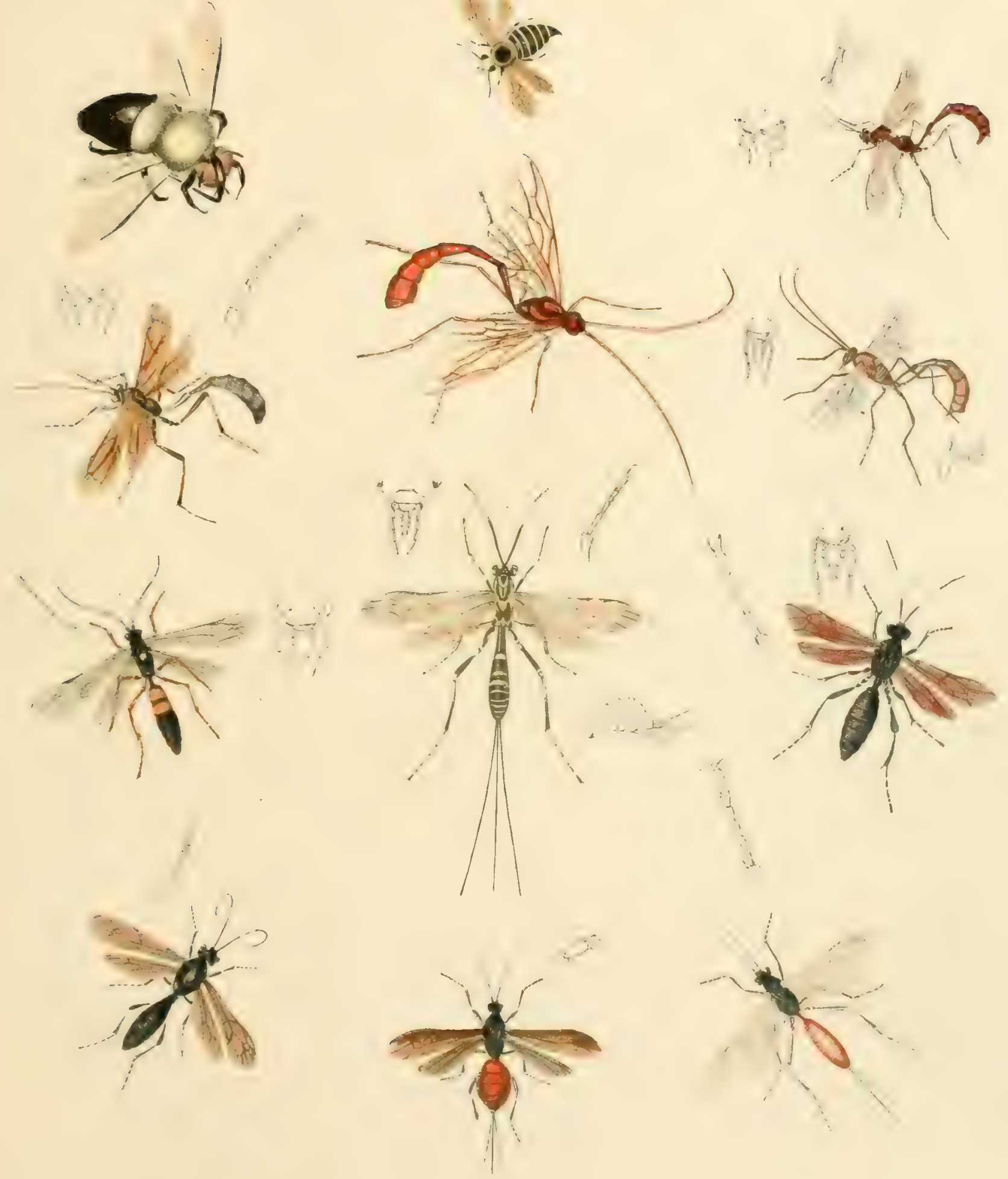




\section{PLATE 2.}

Fig. 1. Syrpites pHILAdelphicl's.

2. I'ndeseribed?

3. Milesia trroiniensis.

4. Undescribed ?

5. Laphira thoracica.

6. Laphira tergisga.

7. Mesca (Caliphora) vomitoria.

५. LAPIIIRA? SERICEA.

9. Sarcophaua georgiNa.

10. Tabands plembets.

11. Midas filates.

12. Tabaycs arebicants. 


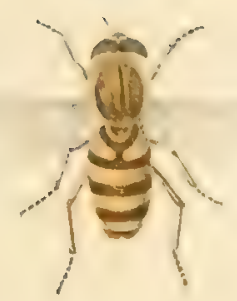

m
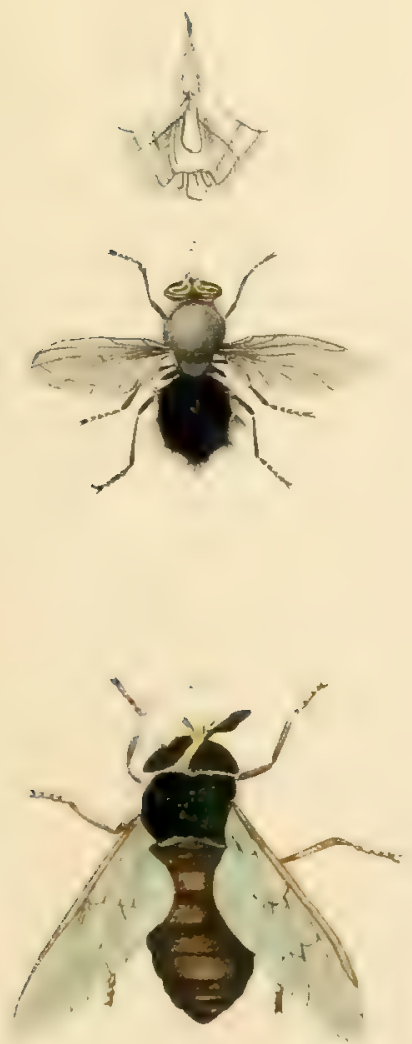
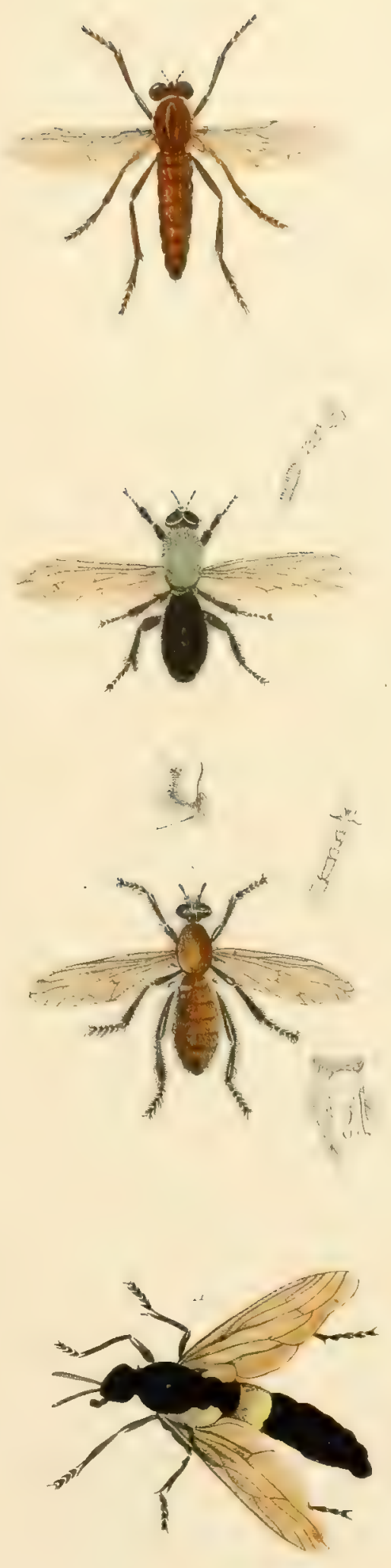
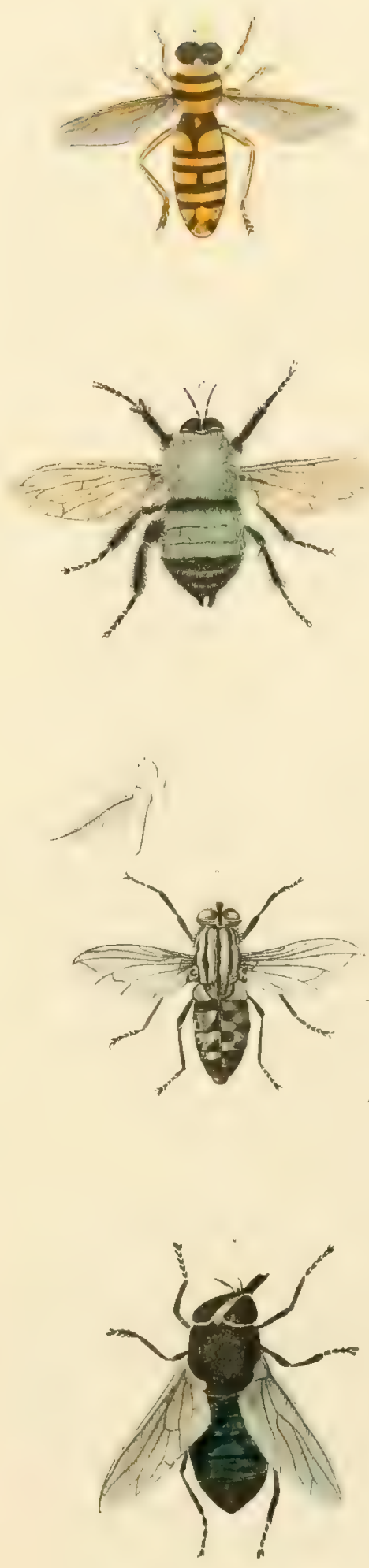
- .

, 


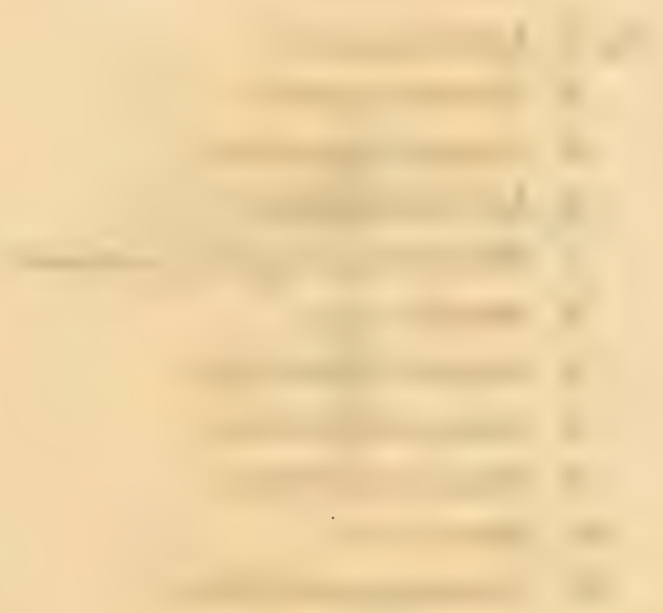

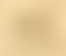




\section{PLATE 20.}

Fig. 1. Leptrs ornata?

2. TABANES LINEOLA?

3. LAPHira (undeseribed?).

4. Leptis quadrata.

5. Ctemophora trinacolata (female).

6. Strpheb -

7. Apris of the Peach leaf.

8. Sinea gtmolatrix.

9. Chrysidida (family).

10. LEPTIB

11. Proctorropid \& (family). 

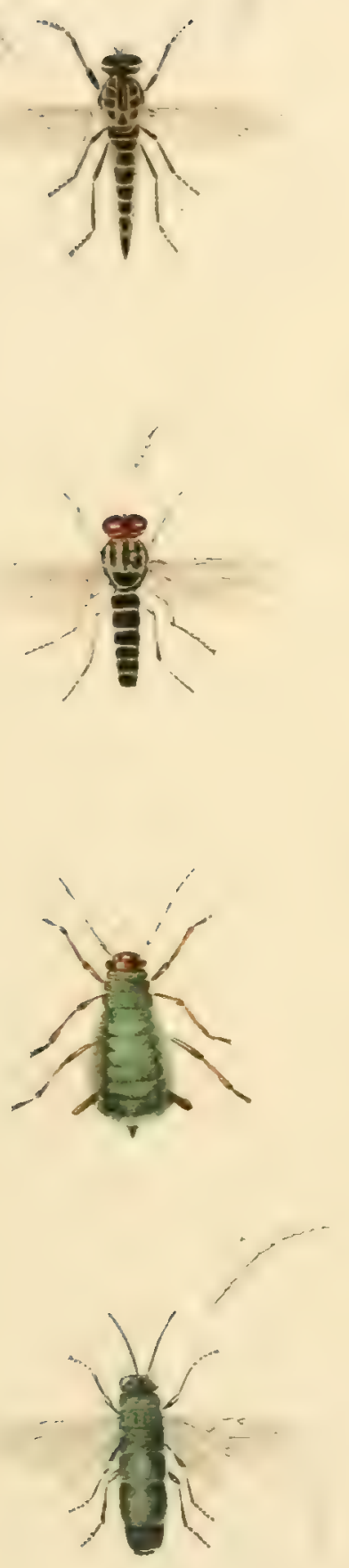

……
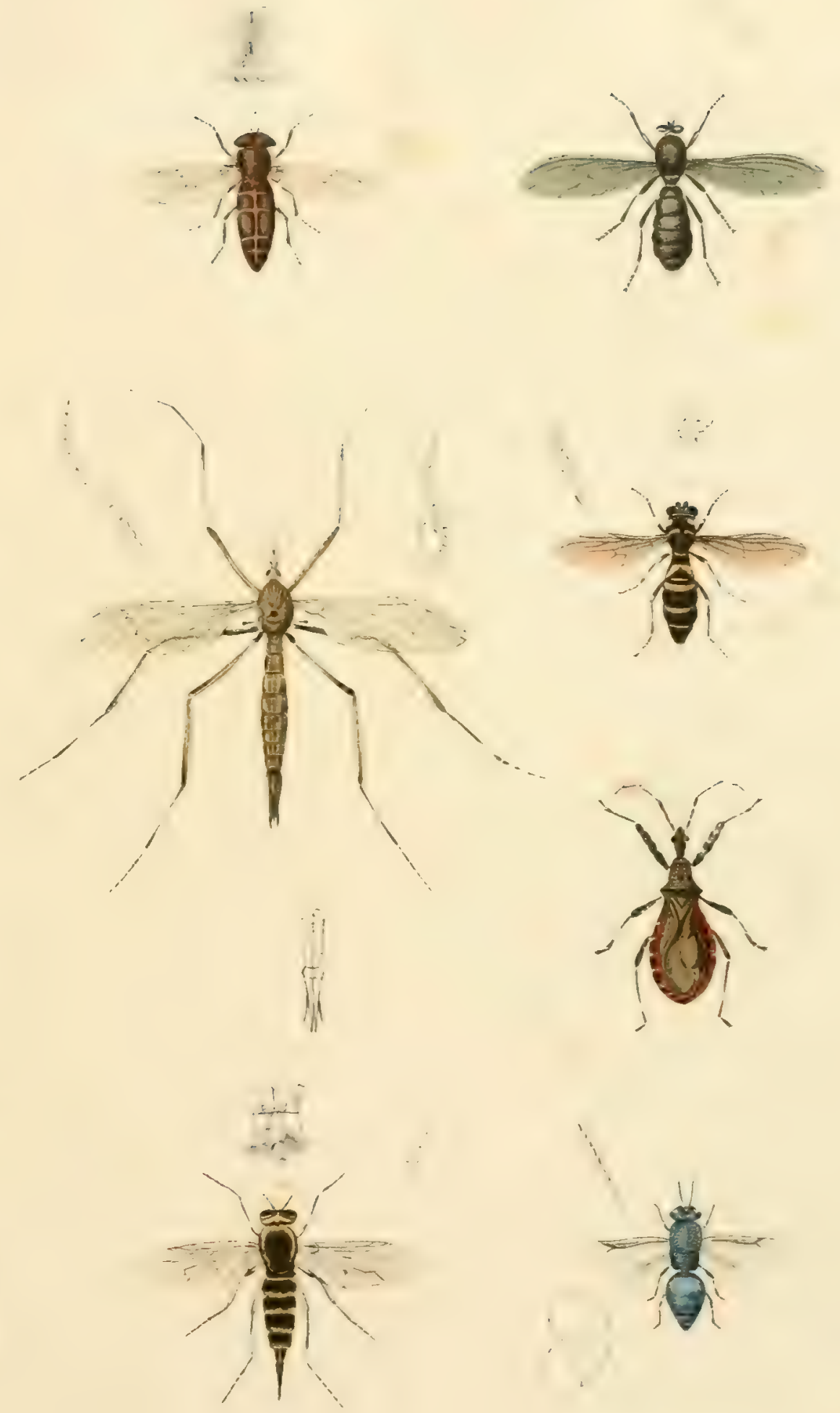




\section{PLITE 30.}

Fig. 1. PuYtocoris bellus.

$\because$ PurTocoris caccinets.

; Pentatoma carnifex.

- Acanteecoma spinosa (young).

$\therefore$ Pentatoma pennstluanica (joung).

i: Hammatocerdo pUrCis.

; Paytocoris lineolates.

$\checkmark$ Pentatoma (young).

() Lraxes turoicus, var. a. 

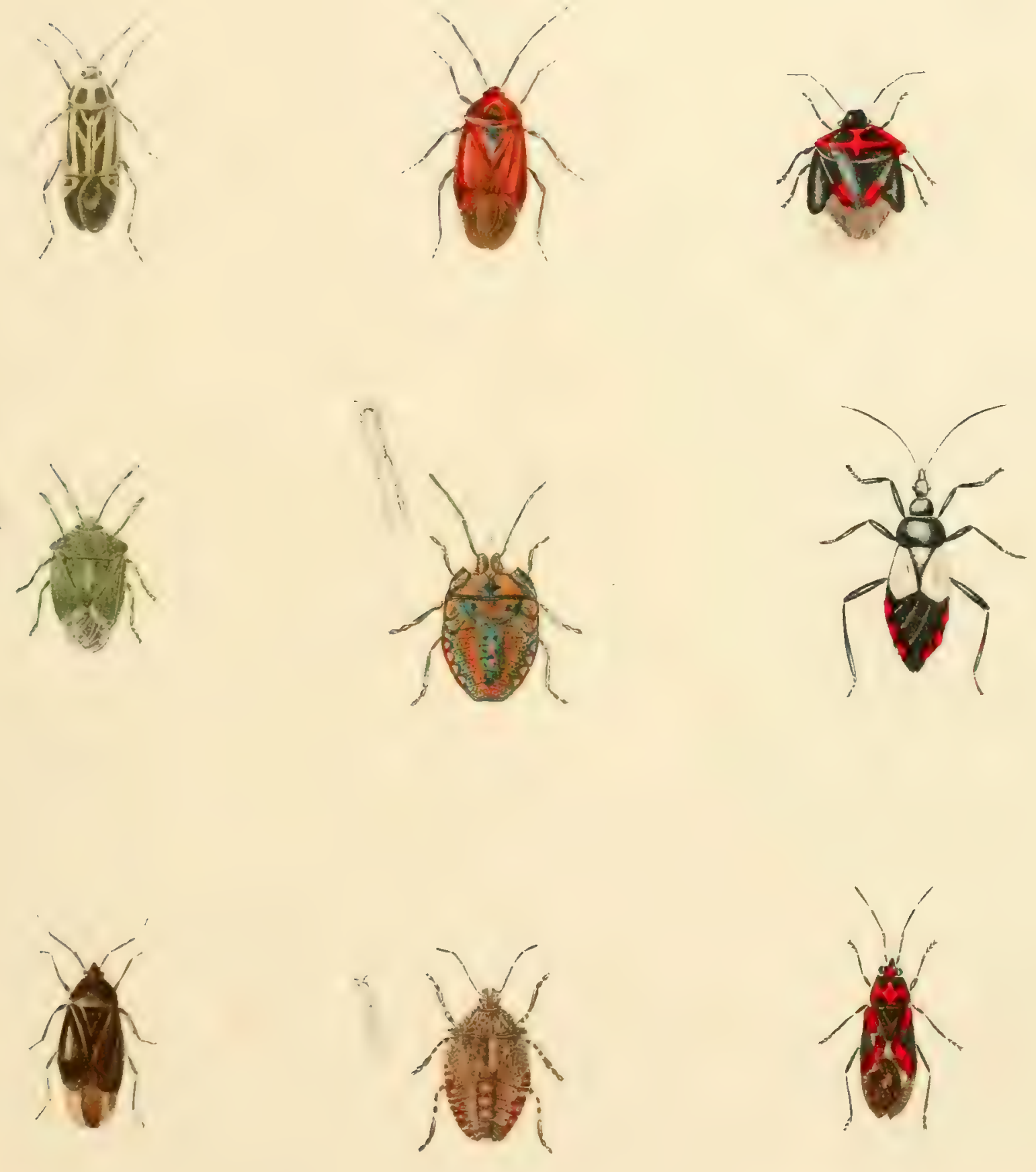



\section{PLATE 31.}

Fig. 1. Cantharis atrata (bis).

2. Ezater (Athous)? -

3. STAPHYLINUS CHRYSURES.

4. Onthophages mecate.

5. Crcloug americana.

6. Staphylines crannipennis.

7. Leptura malachitica.

8. HISTER CONFORMIS.

9. Feronia —

10. TENEBRIO MOLITOR.

11 Buprestis (ANCYLOOHELRA) BTRIATA.

12. Copris - 

. 



\section{PLATE 32.}

Fig. 1. Trearex colomba (female).

2. Tremex (male).

3. UROCERE ALBICORNIS.

4. Mrrmeleon (antlion).

5. Larva of the antlion, upperside.

6. Larva of the antlion, underside.

b. Pupa case of the same.

a. Sand-funnel, or trap.

7. Pirtganea gemifasciata.

8. Hegperia PECKIUd.

9. Sesta pelasats.

9 a. Purtganea bemifasctata.

10. Sesia fociforaris. 

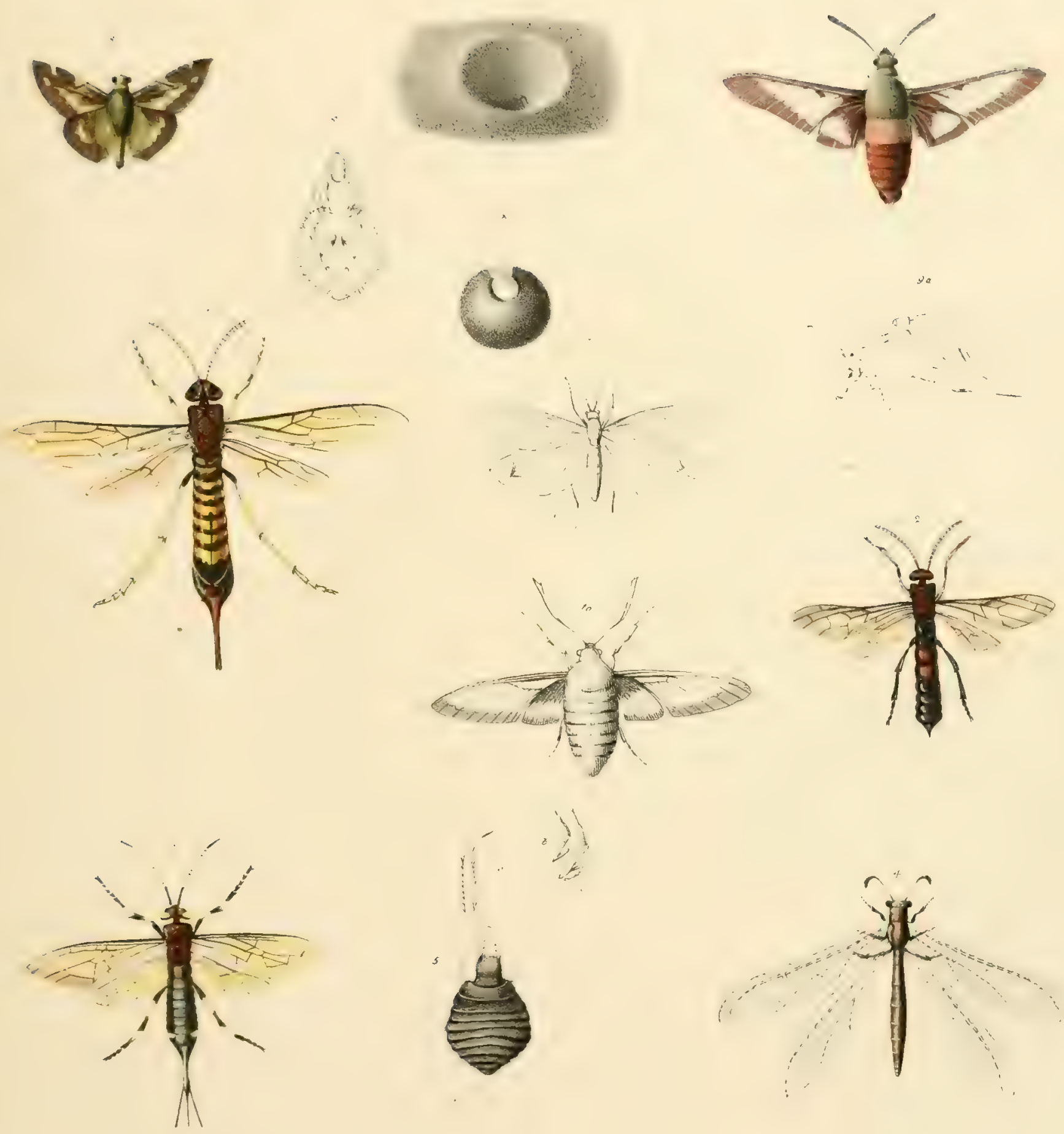


PLATE 33.

Fig. 1. Limenitis tretra.

2. Underside of the same.

3, 5, 6. HiPPARCHIA NEPHELE.

4, 7. Hipparchia alope.

8. ITHYCERES NOVEBORACENSIS. 
1
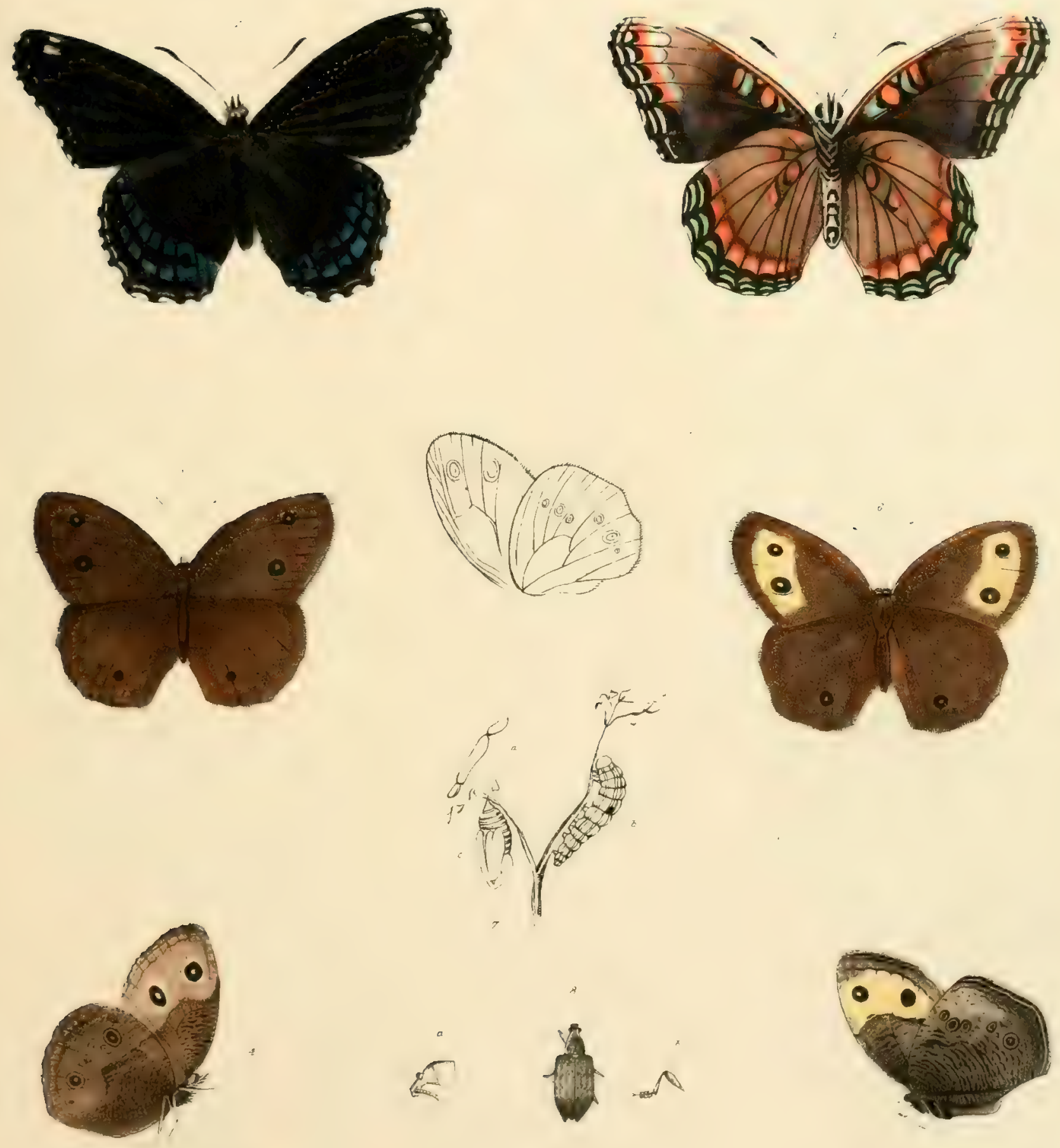


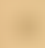

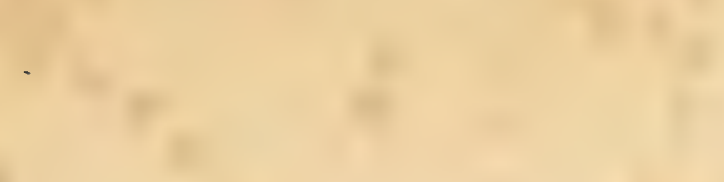

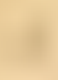

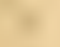

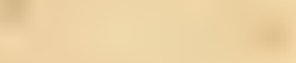

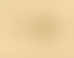

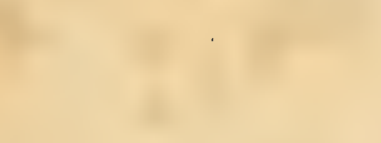

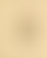

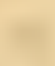

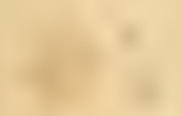

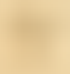

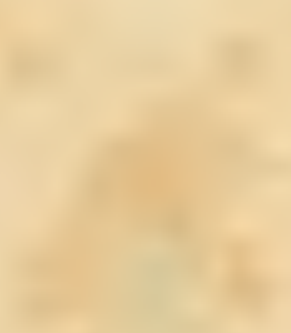

$\sqrt{2}$

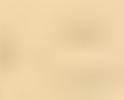

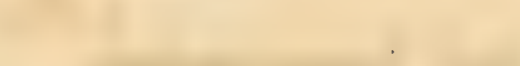

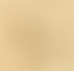

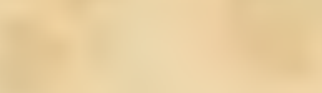

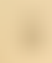

$+2$

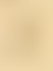

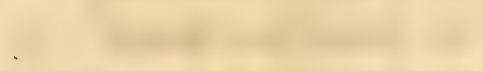

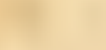

$+2$

$\sqrt{2}+n^{2}$

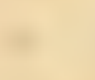

$\sqrt{2}$

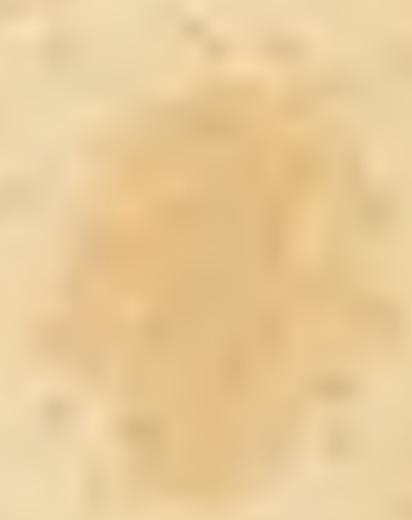

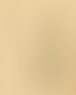

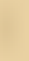

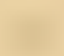

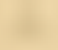

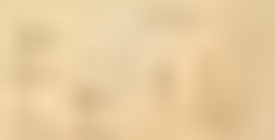

$\sqrt{2}+x^{2}$

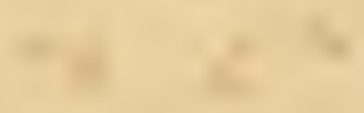
$\sqrt{2+2}+2$

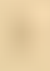




\section{PLATE 34.}

Fig. 1. Podabrog yodestug.

3. STENOCORE CINCTUS.

3. Telephores -

4. Saperda testita.

5. Priones haticolis.

6. SAPERDA TRIDENTA.

7. Saperda -

8. MunuchaMrs pesilited.

9. Cerambix (undescribed?).

10. Priones pexystutanicus.

11. Leptura - 

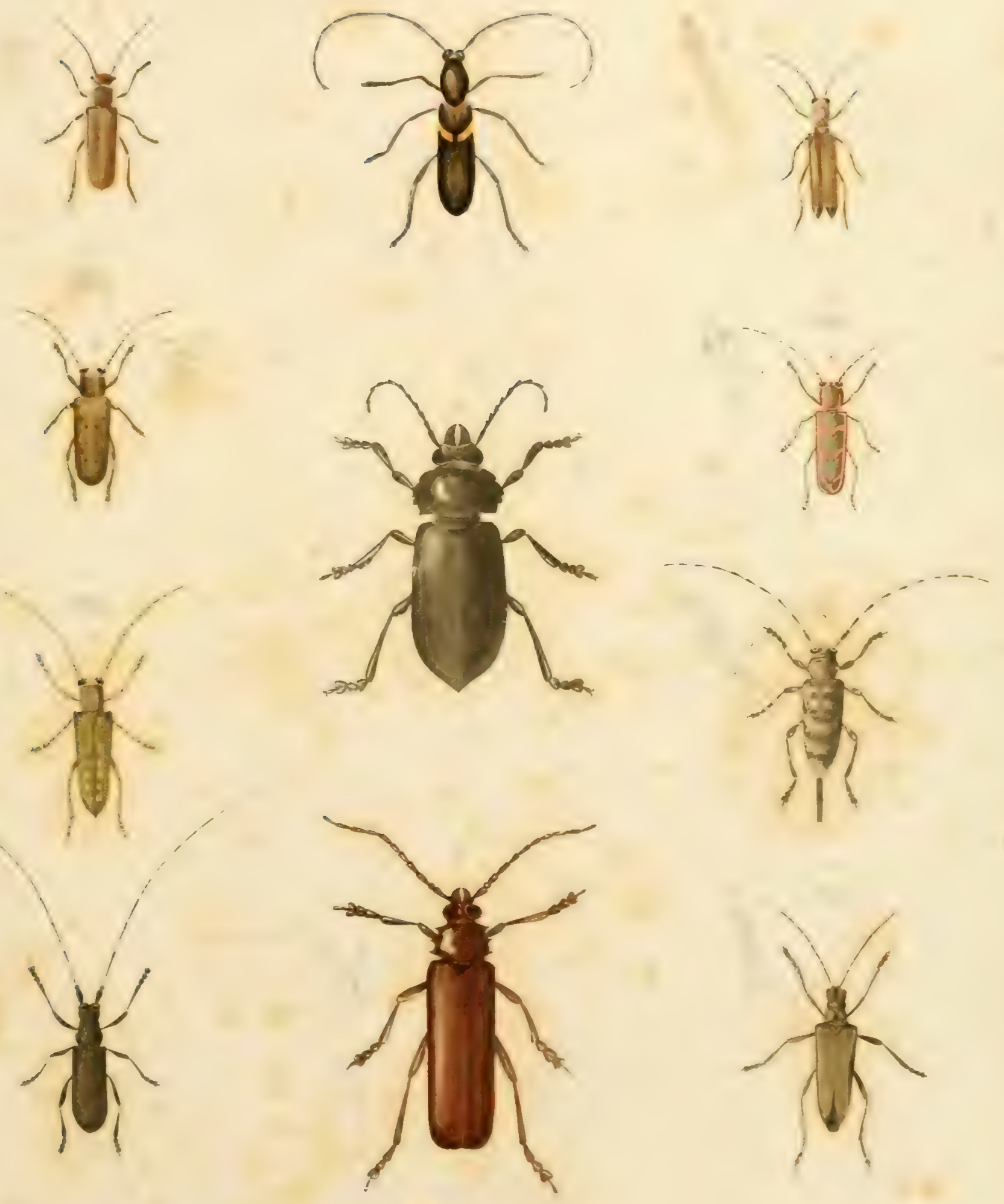



\section{.}

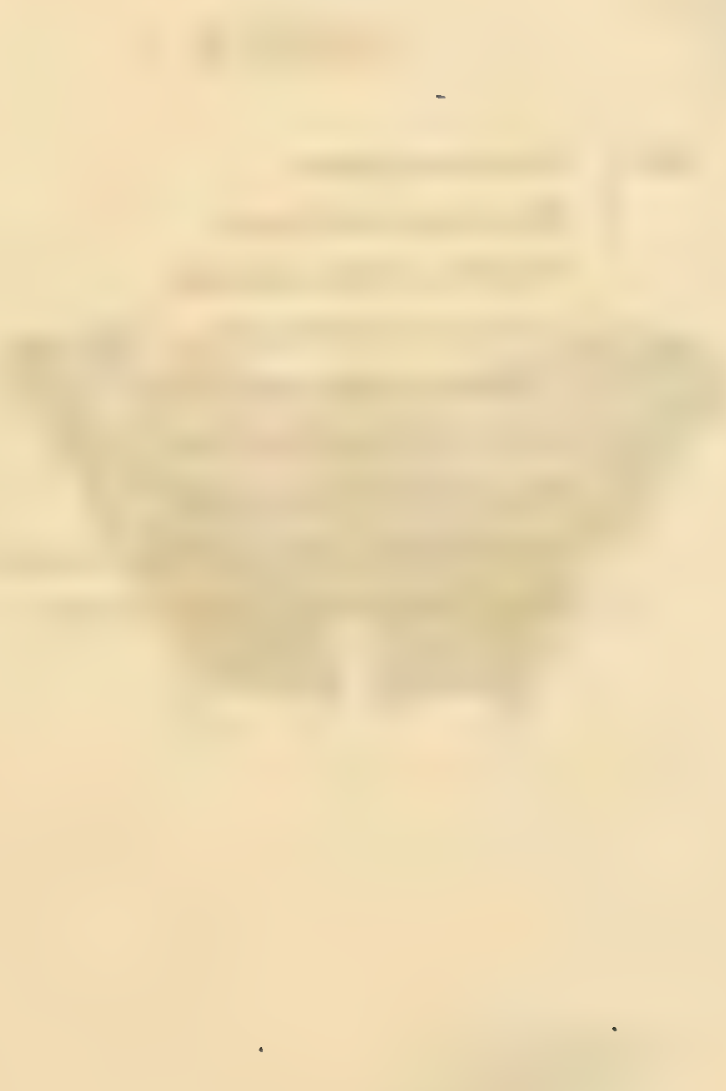




\section{PLATE 35.}

Fig. 1. Colias philodice.

2. Ditto, lower side (female).

3. Vanessa interrogationis.

4. Colias philodice (male).

5. VANessa interrogationis.

6. Pinris nicippe (under side).

7. Pieris nicippe (upper side).

8. Caterpillar of VANEsia interrogationis.

9. Colias philodice (upper side, female). 

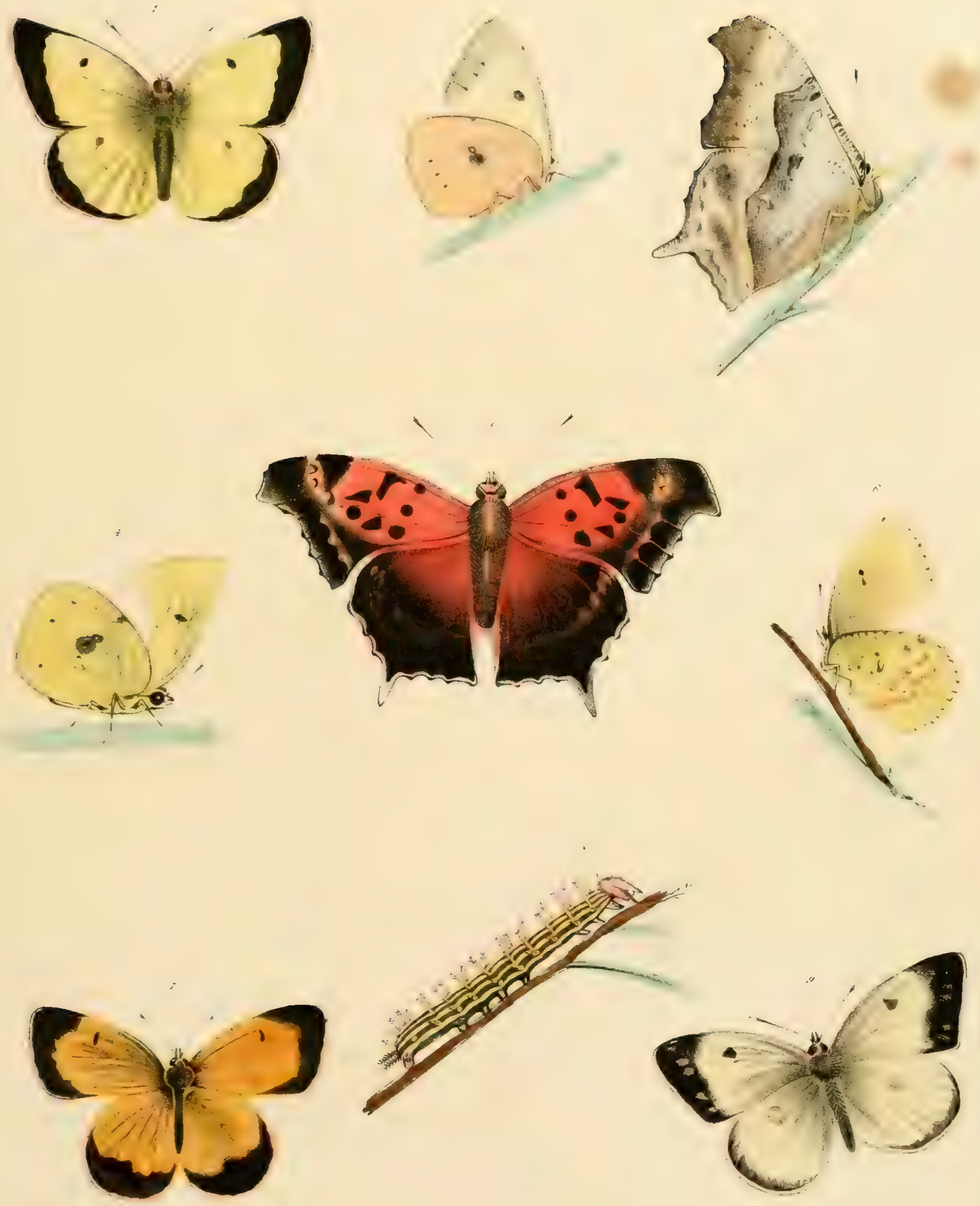

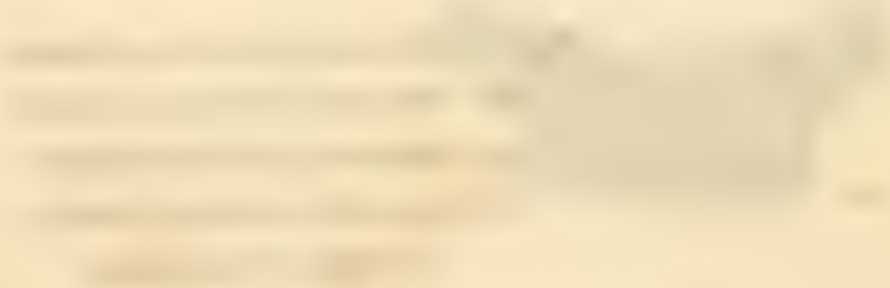

+ 


\section{PLATE 36.}

Fig. 1. Detocampa pellucida (female).

2. Pihalena ofercaria (female).

3. Dryocampa pelluoida (male).

4. Phal ana euercaria (male).

a. Pupa of Dryogampa.

b. Pupa of Phalena.

c. Caterpillar of Dryocarra.

d. Caterpillar of Phalena. 

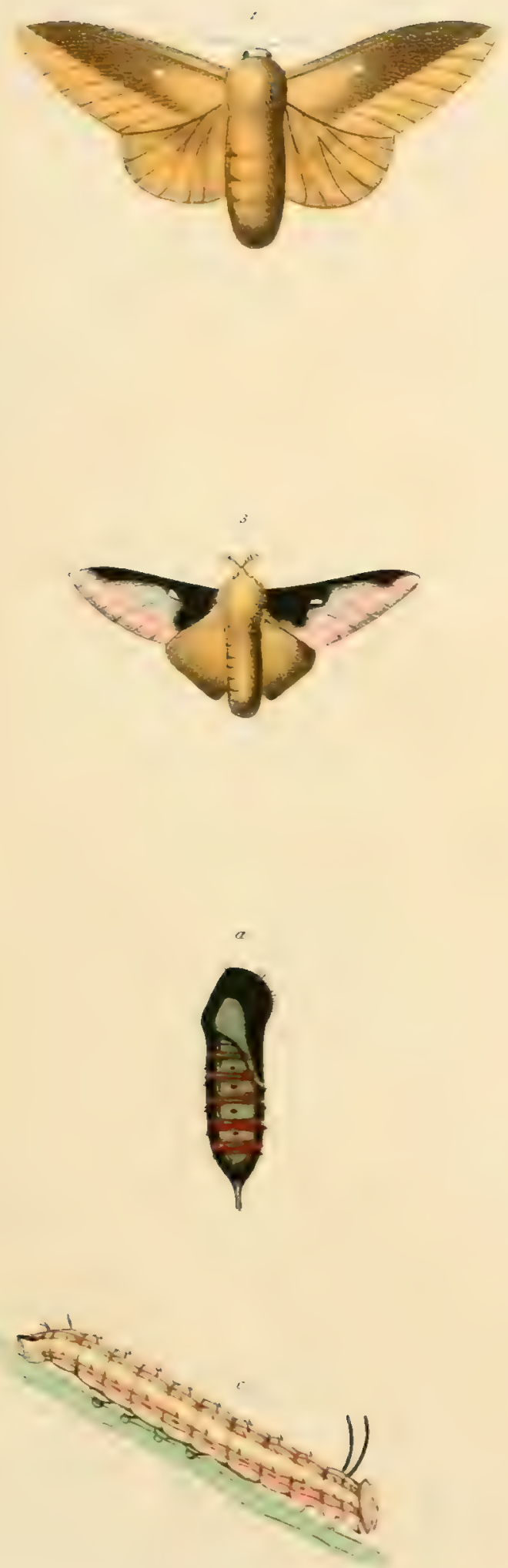

E. Emmons Jr. Del.
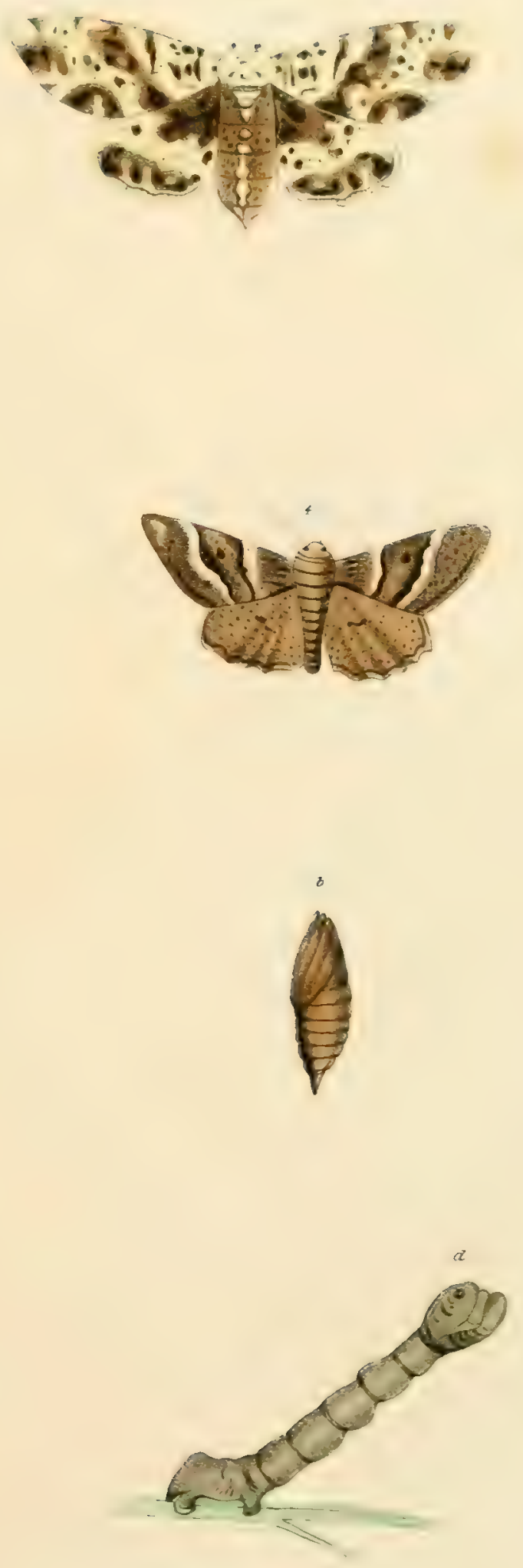

Lith of Rich.H Pease Albany 

. 8 DTh

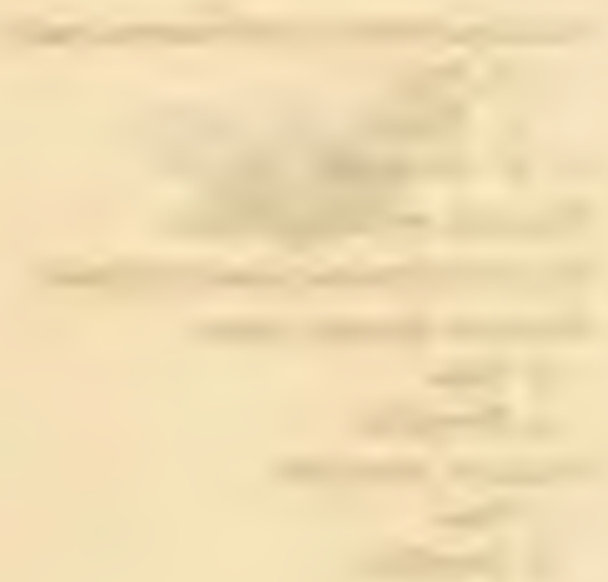




\section{PLA'TE 37.}

Hi . 1. Pual axa (Orgta) ledcostigma (male).

a, b. Pupa.

c. Fenale.

f. Caterpillar.

$\because$ Phalena mecstria (female).

3. Pualdana (Prosra) albifhons (male).

4. Phalena neustria (male).

d. Pupa.

g. Caterpillar.

$\therefore$ I'Halesia albirrons.

e. Pupa.

h. Caterpillar. 

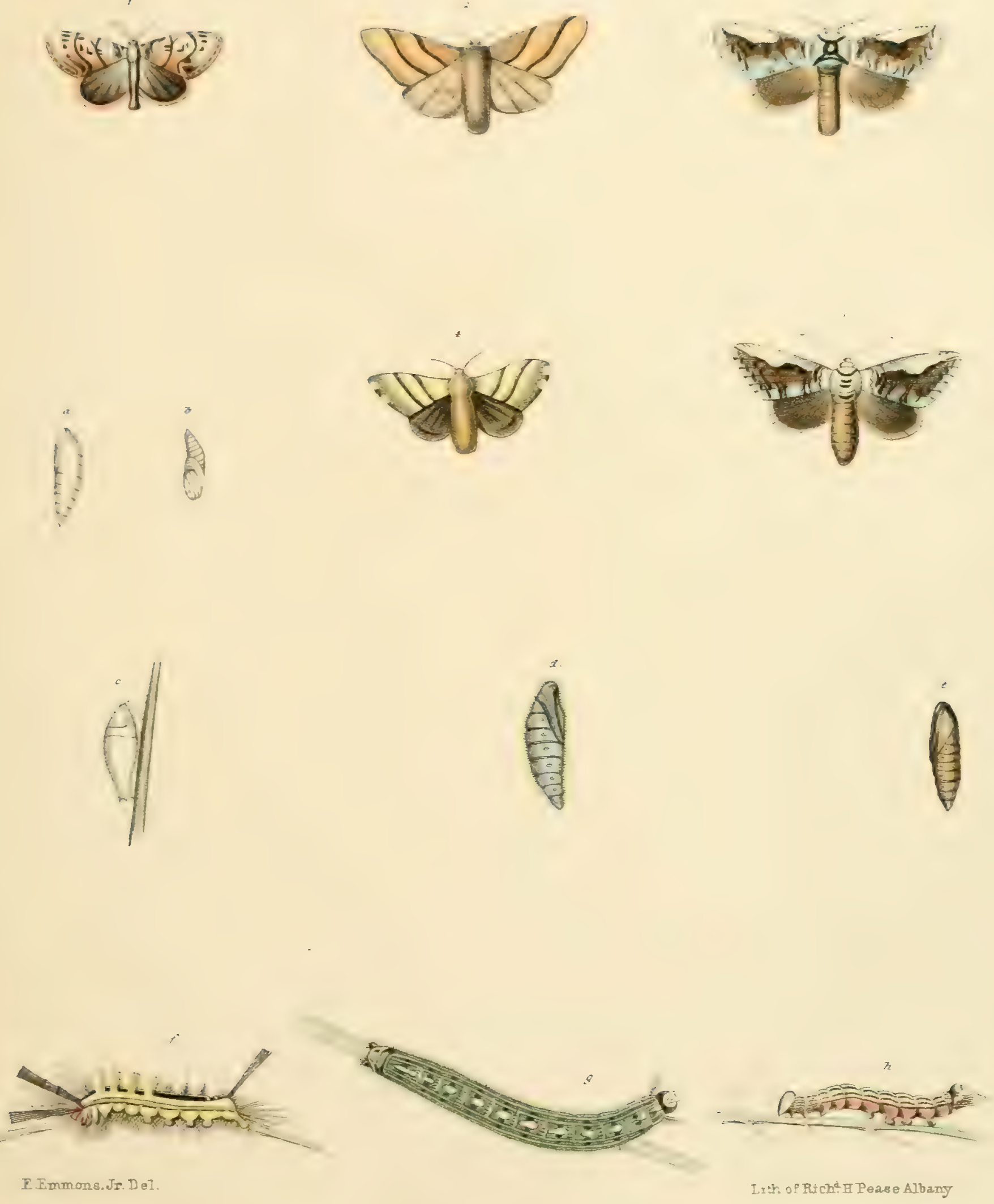

E. Emmons. Jr. Del. 



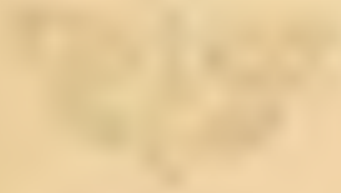

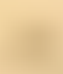




\section{PLATE 39.}

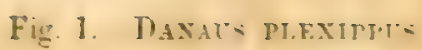

c. Caterpillar.

d. Pupsa.

$\therefore$ Srhisx ontumantates.

a. Cater illar.

b. I'nna.

3. Papilin tirits.

4. Extumis titrris

є. Caterpillar.

f. Pura. 

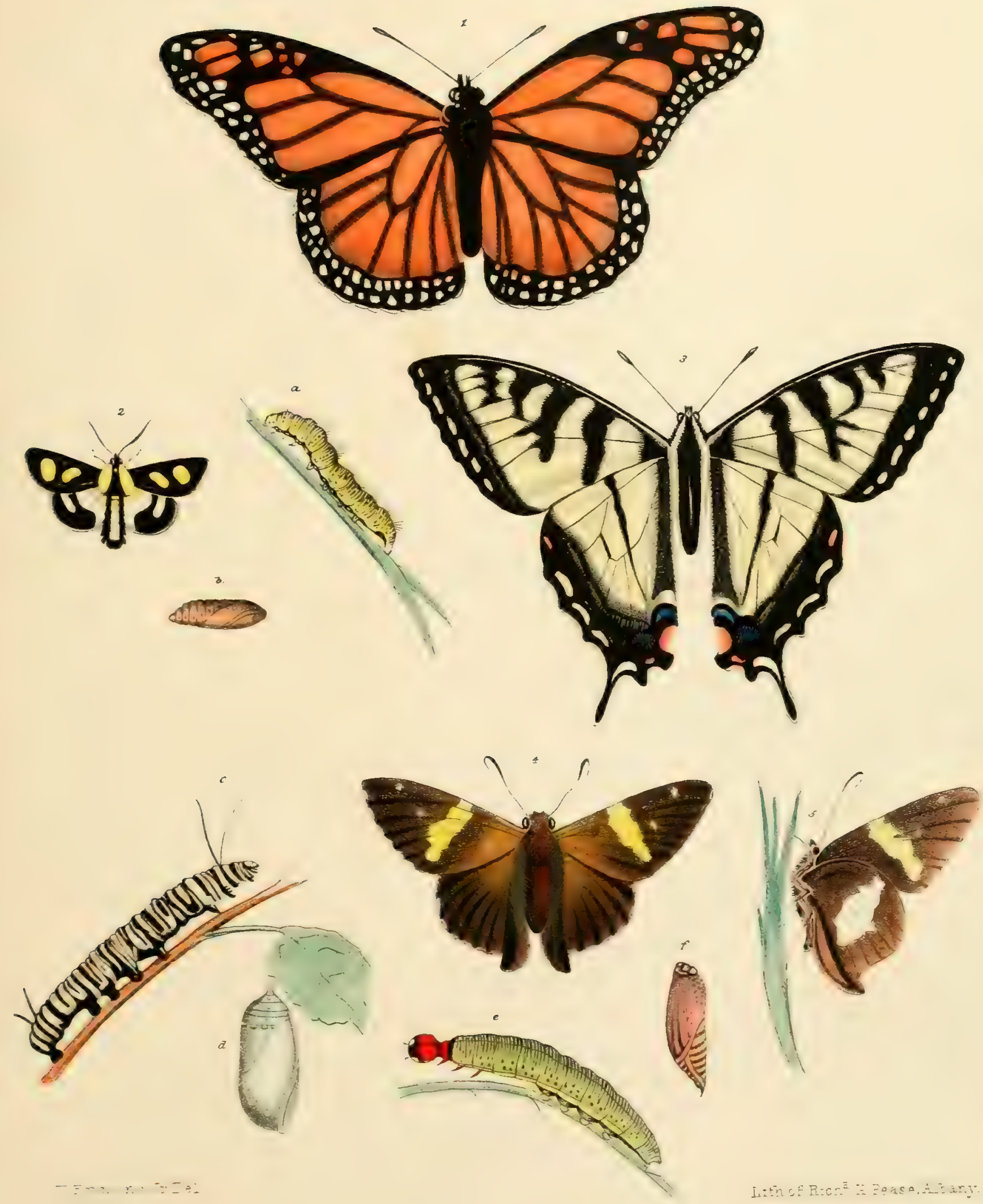



\section{FLATE 39.}

Fig. 1. ATthot LrNA.

$$
\text { b. Papa. }
$$

2. Satcrvia Maia (male and female). $c, d$. Caterrillar.

є. Pupa. 

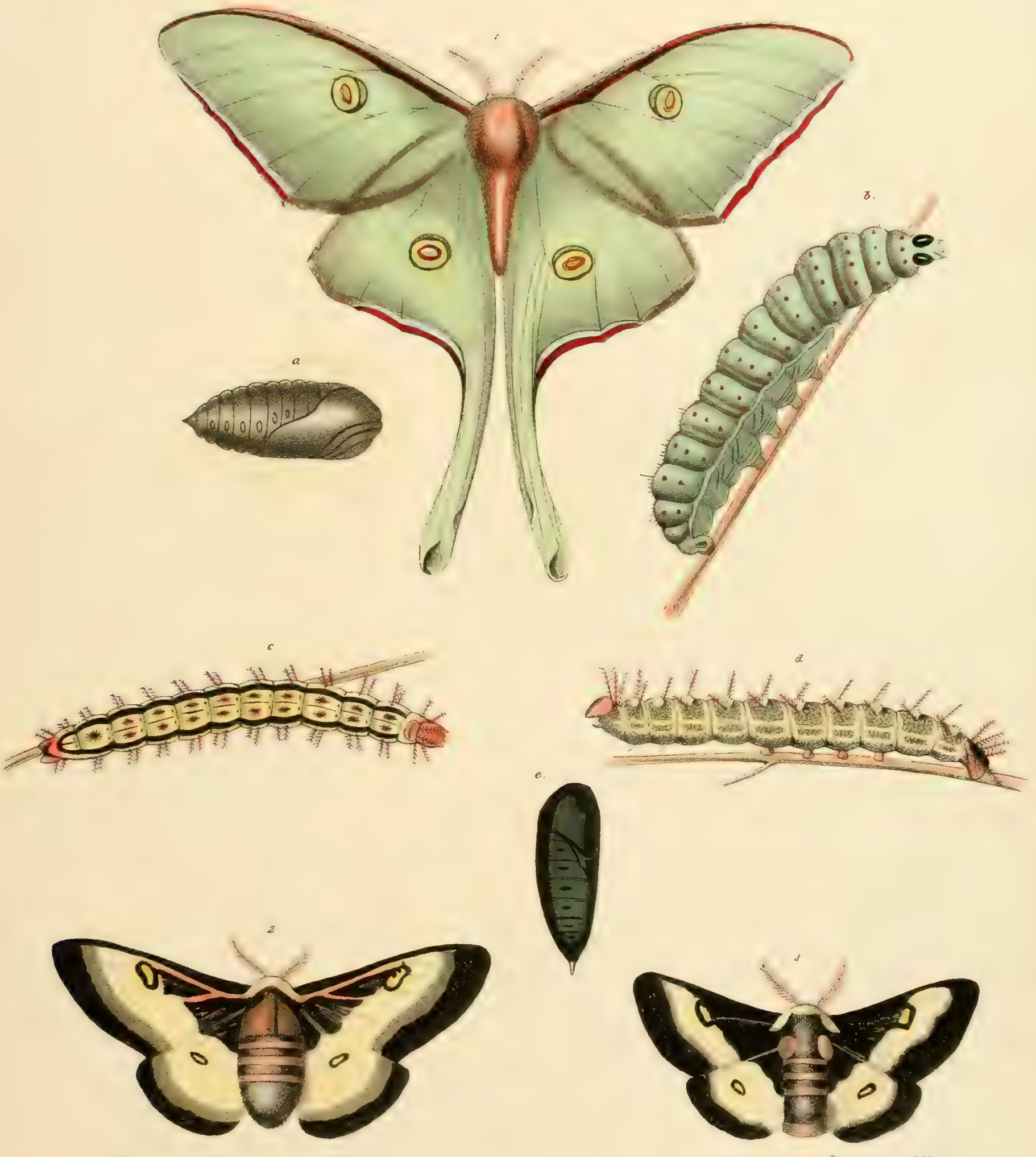

E Emmans, Jr De]

Itth of Riohd II Perse,Albary. 




\section{PLATE 40,}

Fig. 1. SPHINX BRONTES.

2. Geometra argentata.

3. Glatcopis pholus.

4. Smerinthug astryos.

5. Dryocampa virginiensis (vel pellucida?).

b. Geometra serrata.

7. DRYOCAMPA IMPERIALIS. 

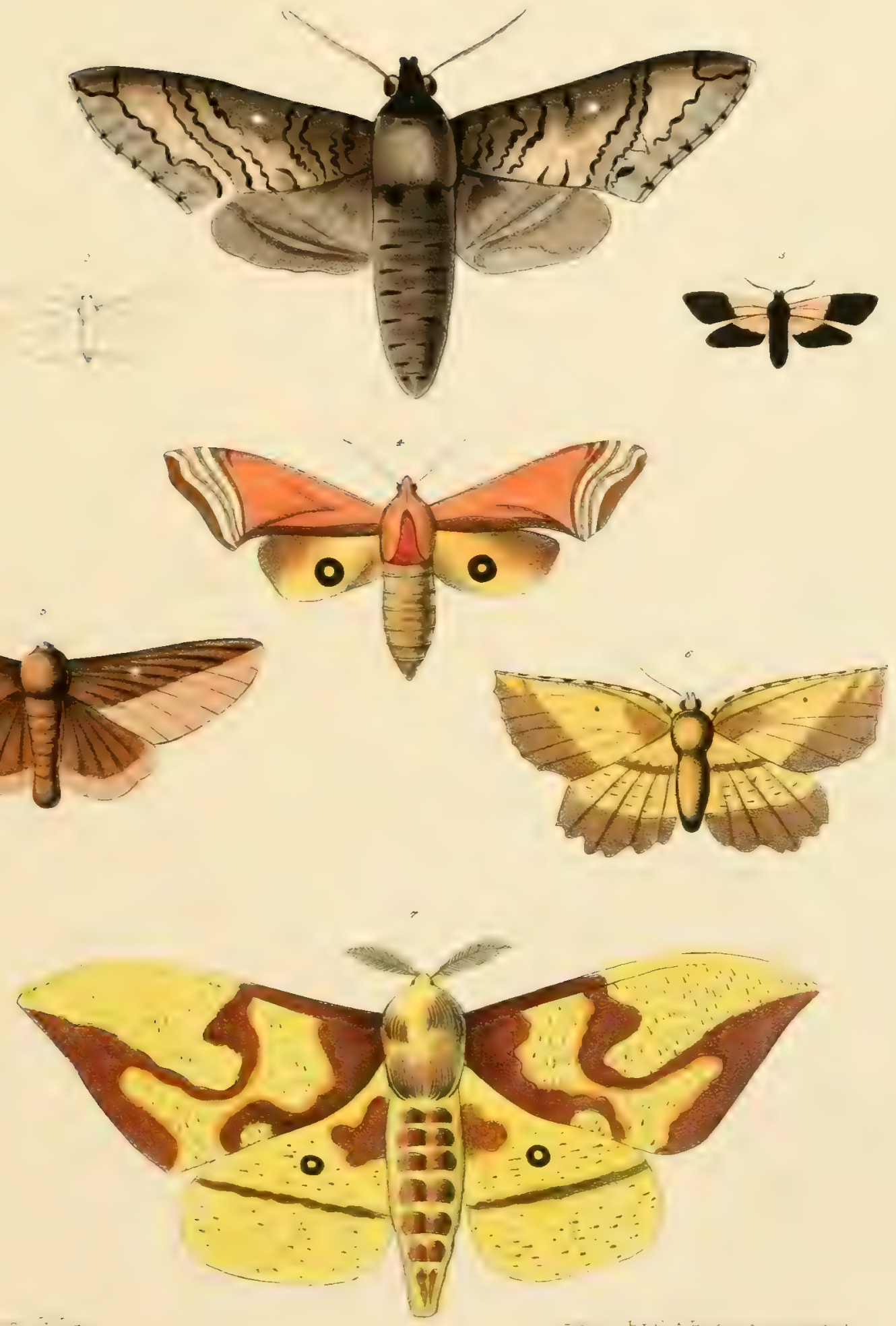




\section{PLITE 41.}

Fig. 1 Phaldena dione.

2. Spilosona acrata (male).

:) Apllusoma argif.

1. Phalema dione (vel Arctia virgo).

$\therefore$ Spllosuma $\triangle \mathrm{CB}$ 正a (female).

i. Catergillar of Phalena dione.

7. strlosoma cenea.

*. Pupa of PhaleNa brone.

3. Mtiloigoma nats.

10. Bupaltes catevahico.

11. Sphosona egle.

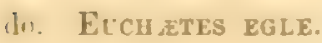




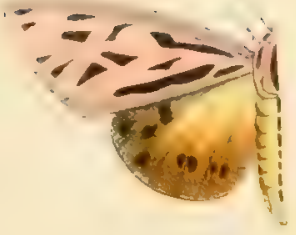

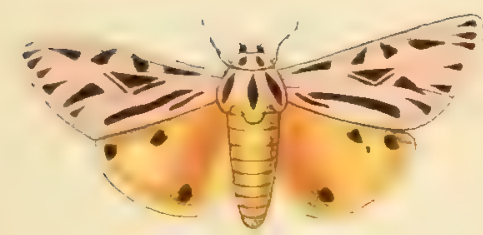

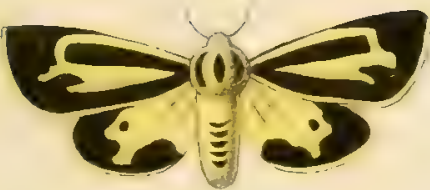

EEmmons, I D D
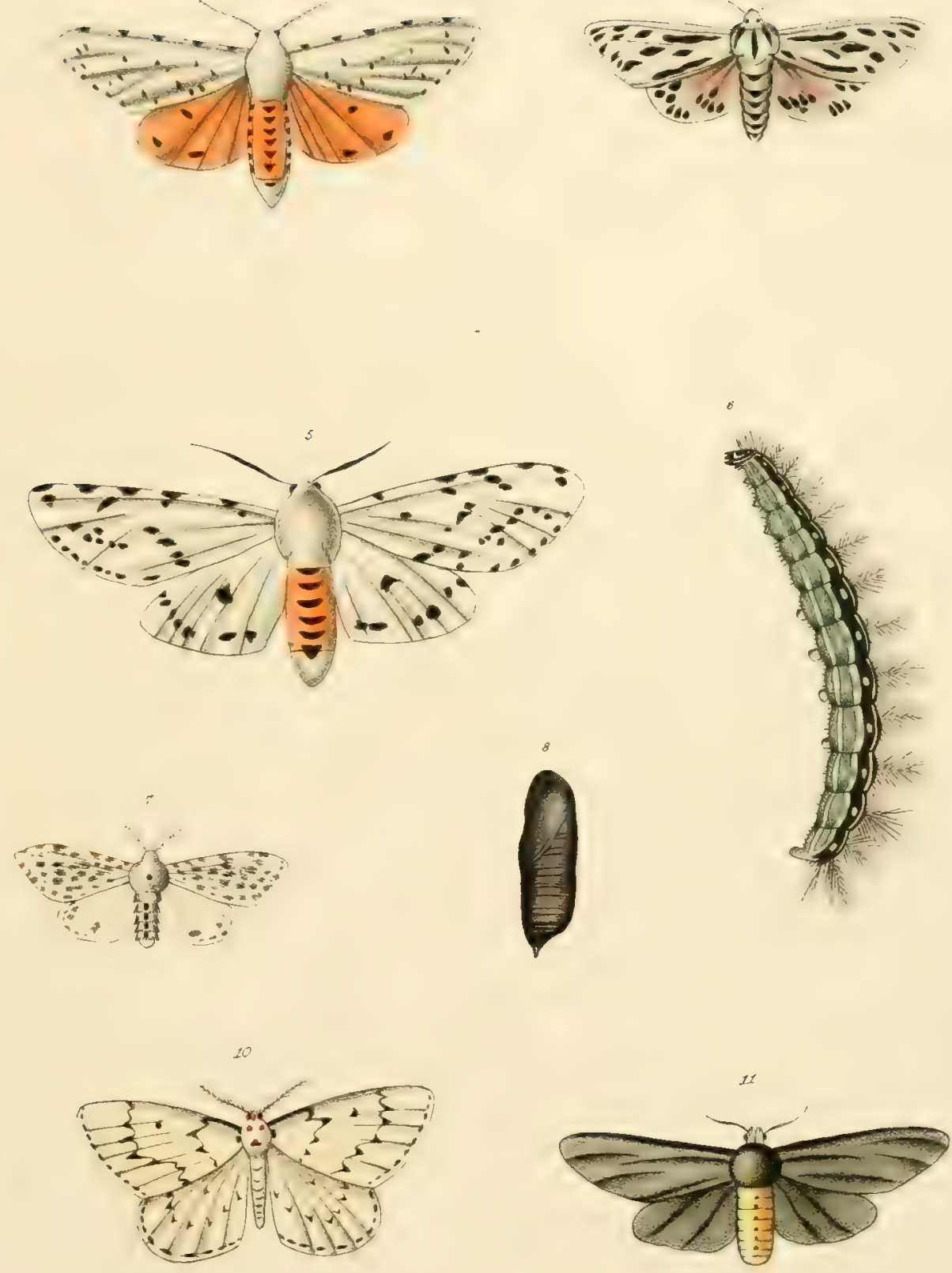

Lrth.of R:ch? H.Peare,Albany. 



\section{PLATE 42.}

Fig. 1. Noctea soramtamis.

‥ GEMETIRA TRINSVEREMLAS.

3. EnEBL' milrsa.

f. Nuctea conthakis.

5. CATWEALA AFFNAS.

(j. Nuctr a nixati.

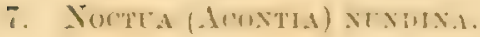

r. Caturala eirone.

9. Foctla (acontia) margaritata.

10. SHinx carolina. 

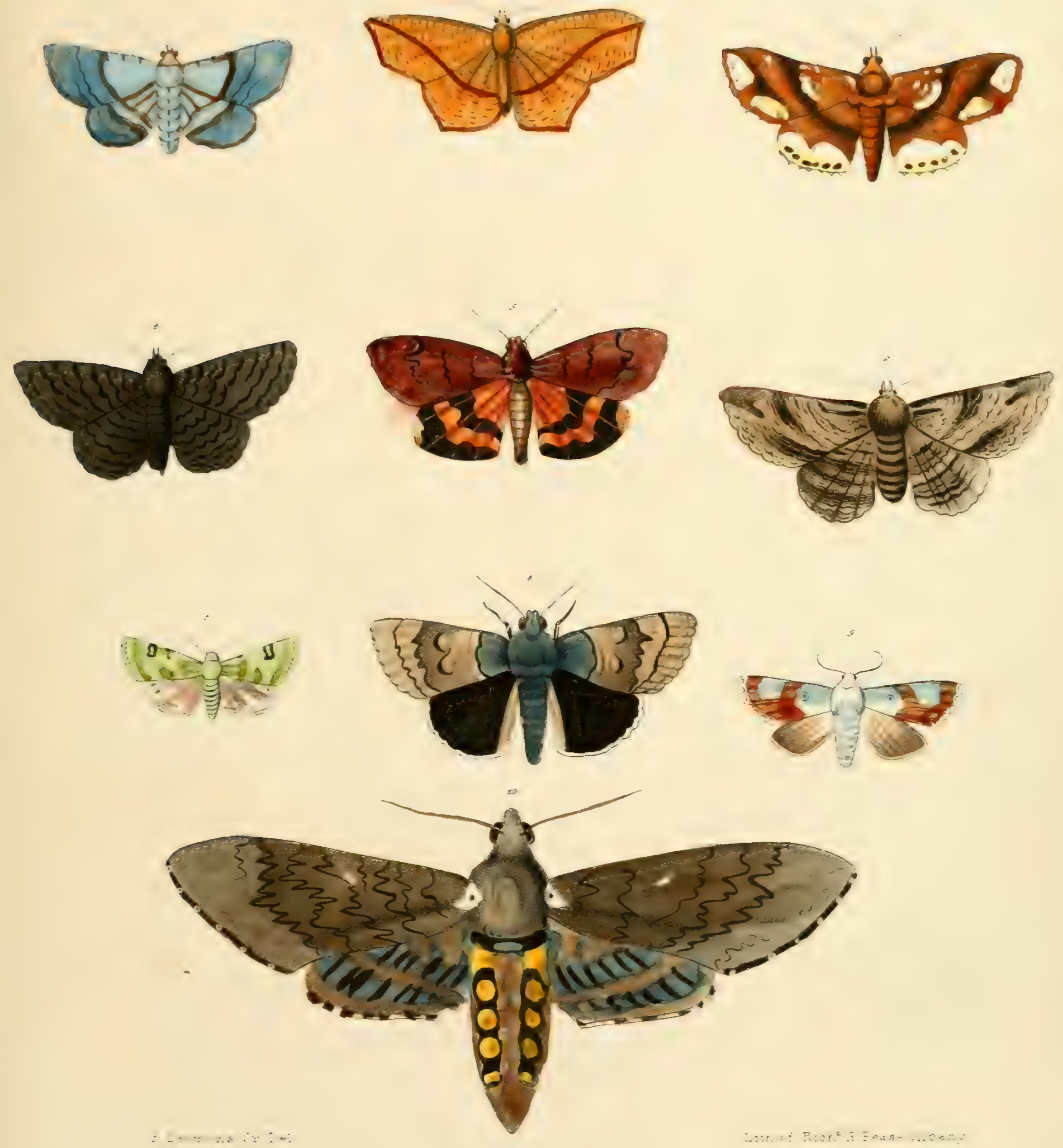


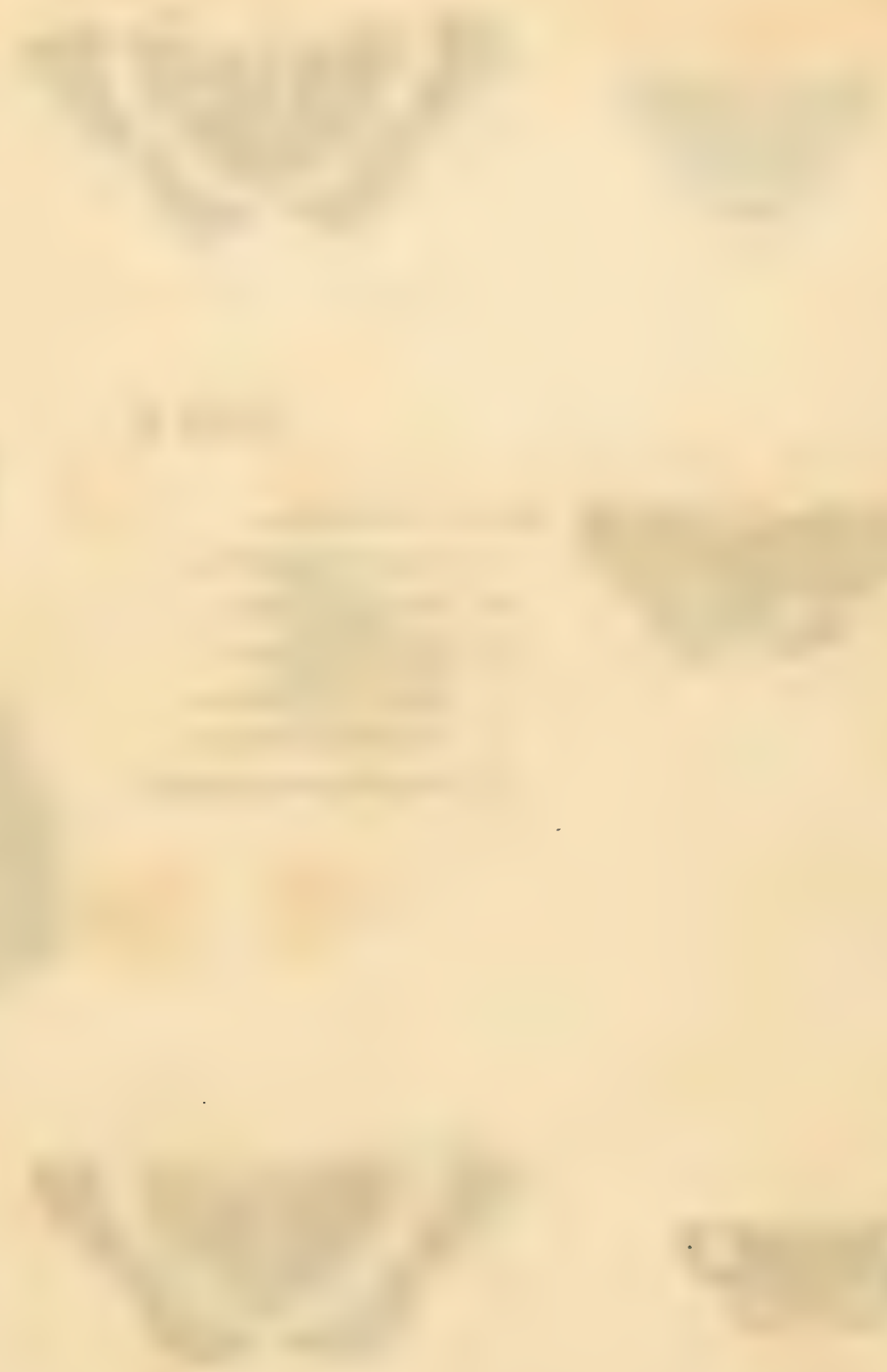


\section{PLATE 43.}

Fig. 1, 3. Trecha acts.

2. LMMENITIS ARTHEMIS.

4, 7. Melitea Pheton.

5, 15. Meltedea pharos.

- Phalexa phylitra.

9. Limenitis arthemis.

10. Callimorpua epryenis. 

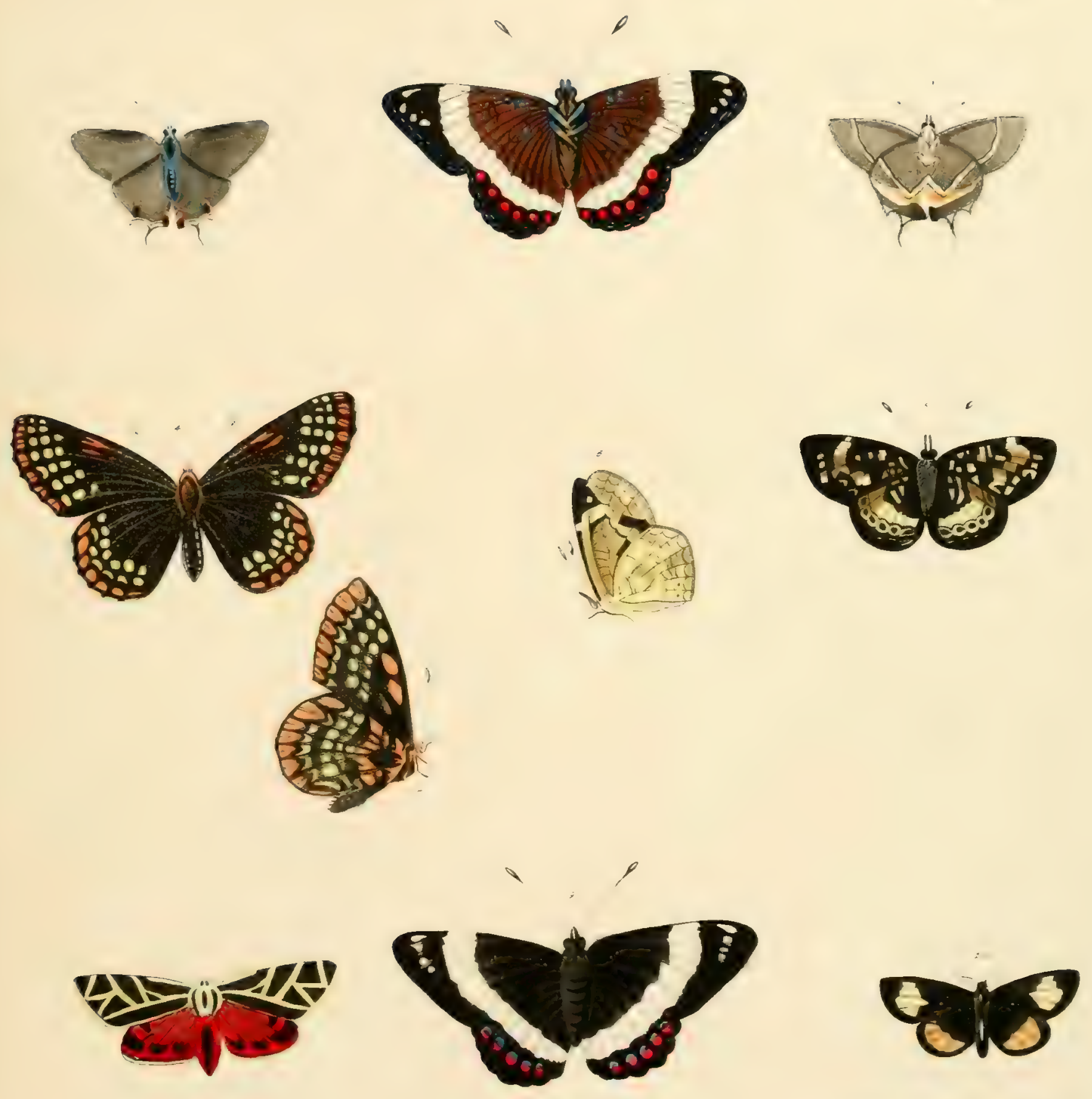

. 


\section{PLITE 11.}

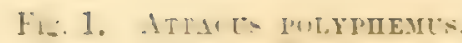

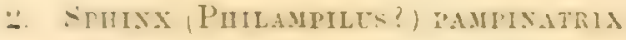

ש. Catenila amasia.

4. Attarts acropla. 

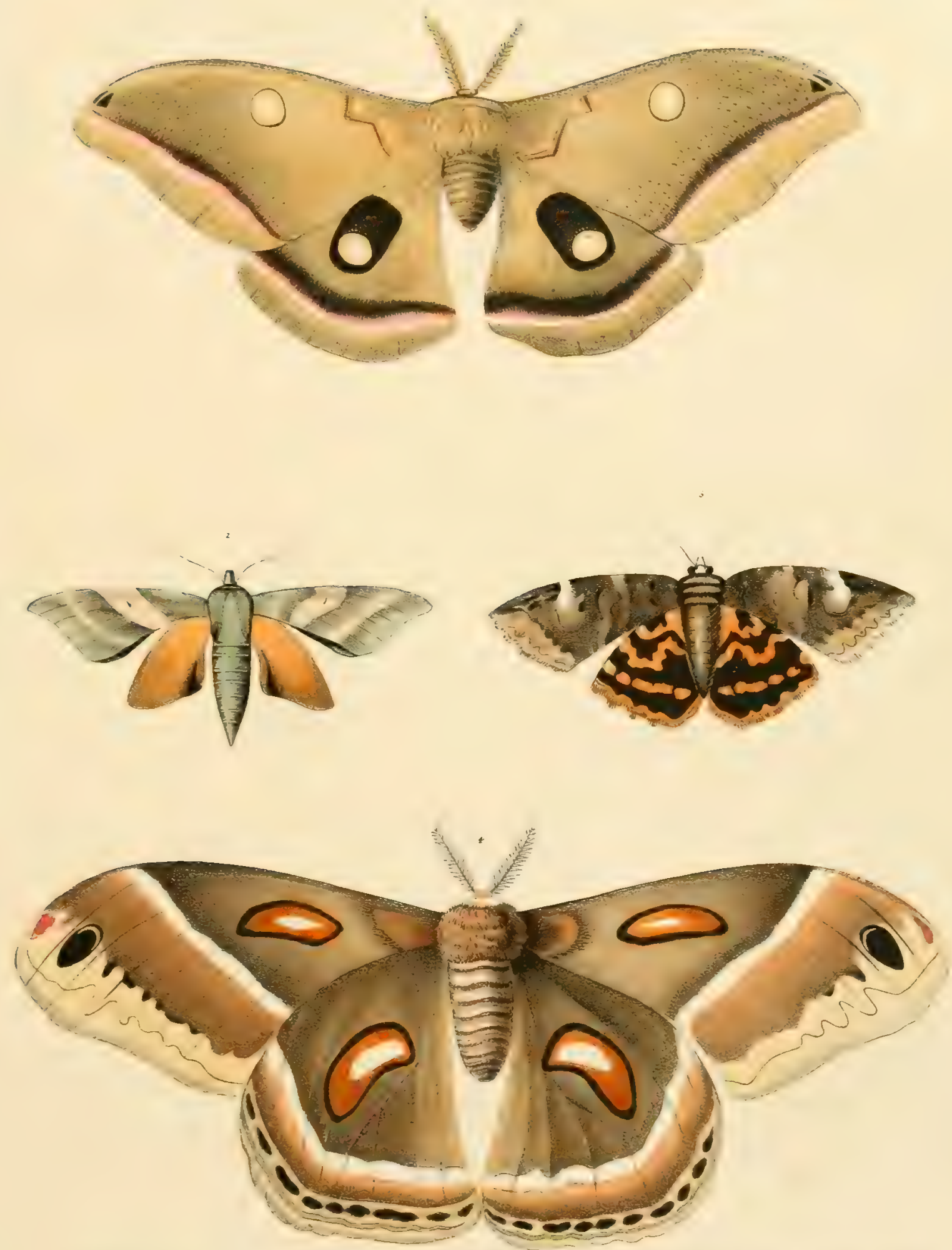



\section{PLATE 45.}

Fig. 1. Cergtocampa americana.

2. AGRUTIS -

3. GDometra -

4. Arctia virginica.

5. Pimlampelus satelitia.

$6,7,8$. Undescribed?

9. BoMBYX? (undescribed).

10. AGROTIS -

11. AGROTIB 

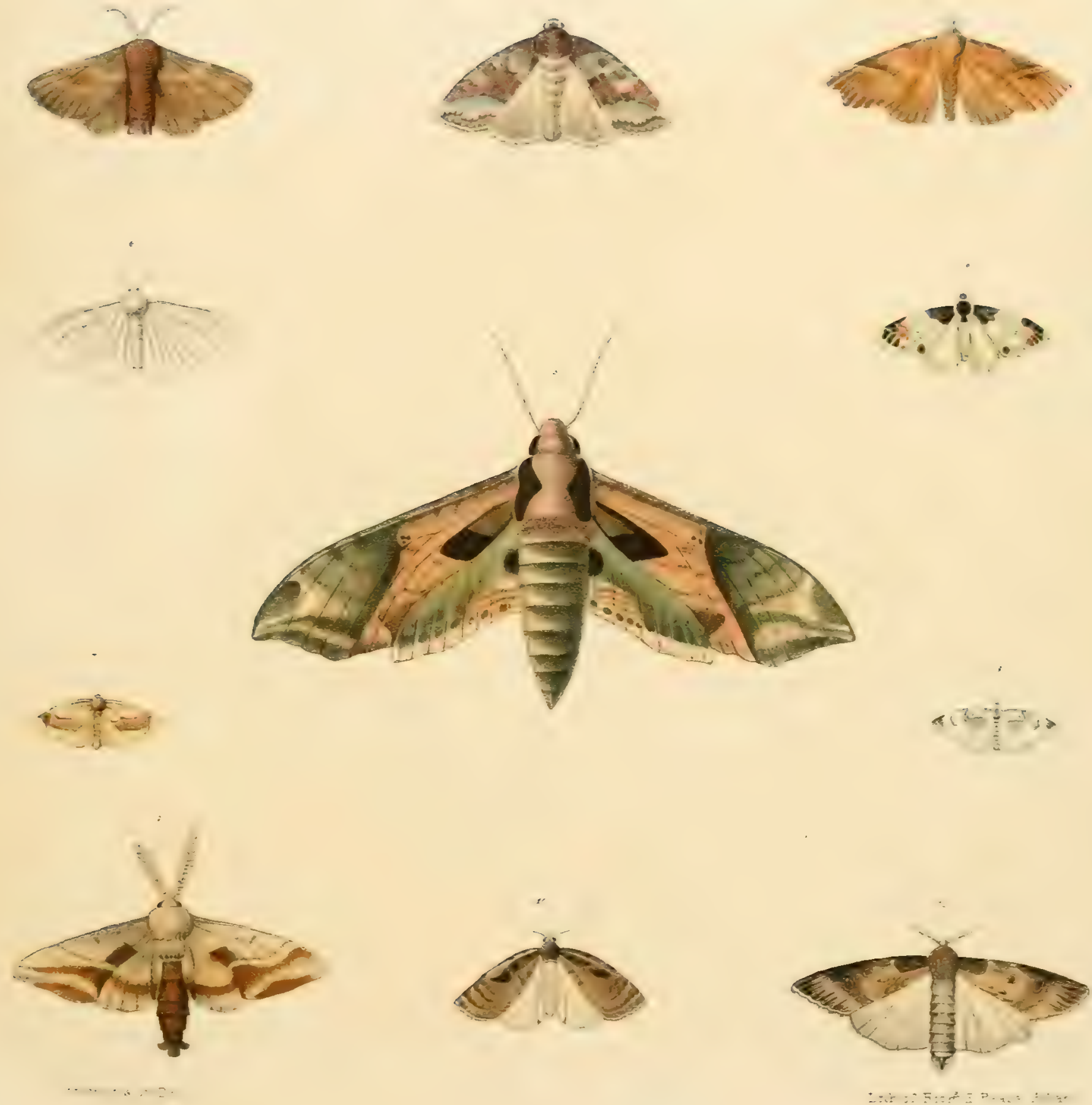

.

I

(. 


\section{PLATE 46.}

Fig. 1, 2. Cynthia cardut.

a. Pupa.

b. Caterpillar.

3. 8. VANESGA URTICEE?

a. Pupa.

b. Caterpillar.

4. Chryophanub phleas.

5. Deiopeia belia.

6. Indeseribed?

7. Blatta nitea. 

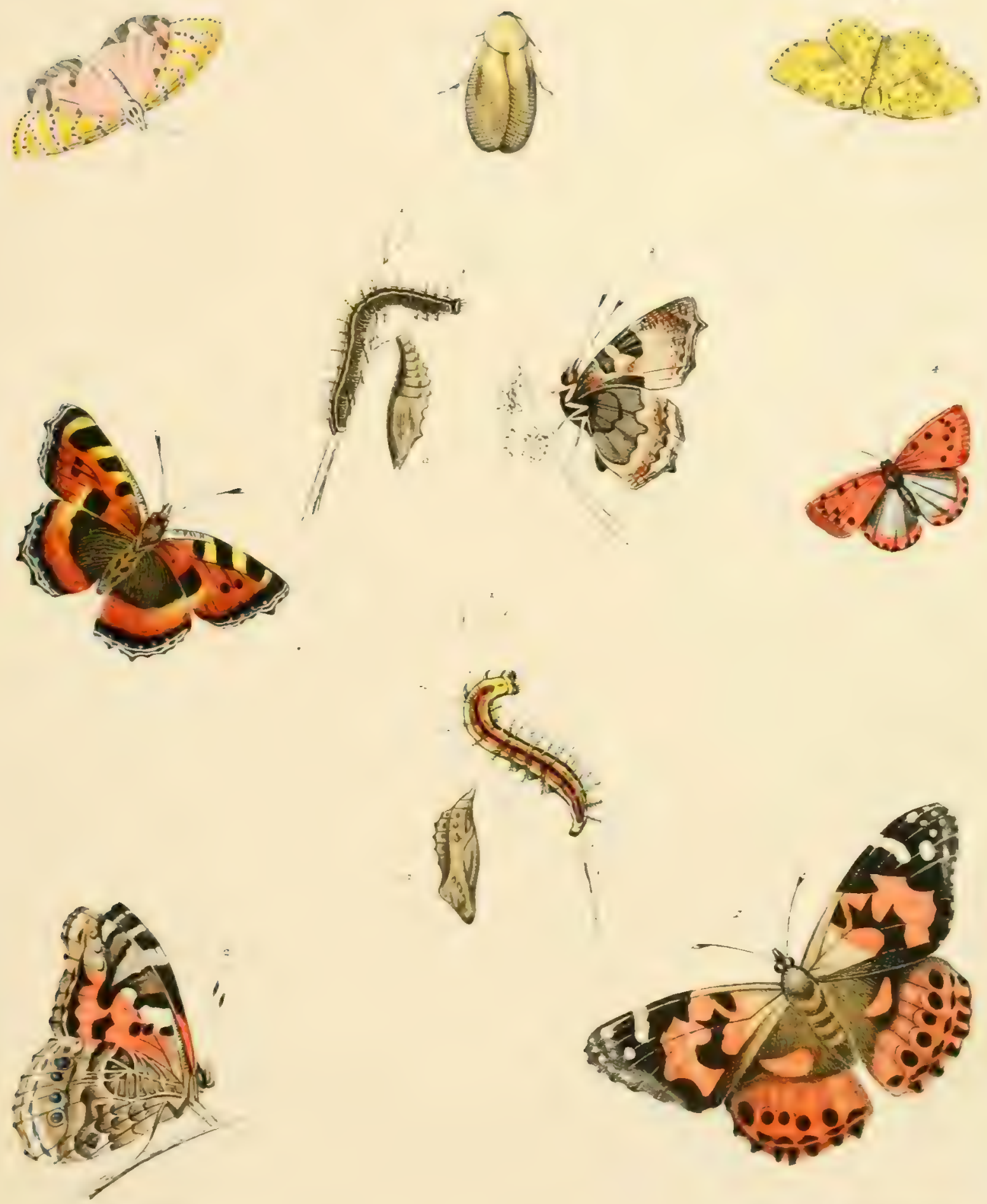



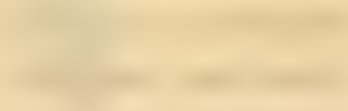

-
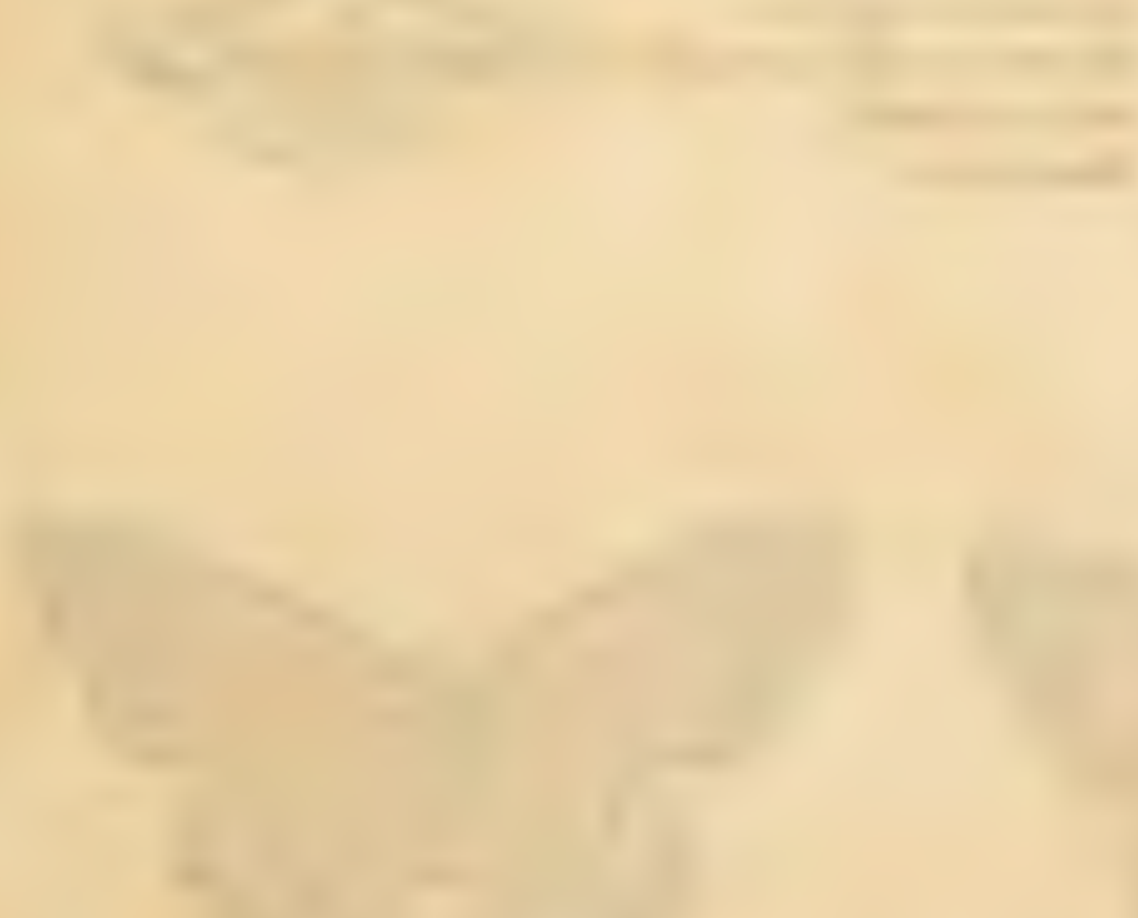


\section{PLATE 47.}

Fig. 1, 2. Limexits dissipptis.

3. Callimorpha partuentee.

4. Carpocapsa poyonella.

5. Catrlarorpha virgexctad.

i. Eggs of the American tent-caterpillar (CLISIOCAMPa A MERICANA).

i. adela degerrella.

8. Ecdryas grata. 

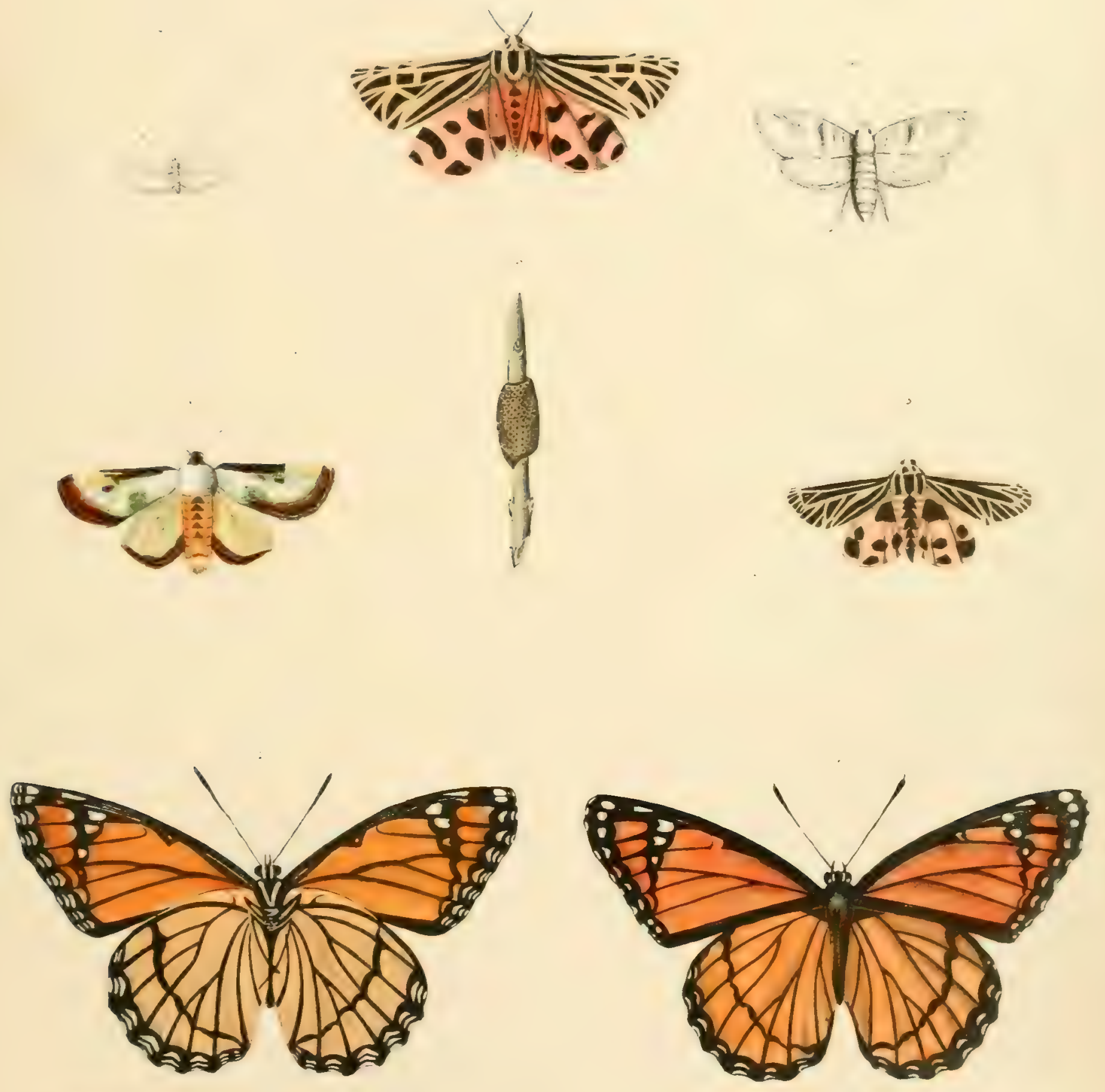


